\title{
IUCN
}

\section{The state of biodiversity in Kuwait}

Zuhair S. Amr

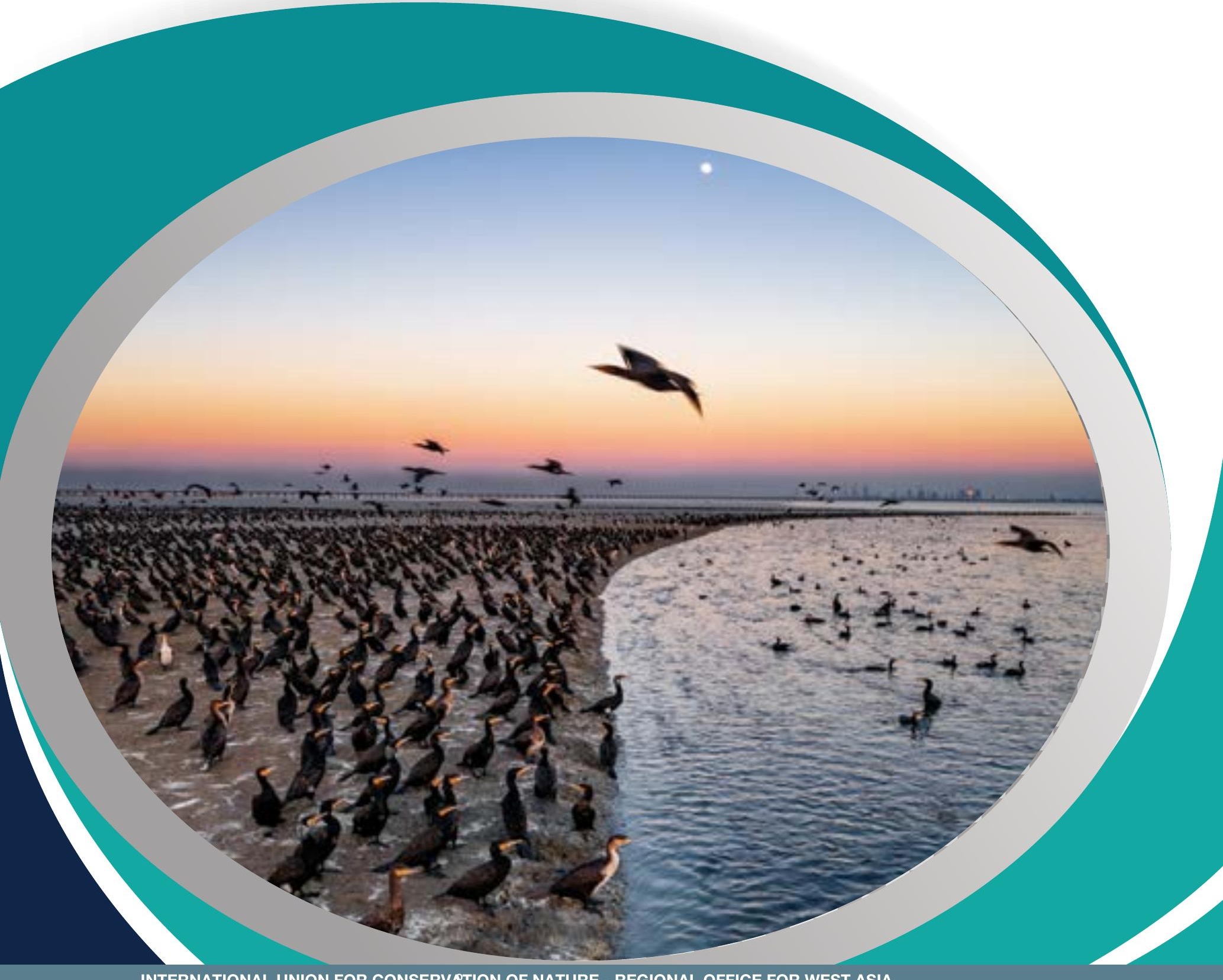

INTERNATIONAL UNION FOR CONSERVATION OF NATURE - REGIONAL OFFICE FOR WEST ASIA

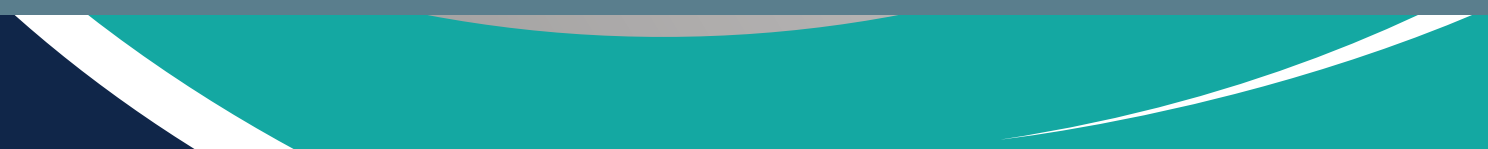




\title{
About Environment Public Authority
}

The Environment Public Authority of Kuwait (EPA) is an independent governmental organization dedicated to environmental action in addition to domestic and international legislation and policy regarding the environment. The Environment Public Authority was founded in 1995 and since then it serves as the epicentre of governmental action regarding the preservation of the environment in Kuwait. Environment and health protection is one of the main priorities of EPA by implementing deliberate plans and projects to protect air, soil, aquatic habitats, coastal habitats, biodiversity, and environmental impact evaluation. EPA focuses on community services and public awareness directed to different groups of the community especially the younger generations as they are the leaders of the future.

\begin{abstract}
About IUCN
IUCN, International Union for Conservation of Nature with its Headquarters in Gland, Switzerland, was created in 1948 as a membership organisation. IUCN is the world's first and largest global environmental network. It is a democratic membership union with more than 1,400 government and nongovernment member organisations, and almost 18,000 volunteer scientists and experts in over 160 countries. IUCN's work is supported by around 900 professional staff in more than 160 countries and hundreds of partners in public, NGO and private sectors around the world. IUCN seeks to help the world find pragmatic solutions to the most pressing environmental and sustainable development challenges. IUCN supports scientific research, manages field projects all over the world and brings governments, nongovernment organisations, United Nations agencies, companies and local communities together to develop and implement policy, laws and best practices.
\end{abstract}

\section{About IUCN Regional Office for West Asia}

The Regional Office for West Asia (ROWA) was established in 2004 in Amman, Jordan. The IUCN West Asian region comprises of 13 countries including Iraq, Jordan, Lebanon, Palestine, the Syrian Arab Republic, Yemen and Iran in addition to the Gulf countries including Bahrain, Oman, Kuwait, Qatar, Kingdom of Saudi Arabia, and the United Arab Emirates. IUCN Regional Office for West Asia aims to be active in all 13 countries in various conservation and sustainable development activities. 
The state of biodiversity in Kuwait Zuhair S. Amr 
The designation of geographical entities in this book, and the presentation of the material, do not imply the expression of any opinion whatsoever on the part of IUCN or other participating organisations concerning the legal status of any country, territory, or area, or of its authorities, or concerning the delimitation of its frontiers or boundaries.

The views expressed in this publication do not necessarily reflect those of IUCN or other participating organisations.

IUCN is pleased to acknowledge the support of its Framework Partners who provide core funding: Ministry of Foreign Affairs of Denmark; Ministry for Foreign Affairs of Finland; Government of France and the French Development Agency (AFD); the Ministry of Environment, Republic of Korea; the Norwegian Agency for Development Cooperation (Norad); the Swedish International Development Cooperation Agency (Sida); the Swiss Agency for Development and Cooperation (SDC) and the United States Department of State.

This publication was developed through the project "Monitoring and documentation of Biodiversity in Kuwait", executed by IUCN Regional Office for West Asia in partnership with Environmental Public Authority of Kuwait (EPA of Kuwait), and funded by the State of Kuwait.

Published by:

Produced by:

Copyright:

Recommended citation:

Project team:

ISBN:

DOI:

Cover photo:

Layout by:
IUCN Gland, Switzerland and the Environmental Public Authority, State of Kuwait, Kuwait

IUCN Regional Office for West Asia (ROWA)

(C) 2021 IUCN, International Union for Conservation of Nature and Natural Resources

Reproduction of this publication for educational or other non-commercial purposes is authorised without prior written permission from the copyright holder provided the source is fully acknowledged.

Reproduction of this publication for resale or other commercial purposes is prohibited without prior written permission of the copyright holder.

Amr, Z.S. (2021), The state of biodiversity in Kuwait. Gland, Switzerland: IUCN; the State of Kuwait, Kuwait: Environmental Public Authority.

From Environmental Public Authority of Kuwait

Dr. Abdullah Alzaidan: Deputy Director General of Technical Affairs Lina Alawadhi: Director of the Biodiversity Conservation Department Shreefa Alsalem: Head of the Wildlife Monitoring Sub department Nadia Alsager: Senior Biology Specialist

Athraa Alhabeeb: Senior Biology Researcher

Shahenaz Boromana: Senior Biology Specialist

From IUCN Regional Office for West Asia

Dr. Hany El Shaer: Regional Director ROWA

Eng. Natalia Boulad: Programme Manager, Protected Areas \& Biodiversity Programme

Eng. Hanna Haddad: Programme Assistant, Protected Areas \& Biodiversity

Programme

Ola Malah: Membership Coordinator

978-2-8317-2134-7 (PDF)

978-2-8317-2135-4 (print)

https://doi.org/10.2305/IUCN.CH.2021.11.en

Faisal Al Nomas

Kifah Fadhil Alshbeeb 


\section{Table of contents}

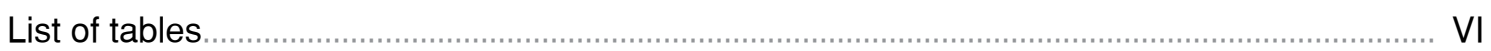

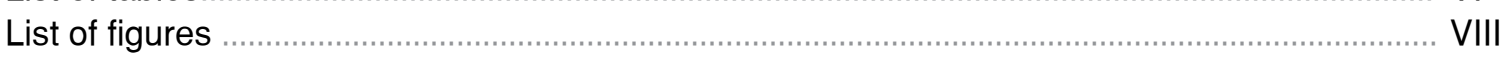

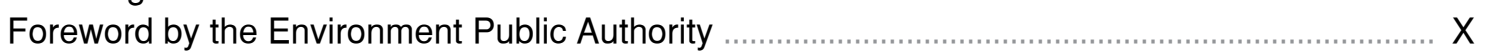

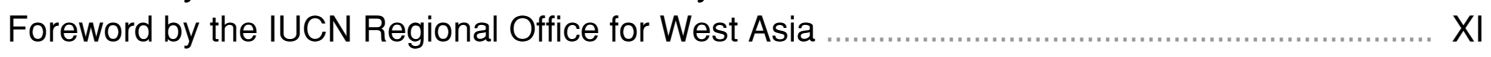

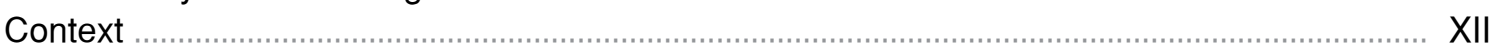

Executive summary

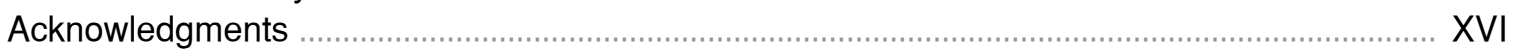

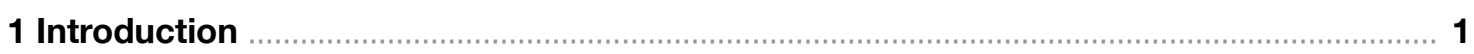

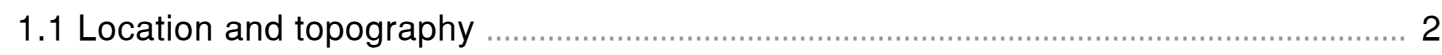

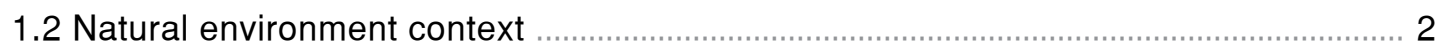

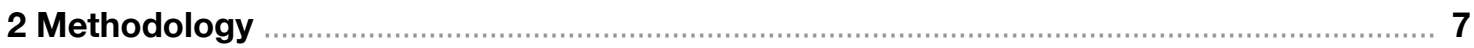

3 Terrestrial and marine vertebrates

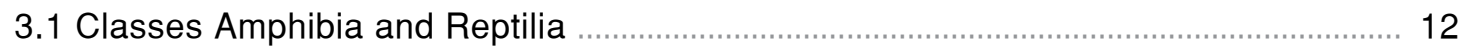

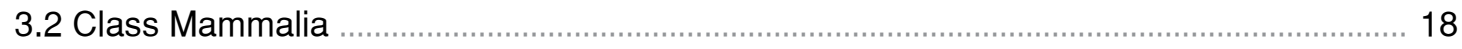

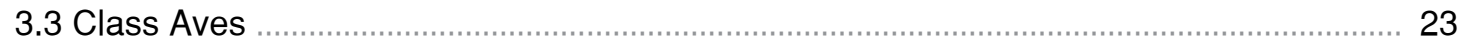

3.4 Classes Chondricthyes and Osteicthyes ……....................................................... 33

4 Arthropoda

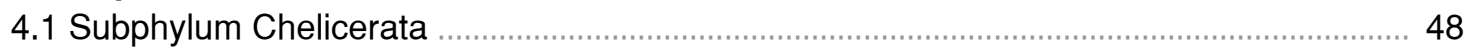

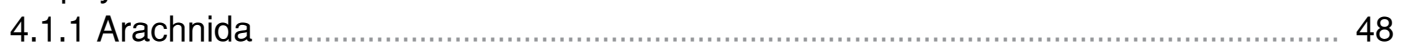

4.1.1.1 Order Scorpiones ..................................................................... 48

4.1.1.2 Order Araneae ............................................................................. 49

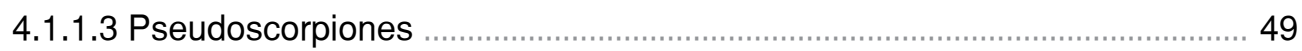

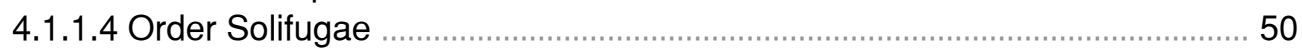

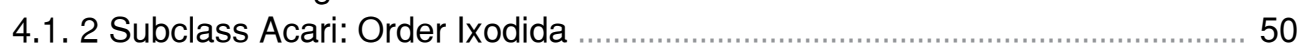

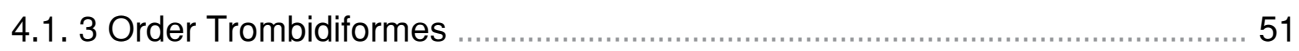

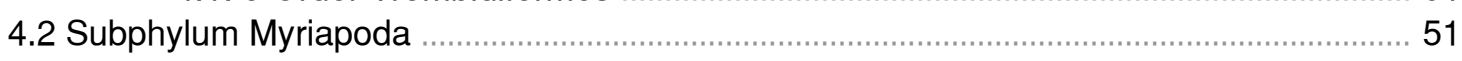

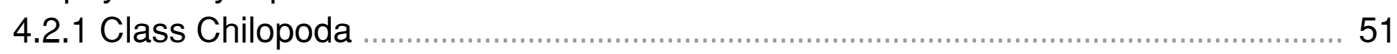

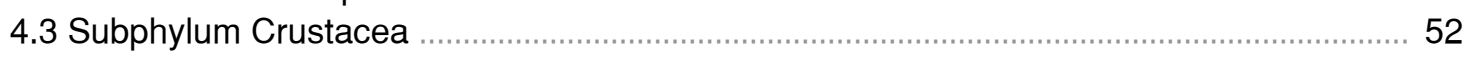

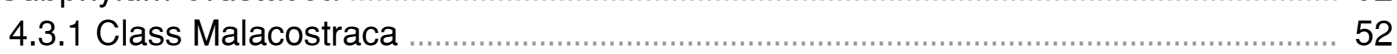

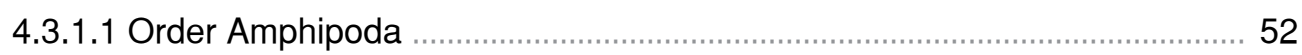

4.3.1.2 Order Decopoda: Suborder Senticaudata …....................................... 55

4.3.1.3 Order Decopoda: Suborder Pleocyemata: Infraorder Caridea ................. 60

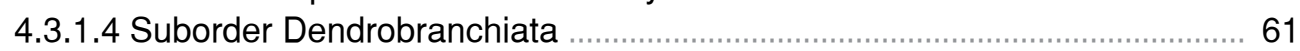

4.3.1.5 Infraorders Achelata, Anomura and Thalassinidea ….......................... 62

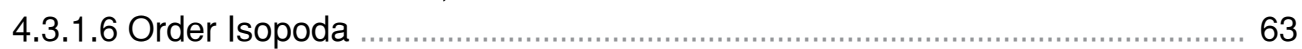

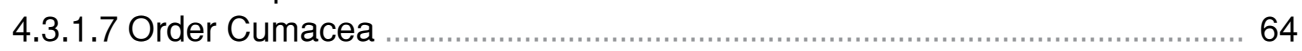

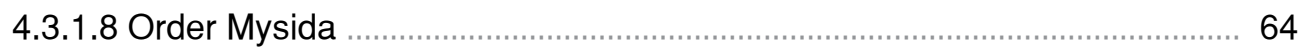

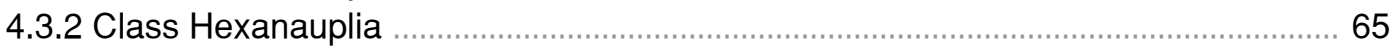

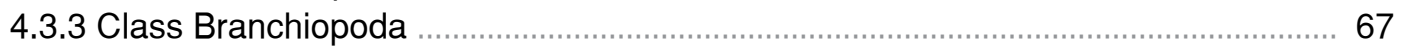




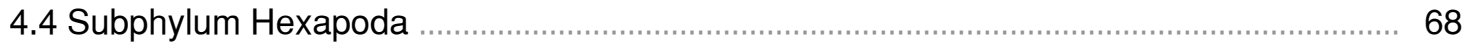

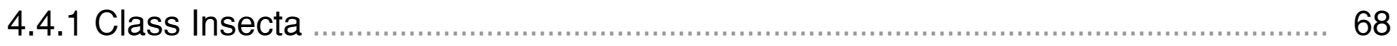

4.4.1.1 Order Odonata (Dragonflies) .................................................. 68

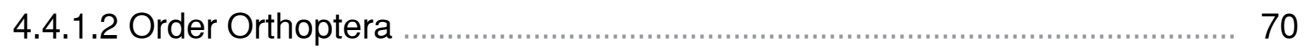

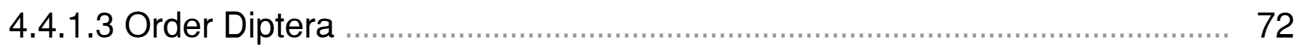

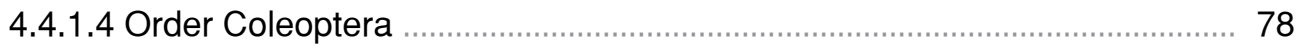

4.4.1.5 Order Mantodea ……………............................................................... 79

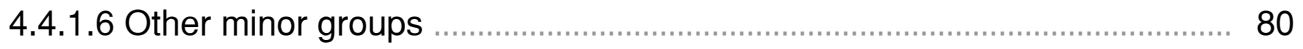

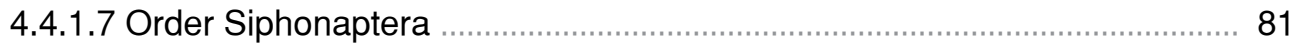

4.4.1.8 Order Neuroptera ……...................................................................... 82

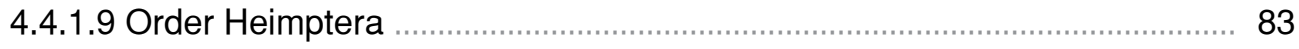

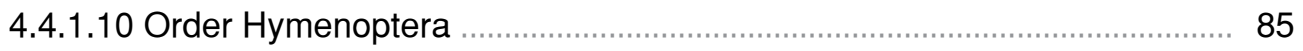

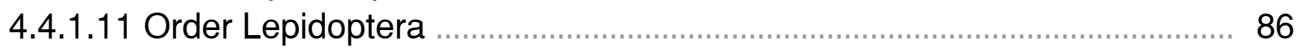

4.4.1.12 Order Mallophaga .................................................................. 90

4.4.1.13 Order Anoplura ……................................................................. 91

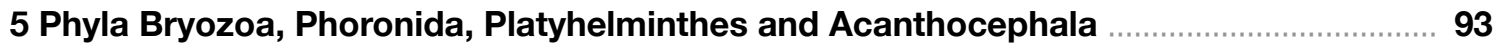

5.1 Phyla Bryozoa and Phoronida Monogenea ……................................................ 94

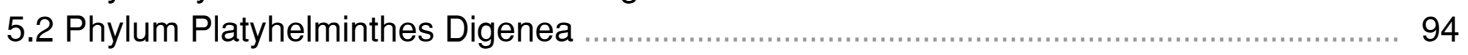

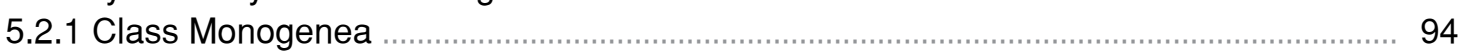

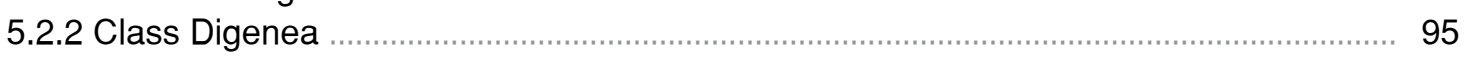

5.3 Phylum Acanthocephala

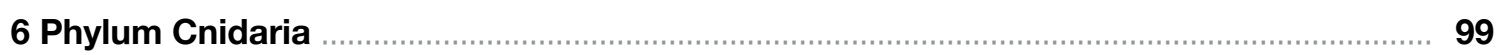

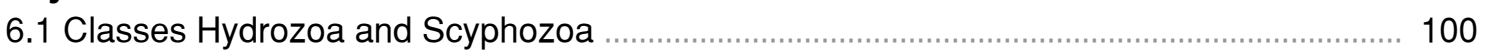

6.2 Class Anthozoa

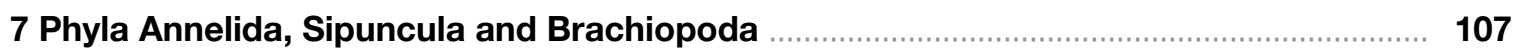

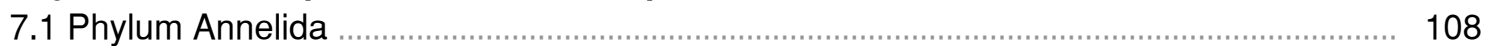

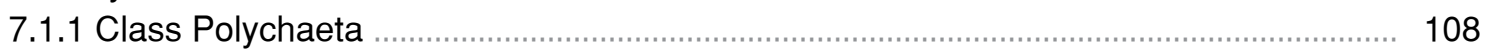

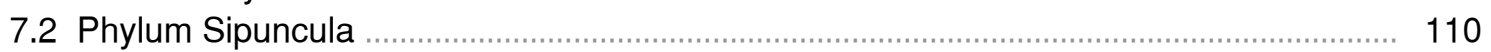

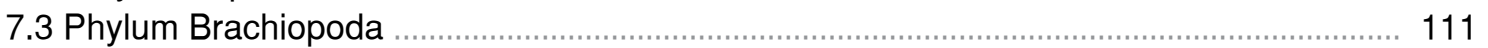

8 Phylum Mollusca

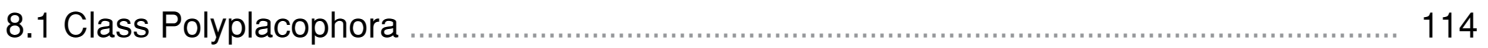

8.2 Class Gastropoda

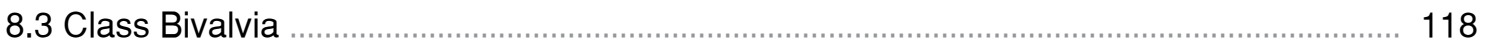

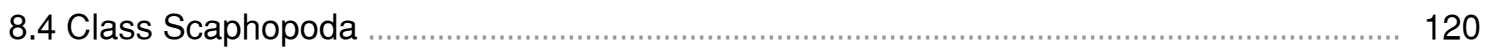

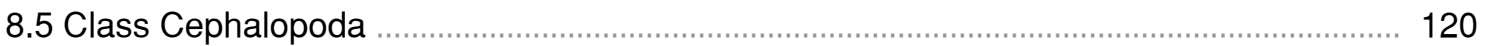

9 Phylum Echinodermata, Hemichordata and Chordata $\ldots \ldots \ldots \ldots \ldots \ldots \ldots \ldots \ldots \ldots \ldots \ldots \ldots \ldots . . .123$

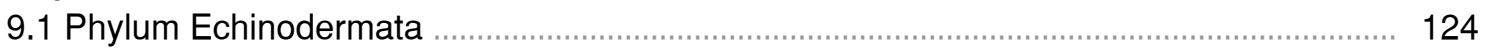

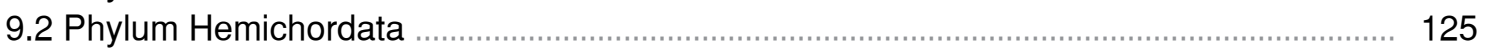

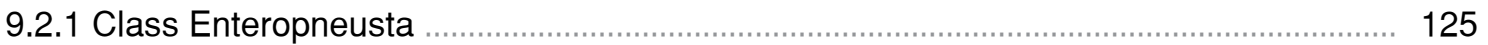

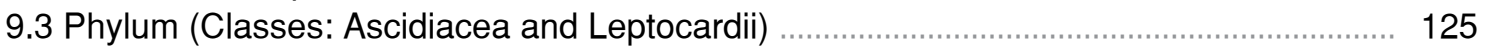




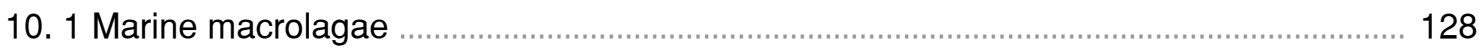

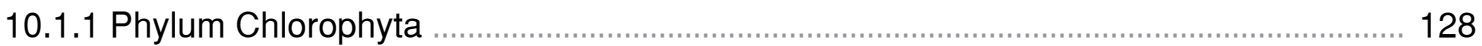

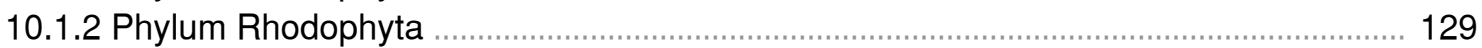

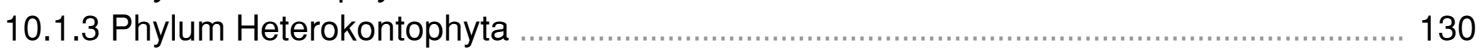

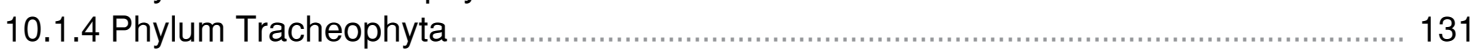

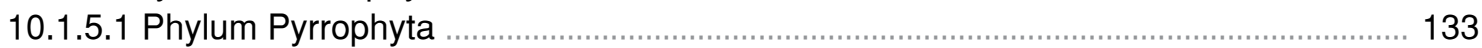

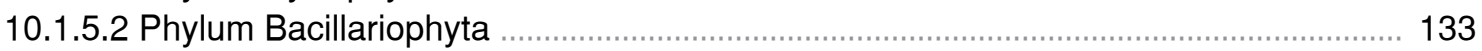

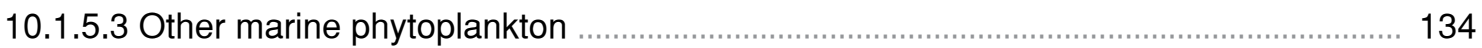

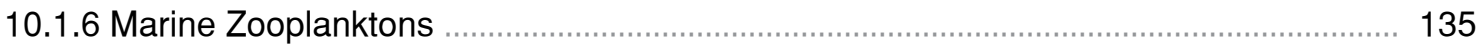

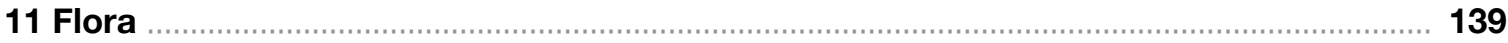

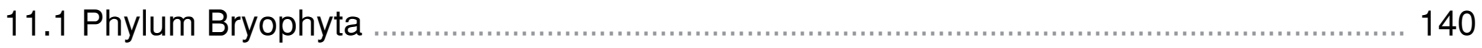

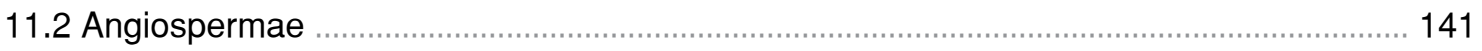

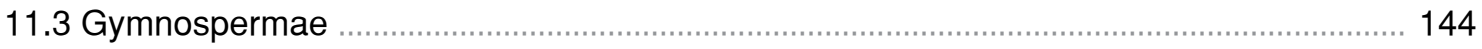

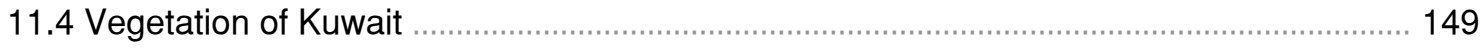

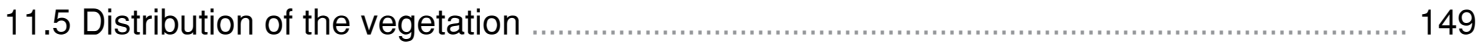

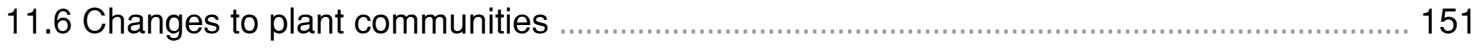

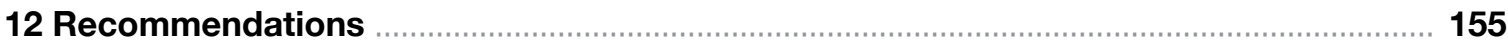

\section{Annexes}

Annex 1: Birds of Kuwait (source: Birdlife International \& http://www.kuwaitbirds.org/birds)... 160 Annex 2: List of fishes recorded from Kuwait (Based on Bishop, 2003) ................................ 175

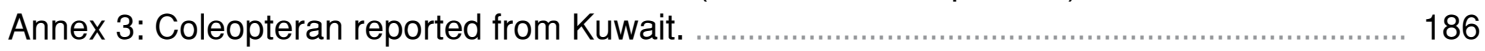
Annex 4: Species of suborder Heteroptera reported from Kuwait. ...................................... 194

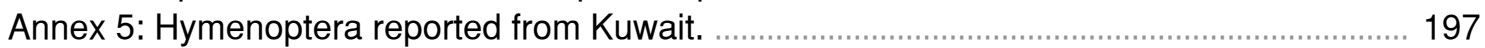
Annex 6: Polychaeta species reported from Kuwait. .................................................. 201 Annex 7: Marine gastropods reported from Kuwait. …………………........................... 207 Annex 8: Bivalevs reported from Kuwait. Annex 9: Dinoflagellates reported from Kuwait. …….................................................... 225

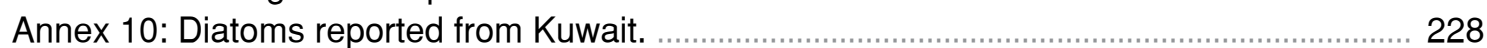

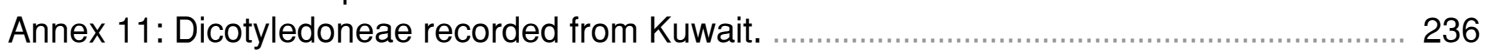
Annex 12 Monocotyledoneae recorded from Kuwait.................................................... 245 


\section{List of tables}

Table 1: Number of species recorded from Kuwait per taxonomic group......................................... XII

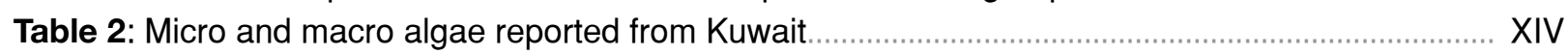

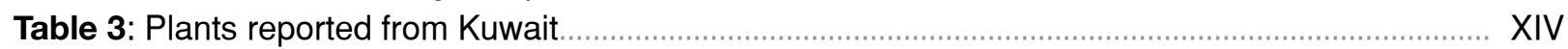

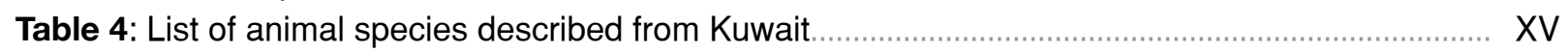

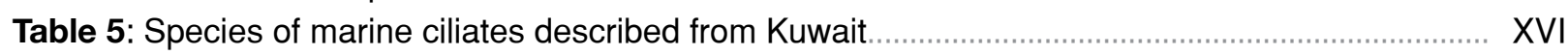

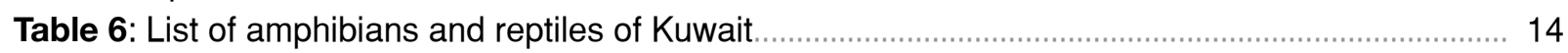

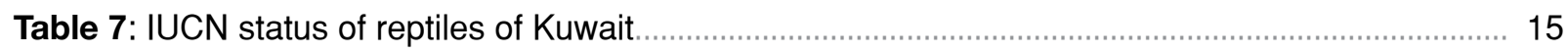

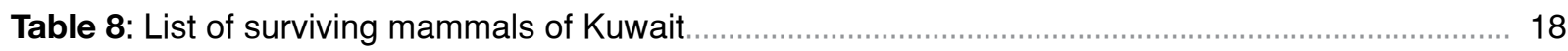

Table 9: Extinct mammals of Kuwait and their IUCN conservation status ......................................... 20

Table 10: Marine mammals reported from Kuwait and their IUCN conservation status ........................ 21

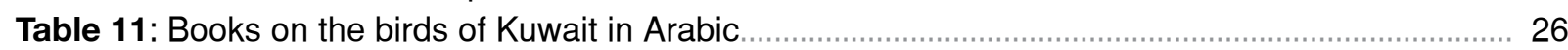

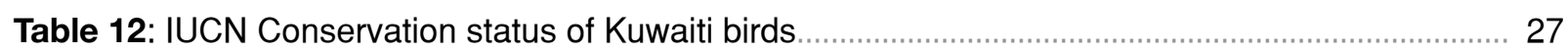

Table 13: IUCN Conservation status of sharks in Kuwait and the Arabian Gulf ............................. 35

Table 14: IUCN Conservation status of rays and guitarfishs in Kuwait and the Arabian Gulf................36

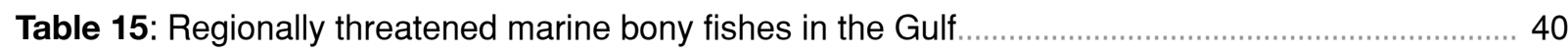

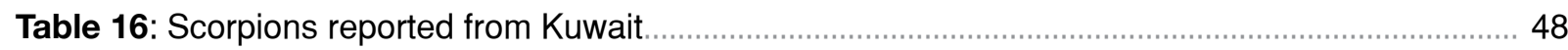

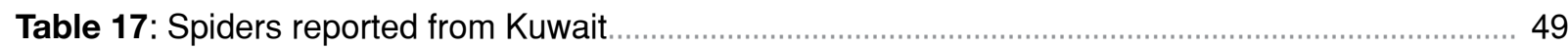

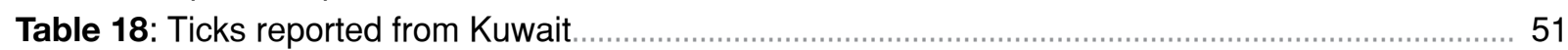

Table 19: Amphipods reported from Kuwait $\left({ }^{*}=\right.$ described from Kuwait) .......................................... 52

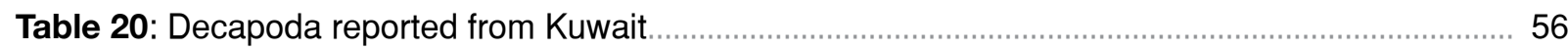

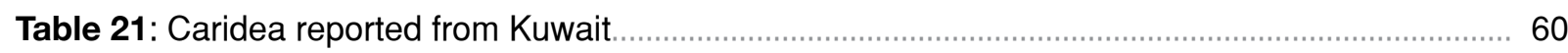

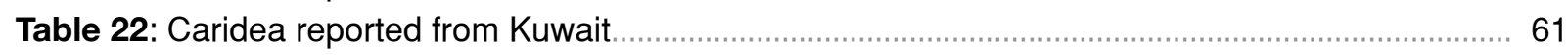

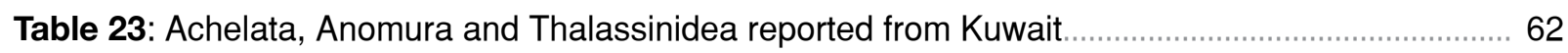

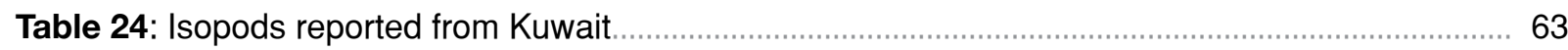

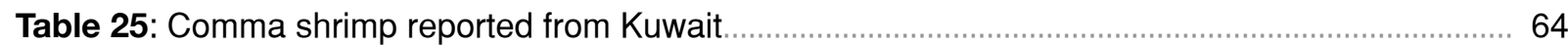

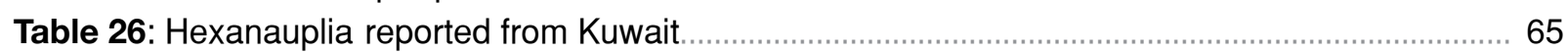

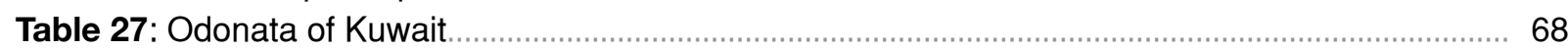

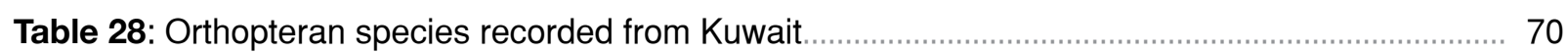

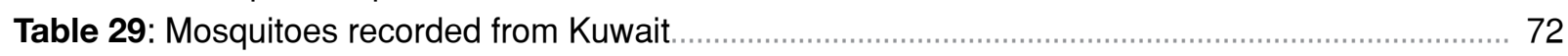

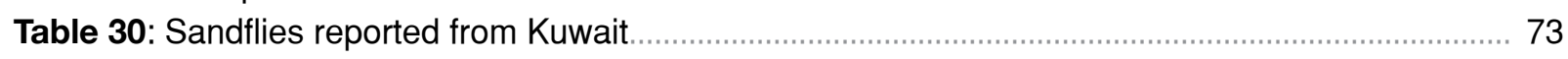

Table 31: Chironomids reported from Kuwait

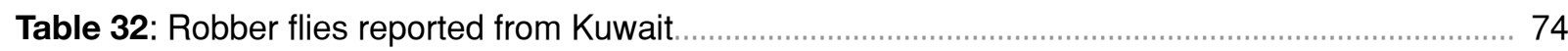

Table 33: Bee flies reported from Kuwait

Table 34: Other families of order Diptera reported from Kuwait $\ldots$

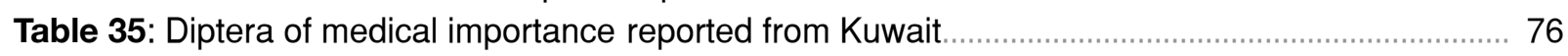

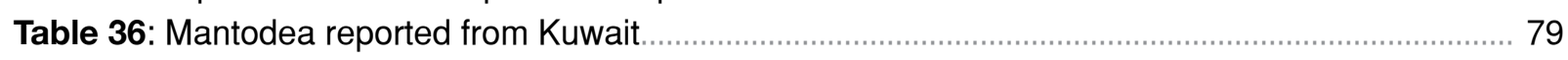

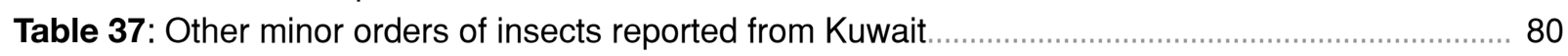

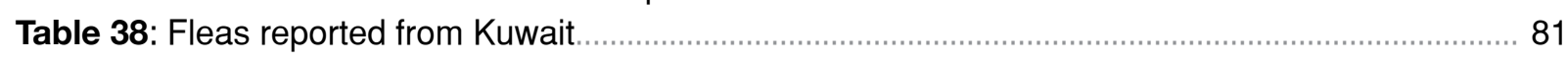

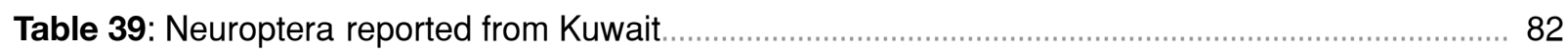

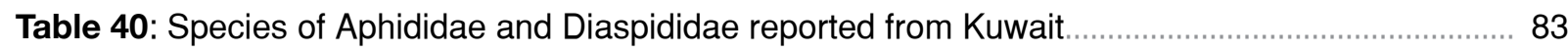

Table 41: Species of Cicadellidae and Delphacidae reported from Kuwait ....................................... 84

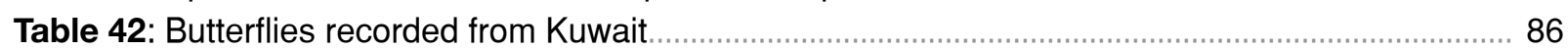

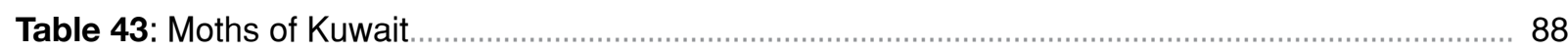

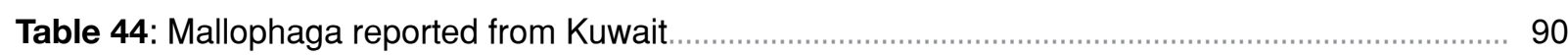




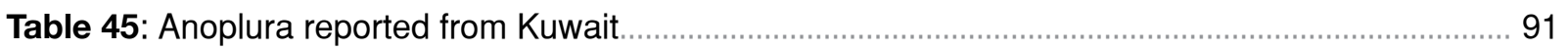

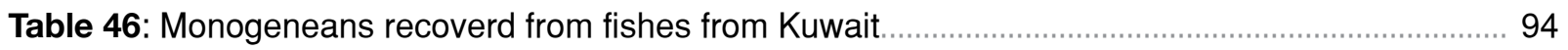

Table 47: Digeneans recoverd from fishes from Kuwait ………………..................................... 95

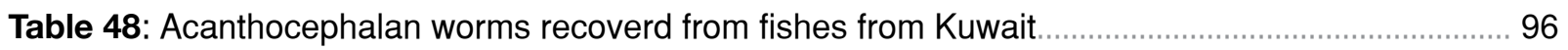

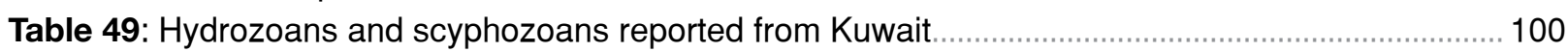

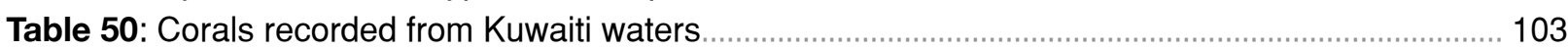

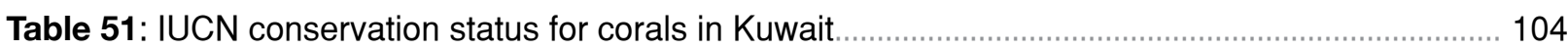

Table 52: Polychaeta species described from Kuwait by Mohammad (1970a \& b; 1971 \&1980) .......... 109

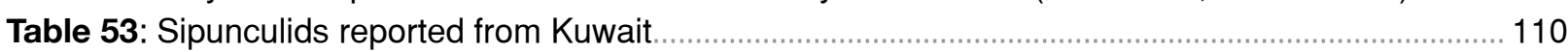

Table 54: Chitons reported from Kuwait

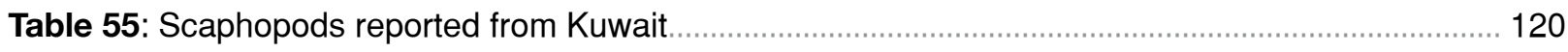

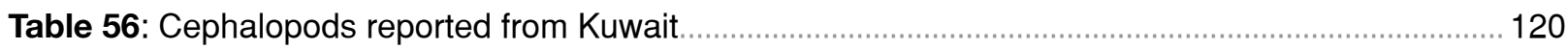

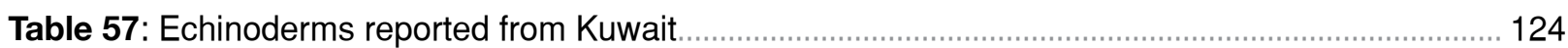

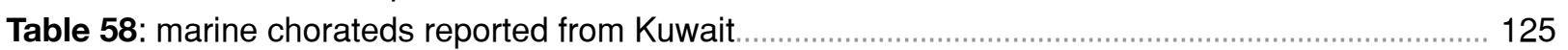

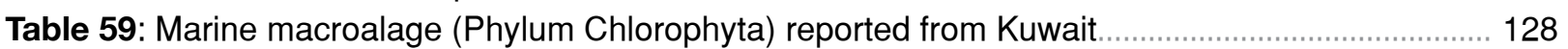

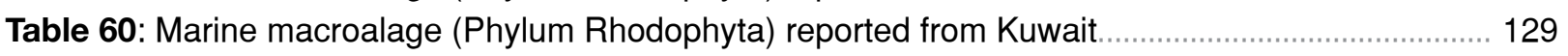

Table 61: Marine macroalage (Phylum Heterokontophyta) reported from Kuwait .................................. 130

Table 62: Marine macroalage (Phylum Tracheophyta) reported from Kuwait $\ldots \ldots \ldots \ldots \ldots \ldots \ldots \ldots \ldots \ldots \ldots \ldots \ldots \ldots \ldots \ldots . . . . .131$

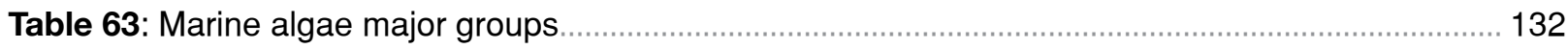

Table 64: Other marine phytoplanktons

Table 65: List of species of Order Tintinnida (Phylum Ciliophora) of the Arabian Gulf ........................ 135

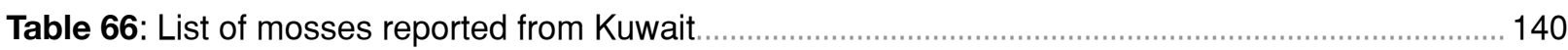

Table 67: Floristic analysis of native and natuarlized plants of Kuwait $\ldots \ldots \ldots \ldots \ldots \ldots \ldots \ldots \ldots \ldots \ldots \ldots \ldots \ldots \ldots \ldots \ldots \ldots \ldots \ldots \ldots . . . .141$ 


\section{List of figures}

Figure 1: Map showing location of the State of Kuwait (Source: http://acc.teachmideast.org) .............. 2

Figure 2: Habitat of Jal Az Zour ridge (Photo from Abdulrahman Al-Sirhan) .......................................... 3

Figure 3: Al Jaharah Nature Reserve (Photo from Faisal Al Nomas) ........................................... 3

Figure 4: Arial photo from Al Jaharah Nature Reserve (Photo from Faisal Al Nomas)........................... 4

Figure 5: Arial photo from Failka island (Photo from Faisal Al Nomas) …..................................... 4

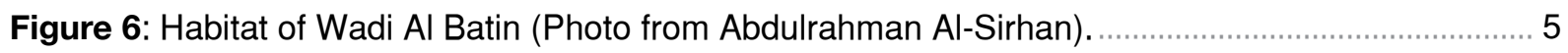

Figure 7: Some reptiles from Kuwait. Stenodactylus affinis (Photo from Abdulrahman Al-Sirhan)...........12

Figure 8: Some reptiles from Kuwait. Trapelus agnetae (Photo from Abdulrahman AI-Sirhan). ............13

Figure 9: Some reptiles from Kuwait. Trapelus persicus (Photo from Abdul Aziz Al Yousef)................ 15

Figure 10: Some mammals from Kuwait. Long-eared Hedgehog, Hemiechinus auritus. (Photos from Abdul Al-Azizi Al Yousef).

Figure 11: Some mammals from Kuwait. Lesser Jerboa, Jaculus jaculus. (Photos from Abdul

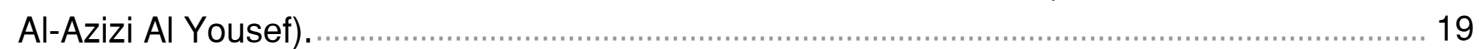

Figure 12: Some mammals from Kuwait. The Red Fox, Vulpes vulpes. (Photo from Faisal Al Nomas).

Figure 13: Some mammals from Kuwait. Cheesman's Gerbil, Gerbillus cheesmani. (photos from

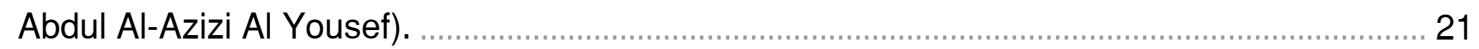

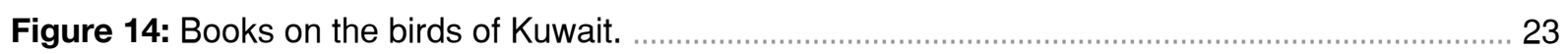

Figure 15: Birds of Kuwait. A female feeding its chicks (Photos from Abdul Al-Azizi Al Yousef)......... 26

Figure 16: Some birds from Kuwait. A. The Asian desert warbler, Sylvia nana. B. Barred Warbler, Sylvia nisoria. C. Black-eared Wheatear, Oenanthe hispanica. D. Blue-cheeked Beeeater, Merops persicus. E. Common Kingfisher, Alcedo atthis. F. Temminck's Horned Lark, Eremophila bilopha. G. Goldfinch, Carduelis carduelis. H. White-throated Kingfisher, Halcyon smyrnensis. (All photos from Abdul Al-Aziz Al Yousef).

Figure 17: Some aquatic birds from Kuwait. A. Greater Flamingo, Phoenicopterus roseus. B. Little Egret, Egretta garzetta. C. Grey-headed Swamphen, Porphyrio poliocephalus. D. Great Snipe, Gallinago media. E. Red-wattled lapwing, Vanellus indicus. (All photos from Abdul Al-Aziz Al Yousef).

Figure 18: Some raptors from Kuwait. A. Lilith Owl, Athene noctua lilith. B. Griffon Vulture, Gyps fulvus. C. Sparrowhawk, Accipiter nisus. D. Long-eared Owl, Asio otus. (All photos from

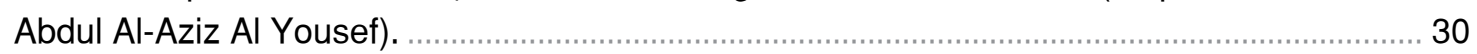

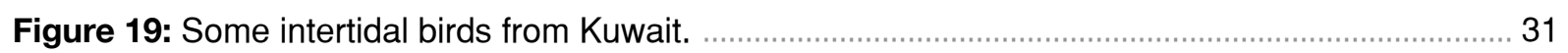

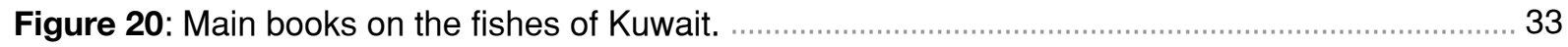

Figure 21: Books on sharks of the Arabian Gulf.

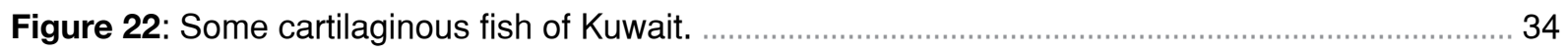

Figure 23: Coral fishes from the Arabian Gulf. A. Acanthurus sohal. B. Abudefduf vaigiensis. C. Chaetodon melapterus. D. Chlorurus sordidus. E. Apogon cyanosoma. F. Chaetodon

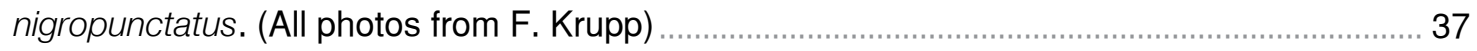

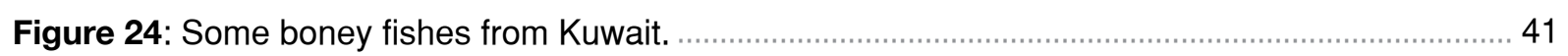

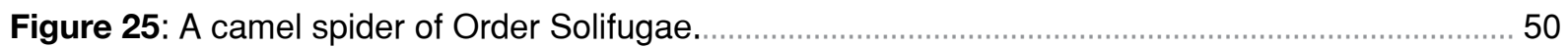


Figure 26: Cover for the field guide of Amphipods of Kuwait.

Figure 27: Books published on the crabs of Kuwait and the Arabian Gulf. .................................... 55

Figure 28: The rounded ghost crab, Ocypode rotundata (Photo from F. Krupp). ……......................... 55

Figure 29: Intertidal crabs from Kuwait.

Figure 30: Books in Arabic on the insects of Kuwait.

Figure 31: Dargonflies from Kuwait, Crocothemis erythrea (Photos from Mohammad El

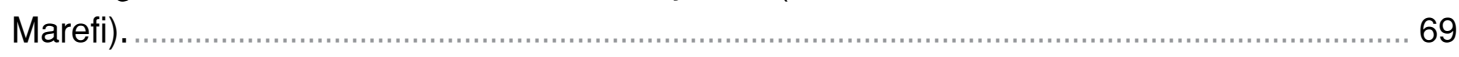

Figure 32: Dargonflies from Kuwait, Crocothemis servilia (Photos from Mohammad El Marefi)........... 69

Figure 33: A grasshopper of family Acrididae (Photos from Abdul Al-Aziz Al Yousef)........................... 71

Figure 34: The praying mantis, Blepharopsis mendica (Photos from Abdul Al-Aziz Al Yousef)............. 79

Figure 35: The plain tiger butterfly, Danaus chrysippus (Photos from Mohammad El Marefi).............. 87

Figure 36: Corals from the Arabian Gulf. Acropora clathrate (Photos from F. Krupp)........................ 101

Figure 37: Corals from the Arabian Gulf. Platygyra daedalea (Photos from F. Krupp)......................... 102

Figure 38: Corals from the Arabian Gulf. Tubastrea coccinea (Photos from F. Krupp)....................... 102

Figure 39: Books on the corals of Kuwait.

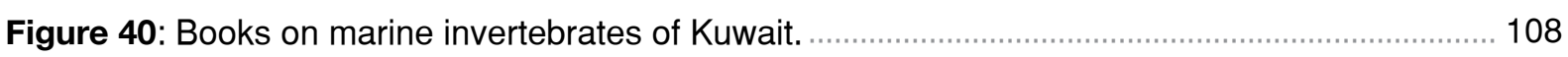

Figure 41: Nudibranch from Kuwait. A. Chromodoris annulata (Photo from A. Alhafez). B. Chromodoris annulata non spectacle (Photo from I. Basuny). C. Chromodoris obsolete (Photo from R. Pelczynski). D. Glossodoris cf. pallida (Photo from S. J. Howlett). E. Plocamopherus ocellatus (Photo from A. Wilson). F. Phyllidia (Fryeria) rueppelii (Photo

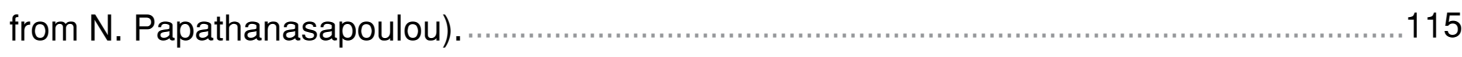

Figure 42: Some common gastropods in the intertidal waters of Kuwait. $\ldots \ldots \ldots \ldots \ldots \ldots \ldots \ldots \ldots \ldots \ldots \ldots \ldots \ldots \ldots \ldots . . . . . . . . . . .117$

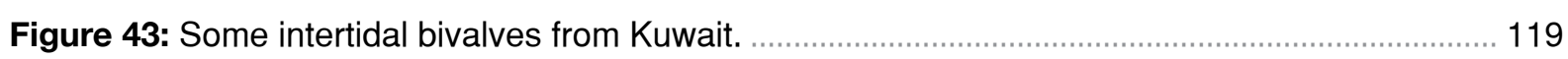

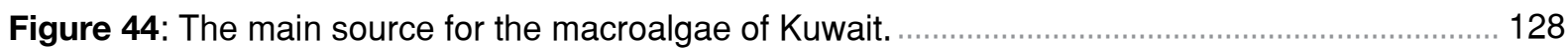

Figure 45: Books on the phytoplanktons and diatoms of Kuwait.

Figure 46: Books on the flora of Kuwait.

Figure 47: Cover of the historical book of the wild flowers of Kuwait and Bahrain by Dickson

(1955) . . . . . 142

Figure 48: Bushes of Kuwait. A. Rhanterium epapposum. B. Lycium shawii. C. Haloxylon salicornicum. D. Salsola imbricata (All photos from Abdul Rahman Al-Sirhan). ...................... 142

Figure 49: Some flowering plants from Kuwait. A. Gagea reticulata. B. Senecio glaucus. C. Rhanterium epapposum. (All photos from M. Al-Dosari).

Figure 50: Some flowering plants from Kuwait. A. Cakile arabica. B. Echium rauwolfii. C. Haloxylon salicornicum. D. Mathiola longipetala. E. Rumex vesicarius. F. Calligonum

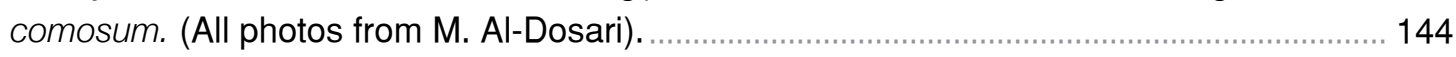

Figure 51: A poster showing some flowering plants from Kuwait.

Figure 52: Vegetation map of Kuwait showing five plant communities (Source: Halwagy and

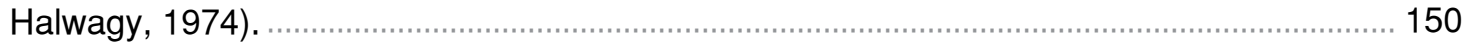

Figure 53: Current vegetation map of Kuwait (source: Omar et al., 2001). $\ldots \ldots \ldots \ldots \ldots \ldots \ldots \ldots \ldots \ldots \ldots \ldots \ldots \ldots . . .151$ 


\section{Foreword by the Environment Public Authority}

It is with great please to present The status of biodiversity in Kuwait report which is an outcome conducted between the various local Kuwaiti scientists, and experts from both governmental and non-governmental authorities, under the guidance and collaboration of IUCN "International Union for Conservation of Nature". Publications in relation to Kuwait's Biodiversity are scarce. Such report was long awaited to be accomplished and finalized to focus on the various biological components and threats facing the environment of Kuwait.

The negative anthropogenic impacts on biodiversity leading to their popula8on reduction and in some cases species extinction are threats that are well known and recognized globally. As a result, the protection of biodiversity is an important component for the survival of our environment.

As a decision maker, having the role of the Director General of Environment Public Authority, I am committed to improve the status of the environment locally, regionally and interna8onally to preserve and protect the diversity of environments and their biological components through implementing environmental laws, regulations and international treaties to reach a healthier and better environment which leads to natural resource sustainability, and a better health for our current and future generations.

Furthermore, this report will be a guideline for scientific research that promotes filling the missing gaps in Kuwait's biodiversity and raising awareness of the importance of biodiversity. I hope that readers of this report will find motivation and take the necessary action to conserve Kuwait's environment with its various marine and desert Flora and Fauna.

It would be a great achievement if one could go to the desert and wit-ness a gazelle chased by a cheetah or find a massive area covered with al Arfaj after the rainfall season. This could be done by spreading awareness and establishing rehabilitation centers supporting, research through the collaboration and cooperation between both regional and international organizations.

\section{His Excellency Sheikh / Abdullah Al-Ahmad Al- Hamoud Al-Sabah}

Director General of the Environment Public Authority and Chairman of the Board of Directors 


\section{Foreword by the IUCN Regional Office for West Asia}

I am pleased to present this important report which was one of the significant deliverables of the project "Monitoring and documentation of biodiversity in Kuwait". This project, which was executed by IUCN's Regional Office for West Asia and funded by the Environment Public Authority (EPA) of Kuwait, is only a start of promising collaboration between IUCN and the State of Kuwait for enhancing biodiversity knowledge base and related decision-making process on the national level.

As you read this report, you will see extensive literature search to reveal the elements of biodiversity in the State of Kuwait. Hundreds of published scientific papers and reference books were reviewed to amass all species, fauna and flora that were reported from Kuwait. Conservation status for several key groups according to the IUCN listing is also included. This report represents the first attempt to summarize and identify the elements of animal and plant biodiversity, and point out missing information on other little-known groups. This will stimulate researchers to explore the biodiversity of such minor groups (e.g. Scorpions, spiders, land and freshwater snails and sponges). Further studies are urgently needed to identify invasive species (fauna and flora). Update of the status of mammals, including marine and terrestrial (Population size, distribution and trends; life history and ecology; research and monitoring to support a conservation strategy) is among the priority list for research. Further studies on reptiles in eastern and southern Kuwait should be conducted. With current changes in nomenclature, the molluscan fauna of Kuwait will also requires an update.

We are looking forward for further collaboration in the future with the Environment Public Authority EPA of Kuwait to develop a robust system for documenting the biodiversity of Kuwait, addressing the remaining knowledge gaps like developing the National Red Lists for Kuwait in addition to understanding the direct and indirect benefits of biodiversity in the State of Kuwait. There is also a growing need for large-scale research to guide management of coral reefs and their stressors, as these operate at much larger scales than the national borders within which most research currently occurs.

I would finally like to thank the author of the report, and all national and regional experts who have had important contributions in providing data, access to publications and reviewed the publication. I would also like to thank the project implementation teams at both IUCN ROWA and the EPA of Kuwait for their hard work which has resulted in the production of this important publication.

\section{Dr. Hany El Shaer, Regional Director IUCN Regional Office for West Asia}




\section{Context}

The Government of Kuwait's Environment Public Authority (EPA) and the International Union for Conservation of Nature (Regional Office for West Asia, IUCN-ROWA) are collaborating on the project entitled "Monitoring and Documentation of Biodiversity in Kuwait". Its primary aim is to document all of the biodiversity elements in the State of Kuwait based on collecting previous records and updating the biodiversity components through fieldwork. The project will also provide training to the Environment Public Authority staff and faciliatet further study of the biodiversity of Kuwait, using both modern and standard procedures. Within this larger project, the following component of this report is considerd vital:

"Extract all published data on the various groups of animal, plants and other groups of living organisms that are present in the State of Kuwait and describe the status of the species with emphasis on those that are in threat of extinction".

A good number of different sectors of the State have an interest in biodiversity, presenting opportunity for enhanced collaboration and partnerships; the General Authority for Environment, the General Authority for Agriculture and Fisheries Affairs, Kuwait University, and the Kuwait Institute for Scientific Research (KISR). The latter is responsible for the management, conservation and research of biodiversity in the State of Kuwait. Nongovernmental organisations (NGOs), such as The Environmental Protection Society and the Voluntary Action Center in Kuwait also seek to conserve and manage biodiversity. This report and the recommended follow-up activities will therefore be of interest to such organisations and institutes. 


\section{Executive summary}

This report is based on extensive literature search to reveal the elements of biodiversity in the State of Kuwait. Hundreds of published scientific papers and reference books were reviewied to amass all species, fauna and flora, that were reported from Kuwait. Conservation status for several groups according to the IUCN listing are included. Despite its small area, Kuwait enjoys a rich fauna, given its desert and marine habitats. For the vertebrate's fauna, one amphibians, 39 species of reptiles, 30 mammalian species, 415 species of birds, 305 species of bony fishes and 42 cartilaginous fishes were documented (Table 1).

Table 1: Number of species recorded from Kuwait per taxonomic group.

\begin{tabular}{|c|c|c|c|}
\hline Taxonomic group & No. of species & Taxonomic group & No. of species \\
\hline Amphibians & 1 & Other minor Order & 18 \\
\hline Reptiles & 45 & Order Siphonaptera & 8 \\
\hline Mammals & 30 & Order Neuroptera & 13 \\
\hline Birds & 407 & Order Heimptera & 99 \\
\hline Boney fishes & 305 & Order Hymenoptera & 122 \\
\hline Cartilaginous fishes & 42 & Order Lepidoptera & 87 \\
\hline Arthropoda & & Order Mallophaga & 4 \\
\hline Class Arachnida & & Order Anoplura & 3 \\
\hline Order Scorpiones & 5 & Phylum Bryozoa & 2 \\
\hline Order Araneae & 3 & Phylum Phoronida & 1 \\
\hline Order Pseudoscorpiones & 1 & Phylum Platyhelminthes & \\
\hline Order Solifugae & 1 & Class Monogenea & 10 \\
\hline Order Ixodida & 5 & Class Digenea & 17 \\
\hline Order Trombidiformes & 2 & Phylum Acanthocephala & 3 \\
\hline Class Chilopoda & 1 & Phylum Cnidaria & \\
\hline Class Malacostraca & & Class Hydrozoa & 13 \\
\hline Order Amphipoda & 73 & Class Scyphozoa & 1 \\
\hline Order Decopoda & 56 & Class Anthozoa & 35 \\
\hline Caridea & 12 & Phylum Annelida & \\
\hline Dendrobranchiata & 13 & Class Polychaeta & 116 \\
\hline Achelata & 1 & Phylum Sipuncula & 3 \\
\hline Anomura & 6 & Phylum Brachiopoda & 1 \\
\hline Thalassinidea & 1 & Phylum Mollusca & \\
\hline Order Isopoda & 13 & Class Polyplacophora & 6 \\
\hline Cumacea & 10 & Class Gastropoda & About 300 \\
\hline
\end{tabular}




\begin{tabular}{|l|c|l|c|}
\hline \multicolumn{1}{|c|}{ Taxonomic group } & No. of species & \multicolumn{1}{c|}{ Taxonomic group } & No. of species \\
\hline Order Mysida & 2 & Class Bivalvia & 110 \\
\hline Class Hexanauplia & 60 & Class Scaphopoda & 6 \\
\hline Class Insecta & & Class Cephalopoda & 4 \\
\hline Order Odonata & 12 & Phylum Echinodermata & 16 \\
\hline Order Orthoptera & 31 & Phylum Hemichordata & 1 \\
\hline Order Diptera & 77 & Phylum Chordata & 3 \\
\hline Order Coleoptera & 225 & & \\
\hline Order Mantodea & 5 & & \\
\hline
\end{tabular}

Macro and micro algae are represented in eight phyla with a total of 402 species (Table 2).

Table 2: Micro and macro algae reported from Kuwait

\begin{tabular}{|l|c|}
\hline \multicolumn{1}{|c|}{ Phylum } & No. of species \\
\hline Chlorophyta & 30 \\
\hline Rhodophyta & 30 \\
\hline Heterokontophyta & 27 \\
\hline Tracheophyta & 2 \\
\hline Pyrrophyta & 105 \\
\hline Bacillariophyta & 202 \\
\hline Chromophyta & 4 \\
\hline Cyanophyta & 2 \\
\hline
\end{tabular}

As for terrestrial plants, a total of 378 native species (Omar et al., 2007) belonging to 57 families (44 Dicotyledoneae, 11 Monocotyledoneae, 1 Gymnospermae and 1 Pteridophyta) (Table 3).

Table 3: Plants reported from Kuwait

\begin{tabular}{|l|c|}
\hline \multicolumn{1}{|c|}{ Phylum } & No. of species \\
\hline Angiospermae & 376 \\
\hline Gymnospermae & 1 \\
\hline Pteridophyta & 1 \\
\hline
\end{tabular}

About 54 species of animals, mostly marine, were described as new to science from Kuwait. This includes 30 species of arthropods, four species of Platyhelminthes, 17 species of marine Polychaeta and others (Table 4). 
Table 4: List of animal species described from Kuwait

\begin{tabular}{|c|c|c|}
\hline Phylum & Class/order & Species \\
\hline \multirow[t]{30}{*}{ Arthropoda } & Trombidiformes & Actacarus arabius (Bartsch, 2004) \\
\hline & & Scaptognathides delicatulus (Bartsch, 2004) \\
\hline & Amphipoda & Protohyale arabica Myers \& Nithyanandan, 2016 \\
\hline & & Bemlos acuticoxa Myers \& Nithyanandan, 2016 \\
\hline & & Laticorophium bifurcatum Myers \& Nithyanandan, 2016 \\
\hline & & Podocerus mamlahensis Myers \& Nithyanandan, 2016 \\
\hline & & Latigammaropsis pseudojassa Myers \& Nithyanandan, 2016 \\
\hline & & Ceradocus alama Myers \& Nithyanandan, 2016 \\
\hline & & Maera irregularis Myers \& Nithyanandan, 2016 \\
\hline & Decopoda & Leptochryseus kuwaitense (Jones \& Clayton, 1983) \\
\hline & & Manningis arabicum (Jones \& Clayton, 1983) \\
\hline & & Alpheus lutosus Anker \& De Grave. 2009 \\
\hline & Isopoda & Anilocra monoma Bowman \& Tareen, 1983 \\
\hline & & Catoessa gruneri Bowman \& Tareen, 1983 \\
\hline & & Joryma sawayah Bowman \& Tareen, 1983 \\
\hline & & Nerocila arres Bowman \& Tareen, 1983 \\
\hline & & Nerocila kisra Bowman \& Tareen, 1983 \\
\hline & & Nerocila sigani Bowman \& Tareen, 1983 \\
\hline & Siphonostomatoida & Caligus kuwaitensis Kabata \& Tareen, 1984) \\
\hline & Cyclopoida & Bereacanthus clava (Ho \& Sey, 1997) \\
\hline & & Irodes kuwaitensis Ho et al. (1999) \\
\hline & Calanoida & Labidocera kuwaitiana Prusova \& Al-Yamani, 2014 \\
\hline & & Hatschekia seyi Ho \& Kim, 2001 \\
\hline & & Hatschekia nodosa Ho \& Kim, 2001 \\
\hline & Coleoptera & Pentodon kuwaitense Endrödi \& Al-Houty, 1985 \\
\hline & Heteroptera & Xylocoris etawahii Ghauri, 1985 \\
\hline & & Xylocoris wasmiai Ghauri, 1985 \\
\hline & Hymenoptera & Monomorium subcomae Lush, 2008 \\
\hline & & Monomorium hemame Collingwood \& Agosti, 1996 \\
\hline & & Monomorium buettikeri Collingwood \& Agosti, 1996 \\
\hline \multirow[t]{4}{*}{ Platyhelminthes } & Trematoda & Lepidotrema kuwaitense Kritsky et al. 2000 \\
\hline & & Lamellodiscus furcillatus Kritsky et al. 2000 \\
\hline & & Protolamellodiscus senilobatus Kritsky et al. 2000 \\
\hline & & Bookhoutia oligognatha Mohammad, 1973 \\
\hline
\end{tabular}




\begin{tabular}{|l|l|l|}
\hline Phylum & Class/order & \multicolumn{1}{|c|}{ Species } \\
\hline & & Imajimaea zonata (Mohammad, 1973) \\
\hline Annelida & Polychaeta & Isolda albula Mohammad, 1971 \\
\hline & & Kuwaita magna Mohammad, 1973 \\
\hline & Leiochone annulata (Mohammad, 1980) \\
\hline & Magelona pulchella Mohammad, 1980 \\
\hline & Mesopothelepus macrothoracicus (Mohammad, 1980) \\
\hline & Neanthes deplanata (Mohammad, 1971) \\
\hline & Neoleprea clavata Mohammad, 1973 \\
\hline & Nereis (Nereis) neogracilis Mohammad, 1970 \\
\hline & Paucibranchia gemmata (Mohammad, 1973) \\
\hline & Phylo kubbarensis Mohammad, 1980 \\
\hline & Phylo kuwaitica Mohammad, 1970 \\
\hline & Polydora spondylana Mohammad, 1973 \\
\hline & & Prionospio rotalis Mohammad, 1970 \\
\hline & Pseudostreblosoma longum (Mohammad, 1973) \\
\hline & & Scyphoproctus aciculatus Mohammad, 1980 \\
\hline & & Notoplax arabica Kaas \& Van Belle, 1988 \\
\hline & &
\end{tabular}

Seven species of marine ciliates were described from Kuwait (Table 5)

Table 5: Species of marine ciliates described from Kuwait

\begin{tabular}{|l|}
\hline \multicolumn{1}{|c|}{ Species } \\
\hline Luminella kuwaitensis Skryabin and Al-Yamani, 2007 \\
\hline Leprotintinnus bubiyanicus Skryabin and Al-Yamani, 2007 \\
\hline Metacylis pithos Skryabin and Al-Yamani, 2006 \\
\hline Eutintinnus conicus Skryabin \& Al-Yamani, 2007 \\
\hline Eutintinnus contractus Skryabin \& Al-Yamani, 2007 \\
\hline Tintinnopsis failakkaensis Skryabin \& Al-Yamani, 2007 \\
\hline
\end{tabular}

Recommendations include conducting further studies on the following groups due to limited data (Scorpions, spiders, land and freshwater snails and sponges). Studies are needed to identify invasive species (fauna and flora). Update the status of mammals, including marine and terrestrial (Population size, distribution and trends; life history and ecology; research and monitoring to support a conservation strategy). Further studies on reptiles in eastern and southern Kuwait should be conducted. Further entomological research especially arthropods that can transmit diseases should be carried out. With current changes in nomenclature, the molluscan fauna of Kuwait requires an update. Herpetology book for Kuwait reptiles should be published. The publications of Kuronuma and Abe (1972; 1986) should be updated, considering adding additional records on fishes of Kuwait. Other recommendations are included in the recommendation section. 


\section{Acknowledgments}

I would like to thank Dr. Hany El Shaer (Regional Director), Mrs. Natalia boulad (Programme Manager) and Mrs. Ola Al Mallah (Membership Coordinator) and Mr. Hanna Haddad (Consultant at Biodiversity and Protected Areas Programme) from the IUCN Regional Office for West Asia (ROWA) in Amman, Jordan, for all their help and logistic support during this missionMy gratitudes are extend to Dr. Abdullah Al-Zaidan (Head of Biodiversity Conservation), and Miss. Shereefa Al-Salem (Head of Wildlife monitoring section - Project co-director) from the Environment Public Authority (EPA), Kuwait, for their continuous support and arrangements for both field visits and Kuwaiti institutes related to biodiversity research.

I would like to acknowledge the discussions and information exchange made by staff of Kuwait Institute for Scientific Research (KISR), namely; Mr. Ali Al-Baz (Resource Coordinator) for the tour in the different laboratories at KISR Salmayeh branch, Dr. Turki Al-Said, Dr. Shaker Alhazeem, Dr. Mohsen Al-Husaini, Mrs. Shayma al Qlaf (Research Assistant) at the Center of Environmental \& Biological Research, for the tour in the different laboratories at KISR, Shwaikh branch, Dr. Tareq Madouh, Dr. Matra Al-Mutari Ms Sasini Isathali, Ms. Anita Jasmine. Special thanks are extended to Dr. Manal Al Kandari for her valuable help and comments on the marine fauna of Kuwait.

The outstanding hospitality and data gathering from Kuwait University Department of Biology staff is hereby acknowledged; namely; Dr. Amani AI Ziadan, for her valuable comments, Dr. Saud Al Mazrooei, Mr. K.T. Mathew and Mrs. Modi Al Dosari (Kuwait University Herbarium) for showing me the herbarium and the biotechnology center. I am also indebted to Dr. Wasmia Al-Houty for her comments on certain taxa of the insects of Kuwait.

My thanks are extended to Mr. Abdul Aziz Al-Yousef (EPA) for the excellent photographs for birds, mammals and reptiles taken from Kuwait, Mr. Abdul Rahman Al Serhan for the images for reptiles from Kuwait, Dr. Friedhelm Krupp (Curator of Fishes, Senckenberg Research Institute), for the marine animals photos. My gratitude is also extended to Prof. Graham Oliver (National Museum of Wales, UK) for the discussion on the Mollusca of Kuwait and providing me with literature on the Mollusca of Kuwait.

I would like to thank Dr. Majda K. Suleiman and Dr. Sheena Jacob (KISR), Mrs. Nadya Al Sager (EPA, Senior Biology specialist) and Mrs. Modi Al Dosari (Kuwait University Herbarium) for their critical comments that enhanced the flora section. My sincere thanks to Dr. Dareen Almojil (New York University-Abu Dhabi) for her outstanding input and valuable comments on the sharks and rays section. Special thanks are also extended to Shahnaz Ibrahim (EPA, Senior Biology specialist), Fatma Al bloushi (EPA, Biology specialist), Aisha Al Marhoun (EPA, Biology Researcher), Wafeyah Aloqab (EPA, Biology Researcher), Abdulaziz Al Yousif (EPA, Administrative Coordinator), Alanood Al Misbah (EPA, Junior Biology Researcher), and Jomana Al Khamees (EPA, Junior Biology Researcher) for their comments and additions to the taxonomic list. 


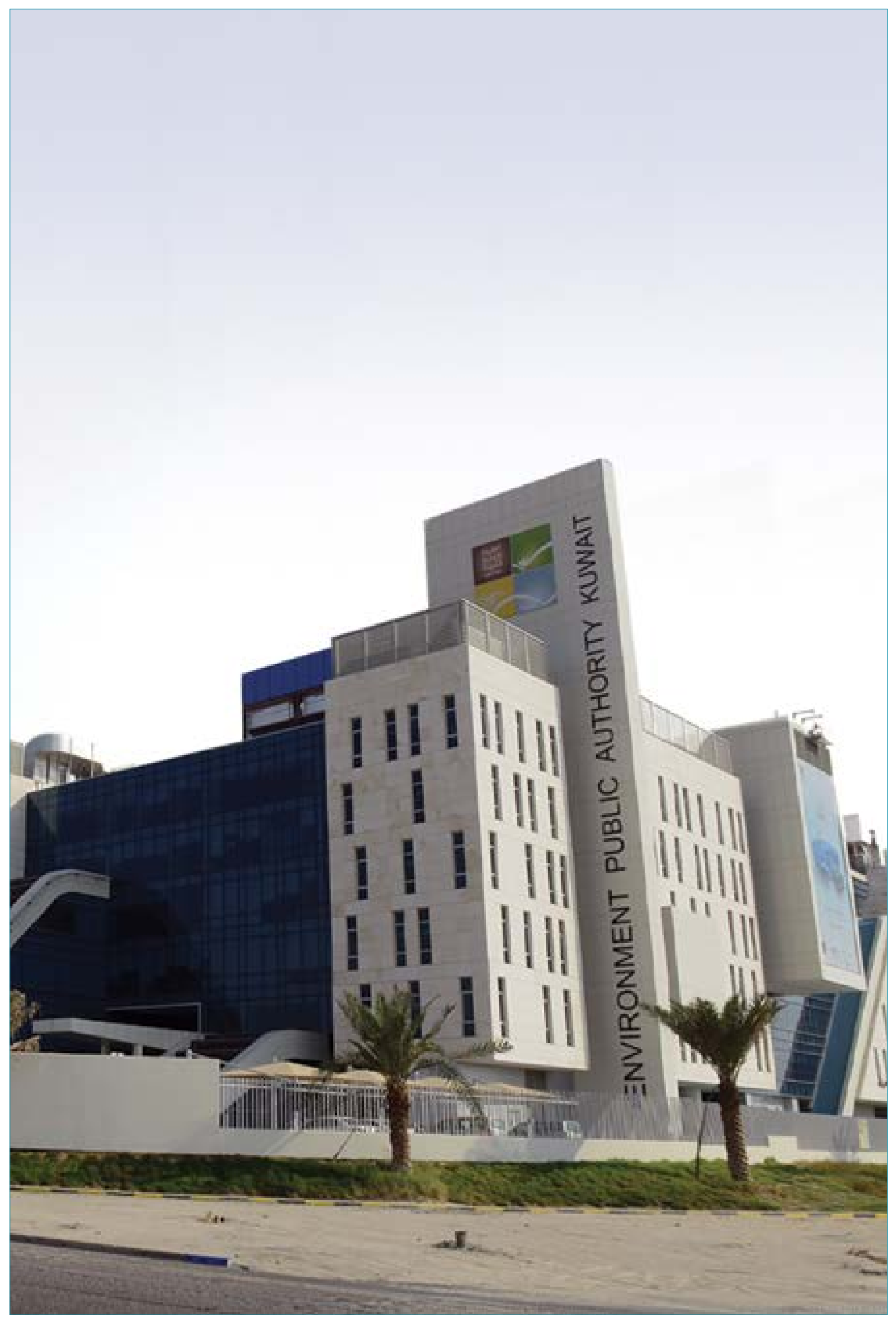

Environmental Public Authority of Kuwait (Photo from EPA website) 


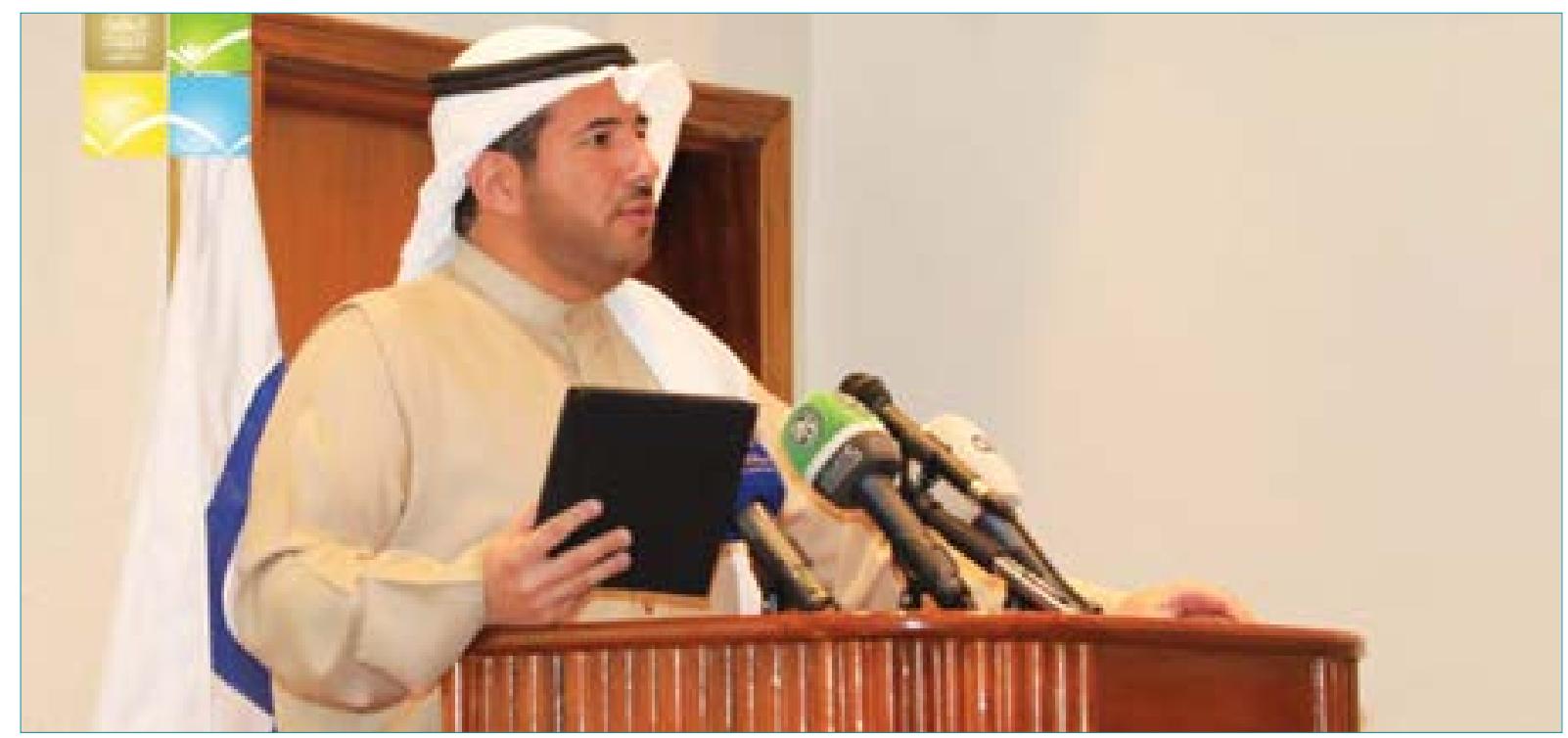

His Excellency Sheikh Abdullah Al-Ahmad Al- Hamoud Al-Sabah, Director General of the Environment Public Authority and Chairman of the Board of Directors, launching the project on 10 February 2019 (Photo by Ola Malah).

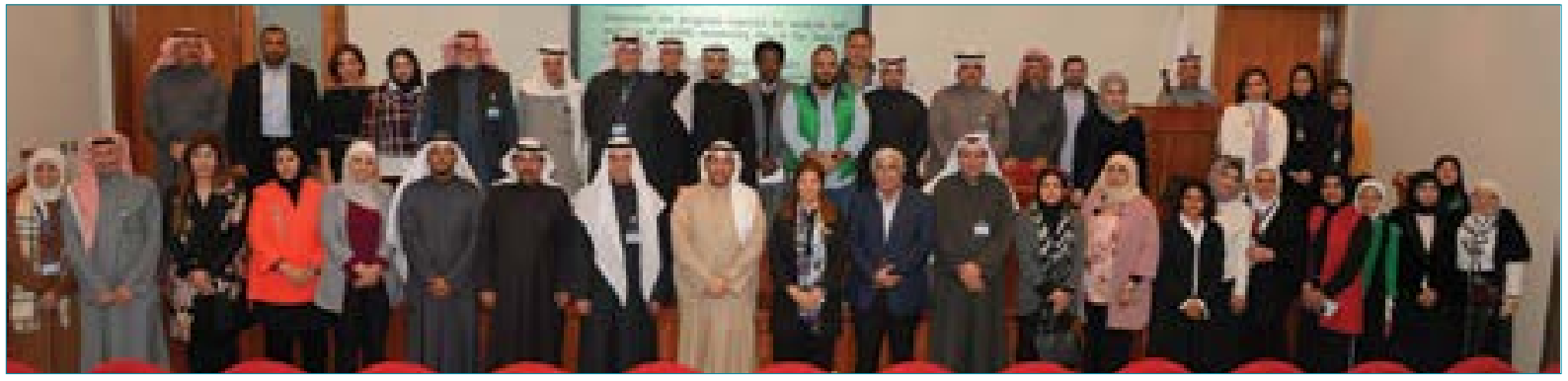

Participants during the project launching (Photo by Ola Malah).

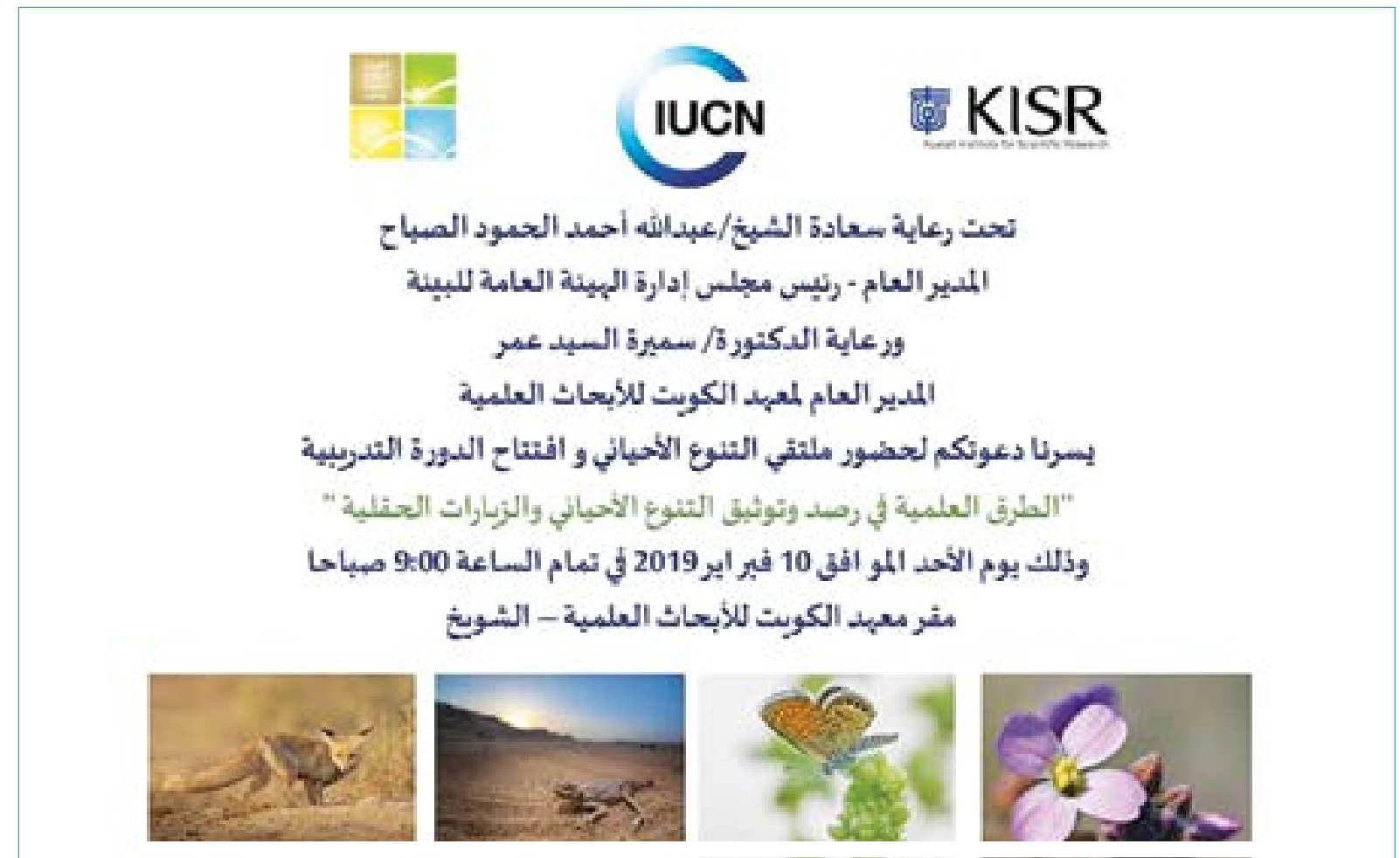

Invitation logo for the project launching (Photo by Ola Malah). 

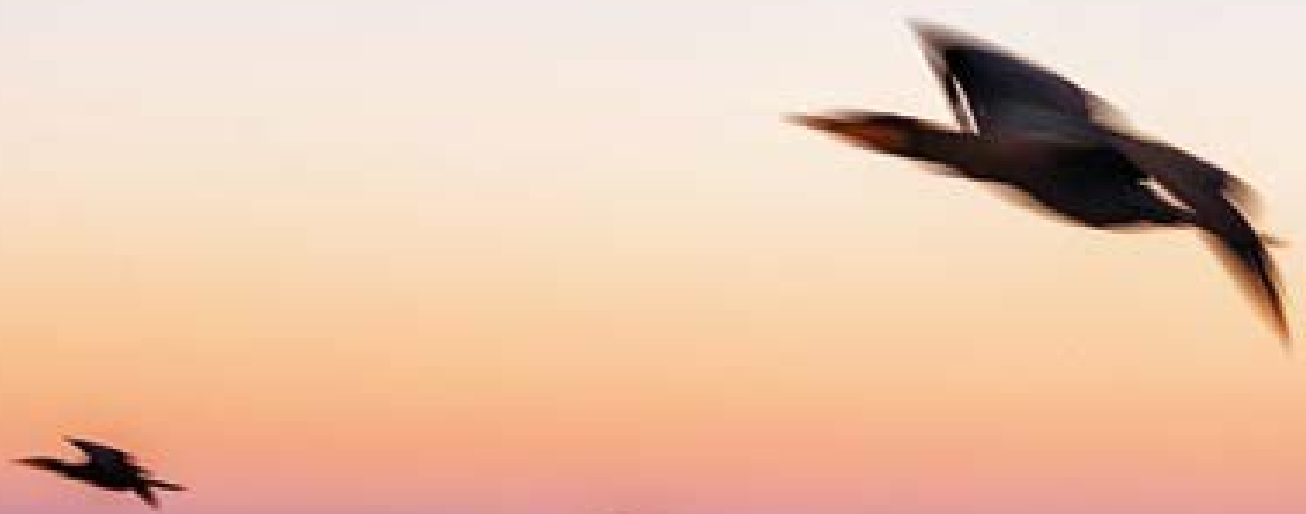

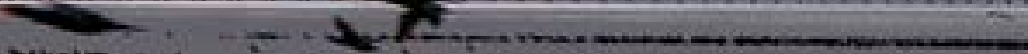

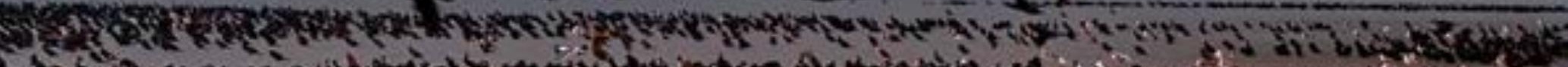

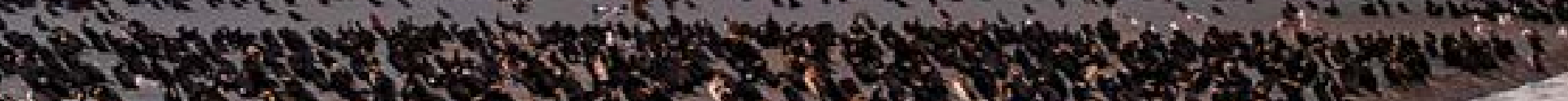
S.

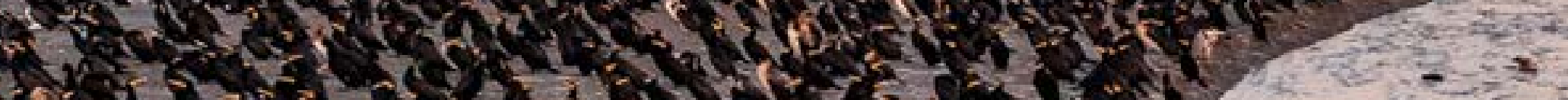

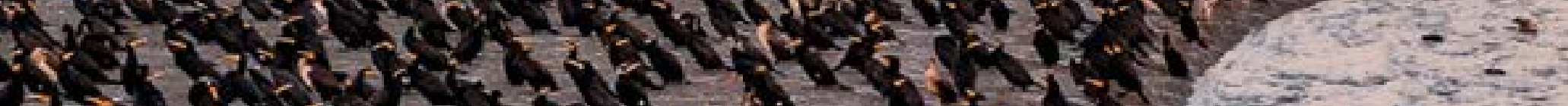

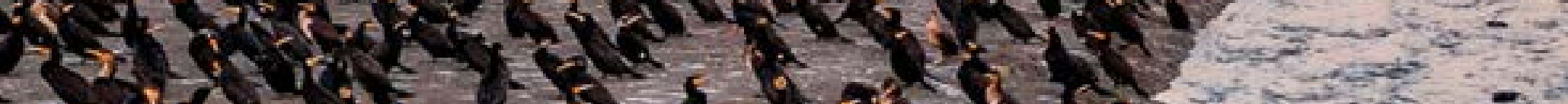

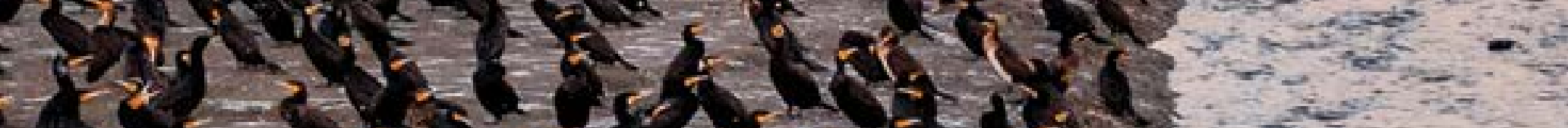

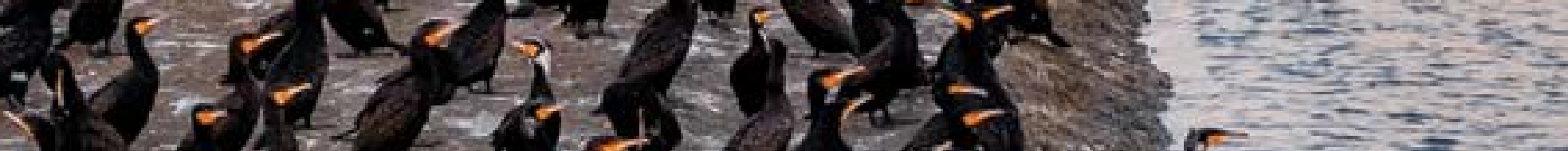

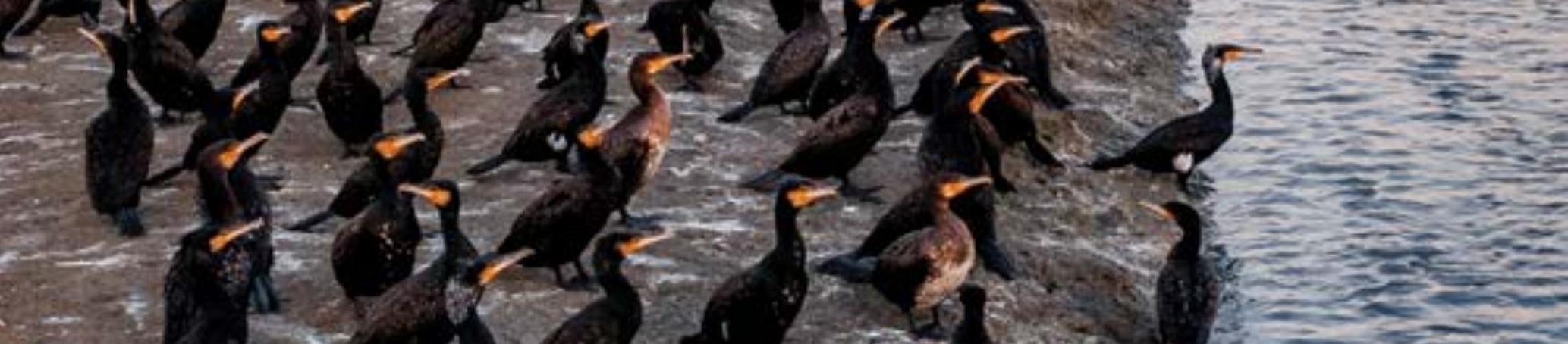
(Poto from Faisal Al Nomas)

(Photo from Faisal Al Nomas) 


\section{Introduction}

\subsection{Location and topography}

The total area of the State Kuwait is $17,818 \mathrm{~km}^{2}$ of land and about $1,000 \mathrm{~km}^{2}$ of off-shore islands. It is situated in the most northwestern corner of the Arabian Gulf (Figure 1). Kuwait is an arid country and consists mainly of desert land. It is bordered by Saudi Arabia to the south and southwest and with Iraq to the north and northwest. The landscape is relatively flat, broken only by occasional low sand dunes and shallow depressions. The surface elevates gently fram east to west reaching about
$300 \mathrm{~m}$ above sea level at Al-Shigaya and Al-salmi. The eastern part of the state, including all of the inhabited area, is overlooking the Arabian Gulf with coastline that extends about $195 \mathrm{~km}$.

\subsection{Natural environment context}

\section{Geographic setting}

Located within the northeastern part of the Arabian Desert, Kuwait is characterized by flat to gently rolling open desert with very few minor elevations, wadis, depressions, some low dunes,

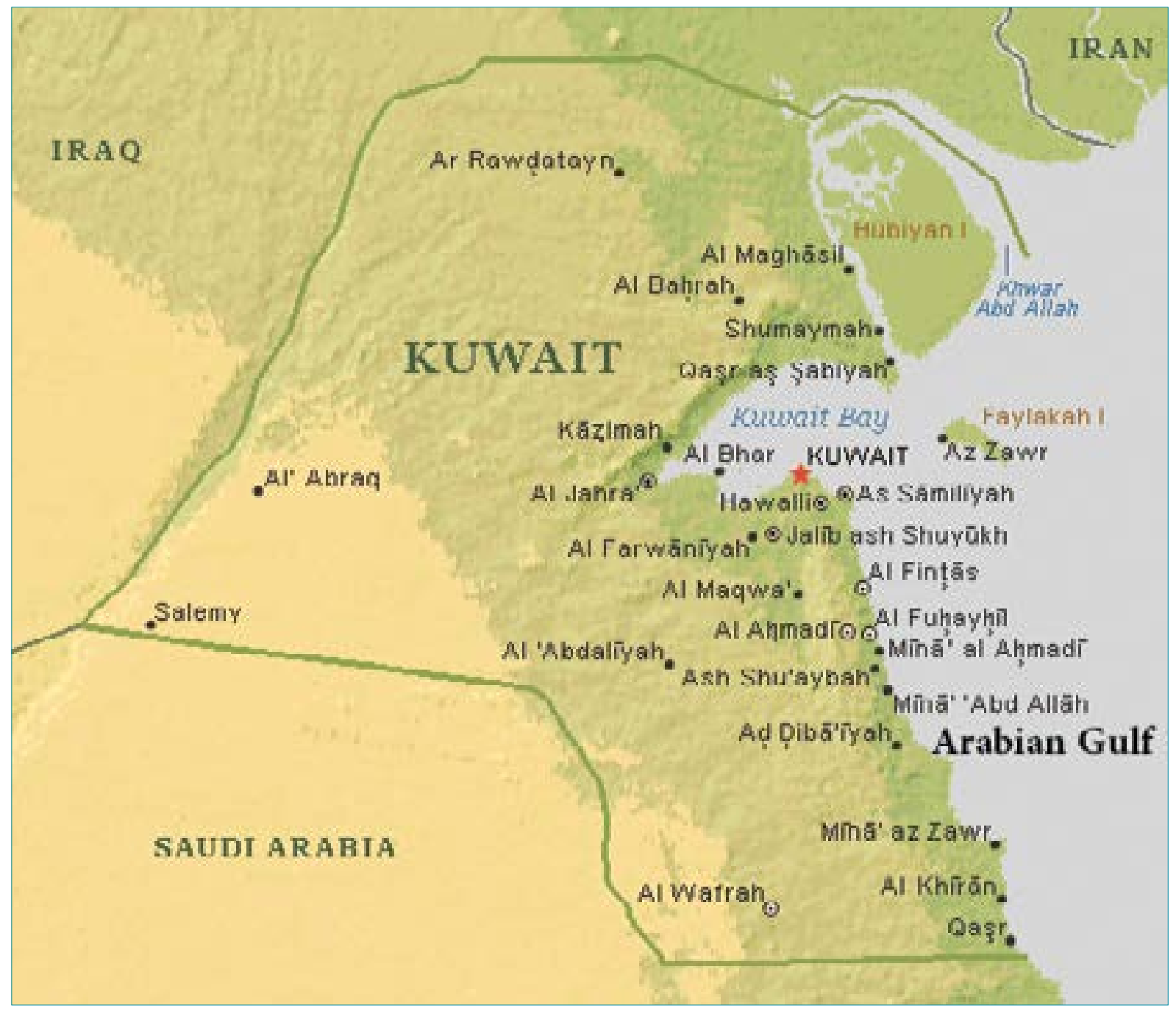

Figure 1: Map showing location of the State of Kuwait (Source: http://acc.teachmideast.org). 


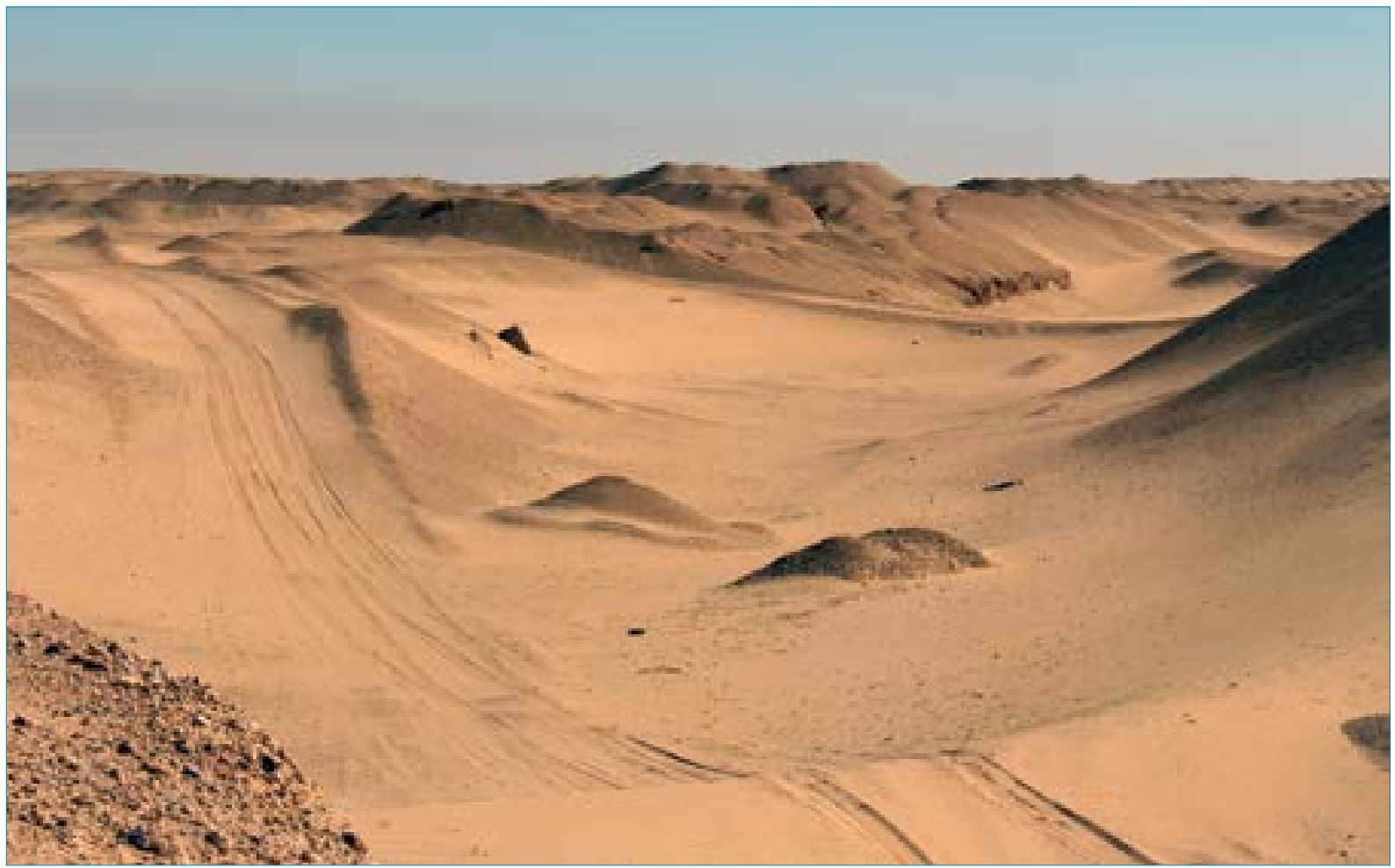

Figure 2: Habitat of Jal Az Zour ridge (Photo from Abdulrahman Al-Sirhan).

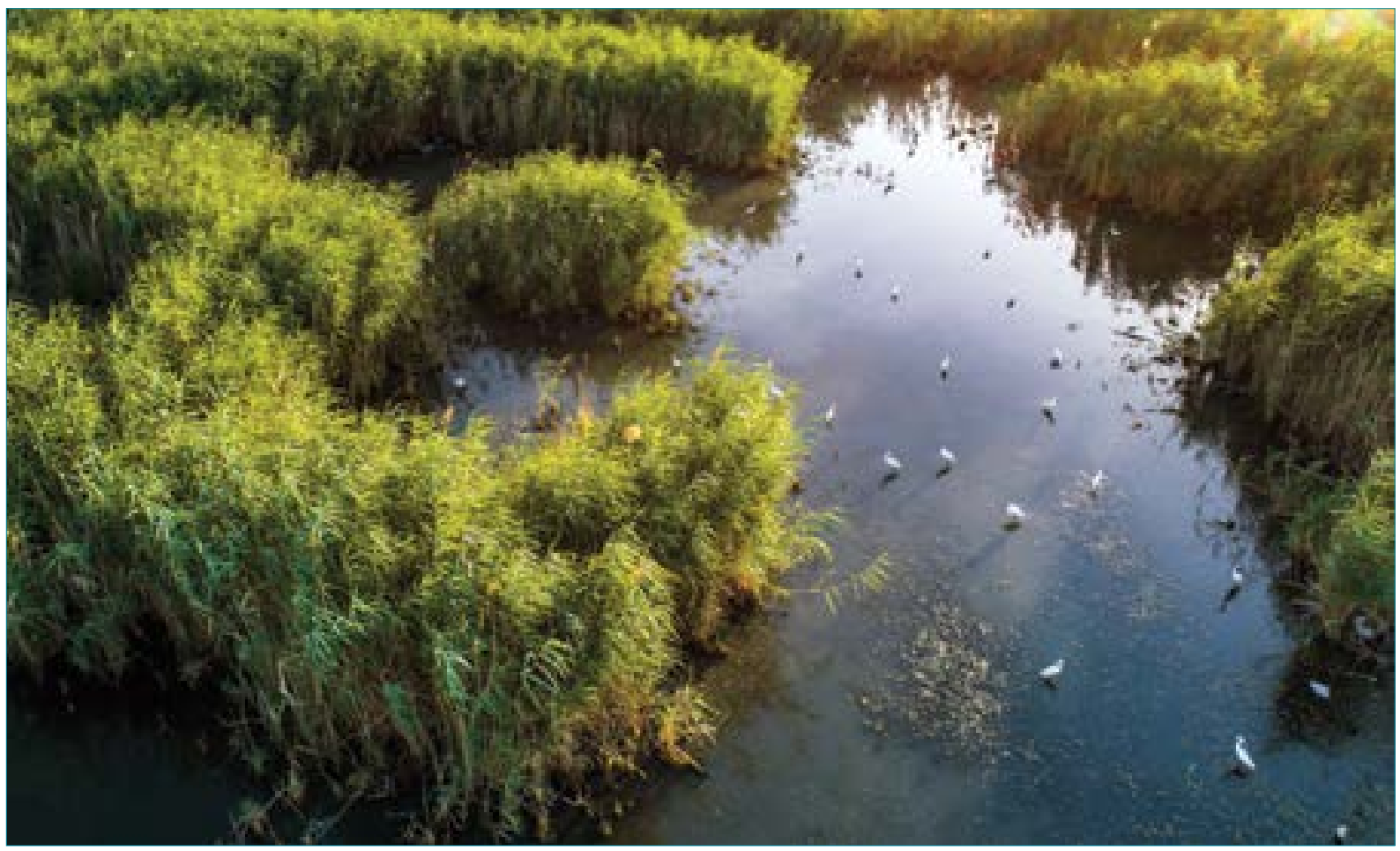

Figure 3: Al Jaharah Nature Reserve (Photo from Faisal Al Nomas).

coastal salt marshes and small off-shore islands (Halwagy et al., 1982; Halwagy \& El-Saadawi, 1992).

From a geological point of view, the Gulf is a very recent sea. Resulting from the eastward migration of the Arabian plate, the Gulf basin was probably formed during the Late Pliocene Era, only three or four million years ago. The Gulf is one of the youngest bodies of water in the world and also one of the shallowest. The average depth is 36 meters, with a maximum depth of 90-100 meters along the Iranian coast. Due to the high evaporation (about ten times greater than the input from rainfalls and rivers), salinity of the water in the northern Gulf 


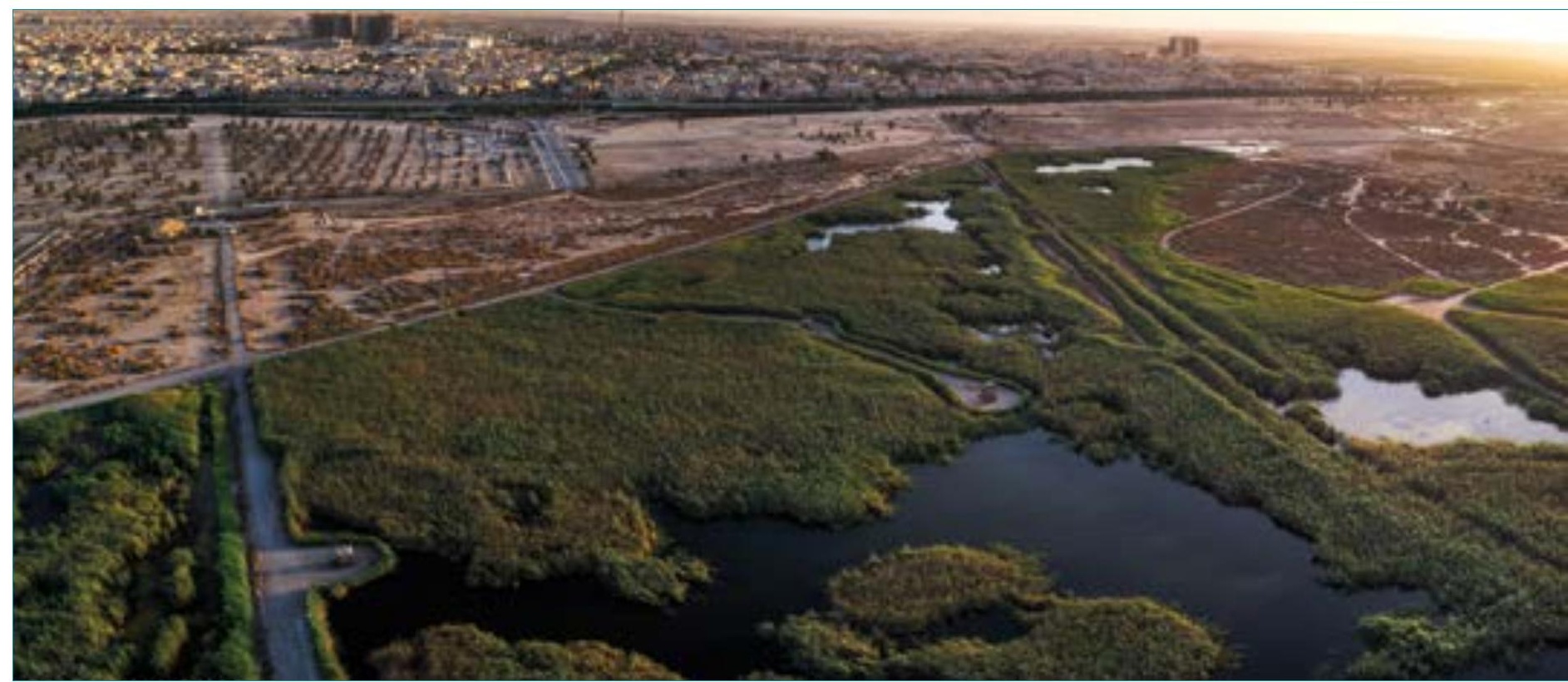

Figure 4: Arial photo from Al Jaharah Nature Reserve (Photo from Faisal Al Nomas).

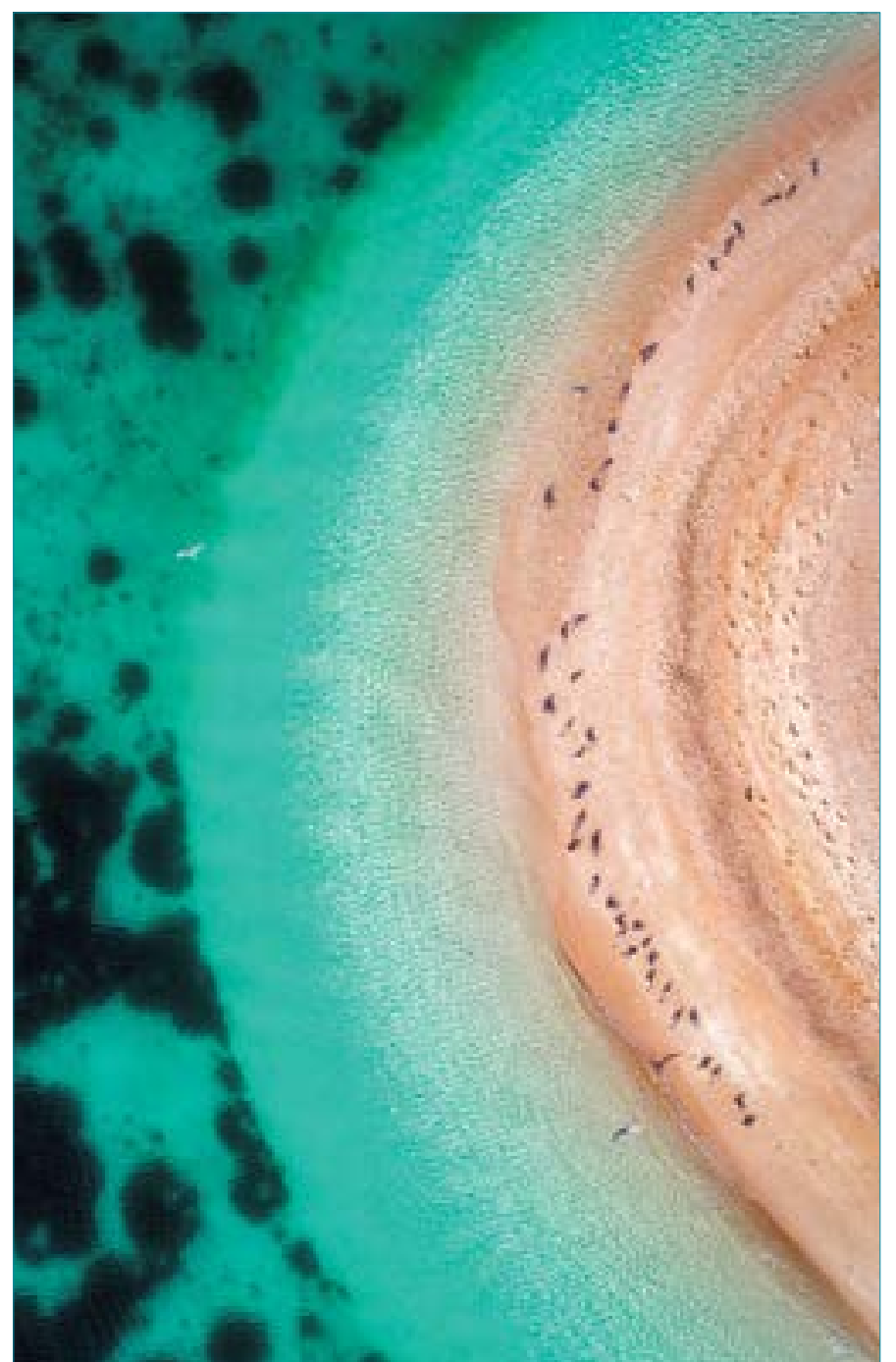

Figure 5: Arial photo from Failaka island (Photo from Faisal Al Nomas). is quite high. The water along the coast of Kuwait shows salinities of around 40 ppt, and along the Saudi Arabian coast between 35-40 ppt. However, in shallow water the salinity can become much higher. A salinity as high as 70 ppt has been reported in the Gulf of Salwah and in the inner parts of the Kuwait Bay. Tides in the area are basically semi-diurnal and vary from 2 to 3 meters along the Saudi Arabian and Kuwaiti coasts (Lindén et al., 2004; Omar et al., 2007).

\section{Phasical parameters}

The physical factors mainly in the form of extreme temperature fluctuations and elevated salinity exert considerable natural stress on the marine and coastal ecosystems of the Gulf. As a consequence, the biodiversity is significantly lower compared with the Indian Ocean. Because of the relative shallowness, the Gulf supports highly productive coastal habitats, such as the extensive intertidal mud-flats and seagrass beds. Along parts of the coast there are also areas of dwarf mangrove and coral reefs. However, the coral reefs show relatively very low biodiversity. Many species of corals as well as other species of animals and several plants in the area live close to their tolerance thresholds. In the northern Gulf, most of the subtidal areas are soft sediment bottoms. Extensive seagrass beds mostly 


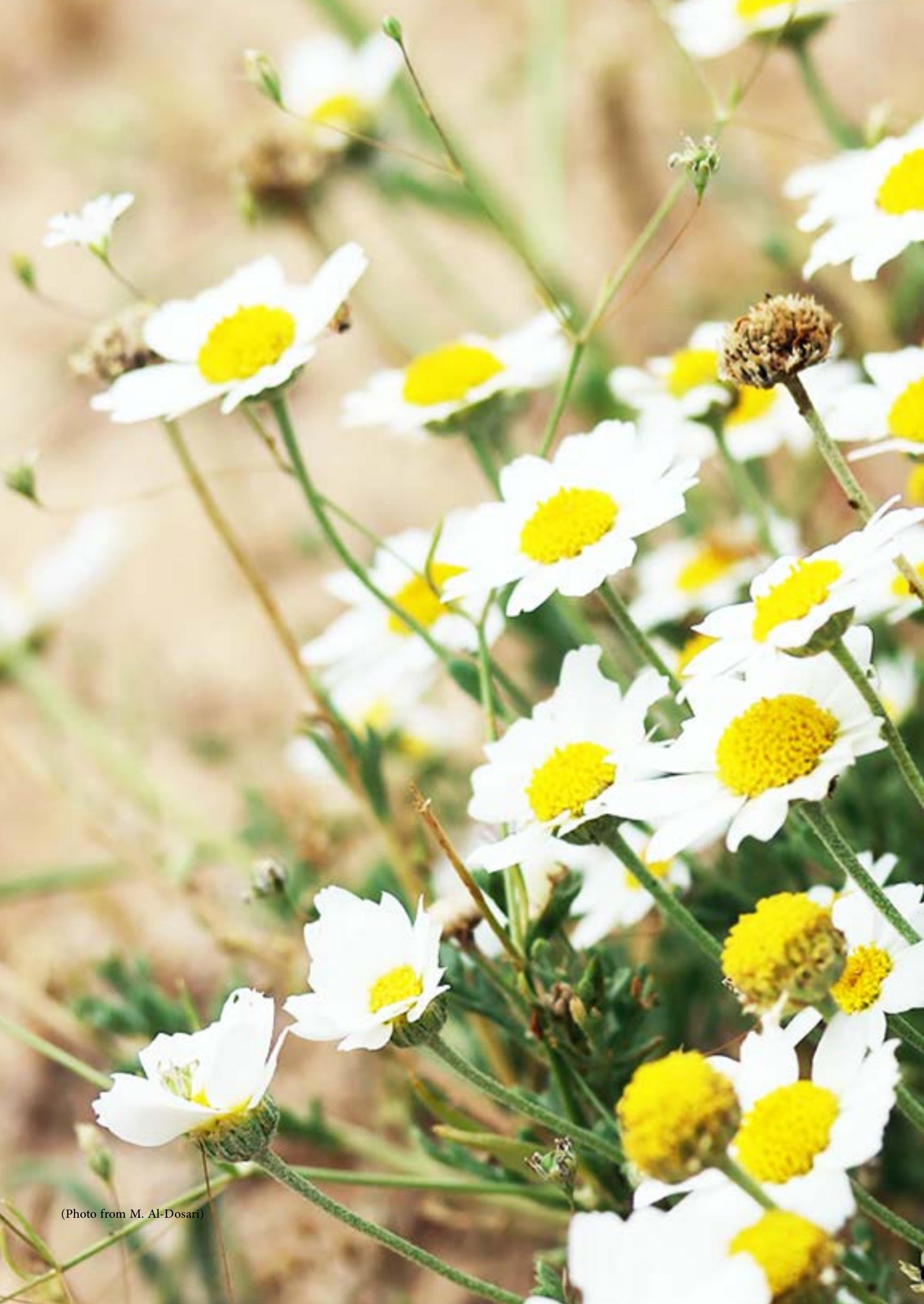





\section{Methodology}

Extensive literature review was conducted through all databases, including google scholar, biological abstract and others.

\section{Birds:}

BirdLife International

Kuwait Birds and Kuwait bird official site (www. kuwaitbirds.org/birds).

\section{Mammals:}

Cowan, P.J. (2013). 'An annotated checklist of the mammals of Kuwait'. Sultan Qaboos University Journal for Science 18:19-24.

Harrison, D.L. and Bates, P.J.J. 1991. Mammals of Arabia. Harrison Zoological Museum. Kent, UK.

\section{Reptiles:}

Sindaco, R. and Jeremcenko, V.K. (2008). The Reptiles of the Western Palearctic. Volume 1. Annotated Checklist and Distributional Atlas of the Turtles, Crocodiles, Amphisbaenians and Lizards of Europe, North Africa, Middle East and Central Asia. Edizioni Belvedere, Latina, Italy.

Sindaco, R., Venchi, A. and Grieco, C. (2013). The Reptiles of the Western Palearctic, Volume 2: Annotated Checklist and Distributional Atlas of the Snakes of Europe, North Africa, Middle

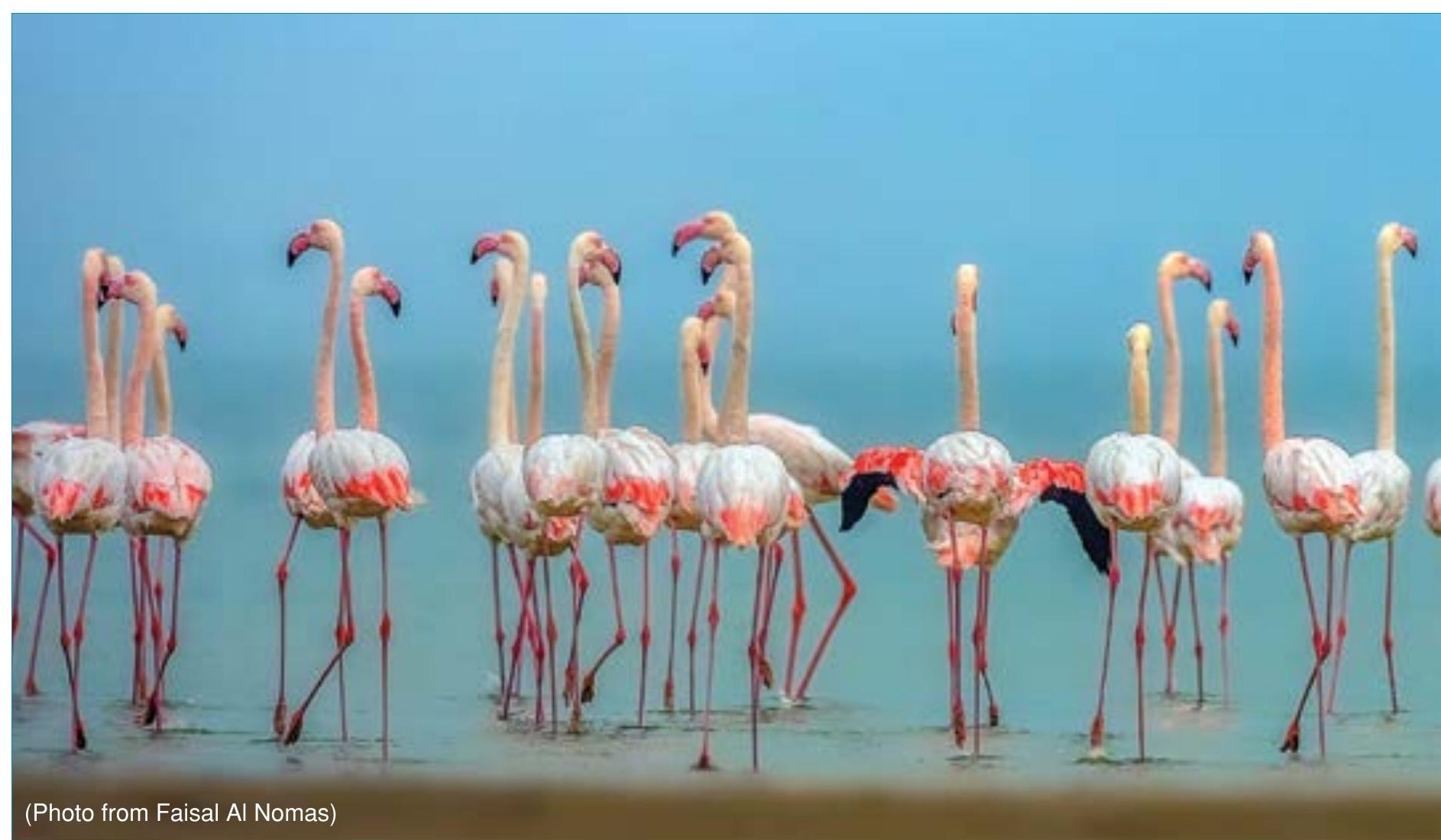




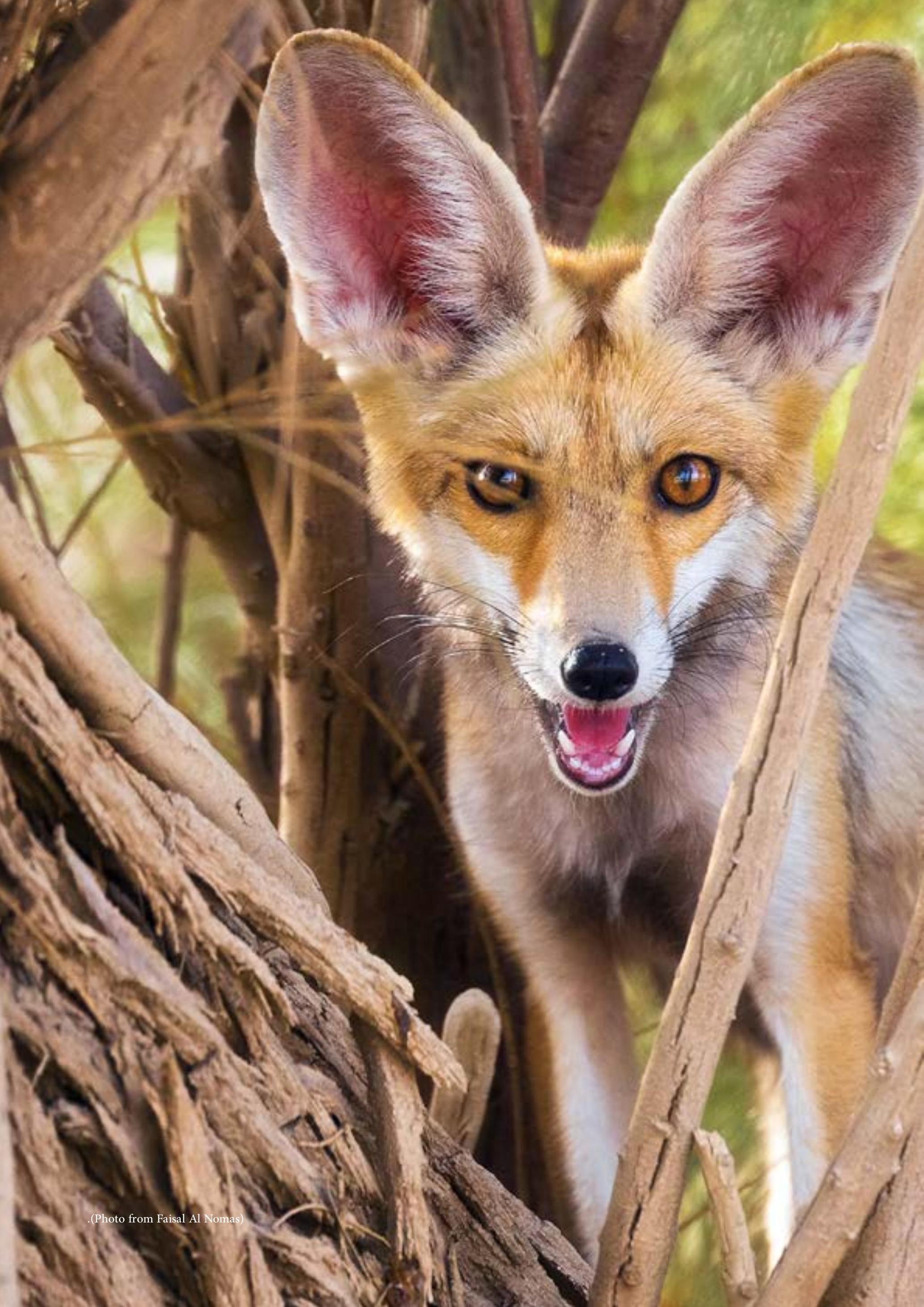




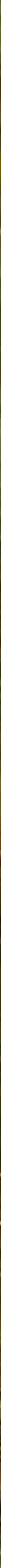




\section{Terrestrial and marine vertebrates}

\subsection{Classes Amphibia and Reptilia}

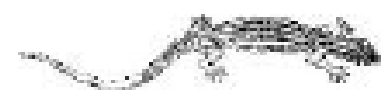

A single species of amphibians occurs in Kuwait, while 45 species of reptiles have been recorded to the herpetofauna of Kuwait. They are represented by species in 14 families (Table 6, Figure 7-9). The first work on the reptiles of Kuwait was published by Eissa \& El Assy (1975). They reported 28 species, however, two species may represent misidentification (Uromastyx thomasi and Agama jayakari). Both species are known from Oman and eastern Arabia. Five species of lizards were recorded from Al Wafra area (Al-Khalifa et al., 2012). An illustrated guide to the horned viper of Kuwait was published by Al-Fares \& Al-Metairie (2014) with a series of photographs.
Recent studies added and the melanistic whip snake, Dolichophis jugularis (Al-Mohanna et al., 2007) with doubts on the presence of both the Arabian Cobra and the Black Desert Snake, three species of Geckos; Murray's Comb-fingered Gecko, Stenodactylus affinis, and Gulf Sand Gecko, Stenodactylus khobarensis (Al-Sirhan, 2009; Metallinou et al., 2012) and the Web-footed Sand Gecko, Stenodactylus arabicus (Delima \& Al-Nasser, 2007), the Small-spotted Desert Lizard, Mesalina guttulata (Al-Sirhan, 2008). Al-Sirhan \& Brown (2010) gave an account on the distribution of two species of the genus Phrynocephalus in Kuwait. Clayton \& Pilcher (1983) reported

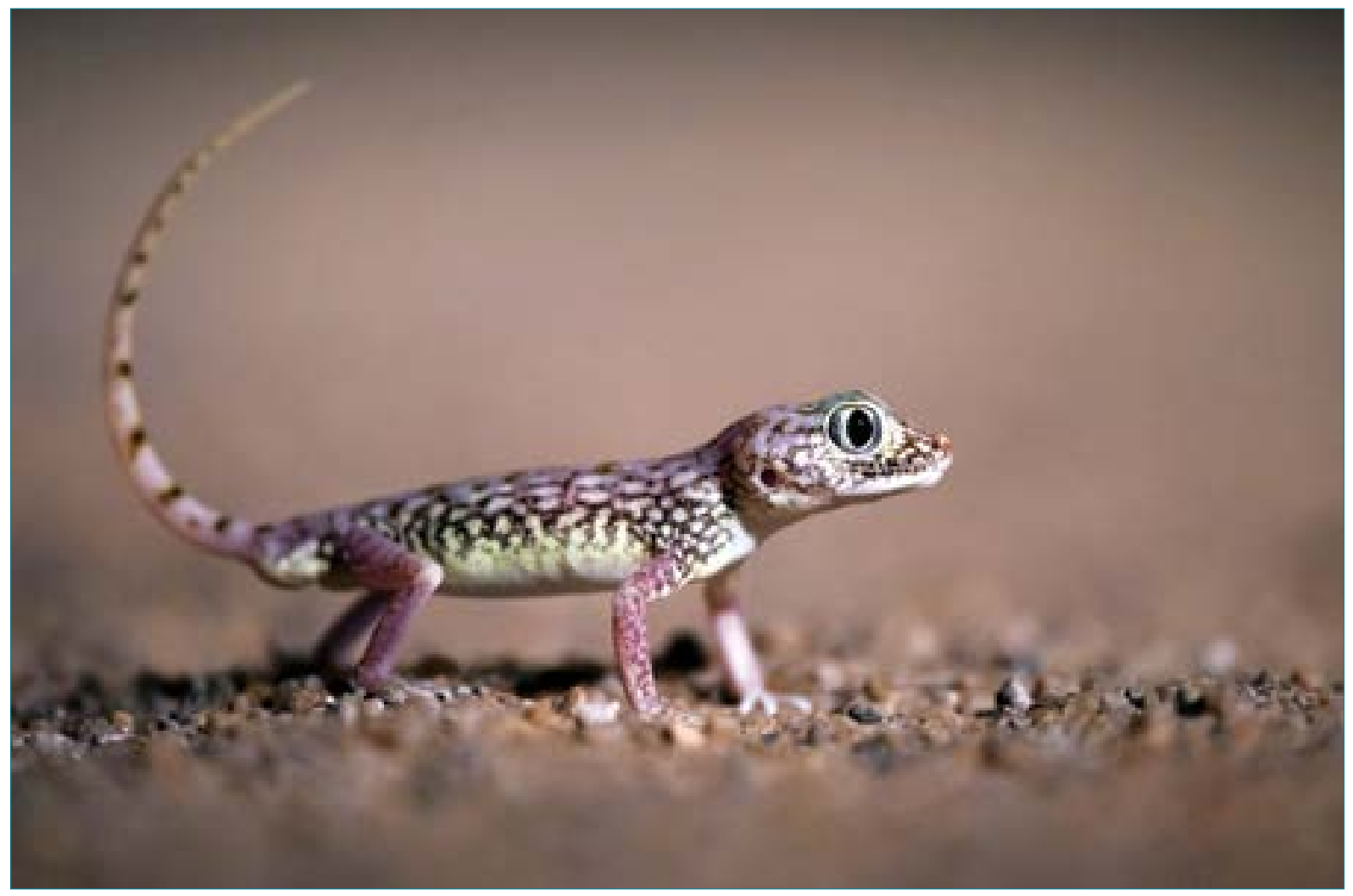

Figure 7: Some reptiles from Kuwait. Stenodactylus affinis (Photo from Abdulrahman Al-Sirhan). 


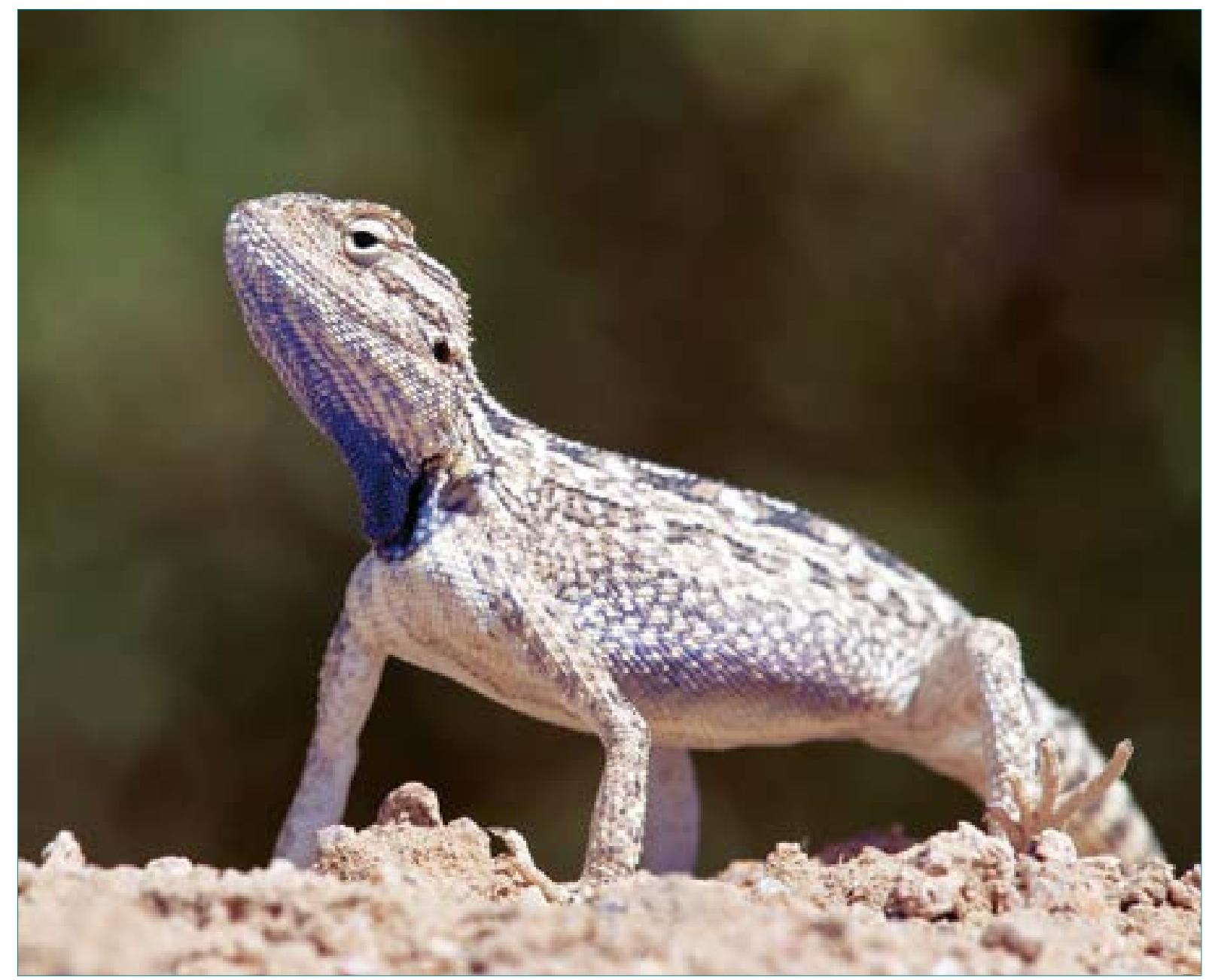

Figure 8: Some reptiles from Kuwait. Trapelus persicus (Photo from Abdul Aziz Al Yousef).

Ablepharus pannonicus from Kuwait. Al-Houty et al. (2015) reported Bufo viridis (=Bufotes boulengeri) from ephemeral pools in Kuwait.

The Spiny-tailed Lizard, Uromastyx aegyptius, was the focus of several studies. Food plants consumed by this species were studied by Robinson (1995). Wilms \& Böhme (2007) revised the distribution and systematics of lizards of the genus Uromastyx in Arabia, including Kuwait. Al-Sayegh (2017) conducted a study on its ecophysiological implications of conservation. A recent account on sea snakes of the Arabian Gulf with an illustared key was published by RezaieAtagholipour et al. (2016).

In total, five species of marine turtles have been recorded from Kuwait (Caretta caretta, Chelonia mydas, Eretmochelys, Lepidochelys olivacea and imbricata Lepidochelys olivacea). The marine turtles of Kuwait received a good attention, with several studies on their taxonomy and biology (Gasperetti et al., 1993; Al-Merghani et al., 1996; Al-Mohanna \& Meakins, 1998 \& 2000a \& b;
Meakins \& Al-Mohanna, 2000 \& 2003; Bishop et al., 2007; Bishop \& Alsaffar, 2008; Al Mohanna \& George, 2010; Al-Mohanna et al., 2013; Rees et al., 2013). Conversation status of the marine turtles and other reptiles is presented in Table (7).

Other studies focused on the biology of some desert species (Agama persica = Trapelus persicus and Diplometopon zarudnyi) (CloudsleyThompson, 1979). Sey \& Al-Ghaith (2000) examined the helminths of the green toad and spiny tailed lizard in Kuwait. Several papers on the hematology of Kuwait lizards were published including localities for the studied material (AbdelFattah et al., 1974; Al-Badry, 1975; Al-Badry et al., 1975; Al-Badry \& Al-Sdirawi, 1976; Al-Balool, 1976).

The impact of oil pollution on body size, weight, timing of morning emergence, basking and foraging behaviors and substrate preferences of Acanthodactylus scutellatus in Kuwait was investigated (Al-Hashem et. al., 2008; Al-Hashem \& Brain, 2009a \& b). 
Table 6: List of amphibians and reptiles of Kuwait.

\begin{tabular}{|c|c|c|}
\hline Class & Family & Species \\
\hline Amphibia & Bufonidae & Bufotes boulengeri (Lataste, 1879) \\
\hline \multirow[t]{45}{*}{ Reptelia } & Cheloniidae & Eretmochelys imbricata (Linnaeus, 1766) \\
\hline & & Chelonia mydas (Linnaeus, 1758) \\
\hline & & Caretta caretta (Linnaeus, 1758) \\
\hline & & Lepidochelys olivacea (Eschscholtz, 1829) \\
\hline & Dermochelyidae & Dermochelys coriacea (Vandelli, 1761) \\
\hline & Agamidae & Phrynocephalus arabicus Anderson, 1984 \\
\hline & & Phrynocephalus maculatus Anderson, 1872 \\
\hline & & Trapelus agnetae (Werner, 1929) \\
\hline & & Trapelus flavimaculatus Rüppell, 1835 \\
\hline & & Trapelus persicus (Blanforld, 1804) \\
\hline & & Uromastyx aegyptia (Forsskål, 1775) \\
\hline & Gekkonidae & Bunopus tuberculatus Blanford, 1874 \\
\hline & & Cyrtopodion scabrum (Heyden, 1827) \\
\hline & & Hemidactylus turcicus Linnaeus, 1758) \\
\hline & & Hemidactylus flaviviridis Rüppell, 1835 \\
\hline & & Hemidactylus persicus Anderson, 1872 \\
\hline & & Pseudoceramodactylus khobarensis Haas, 1957 \\
\hline & & Stenodactylus doriae (Blanford, 1874) \\
\hline & & Stenodactylus affinis (Murray, 1884) \\
\hline & & Stenodactylus slevini Haas, 1957 \\
\hline & & Trigonodactylus arabicus (Haas, 1957) \\
\hline & Lacertidae & Acanthodactylus boskianus (Daudin, 1802) \\
\hline & & Acanthodactylus opheodurus Arnold, 1980 \\
\hline & & Acanthodactylus schmidti Haas, 1957 \\
\hline & & Acanthodactylus scutellatus (Audouin, 1827) \\
\hline & & Mesalina brevirostris Blanford, 1874 \\
\hline & & Mesalina guttulata (Lichtenstein, 1823) \\
\hline & Scincidae & Ablepharus pannonicus (Fitzinger, 1824) \\
\hline & & Scincus mitranus Anderson, 1871 \\
\hline & & Scincus scincus (Linnaeus, 1758) \\
\hline & Trogonophidae & Diplometopon zarudnyi Nikolsky, 1907 \\
\hline & Varanidae & Varanus griseus (Daudin, 1803) \\
\hline & Boidae & Eryx jayakari Boulenger, 1888 \\
\hline & Colubridae & Dolichophis jugularis (Linnaeus, 1758) \\
\hline & & Lytorhynchus diadema (Duméril et al.1854) \\
\hline & & Platyceps ventromaculatus (Gray, 1834) \\
\hline & & Spalerosophis diadema cliffordii (Schlegel, 1837) \\
\hline & Elapidae & Hydrophis cyanocinctus Daudin, 1803 \\
\hline & & Hydrophis gracilis (Shaw, 1802) \\
\hline & & Hydrophis platurus (Linnaeus, 1766) \\
\hline & & Hydrophis viperinus (Schmidt, 1852) \\
\hline & Typhlopidae & Indotyphlops braminus (Daudin, 1803) \\
\hline & Psammophiidae & Psammophis schokari (Forsskål, 1775) \\
\hline & & Rhagerhis moilensis (Reuss, 1834) \\
\hline & Viperidae & Cerastes gasperetti Leviton \& Anderson, 1967 \\
\hline
\end{tabular}




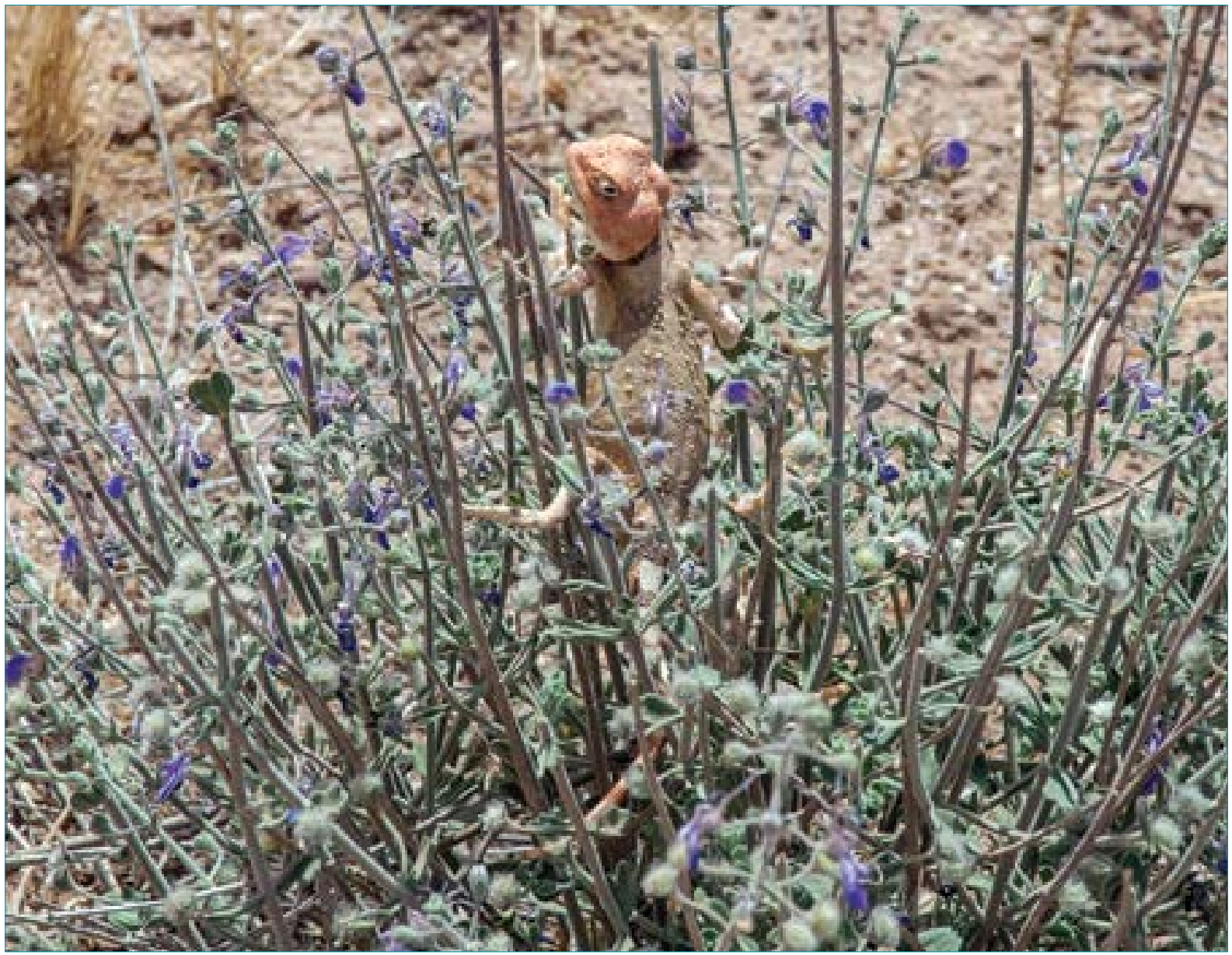

Figure 9: Some reptiles from Kuwait. Trapelus agnetae (Photo from Abdulrahman Al-Sirhan).

Table 7: IUCN status of reptiles of Kuwait.

\begin{tabular}{|l|l|l|c|}
\hline \multicolumn{1}{|c|}{ Family } & \multicolumn{1}{|c|}{ species } & \multicolumn{1}{c|}{ Common name } & IUCN Global Status \\
\hline Agamidae & Uromastyx aegyptia & Egyptian Spiny-tailed Lizard & VU \\
\hline Cheloniidae & Caretta caretta & Loggerhead Turtle & VU \\
\hline & Chelonia mydas & Green Turtle & EN \\
\hline & Eretmochelys imbricata & Hawksbill Turtle & CR \\
\hline & Lepidochelys olivacea & Olive Ridley Turtle & VU \\
\hline Dermochelyidae & Dermochelys coriacea & Leatherback Sea Turtle & VU \\
\hline
\end{tabular}

\section{References}

Abdel-Fattah, R.F., Al-Badryan, K.S. and Al-Balool, D.F. (1974). 'Haematological studies on some reptiles from Kuwait Part I. Some corpuscular constants, blood glucose, and electrophoretic examination of blood proteins of the lizard Agama persica'. Journal of the University of Kuwait (Science) 1: 129-134.

Al-Badry K.S. and Abdel-Fattah, R.F. (1975). 'Hematological studies on some reptiles from Kuwait Part II. Some corpuscular constants blood glucose total plasma protein and electrophoretic examination of blood proteins of the lizard Uromastix microlepis'. Journal of the University of Kuwait (Science) 2: 153-158. 
Al-Badry, K.S. (1975). 'Haematological studies on some reptiles from Kuwait Part III. Some corpuscular constants, blood glucose, total plasma protein and electrophoretic examination of blood proteins of the lizards Acanthodactylus scutellatus and Eremias brevirostris'. Journal of the University of Kuwait (Science) 2: 159-165.

Al-Badry, K.S. and Al-Sdirawi, F.A. (1976). 'Haematological studies on oame reptiles from Kuwait'. Journal of the University of Kuwait (Science) 3:143-160.

Al-Balool, F.Y. (1976). 'Studies on the absorption of glucose from the small intestine of Uromastix microlepis'. MSc. thesis. Kuwait: University of Kuwait.

Al Fares, A. and Al-Mutari, M. (2014). Classification Guide for Horned Viper in Kuwait Environment. Kuwait Institute for Scientific Research, Kuwait.

Al-Hashem, M. and Brain, P.F. (2009a). 'Changed substrate preferences shown by Fringe-toed Lizards, Acanthodactylus scutellatus, from Kuwait's Al-Burgan oil field (Reptilia: Lacertidae)'. Zoology in the Middle East 46:41-45.doi.org/10.1080/09397140.2009.10638326

Al-Hashem, M. and Brain, P.F. (2009b). 'Effects of oil pollution on body size and weight of the sand lizard Acanthodactylus scutellatus at the greater Al-Burgan oil field in Kuwait'. Research Journal of Environmental Toxicology 3: 56-59.doi org/10.3923/rjet.2009.56.59

Al-Hashem, M., Brain, P.F. and Omar, S.A. (2008). 'Effects of oil pollution at Kuwaitıs Greater AlBurgan oil field on the timing of morning emergence, basking and foraging behaviors by the sand lizard Acanthodactylus scutellatus'. Pakistan Journal of Biological Sciences 11:589-594. doi org/10.3923/pjbs.2008.589.594.

Al-Hashem, M.A. and Brain, P.F. (2009). 'Effects of oil pollution on body size and weight of the desert lizard Acanthodactylus scutellatus at the Greater Al-Burgan oil field in Kuwait'. Research Journal of Environmental Toxicology 3: 56-59.doi org/10.3923/rjet.2009.56.59

Al-Houty, W., Behbehani, M. and Aborbiya, M. (2015). 'Some environmental and biological characteristics of ephemeral pools in the State of Kuwait'. International Journal of Technology Enhancements \& Emerging Engineering Research 3: 9-17.https://www.ijteee.org/final-print/oct2015/SomeEnvironmental-And-Biological-Characteristics-of-Ephemeral-Pools-in-the-State-of-Kuwait.pdf

Al-Khalifa, H., Al-Nasser, A., Abbas, M.S. and Dashti, J. (2012). 'Biodiversity and conservation of Wildlife at the Wafra area in Kuwait'. Biodiversity Journal 3: 179-188. http://www.biodiversityjournal. com/pdf/3(3)_179-188.pdf

Al-Merghani, M., Miller, J.D., Al-Mansi, A., Khushaim, O. and Pilcher, N.J. (1996). 'The marine turtles of the Arabian Gulf, NCWCD studies 1991-1994'. In: F. Krupp, A.H. Abuzinada I.A. \& Nader (eds.), A Marine Wildlife Sanctuary for the Arabian Gulf: Environmental Research and Conservation Following the. 1991 Gulf War Oil Spill, pp. 351-359. Riyadh, Saudi Arabia: National Commission for Wildlife Conservation and Development.

Al-Mohanna, S.Y., Jaman, S. and Meakins, R.H. (1997). 'First report of a melanistic whip snake Coluber jugularis Linnaeus 1758 from the Arabian Peninsula'. Zoology in the Middle East 14: 73-76.doi. org/10.1080/09397140.1997.10637706

Al-Mohanna, S.Y. and Meakins, R.H. (1998). Study of the biology of marine Turtles and their marine environment in Kuwait. Phase 1: A study of the sea turtles present in Kuwait and some notes on their comparative morphology. Kuwait Foundation for the Advancement of Science, Final Report for Project 96.01.01, Kuwait.

Al-Mohanna, S.Y. and Meakins, R.H. (2000a). 'Recent records of marine turtles (Chelonia mydas, Caretta caretta, and Eretmochelys imbricata) in Kuwait'. Zoology of the Middle East 20: 33-36. doi.org/10.1080/09397140.2000.10637809

Al-Mohanna S.Y. and Meakins RH. (2000b). 'First record of the leatherback turtle, Dermochelys coriacea, from Kuwait'. Zoology in the Middle East 21: 27-29.doi.org/10.1080/09397140.2000.10637830

Al-Mohanna, S.Y., Al-Zaidan, A.S.Y. and George, P. (2013). 'Green turtles (Chelonia mydas) of the north-western Arabian Gulf, Kuwait: the need for conservation'. Aquatic Conservation: Marine \& Freshwater Ecosystems, 24: 166-178.

Al Mohanna, S.Y. and George, P. (2010). 'Assessment of the origin of a loggerhead turtle, Caretta caretta, found in Kuwaiti waters, using mitochondrial DNA'. Zoology in the Middle East 49:3944.doi.org/10.1080/09397140.2010.10638387

Al-Nassar, N.A. (1976). 'Anatomical studies, osteology and gut histology of the amphisbaenian Diplometopon zarudnyi inhabiting Kuwait'. MSc. thesis.Kuwait: University of Kuwait. 
Al-Sayegh, M. (2017). 'Eco-physiological Implications of Conservation of Dhubs (Uromastyx aegyptius) in Kuwait'. PhD. thesis. Tempe:Arizona State University.

Al-Sirhan, A. (2008). 'First record of the Small-spotted Desert Lizard, Mesalina guttulata (Lichtenstein, 1823) (Sauria: Lacertidae), from Kuwait'. Zoology in the Middle East 45: 110-111.doi.org/10.10 80/09397140.2008.10638315

Al-Sirhan, A. (2009). 'Two new records of Stenodactylus spp. from Kuwait'.Zoology in the Middle East 47:108-109. doi.org/10.1080/09397140.2009.10638353

Al-Sirhan, A-R. and Brown, G. (2010). 'The status of the two Toad-headed Agamas, Phrynocephalus arabicus (Anderson, 1894) and P. maculatus (Anderson, 1872), in Kuwait'.Zoology in the Middle East 51:23-30. doi.org/10.1080/09397140.2010.10638437

Bishop, J.M. and Alsaffar, A.H. (2008). 'Quantitative observations on marine mammals and reptiles of Kuwait's Boubyan Island'. Zoology in the Middle East 43:1:3-12.doi.org/10.1080/09397140.20 08.10638263

Bishop, J.M., Deshti, T. \& Al-Ayoub, S. (2007). 'The Arabian Gulf's first record of the Olive Ridley, Lepidochelys olivacea, from Kuwait'. Zoology in the Middle East 42:1,102-103.doi.org/10.1080 /09397140.2007.10638253

Clayton, D. and Wells, K.(1987). Discovering Kuwaitıs wildlife. Fahed Al-Marzouk Press, Kuwait

Clayton, D. and Pilcher, C. (1983). Kuwait's Natural History: An Introduction. Kuwait Oil Co. Ltd., Kuwait.

Cloudsley-Thompson, J.L. (1979). 'Water loss and locomotory activity in Agama persica and Diplometopon zarudnyi from Kuwait'. Journal of Arid Environment 1:273-277. doi.org/10.1016/ S0140-1963(18)31777-4

Delima, E.C. and Al-Nasser, A. (2007). 'New record of the Web-footed Sand Gecko, Stenodactylus arabicus (Haas, 1957) (Sauria: Gekkonidae), from Kuwait'. Zoology in the Middle East 41:111112.

Eissa, S.M. and El-Assy, Y.S. (1975). 'Record of certain reptilian species found in Kuwait'. Journal of the University of Kuwait (Science) 2: 123-145.

El-Assy, S. and Al-Nassar, N. A. (1976). 'Morphological study of the cranial osteology of the amphisbaenian Diplometopon zarudnyi'. Journal of the University of Kuwait (Science) 3:113-141.

Gasperetti, J, Stimson, A.F., Miller, J.D., Ross, J.P. and Gasperetti, P.R. (1993). 'Turtles of Arabia'. Fauna of Saudi Arabia 13: 170-367.

Meakins, R. H. and Al-Mohanna, S. Y. (2003). 'Some problems and the importance of reptile biodiversity in Kuwait'. Journal of Arid Environments 54: 209-217. doi.org/10.1006/jare.2001.0877

Meakins, R.H. and Al-Mohanna, S.Y. (2000). 'Sea turtles in Kuwait after the Gulf War'. Marine Turtle Newsletter 88: 7-8.http://www.seaturtle.org/mtn/archives/mtn88/mtn88p7.shtml

Metallinou, M., Arnold, E.N., Crochet, P., Geniez, P., Brito, J.C., Lymberakis, P., Baha El Din, S., Sindaco, R., Robinson, M.and Carranza, S. (2012). 'Conquering the Sahara and Arabian deserts: Systematics and biogeography of Stenodactylus geckos (Reptilia: Gekkonidae) '. BMC Evolutionary Biology 12: 1. doi.org/10.1186/1471-2148-12-258

Rees, A.F., Al Hafez, A., Lloyd, J.R., Papathansopoulou, N. and Godley, B.J. (2013). 'Green turtles, Chelonia mydas, in Kuwait: Nesting and movements'. Chelonian Conservation and Biology 12:157-163. doi.org/10.2744/CCB-1030.1

Rezaie-Atagholipour, M., Ghezellou, P., Hesni, M.A., Dakhteh, S.M.H., Ahmadian, H. and Vidal, N. (2016). 'Sea snakes (Elapidae, Hydrophiinae) in their westernmost extent: an updated and illustrated checklist and key to the species in the Persian Gulf and Gulf of Oman'. ZooKeys 622:129-164.doi.org/10.3897/zookeys.622.9939

Robinson, M. D. (1995). 'Food plants and energetics of the herbivorous lizard, Uromastyx aegyptius microlepis, in Kuwait'. Journal of the University of Kuwait (Science) 22:255-262.

Sey, O. and Al-Ghaith, L. (2000). 'Helminths of green toads Bufo viridis Laurenti, 1789 and spiny tailed lizards, Uromastyx microlepis Blanford, 1874 of Kuwait'. Miscellanea Zoologica Hungarica 13. 21-27.

Wilms, T.M. and Böhme, W. (2007). 'Review of the taxonomy of the spiny-tailed lizards of Arabia (Reptilia: Agamidae: Leiolepidinae: Uromastyx) '. Fauna of Arabia 23: 435-468. 


\subsection{Class Mammalia}

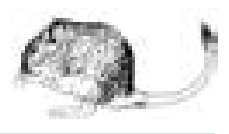

The mammals of Kuwait include some 29 species in six orders (Carnivora, Cetacea Chiroptera, Eulipotyphla, Lagomorpha and Rodentia) (Table 8, Figure 10-13). Species of order Rodentia constitutes the highest number. Cowan (2013) gave the most comprehensive review on the mammals of Kuwait. He listed 25 species of confirmed presence, four are uncommon or rare visitors, seven used to occur and are considered by now extinct (Table 9), and two are of doubtful provenance.

Table 8: List of surviving mammals of Kuwait.

\begin{tabular}{|l|l|l|}
\hline \multicolumn{1}{|c|}{ Order } & \multicolumn{1}{|c|}{ Species } \\
\hline Eulipotyphla & Long-eared hedgehog & Hemiechinus auritus (Gmelin 1770) \\
\hline & Ethiopian hedgehog & Paraechinus aethiopicus (Ehrenberg 1833) \\
\hline Chiroptera & Naked-rumped tomb bat & Taphozous nudiventris Cretzschmar 1830 \\
\hline & Trident leaf-nosed bat & Asellia tridens ( E. Geoffroy 1813) \\
\hline & Kuhl's pipistrelle & Pipistrellus kuhlii (Kuhl 1819) \\
\hline Carnivora & Red fox & Vulpes vulpes (Linnaeus 1758) \\
\hline & Honey badger & Mellivora capensis (Schreber 1776) \\
\hline & Indian grey mongoose & Herpestes edwardsi (E. Geoffroy 1818) \\
\hline & Wildcat & Felis silvestris (Schreber 1777) \\
\hline & Sand cat & Felis margarita (Loche 1858) \\
\hline & Sei whale & Balaenoptera borealis Lesson 1828 \\
\hline & Blue whale & Balaenoptera musculus (Linnaeus 1758) \\
\hline & False killer whale & Pseudorca crassidens (Owen 1846) \\
\hline & Indo-Pacific humpback dolphin & Sousa chinensis (Osbeck 1765) \\
\hline & Indo-Pacific bottlenose dolphin & Tursiops aduncus (Ehrenberg 1833) \\
\hline & Finless porpoise & Neophocaena phocaenoides (G. Cuvier 1829) \\
\hline & Cape hare & Lepus capensis (Linnaeus 1758) \\
\hline & Indian crested porcupine & Hystrix indica Kerr 1792 \\
\hline & Euphrates jerboa & Allactaga euphratica Thomas 1881 \\
\hline & Lesser jerboa & Jaculus jaculus (Linnaeus 1758) \\
\hline & Black rat & Rattus rattus (Linnaeus 1758) \\
\hline & Brown rat & Rattus norvegicus (Berkenhout 1769) \\
\hline & House mouse & Mus musculus Linnaeus 1758 \\
\hline & Baluchistan gerbil & Gerbillus nanus Blanford 1875 \\
\hline & Wagner's gerbil & Gerbillus dasyurus (Wagner 1842) \\
\hline & Cheesman's gerbil & Gerbillus cheesmani Thomas 1919 \\
\hline & Indian gerbil & Tatera indica (Hardwicke 1807) \\
\hline & Libyan jird & Meriones libycus Lichtenstein 1823 \\
\hline & Sundevall's jird & \\
\hline & & Meriones crassus Sundevall 1842 \\
\hline & &
\end{tabular}


Clayton \& Pilcher (1983) and Clayton \& Wells (1987) reported on several mammalian species in Kuwait. Bishop \& Alsaffar (2008) made sightings of the Indo-Pacific Humpback Dolphins (Sousa chinensis) in the immediate vicinity of Boubyan
Island. Dugong was reported before the 1950's from Kuwait. It is still present in the Arabian Gulf (Preen, 2004; Al-Abdulrazzak. \& Pauly, 2017). The conservation status of marine mammals in the Arabian Gulf is summarized in Table (5).

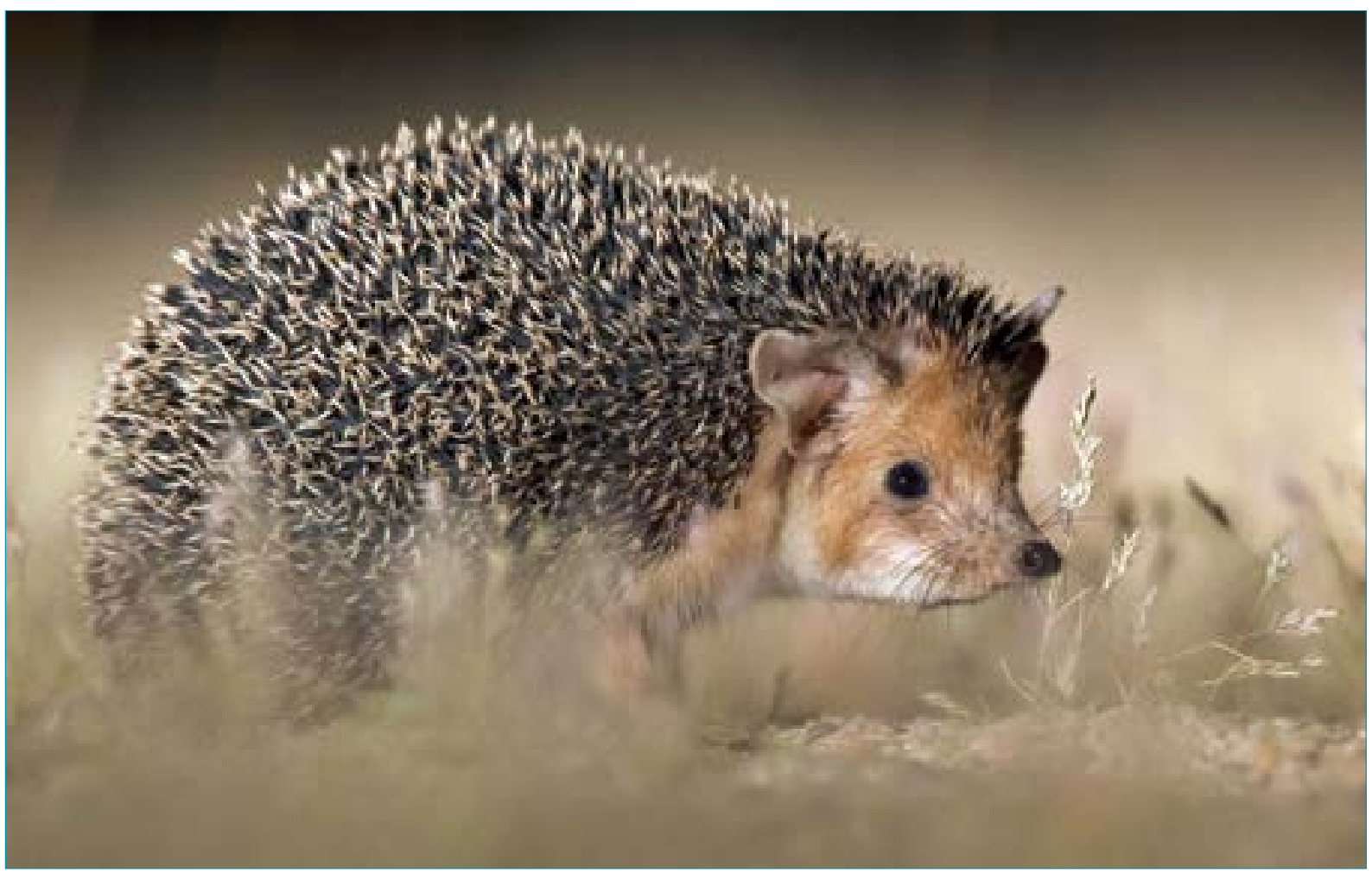

Figure 10: Some mammals from Kuwait. Long-eared Hedgehog, Hemiechinus auritus (Photos from Abdul Al-Azizi Al Yousef).

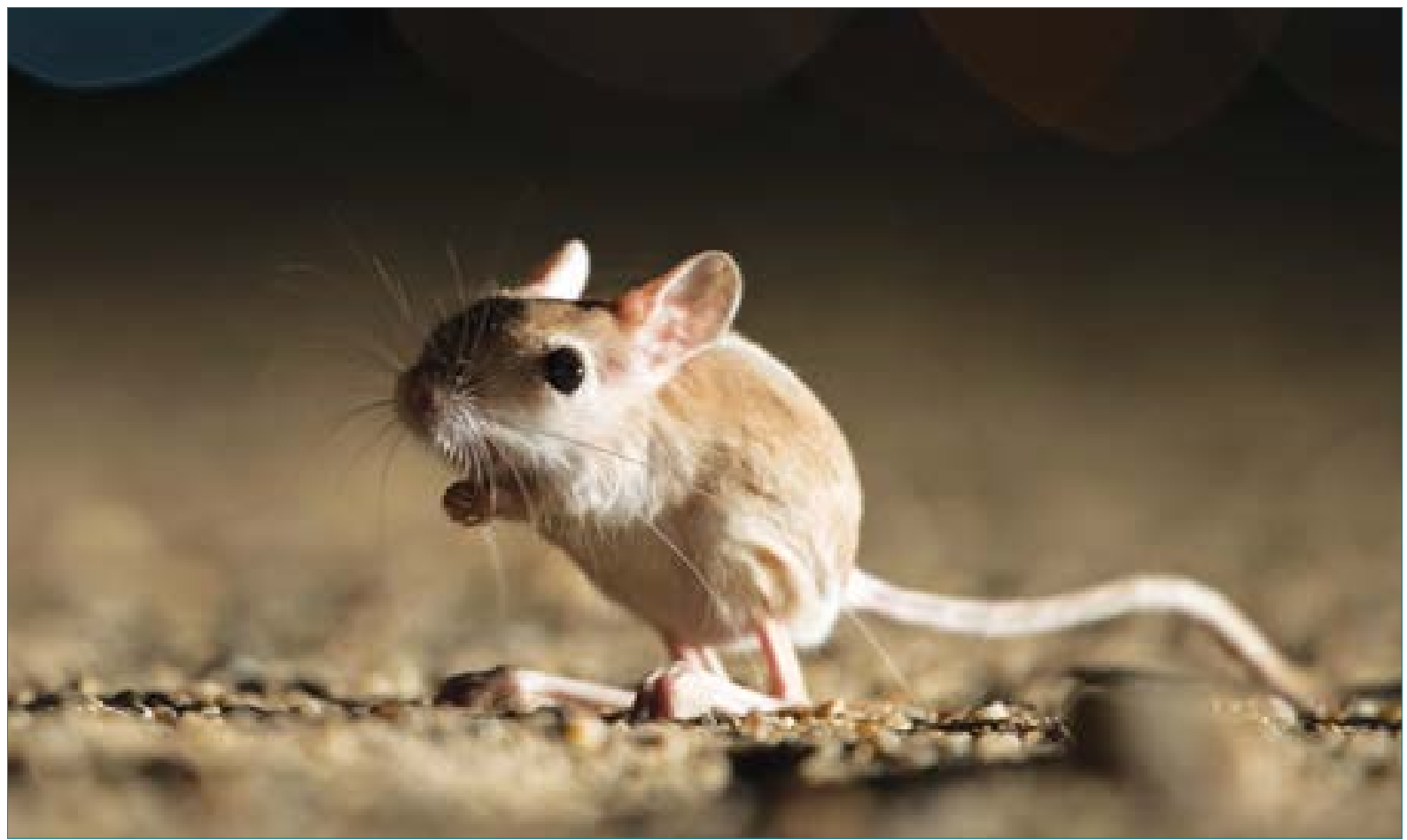

Figure 11: Some mammals from Kuwait. Lesser Jerboa, Jaculus jaculus (Photos from Abdul Al-Azizi Al Yousef). 
Table 9: Extinct mammals of Kuwait and their IUCN conservation status.

\begin{tabular}{|l|l|c|c|}
\hline Common name & \multicolumn{1}{|c|}{ Species } & $\begin{array}{c}\text { IUCN Global } \\
\text { Status }\end{array}$ & $\begin{array}{c}\text { IUCN Regional } \\
\text { Status }\end{array}$ \\
\hline Wolf & Canis lupus Linnaeus 1758 & LC & LC \\
\hline Caracal & Caracal caracal (Schreber 1776) & LC & NT \\
\hline Cheetah & Acinonyx jubatus (Schreber 1776) & VU & EN \\
\hline Arabian oryx & Oryx leucoryx (Pallas 1777) & VU & EN \\
\hline Saudi gazelle & Gazella saudiya (Carruthers and Schwarz 1935) & EX & \\
\hline Fennec fox & Vulpes zerda (Zimmermann 1780) & LC & LC \\
\hline Dugong & Dugong dugon (Müller, 1776) & VU & \\
\hline
\end{tabular}

The ecology of the Lesser Jerboa, Jaculus jaculus, was studied in Al-Jalia area (Eissa et al., 1975) and Kabd (Al-Mutairi et al., 2012). Harrison \& Bates (1991) mentioned records of Pipistrellus kuhlii based on specimens at the British Museum of Natural History (BMNH). Cheesman (1921) described the subspecies Felis silvestris iraki from northern Kuwait. Dickson (1949) reported the Caracal from Kuwait. Clayton (1991) recovered Meriones libycus, Jaculus jaculus and Gerbillus cheesmani from the Little Owl pellets in Kuwait. Al-Khalifa et al. (2012) reported the Red Fox, vulpes vulpes, Al Wafra area. Vesey-Fitzgerald (1953) reported on the rodents of Kuwait.

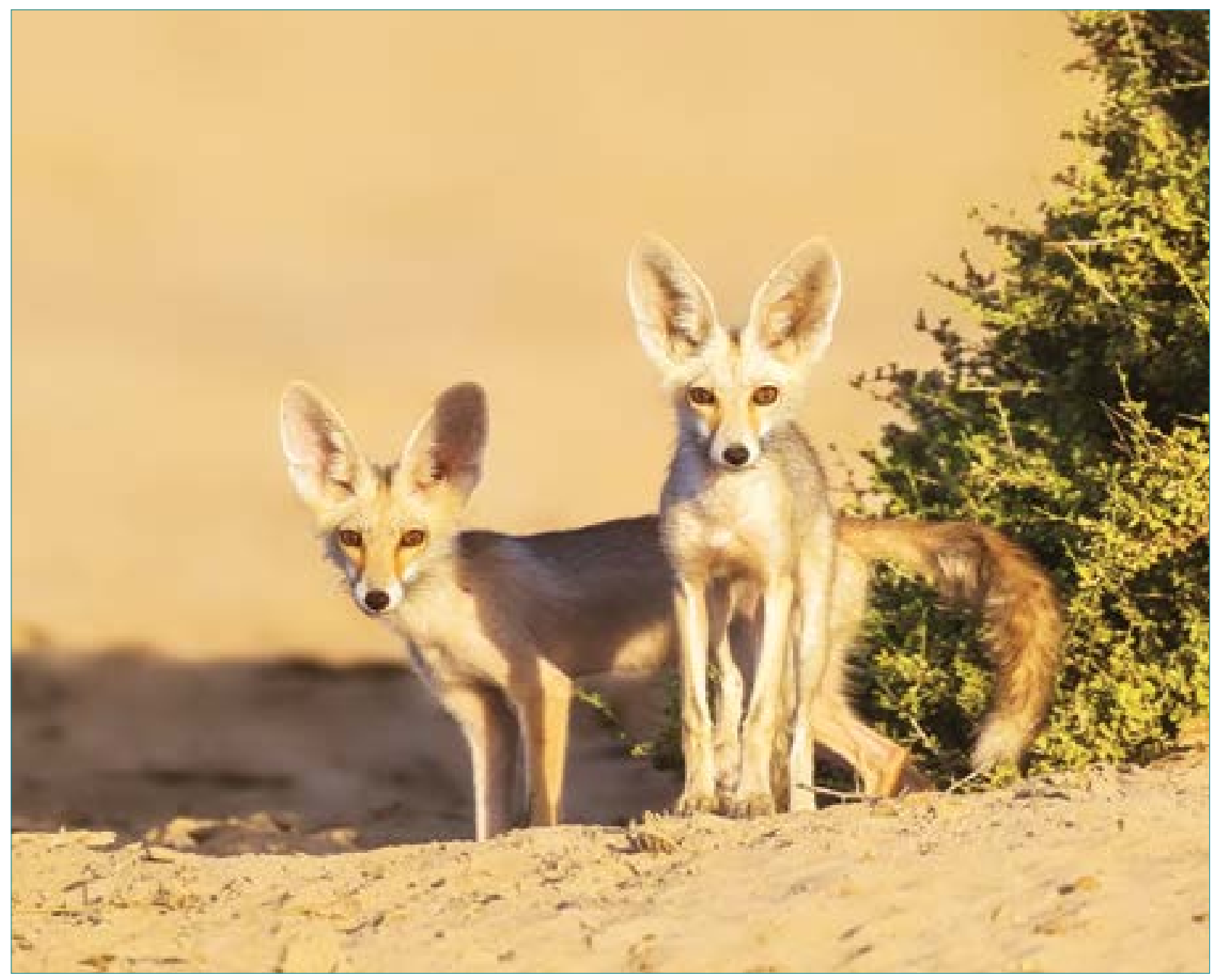

Figure 12: Some mammals from Kuwait. The Red Fox, Vulpes vulpes (Photo from Faisal Al Nomas). 


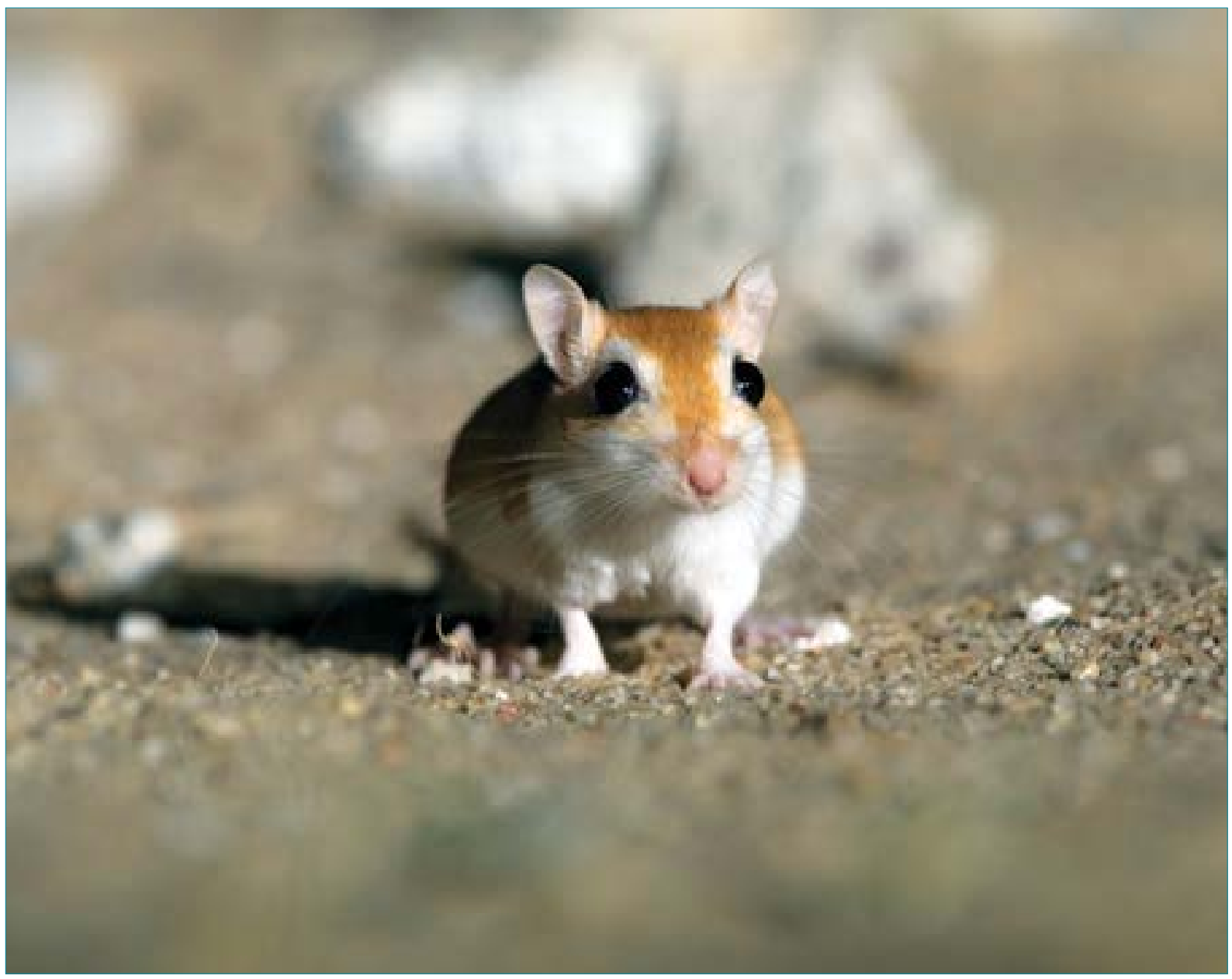

Figure 13: Cheesman's Gerbil, Gerbillus cheesmani (Photos from Abdul Al-Azizi Al Yousef).

Table 5: Threatened marine mammals reported from Kuwait and their IUCN conservation status.

\begin{tabular}{|l|l|l|}
\hline \multicolumn{1}{|c|}{ Common name } & \multicolumn{1}{c|}{ Species } & \multicolumn{1}{c|}{ EN } \\
\hline Sei whale & Balaenoptera borealis & EN \\
\hline Blue whale & Balaenoptera musculus & NT \\
\hline False killer whale & Pseudorca crassidens & VU \\
\hline Indo-Pacific humpback dolphin & Sousa chinensis & DD \\
\hline Indo-Pacific bottlenose dolphin & Tursiops aduncus & VU \\
\hline Finless porpoise & Neophocaena phocaenoides & VU \\
\hline Dugong & Dugong dugon & \\
\hline
\end{tabular}

Other studies on the ectoparasites of rodents included distributional data (Al-Taqi et al., 1983) and endoparasites, whereas the nematode, $A b$ breviata kuwaitensis, was described from Gerbillus cheesmani and Meriones crassus (Damian \& Behbahani, 1982). Al-Karmi \& Behbehani (1980) found Meriones crassus in Kuwait infected with Toxoplasma gondii. Khalil \& Abdul-Salam (1985) described new species of nematodes (Seuratum kuwaitensis and Spirura auriti) from the Longeared Hedgehog, Hemiechinus auritus, from Kuwait. Zaghloul et al. (1986) studied the biology and parasites of the Indian Gerbil, Tatera indica. Salit et al. (1986) studied in details the morphology and ecology of Tatera indica. 


\section{References}

Al-Abdulrazzak, D. and Pauly, D. (2017). 'Reconstructing historical baselines for the Persian/Arabian Gulf Dugong, Dugong dugon (Mammalia: Sirena) '. Zoology in the Middle East 63:95-102.doi.or $\mathrm{g} / 10.1080 / 09397140.2017 .1315853$

Al-Karmi, T. and Behbehani, K. (1980). 'Epidemiology of toxoplasmosis in Kuwait. II. Toxoplasma gondii in the desert rodent, Meriones crassus'. Transactions of the Royal Society of Tropical Medicine and Hygiene 74:745-746.doi:10.1016/0035-9203(80)90191-1

Khalil, L.F. and Abdul-Salam, J. (1985). 'Helminth parasites of the hedgehog, Hemiechinus auritus in Kuwait with description of two new nematodes Seuratum kuwaitensis and Spirura auriti'. Journal of the University of Kuwait (Science) 12:113-127.

Al-Mutairi, M., Mata, F. and Bhuller, R. (2012).'The effect of habitat degradation, season and gender on morphological parameters of lesser jerboas (Jaculus jaculus L.) in Kuwait'. Animal Biodiversity \& Conservation 35:119-124.

Al-Taqi, M.and Al-Ziady, S. (1983). 'Ectoparasites of rodents in Kuwait'. Proceedings of the 1st Symposium on Recent Advances in Rodent Control 107-114.

Bard, F.M. and Asker, R. L. (1984). 'Prevalence of non-Robertsonian polymorphism in the gerbil Gerbillus cheesmani from Kuwait'. Genetica 52: 17-22.doi.org/10.1007/BF00121809.

Bishop, J.M. and Alsaffar, A.H. (2008). 'Quantitative observations on marine mammals and reptiles of Kuwait's Boubyan Island'. Zoology in the Middle East 43:1:3-12.doi.org/10.1080/09397140.20 08.10638263

Clayton, D. and Wells, K. (1987). Discovering Kuwait's Wildlife. Fahed Al-Marzouk Press, Kuwait.

Clayton, D. and Pilcher, C. (1983). Kuwait's Natural History: An Introduction. Kuwait, Oil Co. Ltd., Kuwait.

Clayton, D. A. (1991). 'The Little Owl Athene noctua and its food in Kuwait'. Sandgrouse 13: 2-6.

Cowan, P.J. (2013). 'An annotated checklist of the mammals of Kuwait'. Sultan Qaboos University Journal for Science 18:19-24.

Damian, E. and Behbahani, B. (1982). 'Abbreviata (Abbreviata) kuwaitensis a parasiticnematode of rodents in Kuwait'. Proceedings of the 1st Symposium on Recent Advances in Rodent Control 115-134.

Eissa, S.M., El-Ziyadi, S.M. and Ibrahim, M.M. (1975). 'Autecology of the jerboa Jaculus jaculus inhabiting Al-Jalia desert area, Kuwait'. Journal of the University of Kuwait (Science) 2: 111-120.

Green, AA. (1986). 'Status of large mammals of northern Saudi Arabia'. Mammalia 50:483-94.doi. org/10.1515/mamm.1986.50.4.483

Harrison, D.L. and Bates, P.J.J. (1991). Mammals of Arabia. Harrison Zoological Museum. Kent, UK.

Khalil, L.F., Hassounah, O. and Behbehani, K. (1979). 'Helminth parasites of rodents in Kuwait with the description of a new species Abbreviata kuwaitensis (Nematoda: Physalopteridae)'. Systematic Parasitology 1:67-73. doi.org/10.1007/BF00009775

Preen, A. (2004). 'Distribution, abundance and conservation status of dugongs and dolphins in the southern and western Arabian Gulf'. Biological Conservation 118: 205-218.doi.org/10.1016/j. biocon.2003.08.014

Salit, A.M., Omar, T. and Zaghloul, T.M. (1986). 'The Indian Gerbil, Tatera indica, in Kuwait: morphology, ecology and control'. Proceedings of the 2nd Symposium on Recent Advances in Rodent Control 63-72.

Vesey-Fitzgerald, D. (1953). 'Notes on some rodents from Saudi Arabia and Kuwait'. Journal of Bombay Natural History Society 51: 424-428.

Zaghloul, T.M., Zakaria, M. and Salit, A.M. (1986). 'The Indian Gerbil, Tatera indica, in Kuwait: Biotoxic studies, ectoparasites and endoparasite infection'. Proceedings of the 2nd Symposium on Recent Advances in Rodent Control 53-62. 


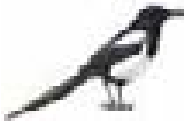

Perhaps the birds of Kuwait were the most investigated group. This is mostly due to interest of local and foreign birdwatchers in Kuwait. Several papers included data on the Kuwait birds (Haynes, 1979; Pilcher, 1992, 1994 \&1996; Cleere et al., 2000; Cowan \& Pilcher, 2003; Ramadan et al., 2004). The birds of Al Jahara Protected area was studied with details on migrant and resident birds (Al-Saqer, 2003). A comprehensive study on four species of desert larks in Kuwait was published by Brown (2009). Cowan (1990) and Bom \& alNasrallah (2015) and studied the biology the Crab Plovers on Bubiyan Islands.
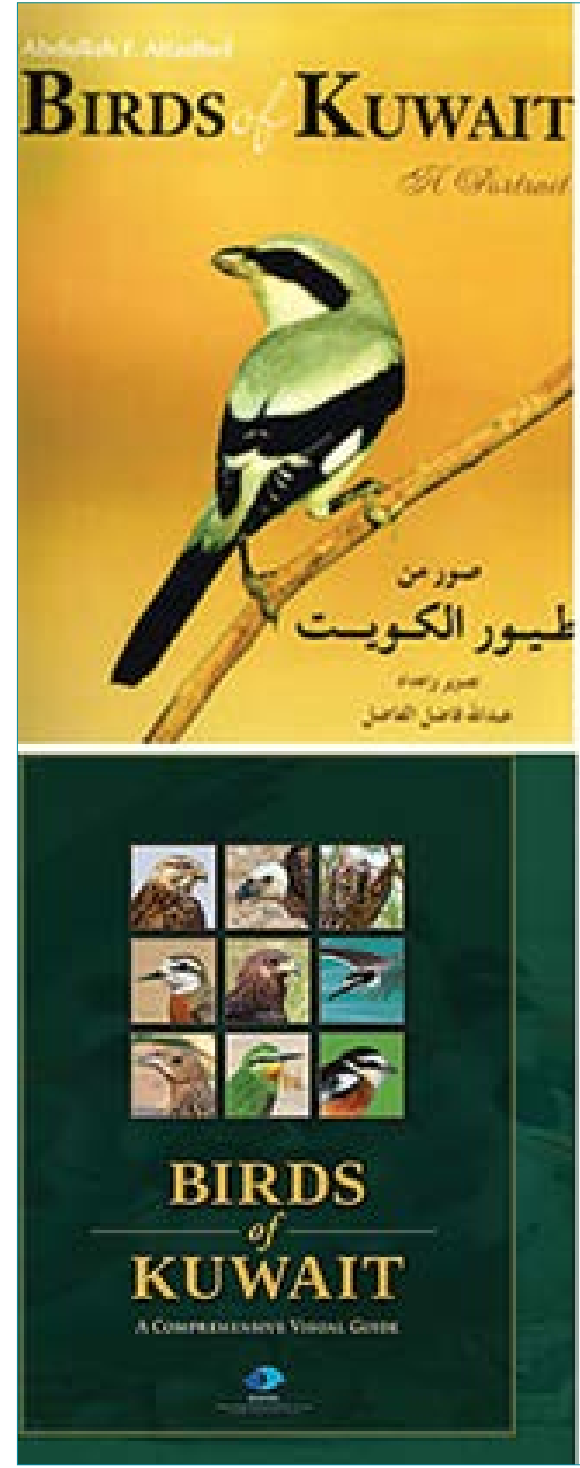

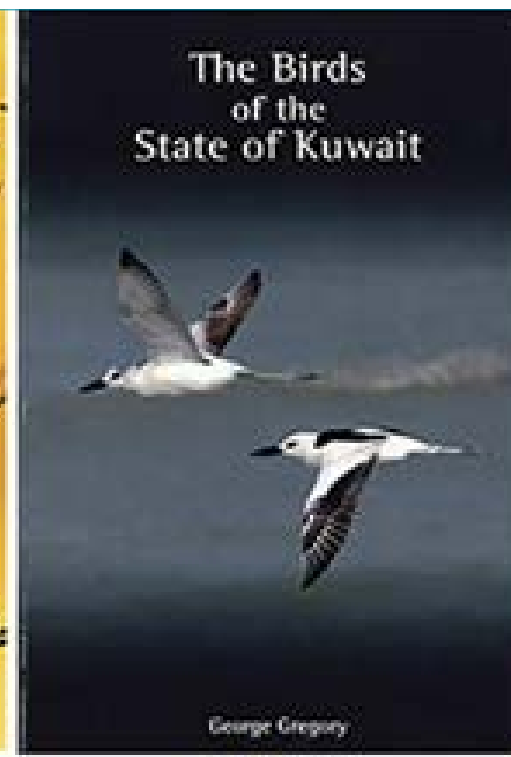

Q. $\sin x$

Birds of Kuwait

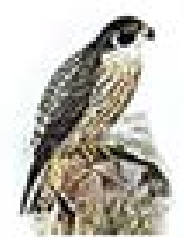

mensidener

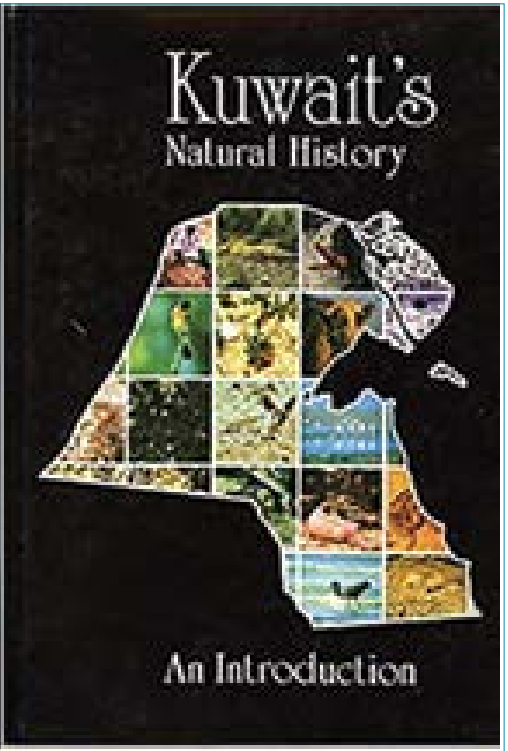

Binds

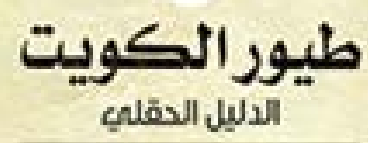

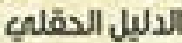

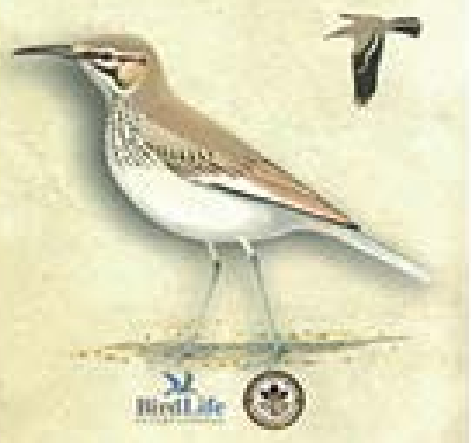

Figure 14: Books on the birds of Kuwait. 


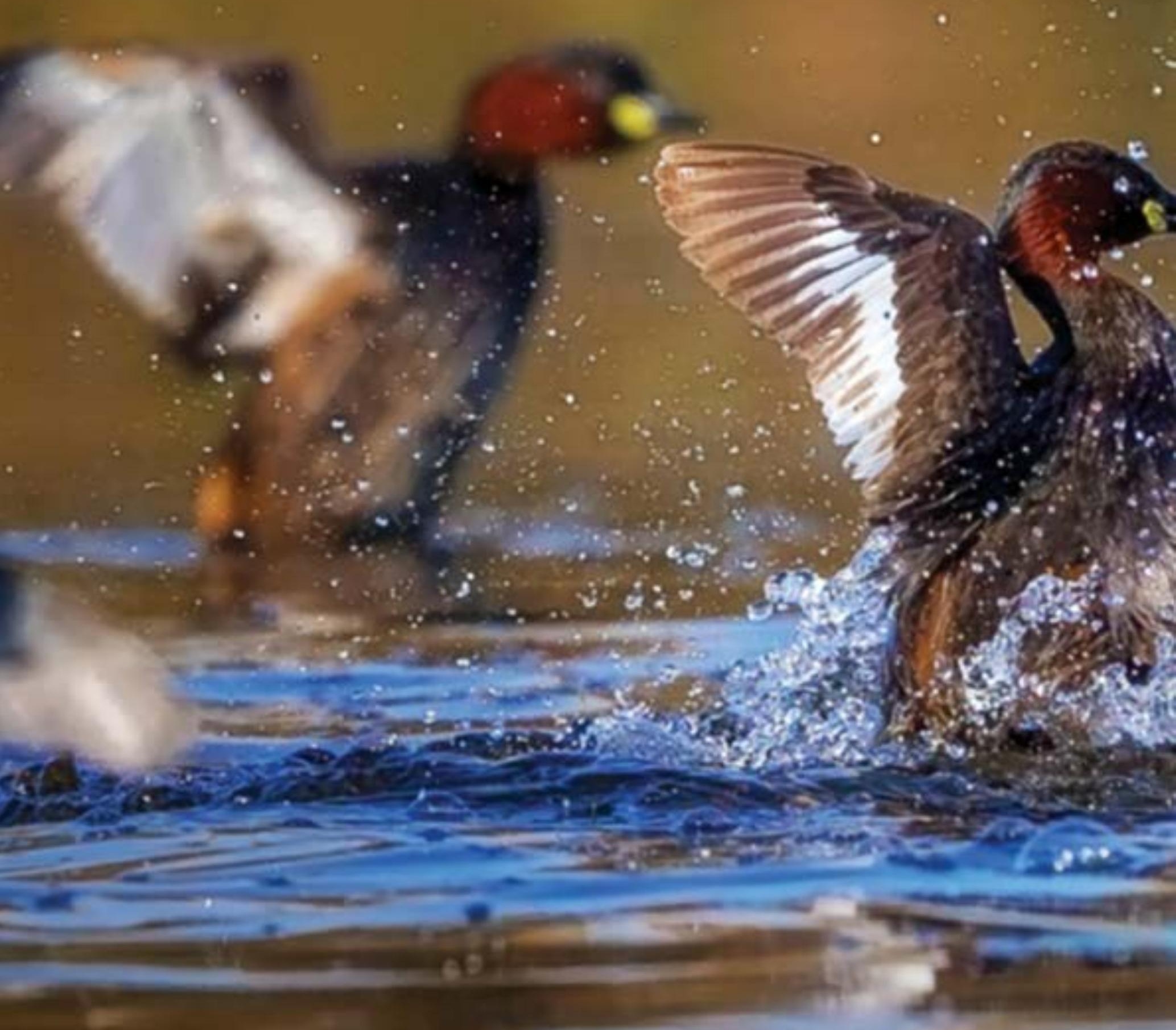



So far, 412 species, including 18 subspecies of birds in 65 families (Figures 15-19) have been recorded from Kuwait according to observations published by BirdLife International and Kuwait Birds (www.kuwaitbirds.org/birds) (Annex 1). Only 33 species are considered resident. In 2013, Al Sareea' et al (2013) listed 384 species of birds in Kuwait. Pope \& Zogaris (2012) listed 390 species and 17 subspecies in Kuwait. The most recent book on the birds of Kuwait was published by Daunicht (2018). It includes accounts and details on the conservation status for each species (Figure 14).

Several books were published on the birds of Kuwait. Local books were published on the birds of Kuwait (Table 11). The first book in Arabic and English was published by Alfadhel (2005). Gregory (2005) published at the same time his book on the birds of the Sate of Kuwait. Al Nasrallah (2011) published a book of birds of the Sabah Al-Ahmad Natural Reserve.

Table 11: Books on the birds of Kuwait in Arabic.

\begin{tabular}{|c|c|c|c|}
\hline Year & Title in Arabic & Authors & Publisher \\
\hline 1987 & طيور الكويت الربيعية & 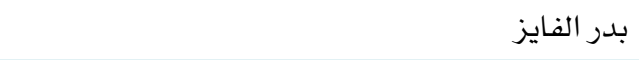 & مطابع الرسـالة، الكويت \\
\hline 1999 & 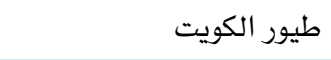 & مشعل الجريوي & 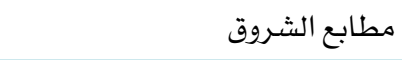 \\
\hline 2002 & طيور الكويت-ستجل مصور & عبد الله صادق الحداد و فوزية عبد العزيز السديراوي & مركز البحوث والدراسات الكويتية \\
\hline 2008 & 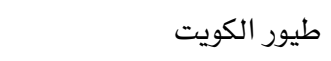 & أمل الغانم ر رسوم وإخراج فاطمة السنان & مركز البحوث والدراسـات الكويتية \\
\hline
\end{tabular}

Of the 415 bird species reported from Kuwait, 27 have IUCN conservation status (Figures 1519). The Sociable Lapwing is listed as critically endangered, Egyptian Vulture, the Saker Falcon and Basra Reed Warbler are listed as endangered, 14 are considered as near threatened while nine are vulnerable (Table 12). For regional assessment see (Symes et al., 2015).

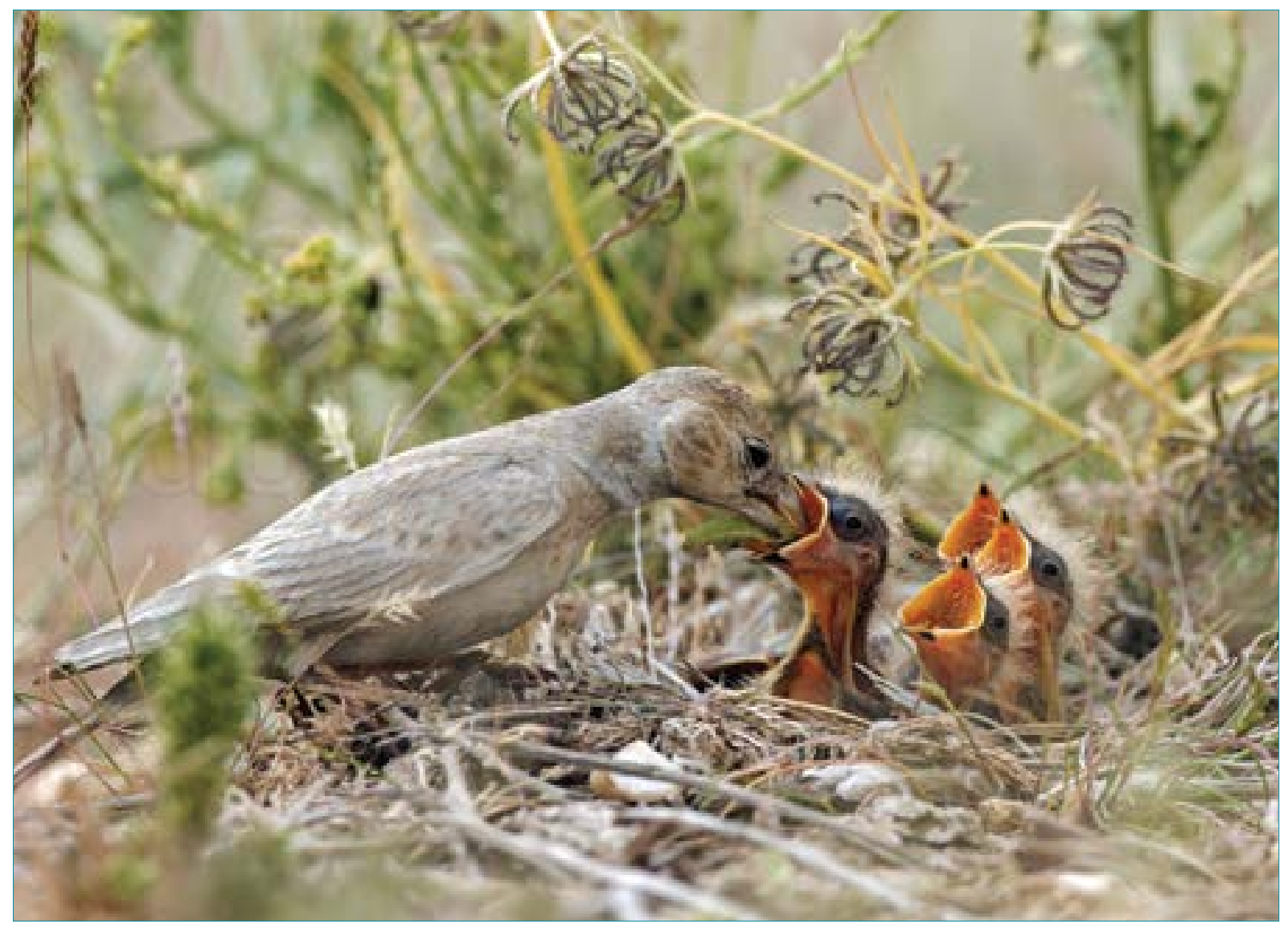

Figure 15: Birds of Kuwait. A female feeding its chicks (Photos from Abdul Al-Azizi Al Yousef). 
Table 12: Threatened and Near Threaten of birds species of Kuwait according to the IUCN Red List .

\begin{tabular}{|c|c|c|c|}
\hline Common name & Scientific name & Arabic name & IUCN status \\
\hline Ferruginous Duck & Aythya nyroca & البط الكستتائي & NT \\
\hline Marbeld Duck & Marmaronetta angustirostris & الحذف الرخامي & VU \\
\hline Long-tailed Duck & Clangula hyemalis & البط طويل الذيل & VU \\
\hline Sooty Shearwater & Puffinus griseus & جلم الماء الفاحم & NT \\
\hline Lesser Flamingo & Phoeniconaias minor & 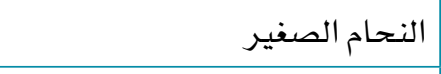 & NT \\
\hline Egyptian Vulture & Neophron percnopterus & | الرخمة المصرية & EN \\
\hline Cinereous Vulture & Aegypius monachus & 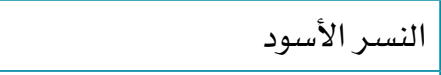 & NT \\
\hline Pallid Harrier & Circus macrourus & | ل المرزة الباهتة & NT \\
\hline Red-footed Falcon & Falco vespertinus & البزيق الشائع & NT \\
\hline Sooty Falcon & Falco concolor & الصقر الأسخم & NT \\
\hline Saker Falcon & Falco cherrug & الصقر الحر & EN \\
\hline Sociable Lapwing & Vanellus gregarius & الزقزاق الإجتماعي & CE \\
\hline Great Snipe & Gallinago media & الشنقب الكبير & NT \\
\hline Black-tailed Godwit & Limosa limosa & بقويقة سلطانية & NT \\
\hline Eurasian Curlew & Numenius arquata & كروان الماء الكبير & NT \\
\hline Black-winged Pratincole & Glareola nordmanni & أبو اليسر أسود الجناح & NT \\
\hline European Roller & Coracias garrulus & الشقراق الأوربي & NT \\
\hline Basra Reed Warbler & Acrocephalus griseldis & | دخلة القصب البصرية & EN \\
\hline Semi-collared Flycatcher & Ficedula semitorquata & خاطف الذباب شبه المطوق & NT \\
\hline Eastern Cinereous Bunting & Emberiza cineracea semenowi & بلبل الشعير السوري الشرقي & NT \\
\hline Dalmatian Pelican & Pelecanus crispus & البجعة الكدراء & VU \\
\hline Lappet-faced Vulture & Torgos tracheliotos & 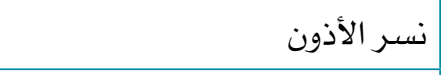 & VU \\
\hline Greater Spotted Eagle & Aquila clanga & العقاب المنقطة الكبيرة & VU \\
\hline Macqueen's Bustard & Chlamydotis macqueenii & الحبارى الآسيوية (حبارى ماكويني) & VU \\
\hline Great Knot & Calidris tenuirostris & الطيطوى الكبيرة & VU \\
\hline Socotra Cormorant & Phalacrocorax nigrogularis & غاق سقطري & VU \\
\hline
\end{tabular}



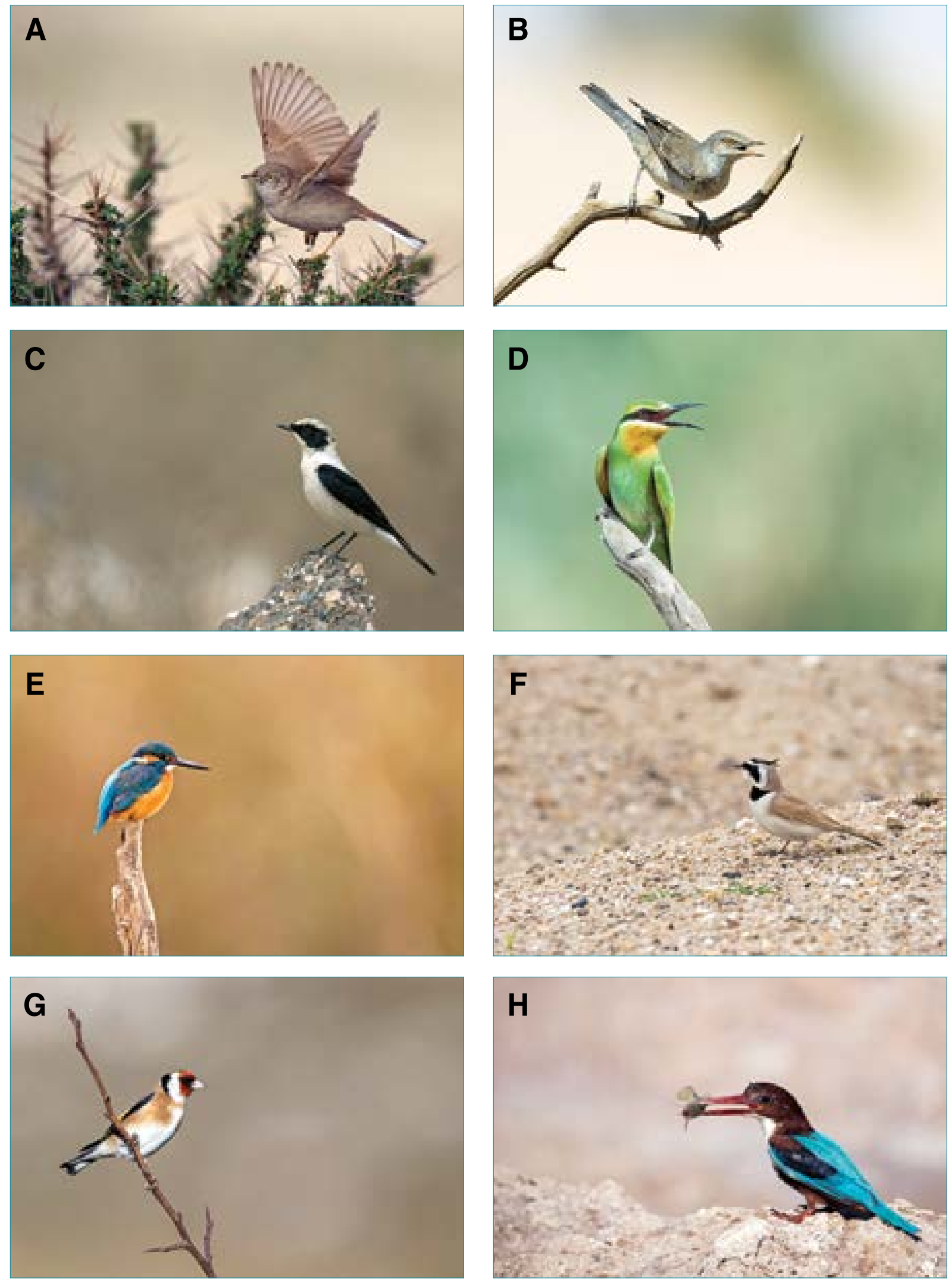

Figure 16: Some birds from Kuwait. A. The Asian desert warbler, Sylvia nana. B. Barred Warbler, Sylvia nisoria. C. Black-eared Wheatear, Oenanthe hispanica. D. Blue-cheeked Bee-eater, Merops persicus. E. Common Kingfisher, Alcedo atthis. F. Temminck's Horned Lark, Eremophila bilopha. G. Goldfinch, Carduelis carduelis. H. White-throated Kingfisher, Halcyon smyrnensis. (All photos from Abdul Al-Aziz Al Yousef). 

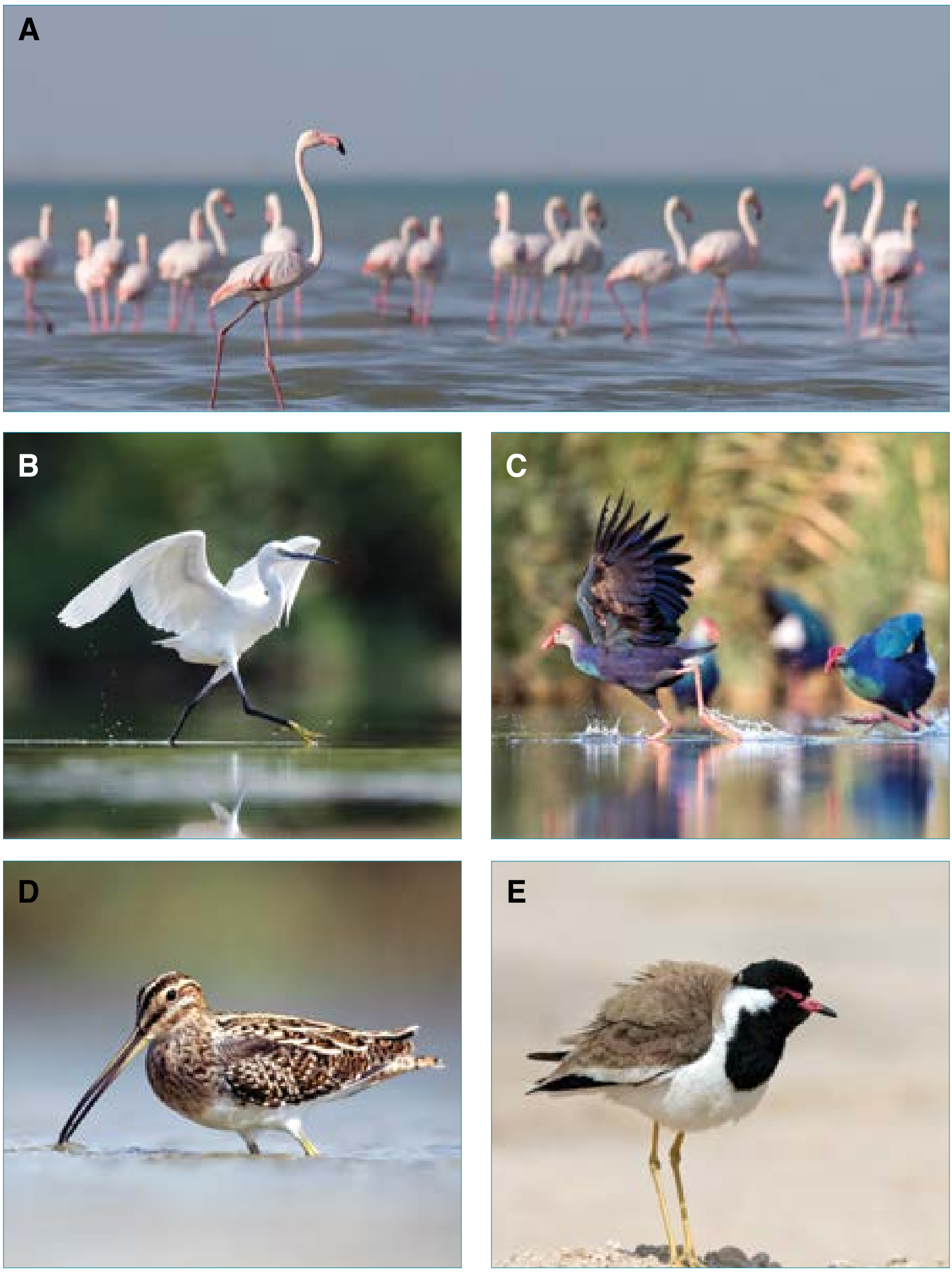

Figure 17: Some aquatic birds from Kuwait. A. Greater Flamingo, Phoenicopterus roseus. B. Little Egret, Egretta garzetta. C. Grey-headed Swamphen, Porphyrio poliocephalus. D. Great Snipe, Gallinago media. E. Red-wattled lapwing, Vanellus indicus. (All photos from Abdul Al-Aziz Al Yousef). 

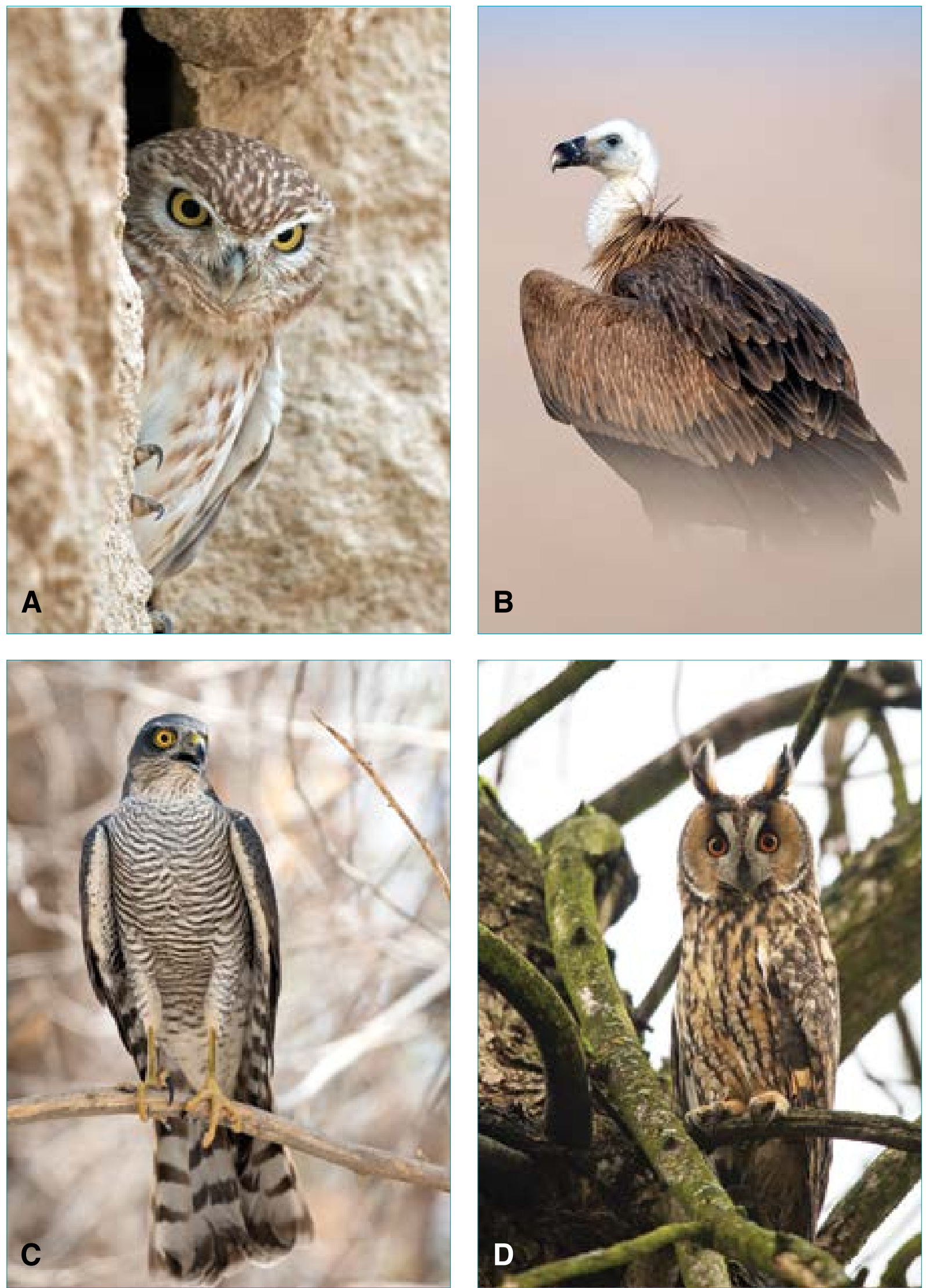

Figure 18: Some raptors from Kuwait. A. Lilith Owl, Athene noctua lilith. B. Griffon Vulture, Gyps fulvus. C. Sparrowhawk, Accipiter nisus. D. Long-eared Owl, Asio otus. (All photos from Abdul Al-Aziz Al Yousef). 


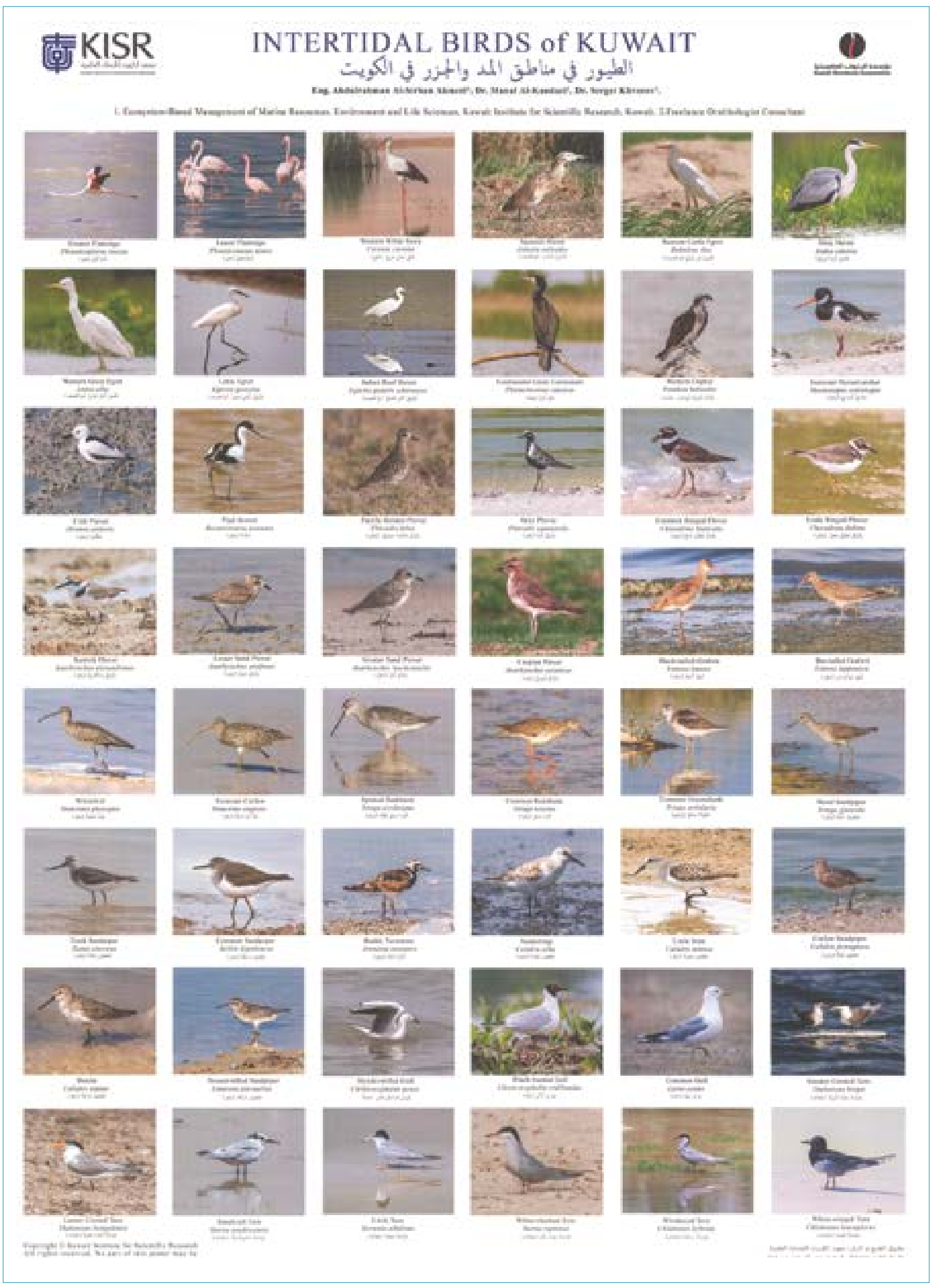

Figure 19: Some intertidal birds from Kuwait. 


\section{References}

Al Nasrallah, K., 2011. The Birds of the Sabah Al-Ahmad Natural Reserve. Kuwait.

Al-Saqer, N.A. 2003. 'Birds of the Jahra conserved area'. Journal of Arid Environments, 54: 203-207.

Bom, R.A. \& al-Nasrallah, K. 2015. 'Counts and breeding biology of Crab Plovers a Dromas ardeola on Bubiyan Islands, Kuwait, in 2012-2014'. Wader Study, 122(3): 212-220.

Bonser, R., Al-Sirhan, A., Crochet, P-A., Legrand, V., Monticelli, D. \& Pope, M. 2012. 'Birding Kuwait'. Birding World, 24: 1-18.

Brown, G. 2009. 'Observations on the cooling behaviour, and associated habitat, of four desert lark species (Alaudidae) in two areas of Kuwait'. Sandgrouse, 31:6-14.

Caulton, E. \& Keddie, D. 1989. 'Environmental conservation problems in Kuwait'. The Environmentalist, 9 (3): 219-228.

Cleere, N., Kelly, D. \& Pilcher, C.W.T. 2000. 'Results from a late autumn ringing project in Kuwait, 1995'. Ringing \& Migration, 20:186-190.

Cowan, P.J. \& Pilcher, C.W.T. 2003. 'The status of desert birds in Kuwait'. Sandgrouse 25: 122-125.

Cowan, P.J. 1990. 'The crab plover in Kuwait and the northern Arabian Gulf: a brief review and some new counts'. Ornithological Society of the Middle East Bulletin, 25: 6-9.

Daunicht, W. 2018. Birds of Kuwait. Kindle Store.

Gregory, G. 2005. The birds of the State of Kuwait. Stegness.

Gregory, G., Robertson, P. \& Thomas, B., 2001. 'Reduction of bird shooting in Kuwait'. Sandgrouse 23(1): 34-38.

Haynes, P.R. 1979. 'Notes on the status and distribution of the birds of Kuwait'. Newsletter of Ahmadi Natural History, Field Study Group, 20: 1-20.

Jennings, M.S. 2010. 'Atlas of the Breeding Birds of Arabia'. Fauna of Arabia, 25:1-751.

Kuwait Environmental Protection Society. 2012. Unjustified Shooting of Birds in Kuwait: The reality and proposed solutions. Compiled by C. Canzanella. KEPS, Kuwait.

Kuwait Oil Company. 2013. Abdelliya Preserve - Kuwait Oil Company. A photographic album produced by Omar Ali Sadeq, Mohammad Al-Dosari, Naser Faleh Alhajri, Ayman Alkanderi. 63 p.

Pilcher, C.W.T. 1992. Gulf War Pollution; befouling of Kuwait's bird species. Report to Kuwait Environment Protection Council, 148 pp.

Pilcher, C.W.T. 1994. 'Kuwait's Jahra Pool Reserve under threat'. Phoenix, 11: 18.

Pilcher, C.W.T. 1996. Spring Ringing Project 1995. Report to Kuwait Environment Council, 324 pp.

Pilcher, C. \& Shehab, M. 1994. State of Kuwait. In: Important Bird Areas of the Middle East. Evans, M. (Ed.). BirdLife Conservation Series No 2. pp 230-238. BirdLife International, Cambridge, UK.

Pope, M. \& Zogaris, S. (Eds.) 2012. Birds of Kuwait: A comprehensive visual guide. Nicosia, Cyprus. KUFPEC/ Biodiversity East.

Ramadan, E., Al-Nasrallah, K. \& Gregory, G. 2004. 'Bubiyan Island: a rich Kuwait avifauna'. Sandgrouse, 26: 23-26.

Symes, A., Taylor, J., Mallon, D., Porter, R., Simms, C. \& Budd, K. 2015. The Conservation Status and Distribution of the Breeding Birds of the Arabian Peninsula. Cambridge, UK and Gland, Switzerland: IUCN, and Sharjah, UAE: Environment and Protected Areas Authority 


\subsection{Classes Chondricthyes and Osteicthyes}

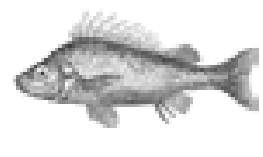

The first study to investigate the marine fishes of Kuwait was published by Kuronuma \& Abe (1972) (Figure 20). They listed 130 species of marine fishes. This was followed by a number of books and papers (Al-Hassan et al., 1988; Bishop \& Abdul-Ghaffar, 1993; Al-Baz et. al., 1999); including the illustrated books of Carpenter et al. (1997a \& b),

Other papers discussed commercial fishing in Kuwait (Hussain \& Abdullah, 1977; Mathews \& Samuel, 1985; Morgan 1985a \& b; Samuel \& Bawazeer,1985; Mathews \& Samuel, 1987; Samuel et al., 1987; Bawazeer, 1987a \& b, 1989; Abou-Seedo, 1992; Chen et al., 2012a \& b; Moore et al., 2012; Ye et al., 2000), reproductive biology and ecology (Abu-Hakima, 1987; Baddar, 1987; Mathews \& Samuel 1987; Samuel \& Mathews, 1985; Samuel \& Mathews, 1987; Wright, 1988, 1989a, b \& C, 1990; Ismail \& Clayton, 1990; Randall, 1994; Randall et al., 1994; Al-Baz \& Grove, 1995; Dadzie et al., 1998, 2000a, b \& c; Ismail et al., 1998; Al-Yamani et al., 1999; Almatar et al., 2000; Al-Husaini et al., 2001; Bishop et al., 2016); and the biology of mudskippers (Clayton, 1987; Clayton \& Vaughan, 1982, 1986 \& 1988, Clayton \& Wright, 1989; Wright et al., 1990 \& 1996; Al-Behbehani \& Ebrahim, 2010). The coral reef fishes of Kuwait were studied extensively along with the corals of Kuwait (Harrison et al., 1997; Downing, 1989a, b, c \& d; Downing et al., 1989; Literathy et al., 1989).
Based on Bishop (2003) and Moore et al. (2010), the Kuwait ichthyofaunal checklist includes 348 species belonging to 95 families (Annex 2). Sharks and rays are represented by 3027 species respectively (including three unidentified species of rays, while bony fishes (Actinopterygii) accounts for 305 species. Thirty-five families are represented by a single species only, and 20 families are represented by just two species. The most common fish families is the Carangidae with 32 species, followed by family Gobidae with 26 species. Clupeids are represented by 11 species and include the seasonally popular anadromous Hilshashad (Tenualosailisha). Kuwait's seabreams (Sparidae family) number 10 species and include the popular species sobaity (Sparidentex hasta) and sheim (Acanthopagrus latus). Wrasses (Family: Labridae) are also represented by 10 species. Kuwait's snappers (Family: Lutjanidae), of which the hamra is a member, number nine, and the number of blennies (Family: Blennidae) and grunts (Family: Haemulidae) stands at eight species each. The grouper family (Serranidae), of which the hamour is a member, has seven species in Kuwait. Zobaidy (Pampus argenteus) is Kuwait's sole representative of the Stromiteidae family (Bishop, 2003). The sharks of Kuwait and the Arabian Gulf were studied extensively (Goubanov \& Shleib, 1980; Randall, 1986; Moore et al. 2007; Almojil et al. 2015, Jabado \& Ebert, 2015, Almojil, 2016; Almojil et al. 2018).
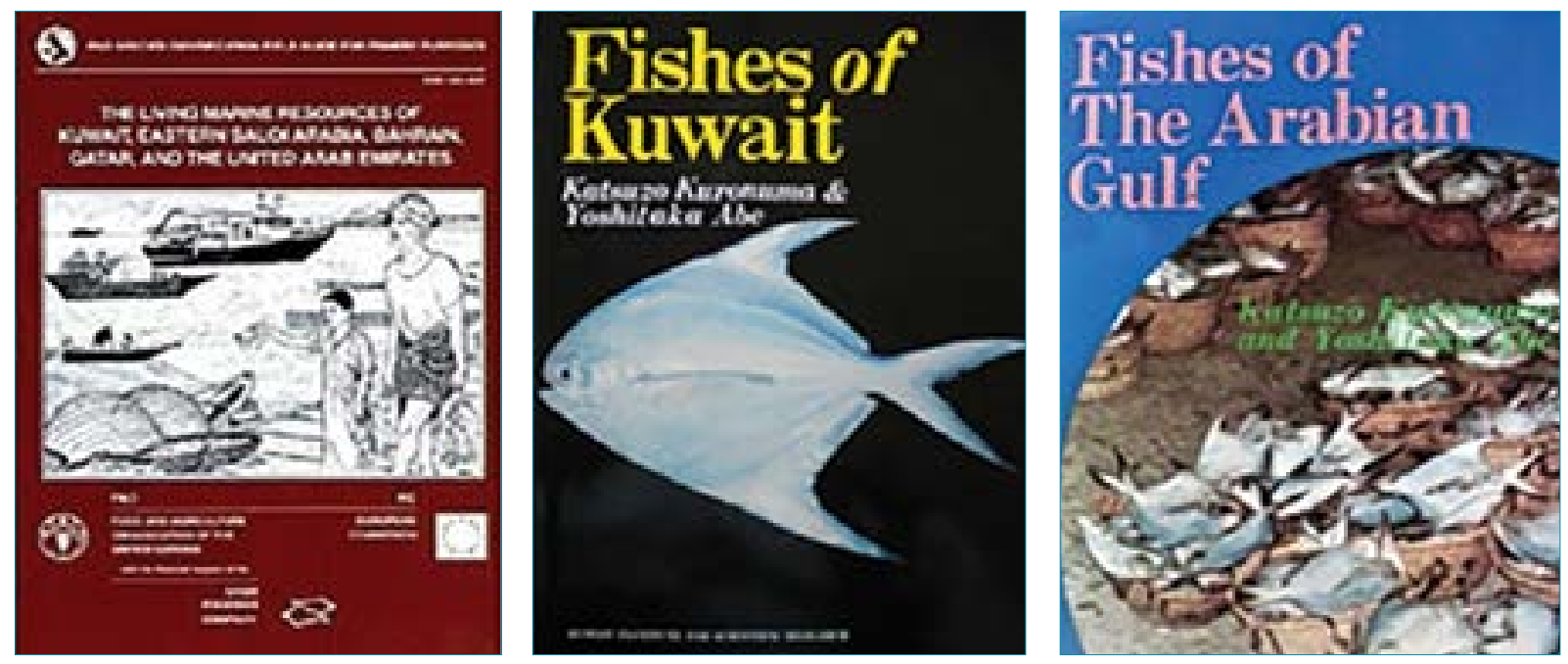

Figure 20: Main books on the fishes of Kuwait. 

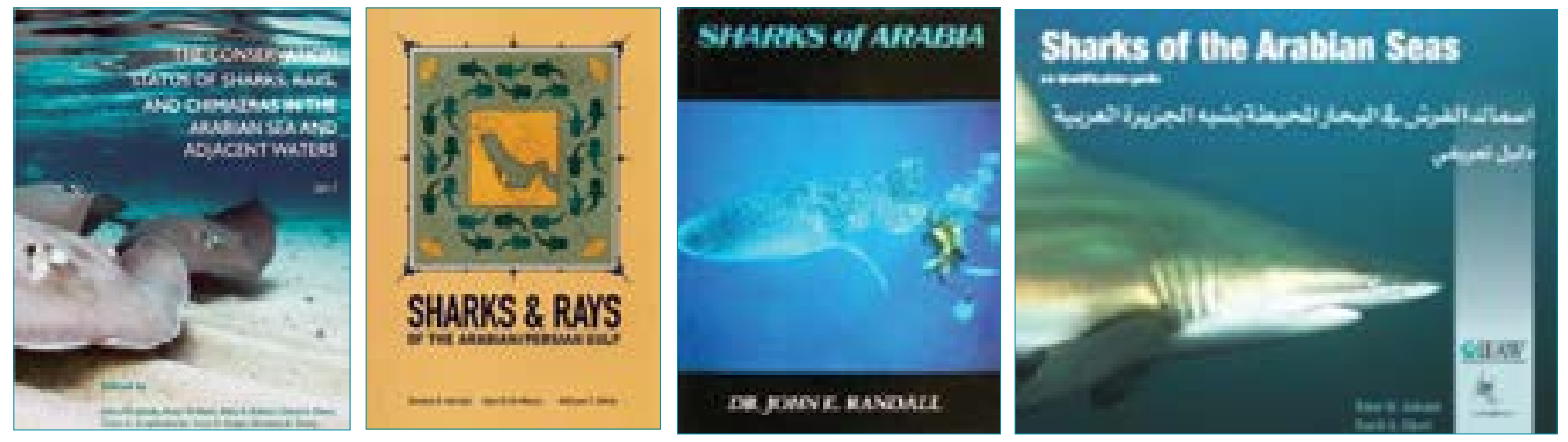

Figure 21: Books on sharks of the Arabian Gulf.

Jabado et al. (2017) gave an outstanding account on the conservation status of sharks, rays, and chimaeras in the Arabian Sea (Figure 21). It includes both the global and regional

assessment for these taxa (Table 13-14). Moore (2017) discussed the extinction risk and the need for urgent conservation action guitarfishes.
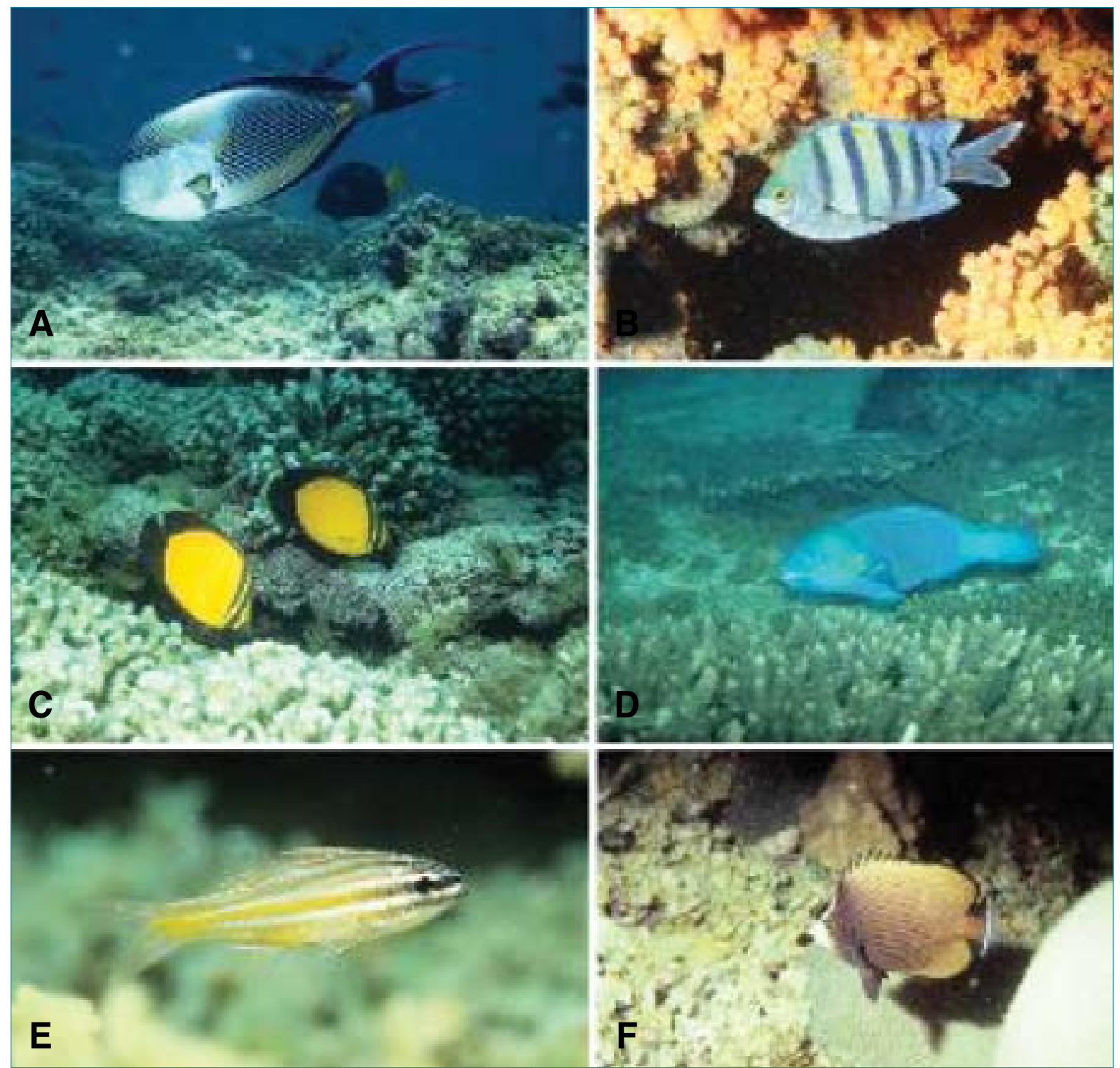

Figure 22: Coral fishes from the Arabian Gulf. A. Acanthurus sohal. B. Abudefduf vaigiensis. C. Chaetodon melapterus. D. Chlorurus sordidus. E. Apogon cyanosoma. F. Chaetodon nigropunctatus. (All photos from F. Krupp) 
Table 13: IUCN Conservation status of sharks in Kuwait and the Arabian Gulf.

\begin{tabular}{|c|c|c|c|c|c|}
\hline \multirow[b]{2}{*}{ Family } & \multirow[b]{2}{*}{ Species } & \multirow[b]{2}{*}{ Common name } & \multicolumn{2}{|c|}{ IUCN } & \multirow{2}{*}{$\begin{array}{l}\text { Trend } \\
\text { (Global) }\end{array}$} \\
\hline & & & $\begin{array}{l}\text { Global } \\
\text { Status }\end{array}$ & $\begin{array}{c}\text { Regional } \\
\text { Status }\end{array}$ & \\
\hline \multirow[t]{19}{*}{ Carcharhinidae } & Carcharhinus amblyrhynchoides & Graceful Shark & NT & VU & unknown \\
\hline & Carcharhinus amblyrhynchos & Grey Reef Shark & NT & EN & unknown \\
\hline & Carcharhinus amboinensis & Pigeye Shark & DD & VU & unknown \\
\hline & Carcharhinus brevipinna & Spinner Shark & NT & VU & unknown \\
\hline & Carcharhinus dussumieri & Whitecheek Shark & NT & EN & decreasing \\
\hline & Carcharhinus falciformis & Silky Shark & NT & NT & decreasing \\
\hline & Carcharhinus humani & Human's Whaler Shark & NE & DD & unknown \\
\hline & Carcharhinus leiodon & Smoothtooth Blacktip Shark & EN & & decreasing \\
\hline & Carcharhinus limbatus & Blacktip Shark & NT & VU & unknown \\
\hline & Carcharhinus leucas & Bull Shark & NT & EN & unknown \\
\hline & Carcharhinus macloti & Hardnose Shark & NT & NT & unknown \\
\hline & Carcharhinus melanopterus & Blacktip Reef Shark & NT & VU & decreasing \\
\hline & Carcharhinus plumbeus & Sandbar Shark & VU & EN & decreasing \\
\hline & Carcharhinus sorrah & Spottail Shark & NT & VU & unknown \\
\hline & Galeocerdo cuvier & Tiger Shark & NT & VU & decreasing \\
\hline & Loxodon macrorhinus & Sliteye Shark & LC & NT & unknown \\
\hline & Negaprion acutidens & Sicklefin Lemon Shark & VU & EN & decreasing \\
\hline & Rhizoprionodon acutus & Milk Shark & LC & NT & unknown \\
\hline & Rhizoprionodon oligolinx & Grey Sharpnose Shark & LC & NT & unknown \\
\hline \multirow[t]{3}{*}{ Hemigaleidae } & Chaenogaleus macrostoma & Hooktooth Shark & VU & VU & unknown \\
\hline & Hemipristis elongata & Snaggletooth Shark & VU & VU & decreasing \\
\hline & Paragaleus randalli & Slender Weasel Shark & NT & VU & unknown \\
\hline \multirow[t]{2}{*}{ Sphyrnidae } & Sphyrna lewini & Scalloped Hammerhead & EN & EN & unknown \\
\hline & Sphyrna mokarran & Great Hammerhead & EN & EN & decreasing \\
\hline Ginglymostomatidae & Nebrius ferrugineus & Tawny Nurse Shark & VU & NT & decreasing \\
\hline Hemiscylliidae & Chiloscyllium arabicum & Arabian Carpetshark & NT & & decreasing \\
\hline Odontaspididae & Carcharias taurus & Sandtiger Shark & VU & $\mathrm{CR}$ & unknown \\
\hline Rhincodontidae & Rhincodon typus & Whale Shark & EN & EN & decreasing \\
\hline Stegostomidae & Stegostoma fasciatum & Zebra Shark & EN & VU & decreasing \\
\hline Triakidae & Mustelus mosis & Arabian Smoothhound & DD & LC & unknown \\
\hline
\end{tabular}


Table 14: IUCN Conservation status of rays and guitarfishs in Kuwait and the Arabian Gulf.

\begin{tabular}{|c|c|c|c|c|c|}
\hline \multirow[b]{2}{*}{ Family } & \multirow[b]{2}{*}{ Species } & \multirow[b]{2}{*}{ Common name } & \multicolumn{2}{|c|}{ IUCN } & \multirow{2}{*}{$\begin{array}{l}\text { Trend } \\
\text { ((Global }\end{array}$} \\
\hline & & & $\begin{array}{l}\text { Global } \\
\text { Status }\end{array}$ & $\begin{array}{l}\text { Regional } \\
\text { Status }\end{array}$ & \\
\hline \multirow[t]{2}{*}{ Aetobatidae } & Aetobatus flagellum & Eagle Ray & EN & EN & decreasing \\
\hline & Aetobatus ocellatus & Spotted Eagle Ray & VU & VU & decreasing \\
\hline \multirow[t]{6}{*}{ Dasyatidae } & Brevitrygon walga & Scaly Whipray & NT & & decreasing \\
\hline & Megatrygon microps & Smalleye Stingray & DD & VU & unknown \\
\hline & Maculabatis randalli & Arabian Banded Whipray & LC & & stable \\
\hline & Himantura uarnak & Reticulate Whipray & VU & VU & decreasing \\
\hline & Pastinachus sephen & Cowtail Ray & NT & & decreasing \\
\hline & Taeniurops meyeni & Blotched Fantail Ray & VU & NT & decreasing \\
\hline Gymnuridae & Gymnura poecilura & Longtail Butterfly Ray & NT & NT & decreasing \\
\hline \multirow[t]{2}{*}{ Myliobatidae } & Aetomylaeus nichofi & Banded Eagle Ray & VU & VU & decreasing \\
\hline & Aetomylaeus milvus & Ocellate Eagle Ray & EN & & decreasing \\
\hline \multirow[t]{4}{*}{ Mobulidae } & Mobula eregoodootenkee & Longhorned Pygmy Devil Ray & NT & NT & unknown \\
\hline & Mobula kuhlii & Shortfin Devilray & DD & NT & decreasing \\
\hline & Glaucostegus granulatus & Sharpnose Guitarfish & CR & EN & decreasing \\
\hline & Glaucostegus halavi & Halavi Guitarfish & $\mathrm{CR}$ & & decreasing \\
\hline \multirow[t]{3}{*}{ Rhinidae } & Rhina ancylostoma & Bowmouth Guitarfish & CR & VU & decreasing \\
\hline & Rhynchobatus djiddensis & Whitespotted Wedgefish & $\mathrm{CR}$ & EN & decreasing \\
\hline & Rhynchobatus laevis & Smoothnose Wedgefish & $\mathrm{CR}$ & EN & decreasing \\
\hline \multirow[t]{2}{*}{ Rhinobatidae } & Rhinobatos punctifer & Spotted Guitarfish & NT & & decreasing \\
\hline & Rhinoptera jayakari & Oman Cownose Ray & NE & EN & \\
\hline \multirow[t]{2}{*}{ Pristidae } & Pristis zijsron & Green Sawfish & CR & CR & decreasing \\
\hline & Anoxypristis cuspidata & Narrow Sawfish & ED & CR & decreasing \\
\hline \multirow[t]{2}{*}{ Torpedinidae } & Torpedo panthera & Panther Torpedo & DD & DD & unknown \\
\hline & Torpedo sinuspersici & Marbled Electric Ray & DD & DD & unknown \\
\hline
\end{tabular}

Buchanan et al. (2016) identified fishes that are coral-dependent in the Arabian Gulf; including their regional distribution, population status, life history characteristics, and major threats that affects their likelihood of extinction (Figure 23). Recently, Buchanan et al. (2019) evaluated the regional conservation status of 471 species of bony marine fishes in the Arabian Gulf. Major threats are related to coral dependent and coral associated species, fisheries and restricted range (Table 15). 


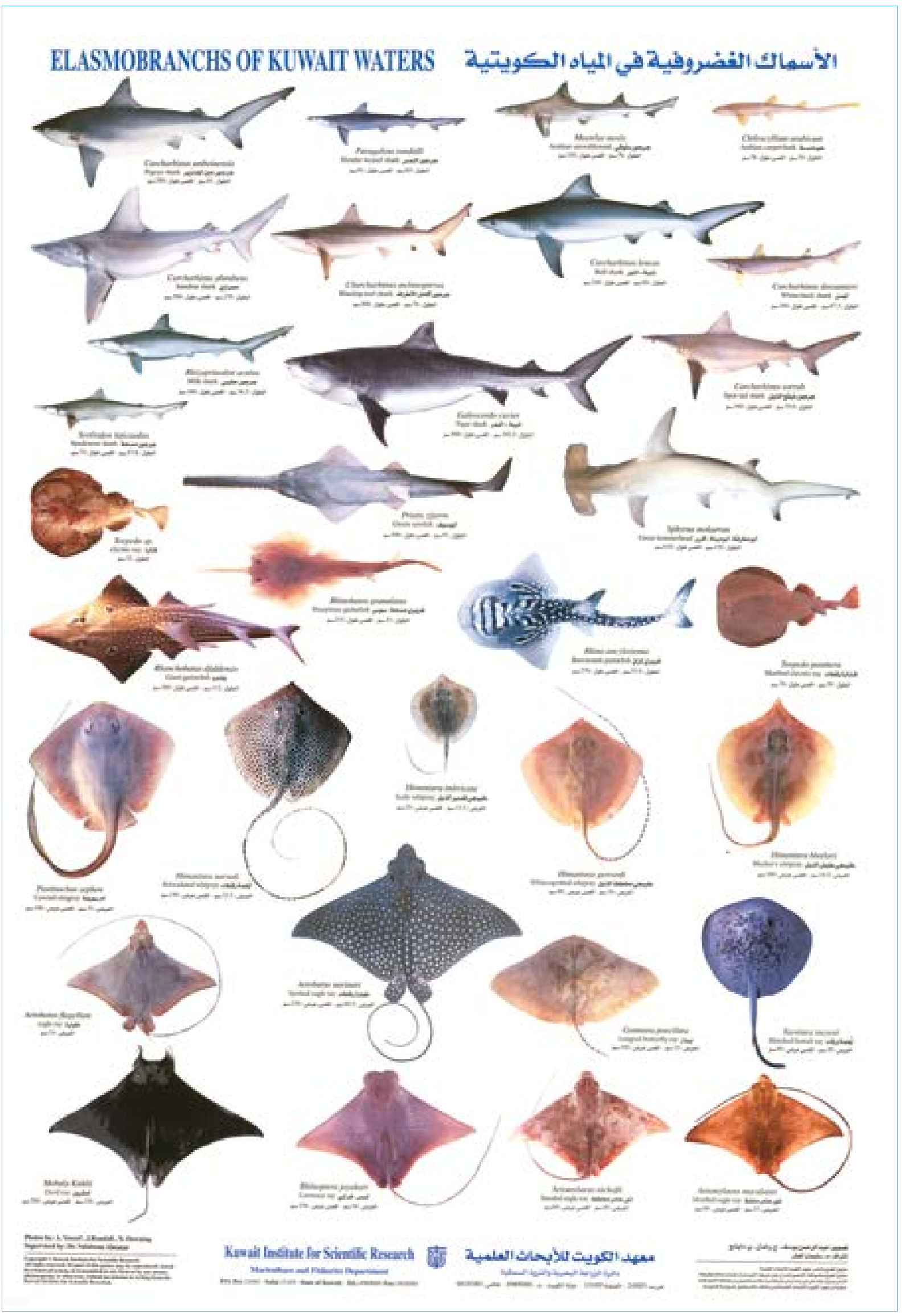

Figure 23: Some cartilaginous fish of Kuwait. 


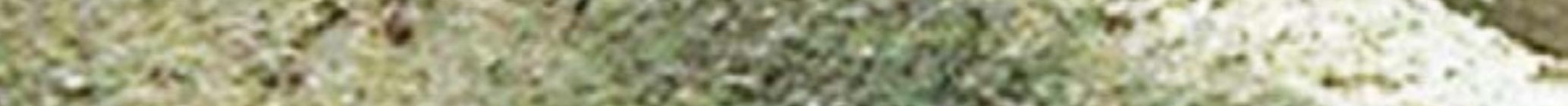

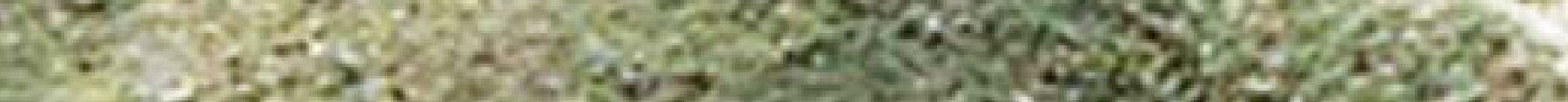

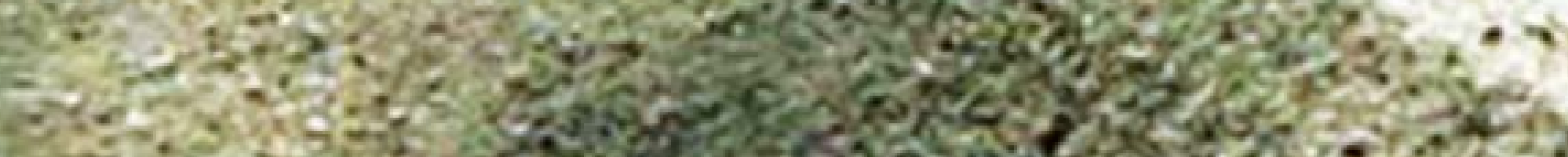

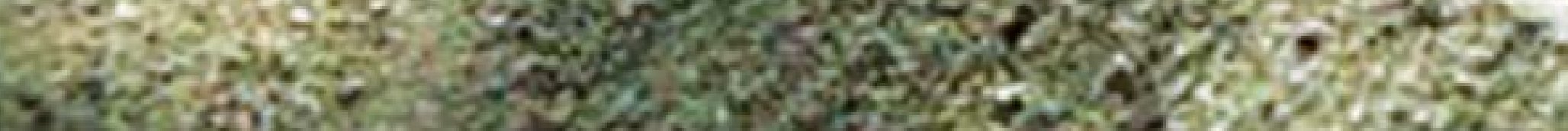

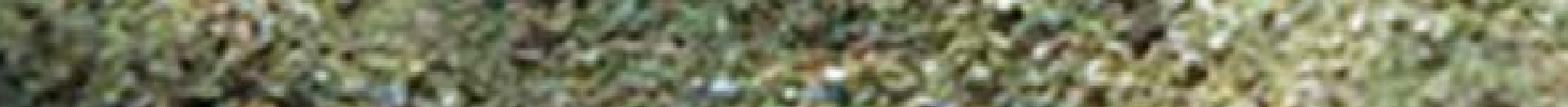

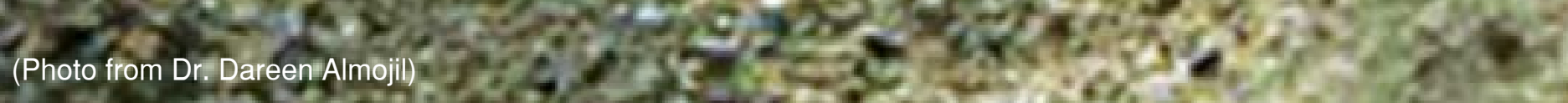

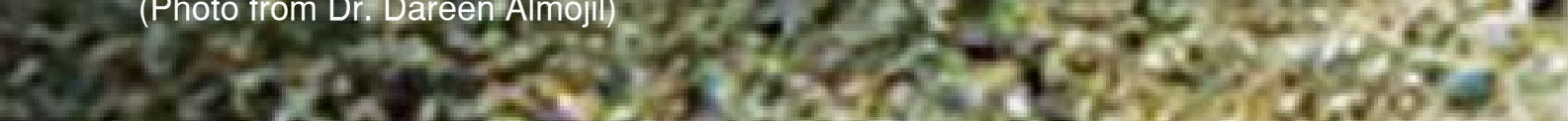

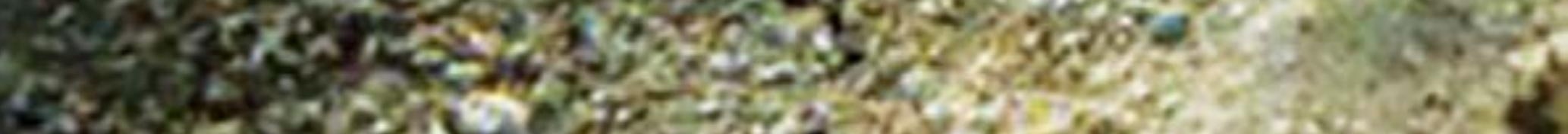




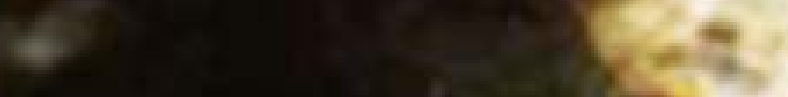

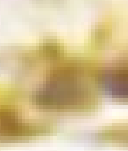
$\cos 20$ $+2+2$

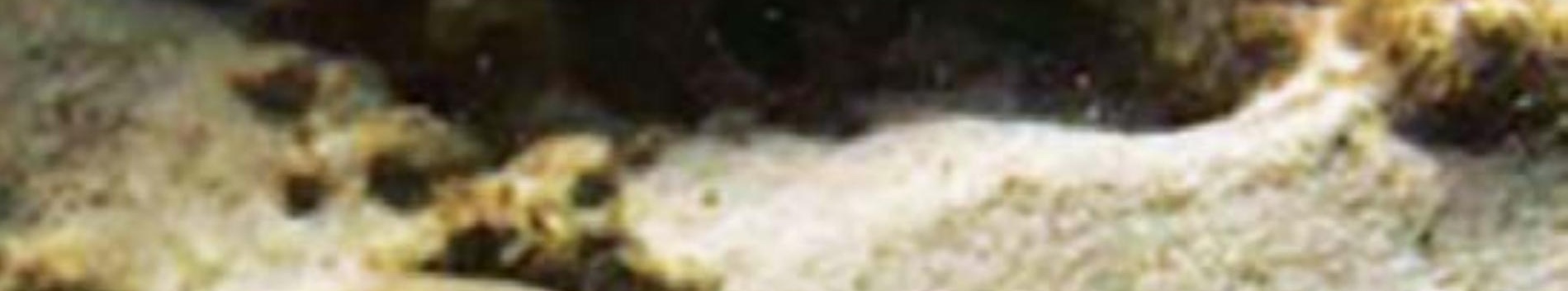
$x^{2}=1$

$+$

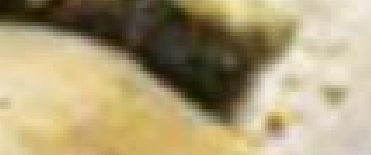

8

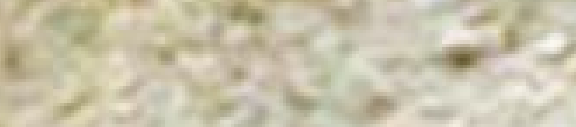

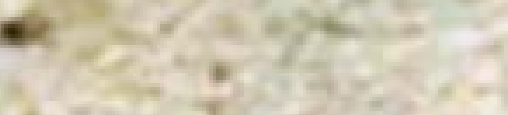

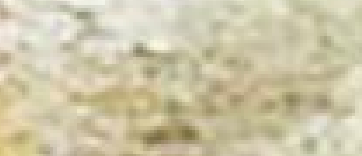

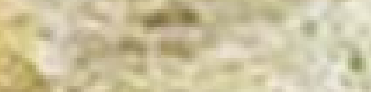

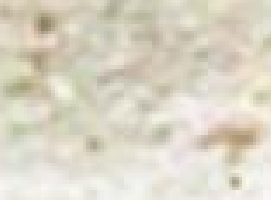

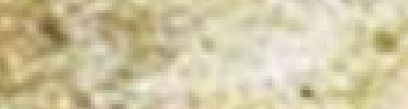

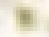

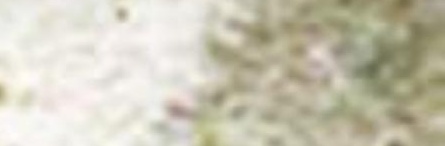

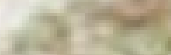

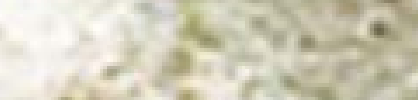

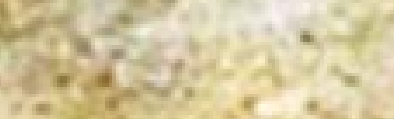

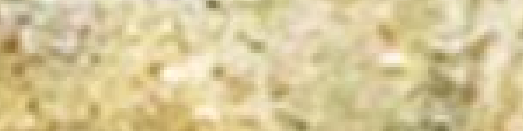

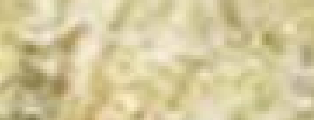

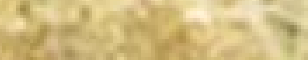

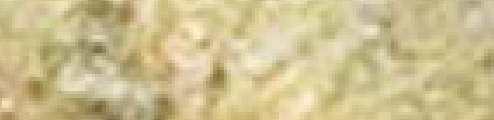

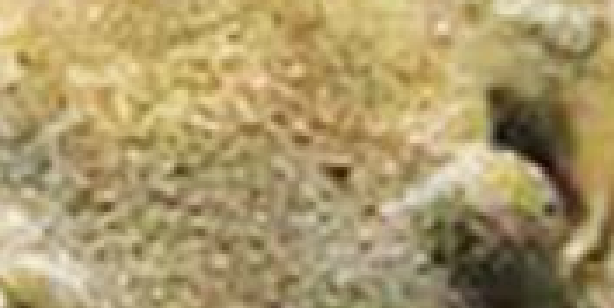

-

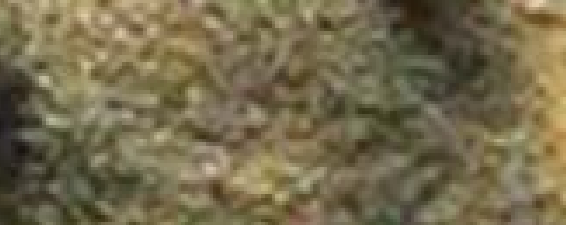

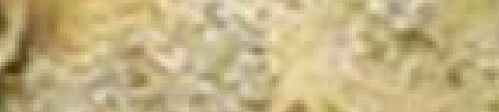

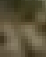

ansisis

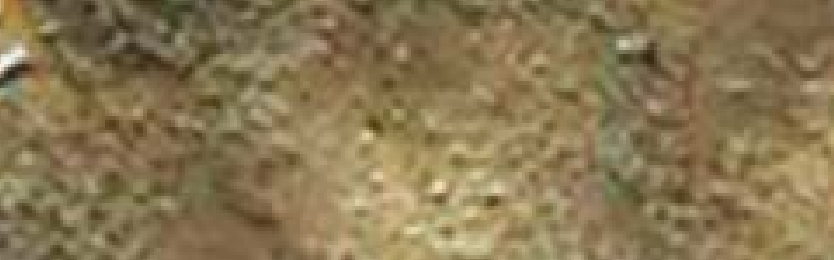

$3, y=-1$

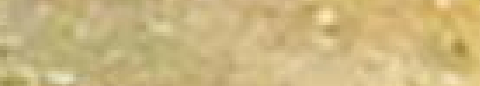

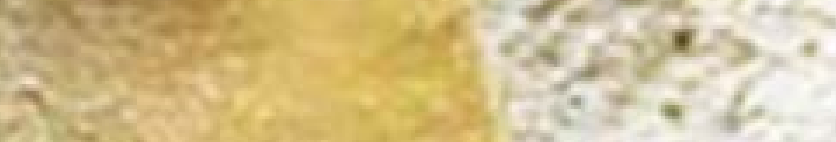

6.t.

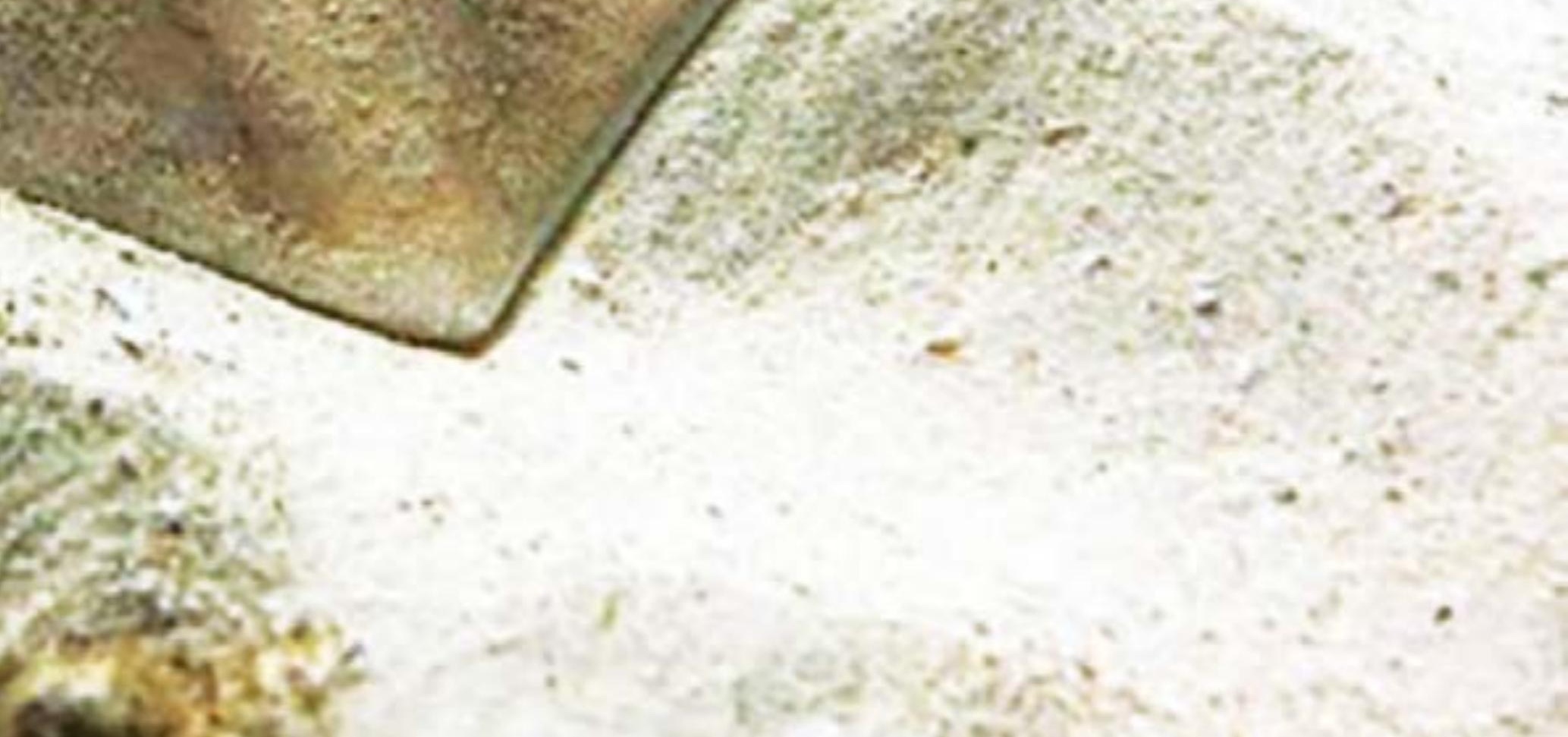


Table 15: Regionally threatened marine bony fishes in the Gulf.

\begin{tabular}{|c|c|c|c|}
\hline Family & Species & IUCN status & Cause of threat \\
\hline \multirow[t]{2}{*}{ Acanthuridae } & Acanthurus sohal & VU & Coral dependent \\
\hline & Zebrasoma xanthurum & VU & Coral dependent \\
\hline \multirow[t]{2}{*}{ Blenniidae } & Alticus kirkii & VU & Restricted range \\
\hline & Omobranchus mekranensis & VU & Restricted range \\
\hline \multirow[t]{2}{*}{ Caesionidae } & Caesio lunaris & VU & Coral associated \\
\hline & Caesio varilineata & VU & Coral associated \\
\hline \multirow[t]{3}{*}{ Chaetodontidae } & Chaetodon melapterus & VU & Coral dependent \\
\hline & Chaetodon nigropunctatus & VU & Coral dependent \\
\hline & Heniochus acuminatus & VU & Coral dependent \\
\hline \multirow[t]{2}{*}{ Gobiidae } & Gobiodon citrinus & EN & Coral dependent \\
\hline & Gobiodon reticulatus & VU & Coral dependent \\
\hline \multirow[t]{5}{*}{ Labridae } & Scarus ghobban & EN & Coral dependent \\
\hline & Chlorurus sordidus & VU & Coral dependent \\
\hline & Halichoeres marginatus & VU & Coral dependent \\
\hline & Scarus ferrugineus & VU & Coral dependent \\
\hline & Scarus persicus & VU & Coral dependent \\
\hline Mugilidae & Liza klunzingeri & VU & Fisheries \\
\hline Polynemidae & Eleutheronema tetradactylum & EN & Fisheries \\
\hline \multirow[t]{9}{*}{ Pomacentridae } & Abudefduf vaigiensis & VU & Coral dependent \\
\hline & Amphiprion clarkii & EN & Coral dependent \\
\hline & Chromis flavaxilla & VU & Coral dependent \\
\hline & Chromis xanthopterygia & EN & Coral dependent \\
\hline & Dascyllus trimaculatus & VU & Coral dependent \\
\hline & Neopomacentrus cyanomos & VU & Coral dependent \\
\hline & Pomacentrus aquilus & EN & Coral dependent \\
\hline & Pomacentrus leptus & EN & Coral dependent \\
\hline & Pomacentrus trichourus & EN & Coral dependent \\
\hline Sciaenidae & Otolithes ruber & VU & Fisheries \\
\hline Scombridae & Scomberomorus commerson & VU & Fisheries \\
\hline Stromateidae & Pampus argenteus & VU & Fisheries \\
\hline
\end{tabular}

Grabe et al. (1992) identified 50 larval fish taxa from Kuwait's waters. They found dominant families to be Sparidae-type larvae, in addition to larvae of clupeids and gobies. The predominant families of fish larvae in the western Arabian Gulf according to Houde et al. (1986) were Engrauilidae, Gobiidae and Clupeidae, which accounted collectively for about $42.5 \%$ of all fish larvae collected. A total of 53 families of fish larvae were identified, including 41 genera, 24 species and 84 specific types of larvae. Houde et al. (1986) described the spatial and temporal distribution of larval fish in Kuwait's waters. They found a distinct seasonal abundance in the occurrence of larval fish. Most fishes were found to spawn in Kuwait's waters during warm months from late 
spring to early fall. Most of the spawning was by the abundant Engraulidae (anchovies), Gobiidae (gobies) and Clupeidae (herrings). The number of fish larvae taxa and total larval abundance in
Kuwait Bay peaked during late spring and were lowest in winter (Grabe et al., 1992). Important winter spawners included Haemulidae (grunts), Mugilidae (mullet) and Soleidae (flatfish).

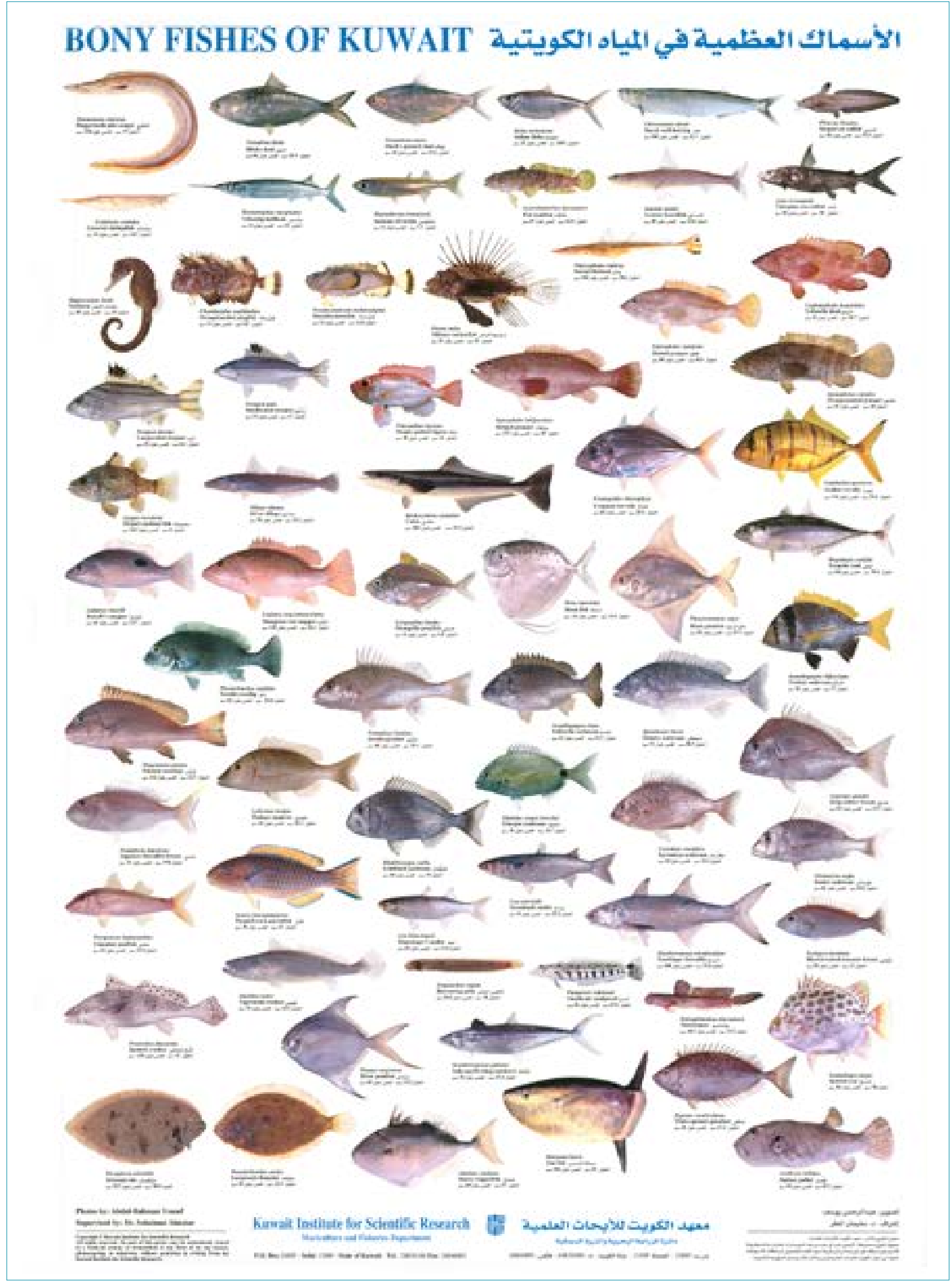

Figure 24: Some boney fishes from Kuwait. 


\section{Reference}

Abou-Seedo, F.S. (1992). 'Abundance of fish caught by stake-traps (hadra) in the intertidal zone in Doha, Kuwait Bay'. Journal of the University of Kuwait (Science) 19: 91-99.

Abu-Hakima, R. (1987). 'Aspects of the reproductive biology of the grouper, Epinephelus tauvina (Forskasl), in Kuwait waters'.Journal of Fish Biology 30: 213-222.doi. org/10.1111/j.1095-8649.1987.tb05746.x

Al-Baz, A.F. and Grove, D.J. (1995). 'Population biology of sbour Tenualosa ilisha (Hamilton-Buchanan) in Kuwait'. Asian Fisheries Science 8: 239-254.

Al-Baz, A.F., Bishop, J.M. and Hamza, B. (1999). 'First Arabian Gulf records of Molidae from Kuwait'. Kuwait Journal of Science \& Engineering 26: 315-320.

Al-Behbehani, B.E. and Ebrahim, H.M.A. (2010). "Environmental studies on the mudskippers in the intertidal zone of Kuwait Bay'. Nature \& Science 8:5.

Al-Hassan, J.M., Clayton, D.A., Thompson, M. and Criddle, R.S. (1988). 'Taxonomy and distribution of ariid catfishes from the Arabian Gulf '. Journal of Natural History 22: 473-487.doi. org/10.1080/00222938800770331

Al-Husaini, M., Al-Ayoub, S. and Dashti, J. (2001).'Age validation of nagroor, Pomadasys kaakan (Cuvier, 1830) (Family: Haemulidae) in Kuwaiti waters'. Fisheries Research 53: 71-81.doi. org/10.1016/S0165-7836(00)00268-X

Almojil, D., Moore, A. B. and White, W.T. (2015). Sharks and rays of the Arabian/Persian Gulf. MBG (INT) Ltd.

Almojil, D. (2016). 'Conservation of two reef shark species along the Arabian coasts: insights from fishermens' knowledge and molecular tools'. PhD thesis. Cambridge: University of Cambridge.

Almojil, D., Cliff, G. and Spaet, J.L. (2018). 'Weak population structure of the Spot-tail shark Carcharhinus sorrah and the Blacktip shark $C$. limbatus along the coasts of the Arabian Peninsula, Pakistan, and South Africa'. Ecology \& evolution 8: 9536-9549.doi.org/10.1002/ece3.4468

Almatar, S., Al-Abdul Elah, K. and Abu-Rezq, T. (2000). 'Larval developmental stages of laboratory-reared silver pomfret, Pampus argenteus'. Ichthyological Research 47: 137-141.doi. 10.1007/ BF02684233

Al-Yamani, F., Bishop, J., Al-Hossaini, M., Subba Rao, D.V., Al-Attar, M., Sulman, M., AbdelJawad, M., Al-Tabtabaei, M., Behbahani, M. and Morgan, G.R. (1999). Development study for the optimal utilization of the marine environment. Task 2. Current and planned utilization and management of Kuwait's marine environment. Kuwait Institute for Scientific Research, Report No. KISR5511, Kuwait.

Baddar, M.K. (1987). 'A preliminary study of the population dynamics of a sheiry, the starry pigface bream'. Kuwait Bulletin of Marine Science 9: 215-220.

Bawazeer, A.S. (1987a). 'The fishery biology and management of the stock of chim, the giant sea catfish Arius thalassinus in Kuwait waters'. Kuwait Bulletin of Marine Science 9: 87-100.

Bawazeer, A.S. (1987b). 'Stock assessment of the largetoothed flounder (khoffah, Pseudorhombus arsius) in Kuwait waters'. Kuwait Bulletin of Marine Science 9: 207-214.

Bawazeer, A.S. (1989). 'The stock and fishery biology of Indian flathead (wahar) Platcephalus indicus (Linnaeus), Family Platycephalidae in Kuwait waters'. Kuwait Bulletin of Marine Science 10: 169-178.

Bishop, J.M. (2003). 'History and current checklist of Kuwait's ichthyofauna'. Journal of Arid Environments 54: 237-256.doi.org/10.1006/jare.2001.0874

Bishop, J.M., Moore, A.B.M., Alsaffar, A.H. and Abdul-Ghaffar, A.R. (2016). 'The distribution, diversity and abundance of elasmobranchs in a modified subtropical estuarine system in Kuwait'. Journal of Applied Ichthyology 32: 75-82. doi.org/10.1111/jai.12980

Bishop, J.M. and Abdul-Ghaffar, A.R. (1993). 'Whale shark observations off Kuwait's coast in 1992'. Journal of Fish Biology 43: 939-940.

Buchanan, J.R., Krupp, F., Burt, J.A., Feary, D.A., Ralph, G.M. and Carpenter, K.E. (2016). 'Living on the edge: Vulnerability of coral-dependent fishes in the Gulf'. Marine Pollution Bulletin 105: 480-488. doi.org/10.1016/j.marpolbul.2015.11.033 
Buchanan, J.R., et al. (2019). 'Regional extinction risks for marine bony fishes occurring in the Persian/ Arabian Gulf'. Biological Conservation 230:10-19. doi.org/10.1016/j.biocon.2018.11.027

Carpenter, K.E., Krupp, F., Jones, D.A. and Zajonz, U. (1997a). Living Marine Resources of Kuwait, Eastern Saudi Arabia, Bahrain, Qatar, and the United Arab Emirates. FAO species identification field guide for fishery purposes. Rome, Italy: Food and Agriculture Organization of the United Nations.

Carpenter, K.E., Harrison, P.L., Hodgson, G., Alsaffar, A.H. and Alhazeem, S.H. (1997b). The Corals and Coral Reef Fishes of Kuwait, pp 166. Safat, Kuwait: Kuwait Institute for Scientific Research and the Environment Public Authority.

Chen, W., Al-Baz, A., Bishop, J.M. and Al-Husaini, M. (2012a). 'Field experiments to improve the efficacy of gargoor (fish trap) fishery in Kuwait's waters'. Chinese Journal of Oceanology and Limnology 30: 535-546. doi.org/10.1007/s00343-012-1212-x

Chen, W., Almatar, S., Alsaffar, A. and Yousef, A.R. (2012b). 'Retained and discarded by catch from Kuwait's shrimp fishery'. Aquatic Science \& Technology 1: 86-100. doi.org/10.5296/ast.v111.2778

Clayton, D.A. and Vaughan, T.C. (1982). 'Pentagonal territories of the mudskipper Boleophthalmus boddarti (Pisces: Gobiidae)'. Copia 1982: 233-235.

Clayton, D.A. and Vaughan, T.C. (1988). 'Ethogram of Boleophthalmus boddarti (Teleostei, Gobiidae), a mudskipper found on the mudflats of Kuwait'. Journal of the University of Kuwait (Science) 15: 115-138.

Clayton, D.A. and Vaughan. T.C. (1986). 'Territorial acquisition in the mudskipper Boleophthalmus boddarti (Pisces: Gobiidae) on the mudflats of Kuwait'. Journal of Zoology 209:501-519. doi. org/10.1111/j.1469-7998.1986.tb03607.

Clayton, D.A. and Wells, K. (1987). Discovering Kuwait's Wildlife, pp 253. Kuwait: Fahad Al-Marzook.

Clayton, D.A. and Wright, J.M. (1989). 'Mud-walled territories and feedingbehaviour of Boleophthalmus boddarti (Pisces: Gobiidae) on the mudflats of Kuwait'. Journal of Ethology 7:91-95.doi. org/10.1007/BF02350029

Clayton, D.A. (1987). 'Why mudskippers build walls'. Behaviour 102: 185-195. doi.10.1163/156853986X00117

Dadzie, S., Abou-Seedo, F. and Al-Shallah, T. (1998). 'The onset of spawning in the silver pomfret, Pampus argenteus (Euphrasen) in Kuwait waters and its implications for management'. Fisheries Management and Ecology 5: 501-510.doi.org/10.1046/j.1365-2400.1998.560501.x

Dadzie, S., Abou-Seedo, F. and Qattan, E. (2000a). 'The food and feeding habits of the silver pomfret, Pampus argenteus (Euphrasen) in Kuwait waters'. Journal of Applied Ichthyology 16:61-67.doi. org/10.1046/j.1439-0426.2000.00150.x

Dadzie, S., Abou-Seedo, F. and AI-Shallal, T. (2000b). 'Reproductive biology of the silver pomfret, Pampus argenteus (Euphrasen), in Kuwait waters'. Journal of Applied Ichthyology 16: 247-253.doi. org/10.1046/j.1439-0426.2000.00237.x

Dadzie, S., Abou-Seedo, F. and Manyala, J.O. (2000c). 'Length-weight relationship and condition factor of Pampus argenteus (Euphrasen, 1788) in Kuwait waters'. Kuwait Journal of Science \&Engineering 27: 123-134.

Downing, N. (1989a). A study of the corals and coral reef fishes of Kuwait. Volume 1. Project outline, summary and recommendations. Kuwait Institute for Scientific Research, Report No. KISR3256, Kuwait.

Downing, N. (1989b). A study of the corals and coral reef fishes of Kuwait. Volume 2. The reef building corals. Kuwait Institute for Scientific Research, Report No. KISR3256, Kuwait.

Downing, N. (1989c). A study of the corals and coral reef fishes of Kuwait. Volume 3, Part A. Text, The coral reef fishes. Kuwait: Kuwait Institute for Scientific Research, Report No. KISR3256, Kuwait.

Downing, N. (1989d). A study of the corals and coral reef fishes of Kuwait. Volume 3, Part B. Tables and Figures, The coral reef fishes. Kuwait Institute for Scientific Research, Report No. KISR3256, Kuwait.

Downing, N., Al-Saffar, A. and Priest, R. (1989). A study of the corals and coral reef fishes of Kuwait. Volume 4. Charting Kuwait's coral reefs. Kuwait Institute for Scientific Research, Report No. KISR3256. Kuwait. 
Grabe, S.A., Lees, D.C. and Allaire, H.P. (1992). 'Macrozooplankton studies in Kuwait Bay (Arabian Gulf). I: Distribution and composition of the ichthyoplankton'. Journal of Plankton Research 14:607-623. doi.org/10.1093/plankt/14.4.607

Goubanov, E. P. and Shleib, N. A. (eds.) (1980). Sharks of the Arabian Gulf. Ministry of Public Works, Agricultural Department, Fisheries Divisions, Kuwait.

Houde, E.D., Almatar, S., Leak, J.C. and Dowd, C.E. (1986). 'Ichthyoplankton abundance and diversity in the western Arabian Gulf'. Kuwait Bulletin of Marine Science 8:107-393.

Harrison, P.L., Alhazeem, S.H. and Alsaffar, A.H. (1997). The ecology of coral reefs in Kuwait and the effects of stressors on corals. (Revised by S. Almatar). Kuwait Institute for Scientific Research, Report No. KISR4994, Kuwait.

Hussain, N.A. and Abdullah, M.A.S. (1977). 'The length-weight relationship, spawning season and food habits of six commercial fishes in Kuwaiti waters'. Indian Journal of Fisheries 24: 181-194.

Ismail, W. and Clayton, D.A. (1990). 'Biology of Omobranchus punctatus (Blenniidae) on rocky shores in Kuwait'. Cybium 14: 285-293.

Ismail, W.A., Al-Abdul-Elah, K. and Al-Yamani, F. (1998). 'Larval development of the back keeled mullet Liza carinata'. Hydrobiologia 385: 87-105.doi.org/10.1023/A:1003438605285

Jabado, R.W. and Ebert, D.A. (2015). Sharks of the Arabian Seas: An Identification Guide. The International Fund for Animal Welfare, Dubai, UAE.

Jabado, R.W., Kyne, P.M., Pollom, R.A., Ebert, D.A., Simpfendorfer, C.A., Ralph, G.M. and Dulvy, N.K. (eds.). (2017). The Conservation Status of Sharks, Rays, and Chimaeras in the Arabian Sea and Adjacent Waters. Environment Agency - Abu Dhabi, UAE and IUCN Species Survival Commission Shark Specialist Group, Vancouver, Canada 236 pp.

Kuronuma, K. and Abe, Y. (1972). Fishes of Kuwait. Safat, Kuwait: Kuwait Institute for Scientific Research.

Last, P.R., Manjaji-Matsumoto, B.M. and Moore, A.B.M. (2012). 'Himantura randalli sp. nov., a new whipray (Myliobatoidea: Dasyatidae) from the Persian Gulf'. Zootaxa, 3327:20-32.

doi.org/10.11646/zootaxa.3327.1.2

Literathy, P., Al-Hawary, M. and Jacob, P.G. (1989). A study of the corals and coral reef fishes of Kuwait. Volume 5. The reef environment. Kuwait Institute for Scientific Research, Report No. KISR3256, Kuwait.

Mathews, C.P. and Samuel, M. (1985). 'Stock assessment and management of newaiby, hamoor, and hamra in Kuwait'. In: Mathews, C.P. (ed.), Proceedings of the 1984 Shrimp and Fin Fisheries Management Workshop, pp. 67-115. Kuwait Institute for Scientific Research, Report No. KISR1856, Kuwait.

Mathews, C.P. and Samuel, M. (1987). 'Growth and mortality and assessments for groupers, Epinephelus spp. from Kuwait'. Kuwait Bulletin of Marine Science, 9: 173-191.

Moore, A.B.M. (2017). 'Are guitarfishes the next sawfishes? Extinction risk and an urgent call for conservation action'. Endangered Species Research 34: 75-88. doi.org/10.3354/esr00830

Moore, A.B.M., White, W.T. and Peirce, R. (2010). 'Additions to the shark fauna of the Persian (Arabian) Gulf '. Zoology in the Middle East 50: 83-88. doi.org/10.1080/09397140.2010.10638415

Moore, A.B.M., Compagno, L.J.V. and Fergusson, I.K. (2007). 'The Persian/Arabian Gulf's sole great white shark Carcharodon carcharias (Lamniformes: Lamnidae) record from Kuwait: misidentification of a sandtiger shark Carcharias taurus (Lamniformes: Odontaspididae)'. Zootaxa 1591: 67-68. doi.org/10.11646/zootaxa.1591.1.3

Moore, A.B.M., McCarthy, I.D., Carvalho, G.R. and Peirce, R. (2012). 'Species, sex, size and male maturity composition of previously unreported elasmobranch landings in Kuwait, Qatar and Abu Dhabi Emirate'. Journal of Fish Biology 80:1619-1642. doi.org/10.1111/j.1095-8649.2011.03210.

Morgan, G.R. (1985a). 'Assessment of sheim (Acanthopaagrus latus) in Kuwait waters'. In: Mathews, C.P. (ed.), Proceedings of the 1984 Shrimp and Fin Fisheries Management Workshop, pp. 116124. Kuwait Institute for Scientific Research, Report No. KISR1862, Kuwait.

Morgan, G.R. (1985b). 'Stock assessment of the pomphret (Pampus argenteus) in Kuwait waters'. Journal du Conseil International pour l'Exploration de la Mer 42: 3-10.doi.org/10.1093/ices$\mathrm{jms} / 42.1 .3$

Randall, J.E. (1986). Sharks of Arabia. IMMEL Publishing, London. 
Randall, J.E. (1994). 'A new genus and six new gobiid fishes (Perciformes: Gobiidae) from Arabian waters'. Fauna of Saudi Arabia 14: 317-340.

Randall, J.E., Downing, N., McCarthy, L.J., Stanaland, B.E. and Tarr, A.B. (1994). 'Fifty-one records of fishes from the Arabian Gulf'. Fauna of Saudi Arabia 14: 220-258.

Samuel, M. and Bawazeer, A.S. (1985). 'A note on the fishery for sobaity (Acanthopagrus cuveiri) in Kuwait'. In: Mathews, C.P. (ed.), Proceedings of the 1984 Shrimp and Fin Fisheries Management Workshop, pp. 142-148. Kuwait Institute for Scientific Research, Report No. KISR1856, Kuwait.

Samuel, M. and Mathews, C.P. (1985). Validating the ageing of newaiby, hamoor, and hamra in Kuwait. In Mathews, C.P. (ed.), Proceedings of the 1984 Shrimp and Fin Fisheries Management Workshop, pp. 56-65. Kuwait Institute for Scientific Research, Report No. KISR1856, Kuwait.

Samuel, M. and Mathews, C.P. (1987). 'Growth and mortality of four Acanthopagrus species'. Kuwait Bulletin for Marine Science 9: 159-171.

Samuel, M., Mathews, C.P. and Baddar, M.K. (1987a). 'Stock assessment of hamrah (Lutjanus coccineus) and Hamoor (Epinephelus tauvina) from the Arabian Gulf using surplus production and dynamic pool models'. Kuwait Bulletin of Marine Science 9: 195-206.

Wright, J.M. (1988a). 'Recruitment patterns and trophic relationships of fish in Sulaibikhat Bay, Kuwait'. Journal of Fish Biology 33: 671-687. doi:10.1111/j.1095-8649.1988.tb05513.x

Wright, J.M. (1988b). 'Seasonal and spatial differences in the fish assemblage of the non-estuarine Sulaibikhat Bay, Kuwait'. Marine Biology 100: 13-20. doi.org/10.1007/BF00392950

Wright, J.M. (1989a). 'Diel variation and seasonal consistency in the fish assemblage of the non-estuarine Sulaibikhat Bay, Kuwait'. Marine Biology 102: 135-142.doi.org/10.1007/BF00391331

Wright, J.M. (1989b). 'Biology of Leiognathus decorus (Leiognathidae) in Sulaibikhat Bay, Kuwait'. Australian Journal of Marine and Freshwater Research 40: 179-185. doi.org/10.1071/MF9890179

Wright, J.M. (1989c). 'Detached chlorophytes as nursery areas for fish in Sulaibikhat Bay, Kuwait'. Estuary and Coastal Shelf Science 28: 185-193. doi.org/10.1016/0272-7714(89)90065-6

Wright, J.M. (1990). 'Annual differences in the fish assemblage of the none estuarine Sulaibikhat Bay, Kuwait'. In: M. Elliot and J.P. Ducrotoy (eds.) Estuaries and coasts: spatial intercomparisons, pp 285-288. Olsen International Symposium Series. Denmark.

Wright, J.M., Abou-Seedo, F. and Clayton, D.A. (1996). 'Long term changes in the fish assemblage of Sulaibikhat Bay, Kuwait'. Kuwait Journal of Science and Engineering 23: 47-60.

Wright, J.M., Clayton, D.A. and Bishop, J.M. (1990). 'Tidal movements of shallow water fishes in Kuwait Bay'. Journal of Fish Biology 37: 959-974.doi: 10.1111/j.1095-8649.1990.tb03599.x

Ye, Y., Alsaffar, A.H. and Mohammed, H.M.A. (2000). 'Bycatch and discards of the Kuwait shrimp fishery'. Fisheries Research 45: 9-19.doi: 10.1016/S0165-7836(99)00105-8 


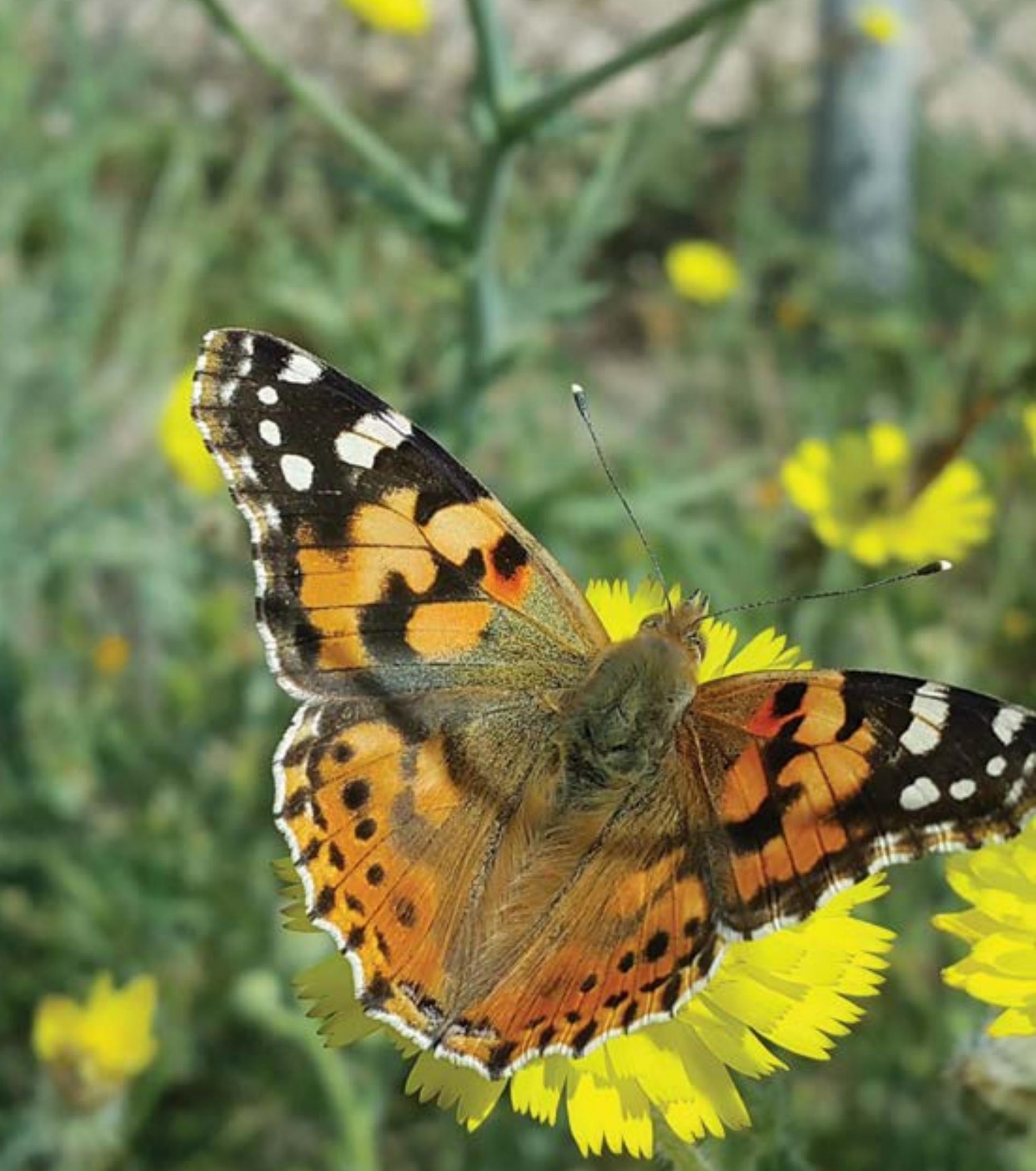

(Photo from Mohammad El Marefi) 



\section{Arthropoda}

Phylum Arthropoda includes all insects, acraines and crustacean. It is considered the largest group of animals with over eight million described species. In Kuwait, this group is represented by terrestrial and marine species. The following account reveals the detailed biodiversity of the arthropods of Kuwait.

\subsection{Subphylum Chelicerata}

\subsubsection{Arachinda}

\subsubsection{Order Scorpiones}

Scorpions are venomous animals. Only few records are available for Kuwait representing five species (Table 11) (Kettel, 1982; Hendrixson, 2006). Clayton \& Pilcher (1983) showed images for some scorpions collected from Kuwait. AlKhalifa et al. (2012) mentioned two species of scorpions from Al- Wafra, however, the record of the Lesser yellow scorpion, Uroplectes alstoni, is doubtful. The record of Compsobuthus arabicus by Clayton \& Pilcher (1983) is erroneous, and it represents Compsobuthus pallidus.

Table 16: Scorpions reported from Kuwait.

\begin{tabular}{|l|l|}
\hline \multicolumn{1}{|c|}{ Species } & \multicolumn{1}{c|}{ Reference } \\
\hline Androctonus crassicauda (Olivier, 1807) & $\begin{array}{l}\text { Clayton \& Pilcher (1983), Hendrixson (2006) } \\
\text { Al-Khalifa et al. (2012) }\end{array}$ \\
\hline Compsobuthus pallidus Hendrixson, 2006 & Hendrixson (2006) \\
\hline Apistobuthus pterygocercus & Lourenço (1998) \\
\hline Scorpio maurus & \\
\hline Leiurus hebraeus & Clayton \& Pilcher (1983), \\
\hline
\end{tabular}

\section{Referenes}

Kettel, J. (1982). 'Scorpions of Kuwait'. Ahmadi Natural History and Field Studies Group Newsletter 21: 6-8. Hendrixson, B. E. (2006). 'Buthid scorpions of Saudi Arabia, with notes on other families (Scorpiones: Buthidae, Liochelidae, Scorpionidae)'. Fauna of Arabia 21: 33-120.

Clayton, D. and Pilcher, C. (1983). Kuwaitıs Natural History: An Introduction. Kuwait, Oil Co. Ltd., Kuwait. Al-Khalifa, H., Al-Nasser, A., Abbas, M.S. and Dashti, J. (2012). 'Biodiversity and conservation of Wildlife at the Wafra area in Kuwait'. Biodiversity Journal 3: 179-188.

Lourenço,W.R. (1998). 'A new species of Apistobuthus Finnegan, 1932 (Chelicerata, Scorpiones, Buthidae) from Iran'. Entomol. Mitt. zool. Mus., Hamburg 12: 237-244. 


\subsubsection{Order Araneae}

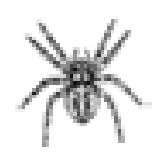

Very little is known about the spiders of Kuwait. Two species of Latrodectus (Knoflach \& Van Harten, 2002a \& b), and one crab spiders (Muster, 2009) were reported (Table 17). Unidentified spiders epresenting jumping spider (Salticidae), long-legged spider (Pholcidae), orb-weaver spider (Araneidae) and wolf spider (Lycosidae) were reported from Wafra (Al-Khalifa et al., 2012). Clayton \& Pilcher (1983) depected several images for unidentified spiders in Kuwait.

Table 17: Spiders reported from Kuwait.

\begin{tabular}{|l|l|}
\hline \multicolumn{1}{|c|}{ Species } & \multicolumn{1}{c|}{ Reference } \\
\hline Latrodectus cinctus Blackwall, 1865 & (Knoflach \& Van Harten (2002 \& b \\
\hline Latrodectus renivulvatus & (Knoflach \& Van Harten (2002a \& b \\
\hline Halodromus patellidens & (Muster (2009 \\
\hline
\end{tabular}

\section{References}

Al-Khalifa, H., Al-Nasser, A., Abbas, M.S. and Dashti, J. (2012). 'Biodiversity and conservation of Wildlife at the Wafra area in Kuwait'. Biodiversity Journal 3: 179-188.

Clayton, D. and Pilcher, C. (1983). Kuwait,s Natural History: An Introduction. Kuwait, Oil Co. Ltd., Kuwait. Knoflach, B. and Van Harten, A. (2002a). 'The genus Latrodectus (Araneae: Theridiidae) from mainland Yemen, the Socotra Archipelago and Adjacent countries'. Fauna of Arabia 19: 321-361.

Knoflach, B. and Van Harten, A. (2002b). 'Die Schwarzen Witwen von Arabia Felix (Araneae: Theridiidae)'. Österreichische Entomologische Gesellschaf 6:10-12.

Muster, C. (2009). 'The Ebo-like running crab spiders in the Old World (Araneae, Philodromidae)'. In: Stoev $\mathrm{P}$, Dunlop J, Lazarov S (eds). 'A life caught in a spiderıs web. Papers in arachnology in honour of Christo Deltshev'. ZooKeys 16: 47-73.

\subsubsection{Order Pseudoscorpiones}

One species of pseudoscorpions, Minniza persica, was reported from Kuwait (Nassirkhani \& Shoushtari, 2014).

\section{Referenes}

Nassirkhani, M. and Shoushtari, R.V. (2014). 'Redescription and remarks on the species Minniza persica (Pseudoscorpiones: Olpiidae) from Iran'. Zoology in the Middle East 60: 272-277.doi.org/10 $.1080 / 09397140.2014 .939814$ 


\subsubsection{Order Solifugae}

Very little is known about camel spiders in Kuwait. Only a single species, Galeodis arabs (Koch, 1842), was reported from Wafra area (Al-Khalifa et al., 2012). Also, Clayton \& Pilcher (1983) showed an image for one camel spider.

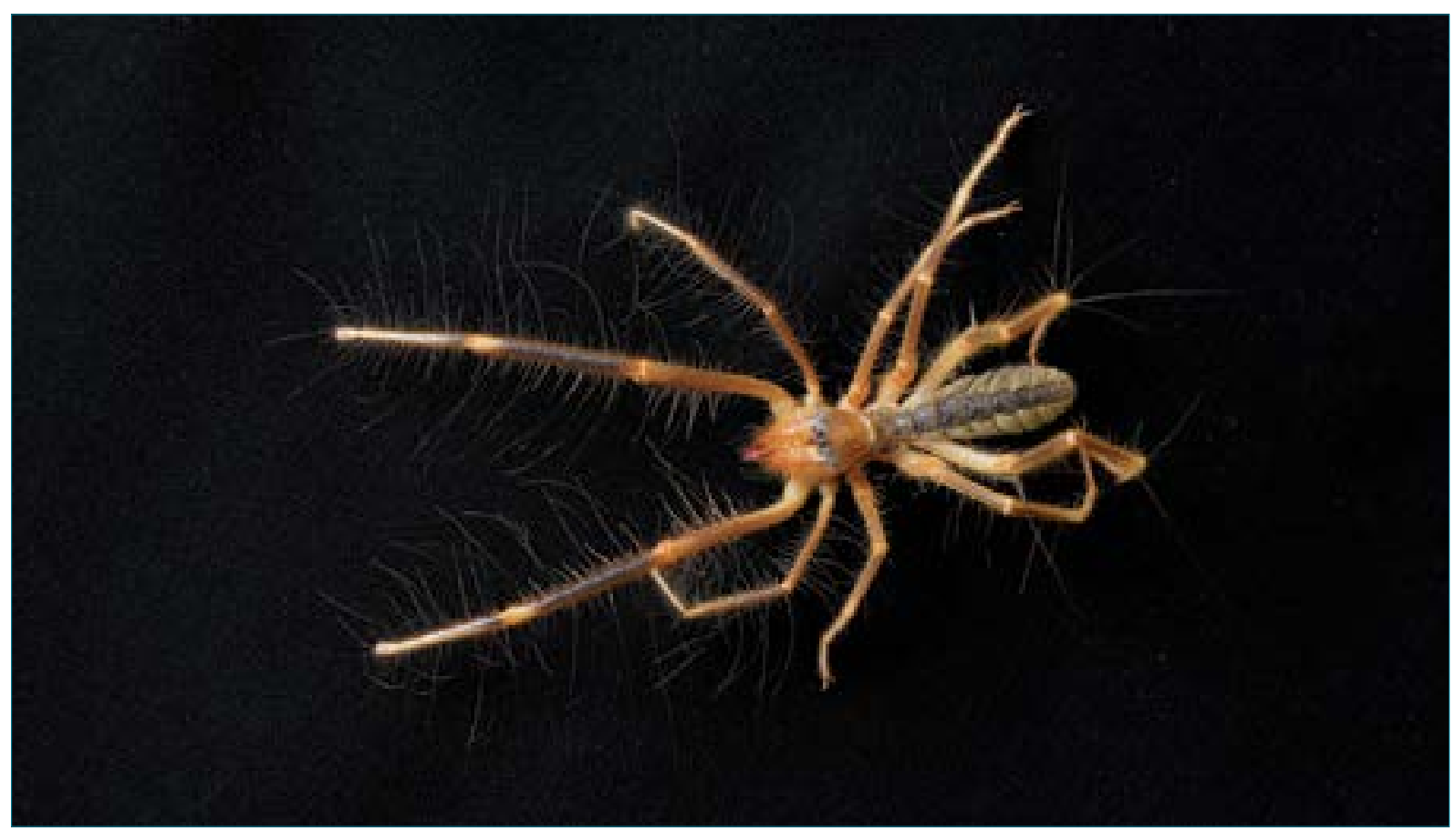

Figure 25: A camel spider of Order Solifugae (Photo from Zuhair Amr).

\section{Reference}

Al-Khalifa, H., Al-Nasser, A., Abbas, M.S. and Dashti, J. (2012). 'Biodiversity and conservation of Wildlife at the Wafra area in Kuwait'. Biodiversity Journal 3: 179-188.

Clayton, D. and Pilcher, C. 1983. Kuwaitss Natural History: An Introduction. Kuwait, Oil Co. Ltd., Kuwait.

\subsection{Subclass Acari: Order Ixodida}

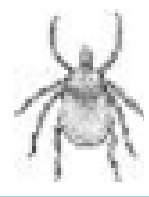

Tick are ectoparasites feeding on blood of some terrestrial vertebrates. Still very little is known about this order. Ticks associated with rodents and camels were reported (Converse \& Moussa,
1982; Al-Taqi \& Al-Ziady, 1983; Zemtsova et al., 2016). Five species of both soft and hard ticks were reported from Kuwait (Table 18). 
Table 18: Ticks reported from Kuwait.

\begin{tabular}{|l|l|l|}
\hline \multicolumn{1}{|c|}{ Family } & \multicolumn{1}{|c|}{ Species } & \multicolumn{1}{|c|}{ Host } \\
\hline Ixodidae & Rhipicephalus leporis & Lepus capensis \\
\hline & Rhipicephalus sanguineus & Jaculus jaculus \\
\hline & Hyalomma dromedarii & $\begin{array}{l}\text { Jaculus jaculus, Gerbillus cheesmani, Meriones } \\
\text { crassus, camels }\end{array}$ \\
\hline & Hyalomma anatolicum excavatum & Gerbillus cheesmani, Meriones crassus \\
\hline Argasidae & Ornithodorus erraticus & Mus musculus \\
\hline
\end{tabular}

\section{References}

Al-Taqi, M. and Al-Ziady, S. (1983). 'Ectoparasites of rodents in Kuwait'. Proceedings of the 1st Symposium on Recent Advances in Rodent Control 107-114.

Converse, J.D. and Moussa, M.I. (1982). 'Quaranfil virus from Hyalomma dromedarii (Acari: Ixodoidea) collected in Kuwait, Iraq, and Yemen'. Journal of Medical Entomology 19: 209-210. doi. org/10.1093/jmedent/19.2.209

Zemtsova, G.E., Apanaskevich, D.A., Reeves, W.K., Hahn, M., Snellgrove, A. and Levin, M.L. (2016). 'Phylogeography of Rhipicephalus sanguineus sensu lato and its relationships with climatic factors'. Experimental \& Applied Acarology 69:191-203. doi.org/10.1007/s10493-016-0035-4

\subsection{Order Trombidiformes}

Two species of acarines were described from the shores of southern Kuwait; Actacarus arabius and Scaptognathides delicatulus (Bartsch, 2004).

\section{References}

Bartsch, I. (2004). 'Psammophilous Halacarid mites From Kuwait: Description of species of the Genera Actacarus and Scaptognathides (Acari: Halacaridae)'. Zootaxa 755: 1-8. doi.org/10.11646/ zootaxa.755.1.1

\subsection{Subphylum Myriapoda}

\subsubsection{Class Chilopoda}

Only one record of chilopod, Scolopendra valida, was reported from Kuwait (Reeves, 2016).

\section{References}

Reeves, W.K. (2016). 'First national records for Scolopendra valida (Chilopoda: Scolopendromorpha: Scolopendridae) from kuwait'. Entomological News 126:150-151. doi.org/10.3157/021.126.0212 


\subsection{Subphylum Crustacea}

\subsubsection{Class Malacostraca}

\subsubsection{Order Amphipoda}

A total of 73 species of the order Amphipoda were identified and included in the guidebook. Of these, 60 species are considered to be new records for Kuwait and 55 species are recorded for the first time for the Arabian Gulf, whereas 19 species are considered as the first description of the new for science species Al-Yamani et al. (2019). Al-Yamani et al. (2012) listed several species of amphipods from Kuwait along with high quality illustrations. Seven new species of Amphipoda were described from Kuwait (Myers \& Nithyanandan, 2016).

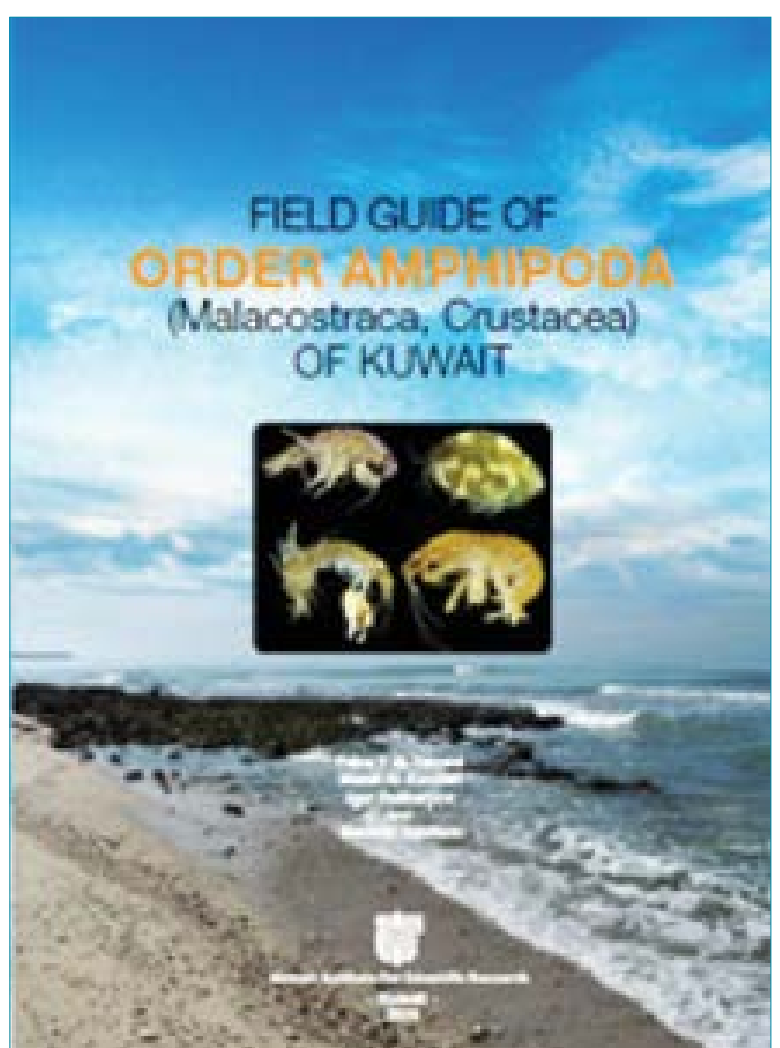

Figure 26: Cover for the field guide of Amphipods of Kuwait.

Table 19: Amphipods reported from Kuwait $\left({ }^{*}=\right.$ described from Kuwait)

\begin{tabular}{|l|l|}
\hline \multicolumn{1}{|c|}{ Family } & \multicolumn{1}{c|}{ Species } \\
\hline Ampeliscidae & Ampelisca euroa Lowry \& Poore, 1985 \\
\hline & Ampelisca sp. 1 \\
\hline & Ampelisca sp. 2 cf. brevicornis \\
\hline & Ampelisca sp. 3 cf. misakiensis \\
\hline & Ampelisca sp. 4 cf. rubella \\
\hline & Ampelisca sp. 5 cf. taynamensis \\
\hline & Ampelisca sp. 6 cf. tulearensis 7 \\
\hline Amphilochidae & Byblis sp. \\
\hline & Apolochus sp. 1 cf. kailua \\
\hline & Apolochus sp. 2 cf. menehune \\
\hline
\end{tabular}




\begin{tabular}{|c|c|}
\hline Family & Species \\
\hline \multirow[t]{5}{*}{ Ampithoidae } & Ampithoe ramondi Audouin, 1826 \\
\hline & Ampithoe sp. 1 \\
\hline & Ampithoe sp. 2 cf. kava \\
\hline & Cymadusa setosa (Haswell, 1879) \\
\hline & Biancolina sp. \\
\hline \multirow[t]{4}{*}{ Aoridae } & Bemlos acuticoxa Myers \& Nithyanandan, $2016^{*}$ \\
\hline & Globosolembos indicus (Ledoyer, 1967) \\
\hline & Grandidierella gilesi Chilton, 1921 \\
\hline & Grandidierella sp. \\
\hline \multirow[t]{2}{*}{ Caprellidae } & Deutella sp. \\
\hline & Metaprotella macoranicus Momtazi \& Sari, 2013 \\
\hline Cheirocratidae & Cheirocratus sp. \\
\hline \multirow[t]{2}{*}{ Colomastigidae } & Colomastix sp. 1 \\
\hline & Colomastix sp. 2 \\
\hline \multirow[t]{3}{*}{ Corophiidae } & Laticorophium bifurcatum Myers \& Nithyanandan, $2016^{*}$ \\
\hline & Cheiriphotis megacheles (Giles, 1885) \\
\hline & Cheiriphotis sp. cf. walkeri \\
\hline Cyproideidae & Cyproidea sp. cf. serratipalma \\
\hline \multirow[t]{2}{*}{ Dexaminidae } & Paradexamine sp. 1 cf. latifolia \\
\hline & Paradexamine sp. 2 cf. orientalis \\
\hline \multirow[t]{2}{*}{ Eriopisidae } & Eriopisa sp. cf. elongata \\
\hline & Eriopisella sp. \\
\hline \multirow[t]{2}{*}{ Hyalidae } & Parhyale basrensis Salman, 1986 \\
\hline & Protohyale arabica Myers \& Nithyanandan, $2016^{*}$ \\
\hline \multirow[t]{3}{*}{ Ischyroceridae } & Ericthonius sp. cf. forbesii \\
\hline & Ischyrocerus sp. \\
\hline & Orientoecetes arabicus (Barnard \& Thomas, 1984) \\
\hline \multirow[t]{3}{*}{ Leucothoidae } & Leucothoe gracilis (Haswell, 1879) \\
\hline & Leucothoe sp. cf. richiardii \\
\hline & Paranamixis sp. cf. ledoyeri \\
\hline Liljeborgiidae & Idunella demersalis (Sivaprakasam, 1972) \\
\hline Lysianassidae & Socarnoides sp. \\
\hline \multirow[t]{3}{*}{ Maeridae } & Ceradocus (Denticeradocus) alama Myers \& Nithyanandan, 2016* \\
\hline & Elasmopus alkhiranensis Myers \& Momtazi, 2015 \\
\hline & Maera irregularis Myers \& Nithyanandan, $2016^{*}$ \\
\hline
\end{tabular}




\begin{tabular}{|c|c|}
\hline Family & Species \\
\hline Maxillipiidae & Maxillipius rectitelson Ledoyer, 1973 \\
\hline \multirow[t]{2}{*}{ Megaluropidae } & Megaluropus excavatus Ledoyer, 1979 \\
\hline & Megaluropus sp. cf. monasteriensis \\
\hline \multirow[t]{2}{*}{ Melitidae } & Dulichiella fresnelii (Audouin, 1826) \\
\hline & Melita persia Momtazi \& Sari, 2014 \\
\hline Melphidippidae & Melphisana madagascarensis Ledoyer, 1984 \\
\hline Neomegamphopidae & Neomegamphopus sp. \\
\hline \multirow[t]{4}{*}{ Oedicerotidae } & Perioculodes sp. 1 \\
\hline & Perioculodes sp. 2 cf. megapleon \\
\hline & Perioculodes sp. 3 cf. serra \\
\hline & Pontocrates sp. cf. arenarius \\
\hline \multirow[t]{7}{*}{ Photidae } & Latigammaropsis pseudojassa Myers \& Nithyanandan, 2016* \\
\hline & Latigammaropsis sp. 1308 \\
\hline & Latigammaropsis sp. 2 cf. atlantica \\
\hline & Photis hawaiensis J.L. Barnard, 1955 \\
\hline & Photis sp. 1 \\
\hline & Photis sp. 2 cf. bifurcata \\
\hline & Photis sp. 3 cf. viuda \\
\hline Phoxocephalidae & Brolgus sp. cf. mamak \\
\hline Platyischnopidae & Indischnopus herdmani (Walker, 1904) \\
\hline \multirow[t]{2}{*}{ Podoceridae } & Laetmatophilus sp. \\
\hline & Podocerus mamlahensis Myers \& Nithyanandan, 2016* \\
\hline Pontogeneiidae & Abdia latipalpus (Walker \& Scott, 1903) \\
\hline Tryphosidae & Orchomenella sp. \\
\hline \multirow[t]{2}{*}{ Stenothoidae } & Stenothoe gallensis Walker, 1904 \\
\hline & Stenothoe sp. cf. aucklandicus \\
\hline \multirow[t]{2}{*}{ Urothoidae } & Urothoe sp. 1 \\
\hline & Urothoe sp. 2 cf. intermedia \\
\hline
\end{tabular}

\section{References}

Al-Yamani, F.Y., Skryabin, V., Boltachova, N., Revkov, N., Makarov, M., Grinstov, V. and Kolesnikova, E. (2012). Illustrated Atlas on the Zoobenthos of Kuwait, pp 383. Kuwait Institute for Scientific Research.

Al-Yamani F.Y., Al-Kandari, M., Polikarpov, I. and Grintsov, V. (2019). Field guide of order Amphipoda (Malacostraca, Crustacea) of Kuwait. Kuwait: Kuwait Institute for Scientific Research. p 390. ISBN 978-99966-37-19-3

Myers, A.A. and Nithyanandan, M. (2016). 'The Amphipoda of Sea City, Kuwait.-The Senticaudata (Crustacea)'. Zootaxa 4072: 401-429. doi.org/10.11646/zootaxa.4072.4.1 


\subsubsection{Order Decopoda Suborder Senticaudata}

Fifty-two species in 20 families of marine crabs were reported from Kuwait (Table 20, Figures 28 \& 29). Several papers were published in which

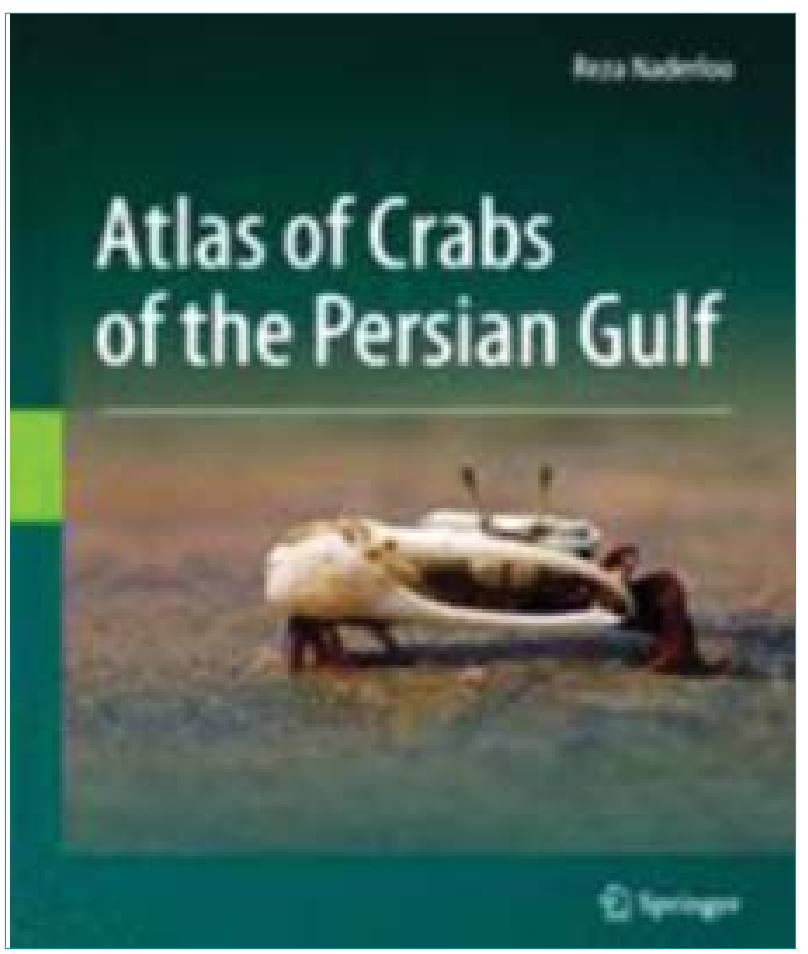

two species was described as new to science, Leptochryseus kuwaitensis and Manningis arabicum (Jones \& Clayton, 1983; Collins et al.,

Figure 27: Books published on the crabs of Kuwait and the Arabian Gulf.

1984; Jones, 1986a \& b; Snowden et al., 1991, 1994 \& 1995; Carpenter et al., 1997; Apel \& Spiridonov, 1998; Apel, 2001 Al-Yamani et al., 2012; Al-Wazzan et al., 2018). The main reference on the crabs of the Arabian Gulf was published by Naderloo (2017) with full colored illustration and distribution maps (Figure 27).

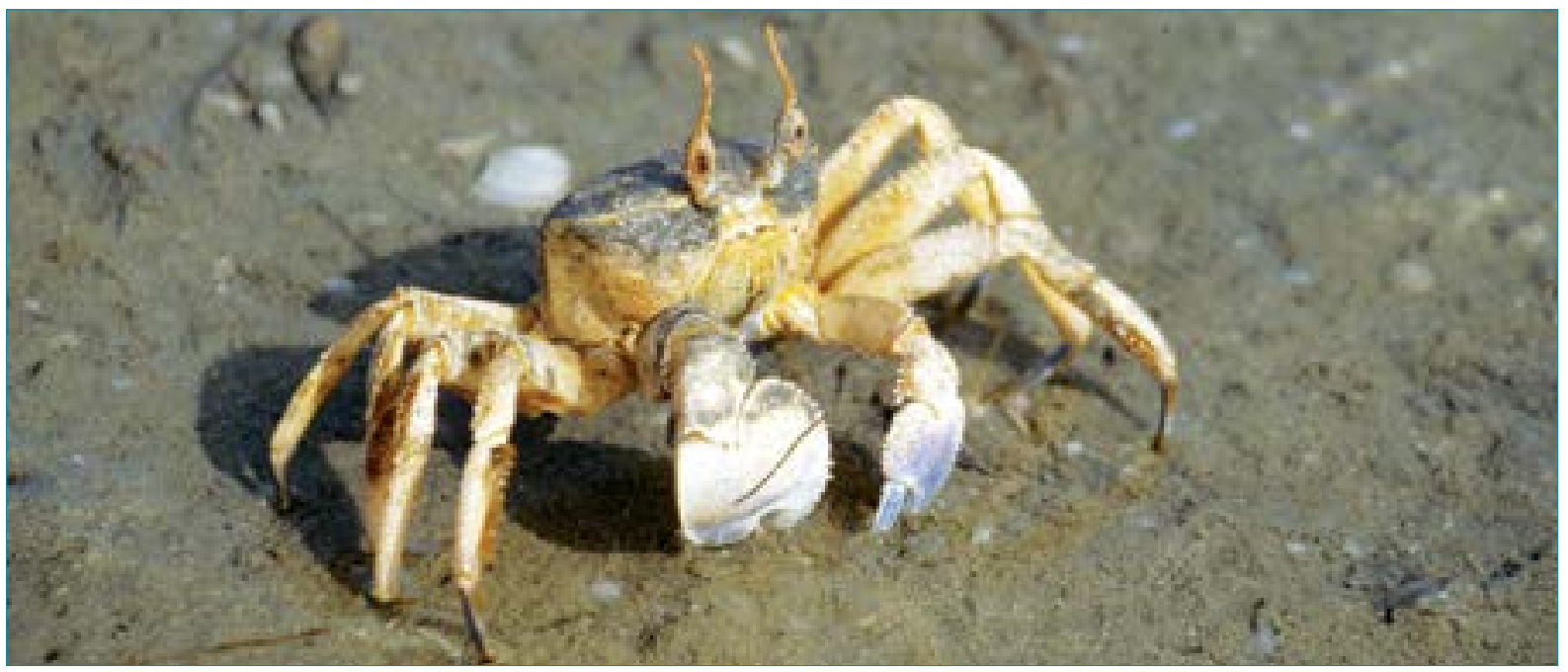

Figure 28: The rounded ghost crab, Ocypode rotundata (Photo from F. Krupp). 
Table 20: Decapoda reported from Kuwait.

\begin{tabular}{|c|c|}
\hline Family & Species \\
\hline \multirow[t]{2}{*}{ Matutidae } & Matuta planipes Fabricius, 1798 \\
\hline & Matuta victor (Fabricius, 1781) \\
\hline \multirow[t]{2}{*}{ Dorippidae } & Dorippe quadridens (Fabricius, 1793) \\
\hline & Dorippoides nudipes Manning \& Holthuis, 1986 \\
\hline Oziidae & Epixanthus frontalis (H. Milne Edwards, 1834) \\
\hline Euryplacidae & Eucrate crenata (De Haan, 1835) \\
\hline \multirow[t]{10}{*}{ Leucosiidae } & Arcania erinacea (Fabricius, 1787) \\
\hline & Hiplyra sagitta Galil, 2009 \\
\hline & Hiplyra variegata (Rüppell, 1830) \\
\hline & Ixa holthuisi Tirmizi, 1970 \\
\hline & Lyphira perplexa Galil, 2009 \\
\hline & Nursia plicata (Herbst, 1803) \\
\hline & Ryphila cancellus (Herbst, 1783) \\
\hline & Philyra sp. \\
\hline & Seulocia anahita Galil, 2005 \\
\hline & Urnalana hilaris (Nobili, 1905 \\
\hline \multirow[t]{3}{*}{ Epialtidae } & Menaethius monoceros (Latreille, 1825) \\
\hline & Hyastenus hilgendorfi de Man, 1887 \\
\hline & Cyphocarcinus capreolus (Paul'son, 1875) \\
\hline Parthenopidae & Enoplolambrus carenatus (H. Milne Edwards, 1834) \\
\hline \multirow[t]{5}{*}{ Portunidae } & Charybdis (Charybdis) hellerii (A. Milne-Edwards, 1867) \\
\hline & Charybdis (Charybdis) natator (Herbst, 1794) \\
\hline & Charybdis (Goniohellenus) longicollis Leene, 1938 \\
\hline & Portunus segnis (Forskål, 1775) \\
\hline & Xiphonectes hastatoides (Fabricius, 1798) \\
\hline \multirow[t]{2}{*}{ Xanthidae } & Actaea jacquelinae Guinot, 1976 \\
\hline & Leptodius exaratus (H. Milne Edwards, 1834) \\
\hline Galenidae & Halimede tyche (Herbst, 1801) \\
\hline \multirow[t]{3}{*}{ Pilumnidae } & Eurycarcinus orientalis A. Milne-Edwards, 1867 \\
\hline & Pilumnus longicornis Hilgendorf, 1878 \\
\hline & Pilumnus vespertilio (Fabricius, 1793) \\
\hline \multirow[t]{3}{*}{ Grapsidae } & Grapsus granulosus H. Milne Edwards, 1853 \\
\hline & Grapsus albolineatus Latreille, in Milbert, 1812 \\
\hline & Metopograpsus messor (Forskål, 1775) \\
\hline
\end{tabular}




\begin{tabular}{|l|l|}
\hline \multicolumn{1}{|c|}{ Family } & \multicolumn{1}{|c|}{ Species } \\
\hline Sesarmidae & Chiromantes boulengeri (Calman, 1920) \\
\hline & Nanosesarma sarii Naderloo \& Türkay, 2009 \\
\hline & Parasesarma persicum Naderloo \& Schubart, 2010 \\
\hline Varunidae & Erocheir hepuensis Dai, 1991 \\
\hline & Metaplax indica H. Milne Edwards, 1852 \\
\hline Camptandriidae & Leptochryseus kuwaitense (D.A. Jones \& Clayton, 1983) \\
\hline & Manningis arabicum (Jones \& Clayton, 1983) \\
\hline & Nasima dotilliformis (Alcock, 1900) \\
\hline & Opusia indica (Alcock, 1900) \\
\hline & Tylodiplax sp. \\
\hline Dotillidae & Dotilla blanfordi Alcock, 1900 \\
\hline & Ilyoplax frater (Kemp, 1919) \\
\hline & Ilyoplax sp. \\
\hline Scopimera crabicauda Alcock, 1900 \\
\hline Sesarmidae & Ilyograpsus rhizophorae Barnard, 1955 \\
\hline Macrophthalmidae & Chaenostoma sinuspersici (Naderloo \& Türkay, 2011) \\
\hline & Macrophthalmus (Macrophthalmus) sulcatus H. Milne Edwards, 1852 \\
\hline & Venitus dentipes (Lucas, 1836) \\
\hline Ocypode rotundata Miers, 1882 \\
\hline Austruca iranica (Pretzmann, 1971) \\
\hline Austruca sindensis (Alcock, 1900) \\
\hline Nanosesarma minutum (DeMann, 1887) \\
\hline
\end{tabular}


䨏KISR

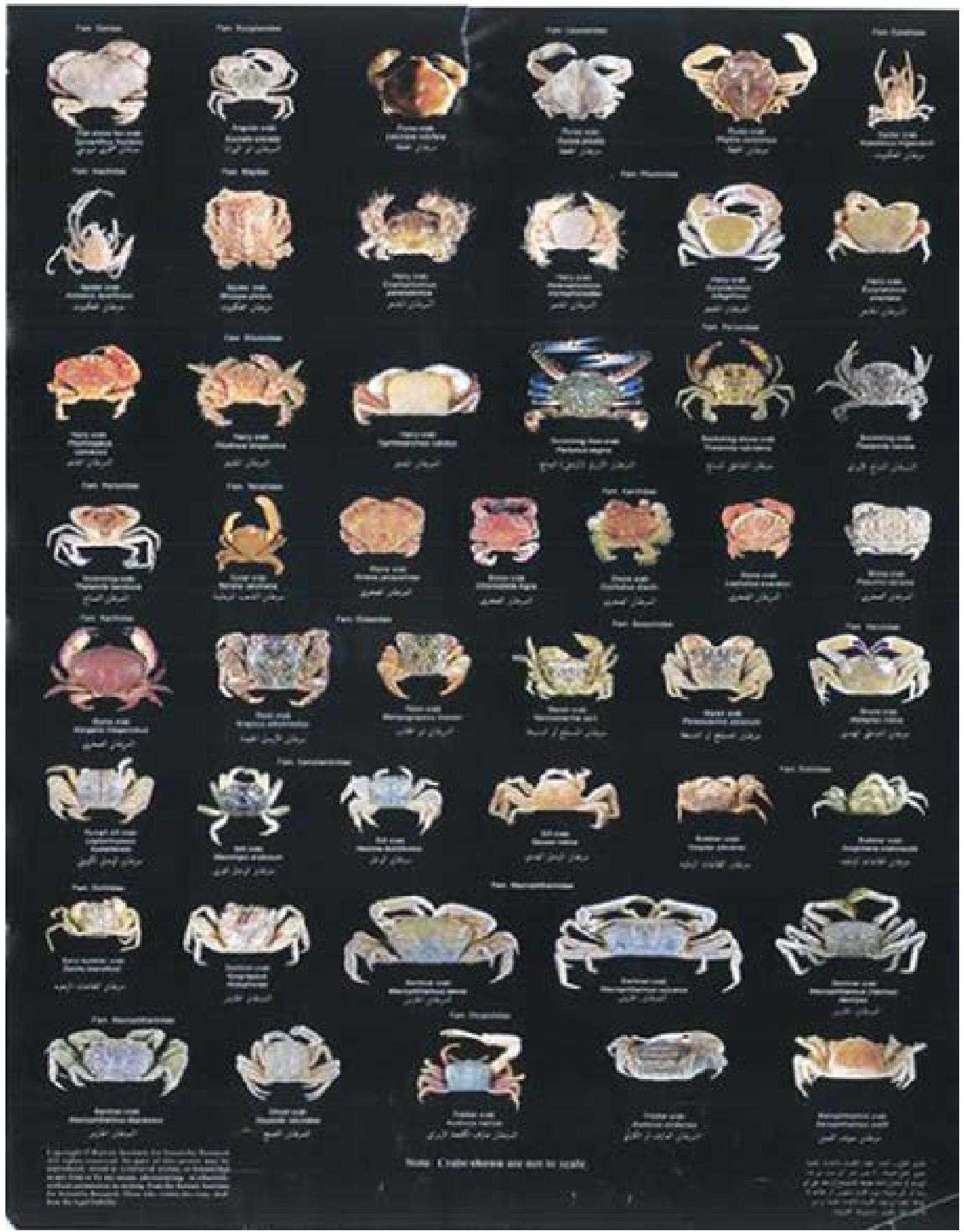

Figure 29: Intertidal crabs from Kuwait. 


\section{References}

Al-Wazzan, Z., Le Vay, L., Behbehani, M. and Giménez, L. (2018). 'Hatching rhythm and larval release in Leptodius exaratus (H. Milne Edwards, 1834) (Decapoda: Brachyura: Xanthidae) from rocky shores in Kuwait'. Journal of Crustacean Biology 38: 804-811. doi.org/10.1093/jcbiol/ruy080

Al-Yamani, F.Y., Skryabin, V., Boltachova, N., Revkov, N., Makarov, M., Grinstov, V. and Kolesnikova, E. (2012). Illustrated Atlas on the Zoobenthos of Kuwait, pp. 383. Kuwait Institute for Scientific Research.

Apel, M. (2001). Taxonomie und Zoogeographie der Brachyura, Paguridea und Porcellanidae (Crustacea: Decapoda) des Persisch-Arabischen Golfes. Fachbereich Biologie, Frankfurt am Main.

Apel, M. and Spiridonov, V.A. (1998). 'Taxonomy and zoogeography of the portunid crabs (Crustacea: Decapoda: Brachyura: Portunidae) of the Arabian Gulf and adjacent waters'. Fauna of Arabia 17:159-331.

Carpenter, K.E., Krupp, F., Jones D.A. and Zajonz, U. (1997). The living marine resources of Kuwait, Eastern Saudi Arabia, Bahrain, Qatar, and the United Arab Emirates. FAO Species Identification Field Guide for Fishery Purposes, Rome. http://www.fao.org/3/v8729e/v8729e00.htm

Collins, M.J, Jones, D.A. and Clayton, D.A. (1984). 'Redescription of Uca sindensis (Alcock, 1900) (Brachyura: Ocypodidae) with notes on the ecology of a population from Kuwait'. Journal of Crustacean Biology 4:318-328. doi.org/10.2307/1548029

Jones, D. and Clayton, D. (1983). 'The systematics and ecology of crabs belonging to the genera Cleistostoma De Haan and Paracleistostoma De Man on Kuwait mudflats'. Crustaceana 45:183199. doi.org/10.1163/156854083X00613

Jones, D.A. (1986a). A field guide to the sea shores of Kuwait and the Arabian Gulf. University of Kuwait, Distributed by Blandford Press, Poole.

Jones, D.A. (1986b). 'Ecology of the rocky and sandy shores of Kuwait'. In: Halwagy, R., Clayton, D.A. \& Behbehani, M (eds) Marine environment and pollution, proceedings of the 1st Arabian Gulf Conference on Environment and Pollution, pp 69-81. University of Kuwait, Kuwait.

Naderloo, R. (2017). Atlas of Crabs of the Persian Gulf. Springer.

Snowden, R.J., Clayton, D.A. and Al-Taher, E.Y. (1991). 'Population biology of Ilyoplax stevensi (Brachyura: Ocypodidae) on a Kuwait mudflat'. Marine Ecology Progress Series 71:219-225. doi.org/10.3354/meps071219

Snowden, R.J., Clayton, D.A. and Al-Taher, E.Y. (1994). 'Aspects of the ecology of Tylodiplax indica Alcock (Brachyura: Ocypodidae) on a Kuwait mudflat'. Journal of the University of Kuwait (Science) 21:219-228.

Snowden, R.J. and Clayton, D.A. (1995). 'Aspects of the life history and seasonal ecology of Nasima dotilliformis (Alcock) (Brachyura: Ocypodidae) on a Kuwait mudflat'. Journal of the University of Kuwait (Science) 22:84-94. 


\subsubsection{Suborder Pleocyemata Infraorder Caridea}

The Caridea, commonly known as caridean shrimp are represented by 12 species and two unidentified dpecies in four families (Table 21). Anker \& De Grave (2009) described a new species from
Kuwait, Alpheus lutosus. Several papers included records from Kuwait (Motoh, 1975; Jones, 1986; Grabe \& Lees, 1995; De Grave \& Ashelby, 2011).

Table 21: Caridea reported from Kuwait.

\begin{tabular}{|l|l|l|l|}
\hline Infraorder & Superfamily & \multicolumn{1}{|c|}{ Family } & \multicolumn{1}{c|}{ Species } \\
\hline Caridea & Alpheoidea & Alpheidae & Alpheus sp. \\
\hline & & & Alpheus djeddensis (Coutie`re, 1897) \\
\hline & & & Alpheus lutosus Anker \& De Grave. 2009 \\
\hline & & & Athanas sp \\
\hline & & & Athanas dimorphus (Ortmann, 1894) \\
\hline & & & Athanas rhothionastes (Banner \& Banner, 1960) \\
\hline & & Palaemonidae & Periclimenes obscurus (Kemp, 1922) \\
\hline & Hippolytidae & Latreutes anoplonyx Kemp, 1914 \\
\hline & & Saron marmoratus (Olivier, 1811) \\
\hline & & Lysmatidae & Lysmata vittata (Stimpson, 1860) \\
\hline & & Ogyrididae & Ogyrides orientalis (Stimpson, 1860) \\
\hline
\end{tabular}

\section{References}

Anker, A. and De Grave, S. (2009). 'A new snapping shrimp (Crustacea Decapoda, Alpheidae, Alpheus) from the estuarine mudflats of Kuwait'. Zool. Med. Leiden 83: 811-817.

Motoh, H. (1975). A report on macruran Decapoda from the north-western Arabian Gulf along the coast of Kuwait. Kuwait Institute for Scientific Research MAB II.VIII.75: 1-25.

Grabe, S.A. and Lees, D.C. (1995). 'Macrozooplankton studies in Kuwait Bay (Arabian Gulf). III. Distribution and composition of larval pleocyemate decapod Crustacea'. Journal of Plankton Research 17:955-963. doi.org/10.1093/plankt/17.5.955

Jones, D.A. (1986). A field guide to the seashores of Kuwait and the Arabian Gulf. University of Kuwait and Blandford Press, Dorset.

De Grave, S. and Ashelby, C.W. (2011). 'Notes on some shrimp species (Decapoda: Caridea) from Qatar, with an annotated checklist of marine caridean species known from the Persian Gulf'. Marine Biodiversity Records 4: 1-7. doi.org/10.1017/S1755267211000224 


\subsubsection{Suborder Dendrobranchiata}

Dendrobranchiata is a suborder of decapod shrimps, commonly known as prawns. Thirteen species in two families have been recorded (Table
22) from Kuwait (Motoh, 1975; Al-Yamani \& Khvorov, 2007; Bishop et al., 2008; Al-Yamani et al., 2012).

Table 22: Dendrobranchiata reported from Kuwait.

\begin{tabular}{|l|l|}
\hline \multicolumn{1}{|c|}{ Family } & \multicolumn{1}{c|}{ Species } \\
\hline & Acetes japonicus \\
\hline Sergestidae & Sergestis sp. \\
\hline Penaeidae & Ganjampenaeopsis uncata \\
\hline & Megokris pescadoreensis \\
\hline & Metapenaeopsis stridulans \\
\hline & Metapenaeus affinis \\
\hline & Metapenaeus stebbingi \\
\hline & Parapenaeopsis stylifera \\
\hline & Penaeus japonicus \\
\hline & Penaeus latisulcatus \\
\hline & Penaeus semisulcatus \\
\hline & Solenocera crassicornis \\
\hline & Trachysalambria curvirostris \\
\hline
\end{tabular}

\section{References}

Al-Yamani, F. and Khvorov, S.A. (2007). 'Spatial and temporal variability in larval decapod abundance in Kuwait's waters off Bubiyan Island'. International Journal of Oceans and Oceanography 2: 69-84.

Al-Yamani, F.Y., Skryabin, V., Boltachova, N., Revkov, N., Makarov, M., Grinstov, V. and Kolesnikova, E. (2012). Illustrated Atlas on the Zoobenthos of Kuwait, pp 383. Kuwait Institute for Scientific Research.

Bishop, J. M., Ye, Y., Alsaffar, A. H., Al-Foudari, H. M. and Al-Jazzaf, S. (2008). 'Diurnal and nocturnal catchability of Kuwait's commercial shrimps'. Fishery Research 94: 58-72. doi.org/10.1016/j. fishres.2008.06.020

Motoh, H. (1975). A report on macruran Decapoda from the north-western Arabian Gulf along the coast of Kuwait. Kuwait Institute for Scientific Research MAB II.VIII.75: 1-25. 


\subsubsection{Infraorders Achelata, Anomura and Thalassinidea}

These are the Sand Crabs, Left-handed Hermit Crabs, Porcelain Crabs, Slipper Lobsters and Ghost shrimp. They are represented by at least eight species (Table 23) (Motoh, 1975; Carpenter et al., 1997a; Al-Yamani et al., 2012).

Table 23: Achelata, Anomura and Thalassinidea reported from Kuwait.

\begin{tabular}{|l|l|l|}
\hline \multicolumn{1}{|c|}{ Infraorder } & \multicolumn{1}{|c|}{ Family } & \multicolumn{1}{c|}{ Species } \\
\hline Achelata & Scyllaridae & Thenus orientalis (Lund, 1793) \\
\hline Anomura & Hippidae & Emerita holthuisi Sankolli, 1965 \\
\hline & Diogenidae & Diogenes sp. \\
\hline & & Paguristes sp. \\
\hline & Porcellanidae & Petrolisthes carinipes (Heller, 1861) \\
\hline & & Petrolisthes rufescens (Heller, 1861) \\
\hline & & Raphidopus sp. \\
\hline Thalassinidea & Callianassidae & Callianassa sp. \\
\hline
\end{tabular}

\section{References}

Al-Yamani, F.Y., Skryabin, V., Boltachova, N., Revkov, N., Makarov, M., Grinstov, V. and Kolesnikova, E. (2012). Illustrated Atlas on the Zoobenthos of Kuwait, pp 383. Kuwait Institute for Scientific Research.

Carpenter, K.E., Krupp, F., Jones, D.A. and Zajonz, U. (1997a). Living Marine Resources of Kuwait, Eastern Saudi Arabia, Bahrain, Qatar, and the United Arab Emirates, pp 293. FAO species identification field guide for fishery purposes. Rome, Italy: Food and Agriculture Organization of the United Nations.

Motoh, H. (1975). A report on macruran Decapoda from the north-western Arabian Gulf along the coast of Kuwait. Kuwait Institute for Scientific Research MAB II.VIII.75: 1-25. 


\subsubsection{Order Isopoda}

In total, 13 species of isopods were reported from Kuwait (Bowman \& Tareen, 1983; Mathews \& Samuel, 1987; Al-Yamani et al., 2012) (Table 24). Bowman \& Tareen (1981 \&1983) described seven new species of parasitic isopods parasitizing fishes in Kuwait. Mathews \& Samuel (1987) reported on Livoneca sp. recovered from Helotes sexlineatus.

Table 24: Isopods reported from Kuwait.

\begin{tabular}{|c|c|c|}
\hline Family & Parasite & Fish host \\
\hline \multirow[t]{10}{*}{ Cymothoidae } & Anilocra monoma Bowman \& Tareen, 1983 & $\begin{array}{l}\text { Acanthopagrus s latus, Hilsa ilisha, } \\
\text { Nematalosus nasus, Johnius aneus }\end{array}$ \\
\hline & Nerocila (Nerocila) phaiopleura Bleeker, 1857 & Chirocentrus darab, Dussumieria acuta \\
\hline & Nerocila (Emphylia) kisra Bowman \& Tareen, 1983 & $\begin{array}{l}\text { Therapon puta, Scomberomorus sp., } \\
\text { Polydactylus sp., Ilisha indica, Helotes } \\
\text { sexlineatus, Acanthopagrus cuvieri, } \\
\text { Pelates quadrilineatus, Kathala axillaris }\end{array}$ \\
\hline & Nerocila (Nerocila) sigani Bowman \& Tareen, 1983 & Siganus oramin \\
\hline & Nerocila (Nerocila) arres Bowman \& Tareen, 1983 & $\begin{array}{l}\text { Epinephalus tauvina, Acanthopagrns latus, } \\
\text { Nemipterus japonicus, Nemipterus tolu }\end{array}$ \\
\hline & Catoessa gruneri Bowman \& Tareen, 1983 & $\begin{array}{l}\text { Leiognathus fasciatus, Ilisha indica, } \\
\text { Therapon puta, Leiognathus daura }\end{array}$ \\
\hline & Joryma sawayah Bowman \& Tareen, 1983 & Ilisha indica, Therapon puta \\
\hline & Mothocya sp. & Strongylura strongylura \\
\hline & Cymothoa eremita? (Brunnich, 1783) & Pampus argenteus, Sphyraena obtusata \\
\hline & Livoneca sp. & Helotes sexlineatus \\
\hline Anthuridae & Apanthura sandalensis Stebbing, 1900 & \\
\hline Gnathiidae & Gnathia sp. & \\
\hline Lernaeopodidae & Thysanote alternans Kabata \& Tareen, 1981 & Polynemus sextarius \\
\hline
\end{tabular}

\section{References}

Al-Yamani, F.Y., Skryabin, V., Boltachova, N., Revkov, N., Makarov, M., Grinstov, V. and Kolesnikova, E. 2012. Illustrated Atlas on the Zoobenthos of Kuwait, pp 383. Kuwait Institute for Scientific Research.

Bowman, T.E. and Tareen, I.U. (1983). 'Gymothoidae from fishes of Kuwait (Arabian Gulf) (Crustacea: Isopoda)'. Smithsonian Contributions to Zoology 382:1-30.

Mathews, C. P. and Samuel, M. (1987). 'The incidence of Livoneca sp. (Isopoda) on Helotes sexlineatus (Pisces) in Kuwait waters'. Journal of Applied Ichthyology 3: 142-144. doi. org/10.1111/j.1439-0426.1987.tb00467.x

Mathews, C. P., El-Musa, M., Al-Hossaini, M. Samuel, M., and Abdul-Ghaffar, A. R. (1988). 'Infestation of Epipenaenon elegans on Penaeus semisulcatus and their use as biological tags'. Journal of Crustacean Biology 8: 53-62. doi.org/10.1163/193724088X00071 


\subsubsection{Order Cumacea}

Species of this order are known as hooded shrimp or comma shrimp. Only three identified species and seven unidentified species (Table 25) have been recorded from Kuwait (Al-Yamani et al., 2012).

Table 25: comma shrimp reported from Kuwait.

\begin{tabular}{|l|l|}
\hline \multicolumn{1}{|c|}{ Family } & \multicolumn{1}{|c|}{ Species } \\
\hline Bodotriidae & Bodotria sp. \\
\hline & Cumopsis sp. \\
\hline & Cyclaspis sp. \\
\hline & Eocuma affine Calman, 1904 \\
\hline & Eocuma rosae Corbera and Galil, 2007 \\
\hline & Eocuma sp. \\
\hline & Iphinoe maeotica Sowinskyi, 1893 \\
\hline & Iphinoe sp. \\
\hline & Campylaspis sp. \\
\hline Nannastacidae & Cumella sp. \\
\hline
\end{tabular}

\section{References}

Al-Yamani, F.Y., Skryabin, V., Boltachova, N., Revkov, N., Makarov, M., Grinstov, V. and Kolesnikova, E. (2012). Illustrated Atlas on the Zoobenthos of Kuwait, 383 pp. Kuwait Institute for Scientific Research.

\subsubsection{Order Mysida}

This order is represented by one species Rhopalophthalmus tattersallae (Grabe, 1989) and one unidentified species of the genus Gastrosaccus (Al-Yamani et al., 2012).

\section{References}

Al-Yamani, F.Y., Skryabin, V., Boltachova, N., Revkov, N., Makarov, M., Grinstov, V. and Kolesnikova, E. (2012). Illustrated Atlas on the Zoobenthos of Kuwait, pp 383. Kuwait Institute for Scientific Research.

Grabe, S.A. (1989). 'Some aspects of the biology of Rhopalophthalmus tattersallae Pillai, 1961 (Crustacea, Mysidacea) and extension of range into the Khor-Al-Sabiya, Kuwait (Arabian Gulf) '. Proceedings of the Biological Society of Washington 102:726-731.

Jones, D.A. (1986). A field guide to the sea shores of Kuwait and the Arabian Gulf, pp 192. University of Kuwait, Blandford Press, Poole. 


\subsubsection{Class Hexanauplia}

The Hexanauplia is a class of crustaceans that includes Copepoda, Tantulocarida, acorn barnacle and the Thecostraca. Many species of copepoda are external parasites on fishes. Fifty nine species of copepods were reported from Kuwait (Table 26). Twenty-three species of parasitic Copepoda were reported on marine fishes in Kuwait (Ho \&
Sey 1996) and by Al-Yamani \& Prusova (2003). Ho \& Kim (1997 \& 2001) and Ho et al. (1999) described several new species of coppods parasitizing fishes in kuwait. Kabata \& Tareen (1984) also described new species for Kuwait including, Caligus kuwaitensis.

Table 26: Hexanauplia reported from Kuwait.

\begin{tabular}{|c|c|c|c|c|}
\hline Order & Family & Species & Fish host & Reference \\
\hline \multirow[t]{8}{*}{ Siphonostomatoida } & Caligidae & Caligus kuwaitensis & Plotossus anguillaris & Kabata \& Tareen (1984) \\
\hline & Hatschekidae & Hatschekia seyi & Heniochus acuminatus & Ho \& Kim (2001) \\
\hline & & Hatschekia nodosa & Lutjanus coccineus & Ho \& Kim (2001) \\
\hline & & Hatschekia tanysoma & Lutjanus fulviflamma & Ho \& Kim (2001) \\
\hline & Lernanthropidae & Lernanthropus cadenati & Acanthopagrus berda & Ho \& Sey (1996) \\
\hline & & Anuretes anomalus & Plectorhynchus cinctus & Ho \& Sey (1996) \\
\hline & Lernaeopodidae & Sparidicola lithognathi & Acanthopagrus latus & Kabata \& Tareen (1987) \\
\hline & & Thysanote alternans & Polynemus sextarius & \\
\hline \multirow[t]{12}{*}{ Cyclopoida } & Bomolochidae & $\begin{array}{l}\text { Nothobomolochus triceros } \\
\text { (Bassett-Smith, 1898) }\end{array}$ & Pampus argenteus & Ho et al. (2000) \\
\hline & & $\begin{array}{l}\text { Orbitacolax hapalogenyos } \\
\text { (Yamaguti \& Yamasu, 1959) }\end{array}$ & $\begin{array}{l}\text { Hemirhamphus } \\
\text { marginatus }\end{array}$ & Ho et al. (2000) \\
\hline & Taeniacanthidae & Irodes kuwaitensis & Upeneus sulpureus & Ho et al. (1999) \\
\hline & Chondracanthidae & Berea clava & Pseudorhombus arsius & Ho \& Sey (1997) \\
\hline & Oithonidae & Oithona fallax & & Michel \& Herring (1984) \\
\hline & & Oithona hamata & & Michel \& Herring (1984) \\
\hline & Clausidiidae & Saphirella sp. & & Michel \& Herring (1984) \\
\hline & Oncaeidae & Triconia conifera & & Michel \& Herring (1984) \\
\hline & & Conaea sp. & & Michel \& Herring (1984) \\
\hline & Corycaeidae & Corycaeus sp. & & Michel \& Herring (1984) \\
\hline & Sapphirinidae & Sapphirina sp. & & Michel \& Herring (1984) \\
\hline & & Copilia sp. & & Michel \& Herring (1984) \\
\hline \multirow[t]{4}{*}{ Calanoida } & Calanidae & Canthocalanus pauper & & Michel \& Herring (1984) \\
\hline & Eucalanidae & Subeucalanus monachus & & Michel \& Herring (1984) \\
\hline & & Subeucalanus flemingeri & & Prusova et al. (2001) \\
\hline & Paracalanidae & Acrocalanus gibber & & Michel \& Herring (1984) \\
\hline
\end{tabular}




\begin{tabular}{|c|c|c|c|c|}
\hline Order & Family & Species & Fish host & Reference \\
\hline & & Paracalanus aculeatus & & Michel \& Herring (1984) \\
\hline & & Parvocalanus crassirostris & & Michel \& Herring (1984) \\
\hline & & Bestiolina arabica & & Ali et al. (2007) \\
\hline & Centropagidae & Centropages furcatus & & Michel \& Herring (1984) \\
\hline & & Centropages orsinii & & Michel \& Herring (1984) \\
\hline & & Centropages tenuiremis & & Michel \& Herring (1984) \\
\hline & Pseudodiaptomidae & Pseudodiaptomus marinus & & Michel \& Herring (1984) \\
\hline & Temoridae & Temora discaudata & & Michel \& Herring (1984) \\
\hline & & Temora turbinata & & Michel \& Herring (1984) \\
\hline & Candaciidae & Candacia bradyi & & Michel \& Herring (1984) \\
\hline & Pontellidae & Calanopia elliptica & & Michel \& Herring (1984) \\
\hline & & Calanopia minor & & Michel \& Herring (1984) \\
\hline & & Labidocera acutifrons & & Michel \& Herring (1984) \\
\hline & & Labidocera kroyeri & & Michel \& Herring (1984) \\
\hline & & Labidocera acuta & & Michel \& Herring (1984) \\
\hline & & Labidocera minuta & & Michel \& Herring (1984) \\
\hline & & Labidocera kuwaitiana & & Prusova \& Al-Yamani, 2014 \\
\hline & & Pontellasp. & & Michel \& Herring (1984) \\
\hline & & Pontellina sp. & & Michel \& Herring (1984) \\
\hline & & Pontellopsis herdmani & & Michel \& Herring (1984) \\
\hline & Acartiidae & Acartia bispinosa & & Michel \& Herring (1984) \\
\hline & & Acartia pacifica & & Michel \& Herring (1984) \\
\hline & & $\begin{array}{l}\text { Acartia (Acanthacartia) } \\
\text { pietschmani }\end{array}$ & & Michel \& Herring (1984) \\
\hline & & Acartia faoensis & & Ali et al. 2009 \\
\hline & Tortanidae & Tortanus forcipatus & & Michel \& Herring (1984) \\
\hline & & $\begin{array}{l}\text { Tortanus (Atortus) } \\
\text { recticaudus }\end{array}$ & & Michel \& Herring (1984) \\
\hline \multirow[t]{5}{*}{ Canuelloida } & Longipediidae & Longipedia sp. & & Michel \& Herring (1984) \\
\hline & Ectinosomatidae & Microsetella rosea & & Michel \& Herring (1984) \\
\hline & & Macrosetella gracilis & & Michel \& Herring (1984) \\
\hline & Tachidiidae & Euterpina acutifrons & & Michel \& Herring (1984) \\
\hline & Peltidiidae & Clytemnestra scutellata & & Michel \& Herring (1984) \\
\hline \multirow[t]{3}{*}{ Monstrilloida } & Monstrillidae & Cymbasoma longispinosum & & Michel \& Herring (1984) \\
\hline & & Pleopis polyphemoides & & \\
\hline & Sididae & Penilia avirostris & & \\
\hline Sessilia & Balanidae & Amphibalanus amphitrite & & \\
\hline
\end{tabular}




\subsubsection{Class Branchiopoda}

A single species of class Branchiopoda (Order Onychopoda, Family Podonidae), Pseudevadne tergestina has been reported from Kuwait.

\section{Reference}

Ali, M. (2010). 'Unusual abundance of Podon spp. in Kuwait Bay, northwestern Arabian Gulf '. Crustaceana 83: 1519-1530. doi.org/10.1163/001121610X538192

Ali, M., Al-Yamani, F. and Khalaf, T. A. (2009). 'Observation of Acartia (Acartiella) faoensis (Copepoda: Calanoida: Acartidae) near Bubiyan Island in the north of Kuwait'. Crustaceana 82: 1073-1077. doi.org/10.1163/156854009X448871

Ali, M., Al-Yamani, F. and Prusova, I. (2007). 'Bestiolina arabica sp. nov. (Copepoda, Calanoida, Paracalanidae), a new species from the northwestern Arabian Gulf'. Crustaceana 80:195-205. doi. org/10.1163/156854007780121429

Al-Yamani, F.Y. and Prusova, I.Y. (2003). Common copepods of the Northwestern Arabian Gulf: Identification Guide, pp 162. Kuwait Institute for Scientific Research, Kuwait.

Ho, J.-S. and Sey, O. (1996). 'Parasitic Copepoda of marine fishes from Kuwait: a preliminary report'. Kuwait Journal of Science \& Engineering 23: 61-69.

Ho, J.-S. and Sey, O. (1997). 'New species of Berea (Copepoda, Chondracanthidae) parasitic on a flounder from Kuwait'. Pakistan Journal of Marine Sciences 6: 53-57.

Ho, J.-S., Kim, I.-Hoi. and Sey, O. (1999). 'New species of Irodes (Copepoda, Taeniacanthidae) parasitic on the goatfish from Kuwait, with a key to the species of Irodes'. Pakistan Journal of Marine Sciences 82:123-129.

Ho, J.-S., Kim, I.-Hoi. and Sey, O. (2000). 'Two species of bomolochid copepods (Crustacea) parasitic on marine fishes of Kuwait'. Proceedings of the Biological Society of Washington 113:670-680.

Ho, J.-S. and I.-Hoi. (2001). 'New species of Hatschekia Poche, 1902 (Copepoda: Hatschekiidae) parasitic on marine fishes of Kuwait'. Systematic Parasitology 49: 73-79.

Kabata, Z. and Tareen, I.U. (1984). 'Description of Caligus kuwaitensis n.sp. (Copepoda: Siphonostomatoida) with comments on Caligus antennatus Boxshall and Gurney, 1980'. Systematic Parasitology 6:57-62. doi.org/10.1007/BF00752617

Kabata, Z. and Tareen, I.U. (1981). 'A new species of Thysanote Kroyer, 1863 (Copepoda, Lernaeopodidae) from the Persian Gulf, with comments on the genus'. Systematic Parasitology 3:97-103. doi.org/10.3750/AIP2008.38.1.04

Kabata, Z. and Tareen, I.U. (1987). 'A new and a rare parasitic copepod from fishes of Kuwait'. Systematic Parasitology 9:137-142. doi.org/10.1007/BF00012191

Michel, H.B. and Herring, D.C. (1984). Diversity and abundance of copepoda in the northwestern Arabian Gulf. Crustaceana, Supplement, Studies on Copepoda II (Proceedings of the First International Conference on Copepoda, Amsterdam, the Netherlands, $24-28$ August 1981) 7:326-335.

Prusova, I. and Al-Yamani, F. (2014). 'A new species of Labidocera (Copepoda, Calanoida, Pontellidae) from the Arabian Gulf'. Crustaceana 87:1149-1167. doi.org/10.1163/15685403-00003348

Prusova, I.Y., Al Yamani, F. and Al Mutairi, H. (2001). 'Subeucalanus flemingeri sp. n. from the Arabian Gulf (Copepoda: Eucalanidae) '. Zoosystematica Rossica 10: 47-54. 


\subsection{Subphylum Hexapoda}

\subsubsection{Class Insecta}

Several publications dealt with the insect fauna of Kuwait were published over the past 80 years. (Uvarov, 1930; Abushama \& Cloudsley-Thompson, 1978; Clayton \& Pilcher, 1983; Al-Houty, 1989, 1997 \& 2011; Horváth \& Zeil, 1996).

Al-Houty (2009) summarized the known species of insects in Kuwait until 2008. Later, Al-Houty (2011) updated the list of recorded insects in Kuwait reaching 684 species.

A series of educational books on the insects of Kuwait were published with good quality illutrations, covering the coleopterans, wasps and ants, butterflies and moths, grasshoppers and amphids (Figure 30).
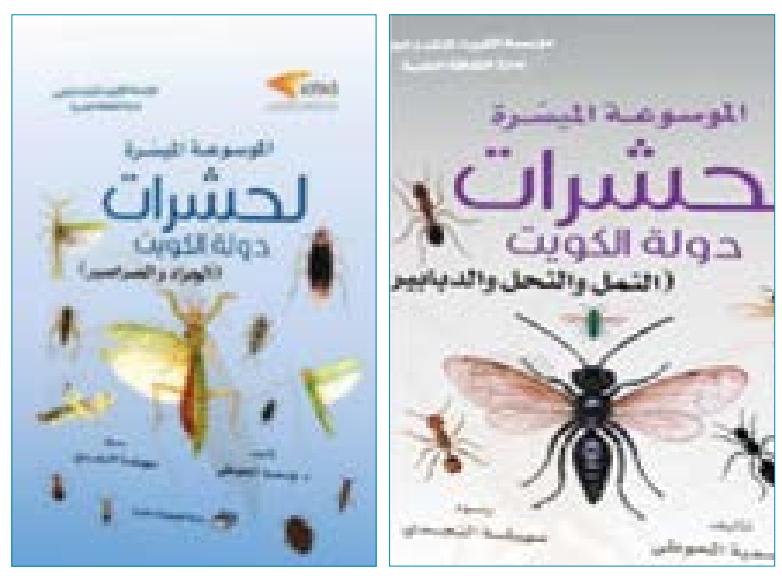

Figure 30: Books in Arabic on the insects of Kuwait

\subsubsection{Order Odonata (Dragonflies)}

The Odonata (Dragonflies) of Kuwait were studied by Al-Houty (1985). So far, a total of 12 species have been recorded (Table 27). More data on the distribution of the dragonflies of Kuwait are included in Waterston \& Pittaway (1991).

Table 27: Odonata of Kuwait

\begin{tabular}{|l|l|l|}
\hline \multicolumn{1}{|c|}{ Suborder } & \multicolumn{1}{|c|}{ Family } & \multicolumn{1}{c|}{ Species } \\
\hline Anisoptera & Aeshnidae & Anax parthenope (Selys 1839) \\
\hline & & Hemianax ephippiger (Bur-meister 1839) \\
\hline & Gomphidae & Lindenia tetraphylla (Vander Linden 1825) \\
\hline & Libellulidae & Crocothemis chaldaeorum Morton, 1920 \\
\hline & & Crocothemis erythraea (Brulle 1832) \\
\hline & & Crocothemis servilia (Drury 1770) \\
\hline & & Orthetrum sabina (Drury 1773) \\
\hline & & Orthetrum taeniolatum (Schneider 1845) \\
\hline & & Selysiothemis nigra (Vander Linden 1825) \\
\hline & & Trithemis annulata (Beauvais 1807) \\
\hline Zygoptera & Coenagrionidae & Trithemis arteriosa (Bur-meister 1839) \\
\hline
\end{tabular}




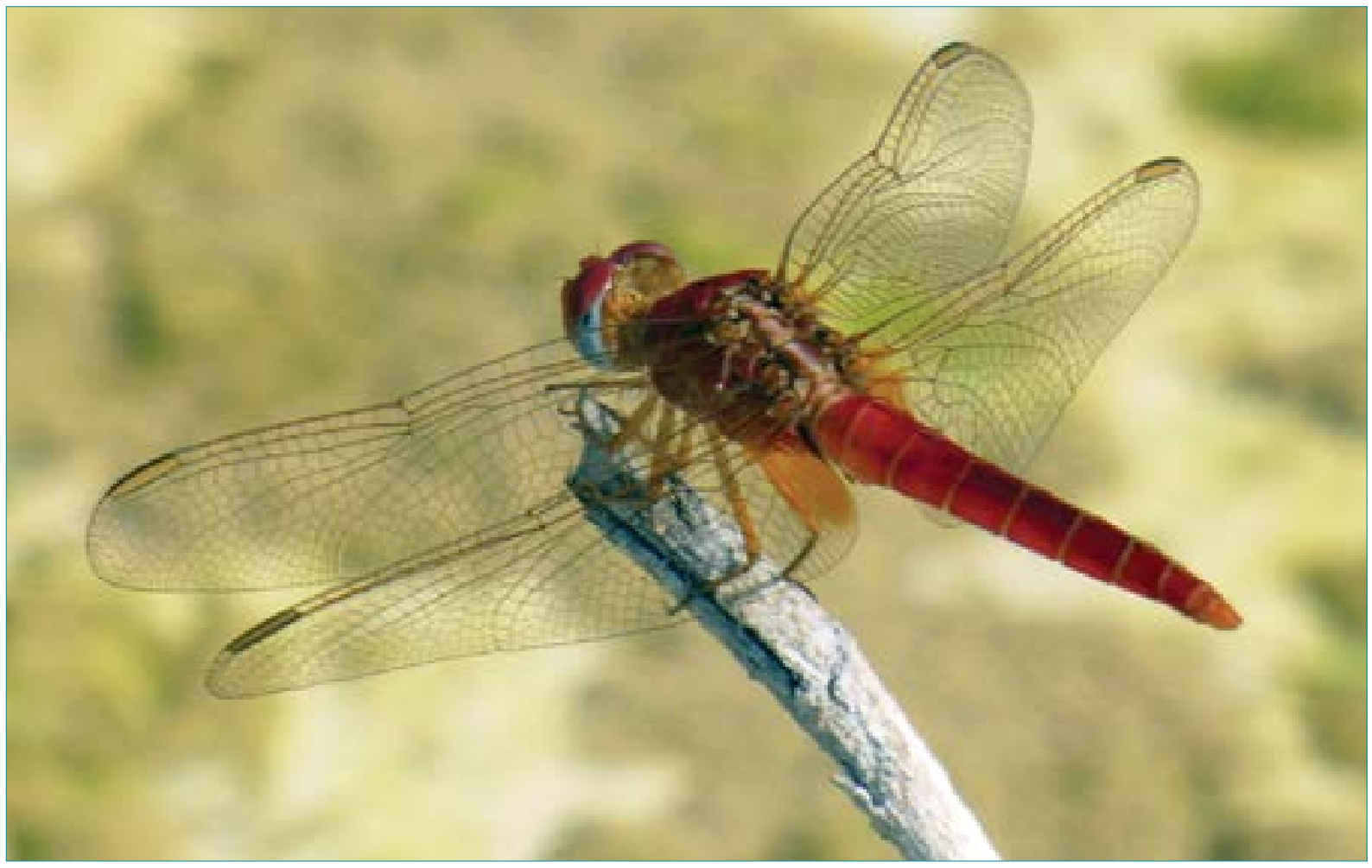

Figure 31: Dargonflies from Kuwait, Crocothemis erythrea (Photo from Mohammad El Marefi).

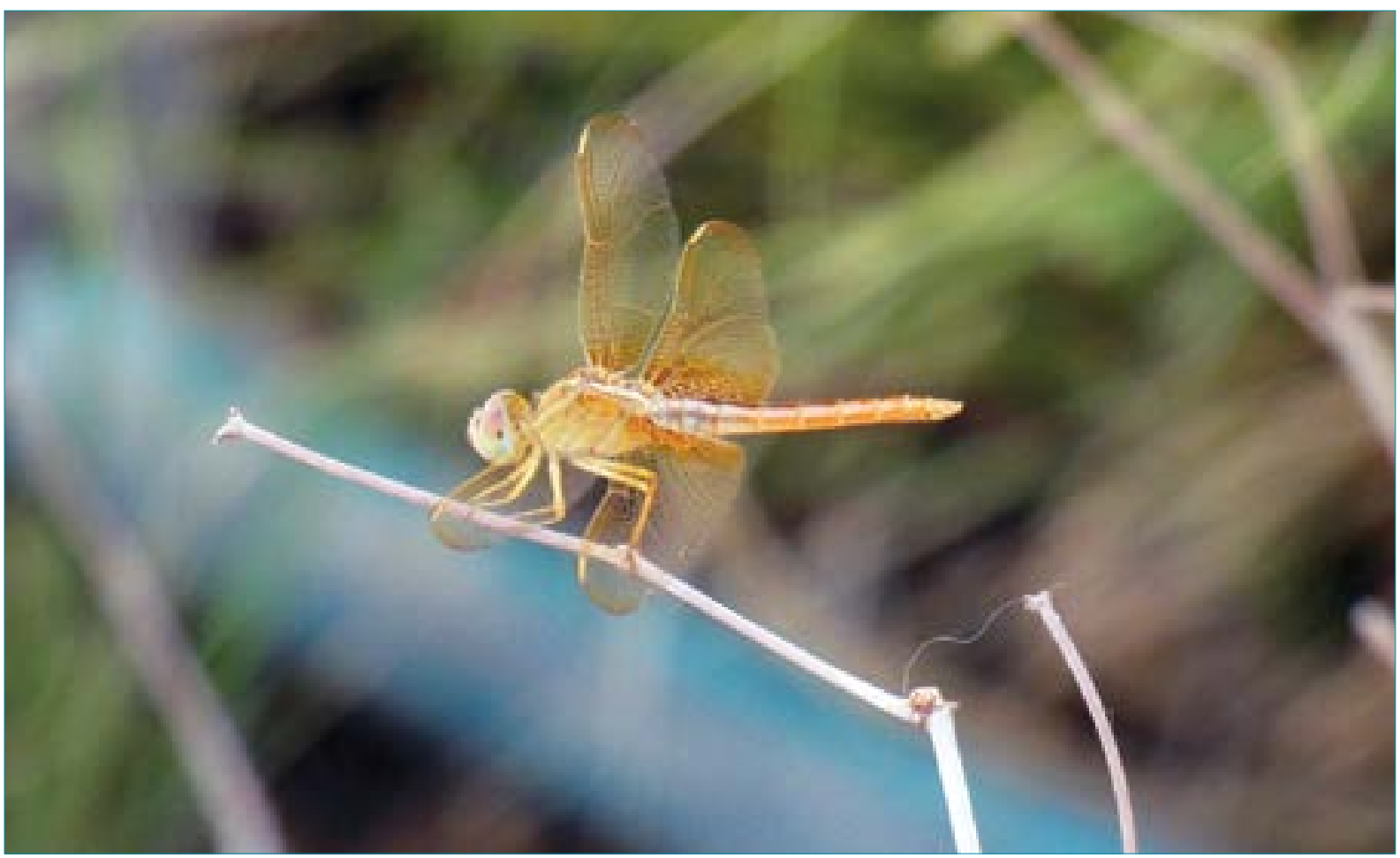

Figure 32: Dargonflies from Kuwait, Crocothemis servilia (Photo from Mohammad El Marefi).

\section{References}

Al-Houty, W. (1985). 'Some Odonata from Kuwait'. Entomologists Monthly Magazine 121: 62.

Waterston, A.R. and Pittaway, A.R. (1991). 'The Odonata or Dragonflies of Oman and neighbouring territories'. Journal of Oman Studies 10: 131-168. 


\subsubsection{Order Orthoptera}

The grasshopper of Kuwait consists of 31 species in five families (Table 28). Our data were based on records of Uvarov (1930), Al-Houty (1997, 2009 \&

2011) and Gorochov (1993)

Table 28: Orthopteran species recorded from Kuwait

\begin{tabular}{|c|c|}
\hline Family & Species \\
\hline \multirow[t]{24}{*}{ Acrididae } & Acrotylus insubricus inficifus Walker 1870 \\
\hline & Aiolopus simulatrix (Walker 1870) \\
\hline & Aiolopus thalassinus (Fabricius 1781) \\
\hline & Anacridium aegypticum (Linnaeus 1764) \\
\hline & Anacridium melanorhodon Dirsh 1953 \\
\hline & Cyclopternacris (Heteracris) muscatensis Popov, 1981 \\
\hline & Duroniella lucasii (Bolívar, 1881) \\
\hline & Heteracris annulosus (Walker 1870) \\
\hline & Hedotettix alienus Uvarov, 1936 \\
\hline & Locusta migratoria (Linnaeus 1758) \\
\hline & Mioscirtus wagneri (Kittary 1849) \\
\hline & Morphacris fasciata (Thunberg 1815) \\
\hline & Ochrilidia geniculata (I. Bouvar 1913 \\
\hline & Pseudosphingonotus paradoxus (Bey-Bienko 1948) \\
\hline & Pseudosphingonotus savignyi (Saussure 1884) \\
\hline & Pyrgmorpha cognata (Uvarov 1943) \\
\hline & Pyrgmorpha conica-bispinosa Hsiung-Kevan 1975 \\
\hline & Schistocerca gregaria (Forskol 1775) \\
\hline & Sphingonotus octofaciatus (Serville 1838) \\
\hline & Sphingonotus rubescens (Walker 1870) \\
\hline & Truxalis grandis Klug 1830 \\
\hline & Truxalis mesopotamic (Dirsh 1956) \\
\hline & Truxalis procera Klug 1830 \\
\hline & Utubius syriacus Bolívar, 1893 \\
\hline Tettigoniidae & Euconocephalus incertus (Walker 1869) \\
\hline \multirow[t]{2}{*}{ Pamphagidae } & Eremotmethis carinatus (Fabricius, 1775) \\
\hline & Thrincus campanulatus Fischer von Waldheim, 1833. \\
\hline \multirow[t]{4}{*}{ Gryllidae } & Acheta domestica Linnaeus 1758 \\
\hline & Gryllodinus kerkennensis (Finot 1893) \\
\hline & Gryllus bimaculatus De Geer, 1773 \\
\hline & Gryllodes sigillatus (Walker, F., 1869) \\
\hline Gryllotalpid & Gryllotalpa gryllotalpa (Linnaeus 1758) \\
\hline
\end{tabular}




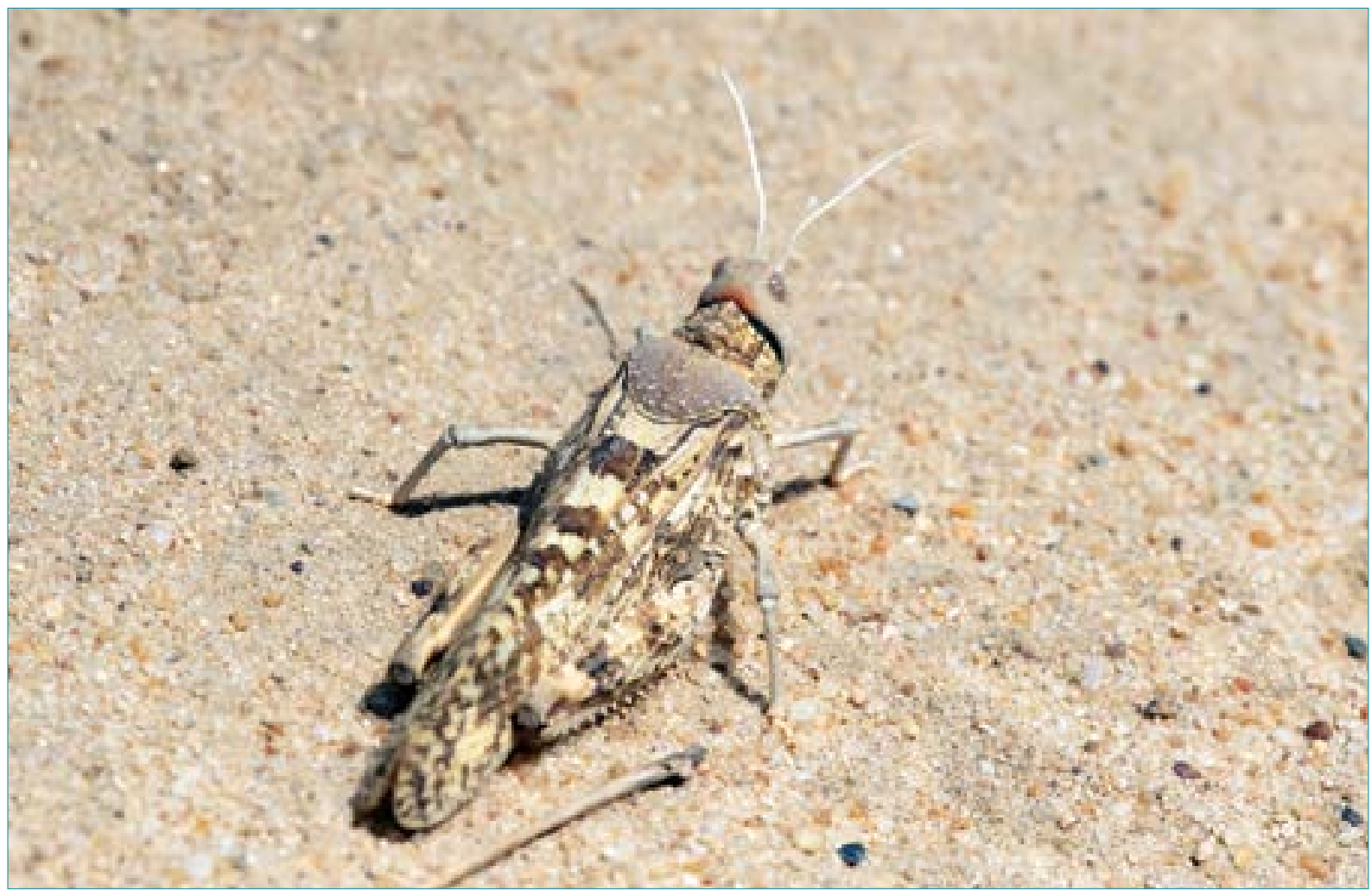

Figure 33: A grasshopper of family Acrididae (Photo from Abdul Al-Aziz Al Yousef).

\section{Reference}

Al-Houty, W. (1997). 'Checklist of the insect fauna of Kuwait'. Kuwait Journal of Science \& Engineering 24:145-162.

Al-Houty, W. (2009). 'Insect biodiversity in Kuwait'. International Journal of Biodiversity \& Conservation $1: 251-257$

Al-Houty, W. (2011). 'Recent insect fauna recorded in Kuwait'. Kuwait Journal of Science \& Engineering 38:81-92.

Gorochov, A.V. (1993). 'Grylloidea (Orthoptera) of Saudi Arabia and adjacent countries'. Fauna of Saudi Arabia 13: 79-97.

Uvarov, B.P. (1930). 'Insects of Kuwait'. In: Dickson, H.R.P., (ed.). 1949. The Arab of the desert, pp. 587-590. George Allen and Unwin Ltd., London. 


\subsubsection{Order Diptera \\ Family Culicidae}

The mosquitoes of Kuwait were studied by Salit et al. (1994 \& 1996). Recently, two additional species were added to the list of the mosquitoes of

Kuwait (Reeves et al., 2016; Colton et al., 2019). It consists of 13 species belonging to four genera (Table 29).

Table 29: Mosquitoes recorded from Kuwait.

\begin{tabular}{|l|l|}
\hline Subfiamily & \multicolumn{1}{|c|}{ Species } \\
\hline Anophelinae & Anopheles pulcherrimus Theobald (1902) \\
\hline & Anopheles pharoensis Theobo1d 1901 \\
\hline & Anopheles stephensi Liston, 1901 \\
\hline Culicinae & Culex pipiens molestus Linnaeus, 1758 \\
\hline & Culex perexiguus Theobald, 1903 \\
\hline & Culex pusillus Macquart, 1850 \\
\hline & Culex quinquefasciatus Say, 1823 \\
\hline & Culex theileri Theobald 1903 \\
\hline & Culex tritaeniorhynchus Giles, 1901 \\
\hline & Culex univittatus Theobald 1901 \\
\hline & Culiseta annulata (Schrank, 1776) \\
\hline & Culiseta longiareolata Macquart, 1838 \\
\hline & Aedes caspius (Pallas, 1771) \\
\hline & \\
\hline &
\end{tabular}

\section{Reference}

Salit, A.M., Zakaria, M., Balba, M. and Zaghloul, T. (1994). 'The mosquito fauna of Kuwait'. Journal of the University of Kuwait (Science) 21:77-84.

Salit, A. M., Al-Tubiakh, S. S., El-Fiki, S. A. and Enan, O. H. (1996). Physical and chemical properties of different types of mosquito aquatic breeding places in Kuwait State. Proceedings of the Second International Conference on Urban Pests, K.B. Wildey (editor). 185-193.

Reeves, W.K., Connors, B., Miller, M.M., Berry, D., White, S., Morey, R.R. and Brooks, C. (2016). 'Culiseta annulata: A new mosquito for Kuwait'. Journal of the American Mosquito Control Association 32: 323-325. doi.org/10.2987/16-6616.1

Colton, L., Miller, M.M. and Reeves, W.K. (2019). 'New national record for Culex perexiguus from Kuwait'. Journal of the American Mosquito Control Association 35: 65-66. doi.org/10.2987/18-6783.1 


\section{Family Psychodidae}

Six species of sandflies were reported from Kuwait (Hussien \& Behbehan, 1976; Lane \& Al-Taqi, 1983) (Table 30). Sandflies are important vectors for leishmaniasis. The disease is known from Jahra district in Kuwait, whereas the disease is caused by L. major.

Table 30: Sandflies reported from Kuwait.

\begin{tabular}{|l|}
\hline \multicolumn{1}{|c|}{ Species } \\
\hline Phlebotomus papatasi (Scopoli 1786) \\
\hline Phlebotomus alexandri Sinton 1928 \\
\hline Sergentomyia antennata (Newstead 1912) \\
\hline Sergentomyia squamipleuris \\
\hline Sergentomyia clydei (Sinton 1928) \\
\hline Tinearia alternata (Say 1824) \\
\hline
\end{tabular}

\section{Reference}

Lane R. P. and Al-Taqi, M. (1983). 'Sandflies (Diptera: Phlebotominae) and leishmaniasis in Kuwait'. Bulletin of Entomological Research 73:633-644. doi.org/10.1017/S000748530000924X

Hussien M. S. and Behbehani, K. (1976). 'The epidemiology of leishmaniasis in Kuwait 1. The occurrence and distribution of Phlebotomus sandflies (Diptera, Psychodidae) '. Zeitschrift Für Angewandte Entomologie 81:433-440. doi.org/10.1111/j.1439-0418.1976.tb04257.x

\section{Family Chironomidae}

Species of this family were reported by Crans- Mendes (2010), and Reeves \& Eple (2016), with a ton \& Judd (1989), Al-Houty (1997), Andersen \& total of nine species (Table 31)

Table 31: Chironomids reported from Kuwait.

\begin{tabular}{|l|}
\hline \multicolumn{1}{|c|}{ Species } \\
\hline Ablabesmyia sp. \\
\hline Chironomus attenuates Walker, 1848 \\
\hline Chironomus calipterus Kieffer, 1908 \\
\hline Chironomus pulcher Wiedemann, 1930 \\
\hline Limnophyes natalensis (Kieffer, 1914) \\
\hline Polypedilum (Polypedilum) nubifer \\
\hline Polypedilum nubeculosum (Meigen 1804) \\
\hline Procladius brevipetiolatus (Goetghebuer 1935) \\
\hline Chironomus dorsalis Meigen, 1818 \\
\hline
\end{tabular}




\section{References}

Al-Houty, W. (1997). 'Checklist of the insect fauna of Kuwait'. Kuwait Journal of Science \& Engineering 24: 145-162.

Andersen, T. and Mendes, H.F. (2010). Order Diptera, family Chironomidae (with the exception of the tribe Tanytarsini). In Harten, A. van (ed.) Arthropod fauna of the United Arab Emirates. Vol. 3. Dar Al Ummah, Abu Dhabi, pp. 564-598.

Cranston, P.S. and Judd, D.D. (1989). 'Diptera: Fam. Chironomidae of the Arabian Peninsula'. Fauna of Saudi Arabia 10:236-289.

Reeves, W.K. and Epler, J.H. (2016). 'New records and a review of the Chironomidae (Diptera) of Kuwait and the United Arab Emirates'. Chironomus Journal of Chironomidae Research 29: 2932. doi.org/10.5324/cjcr.v0i29.2032

\section{Family Asilidae}

The robber flies of Kuwait consists of six species (Al-Houty, 1997) (Table 32).

Table 32: Robber flies reported from Kuwait.

\begin{tabular}{|l|}
\hline \multicolumn{1}{|c|}{ Species } \\
\hline Apoclea algira (Linnaeus 1767) \\
\hline Apoclea femoralis (Wiedemann 1828) \\
\hline Dasypogonjugulum (Loew 1847) \\
\hline Habropogon appendiculatus Schiner 1867 \\
\hline Laphystia erberi Schiner 1865 \\
\hline Machimus cingulatus (Fabricius 1781) \\
\hline
\end{tabular}

\section{References}

Al-Houty, W. (1997). 'Checklist of the insect fauna of Kuwait'. Kuwait Journal of Science \& Engineering 24: $145-162$.

\section{Family Bombyliidae}

A total of 12 species of bee flies (Table 33) were reported from Kuwait by Al-Houty (1997).

Table 33: Bee flies reported from Kuwait.

\begin{tabular}{|l|}
\hline \multicolumn{1}{|c|}{ Species } \\
\hline Anastoechus exalbidus (Wiedemann 1820) \\
\hline Anastoechus miscens Walker, 1871 \\
\hline Anastoechus niveus Hermann 1909 \\
\hline Anastoechus trisignatus Portschinskii 1881 \\
\hline Bombylius medius (Linnaeus 1758) \\
\hline Bombylius megacephalus Portschinskii 1887 \\
\hline Cytherea nucleorum (Becker 1902) \\
\hline Heteralonia mucorea (K1ug 1832) \\
\hline Parachistus pulchellus Greathead 1980 \\
\hline Spogostylum ocyale (Wiedemann 1828) \\
\hline Usia aurata (Fabricius 1794) \\
\hline Villa bivirgata Austen 1937 \\
\hline
\end{tabular}




\section{References}

Al-Houty, W. (1997). 'Checklist of the insect fauna of Kuwait'. Kuwait Journal of Science \& Engineering 24: $145-162$.

\section{Other families of order Diptera}

Other minor families of order Diptera include 14 families (Table 34) with a total of 25 species (AlHouty, 1997 \& 2011).

Table 34: Other families of order Diptera reported from Kuwait.

\begin{tabular}{|c|c|c|}
\hline Family & Common name & Species \\
\hline Agromyzidae & leaf-miner flies & Chromatomiya horticola Goureau 1851 \\
\hline Anthomyidae & Flower flies & Anthomyia tempestatum Wiedemann 1818 \\
\hline \multirow[t]{3}{*}{ Chloropidae } & Frit flies & Aphanotrigonum subfasciella Collin 1949 \\
\hline & & Metopostigma tenuiseta (Loew 1860) \\
\hline & & Ophiomyia beckeri Hendel 1923 \\
\hline \multirow[t]{2}{*}{ Ephydridae } & Shore flies & Actocetor margaritatus (Wiedemann 1830) \\
\hline & & Ephydra flavipes (Macquart 1843) \\
\hline Gasterophilidae & Botflies & Oestrus intestinalis (DeGeer 1776) \\
\hline Hippoboscidae & Louse flies & Hippobosca camelina Leach 1817 \\
\hline \multirow[t]{3}{*}{ Ulidiidae } & Picture-winged flies & Ceraxys urticae Linnaeus 1758 \\
\hline & & Melierio omissa Meigen 1826 \\
\hline & & Physiphora olceae Preyssler 1791 \\
\hline Pipunculidae & Big-headed flies & Tomosvaryella subvirescens (Loew 1872) \\
\hline Piophilidae & Cheese flies & Piophila casei (Linnaeus 1758) \\
\hline Phoridae & Hump-backed flies & Megaselia scalaris Loew, 1866. \\
\hline \multirow[t]{11}{*}{ Syrphidae } & Hoverflies & Conops aneus (Scopoli 1763) \\
\hline & & Episyrphus balteatus (De Geer, 1776) \\
\hline & & Eristalinus taeniops (Wiedemann 1819) \\
\hline & & Eristalinus aeneus (Scopoli 1763) \\
\hline & & Eristalinus megacephalus (Rossi, 1794) \\
\hline & & Eristalis tabanoides (Jaennicke 1867) \\
\hline & & Eumerus turkmenorum Paramanov 1927 \\
\hline & & Ischiodon aegypticus (Wiedemann 1830) \\
\hline & & Metasyrphus luniger (Meigen 1822) \\
\hline & & Syrphus corollae (Fabricius 1794) \\
\hline & & Sphaerophoria turkmenica Bankowska 1964 \\
\hline Tachinidae & Tachina flies & Drino latigena Mesnil, 1944 \\
\hline Therevidae & Stiletto flies & Hoplosathe frauenfeldi (Loew 1856) \\
\hline Coelopidae & & Microprosopa hoberlandti Sifner, 1981 \\
\hline \multirow[t]{2}{*}{ Drosophilidae } & & Drosophila melanogaster (Meigen, 1830) \\
\hline & & Zaprionus idiana Gupta. 1970 \\
\hline
\end{tabular}




\section{References}

Al-Houty, W. (1997). 'Checklist of the insect fauna of Kuwait'. Kuwait Journal of Science \& Engineering 24: 145-162.

Al-Houty, W. (2011). 'Recent insect fauna recorded in Kuwait'. Kuwait Journal of Science \& Engineering 38:81-92.

\section{Diptera of medical importance}

These species have medical importance where they may cause different forms of myiasis (Table 35). The list is based on Al-Houty (1997 \& 2011), Hira et al. (1997 \& 2004) and Al-Mesbah et al. (2011 \& 2012).

Table 35: Diptera of medical importance reported from Kuwait.

\begin{tabular}{|c|c|c|}
\hline Family & Common name & Species \\
\hline \multirow[t]{7}{*}{ Calliphoridae } & Blow flies & Calliphora erythocephala Meigen 1826 \\
\hline & & Calliphora vicina Robineau-Desvoidy 1830 \\
\hline & & Chrysomya albiceps Wiedemann 1819 \\
\hline & & Chrysomya marginalis (Wiedemann, 1830) \\
\hline & & Chrysomya megacephala \\
\hline & & Lucilia cuprina (Wiedemann 1830) \\
\hline & & Lucilia sericata (Meigen 1826) \\
\hline \multirow[t]{8}{*}{ Muscidae } & House flies & Antherigona iota Pont 1981 \\
\hline & & Coenosia attenuata Steinin Becker 1903 \\
\hline & & Limnophora tigrina (Amstein 1860) \\
\hline & & Lipse pygmaea Fallen 1825 \\
\hline & & Musca domestica Linnaeus 1758 \\
\hline & & Musca lucidula (Loew 1856) \\
\hline & & Muscina stabulans (Fallen 1817) \\
\hline & & Stomoxys sp. \\
\hline \multirow[t]{2}{*}{ Oestridae } & Warble flies & Cephalopina titillator (Clark 1816) \\
\hline & & Oestrus ovis Linnaeus 1758 \\
\hline \multirow[t]{4}{*}{ Sarcophagidae } & Flesh flies & Sarcophaga carnaria Linnaeus 1758 \\
\hline & & Sarcophaga haemorrhoidalis Fallen 1817 \\
\hline & & Parasarcophaga ruficornis Fabricius 1794 \\
\hline & & Wohlfahrtia nuba (Wiedemann 1830) \\
\hline \multirow[t]{3}{*}{ Tephritidae } & Fruit flies & Musca helianthi (Rossi 1794) \\
\hline & & Musca oleae Gmelin 1790 \\
\hline & & Musca stellata Fuessly 1775 \\
\hline
\end{tabular}




\begin{tabular}{|l|l|l|}
\hline \multicolumn{1}{|c|}{ Family } & Common name & \multicolumn{1}{c|}{ Species } \\
\hline & & Tephritis capitata (Wiedemann 1824) \\
\hline & & Trypeta amoena (Frauenfeld 1857) \\
\hline & & Trypeta augur Frauenfeld 1857 \\
\hline Fanniidae & & Trupanea stellata (Fuesslin, 1775) \\
\hline Tabanidae & Lesser house flies & Fannia canicularis (Linnaeus, 1761) \\
\hline & Horse flies & Tabanus taeniola Polisot De Beavois 1806 \\
\hline
\end{tabular}

\section{Reference}

Al-Houty, W. (1997). 'Checklist of the insect fauna of Kuwait'. Kuwait Journal of Science \& Engineering 24: 145-162.

Al-Houty, W. (2011). 'Recent insect fauna recorded in Kuwait'. Kuwait Journal of Science \& Engineering 38:81-92.

Al-Mesbah, H., Al-Osaimi, Z. and El-Azazy, O.M.E. (2011). 'Forensic entomology in Kuwait: The first case report'. Forensic Science International 206: e25-e26. doi.org/10.1016/j.forsciint.2010.07.013

Al-Mesbah, H., Moffatt, C., El-Azazy, O.M.E. and Majeed, Q.A.H. (2012). 'The decomposition of rabbit carcasses and associated necrophagous Diptera in Kuwait'. Forensic Science International 217: 27-31. doi.org/10.1016/j.forsciint.2011.09.021

Hira, P.R., Hall, M.J.R., Hajj, B., Al-Ali F., Farooq, R. and Muzairai, I.A. (1997). 'Human myiasis in Kuwait due to Oestrus ovis, Psychoda species and Megaselia species'. Medical Principles \& Practice 6:129-136. doi.org/10.1159/000157540

Hira, P.R., Assad, R.M., Okasha, G., Al-Ali, F.M., Iqbal, J., Mutawali, K.E., Hemry, R., Disney, L. and Hall, M.J.R. (2004). 'Myiasis in Kuwait: nosocomial infections caused by Lucilia sericata and Megaselia scalaris'. The American Society of Tropical Medicine \& Hygiene 70: 386-389. doi. org/10.4269/ajtmh.2004.70.386 


\subsubsection{Order Coleoptera}

The coleopteran fauna of Kuwait consists of 225 species belonging to 28 families (Annex 3). AlHouty (1984) published the first list of Tenebrionidae from Kuwait. Other publications included records for beetles from Kuwait (Abushama \& CloudsleyThompson, 1978; Al-Houty, 1997, 2004 \& 2011; Al-Houty \& Angus, 1999; Penati \& Vienna, 2006; Al-Khalifa et al., 2012). Species of family
Tenebrionidae were the most dominat with 69 species, followed by species in families Meloidae (20 species) and Scarabaeidae (24 species). Endrödi \& Al-Houty (1985) described Pentodon kuwaitense from Kuwait. Edmonds et al. (2019) added new records to the aquatic coleopteran of Kuwait.

\section{Reference}

Abushama, F. and Cloudsley-Thompson, J.L. (1978). 'Desert arthropoda of Kuwait and their distribution'. Entomologists Monthly Magazine 114: 149-150.

Al-Houty, W. (1984). 'Preliminary check-list of Tenebrionidae from Kuwait'. Journal of the University of Kuwait (Science) 11: 261-268.

Al-Houty, W. (1989). Insect fauna of Kuwait, pp 186. Kuwait University Press, Kuwait

Al-Houty, W. (1997). 'Checklist of the insect fauna of Kuwait'. Kuwait Journal of Science \& Engineering 24: 145-162.

Al-Houty W. (2004). 'A faunistic account of the beetles (Coleoptera) of the state of Kuwait'. Kuwait Journal of Science \& Engineering 31: 59-76.

Al-Houty, W. (2009). 'Insect biodiversity in Kuwait'. International Journal of Biodiversity \& Conservation $1: 251-257$

Al-Houty, W. and Al-Musalam, F. (1996). 'Dung consumption of Scarabaeus cristatus from Kuwait'. Zoology in the Middle East 12: 71-74. doi.org/10.1080/09397140.1996.10637691

Al-Houty, W. and Al-Musalam, F. (1997). 'Dung preference of the dung beetle Scarabaeus cristatus Fab (Coleoptera-Scarabaeidae) from Kuwait'. Journal of Arid Environments 35: 511-516. doi. org/10.1006/jare.1996.0179

Al-Houty, W. and Angus, R.B. (1999). 'A preliminary account of some families of aquatic Coleoptera of Kuwait (Coleoptera: Dytiscidae, Gyrinidae, Helophoridae, Hydrophilidae)'. Koleopterologische Rundschau 69: 183-186.

Al-Khalifa, H., Al-Nasser, A., Abbas, M.S. and Dashti, J. (2012). 'Biodiversity and conservation of Wildlife at the Wafra area in Kuwait'. Biodiversity Journal 3: 179-188.

Clayton, D.A. (1991). 'Assortative mating in the dune beetle Erodius sauditus (Tenebrionidae: Erodiini) in Kuwait'. Journal of Arid Environments 21: 81-89. doi.org/10.1016/S0140-1963(18)30730-4

Cloudsley-Thompson, J. L. and Constaninou, C. (1985). 'Biological clocks in desert beetles (Tenebrio nidae), with special reference to Erodius octocostatus Peyerimhof in Kuwait'. Journal of the University of Kuwait (Science) 12: 237-242.

Constantinou, C. and Cloudsley-Thompson, J.L. (1980). 'Circadian rhythmicity in Adesmia cancellata L. (Coleoptera: Tenebrionidae) from Kuwait'. Journal of Arid Environments 3: 319-324. doi. org/10.1016/S0140-1963(18)31637-9

Edmonds, N.J., Foster, G.N., Davison, P.I. and Al-Zaidan, A.S. (2019). 'Additional records of aquatic Coleoptera from Kuwait (Coleoptera: Noteridae, Dytiscidae, Spercheidae, Hydrophilidae)'. Koleopterologische Rundschau 89:11-15.

Endrödi, S. and Al-Houty, W. (1985). 'Pentodon kuwaitense (Endrödi \& Al-houty, 1985) sp. n. from Kuwait (Coleoptera, Melolonthidae)'. Annales historico-naturales Musei Nationalis Hungarici 77:205.

Penati, F. and Vienna, P. (2006). 'An updated catalogue of the Histeridae (Insecta: Coleoptera) of the Arabian Peninsula, with biogeographical remarks'. Zootaxa 1157:1-74. doi.org/10.11646/ zootaxa.1157.1.1

Wrase, D.W. (2009a) 'New or interesting records of Carabid beetles from Europe, Madeira, northern Africa, Turkey, from the Near East, Iran, Iraq, Kuwait, and Pakistan, with nomenclatorial and taxonomic notes (Coleoptera, Carabidae, Bembidiini, Brachinini, Cyclosomini, Elaphrini, Harpalini, Lebiini, Nebriini, Platynini, Pterostichini, Scaritini, Sphodrini, Zabrini)'. Linzer Biologische Beiträge 41: 901-935. 


\subsubsection{Order Mantodea}

Five species in three families (Table 36) of praying mantises have been recorded from Kuwait (Al-Houty, 1997 \& 2011)

Table 36: Mantodea reported from Kuwait.

\begin{tabular}{|l|l|}
\hline \multicolumn{1}{|c|}{ Family } & \multicolumn{1}{c|}{ Species } \\
\hline Mantidae & Ameles spallanzania (Rossi, 1792) \\
\hline & Mantis religiosa Linnaeus 1758 \\
\hline Empusidae & Blepharopsis mendica Giglio-Tos 1917 \\
\hline & Hypsicorypha gracilis (Bur-meister 1838) \\
\hline Eremiaphilidae & Eremiaphila braueri Krauss, 1902 \\
\hline
\end{tabular}

\section{References}

Al-Houty, W. (1997). 'Checklist of the insect fauna of Kuwait'. Kuwait Journal of Science \& Engineering 24: $145-162$.

Al-Houty, W. (2011). 'Recent insect fauna recorded in Kuwait'. Kuwait Journal of Science \& Engineering 38:81-92.

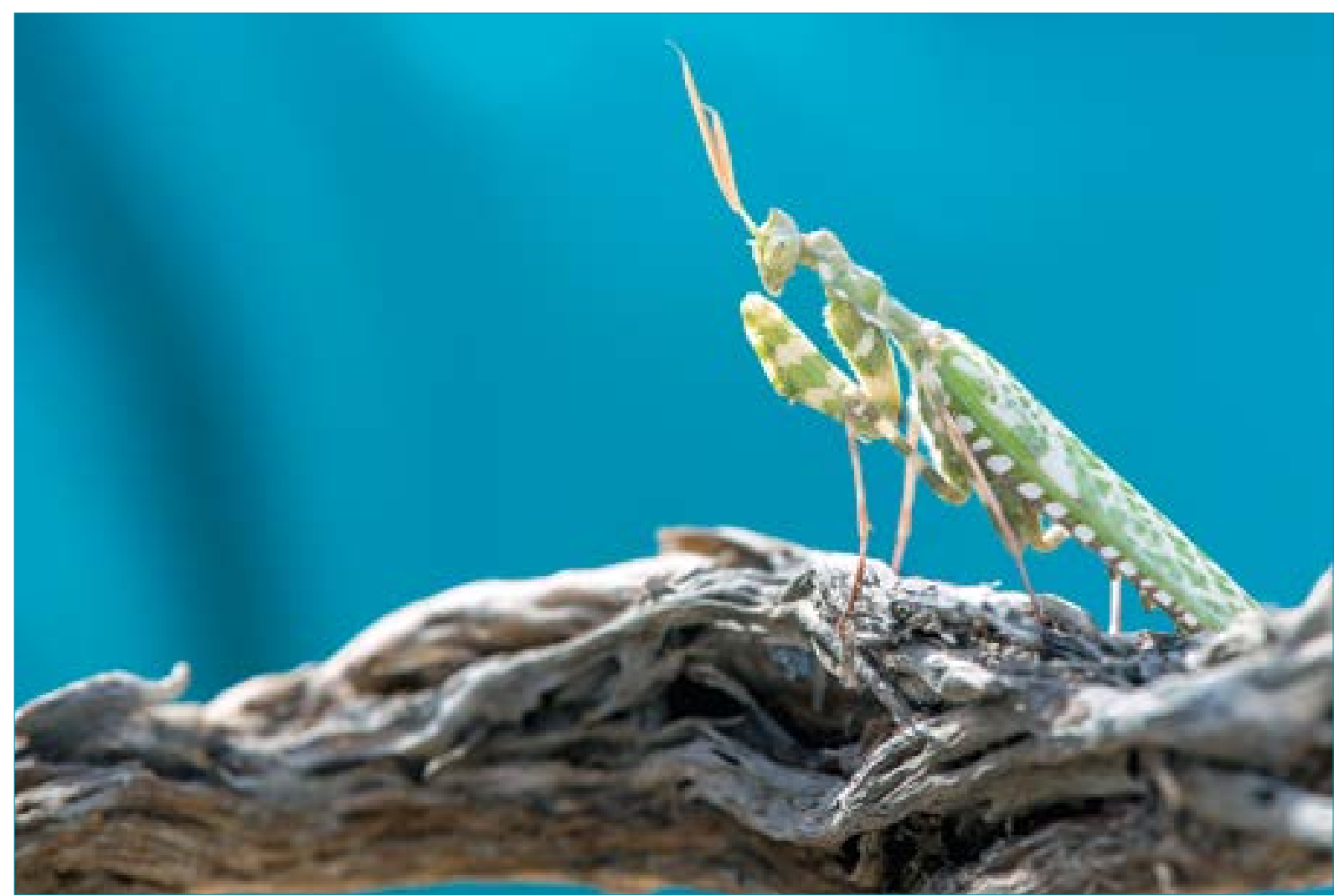

Figure 34: The praying mantis, Blepharopsis mendica (Photo from Abdul Al-Aziz Al Yousef). 


\subsubsection{Other minor groups}

Embiidina Other orders with few number of (twisted-winged parasites), Zygentoma (Silverfish) species including Embiidina (webspinners), and Trichoptera (caddisflies) have been recorded Ephemeroptera (Mayflies), Thysanura (silverfish), from Kuwait (Al-Houty, 1997, 2009 \& 2011) (Table Blattodea Dermaptera (Earwigs), Strepsiptera 37).

Table 37: Other minor orders of insects reported from Kuwait.

\begin{tabular}{|l|l|l|}
\hline \multicolumn{1}{|c|}{ Order } & \multicolumn{1}{|c|}{ Family } & \\
\hline Embiidina & Embiidae & Embia major Imms, 1913 \\
\hline Ephemeroptera & Polymitarcyidae & Polymitarcys savignyi Eaton, 1883 \\
\hline & Baetidae & Cloeon dipterum (Linnaeus, 1761) \\
\hline Thysanura & Lepismatidae & Lepisma saccharina Linnaeus, 1758 \\
\hline & & Thermobia domestica Packard, 1873 \\
\hline Thysanoptera & Thripidae & Thrips tabacci Lindeman 1888 \\
\hline Blattodea & Hodotermitidae & Anacanthotermes vagans (Hagen, 1858) \\
\hline & Rhinotermitidae & Psammotermes hybostoma Desneux 1902 \\
\hline & Blattidae & Blatta lateralis Walker, 1868 \\
\hline & & Blatta mellea Krauss 1902 \\
\hline & & Periplaneta americana (Linnaeus 1758) \\
\hline & Ectobiidae & Blatella germanica (Linnaeus 1767) \\
\hline Zygentoma & & Blattella biligata (Walker 1868) \\
\hline Dermaptera & Labiduridae & Labidura riparia (Pallas 1773) \\
\hline & Labiidae & Libia minor (Linnaeus 1758) \\
\hline Strepsiptera & Menegnillidae & Menegilla arabica Kinzelbach 1979 \\
\hline Trichoptera & Leptoceridae & Ylodes reuteri zarudnyi McLachlan 1880 \\
\hline & Lepismatidae & Thermobia domestica Packard, 1873 \\
\hline
\end{tabular}

\section{References}

Al-Houty, W. (1997). 'Checklist of the insect fauna of Kuwait'. Kuwait Journal of Science \& Engineering 24: 145-162.

Al-Houty, W. (2011). 'Recent insect fauna recorded in Kuwait'. Kuwait Journal of Science \& Engineering 38:81-92. 


\subsubsection{Order Siphonaptera}

Fleas are bloodsucking insects that feeds primarily on mammals and birds. Al-Taqi \& Al-Ziady (1982) studied the fleas associated with rodents in Kuwait. Zaghloul et al. (1985) reported on fleas parasitizing the Indian Gerbil, Tatera indica. eight species have been recorded parasitizing different species of rodents (Table 38).

Table 38: Fleas reported from Kuwait.

\begin{tabular}{|l|l|}
\hline \multicolumn{1}{|c|}{ Family } & \multicolumn{1}{c|}{ Species } \\
\hline Pulicidae & Ctenocephalides canis (Curtis, 1826) \\
\hline & Ctenocephalides felis (Bouché, 1835) \\
\hline & Pulex irritans Linnaeus, 1758 \\
\hline & Synosternus pallidus (Taschenberg 1880) \\
\hline & Xenopsylla astia Rothschild 1911 \\
\hline & Xenopsylla cheopis (Rothschild, 1903) \\
\hline & Xenopsylla conformis (Wagner 1903) \\
\hline & Xenopsylla nubica (Rothschild 1903) \\
\hline
\end{tabular}

\section{Reference}

Al-Taqi, M. and Al-Ziady S. (1983). 'Ectoparasites of rodents in Kuwait'. Proceedings of the 1st Symposium on Recent Advances in Rodent Control 107-114.

Zaghloul, T.M., Zakaria, M. and Salit, A. M. (1986). 'The Indian Gerbil, Tatera indica, in Kuwait: Biotoxic studies, ectoparasites and endoparasite infection'. Proceedings of the 2nd Symposium on Recent Advances in Rodent Control. 


\subsubsection{Order Neuroptera}

Order Neuroptera known as the net-winged insects, includes lacewings, mantidflies, antlions, and their relatives, with about 6,000 descrpied species worldwide. Records from Kuwait were extracted from Meinander (1980), Al-Houty (1997 \& 2011) and Canard \& Thierry (2014), with a total of 13 species (Table 39 ).

Table 39: Neuroptera reported from Kuwait.

\begin{tabular}{|l|l|}
\hline \multicolumn{1}{|c|}{ Family } & \multicolumn{1}{|c|}{ Species } \\
\hline Chrysopidae & Chrysopa carnea (Stephens, 1836) \\
\hline & Chrysoperla concinna (Holze, 1974) \\
\hline & Chrysoperla mutata (Mclachlan, 1898) \\
\hline Myrmeleontidae & Creoleon aegyptiacus (Rambur, 1842) \\
\hline & Creoleon cervinus Holzel, 1983 \\
\hline & Creoleon pullus Holzel, 1983 \\
\hline & Creoleon ultimus Holzel, 1983 \\
\hline & Creoleon cinereus Kimmins, 1943 \\
\hline & Gepella modesta Holzel, 1968 \\
\hline & Myrmeleon hyalinus Olivier, 1811 \\
\hline & Nophis teillardi Navas, 1912 \\
\hline & Quinemurus cinereus Kimmins 1943 \\
\hline Nemopteridae & Halter halteratus (Forskål, 1775) \\
\hline
\end{tabular}

\section{References}

Al-Houty, W. (1997). 'Checklist of the insect fauna of Kuwait'. Kuwait Journal of Science \& Engineering 24: $145-162$.

Al-Houty, W. (2011). 'Recent insect fauna recorded in Kuwait'. Kuwait Journal of Science \& Engineering 38:81-92.

Ábrahám, L. (2014). 'Contribution to the knowledge of the genus Halter (Neuroptera: Nemopteridae)'. Natura Somogyiensis 25: 167-186.

Aspöck, H., Hölzel, H. and Aspöck, U. (2001). 'Kommentierter Katalog der Neuropterida (Insecta: Raphidioptera, Megaloptera, Neuroptera) der Westpaläarktis'. Denisia 2:1-606.

Canard, M. and Thierry, D. (2014). 'The distribution of Chrysoperla mutata (Mclachlan 1898) and Chrysoperla pudica (Navás 1914) (Neuroptera: Chrysopidae)'. Entomofauna 35: 405-412.

Hölzel, H. (1998). 'Zoogeographical features of Neuroptera of the Arabian Peninsula'. In Panelius, S. P. (ed.) Neuropterology 1997. 'Proceedings of the Sixth International Symposium on Neuropterology' (13-16 July 1997, Helsinki, Finland). Acta Zoologica Fennica 209:129-140.

Meinander, M. (1980). 'Insects of Saudi Arabia. Neuroptera: Fam. Nemopteridae'. Fauna of Saudi Arabia 2: $174-178$.

Monserrat, V. J. (1988). 'Revision de las especies de Lertha del Mediterraneo occidental (Neuropteroidea, Planipennia: Nemopteridae)'. Annali del Museo Civico di Storia Naturale Giacomo Doria 87:85113. 


\subsubsection{Order Heimptera}

Suborder Sternorrhyncha

This suborder includes aphids, whiteflies, and scale insects. They were previously included in order Homoptera. This suborder is represented

by two families; Aphididae and Diaspididae, with a total of eight species (Table 40). All records were extracted from Al-Houty (1997).

Table 40: Species of Aphididae and Diaspididae reported from Kuwait.

\begin{tabular}{|l|l|}
\hline \multicolumn{1}{|c|}{ Family } & \multicolumn{1}{|c|}{ Species } \\
\hline Aphididae & Aphis fabae Scopoli, 1763 \\
\hline & Aphis nerii Fonscolombe, 1841 \\
\hline & Brevicoryne brassicae (Linnaeus, 1758) \\
\hline & Myzus persicae (Sulzer, 1776) \\
\hline & Rhopalosiphum maidis (Fitch, 1856) \\
\hline Diaspididae & Aonidiella orientalis (Newstead, 1894) \\
\hline & Parlatoria blanchardii (Targioni-Tozzetti, 1892) \\
\hline & Phoenicococcus marlatti Cockerell, 1899 \\
\hline
\end{tabular}

\section{References}

Al-Houty, W. (1997). 'Checklist of the insect fauna of Kuwait'. Kuwait Journal of Science \& Engineering 24: $145-162$.

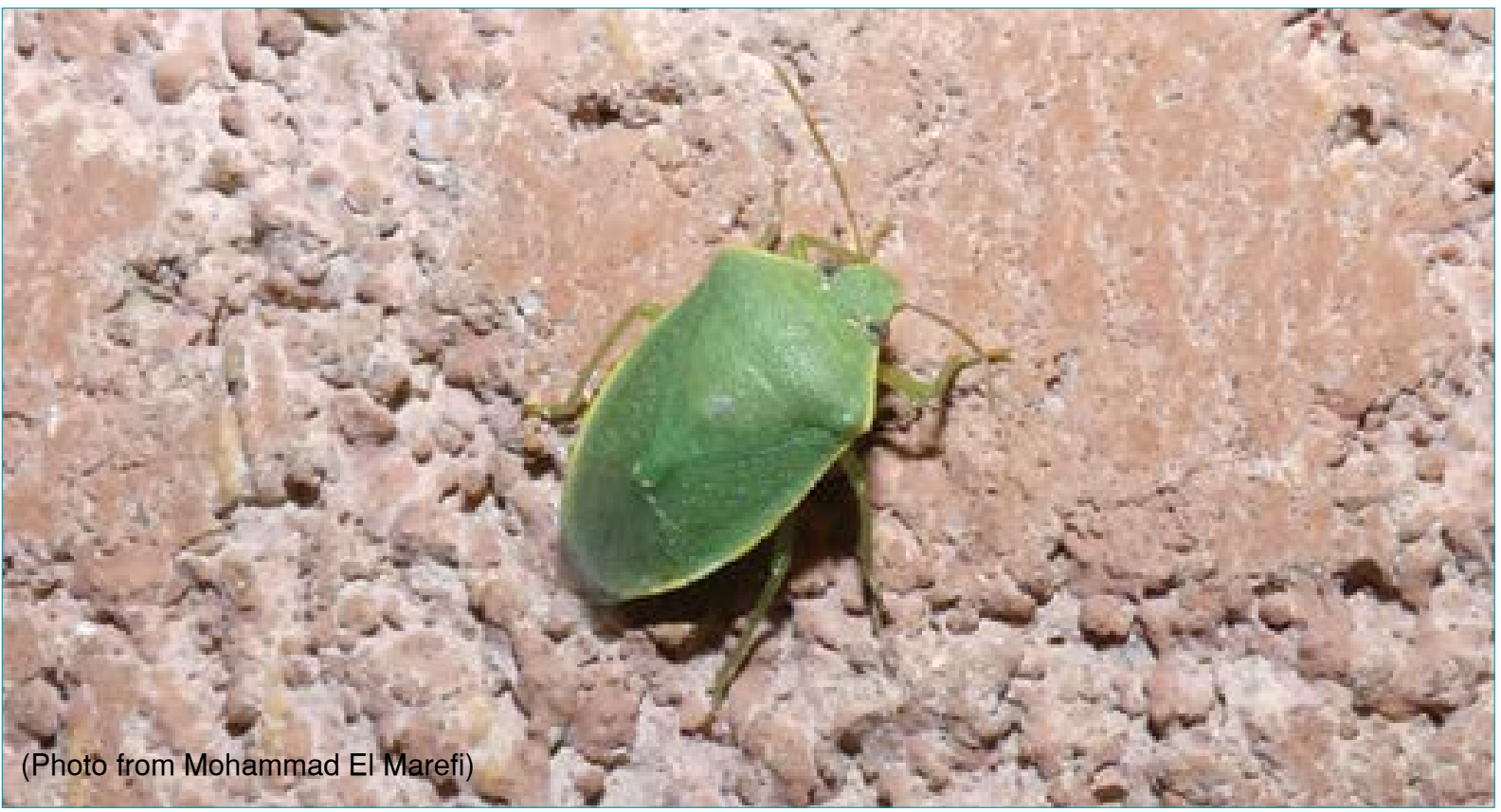




\section{Suborder Auchenorrhyncha}

This suborder includes two families with nine species known from Kuwait (Table 41); the leafhoppers (Cicadellidae) and plant hoppers
(Delphacidae). All records were extracted from Al-

Houty (1997).

Table 41: Species of Cicadellidae and Delphacidae reported from Kuwait.

\begin{tabular}{|l|l|}
\hline \multicolumn{1}{|c|}{ Family } & \multicolumn{1}{c|}{ Species } \\
\hline Cicadellidae & Cicadella viridis (Linnaeus, 1758) \\
\hline & Cicadetta musiva (Germar, 1830) \\
\hline & Empoasca fabae (Harris 1841) \\
\hline & Hecalus glaucescens (Fieber, 1866) \\
\hline & Neoalimus aegyptiacus (Matsumura, 1908) \\
\hline & Neoaliturus tenellus (Baker, 1896) \\
\hline & Paralimnus inexpectatus Dlabola, 1961 \\
\hline & Platypleura arabica Myers, 1928 \\
\hline Delphacidae & Toya propinqua (Fieber, 1866) \\
\hline
\end{tabular}

\section{References}

Al-Houty, W. (1997). 'Checklist of the insect fauna of Kuwait'. Kuwait Journal of Science \& Engineering 24: 145-162.

\section{Suborder Heteroptera}

This suborder includes a wide range of bugs; minute pirate bugs, bed bugs, milkweed bugs, damsel bugs, red bugs stink bugs and scentless plant bugs. It includes 19 families and 82 species (Annex 4). Two species (Xylocoris etawahii and Xylocoris wasmiai) of family Anthocoridae were desriped from Kuwait (Ghauri, 1985). All other records are based on Al-Houty \& Dolling (1999) and Al-Houty (1997 \& 2011). In 1988, an outbreak of bites among human by Leptodemus minutus was reported (Selim et al,. 1990). Al-Houty (1990) reported cases of Nysius feeding on human blood in Kuwait. Also, an outbreak of bed bugs infesations was reported in Kuwait (El-Azazy et al., 2013). A specimen of Bemisia tabaci (Gennadius, 1889) was found in the British museum specimen (NHMUK010134838), collected by W. Al-Houty in 1976 from Kuwait.

\section{References}

Al-Houty, W. (1997). 'Checklist of the insect fauna of Kuwait'. Kuwait Journal of Science \& Engineering 24: $145-162$.

Al-Houty, W. (1990). 'Nysius (Hem., Lygaeidae) sucking human blood in Kuwait'. Entomologist's Monthly Magazine 126:95-96. 
Al-Houty, W. (2011). 'Recent insect fauna recorded in Kuwait'. Kuwait Journal of Science \& Engineering 38:81-92.

Al-Houty, W. and Dolling, W. R. (1999). 'Heteroptera (Hem.) of Kuwait'. Entomologistís Monthly Magazine 135: 85-87.

El-Azazy, O.M.E., Al-Behbehani, B. and Abdou, N-E, M.I. (2013). 'Increasing bedbug, Cimex lectularius, infestations in Kuwait'. Journal of the Egyptian Society of Parasitology 43:415-418. doi.org/ 10.12816/jesp.2013.94818

Ghauri, M. S. K. (1985). 'New Anthocoridae from Kuwait and Ethiopia (Heteroptera)'. Reichenbachia 23: $81-86$.

Linnavuori, R.E. (1986). 'Heteroptera of Saudi Arabia'. Fauna of Saudi Arabia 8: 31-97.

Selim, M. M., Dvorak, R., Khalifa, T., Al-Awadi, I., Al-Humaidi, A. and Al-Faris, M. (1990). 'Insect bite lesions in Kuwait possibly due to Leptodemus minutus'. International Journal of Dermatology 29:507-510. doi.org/ 10.1111/j.1365-4362.1990.tb04846.x

\subsubsection{Order Hymenoptera}

The Hymenoptera of Kuwait includes 122 species in 17 families (Annex 5). The list is based on Al-Houty (1997 \& 2011), Collingwood \& Agosti (1996) and Luch (2008). A detailed study on the Sphecid wasps of Kuwait was published by AlHouty (1978).
Three species of ants (Family Formacidae) were described from Kuwait; Monomorium subcomae (Lush, 2008), Monomorium hemame from Umm al-Hemam (Collingwood \& Agosti, 1996), and Monomorium buettikeri from Anwha Island (Collingwood \& Agosti, 1996).

\section{Reference}

Al-Houty, W. (1987). 'Occurance of Sphecidae in Kuwait'. In: Proceedings of the Symposium of the Fauna and Zoogeography of the Middle East. Krupp, F., Schnider, W. and Kinzelbach, R. (eds.). 168-173.

Al-Houty, W. (1997). 'Checklist of the insect fauna of Kuwait'. Kuwait Journal of Science \& Engineering 24: $145-162$.

Al-Houty, W. (2011). 'Recent insect fauna recorded in Kuwait'. Kuwait Journal of Science \& Engineering 38:81-92.

Collingwood, C. A. and Agosti, D. (1996). 'Formicidae (Insects: Hymenoptera) of Saudi Arabia (Part 2)'. Fauna of Saudi Arabia 15: 300-385.

Lush, M. J. (2008). 'A new species of Monomorium (Hymenoptera: Formicidae) from Kuwait'. Zoology in the Middle East 45: 67-72. doi.org/10.1080/09397140.2009.10638357

Lush. M.J. (2009). 'Some ant records (Hymenoptera: Formicidae) from the Middle East'. Zoology in the Middle East 47: 114-116. doi.org/10.1080/09397140.2009.10638357 


\subsubsection{Order Lepidoptera}

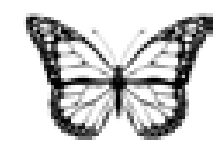

The butterflies and moths of Kuwait were extensively studied (Brown, 1970; Al-Houty, 1983, 1995, 1997 \& 2011). Butterflies of Kuwait conists of 22 species in five families (Table 42). Additional record of Brephidium exilis was reported from Sabah Al Ahmad Sea City (Pope \& Nithyanandan, 2014).

Table 42: Butterflies recorded from Kuwait.

\begin{tabular}{|c|c|c|}
\hline Family & Common name & Species \\
\hline Danaidae & The Plain Tiger & Danaus chrysippus (Linnaeus 1758) \\
\hline \multirow[t]{9}{*}{ Pieridae } & Pioneer White & Anaphaeis aurota (Fabricius, 1793) \\
\hline & Small White Butterfly & Artogeia rapae Schawerda, 1905 \\
\hline & The Clouded Yellow & Colias croceus Pieridae Geofroy, 1785 \\
\hline & The eastern pale clouded yellow & Colias erate marnoana Rogenhofer, 1883 \\
\hline & The Green-striped White & Euchloe belemia (Esper, 1799) \\
\hline & Salmon Arab & Madais fausta (Oliver, 1804). \\
\hline & African Clouded Yellow & Colias electo (Linnaeus, 1763) \\
\hline & Desert White & Pontia glauconome (Klug, 1829) \\
\hline & Common Brimstone & Gonepteryx rhamni \\
\hline \multirow[t]{5}{*}{ Nymphalidae } & Blue Pansy & Junonia orithya (Riley, 1925) \\
\hline & The Red Admiral & Vanessa atalanta (Linnaeus, 1758) \\
\hline & Common Evening Brown & Melanitis leda Linnaeus, 1758 \\
\hline & Painted Lady & Vanessa cardui Linnaeus, 1758 \\
\hline & Danaid Eggfly & Hypolimnas misippus (Linnaeus, 1764) \\
\hline \multirow[t]{5}{*}{ Lycaenidae } & Long-tailed Blue & Lampides boeticus (Linnaeus, 1767) \\
\hline & Little Tiger Blue & Tarucus ballkanicus (Freyer, 1844) \\
\hline & The Mediterranean Pierrot & Tarucus rosaceus (Austaut, 1885) \\
\hline & Dark Grass Blue & Zizeeria karsandra (Moore, 1865) \\
\hline & the Western Pygmy Blue Butterfly & Brephidium exilis (Boisduval, 1852) \\
\hline \multirow[t]{2}{*}{ Papilionidae } & The Lime Swallowtail & Papilio demoleus (Linnaeus, 1764) \\
\hline & The Citrus Swallowtail & Papilio demodocus Esper, 1798 \\
\hline
\end{tabular}

A total of 68 species of moths belonging to eight families have been recorded from Kuwait (Table 43). Family Noctuidae has the highest number of species with 43 species (Al-Houty, 1983, 1995 1997 \& 2011). 


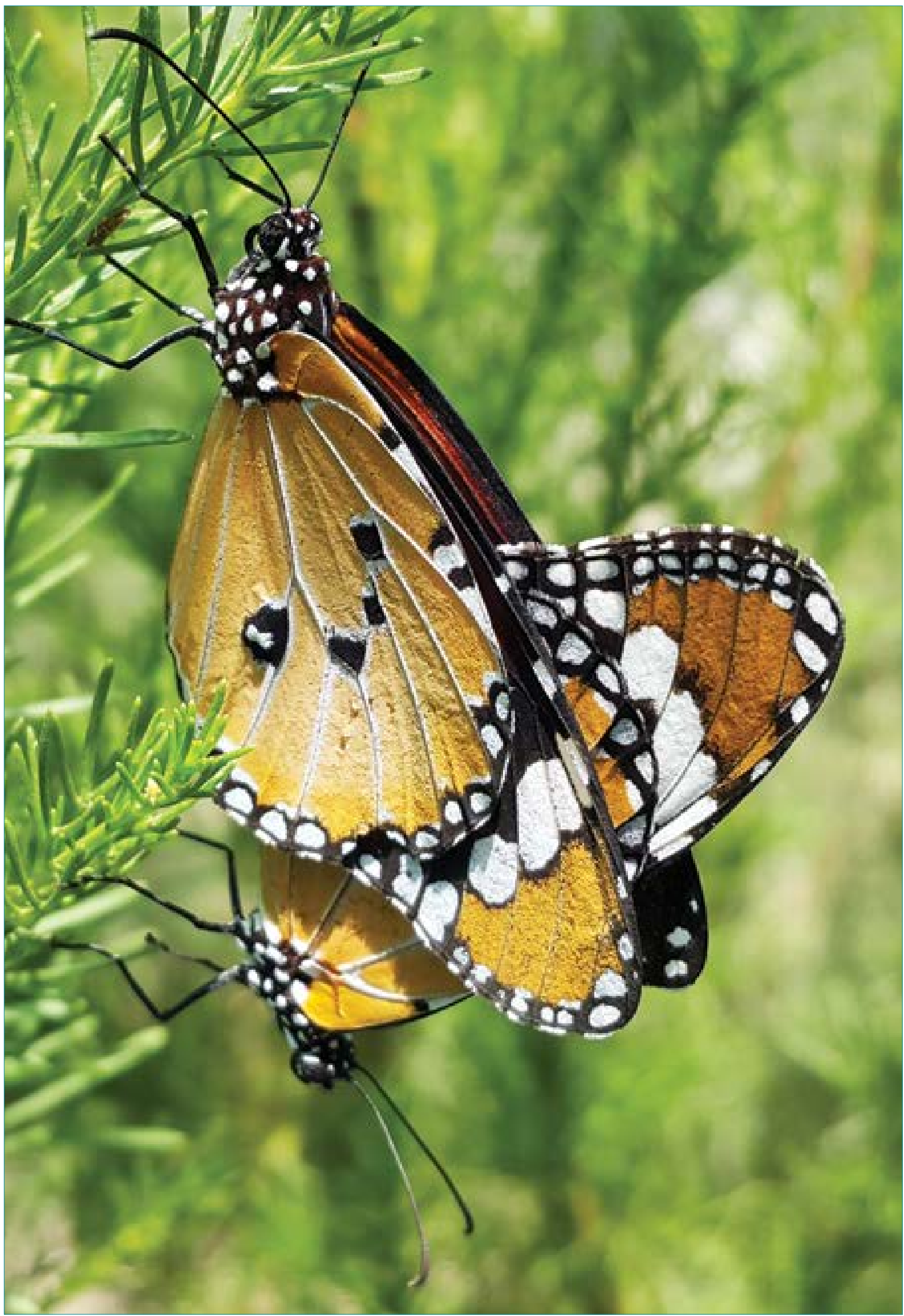

Figure 35: The plain tiger butterfly, Danaus chrysippus (Photo from Mohammad El Marefi). 
Table 43: Moths of Kuwait.

\begin{tabular}{|c|c|}
\hline Family & Species \\
\hline \multirow[t]{2}{*}{ Erebidae } & Utetheisa pulchella (Linnaeus, 1758) \\
\hline & Plutella xylostella (Linnaeus, 1758) \\
\hline \multirow[t]{7}{*}{ Geometridae } & Cyclophora rufistrigata (Hampson, 1896) \\
\hline & Idaea macraria (Staudinger, 1892) \\
\hline & Lithostege notata Bang-Haas, 1907 \\
\hline & Lithostege palaestinensis Wiltshire, 1941 \\
\hline & Rhodometra sacraria (Linnaeus, 1767) \\
\hline & Tephrina disputaria (Guenee, 1858) \\
\hline & Eupithecia ultimaria Boisduval, 1840 \\
\hline \multirow{3}{*}{ Lasiocampidae } & Autosphyla henkei Staudinger, 1879 \\
\hline & Chilena laristana Daniel, 1949 \\
\hline & Streblote siva (Lefebvre, 1827) \\
\hline \multirow[t]{19}{*}{ Noctuidae } & Acontia biskrensis orientalis Brandt, 1939 \\
\hline & Acontia lucida (Hufnagel, 1766) \\
\hline & Agrotis biconica Kollar, 1844 \\
\hline & Agrotis exclamationis Linnaeus, 1758 \\
\hline & Agrotis ipsilon (Hufnagel, 1766) \\
\hline & Agrotis hoggari Rothschild, 1920 \\
\hline & Agrotis sardzeana Brandt, 1941 \\
\hline & Agrotis segetum (Denis \& Schiffermuller, 1775 \\
\hline & Agrotis spinifera (Hübner, 1808) \\
\hline & Anua tirhaca (Cramer, 1777) \\
\hline & Anumeta arabiae Wiltshire, 1961 \\
\hline & Armada maritima Brandt, 1939 \\
\hline & Armada panaceorum (Menetries, 1849) \\
\hline & Autographa gamma (Linnaeus, 1758) \\
\hline & Autophila cerealis Draudt, 1936 \\
\hline & Calphasia kraussi (Rebel, 1895) \\
\hline & Ceracala sana Staudinger \& Rebel, 1901 \\
\hline & Cleonymia chabordis Oberthur, 1876 \\
\hline & Chrysodeixis acuta (Walker, 1858) \\
\hline
\end{tabular}




\begin{tabular}{|c|c|}
\hline Family & Species \\
\hline & Clytie benenotata (Warren, 1888) \\
\hline & Chazaia incarnata (Freyer, 1838) \\
\hline & Chlorissa discessa Walker, 1861 \\
\hline & Cornutiplusia circumjlexa (Linnaeus, 1767) \\
\hline & Ctenoplusia limbirena (Guenée, 1852) \\
\hline & Earias insulana Boisduval, 1833 \\
\hline & Euxoa excellens Grote, 1875 \\
\hline & Helicoverpa armigera (Hubner, 1827) \\
\hline & Helicoverpa zea (Boddie, 1850) \\
\hline & Heliothis nubigera Herrich-Schaffer, 1851 \\
\hline & Heliothis peltigera (Denis \& Schiffermuller, 1775) \\
\hline & Leucania loreyi (Duponchel, 1827) \\
\hline & Metopoceras delicata (Staudinger, 1897) \\
\hline & Metopoceras omar (Oberthur, 1887) \\
\hline & Ozarba algaini Wiltshire, 1983 \\
\hline & Paradrina clavipalpis (Scopoli, 1763) \\
\hline & Rhabinopteryx subtilis (Mabille, 1888) \\
\hline & Spodoptera cilium Guenee, 1852 \\
\hline & Spodoptera exigua (Hugner, 1808) \\
\hline & Spodoptera littoralis (Boisduval, 1833 \\
\hline & Spodoptera litura (Fabricius, 1775) \\
\hline & Thiacidas postica Walker, 1855 \\
\hline & Thria robusta Walker, 1857 \\
\hline & Trichoplusia daubei (Boisduval, 1840) \\
\hline & Trichoplusia ni (Hubner, 1802) \\
\hline Pyralidae & Ephestia kuehniella Zeller, 1879 \\
\hline \multirow[t]{5}{*}{ Sphingidae } & Acherontia atropos (Linnaeus, 1758) \\
\hline & Agrius convolvuli (Linnaeus, 1758 \\
\hline & Daphnis nerii (Linnaeus, 1758) \\
\hline & Hippotion celerio (Linnaeus, 1758) \\
\hline & Hyles lineata livornica (Esper, 1780) \\
\hline
\end{tabular}




\begin{tabular}{|l|l|}
\hline \multicolumn{1}{|c|}{ Family } & \multicolumn{1}{c|}{ Species } \\
\hline & Macroglossum stel/atarum (Linnaeus, 1758) \\
\hline Tinidae & Trichophaga tapetzella (Linnaeus, 1758) \\
\hline Crambidae & Cornifrons ulceratalis Lederer, 1858 \\
\hline & Nomophila noctuella (Denis \& Schiffermüller, 1775) \\
\hline & Chrysoteuchia culmella (Linnaeus, 1758) \\
\hline Gelechiidae & Pectinophora gossypiella \\
\hline
\end{tabular}

\section{Reference}

Al-Houty, W. (1983). 'Butterflies and hawkmoths of Kuwait'. Entomologists, Record 95: 202-204. Al-Houty, W. (1995). Butterflies and Moths of Kuwait, pp116. Kuwait University Press, Kuwait.

Al-Houty, W. (1997). 'Checklist of the insect fauna of Kuwait'. Kuwait Journal of Science \& Engineering 24: $145-162$.

Al-Houty, W. (2000). 'Some Lepidoptera recorded from Kuwait'. Nachrichten des Entomologischen Vereins Apollo 21:109-111.

Brown, J.N.B. (1970). 'Preliminary list of butterflies of Kuwait'. Ahmadi Natural History Field Study Newsletter No.2:7.

Pope, M. and Nithyanandan, M. (2014). 'Record of the Western Pygmy Blue Butterfly Brephidium exilis (Boisduval, 1852) (Lepidoptera: Lycaenidae) from Sabah Al Ahmad Sea City, Kuwait'. Journal of Threatened Taxa 6:6723-6725. doi.org/10.11609/JoTT.04055.6723-5

\subsubsection{Order Mallophaga}

Four species of chewing lice were reported by Al-Houty (1983).

Table 44: Mallophaga reported from Kuwait.

\begin{tabular}{|l|l|}
\hline Family & Species \\
\hline Menoponidae & Menacanthus stramineus (Nitzsch 1818) \\
\hline Philopteridae & Columbicola columbae (Linnaeus 1758) \\
\hline & Goniodes numidae Mjoberg 1910 \\
\hline Trichodectidae & Damalina ovis (Schrank 1781) \\
\hline
\end{tabular}




\subsubsection{Order Anoplura}

Three species of sucking lice were reported by Al-Houty (1983).

Table 45: Anoplura reported from Kuwait.

\begin{tabular}{|l|l|}
\hline \multicolumn{1}{|c|}{ Family } & \multicolumn{1}{|c|}{ Species } \\
\hline Po1yplacidae & Polyplax spinulosa (Bur-meister 1839) \\
\hline Pediculidae & Pediculus humanus humanus Linnaeus 1758 \\
\hline & Pediculus humanus capitis DeGeer 1778 \\
\hline
\end{tabular}




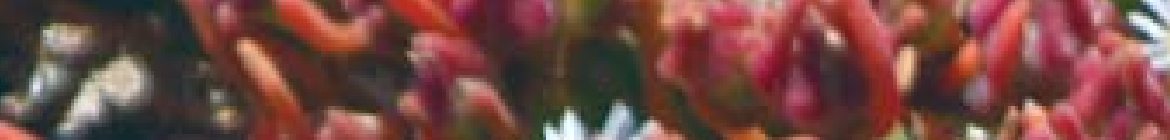

$3, \cos 1 \mathrm{a}$

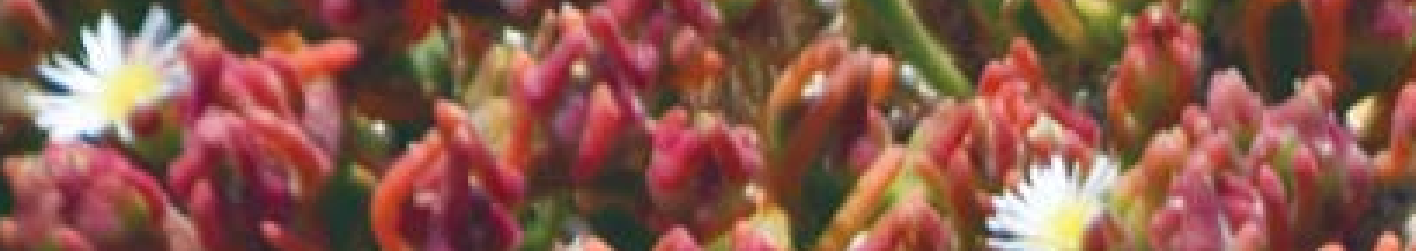

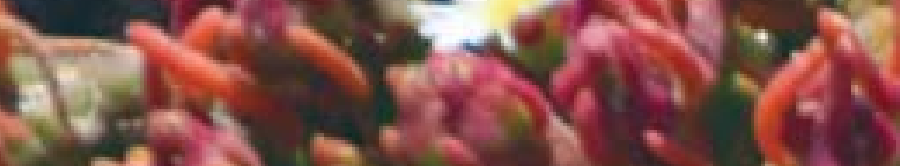
somen hat $x=2$

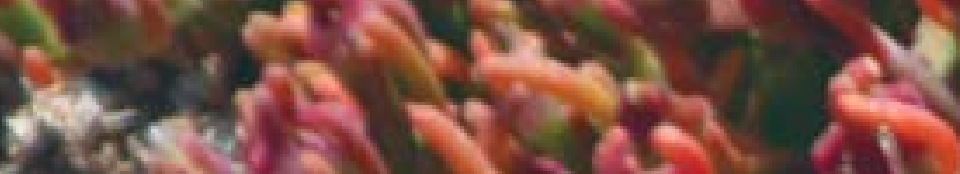
nopere $=$

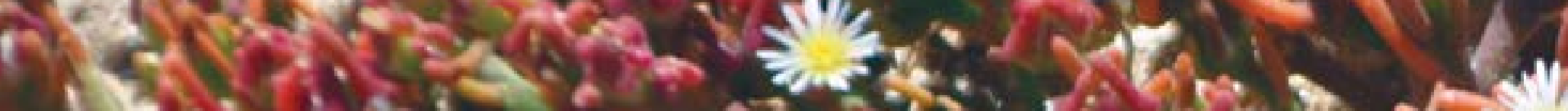

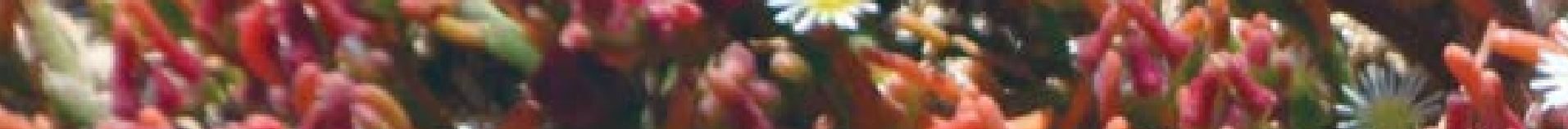

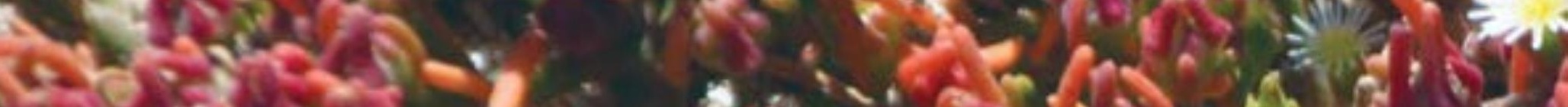

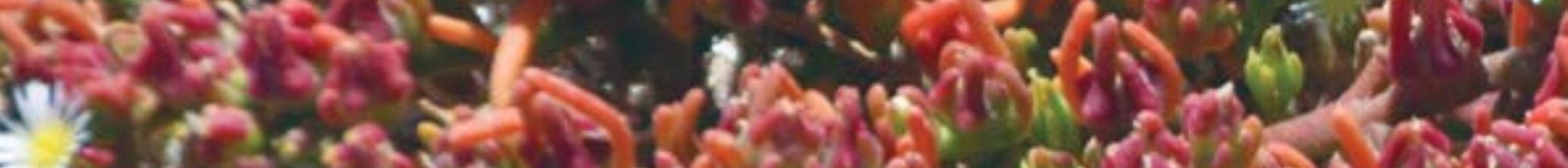

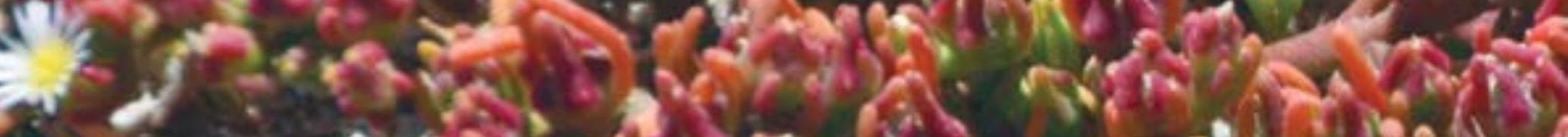

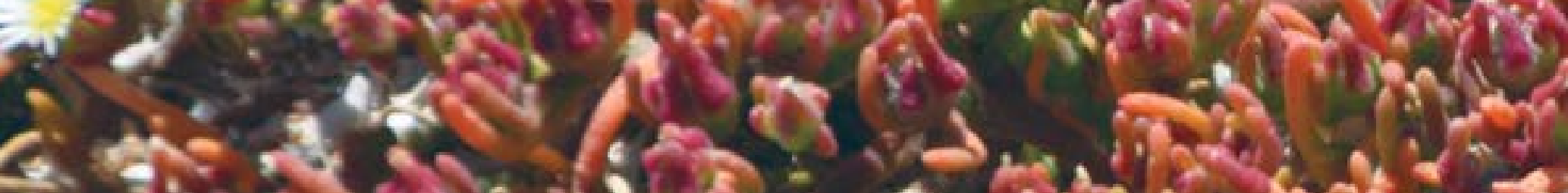

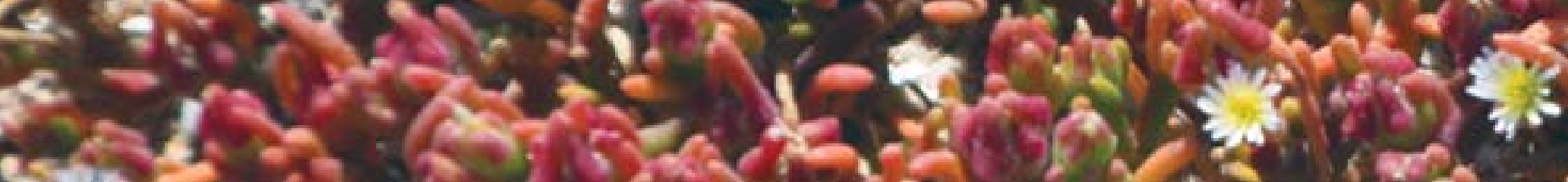

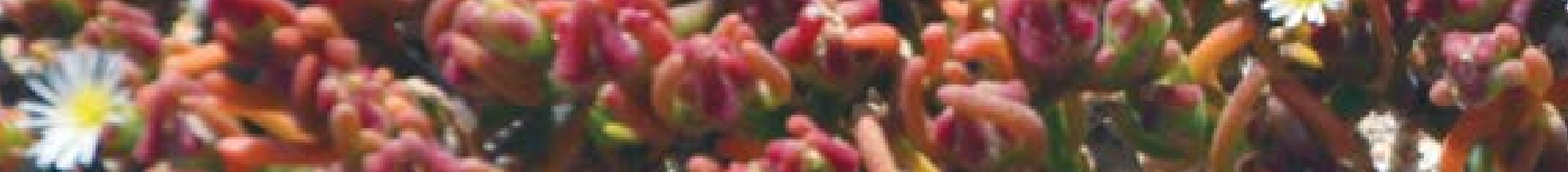

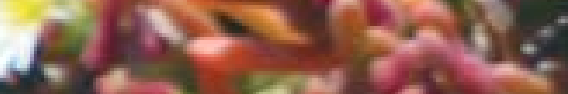

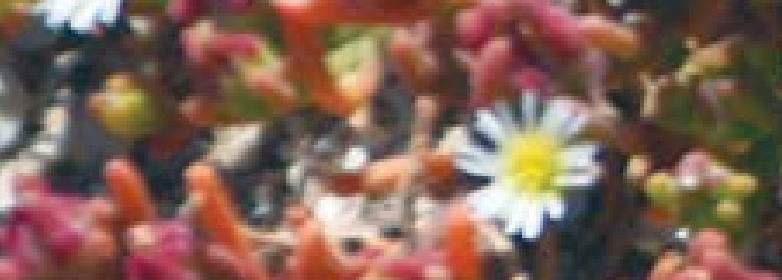

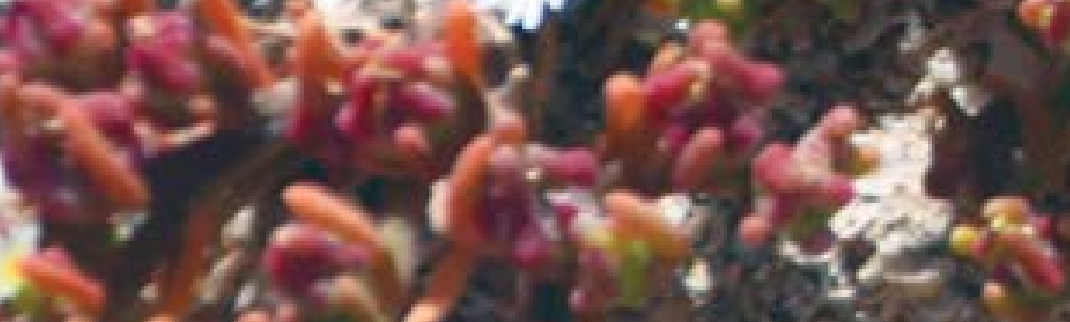
is

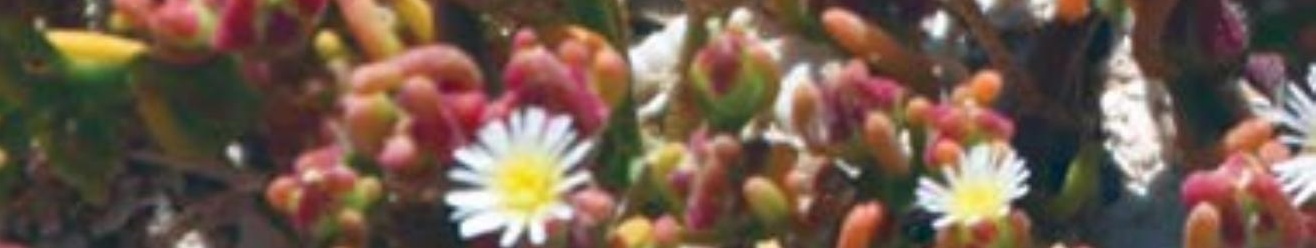





\section{Phyla Bryozoa and Phoronida}

\subsection{Phyla Bryozoa and Phoronida}

Brozoans are also known as moss animals. This phylum is represented by two species (Bugula neritina (Linnaeus, 1758) and Schizoporella errata (Waters, 1878)) and one single unidentified cyphonautes larvae, Phoronida are commonly known as horseshoe worms, with one Actinotrocha larvae (Jones, 1986; Al-Yamani et al., 2011).

\section{Reference}

Al-Yamani, F.Y., Skryabin, V., Gubanova, A., Khvorov, S. and Prusova, I. (eds.) (2011). Marine Zooplankton: Practical Guide for the Northwestern Arabian Gulf. Volume 1. Kuwait Institute for Scientific Research, Kuwait.

Jones, D.A. (1986). A field guide to the sea shores of Kuwait and the Arabian Gulf, pp 192. University of Kuwait, Kuwait.

\subsection{Phylum Platyhelminthes}

\subsubsection{Class Monogenea}

Two species of monogeneans were described from the Yellowfin seabream, Acanthopagrus latus, by Hussey (1986). Kritsky et al. (2000) described three species of monogeans parasitizing fishes from Kuwait (Lepidotrema kuwaitensis, Lamellodiscus furcillatus and Protolamellodiscus senilobatus). In total, 10 species were reported from fishes collected from Kuwait (Table 46).

Table 46: Monogeneans recoverd from fishes from Kuwait.

\begin{tabular}{|l|l|l|}
\hline \multicolumn{1}{|c|}{ Parasite } & \multicolumn{1}{c|}{ Rost } & Krerence \\
\hline Lepidotrema kuwaitensis & Terapon puta & Kritsky et al. (2000) \\
\hline Lamellodiscus furcillatus & Diplodus noct & Kritsk \\
\hline Protolamellodiscus senilobatus & Argyrops spinifer, Argyrops filamentosus & Kritsky et al. (2000) \\
\hline Diplectanum cazauxi & Sphyraena jello, Sphyraena obtusata & Kritsky et al. (2000) \\
\hline Diplectanum sillagonum & Sillago sihama & Kritsky et al. (2000) \\
\hline Pseudolamellodiscus sphyraenae & Sphyraena chrysotaenia & Kritsky et al. (2000) \\
\hline Calydiscoides flexuosus & Nemipterus peronii, Nemipterus bipunctatus & Kritsky et al. (2000) \\
\hline Tareenia acanthopagri & Acanthopagrus latus & Hussey (1986) \\
\hline Polylabris angifer & Acanthopagrus latus & Hussey (1986) \\
\hline Megalocotyloides epinepheli & Epinephelus tauvina & Hussey (1986) \\
\hline
\end{tabular}




\section{References}

Hussey, C.G. (1986). 'Some monogenean parasites of marine perciform fishes of Kuwait'. Journal of Natural history 20:415-430. doi.org/10.1080/00222938600770311

Kritsky, D. C., Jiménez-Ruiz, F. A. and Sey, O. (2000). 'Diplectanids (Monogenoidea: Dactylogyridea) from the gills of marine fishes of the Persian Gulf off Kuwait'. Comparative Parasitology 67: 145-164

\subsubsection{Class Digenea}

Seventeen species of digentic worms (Table 47) were recovered from marine fishes of Kuwait (Al-Yamani, 1979; Al Kawari et al., 1996; Sey \&
Nahhas, 1997; Nahhas \& Sey, 2002; Sey et al., 2003). Proctotrematoides kuwaiti was described as a new species (Sey \& Nahhas, 1997).

Table 47: Digeneans recoverd from fishes from Kuwait.

\begin{tabular}{|c|c|c|}
\hline Parasite & Host fish & Reference \\
\hline Lintonium vibex (Linton, 1900) & Lagocephalus Iunaris & Sey et al. (2003) \\
\hline $\begin{array}{l}\text { Complexobursa vjetnamensis Oshmarin \& } \\
\text { Mamaev, } 1963\end{array}$ & Terapon theraps & Sey et al. (2003) \\
\hline Monascus filiformis (Rudolphi, 1819) & Selaroides leptolepis & Sey et al. (2003) \\
\hline Tergestia pauca Freitas \& Kohn, 1965 & Alepes djedaba & Sey et al. (2003) \\
\hline Transverstotrema licinum Manter, 1970 & $\begin{array}{l}\text { Diplodus noct, Treptodemus latus, } \\
\text { Hemiramphus marginatus }\end{array}$ & Sey et al. (2003) \\
\hline Prosogonotrema bilabiatum Pérez Vigueras, 1940 & $\begin{array}{l}\text { Epinephelus areolatus, Hexangium } \\
\text { sigani, Siganus canaliculatus }\end{array}$ & Sey et al. (2003) \\
\hline Diphterostomum brusinae (Stossich, 1899) & Argyrops spinifer & Sey et al. (2003) \\
\hline Allostomachicola secundus (Srivastava, 1937) & Chirocentrus nudus & \\
\hline Ectenurus trachuri Nikolaeva \& Kovaleva, 1966 & $\begin{array}{l}\text { Trachurus trachurus, Caranx kalla, } \\
\text { Scomberoides commersonianus, } \\
\text { Rachycentron canadum }\end{array}$ & Nahhas \& Sey, (2002) \\
\hline Erilepturus hamate (Yamaguti, 1934) & $\begin{array}{l}\text { Lutjanus russelli, Otolithes } \\
\text { ruber, Pseudorhombus } \\
\text { arsius, Scomberoides } \\
\text { commersonianus, Therapon sp. }\end{array}$ & Nahhas \& Sey, (2002) \\
\hline Lecithocladium angustiovum Yamaguti, 1953 & Caranx kalla & Nahhas \& Sey (2002) \\
\hline Lecithochirium acutum, Chauhan, 1945 & Trichiurus lepturus & Nahhas \& Sey (2002) \\
\hline Aponurus laguncula Looss, 1907 & Siganus oramin & Nahhas \& Sey (2002) \\
\hline Lecithaster indicus Srivastava, 1935 & Otolithes ruber & Nahhas \& Sey (2002) \\
\hline Aphanurus stossichii (Monticelli, 1891) & $\begin{array}{l}\text { Sardinella perforata, llisha } \\
\text { elongate, Thryssa whiteheadi, } \\
\text { Mulloidichthys auriflamma, }\end{array}$ & Nahhas \& Sey (2002) \\
\hline Proctotrematoides kuwaiti & $\begin{array}{l}\text { Synaptura orientalis, } \\
\text { Pseudorhombus arsius }\end{array}$ & Sey \& Nahhas (1997) \\
\hline Opisthodiplomonorchis elongatus Madhavi, 1974 & $\begin{array}{l}\text { Polydactylus sextarius, } \\
\text { Plectorhynchus sp. }\end{array}$ & Sey \& Nahhas (1997) \\
\hline
\end{tabular}




\section{References}

Al-Kandari, M.A., Abdul-Salam, J.M., Moussa, M.A. and Sreelatha, B.S. (2007). 'Seasonal dynamics of the cercarial and metacercarial stages of Maritrema eroliae (Digenea: Microphallidae) '. Acta Zoologica Sinica 53:463-469.

Al Kawari, K.S.R., Saoud, M.F.A. and Ramadan, M. (1996). 'Biodiversity of helminth parasites of fishes in the Arabian Gulf, with special reference to digenetic trematodes and cestodes'. Qatar University Science Journal 16: 141-153.

Al-Yamani, F. Y. (1979). 'Digenetic trematodes of marine fishes from the Kuwaiti coast of the Arabian Gulf'. Thesis. University of the Pacific.

Nahhas, F. M. and Sey, O. (2002). 'Digenetic trematodes from marine fishes off the Coast of Kuwait, Arabian Gulf: Superfamily Hemiuroidea'. Acta Zoologica Academiae Scientiarum Hungaricae 48: $1-20$.

Sey, O. and Nahhas, F. M. (1997). 'Digenetic trematodes of marine fishes from the Kuwaiti coast of the Arabian Gulf: Family Monorchiidae Odhner, 1911'. Journal of the Helmintholgical Society of Washington 64:1-8

Sey, O., Nahhas, F. M., Uch, S. and Vang, C. (2003). 'Digenetic trematodes from marine fishes off the coast of Kuwait, Arabian Gulf: Fellodistomidae and some smaller families, new host and geographic records'. Acta Zoologica Academiae Scientiarum Hungaricae 49: 179-200.

\subsection{Phylum Acanthocephala}

Three species of acanthocephaln worms (Table 48) were found to infest marine fishes of Kuwait (Amin et al., 1984).

Table 48: Acanthocephalan worms recoverd from fishes from Kuwait.

\begin{tabular}{|l|l|}
\hline \multicolumn{1}{|c|}{ Parasite } & \multicolumn{1}{|c|}{ Host } \\
\hline Sclerocollum rubrimaris Schmidt and Paperna, 1978 & Siganus oramin, \\
\hline Serrasentis sagittifer (Linton, 1889) & $\begin{array}{l}\text { Bothus sp., Lutjanus coccineus, Lutjanus } \\
\text { fulviflamma, Nemipterus japonicus, } \\
\text { Nemipterus tolu (Nemipteridae), Otolithus } \\
\text { argenteus }\end{array}$ \\
\hline Neoechinorhynchus sp. & Lisa macrolepis, Pseudorhombus arsius \\
\hline
\end{tabular}

\section{References}

Amin, O.M., Nahhas, F.M., Al-Yamani, F. and Abu-Hakima, R. (1984). 'On three Acanthocephalan species from some Arabian Gulf fishes off the coast of Kuwait'. The Journal of Parasitology 70 : 168-170.doi.org/10.2307/3281951 



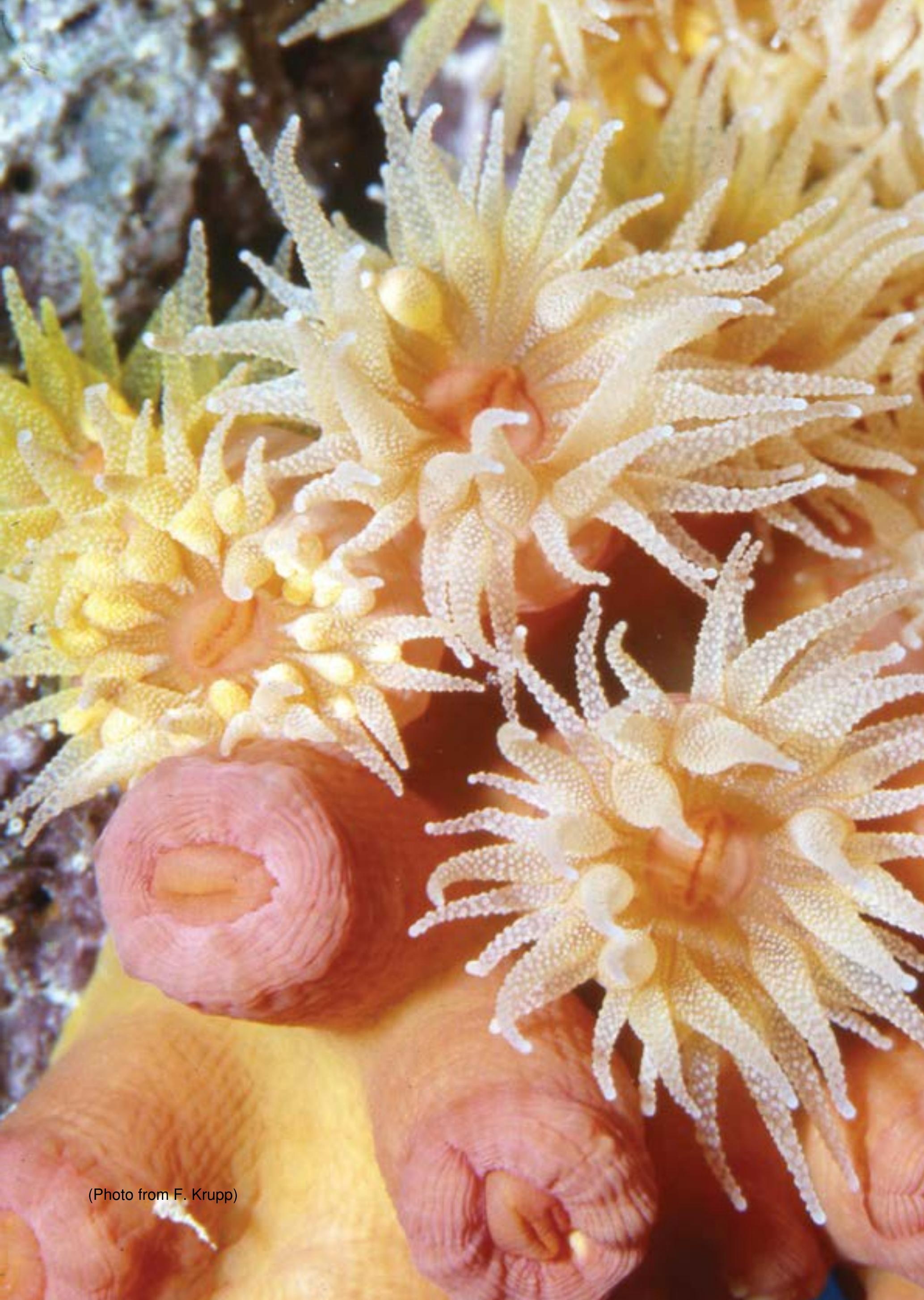




\section{Phylum Cnidaria}

\subsection{Classes Hydrozoa and Scyphozoa}

Class Sycphozoa includes true jellyfish species, while Hydrozoa includes some solitary and some colonia species. Our knowledge on this group is based on Al-Yamani et al. (2011). Scyphozoa is represented by one species, while hydrozoans are represented by 13 species in six families (Table 49).

Table 49: Hydrozoans and scyphozoans reported from Kuwait.

\begin{tabular}{|l|l|l|l|}
\hline \multicolumn{1}{|c|}{ Class } & \multicolumn{1}{|c|}{ Order } & \multicolumn{1}{|c|}{ Family } & \multicolumn{1}{c|}{ Species } \\
\hline Hydrozoa & Anthoathecata & Pandeidae & Amphinema rugosum (Mayer, 1910) \\
\hline & Leptothecata & Eirenidae & Eirene viridula (Peron and Lesueur, 1810) \\
\hline & & & Eutima gegenbauri Haeckel \\
\hline & & Malagazziidae & Octophialucium funerarium (Quoy \& Gaimard, 1827) \\
\hline & & Hydractiniidae & Podocoryna sp. \\
\hline & & Campanulariidae & Clytia discoida (Mayer, 1900) \\
\hline & & & Obelia dichotoma (Linnaeus, 1758) \\
\hline & Trachymedusae & Rhopalonematidae & Aglaura hemistoma Peron \& Lesueur, 1810 \\
\hline & & Geryoniidae & Liriope tetraphyla (Chamisso \& Eysenhardt, 1821) \\
\hline & Semaeostomeae & Pelagiidae & Sanderia malayensis Goette, 1886 \\
\hline & Siphonophorae & Diphyidae & Diphyes chamissonis (Huxley, 1859) \\
\hline Scyphozoa & Rhizostomeae & Catostylidae & Catostylus mosaicus (Quoy and Gaimard, 1824) \\
\hline
\end{tabular}

\section{References}

Al-Yamani, F.Y., Skryabin, V.A., Gubanova A.D., Khvorov S. and Prusova I. (eds.) (2011). Marine Zooplankton Practical Guide for the Northwestern Arabian Gulf. Volume I, pp.196 Kuwait Institute for Scientific Research. 


\subsection{Class Anthozoa}

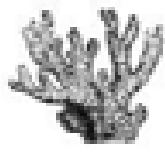

This class includes corals (soft and hard). A total of 35 species in 11 families of hard corals have been reported from the Kuwaiti waters (Table 50) (Hodgson \& Carpenter, 1995; Papathanasopoulou \& Zogaris, 2015). In this paper, detailed information on the taxonomy and distribution of Kuwait' $\mathrm{s}$ corals was given, along with a description of a new species, Acropora arabensis Hodgson \& Carpenter, 1995. An illustrated book with 35 species of corals along with fish species associated with corals was published by Carpenter et al. (1997) and one by Papathanasopoulou \& Zogaris (2015) (Figure 39). There are about 124 fish species, mostly damselfish, hawksbill (Eretmochelys imbri- cata) and green turtles (Chelonia mydas) nest on the coral cays (Pilcher et al., 2000). Other useful publications include McCain et al. (1984), Downing (1985a \& b, 1989a \& b), Downing et al. (1985), Alhazeem et al. (2017), Gholoum et al. (2019).

In Kuwait, coral reefs are confined to the southern part of the country and include a range of offshore platform and smaller patch reefs, and nearshore patch and fringing reef assemblages along the southern coastline (Figure 36-38). All are in shallow water (Pilcher et al., 2000). The conservation status for the corals of Kuwait are summarized in Table (50).

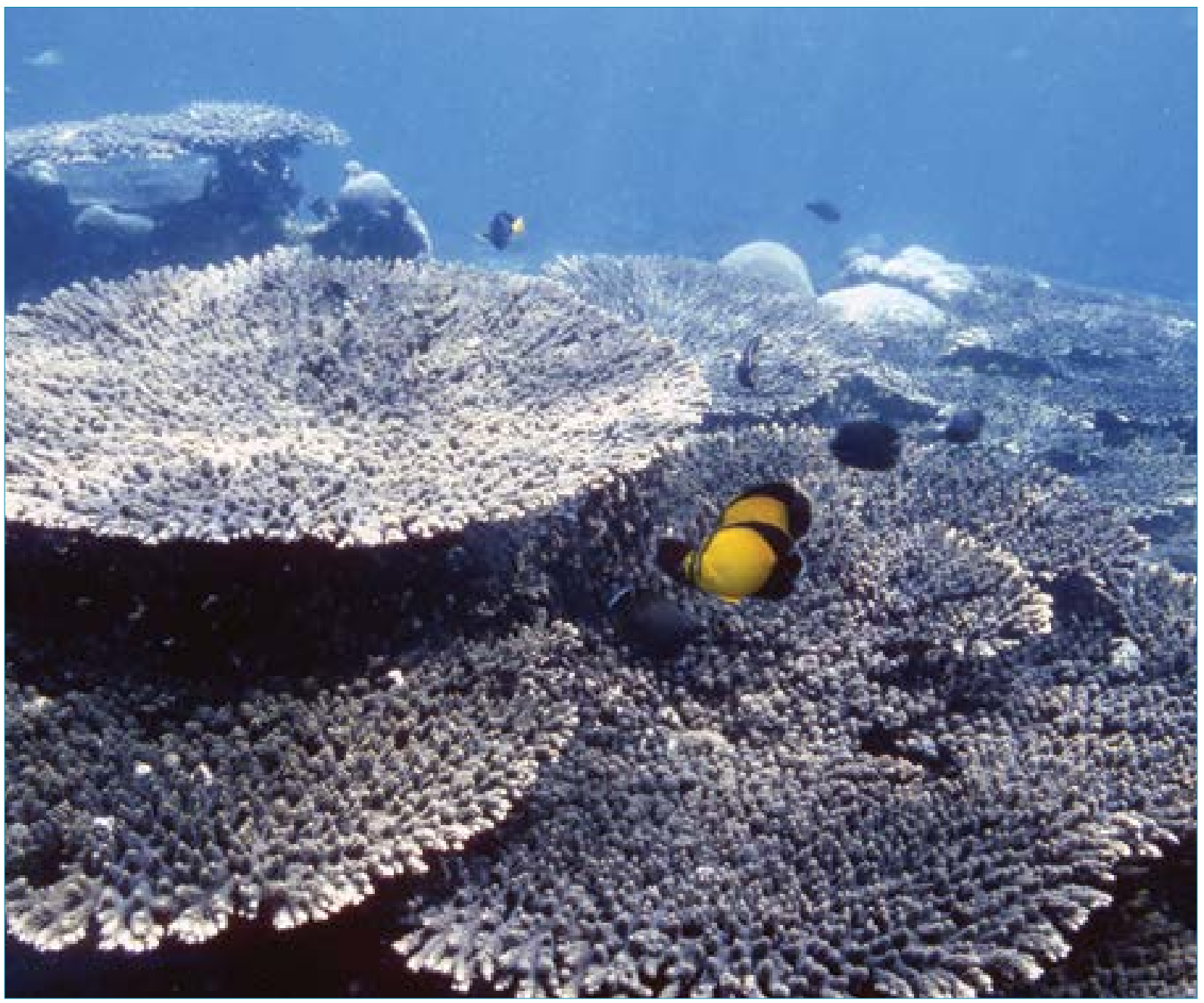

Figure 36: Corals from the Arabian Gulf. Acropora clathrate (Photo from F. Krupp). 


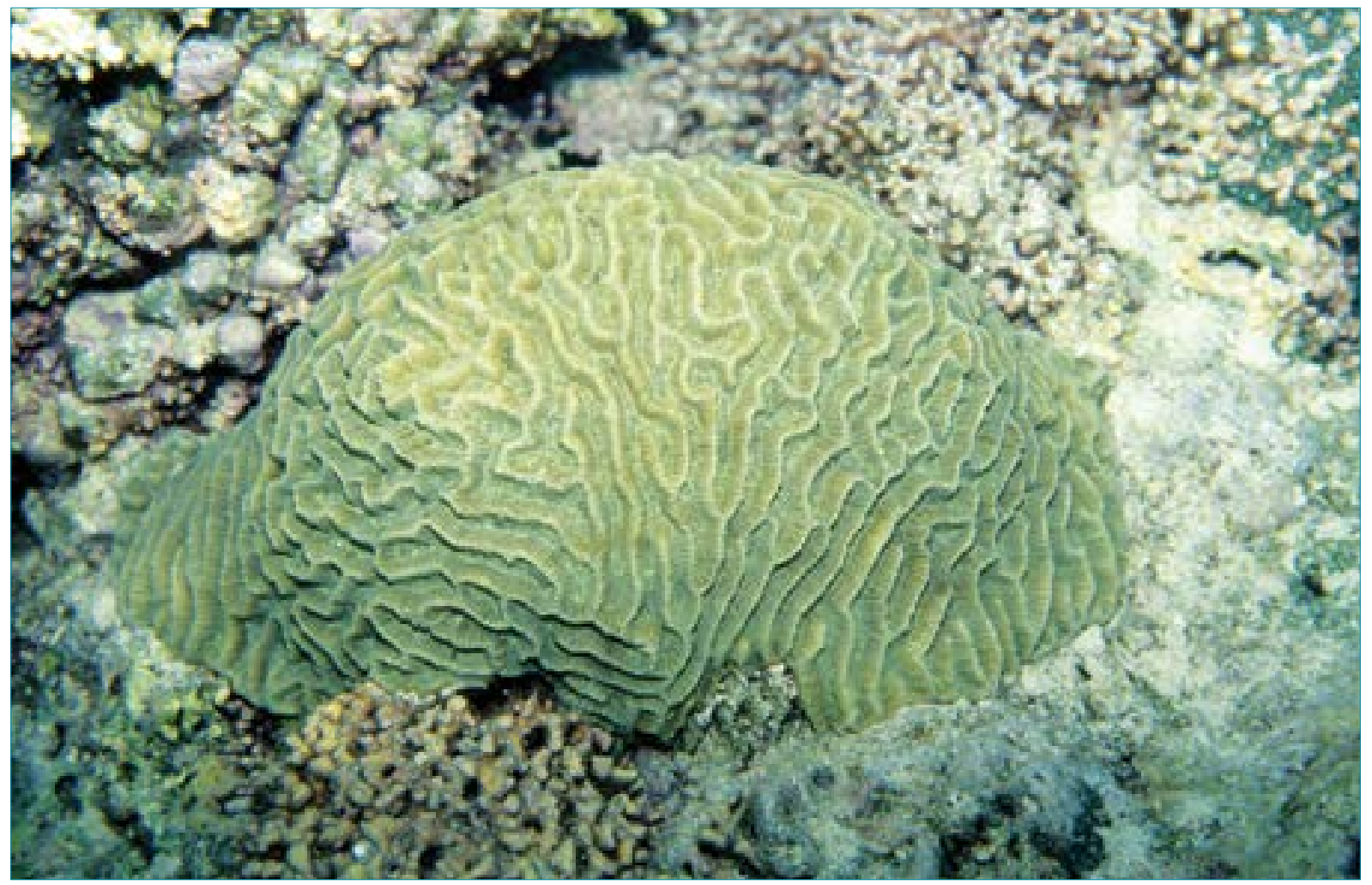

Figure 37: Corals from the Arabian Gulf. Platygyra daedalea (Photo from F. Krupp).

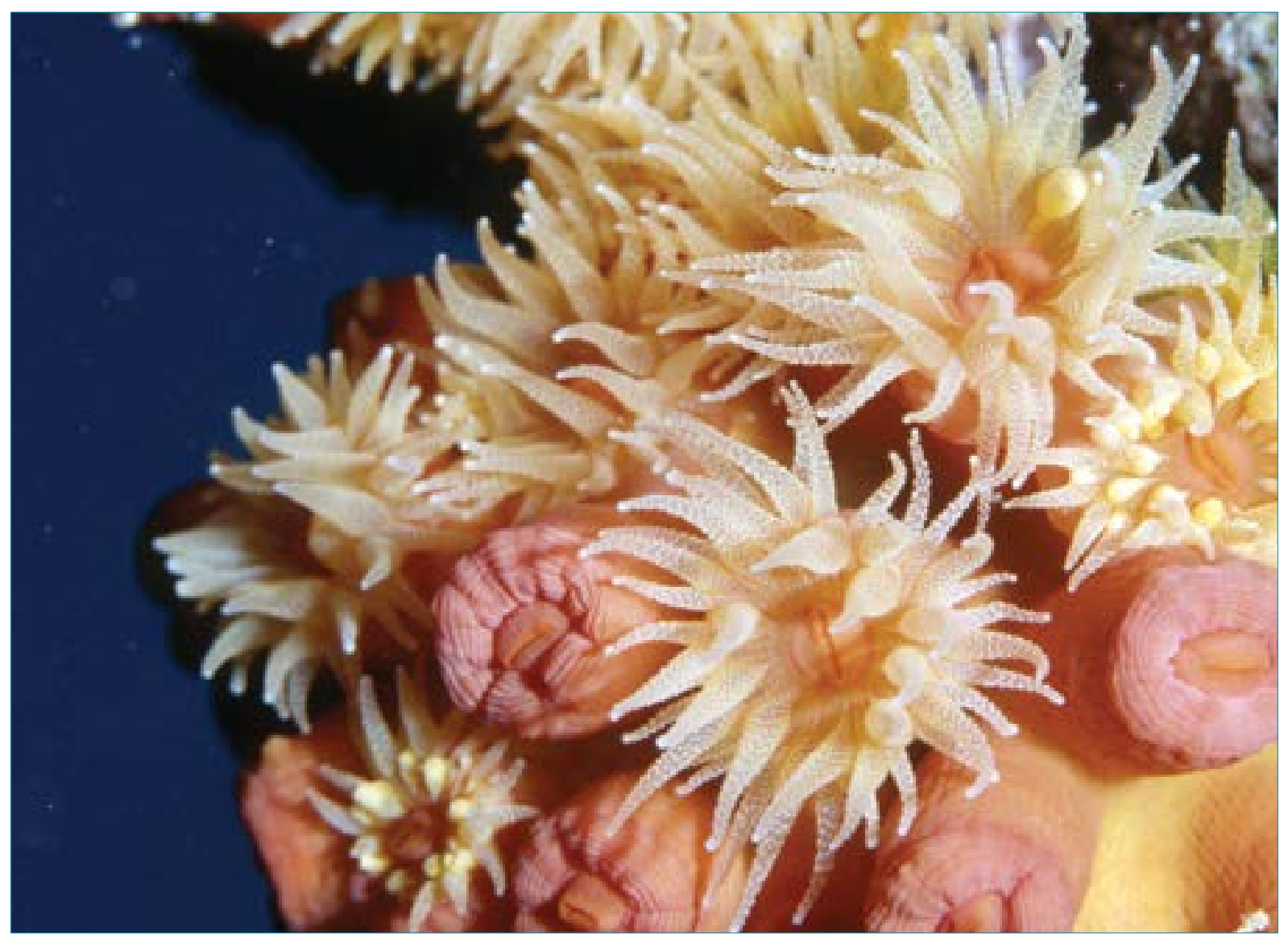

Figure 38: Corals from the Arabian Gulf. Tubastrea coccinea (Photo from F. Krupp). 
Table 50: Corals recorded from Kuwaiti waters.

\begin{tabular}{|c|c|}
\hline Family & Species \\
\hline \multirow[t]{2}{*}{ Pocilloporidae } & Stylophora pistillata (Esper, 1797) \\
\hline & Madracis kirbyi Veron \& Pichon, 1976 \\
\hline \multirow[t]{2}{*}{ Acroporidae } & Acropora clathrata (Brook, 1891) \\
\hline & Acropora arabensis Hodgson \& Carpenter, 1995 \\
\hline \multirow[t]{3}{*}{ Poritidae } & Porites lutea Edwards \& Haime, 1860 \\
\hline & Porites compressa Dana, 1846 \\
\hline & Goniopora lobata Edwards \& Haime, 1860 \\
\hline \multirow[t]{5}{*}{ Siderastreidae } & Siderastrea savignyana Milne-Edwards \& Haime, 1850 \\
\hline & Anomastraea irregularis Marenzeller, 1901 \\
\hline & Psammocora superficialis Gardiner, 1898 \\
\hline & Psammocora contigua (Esper, 1797) \\
\hline & Coscinaraea columna (Dana, 1846) \\
\hline \multirow[t]{2}{*}{ Agariciidae } & Pavona explanulata (Lamarck, 1816) \\
\hline & Pavona decussata (Dana, 1846) \\
\hline \multirow[t]{3}{*}{ Rhizangiidae } & Culicia tenella (Dana, 1846) \\
\hline & Polycyathus marigondoni Verheij \& Best, 1987 \\
\hline & Paracyathus stokesi Milne Edwards \& Haime, 1848 \\
\hline \multirow[t]{2}{*}{ Mussidae } & Acanthastrea echinata (Dana, 1846) \\
\hline & Acanthastrea maxima Sheppard \& Sa1m, 1988 \\
\hline Merulinidae & Hydnophora exesa (Pallas, 1766 \\
\hline \multirow[t]{8}{*}{ Favlldae } & Favia pallida (Dana, 1846) \\
\hline & Favia speciosa (Dana, 1846) \\
\hline & Cyphastrea microphthalma (Lamarck, 1816) \\
\hline & Cyphastrea serailia (Forsskal, 1775) \\
\hline & Favia speciose (Dana, 1846) \\
\hline & Leptastrea transversa Klunzinger, 1879 \\
\hline & Platygyra daedalea (Ellis \& Solander, 1786) \\
\hline & Plesiastrea versipora (Lamarck, 1816) \\
\hline Caryophylliidae & Heterocyathus aequicostatus Edwards \& Haime, 1848 \\
\hline \multirow[t]{6}{*}{ Dendrophylliidae } & Dendrophyllia gracilis Edwards \& Haime, 1948 \\
\hline & Heteropsammia cochlea (Spengler, 1781) \\
\hline & Tubastraea coccinea Lesson, 1829 \\
\hline & Tubastraea tagusensis Wells, 1982 \\
\hline & Turbinaria peltata (Esper, 1794) \\
\hline & Turbinaria reniformis Bernard, 1896 \\
\hline
\end{tabular}



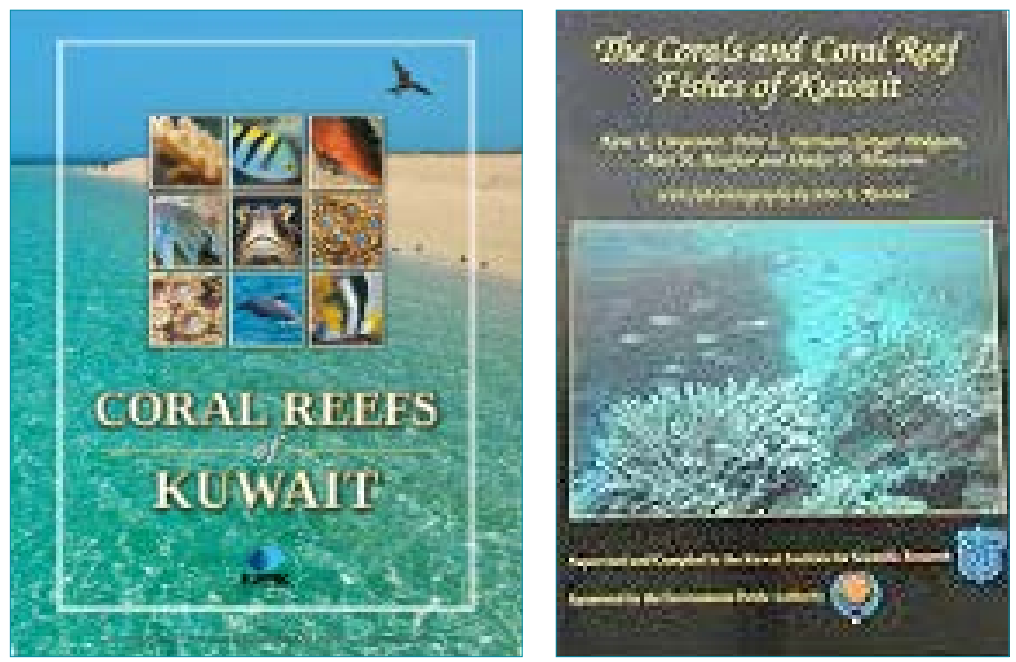

Figure 39: Books on the corals of Kuwait.

Table 51: IUCN conservation status for corals in Kuwait.

\begin{tabular}{|c|c|c|}
\hline Family & Species & Status \\
\hline \multirow[t]{2}{*}{ Acroporidae } & Acropora arabensis & NT \\
\hline & Acropora clathrata & LC \\
\hline \multirow[t]{2}{*}{ Agariciidae } & Pavona decussata & VU \\
\hline & Pavona explanulata & LC \\
\hline Caryophylliidae & Heterocyathus aequicostatus & LC \\
\hline \multirow[t]{3}{*}{ Dendrophylliidae } & Heteropsammia cochlea & LC \\
\hline & Turbinaria peltata & VU \\
\hline & Turbinaria reniformis & VU \\
\hline \multirow[t]{7}{*}{ Favlldae } & Cyphastrea microphthalma & LC \\
\hline & Cyphastrea serailia & LC \\
\hline & Favia pallida & LC \\
\hline & Favia speciosa & LC \\
\hline & Leptastrea transversa & LC \\
\hline & Platygyra daedalea & LC \\
\hline & Plesiastrea versipora & LC \\
\hline Merulinidae & Hydnophora exesa & NT \\
\hline \multirow[t]{2}{*}{ Mussidae } & Acanthastrea echinata & LC \\
\hline & Acanthastrea maxima & NT \\
\hline \multirow[t]{2}{*}{ Pocilloporidae } & Stylophora pistillata & NT \\
\hline & Madracis kirbyi & LC \\
\hline \multirow[t]{3}{*}{ Poritidae } & Goniopora lobata & NT \\
\hline & Porites compressa & LC \\
\hline & Porites lutea & LC \\
\hline \multirow[t]{5}{*}{ Siderastreidae } & Anomastraea irregularis & VU \\
\hline & Coscinaraea columna & LC \\
\hline & Psammocora contigua & NT \\
\hline & Psammocora superficialis & LC \\
\hline & Siderastrea savignyana & LC \\
\hline
\end{tabular}


Surveys that were conducted in 1992 on the offshore and nearshore reefs in Kuwait and Saudi Arabia showed that a small inshore platform reef located near sources of oil spill during the Gulf
War has been partially impacted and the corals recovered and continued to support a healthy fish community (Downing \& Roberts, 1993).

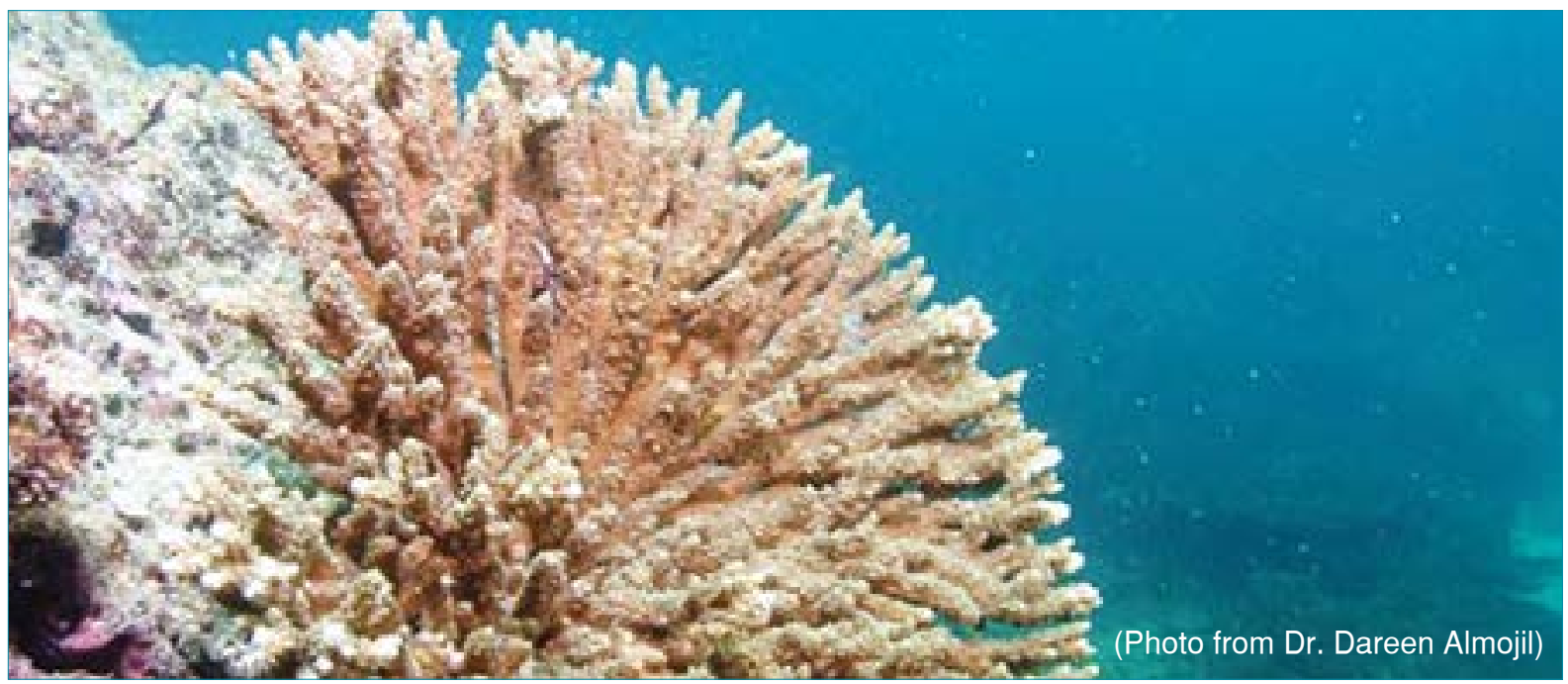

\section{References}

Alhazeem, S.H., Burt, A., Alsaffar, A.H., Chen, W. and Al-Kandari, M.A. (2017). 'Long-term coral community stability in a disturbed marginal reef in Kuwait'. Journal of Water Resources \& Ocean Science 6: 85-89. doi.org/10.11648/j.wros.20170606.12

Carpenter, K.E., P.L. Harrison, G. Hodgson, A.H. Alsaffar and Alhazeem, S.H. (1997). 'The Corals and Coral Reef Fishes of Kuwait', pp 166. Kuwait institute of Scientific Research, Kuwait.

Downing, N. (1985a). 'Coral reef communities in an extreme environment: the northwestern Arabian Gulf '. Proc. 5th Int. Coral Reef Congr. Tahiti 6:343-348.

Downing, N. (1985b). 'Coral reef communities in the northwestern Arabian Gulf '. KISR Ann. Res. Rep., pp. 12-15.

Downing, N., Tubb, R. A., El-Zahr, C. R. and McClure, R. E. (1985). 'Artificial reefs in Kuwait, northern Arabian Gulf'. Bulletin of Marine Science 37: 157-178.

Downing, N. (1989a). 'Final report on a study of the corals and coral reef fishes of Kuwait. Volume III: The coral reef fishes'. Kuwait Institute for Scientific Research, Kuwait.

Downing, N. (1989b). 'Final report: A study of the corals and coral reef fishes of Kuwait, Volume II: the reef building corals'. Kuwait Institute for Scientific Research (Project MB-42), Kuwait.

Downing, N. (1991). 'A survey of the coral islands of Kubbar, Qaru and Umm Al Maradem, Kuwait', 1319 July, 1991. Report to the International Union for the conservation of Nature and the World Wildlife Fund, pp. 1-12.

Downing, N. and Roberts, C. (1993). 'Has the Gulf War affected coral reefs of the northwestern Gulf? '. Marine Pollution Bulletin 27: 149-156. doi.org/10.1016/0025-326X(93)90019-G

Gholoum, M., Bruce, D. and Alhazeem, S. (2019). 'A new image classification approach for mapping coral density in State of Kuwait using high spatial resolution satellite images'. International Journal of Remote Sensing 40: 4787-4816. doi.org/10.1080/01431161.2019.1574991

Hodgson, G. and Carpenter, K. (1995). 'Scleractinian corals of Kuwait'. Pacific Science 49: $227-246$.

McCain, J. C., Tarr, A. B., Carpenter, K. E. and Coles, S. L. (1984). 'Marine ecology of Saudi Arabia, a survey of coral reefs and reef fishes in the northern area, Arabian Gulf, Saudi Arabia'. Fauna of Saudi Arabia 6: 102-126.

Papathanasopoulou, N. and Zogaris, S. (2015). Coral Reefs of Kuwait, pp 270.Kuwait Foreign Petroleum Exploration Company. Kuwait.

Pilcher, N.J., Wilson, S., Alhazeem, S.H. and Shokri, M.R. (2000). 'Status of coral reefs in the Arabian/ Persian Gulf and Arabian Sea region (Middle East)'. In: 'Status of Coral Reefs of the World: 2000'. Clive Wilkinson, C. (ed.), pp. 55-64. Australian Institute of Marine Science 


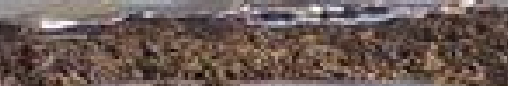
Cot (1)

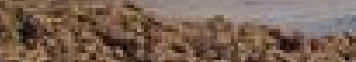

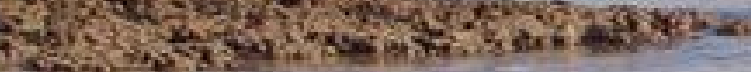

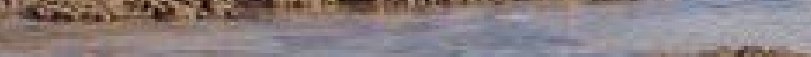

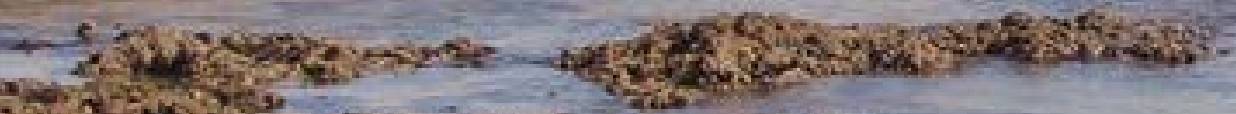

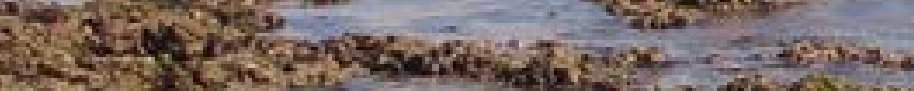

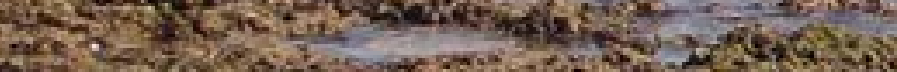

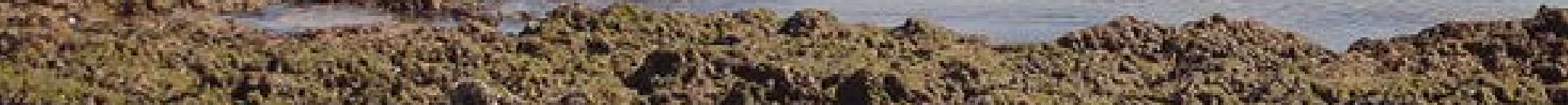

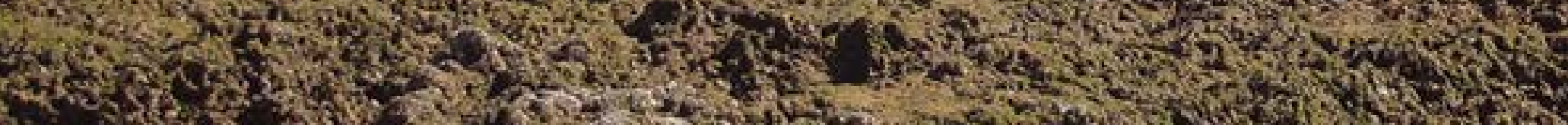

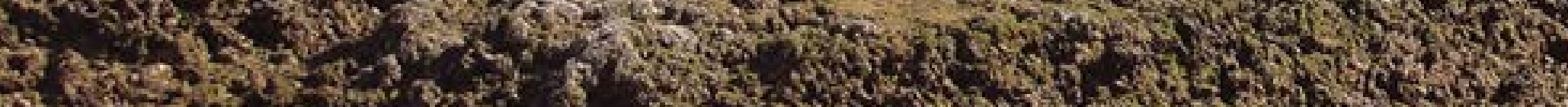

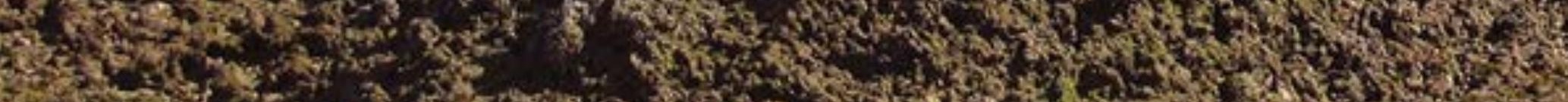

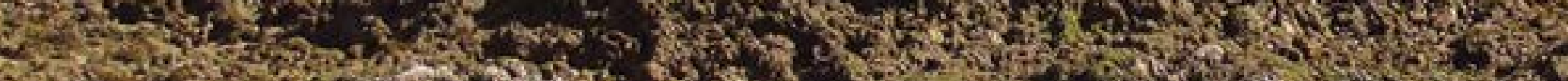

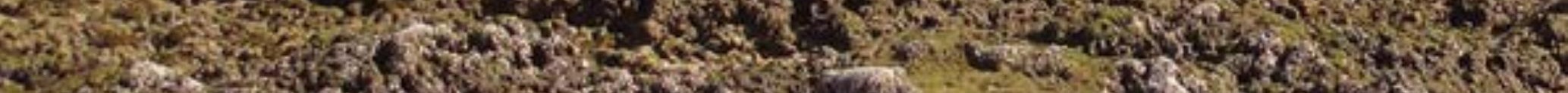

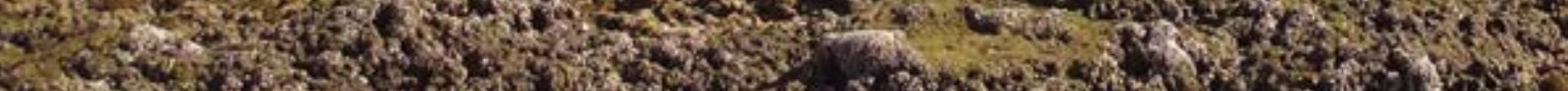

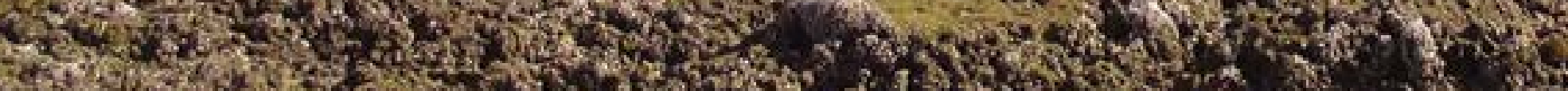

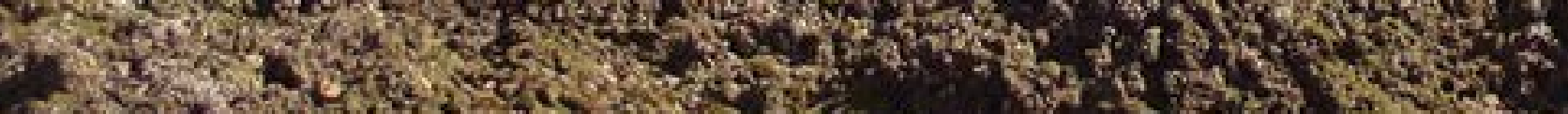

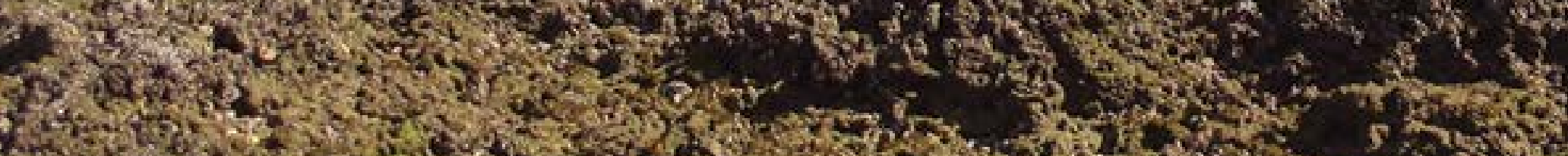

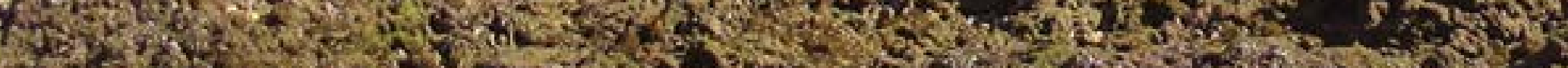
W.

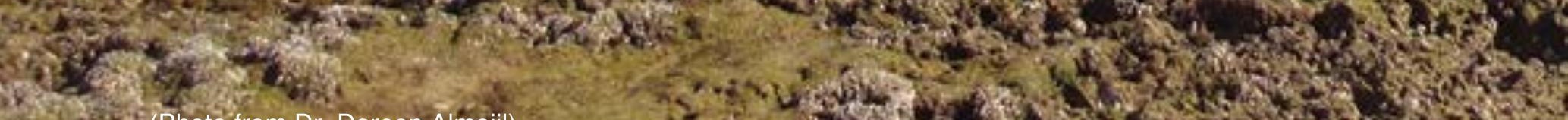
N5: (Photo from Dr. Dareen Almojil)

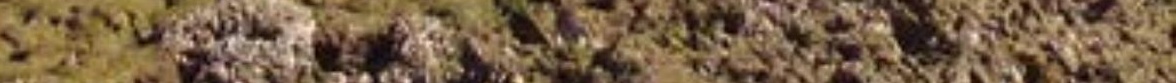

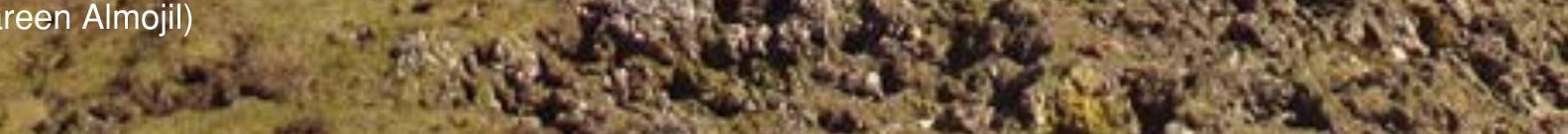

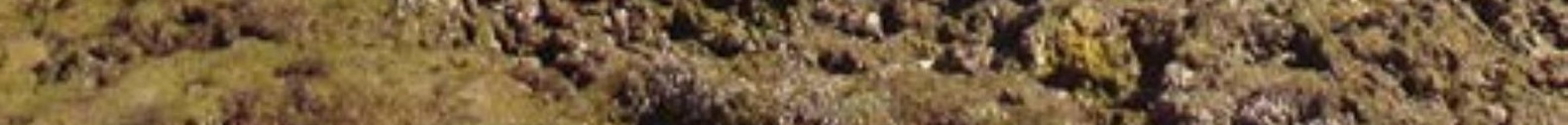

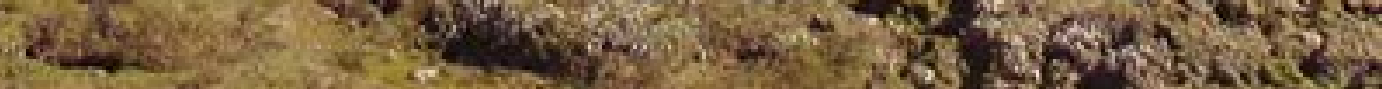




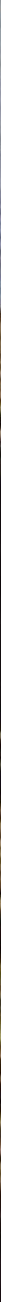




\section{Phylum Annelida}

\subsection{Phylum Annelida}

\subsubsection{Class Polychaeta}

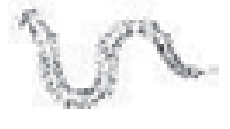

The annalids of Kuwait were studied extensively with a total of 172 species within 46 families, 19 species are new records to the Arabian Gulf and 17 to the Arabian Region. The most abundant species belonged to the family Spionidae, followed by Nereididae, and Serpulidae. (Figure 40) (AlYamani et al., 2009 \& 2012; Jones, 1986; ElSammak et al., 2011; Sun et al., 2017; Al-Kandari et al., 2019) (Annex 6). Mohammad (1970a \& b;
1980 \& 1983) described 18 new species of polychaetes from the waters of Kuwait (Table 52). Other papers discussed malformation of polychaetes (Mohammad, 1981). The genus Kuwaita was revised by Carrera-Parra \& Orensanz, (2002). Species of phylum Echiura are now included in phylum Annelida based on recent molecular studies (Struck et al., 2007).
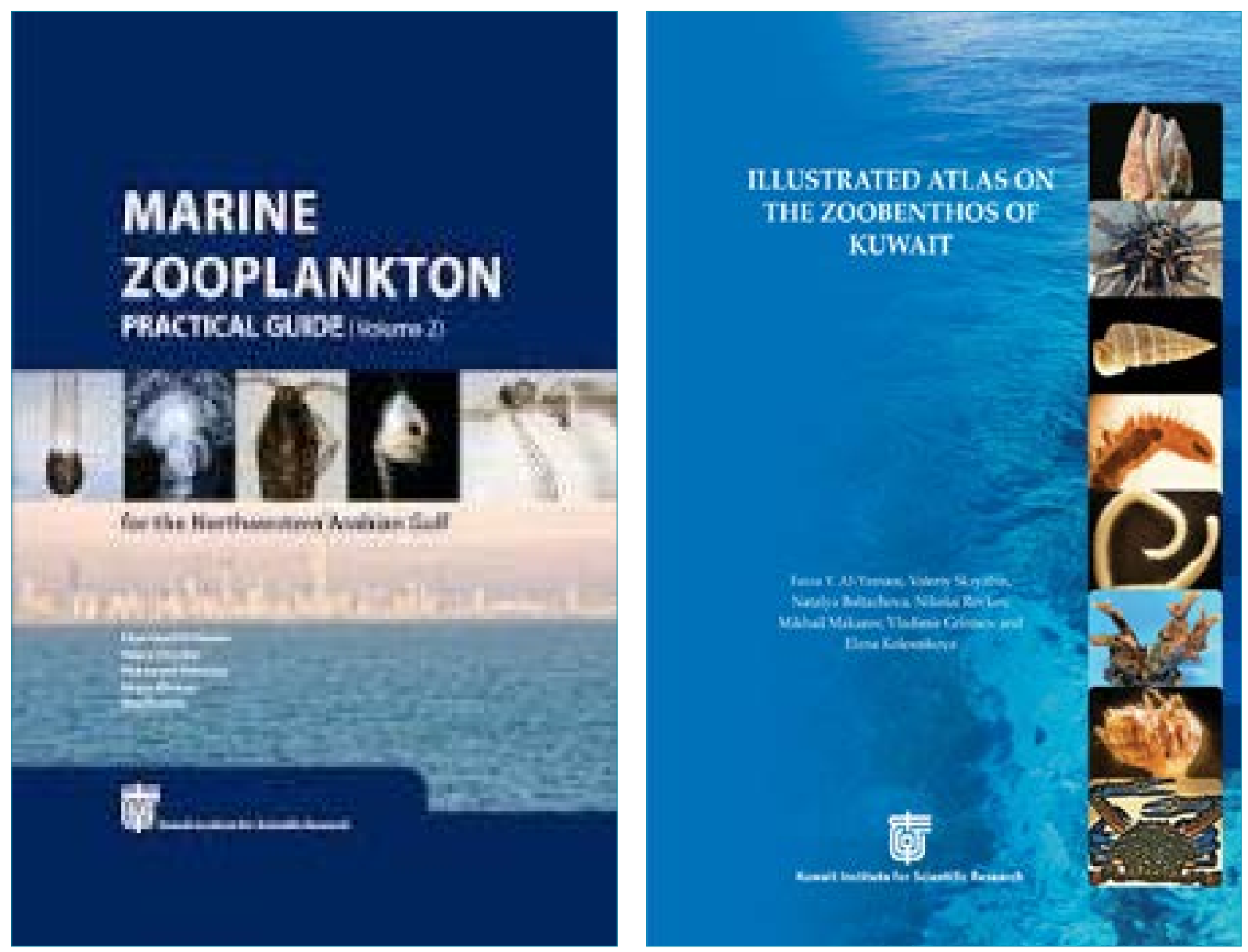

Figure 40: Books on marine invertebrates of Kuwait. 
Table 52: Polychaeta species described from Kuwait by Mohammad (1970a \& b; 1971 \&1980).

\begin{tabular}{|l|l|}
\hline \multicolumn{1}{|c|}{ Family } & \multicolumn{1}{c|}{ Species } \\
\hline Ampharetidae & Isolda albula Mohammad, 1971 \\
\hline Capitellidae & Scyphoproctus aciculatus Mohammad, 1980 \\
\hline Spionidae & Prionospio rotalis Mohammad, 1970 \\
\hline & Polydora spondylana Mohammad, 1973 \\
\hline Nereididae & Nereis (Nereis) neogracilis Mohammad, 1970 \\
\hline & Neanthes deplanata (Mohammad, 1971) \\
\hline Nereis (Nereis) neogracilis Mohammad, 1970 \\
\hline Syllidae & Imajimaea zonata (Mohammad, 1973) \\
\hline Goniadidae & Bookhoutia oligognatha Mohammad, 1973 \\
\hline Eunicidae & Paucibranchia gemmata (Mohammad, 1973) \\
\hline Lumbrineridae & Kuwaita magna Mohammad, 1973 \\
\hline Terebellidae & Pseudostreblosoma longa (Mohammad, 1973) \\
\hline & Neoleprea clavata Mohammad, 1973 \\
\hline & Telothelepus macrothoracicus Mohammad, 1980 \\
\hline Magelonidae & Magelona pulchella Mohammad, 1980 \\
\hline Orbiniidae & Phylo kubbarensis Mohammad, 1980 \\
\hline Phylo kuwaitica Mohammad, 1970 \\
\hline Leiochone annulata (Mohammad, 1980) \\
\hline
\end{tabular}

\section{References}

Al-Kandari, M., Sattari, Z., Hussain, S., Radashevsky, V.I. and Zhadan, A. (2019). 'Checklist of intertidal polychaetes (Annelida) of Kuwait, Northern part of the Arabian Gulf'. Regional Studies in Marine Science 32:100872. doi.org/10.1016/j.rsma.2019.100872

Al-Yamani, F., Boltachova, N., Revkov, N., Makarov, M., Grintsov, V., Kolesnikova, E. and Murina, V. (2009). 'Winter species composition, diversity and abundance of zoobenthos in Kuwait's waters, Arabian Gulf'. Zookeys 31: 17-38. doi.org/10.3897/zookeys.31.74

Al-Yamani, F.Y., Skryabin, V., Boltachova, N., Revkov, N., Makarov, M., Grinstov, V. and Kolesnikova, E. (2012). Illustrated Atlas on the Zoobenthos of Kuwait, pp 383. Kuwait Institute for Scientific Research.

Bu-Olayan, A.H. and Thomas, B.V. (2005). 'Validating species diversity of benthic organisms to trace metal pollution in Kuwait Bay, off the Arabian Gulf'. Applied Ecology and Environmental Research 3: 93-100. doi.org/10.15666/aeer/0302_093100.

Carrera-Parra, L.F. and Orensanz, J.M. (2002). 'Revision of Kuwaita Mohammad, 1973 (Annelida, Polychaeta, Lumbrineridae) '. Zoosystema 24: 273-281.

El-Sammak, A.A., Mostafa, H.M. and Al-Ghadban, A.N. (2011). 'Environmental factors controlling the distribution of sediment infauna, Az-Zour Area, south of Kuwait'. Arab Gulf Journal of Scientific Research 29:168-182.

Gardiner, J., Townsend, Y. and Varvell, P. (2004). A Field Guide of Intertidal Habitats of Kuwait, pp.79. Ecology and Environment, Inc., Kuwait. 
Jones, D.A. (1986). A field guide to the sea shores of Kuwait and the Arabian Gulf, pp 192. Dorset, Blandford Press.

Mohammad, M.B.M. (1970a). 'A new species of the genus Prionospio (Annelida: Polychaeta)'. Hydrobiologia 36: 23-26. doi.org/10.1007/BF00751279

Mohammad, Murad, B. M. (1970b). 'Description of two new species of Nereidae (Annelida: Polychaeta)'. Zoological Journal of the Linnean Society 49: 183-186. doi.org/10.1111/j.1096-3642.1970. tb00734.x

Mohammad, M.B.B. (1971). 'Intertidal polychaetes from Kuwait, Arabian Gulf with descriptions of three new species'. Journal of Zoology 163: 285-303. doi.org/10.1111/j.1469-7998.1971.tb04536.x

Mohammad, M.B.B. (1973). 'New species and records of polychaete annelids from Kuwait, Arabian Gulf'. Zoological Journal of the Linnean Society 52:23-44. doi.org/10.1111/j.1096-3642.1973. tb01876.x

Mohammad, M.B.B. (1980). 'Polychaete annelids from Kuwaitian islands, Arabian Gulf with descriptions of four new species'. Zoological Journal of the Linnean Society 69: 31-42. doi. org/10.1111/j.1096-3642.1980.tb01931.x

Mohammad, M.B.B. (1981). 'Malformations in some polychaete annelids from Kuwait, Arabian Gulf'. Hydrobiologia 78: 129-I31. doi.org/10.1007/BF00007586

Struck, T. H., Schult, N., Kusen, T., Hickman, E., Bleidorn, C., McHugh, D. and Halanych, K.M. (2007). 'Annelid phylogeny and the status of Sipuncula and Echiura'. BMC Evolutionary Biology 7: 57. doi.org/10.1186/1471-2148-7-57

Sun, Y., Al-Kandari, M., Kubal, P., Walmiki, N. and Kupriyanova, E.K. (2017). 'Cutting a Gordian knot of tubeworms with DNA data: the story of the Hydroides operculata-complex (Annelida, Serpulidae)'. Zootaxa 4323: 039-048. doi.org/10.11646/zootaxa.4323.1.3

\subsection{Phylum Sipuncula}

This phylum includes sipunculid worms or peanut worms. Two species and one unidentified species
(Table 53) were reported from Kuwait (Al-Yamani et al., 2012).

Table 53: Sipunculids reported from Kuwait.

\begin{tabular}{|l|l|l|l|}
\hline \multicolumn{1}{|c|}{ Class } & \multicolumn{1}{|c|}{ Order } & \multicolumn{1}{c|}{ Family } & \multicolumn{1}{c|}{ Species } \\
\hline Sipunculidea & Golfingiida & Phascolionidae & Phascolion convestitum Sluiter, 1902 \\
\hline Phascolosomatidea & Phascolosomatida & Phascolosomatidae & Phascolion sp. \\
\hline & & & Apionsoma trichocephalus Sluiter, 1902 \\
\hline
\end{tabular}

\section{References}

Al-Yamani, F.Y., Skryabin, V., Boltachova, N., Revkov, N., Makarov, M., Grinstov, V. and Kolesnikova, E. (2012). Illustrated Atlas on the Zoobenthos of Kuwait, pp 383. Kuwait Institute for Scientific Research. 


\subsection{Phylum Brachiopoda}

One example, Lingula sp. (Family Lingulidae) is known to occur in Kuwaiti waters (Al-Yamani et al., 2012).

\section{References}

Al-Yamani, F.Y., Skryabin, V., Boltachova, N., Revkov, N., Makarov, M., Grinstov, V. and Kolesnikova, E. (2012). Illustrated Atlas on the Zoobenthos of Kuwait, pp 383. Kuwait Institute for Scientific Research. 


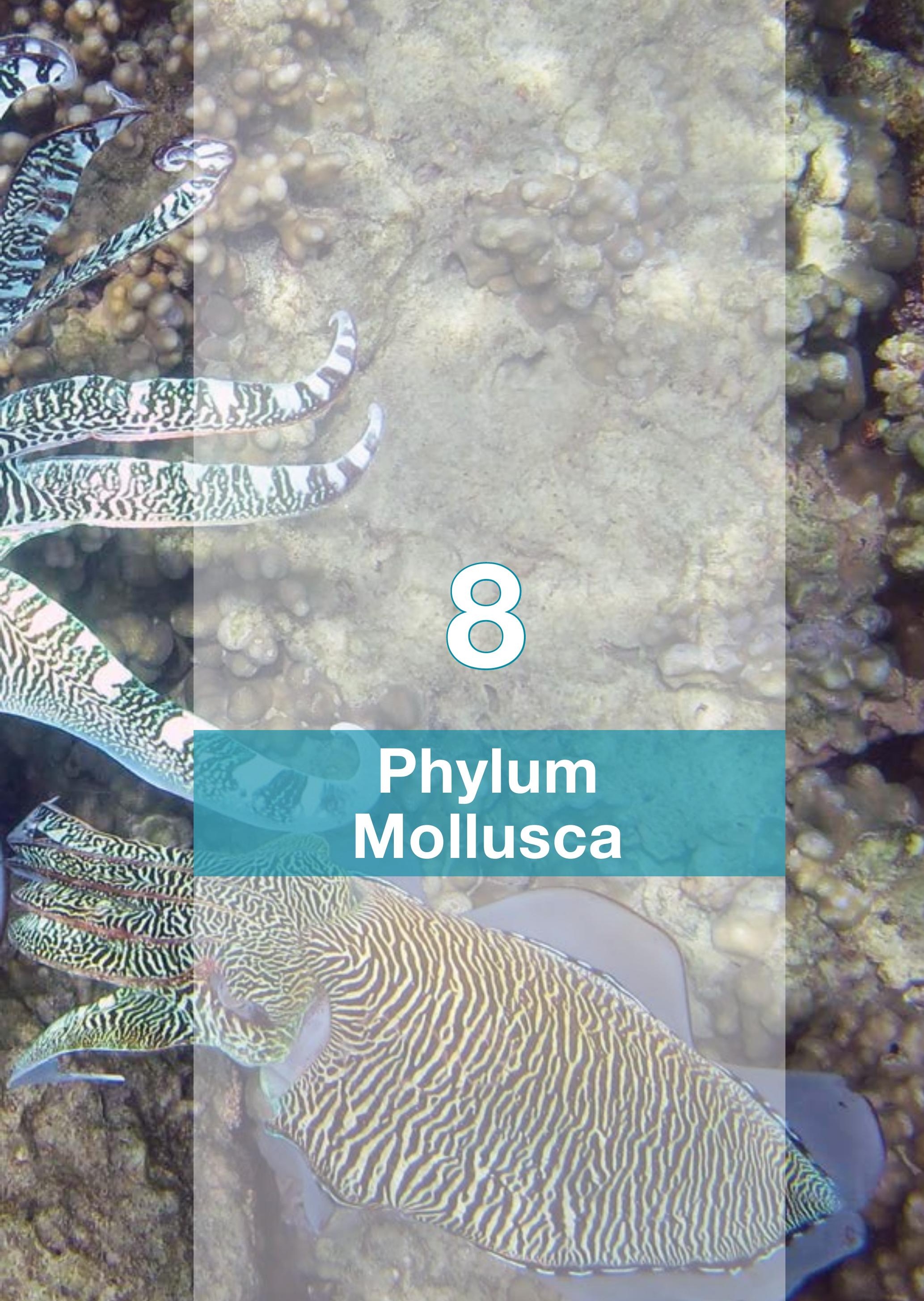




\section{Phylum Mollusca}

\subsection{Class Polyplacophora}

A total of five species and one unidentified species of chitons were reported from Kuwait (Table 54). All records are based on Glayzer et al. (1984) and (Al-Yamani et al., 2012). Notoplax arabica, was described from Kuwait (Kaas \& Van Belle, 1988) and a specimen is at the possession of the British Museum of Natural History.

Table 54: Chitons reported from Kuwait.

\begin{tabular}{|l|l|}
\hline \multicolumn{1}{|c|}{ Family } & \multicolumn{1}{c|}{ Species } \\
\hline Callistoplacidae & Callistochiton barnardi Leloup, 1981 \\
\hline Schizochitonidae & Schizochiton jousseaumei Dupuis, 1917 \\
\hline & Schizochiton sp. \\
\hline Chitonidae & Chiton peregrinus Thiele, 1909 \\
\hline Ischnochitonidae & Ischnochiton yerburyi (E. A. Smith, 1891) \\
\hline Acanthochitonidae & Notoplax arabica Kaas \& Van Belle, 1988 \\
\hline
\end{tabular}

\section{References}

Al-Yamani, F.Y., Skryabin, V., Boltachova, N., Revkov, N., Makarov, M., Grintsov, V. and Kolesnikova, E. (2012). Illustrated Atlas on the Zoobenthos of Kuwait. Kuwait Institute for Scientific Research, Kuwait.

Glayzer, B.A., Glayzer, D.T. and Smythe, K.R. (1984). 'The marine Mollusca of Kuwait, Arabian Gulf'. Journal of Conchology 31: 311-330.

Kaas, P. and Van Belle, R.A. (1988). 'Chitons (Mollusca: Polyplacophora) from the coasts of Oman and the Arabian Gulf '. American Malacological Bulletin 6: 115- 130. 


\subsection{Class Gastropoda}

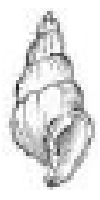

This class includes marine, freshwater and terrestrial snails. In Kuwait, a total of 137 species in 10 orders and 60 families have been recorded from the marine environment (Glayzer et al., 1984; Jones, 1986; Carpenter et al., 1997; Al-Yamani et al., 2009 \& 2012; Nithyanandan, 2012) (Annex 7). The taxonomic position of several families is still unresolved. Some rare Nudibranch are shown in Figure (41), while most common intertidal species are illustrated in Figure (42).
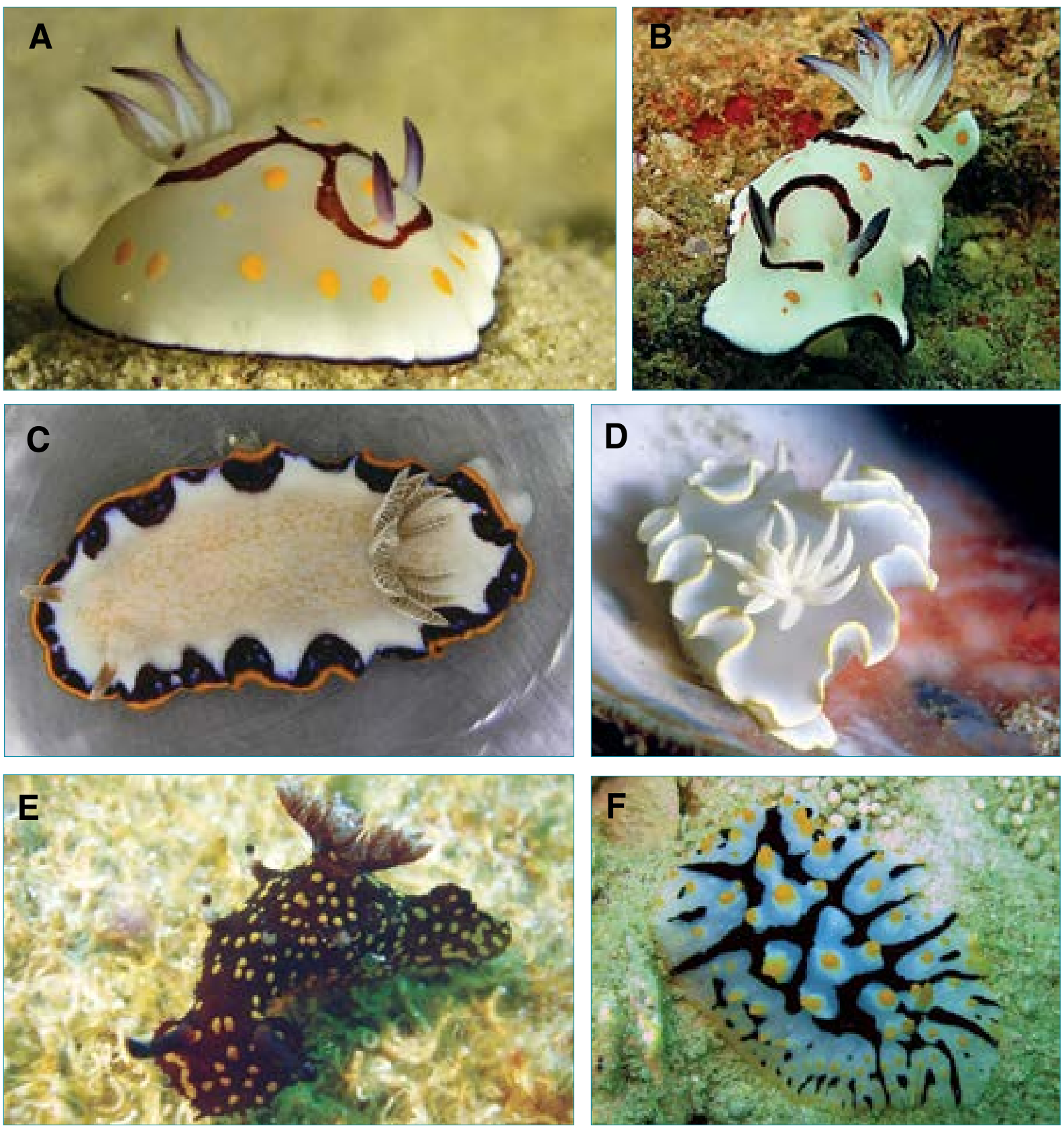

Figure 41: Nudibranch from Kuwait. A. Chromodoris annulata (Photo from A. Alhafez). B. Chromodoris annulata non spectacle (Photo from I. Basuny). C. Chromodoris obsolete (Photo from R. Pelczynski). D. Glossodoris cf. pallida (Photo from S. J. Howlett). E. Plocamopherus ocellatus (Photo from A. Wilson). F. Phyllidia (Fryeria) rueppelii (Photo from N. Papathanasapoulou). 


\section{References}

Al-Yamani, F., Boltachova, N., Revkov, N., Makarov, M., Grintsov, V., Kolesnikova, E. and Murina, G-V. (2009). 'Winter species composition, diversity and abundance of macrozoobenthos in Kuwait's waters, Arabian Gulf'. In: Neubert, E., Amr, Z., Taiti, S. \& Gümüs, B (eds.), Animal Biodiversity in the Middle East. Proceedings of the First Middle Eastern Biodiversity Congress, Aqaba, Jordan, 20-23 October 2008. ZooKeys 31: 17-38. doi org/10.3897/zookeys.31.74

Al-Yamani, F.Y., Skryabin, V., Boltachova, N., Revkov, N., Makarov, M., Grintsov, V. and Kolesnikova, E. (2012). Illustrated Atlas on the Zoobenthos of Kuwait. Kuwait Institute for Scientific Research, Kuwait.

Carpenter, K.E., Harrison, P.L., Hodgson, G., Alsaffar, A.H. and Alhazeem, S.H. (1997). Corals and coral reef fishes of Kuwait. 1st edition. Safat: Kuwait Institute for Scientific Research.

Glayzer B., Glayzer D.T. and Smythe, K.R. (1984). 'The marine Mollusca of Kuwait, Arabian Gulf '. Journal of Conchology 31: 311-330.

Jones, D.A. (1986). A field guide to the sea shores of Kuwait and the Arabian Gulf, pp 192. Dorset, Blandford Press.

Nithyanandan, M. (2012). 'New and rare nudibranch records from Kuwait, Arabian Gulf (Mollusca: Opisthobranchia)'. Marine Biodiversity Records 5: 1-7. doi.org/10.1017/S1755267212000954 


\section{萨KISR}

INTERTIDAL GASTROPODS of KUWAIT

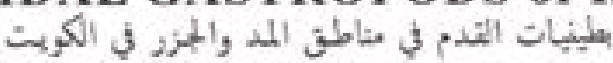

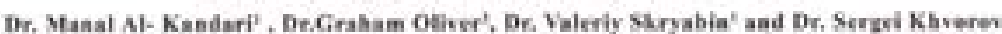

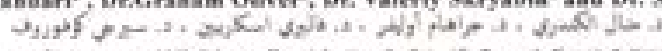

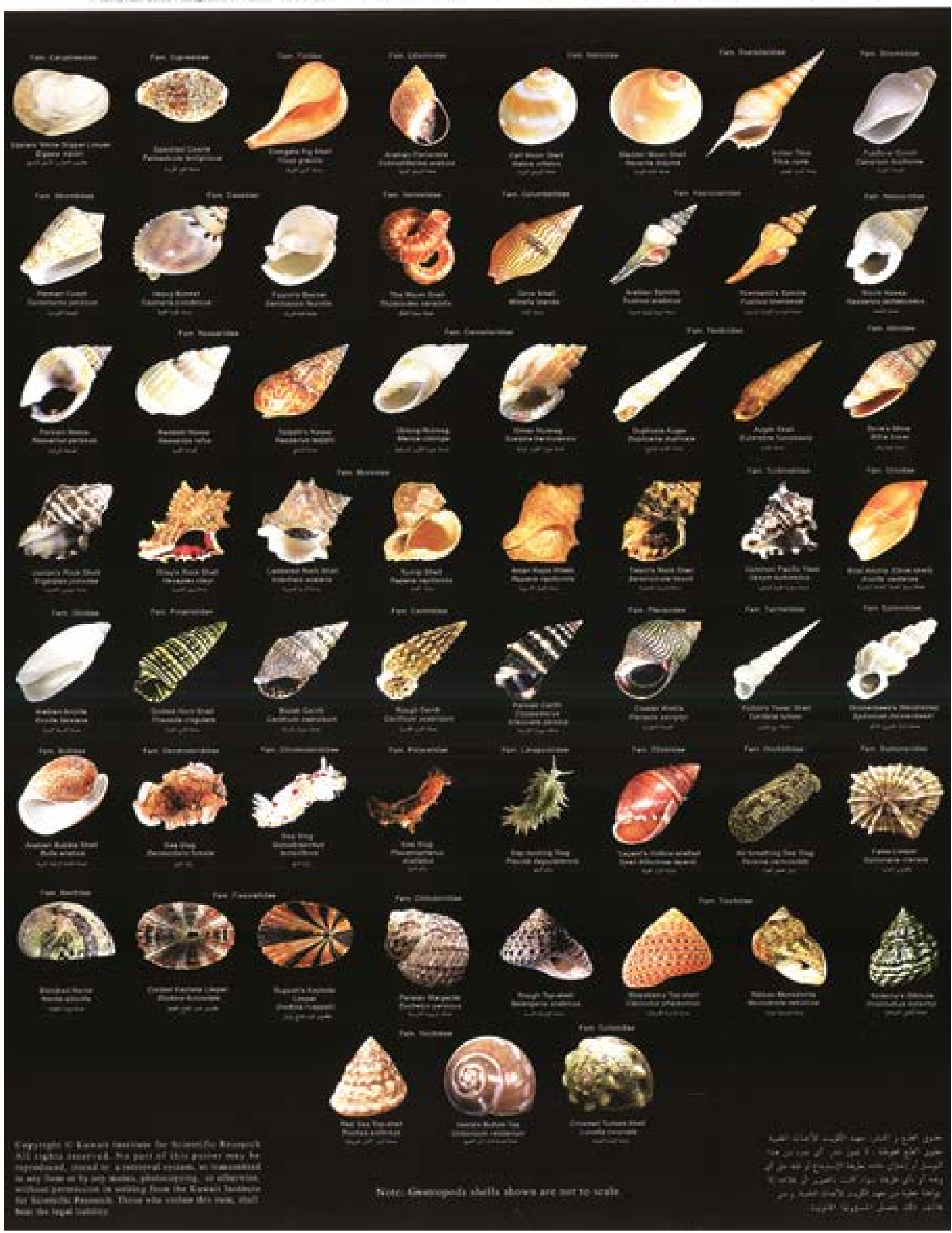

Figure 42: Some common gastropods in the intertidal waters of Kuwait. 


\subsection{Class Bivalvia}

This class includes marine and freshwater species that have laterally compressed bodies enclosed by a shell consisting of two hinged parts. They include the clams, oysters, cockles, mussels, and scallops (Figure 43). So far, 225 species within six orders and 30 families have been identified from Kuwait (Glayzer et al., 1984;
Jones, 1986; Carpenter et al., 1997; Al-Yamani et al., 2009 \& 2012) (Annex 8). A new genus, Larissamya, and a new species, Larissamya comta, were described from Kuwait (Oliver et al., 2017). Recdently, Al Kandari et al. (2020) added new records to the bivalves of Kuwait.

\section{References}

Al-Kandari, M., Oliver, P.G., Chen, W., Skryabin, V., Raghu, M., Yousif, A., Al-Jazzaf, S., Taqi, A. and AlHamad, A. (2020). 'Diversity and distribution of the intertidal Mollusca of the State of Kuwait, Arabian Gulf '. Regional Studies in Marine Science 33:100905. doi.org/10.1016/j. rsma.2019.100905

Al-Yamani, F., Boltachova, N., Revkov, N., Makarov, M., Grintsov, V., Kolesnikova, E. and Murina, G-V. (2009). 'Winter species composition, diversity and abundance of macrozoobenthos in Kuwait's waters, Arabian Gulf'. In: Neubert, E., Amr, Z., Taiti, S. \& Gümüs, B (eds.), Animal Biodiversity in the Middle East. Proceedings of the First Middle Eastern Biodiversity Congress, Aqaba, Jordan, 20-23 October 2008. ZooKeys 31: 17-38. doi org/10.3897/zookeys.31.74

Al-Yamani, F.Y., Skryabin, V., Boltachova, N., Revkov, N., Makarov, M., Grintsov, V. and Kolesnikova, E. (2012). Illustrated Atlas on the Zoobenthos of Kuwait. Kuwait Institute for Scientific Research, Kuwait.

Carpenter K.E., Harrison P.L., Hodgson G., Alsaffar A.H. and Alhazeem S.H. (1997). Corals and coral reef fishes of Kuwait. 1st edition. Safat: Kuwait Institute for Scientific Research

Jones, D.A. (1986). A field guide to the sea shores of Kuwait and the Arabian Gulf, pp 192. Dorset, Blandford Press.

Glayzer B., Glayzer D.T. and Smythe, K.R. (1984). 'The marine Mollusca of Kuwait, Arabian Gulf'. Journal of Conchology 31: 311-330.

Oliver, P. G., Skryabin, V.A. and AI-Ghunaim, A.Y. (2017). 'A new genus and species of galeommatoid bivalve (Mollusca: Bivalvia: Montacutidae) from Kuwait Bay, Arabian Gulf'. Zoology in the Middle East 63: 141-146. doi.org/10.1080/09397140.2017.1299317 


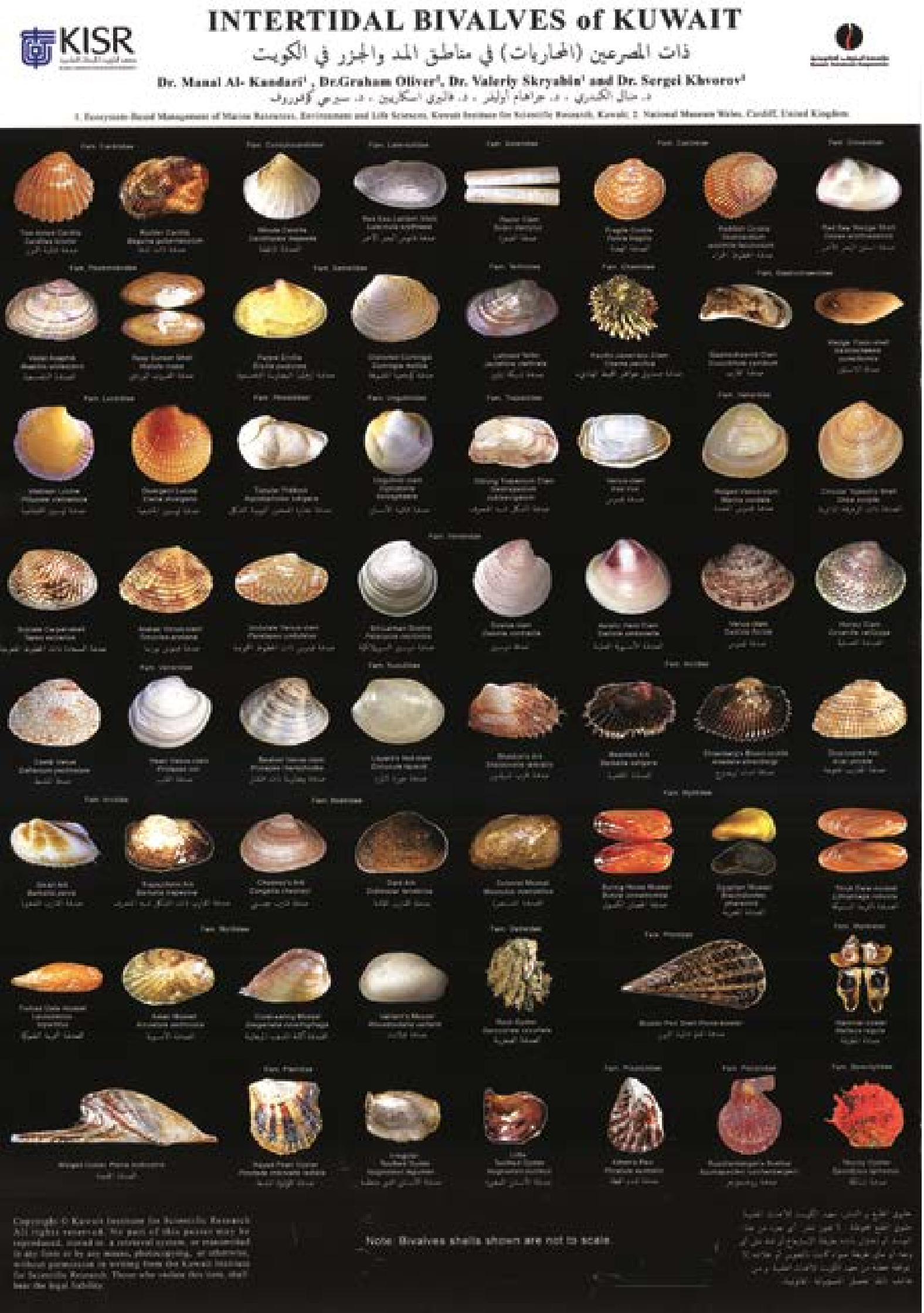

Figure 43: Some intertidal bivalves from Kuwait. 


\subsection{Class Scaphopoda}

Class Scaphopoda is commonly known as the tusk shells since their shells are conical and slightly curved to the dorsal side. Five species have been recorded from Kuwait (Glayzer et al., 1984; Al-Yamani et al., 2012) (Table 55).

Table 55: Scaphopods reported from Kuwait.

\begin{tabular}{|l|l|l|}
\hline \multicolumn{1}{|c|}{ Order } & \multicolumn{1}{c|}{ Family } & \\
\hline Gadilida & Gadilidae & Cadulus euloides Melvill and Standen, 1901 \\
\hline Dentaliida & Dentaliidae & Antalis longitrorsa (Reeve, 1842) \\
\hline & & Dentalium octangulatum Donovan, 1803 \\
\hline & & Dentalium tomlini Melvill, 1918 \\
\hline & & Tesseracme quadrapicalis (Sowerby, 1869) \\
\hline & Laevidentaliidae & Laevidentalium eburneum (Linnaeus, 1767) \\
\hline
\end{tabular}

\section{References}

Al-Al-Yamani, F.Y., Skryabin, V., Boltachova, N., Revkov, N., Makarov, M., Grintsov, V. and Kolesnikova, E. (2012). Illustrated Atlas on the Zoobenthos of Kuwait. Kuwait Institute for Scientific Research, Kuwait.

Glayzer B., Glayzer D.T. and Smythe, K.R. (1984). 'The marine Mollusca of Kuwait, Arabian Gulf'. Journal of Conchology 31: 311-330.

\subsection{Class Cephalopoda}

This class includes cuttlefishs, octopuses and squids. In total, four species hve been reported, two cattelfishes, one octopus and one squid
(Glayzer et al., 1984; Al-Behbehani, 2006; AlYamani et al. 2012) (Table 56).

Table 56: Cephalopods reported from Kuwait.

\begin{tabular}{|l|l|}
\hline \multicolumn{1}{|c|}{ Family } & \multicolumn{1}{|c|}{ Species } \\
\hline Sepiidae & Sepia pharaonis Ehrenberg, 1831ore \\
\hline & Sepiella inermis (Van Hasselt, 1835) \\
\hline Octopodidae & Octopus cyanea Gray, 1849 \\
\hline Loliginidae & Uroteuthis (Photololigo) duvaucelii (d'Orbigny, 1835) \\
\hline
\end{tabular}




\section{References}

Al-Behbehani, B.E. (2006). 'Study of the morphology and parasitic infection of the cuttlefish, Sepia Pharaonis Ehrenberg, 1831 (Cephalopoda: Sepiidae) in the marine water off Kuwait'. Egyptian Journal of Aquatic Biology and Fisheries 10: 211 - 231. doi.org/ 10.21608/ejabf.2006.1910

Al-Yamani, F.Y., Skryabin, V., Boltachova, N., Revkov, N., Makarov, M., Grintsov, V. and Kolesnikova, E. (2012). Illustrated Atlas on the Zoobenthos of Kuwait. Kuwait Institute for Scientific Research, Kuwait.

Glayzer B., Glayzer D.T. and Smythe, K.R. (1984). 'The marine Mollusca of Kuwait, Arabian Gulf '. Journal of Conchology 31: 311-330.

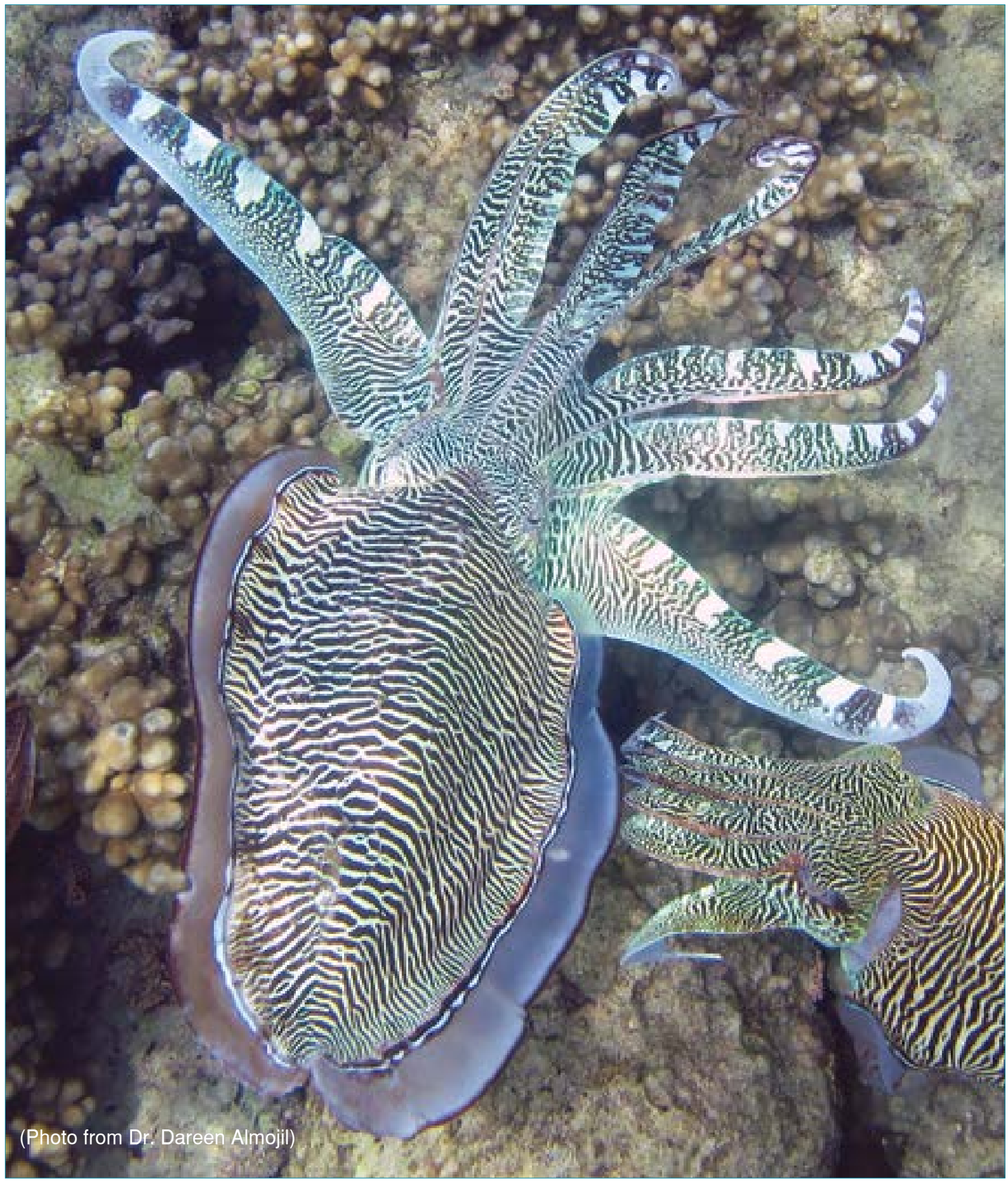




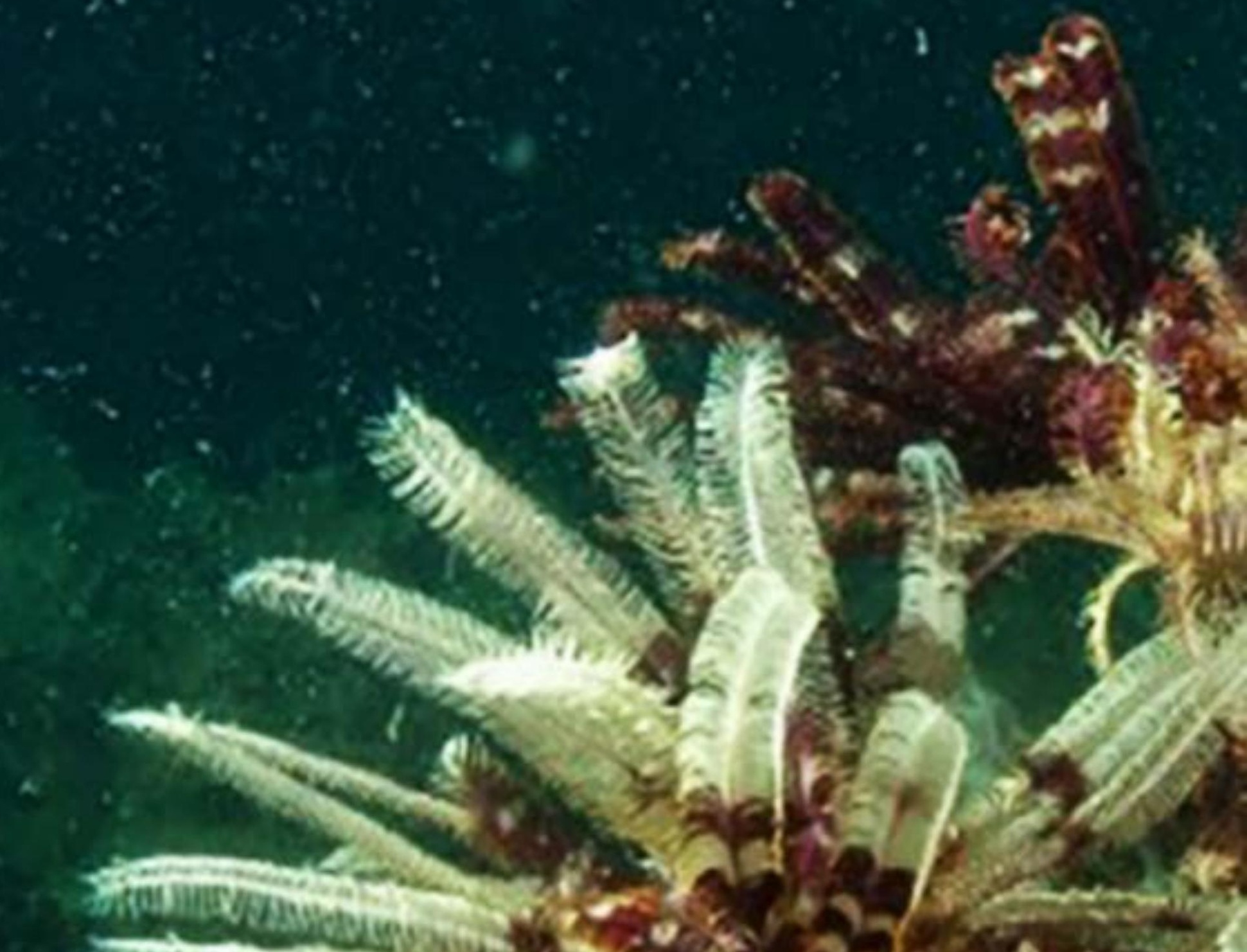

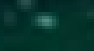

$\sqrt{2}$

-

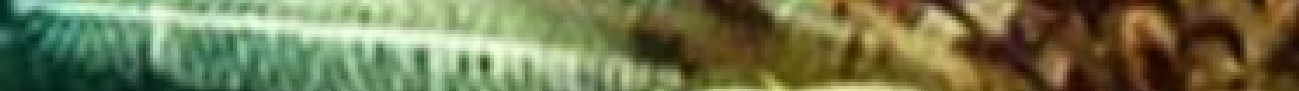

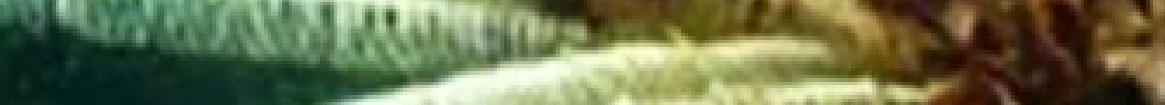


$2+x^{6}, 8$ $\cos 2 y_{3}$ $\frac{2}{2} \times x^{3} 3 x$ $\left(2, x+\frac{3}{3}\right.$ 6yes:

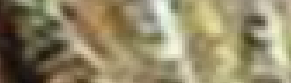
$28.3 \times 3$

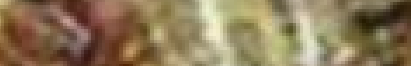
fis 62
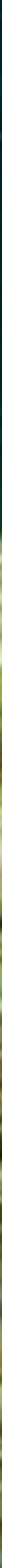


\section{Phyla Echinodermata, Hemichordata and Chordata}

\subsection{Phylum Echinodermata}

This phylum includes the starfish, sea urchins, sand dollars, sea cucumbers and sea lilies. In Kuwait, 16 species of echinoderms belonging to four classes and 12 families (Alsaffar \& Lone,
2000; Al-Yamani et al., 2009 \& 2012) (Table 57). The reproductive cycles of Diadema setosum and Echinometra mathaei were studied in Kuwaiti water (Alsaffar \& Lone, 2000).

Table 57: Echinoderms reported from Kuwait.

\begin{tabular}{|l|l|l|l|}
\hline \multicolumn{1}{|c|}{ Class } & \multicolumn{1}{|c|}{ Order } & \multicolumn{1}{c|}{ Family } & \multicolumn{1}{c|}{ Species } \\
\hline Ophiuroidea & Amphilepidida & Amphiuridae & Amphipholis squamata (Delle Chiaje, 1828) \\
\hline & & & Amphioplus (Lymanella) hastatus (Ljungman, 1867) \\
\hline & & & Amphioplus (Lymanella) sp. \\
\hline & & Ophiotrichidae & Macrophiothrix sp. \\
\hline Echinoidea & Diadematidae & Diadematidae & Diadema setosum (Leske, 1778) \\
\hline & Camarodonta & Echinometridae & Echinometra mathaei (de Blainville, 1825) \\
\hline & Spatangoida & Brissidae & Metalia persica (Mortensen, 1940) \\
\hline & Camarodonta & Temnopleuridae & Temnopleurus toreumaticus (Leske, 1778) \\
\hline & Cidaroida & Cidaridae & Cidaridae gen. sp. \\
\hline & Clypeasteroida & Clypeasteridae & Clypeaster humilis (Leske, 1778) \\
\hline & & Astriclypeidae & Echinodiscus auritus Leske, 1778 \\
\hline Holothuroidea & Aspidochirotida & Holothuriidae & Holothuria (Halodeima) atra Jaeger, 1833 \\
\hline & & & Holothuria (Thymiosycia) arenicola Semper, 1868. \\
\hline & Dendrochirotida & Sclerodactylidae & Ohshimella ehrenbergii (Selenka, 1868) \\
\hline Asteroidea & Valvatida & Asterinidae & Aquilonastra burtoni (Gray, 1840) \\
\hline
\end{tabular}

\section{References}

Alsaffar, A.H. and Lone, K.P. (2000). 'Reproductive cycles of Diadema setosum and Echinometra mathaei (Echinoidea: Echinodermata) from Kuwait (Northern Arabian Gulf)'. Bulletin of Marine Science 67:845-856.

Al-Yamani, F., Boltachova, N., Revkov, N., Makarov, M., Grintsov, V., Kolesnikova, E. and Murina, G-V. (2009). 'Winter species composition, diversity and abundance of macrozoobenthos in Kuwait's 
waters, Arabian Gulf'. In: Neubert, E., Amr, Z., Taiti, S. \& Gümüs, B (eds.), Animal Biodiversity in the Middle East. Proceedings of the First Middle Eastern Biodiversity Congress, Aqaba, Jordan, 20-23 October 2008. ZooKeys 31: 17-38. doi org/10.3897/zookeys.31.74

Al-Yamani, F.Y., Skryabin, V., Boltachova, N., Revkov, N., Makarov, M., Grintsov, V. and Kolesnikova, E. (2012). Illustrated Atlas on the Zoobenthos of Kuwait. Kuwait Institute for Scientific Research, Kuwait.

\subsection{Phylum Hemichordata}

\subsubsection{Class Enteropneusta}

\section{Order Enteropneusta}

A single unidentified species within the family from the Kuwaiti waters (Al-Yamani et al., 2012). Harrimaniidae, Saccoglossus sp., was reported

\section{References}

Al-Yamani, F.Y., Skryabin, V., Boltachova, N., Revkov, N., Makarov, M., Grintsov, V. and Kolesnikova, E. (2012). Illustrated Atlas on the Zoobenthos of Kuwait. Kuwait Institute for Scientific Research, Kuwait.

\subsection{Phylum Chordata (Classes:Ascidiacea and Leptocardii)}

Two identified and one unidentified species were reported from Kuwait marine habitats (Al-Yamani et al., 2012) (Table 58).

Table 58: marine chorateds reported from Kuwait.

\begin{tabular}{|l|l|l|l|}
\hline \multicolumn{1}{|c|}{ Class } & \multicolumn{1}{|c|}{ Order } & \multicolumn{1}{c|}{ Family } & \multicolumn{1}{c|}{ Species } \\
\hline Ascidiacea & Aplousobranchia & Polyclinidae & Polyclinum constellatum Savigny, 1816 \\
\hline & Phlebobranchia & Ascidiidae & Phallusia nigra Savigny, 1816 \\
\hline Leptocardii & phioxiformes & Branchiostomidae & Branchiostoma sp. \\
\hline
\end{tabular}

\section{References}

Al-Yamani, F.Y., Skryabin, V., Boltachova, N., Revkov, N., Makarov, M., Grintsov, V. and Kolesnikova, E. (2012). Illustrated Atlas on the Zoobenthos of Kuwait. Kuwait Institute for Scientific Research, Kuwait. 


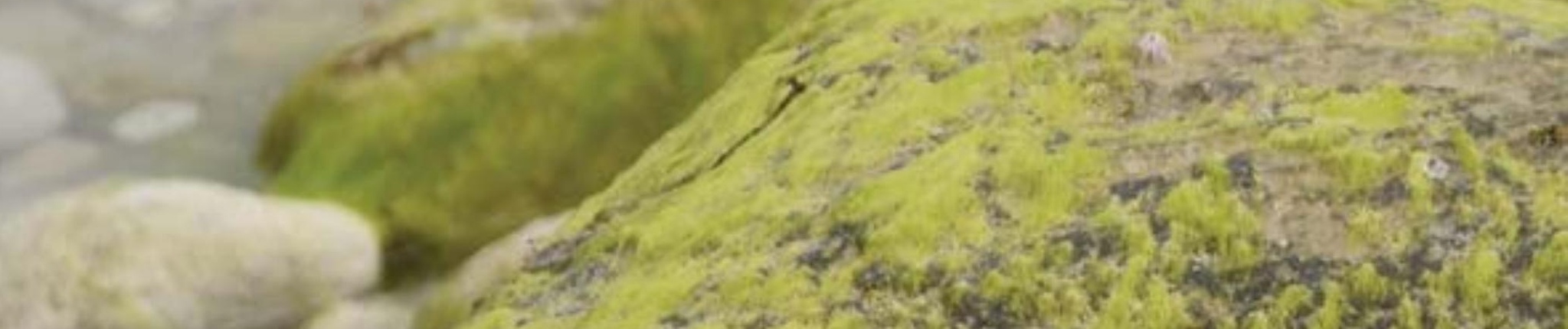

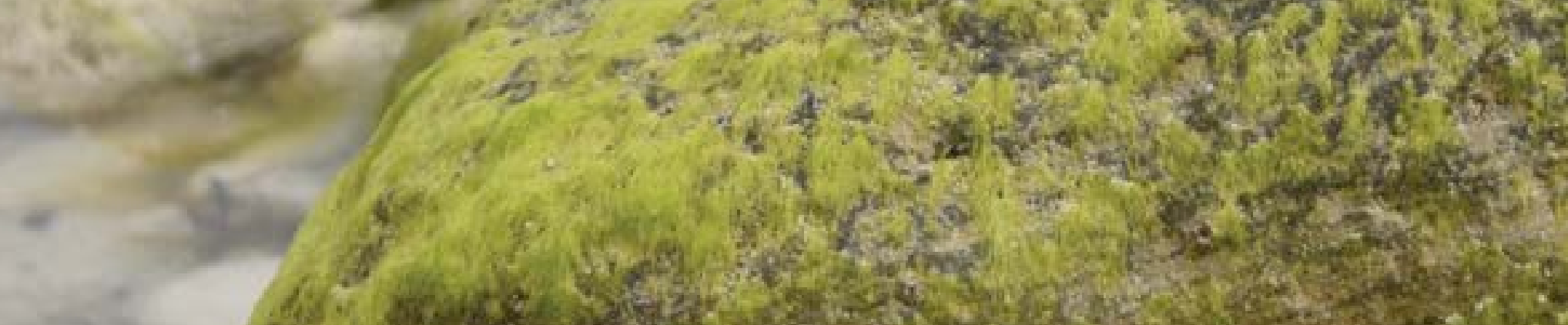

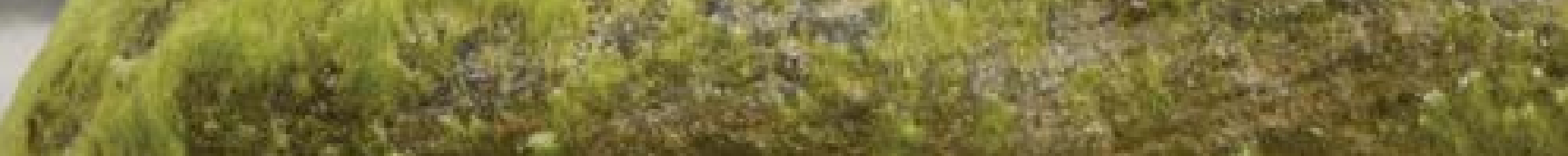
17. 1. Bat.

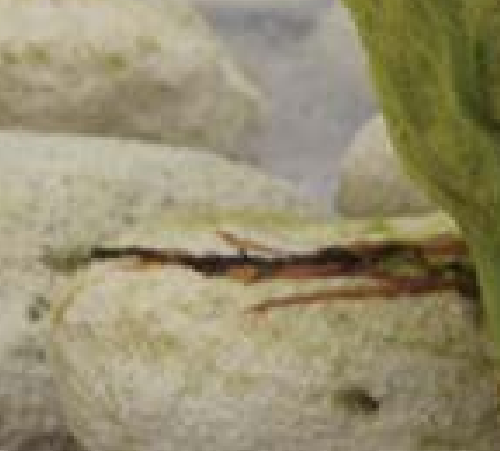

$\operatorname{lin}^{2} x^{2}$

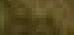

$$
\text { Pets }
$$

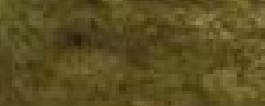

$$
\sin ^{2} x^{2}
$$$$
\text { 당 }
$$

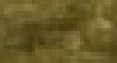

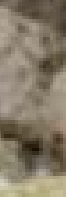




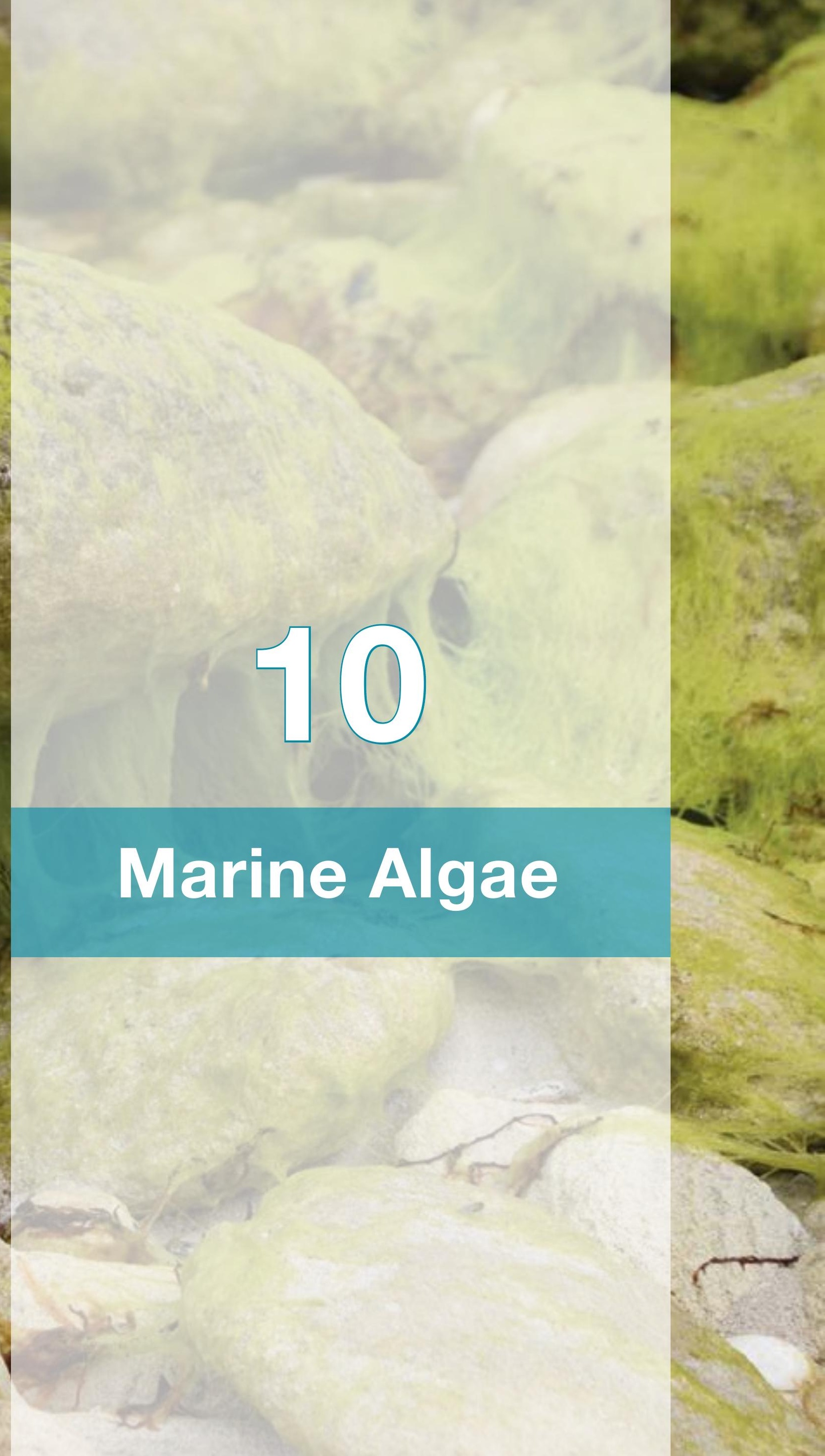




\section{Marine Algae}

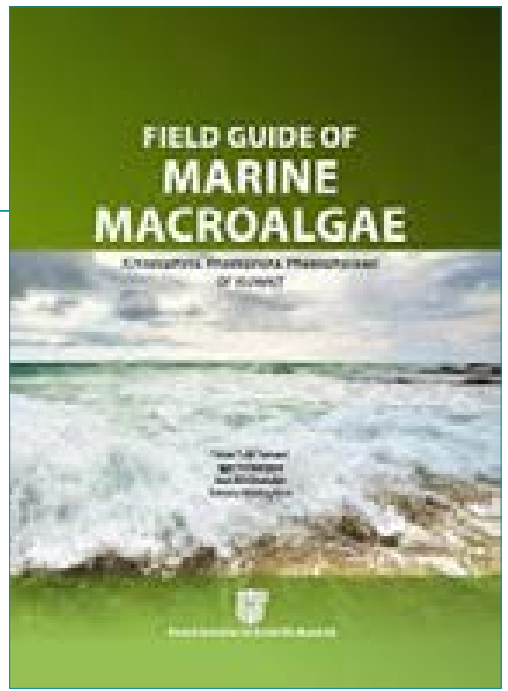

Macroalgae describes seaweeds and other benthic marine algae that are visible to the eye. In Kuwait, macroalgae are represented by several phyla (Chlorophyta, Rhodophyta, Heterokontophyta and Tracheophyta), with a total of 85 species. Marine macroalgae were extensively studied and illustrated atlas was published (Al-Yamani et al., 2014) (Figure 44). Previous studies on the macroalage of Kuwait include Newton (1955), Jones (1986) and Al-Hasan \& Jones (1989).

Figure 44: The main source for the macroalgae of Kuwait.

At the regional level, the marine alage of the Arabian Gulf, especially around the Saudi Arabian cosats, Oman, and the around the Iranian islands were exentsivelly studied in the past (Nizamuddin \& Gessner, 1970; Basson, 1979a, 1979b \& 1990; Sohrabipour \& Rabii, 1999; Subba-Rao \& Al-
Yamani, 1998; Wynne, 2001). The Chemical composition of Arabian Gulf seaweeds was investigated by Kamel (1981) and their potential as a source of minrals was studied by Mohammadi \& Asbchin (2011).

\subsubsection{Phylum Chlorophyta}

This phylum includes the green algae; both the unicellular and multicellular organism. Large marine algae of Kuwait were studied by Al-Yamani et al. (2014). This phylum is represented by Class Ulvophyceae, with a total of 25 species of microalgae (Table 59).

Table 59: Marine macroalage (Phylum Chlorophyta) reported from Kuwait.

\begin{tabular}{|l|l|l|}
\hline \multicolumn{1}{|c|}{ Order } & \multicolumn{1}{|c|}{ Family } & \multicolumn{1}{c|}{ Species } \\
\hline Bryopsidales & Bryopsidaceae & Bryopsis hypnoides J.V. Lamouroux 1809 \\
\hline & & Bryopsis plumosa (Hudson 1778) \\
\hline & Caulerpaceae & Caulerpa sertularioides (S.G. Gmelin 1768) \\
\hline & Dichotomosiphonaceae & Avrainvillea amadelpha (Montagne 1857) \\
\hline
\end{tabular}




\begin{tabular}{|c|c|c|}
\hline Order & Family & Species \\
\hline \multirow[t]{13}{*}{ Cladophorales } & Cladophoraceae & Chaetomorpha aerea (Dillwyn 1806) \\
\hline & & Chaetomorpha crassa (C. Agardh 1824) \\
\hline & & Chaetomorpha indica (Kützing 1843) \\
\hline & & Chaetomorpha linum (O.F. Müller 1778) \\
\hline & & Cladophora coelothrix Kützing 1843 \\
\hline & & Cladophora colabensis Børgesen 1935 \\
\hline & & Cladophora herpestica (Montagne 1842) \\
\hline & & Cladophora koeiei Børgesen 1939 \\
\hline & & Cladophora nitellopsis Børgesen 1939 \\
\hline & & Cladophora sericioides Børgesen 1939 \\
\hline & & Rhizoclonium riparium (Roth 1806) \\
\hline & & Rhizoclonium tortuosum (Dillwyn 1805) \\
\hline & Pithophoraceae & Dictyosphaeria cavernosa (Forsskål 1775) \\
\hline Dasycladales & Polyphysaceae & $\begin{array}{l}\text { Acetabularia caliculus J.V. Lamouroux in Quoy \& } \\
\text { Gaimard } 1924\end{array}$ \\
\hline \multirow[t]{7}{*}{ Ulvales } & Kornmanniaceae & Blidingia minima (Nägeli ex Kützing 1849) \\
\hline & Ulvaceae & Ulva clathrata (Roth 1806) \\
\hline & & Ulva flexuosa Wulfen 1803 \\
\hline & & Ulva intestinalis Linnaeus 1753 \\
\hline & & Ulva lactuca Linnaeus 1753 \\
\hline & & Ulva prolifera O.F. Müller 1778 \\
\hline & & Ulva reticulata Forsskål 177 \\
\hline
\end{tabular}

\subsubsection{Phylum Rhodophyta}

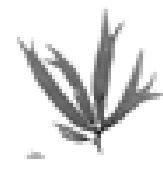

Red marine macroalage are represented by four classes and 30 species (Table 60) (Al-Yamani et al., 2014).

Table 60: Marine macroalage (Phylum Rhodophyta) reported from Kuwait.

\begin{tabular}{|l|l|l|l|}
\hline \multicolumn{1}{|c|}{ Class } & \multicolumn{1}{|c|}{ Order } & \multicolumn{1}{c|}{ Family } & \multicolumn{1}{c|}{ Species } \\
\hline Stylonematophyceae & Stylonematales & Stylonemataceae & Chroodactylon ornatum (C. Agardh 1824) \\
\hline Compsopogonophyceae & Erythropeltidales & Erythrotrichiaceae & Sahlingia subintegra (Rosenvinge 1909) \\
\hline & & & Erythrotrichia carnea (Dillwyn 1807) \\
\hline Bangiophyceae & Bangiales & Bangiaceae & Bangia atropurpurea (Mertens ex Roth 1806) \\
\hline Florideophyceae & Acrochaetiales & Acrochaetiaceae & Acrochaetium savianum (Meneghini 1840) \\
\hline & & & Acrochaetium bahreinii Børgesen 1939 \\
\hline
\end{tabular}




\begin{tabular}{|c|c|c|c|}
\hline Class & Order & Family & Species \\
\hline & Corallinales & Corallinaceae & Jania pumila J.V. Lamouroux 1816 \\
\hline & & & Hydrolithon farinosum (J.V. Lamouroux 1816) \\
\hline & & & Pneophyllum fragile Kützing 1843 \\
\hline & Gelidiales & Gelidiaceae & Gelidium crinale (Hare ex Turner 1815) \\
\hline & & & Gelidium pusillum (Stackhouse 1795) \\
\hline & Halymeniales & Halymeniaceae & Grateloupia filicina (J.V. Lamouroux 1813) \\
\hline & Gigartinales & Cystocloniaceae & Hypnea cornuta (Kützing 1849) \\
\hline & & & Hypnea valentiae (Turner 1809) \\
\hline & Peyssonneliales & Peyssonneliaceae & Peyssonnelia simulans Weber-van Bosse 1916 \\
\hline & Rhodymeniales & Champiaceae & Champia parvula (C.Agardh 1824) \\
\hline & Ceramiales & Ceramiaceae & Centroceras clavulatum (C. Agardh 1822) \\
\hline & & & Ceramium luetzelburgii O.C Schmidt 1924 \\
\hline & & & Gayliella flaccida (Harvey ex Kützing 1862) \\
\hline & & Dasyaceae & Heterosiphonia crispella (C. Agardh 1828) \\
\hline & & Rhodomelaceae & Herposiphonia dendroidea Hollenberg 1968 \\
\hline & & & Chondria dasyphylla (Woodward 1794) \\
\hline & & & Palisada perforata (Bory de Saint-Vincent 1803) \\
\hline & & & Palisada thuyoides (Kützing 1865) \\
\hline & & & Polysiphonia brodiei (Dillwyn 1809) \\
\hline & & & Polysiphonia coacta C.K. Tseng 1944 \\
\hline & & & Polysiphonia denudata (Dillwyn 1809) \\
\hline & & & Polysiphonia kampsaxii Børgesen 1934 \\
\hline & & & Polysiphonia platycarpa Børgesen 1934 \\
\hline & & Spyridiaceae & Spyridia filamentosa (Wulfen 1803) \\
\hline
\end{tabular}

\subsubsection{Phylum Heterokontophyta}

Abdel-Kareem (2009) studied species of the genus Sargassum in the Arabain Gulf, especially around the caost of Saudi Arabia. This phylum is represented by 27 species (Table 61) in two classes (Al-Yamani et al., 2014).

Table 61: Marine macroalage (Phylum Heterokontophyta) reported from Kuwait.

\begin{tabular}{|c|l|l|l|}
\hline \multicolumn{1}{|c|}{ Class } & \multicolumn{1}{|c|}{ Order } & \multicolumn{1}{|c|}{ Family } & \multicolumn{1}{|c|}{ Species } \\
\hline Phaeophyceae & Ectocarpales & Acinetosporaceae & Feldmannia irregularis (Kützing 1845) \\
\hline & & & Feldmannia mitchelliae (Harvey 1852) \\
\hline & Chordariaceae & & Cladosiphon occidentalis Kylin 1940 \\
\hline & & & Myriactula arabica (Kützing 1858) \\
\hline
\end{tabular}




\begin{tabular}{|c|c|c|c|}
\hline Class & Order & Family & Species \\
\hline & & & Myrionema orbiculare J. Agardh 1848 \\
\hline & & & Nemacystus decipiens (Suringar 1872) \\
\hline & & Scytosiphonaceae & Colpomenia sinuosa (Mertens ex Roth 1806) \\
\hline & & & lyengaria stellata (Børgesen 1928) \\
\hline & Sphacelariales & Sphacelariaceae & Sphacelaria novae-hollandiae Sonder 1845 \\
\hline & & & Sphacelaria rigidula Kützing 1843 \\
\hline & & & Sphacelaria tribuloides Meneghini 1840 \\
\hline & Dictyotales & Dictyotaceae & Canistrocarpus cervicornis (Kützing 1859) \\
\hline & & & Dictyota implexa (Desfontaines 1799) \\
\hline & & & Padina boryana Thivy 1966 \\
\hline & & & Padina gymnospora (Kützing 1859) \\
\hline & & & Padina tetrastromatica Hauck 1887 \\
\hline & Fucales & Sargassaceae & Hormophysa cuneiformis (J.F. Gmelin 1792) \\
\hline & & & Polycladia myrica (S.G. Gmelin 1768) \\
\hline & & & Sargassopsis decurrens (R. Brown ex Turner 1811) \\
\hline & & & Sargassum angustifolium C. Agardh 1820 \\
\hline & & & Sargassum aquifolium (Turner 1807) \\
\hline & & & Sargassum asperifolium Hering \& G.Martens ex J. Agardh 1848 \\
\hline & & & Sargassum boveanum J. Agardh 1848 \\
\hline & & & Sargassum fluitans (Børgesen 1914) \\
\hline & & & Sargassum oligocystum Montagne 1845 \\
\hline & & & Sirophysalis trinodis (Forsskål 1775) \\
\hline Xanthophyceae & Vaucheriales & Vaucheriaceae & Vaucheria piloboloides Thuret 1854 \\
\hline
\end{tabular}

\subsubsection{Phylum Tracheophyta}

Species of this phylum are similar to bryophyts. Two species were recorded from Kuwait (Table 62 (AlYamani et al., 2014).

Table 62: Marine macroalage (Phylum Tracheophyta) reported from Kuwait.

\begin{tabular}{|l|l|l|l|}
\hline \multicolumn{1}{|c|}{ Class } & \multicolumn{1}{|c|}{ Order } & \multicolumn{1}{c|}{ Family } & \multicolumn{1}{c|}{ Species } \\
\hline Monocots & Alismatales & Cymodoceaceae & Halodule uninervis (Forsskål 1775) \\
\hline & & Hydrocharitaceae & Halophila ovalis (R. Brown 1810) \\
\hline
\end{tabular}




\section{References}

Abdel-Kareem, M.S.M. (2009). 'Phenetic studies and new records of Sargassum species (Fucales, Phaeophyceae) from the Arabian Gulf Coast of Saudi Arabia'. Acad. J. Plant Sci. 2: 174-181.

Al-Hasan, R. and Jones, W.E. (1989). 'Marine algal flora and seagrasses of the coast of Kuwait'. J. Univ. Kuwait (Science) 16: 289-340.

Al-Yamani, F.Y., Polikarpov, I., Al-Ghunaim, A. and Mikhaylova, T. (2014). Field Guide of Marine Macroalgae (Chlorophyta, Rhodophyta, Phaeophyceae) of Kuwait. Kuwait Institute for Scientific Research.

Basson, P.W. (1979a). 'Marine algae of the Arabian Gulf Coast of Saudi Arabia (first half). Botanica Marina 5:47-64. doi.org/10.1515/botm.1979.22.1.47

Basson, P.W. (1979b). 'Marine algae of the Arabian Gulf Coast of Saudi Arabia (second half)'. Botanica Marina 5:65-82. doi.org/10.1515/botm.1979.22.2.65

Basson, P.W. (1992). 'Checklist of marine algae of the Arabian Gulf'. J. Univ. Kuwait (Science) 19: 217232.

Jones, D.A. (1986). A Field Guide to the Seashore of Kuwait and the Arabian Gulf, pp 192. UK: Blandford Press.

Kamel, B.S. (1981). 'Chemical composition of Arabian Gulf seaweeds'. Lebensmittel-Wissenschaftlich über Technologie 14:160-162.

Mohammadi, M. and Asbchin, S.A. (2011). 'The seaweeds of Persian Gulf: A potential sources of mineral'. World Appl. Sci. J. 14: 37-41.

Newton, L.M. (1955). 'The marine algae of Kuwait'. In The Wild Flowers of Kuwait and Bahrain. Edited by V. Dickson. London: Allen and Unwin, pp. 100-102.

Nizamuddin, M. and Gessner, F. (1970). 'The marine algae of northern part of the Arabian Sea and of the Persian Gulf. "Meteor"'. Forschungs-Ergebnisse Reihe D 6: 1-42.

Sohrabipour, J. and Rabii, R. (1999). 'A list of marine algae of seashores of Persian Gulf and Oman Sea in the Hormozgan province'. Iranian Journal of Botany 8:131-162.

Subba Rao, D. and Al-Yamani, F. 1998. 'Phytoplankton ecology in the waters between Shatt Al-Arab and Straits of Hormuz, Arabian Gulf: A review'. Plankton Biology \& Ecology 45: 101-116.

Wynne, M.J. (2001). 'New records of benthic marine algae from the Sultanate of Oman, northern Arabian Sea'. II. Nova Hedwigia 72:347-374. doi.org/10.1127/nova.hedwigia/72/2001/347

\subsubsection{Marine Macroalgae}

Table 63: Marine algae major groups.

\begin{tabular}{|l|l|c|}
\hline & & \\
\hline Pyrrophyta & dinoflagellates & 246 \\
\hline & flagellates & 32 \\
\hline & Cyanobacteria & 2 \\
\hline & photosynthetic ciliate & 1 \\
\hline Bacillariophyta & diatoms & 246 \\
\hline
\end{tabular}




\subsubsection{Phylum Pyrrophyta}

The dinoflagellates of Kuwait consists of about 105 species (Annex 9), in two class, 5 orders, 17 families and 37 genera (Al-Kandari et al., 2009) (Figure 45). Several other papers dealt with algal bloom and harm affecting fish (Heil et al., 2001; Al- Yamani et al., 2002 \& 2012; Gilbert et al., 2002).
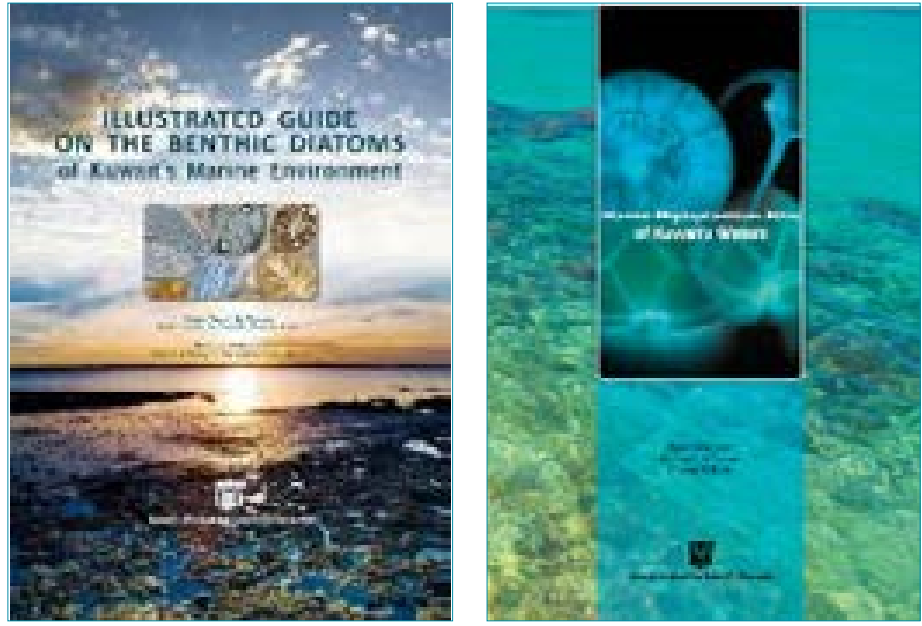

Figure 45: Books on the phytoplanktons and diatoms of Kuwait.

\section{References}

Al- Yamani, F., Ismail, W., Al-Rifaie, K., M'Harzi, Arao, D.V.S., Lennox, A., Saeed, T., Al-Ghadban, A.N., AlMatrouk, K., Bahlol, M. and Al-Khabaz, (2002). Oceanographic and environmental assessment of Kuwait Bay in relevance to toxic algal blooms. Final report, restricted, FM028K. Kuwait Institute for Scientific Research, Report No. KISR 6558, July 2002.

Al-Yamani, F., Saburova, M. and Polikarpov, I. (2012.) 'A preliminary assessment of harmful algal blooms in Kuwait's marine environment'. Aquatic Ecosystem Health \& Management 15:64-72. doi.org/10.1080/14634988.2012.679450

Al-Kandari, M., Al-Yamani, F.Y. and Al-Rifaie, K. (2009). 'Marine Phytoplankton Atlas of Kuwait's Waters'. Kuwait Institute for Scientific Research, Safat: Kuwait.

Gilbert, P.M., Landsberg, J.H., Evans, J.J., Al-Sarawi, M.A., Faraj, M., Al-Jarallah, M.A., Haywood, A., Ibrahem, S., Klesius, P., Powell, C., and Shoemaker, C. (2002). 'A Fish kill of massive proportion in Kuwait Bay, Arabian Gulf, 2001: The roles of bacterial disease, harmful algae, and eutrophication'. Harmful Algae 1:215-231. doi.org/10.1016/S1568-9883(02)00013-6

Heil, C.A., Glibert, P.M., Al-Sarawi, M.A., Faraj, M., Behbehani, M. and Husain, M. (2001). 'First record of a fish-killing Gymnodinium sp. bloom in Kuwait Bay, Arabian Sea: chronology and potential causes'. Mar. Ecol. Prog. Ser. 214: 15-23. doi.org/10.3354/meps214015

\subsubsection{Phylum Bacillariophyta}

A total of 202 species of diatoms representing three classes, 28 orders, 44 families and 75 genera (Annex 10) were reported from the Kuwaiti waters (Hendey, 1970; Dorgham et al., 1987; Jacob \& AlMuzaini, 1990; Basson, 1992; Subba Rao \& Al-Yamani, 1998; Subba Rao et al., 2003; Al-Kandari et al., 2009). Al-Yamani \& Saburova (2011 \& 2019) published the most comprehensive list of the diatoms of Kuwait, which were fully illustareted. 


\section{References}

Al-Yamani, F.Y. and Saburova, M.A. (2011). Illustrated Guide on the Benthic Diatoms of Kuwait,s Marine Environment. Kuwait Institute for Scientific Research, Safat, Kuwait.

Al-Yamani, F., Saburova, M. (2019). Marine Phytoplankton of Kuwait's Waters. Vol. 2. Diatoms. Kuwait Institute for Scientific Research, Kuwait, 336 p. ISBN 978-99966-37-20-9.

Al-Kandari, M., Al-Yamani, F.Y. and Al-Rifaie, K. (2009). Marine Phytoplankton Atlas of Kuwait's Waters. Kuwait Institute for Scientific Research, Safat, Kuwait.

Basson, P.W (1992). 'Checklist of marine algae of the Arabian Gulf'. Journal of the University of Kuwait (Science) 19: 217-230.

Dorgham, M.M., Muftah, A. and El-Deeb, K.Z. (1987). 'Plankton studies in the Arabian Gulf: II- The autumn phytoplankton in the northwestern area'. Arab Gulf J. Scient. Res. Agric. Biol. Sci. 5 215-235.

Bu-Olayan, A.H., Al-Hassan, R., Thomas, B. V. and Subrahmanyam, M.N.V. (2001). 'Impact of trace metals and nutrients levels on phytoplankton from the Kuwait Coast'. Environment International 26: 199-203. doi.org/10.1016/S0160-4120(00)00106-9

Hendey, N.I. (1970). 'Some littoral diatoms of Kuwait'. Nova Hedwigia 31:101-167.

Ismail, W.A., Al-Yamani, F.Y. and Al-Rifaie, K. (1999). Guide for the phytoplankton of the Arabian Gulf. Kuwait Institute of Scientific Research, Report No. KISR 5607, Kuwait.

Jacob, P.G. and Al-Muzaini, S. (1990). Marine plants of the Arabian Gulf: A literature review. Kuwait Institute of Scientific Research, Report No. KISR 3426, Kuwait.

Subba Rao, D.V. and Al-Yamani, F. (1998). 'Phytoplankton ecology in the waters between Shatt Al-Arab and Straits of Hormuz, Arabian Gulf: A review'. Plankton Biol. Ecol. 45: 101-116.

Subba Rao, D.V., Al-Yamani, F., Lennox, A., Pan, Y., Al-Said, T.F.O. (1999). 'Biomass and production characteristics of the first red tide noticed in Kuwait Bay, Arabian Gulf'. J. Plankton Res. 21: 805-810. doi.org/10.1093/plankt/21.4.805

Subba Rao, D.V., Al-Hassan, J.M., Al-Yamani, F., Al-Rafaie, K., Ismail, W., Nageswara Rao, C.V. and Al-Hassan, M. (2003). 'Elusive red tides in Kuwait coastal waters'. Harmful Algae News 24 $10-13$.

\subsubsection{Other marine phytoplankton}

Al-Kandari et al. (2009) and Subba Rao \& Al-Yamani (1998) have summarized available knowledge of phytoplankton from the northern Arabian Gulf and described the region as a distinct biotope, with a north-south gradient in phytoplankton diversity and abundance. Other published reports include Jacob et al. (1979), Al-Hasan et al. (1983 \&1989) and Jones (1986).

Table 64: Other marine phytoplanktons.

\begin{tabular}{|l|l|l|l|l|}
\hline \multicolumn{1}{|c|}{ Phylum } & \multicolumn{1}{|c|}{ Class } & \multicolumn{1}{c|}{ Family } & \multicolumn{1}{c|}{ Species } \\
\hline Chromophyta & Cryptophyceae & Cryptononadales & Cryptononadaceae & Plagioselmis sp. 1 \\
\hline & Raphidophyceae & & Chattonellaceae & Heterosigma akashiwo (Hada) Hara et Chihara 1987 \\
\hline & Dictyochophyceae & Dictyochalis & Dictyochaceae & Dictyocha fibula Ehrenberg 1839 \\
\hline & & & & Dictyocha speculum Ehrenberg 1839 \\
\hline & Prymnesiophyceae & Prymnesiales & Phaeocystaceae & Phaeocystis sp. 1 \\
\hline
\end{tabular}




\begin{tabular}{|l|l|l|l|l|}
\hline \multicolumn{1}{|c|}{ Phylum } & \multicolumn{1}{|c|}{ Class } & \multicolumn{1}{c|}{ Order } & \multicolumn{1}{c|}{ Family } & \multicolumn{1}{c|}{ Species } \\
\hline Chlorophyta & Euglenophyceae & Euglenales & Eutreptiaceae & Eutreptiella sp. 1 \\
\hline & Prasinophyceae & Chlorodendrales & Halosphaeraceae & Pterosperma undulatum Ostenfeld in Ostenfeld et Schmidt 1902 \\
\hline & & & & Pyramimonas sp. \\
\hline & Chlorophyceae & Volvocales & Dunaliellaceae & Dunaliella salina (Dunal) Teodoresco 1905 \\
\hline Cyanophyta & Cyanophyceaea & Oscillatoriales & Phormidiaceae & Trichodesmium erythraeum Ehrenberg 1830 \\
\hline & & & & Spirulina sp. 1 \\
\hline
\end{tabular}

\section{References}

Al-Hasan, R. H. and Sallal, A-K. J. (1985). 'Preliminary studies on a halotolerant alga: Dunaliella sp. from Kuwait salt marshes'. Journal of University of Kuwait 12: 205-214.

Al-Hasan, R. H. and Jones, W. E. (1989). 'Marine algal flora and sea grasses of the coast of Kuwait'. Journal of University of Kuwait 16: 289-340.

Al-Kandari, M., Al-Yamani, F.Y. and Al-Rifaie, K. (2009). 'Marine Phytoplankton Atlas of Kuwait's Waters'. Kuwait Institute for Scientific Research, Safat, Kuwait.

Jacob, P.G., Zarba, M.A. and Anderlini, V. (1979). 'Hydrography, chlorophyll and plankton of the Kuwaiti coastal waters'. Indian Journal of Mar. Sci. 8:150-154.

Jones, D. A. (1986). A field guide to the sea shores of Kuwait and the Arabian Gulf, pp 192. University of Kuwait.

\subsubsection{Marine Zooplanktons Phylum Ciliophora}

Al-Yamani et al. (2011) listed 73 species of ciliates from the Arabian Gulf, where as seven species were described from Kuwait (Skryabin \& Al-Yamani, 2006 \& 2007a). Composition, distribution and seasonal changes of tintinnids around Bubiyan Island was studied (Skryabin \& Al-Yamani, 2007b).

Table 65: List of species of Order Tintinnida (Phylum Ciliophora) of the Arabian Gulf.

\begin{tabular}{|l|l|}
\hline \multicolumn{1}{|c|}{ Family } & \multicolumn{1}{c|}{ Species } \\
\hline Tintinnidiidae & Leprotintinnus bubiyanicus Skryabin \& Al-Yamani, 2007 \\
\hline & Leprotintinnus elongatus Skryabin \& Al-Yamani, 2007 \\
\hline & Leprotintinnus nordqvisti (Brandt, 1906) \\
\hline Codnellidae & Tintinnopsis acuminata Daday, 1887 \\
\hline & Tintinnopsis ampla Hada, 1937 \\
\hline & Tintinnopsis angusta Meunier, 1910 \\
\hline & Tintinnopsis baltica Brandt, 1986 \\
\hline & Tintinnopsis beroidea Stein, 1867 \\
\hline & Tintinnopsis compressa Daday, 1887 \\
\hline
\end{tabular}




\begin{tabular}{|c|c|}
\hline \multirow[t]{2}{*}{ Family } & Species \\
\hline & Tintinnopsis dadayi Kofoid, 1905 \\
\hline & Tintinnopsis directa Hada, 1932 \\
\hline & Tintinnopsis failakkaensis Skryabin \& Al-Yamani, 2007 \\
\hline & Tintinnopsis gracilis Kofoid \& Campbell, 1929 \\
\hline & Tintinnopsis karajacensis Brandt, 1896 \\
\hline & Tintinnopsis lobiancoi Daday, 1887 \\
\hline & Tintinnopsis lohmannii Laackmann, 1906 \\
\hline & Tintinnopsis mortensenii Schmidt, 1901 \\
\hline & Tintinnopsis nana Lohmann, 1908 \\
\hline & Tintinnopsis orientalis Kofoid \& Campbell, 1929 \\
\hline & Tintinnopsis parva Merkle, 1909 \\
\hline & Tintinnopsis parvula Jörgensen, 1912 \\
\hline & Tintinnopsis radix Imhof, 1886 \\
\hline & Tintinnopsis rotundata Jörgensen, 1899 \\
\hline & Tintinnopsis sacculus Brandt, 1896 \\
\hline & Tintinnopsis schotti Brandt, 1906 \\
\hline & Tintinnopsis tocantinensis Kofoid \& Campbell, 1929 \\
\hline & Tintinnopsis turbo Meunier, 1919 \\
\hline & Tintinnopsis undella Meunier, 1910 \\
\hline & Tintinnopsis urnula Meunier, 1910 \\
\hline Codonellopsidae & Codonellopsis Iusitanica Jörgensen, 1924 \\
\hline & Codonellopsis morchella (Cleve, 1900) \\
\hline & Codonellopsis ostenfeldi (Schmidt, 1901) \\
\hline Dictyocystidae & Dyctiocysta duplex Brandt, 1906 \\
\hline & Luminella kuwaitensis Skryabin \& Al-Yamani, 2007 \\
\hline Metacylididae & Coxliella annulata (Daday, 1886) \\
\hline & Helicostomella longa Kofoid \& Campbell, 1929 \\
\hline & Metacylis jorgenseni (Cleve, 1902) \\
\hline & Metacylis lucasensis Kofoid \& Campbell, 1929 \\
\hline & Metacylis pithos Skryabin \& Al-Yamani, 2007 \\
\hline & Metacylis tropica Duran, 1957 \\
\hline & Metacylis sp. \\
\hline Ascampbelliellidae & Ascampbelliella obscura (Brandt, 1906) \\
\hline Petalotrichidae & Petalotricha ampulla (Fol, 1881) \\
\hline Rhabdonellidae & Protorhabdonella curta (Cleve, 1901). \\
\hline & Protorhabdonella simplex (Cleve, 1900) \\
\hline & Rhabdonella conica Kofoid \& Campbell, 1929 \\
\hline & Rhabdonella striata (Biedermann, 1893) \\
\hline
\end{tabular}




\begin{tabular}{|l|l|}
\hline \multicolumn{1}{|c|}{ Family } & \\
\hline & Rhabdonella sp. \\
\hline Xystonellidae & Parundella lohmanni Jörgensen, 1924 \\
\hline & Xystonella treforti (Daday, 1887) \\
\hline & Xystonellopsis gaussi (Laackmann, 1909) \\
\hline & Favella adriatica (Imhof, 1886) \\
\hline & Favella campanula (Schmidt) Jörgensen, 1924 \\
\hline & Favella ehrenbergi (Claparede \& Lachmann) \\
\hline & Favella panamensis Kofoid \& Campbell, 1929 \\
\hline Undellidae & Undella dilatata Kofoid and Campbell, 1929 \\
\hline Tintinnidae & Amphorellopsis acuta (Schmidt) Kofoid \& Campbell, 1929 \\
\hline & Amphorides amphora (Claparede \& Lachmann, 1858) \\
\hline & Amphorides quadrilineata Jörgensen, 1924 \\
\hline & Dadayiella cuspis Kofoid \& Campbell, 1929 \\
\hline & Dadayiella ganymedes (Entz, 1884) \\
\hline & Eutintinnus apertus (Kofoid \& Campbell, 1929) \\
\hline & Eutintinnus conicus Skryabin \& Al-Yamani, 2007 \\
\hline & Eutintinnus contractus Skryabin \& Al-Yamani, 2007 \\
\hline & Eutintinnus fraknoi (Daday, 1887) \\
\hline & Eutintinnus lusus-undae (Entz, 1885) \\
\hline & Eutintinnus macilentus (Jörgensen, 1924) \\
\hline Eutintinnus tenue Kofoid and Campbell, 1929 \\
\hline Eutintinnus turgescens (Kofoid and Campbell, 1929) \\
\hline Eutintinnus sp. \\
\hline Salpingella attenuata Jörgensen, 1924 \\
\hline & Salpingella rotundata Jörgensen, 1924 \\
\hline & \\
\hline & \\
\hline & \\
\hline &
\end{tabular}

\section{References}

Al-Yamani, F.Y., Skryabin, V.A., Gubanova, A.D., Khvorov, S.and Prusova, I. (2011). Marine Zooplankton Practical Guide for the Northwestern Arabian Gulf. Volume I, pp 196. Kuwait Institute for Scientific Research.

Skryabin, V.A. and Al-Yamani, F.Y. (2007a). 'New species of genera Leprotintinnus and Luminella (Ciliophora, Spirotrichea, Tintinnida) from Kuwait's Waters of the Arabian Gulf'. Kuwait Journal of Science \& Engineering 34: 79-90.

Skryabin V.A. and Al-Yamani, F.Y. (2007b). 'Composition, distribution and seasonal changes of tintinnids in the northwestern Arabian Gulf around the Bubiyan Island'. International Journal of Oceans \& Oceanography 2: 99-106.

Skryabin V.A. and Al-Yamani, F.Y. (2006). 'New species of genera Tintinnopsis, Metacylis and Eutintinnus (Ciliophora, Spirotrichea, Tintinnida) from Kuwait's Waters of the Arabian Gulf'. Russian Journal of Marine Biology 32: 302-308. doi.org/10.1134/S1063074006050075 


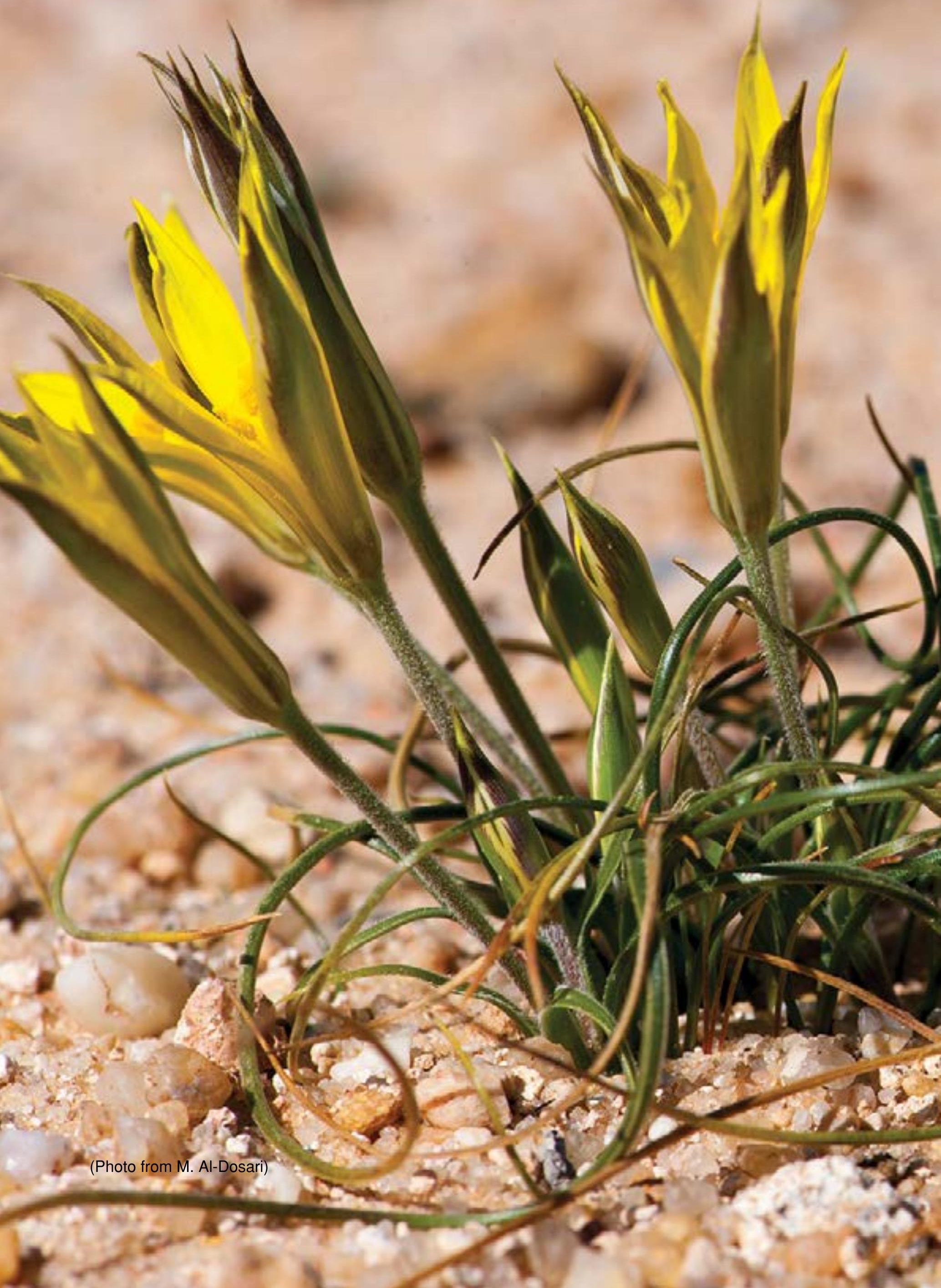




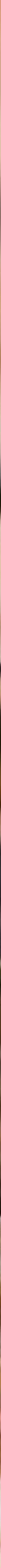




\section{Flora}

\subsection{Phylum Bryophyta}

The mosses of Kuwiat received much attention that revealed the presence of at least 15 species (El-Saadawi, 1976 \& 1979; Halwagy \& El-Saadawi, 1992). An elaporate key for the mosses of Kuwait was given by El-Saadawi (1979) with details on their distribution. Other studies indicated some records (Rechinger, 1964; Townsend \& Guest, 1966; Migahid \& Hammouda, 1974).

Table 66: List of mosses reported from Kuwait.

\begin{tabular}{|l|l|}
\hline \multicolumn{1}{|c|}{ Family } & \multicolumn{1}{c|}{ Species } \\
\hline Pottiaceae & Aloina rigida (Hedw.) \\
\hline & Barbula sp \\
\hline & Barbula vinealis Brid \\
\hline & Crossidium chloronotos (Brid.) \\
\hline & Crossidium squamigerum (Viv.) \\
\hline & Gymnostomum calcareum \\
\hline & Pottia davalliana (Sm.) \\
\hline & Pterygoneurum ovatum (Hedw.) \\
\hline & Timmiella anomala \\
\hline & Tortula atrovirens (Sm.) \\
\hline Bryaceae & Trichostomopsis haussknechtii (Jur. \& Milde) \\
\hline & Bryum sp. \\
\hline Funariaceae & Leptobryum pyriforme (Hedw.) \\
\hline & Funaria hygrometrica Hedw \\
\hline & Physcomitrium pyriforme (Hedw.) \\
\hline
\end{tabular}

\section{References}

El-Saadawi, W.E. (1976). 'Some mosses from Kuwait'. The Bryologist 79:515-518.

El-Saadawi, W.E. (1979). 'Contribution toward a moss flora of Kuwait'. Journal of Kuwait University (Science) 6:125-151.

Halwagy, M. and El-Saadawi, W. (1992). 'Drought and changes in the bryoflora and angiosperm flora in Kuwaitintheyears 1974-1990'. ActaBot. Neerl.41:83-195183. doi.org/10.1111/j.1438-8677.1992. tb00497.x

Migahid, A. M. and Hammouda, M. A. (1974). Flora of Saudi Arabia. Riyad University. Riyad.

Rechinger, K. H. (1964). Flora of Lowland Iraq. Cramer.

Townsend, C. C. and Guest, E. (eds.). (1966). Flora of Iraq 2, Pteridophyta, Gymnospermae and Rosaceae. Baghdad. 


\subsection{Angiospermae, Gymnospermae and Pteridophyta}

These are the flowering plants. They include two main divisions; Dicotyledoneae and Monocotyledoneae (Annex 11 \& 12). A total of 376 native species belonging to 55 families (44 Dicotyledoneae and 11 Monocotyledoneae) of flowering plants were reported from Kuwait (Omar et al. (2007). Family names are mostly those recommended by the Angiosperm Phylogeny Group (2003), with the modern names being used for Apiaceae, Asteraceae, Brassicaceae, Fabaceae, Lamiaceae and others. List of species mentioned in Omar et al. (2007) was distributed as per the new family names. Twenty-five species are naturalized either by cultivation or naturally (Abdullah, 2017). For the updated list, including introduced and cultivated plant, see Abdullah, (2017).

Species wise, family Poaceae includes 70 species, Asteraceae with 46 species, Brassicaceae with 34 and Fabaceae includes 28 species, while Amaranthaceae and Chenopodiaceae together have 30 species (Omar et al., 2007) (Figures 48-51).

This checklist is mostly based on Boulos (1988), Boulos \& Al-Dosari (1994), Omar et al. (2007) and Mathew et al. (2012). Other major sources on the

Table 67: Floristic analysis of Angiosperms (native plants) of Kuwait (Omar et al., 2007)

\begin{tabular}{|l|c|c|c|}
\hline \multicolumn{1}{|c|}{ Group } & Families & Genera & Species \\
\hline Angiospermae & 55 & 234 & 376 \\
\hline Monocots & 11 & 54 & 86 \\
\hline Dicots & 44 & 184 & 290 \\
\hline
\end{tabular}
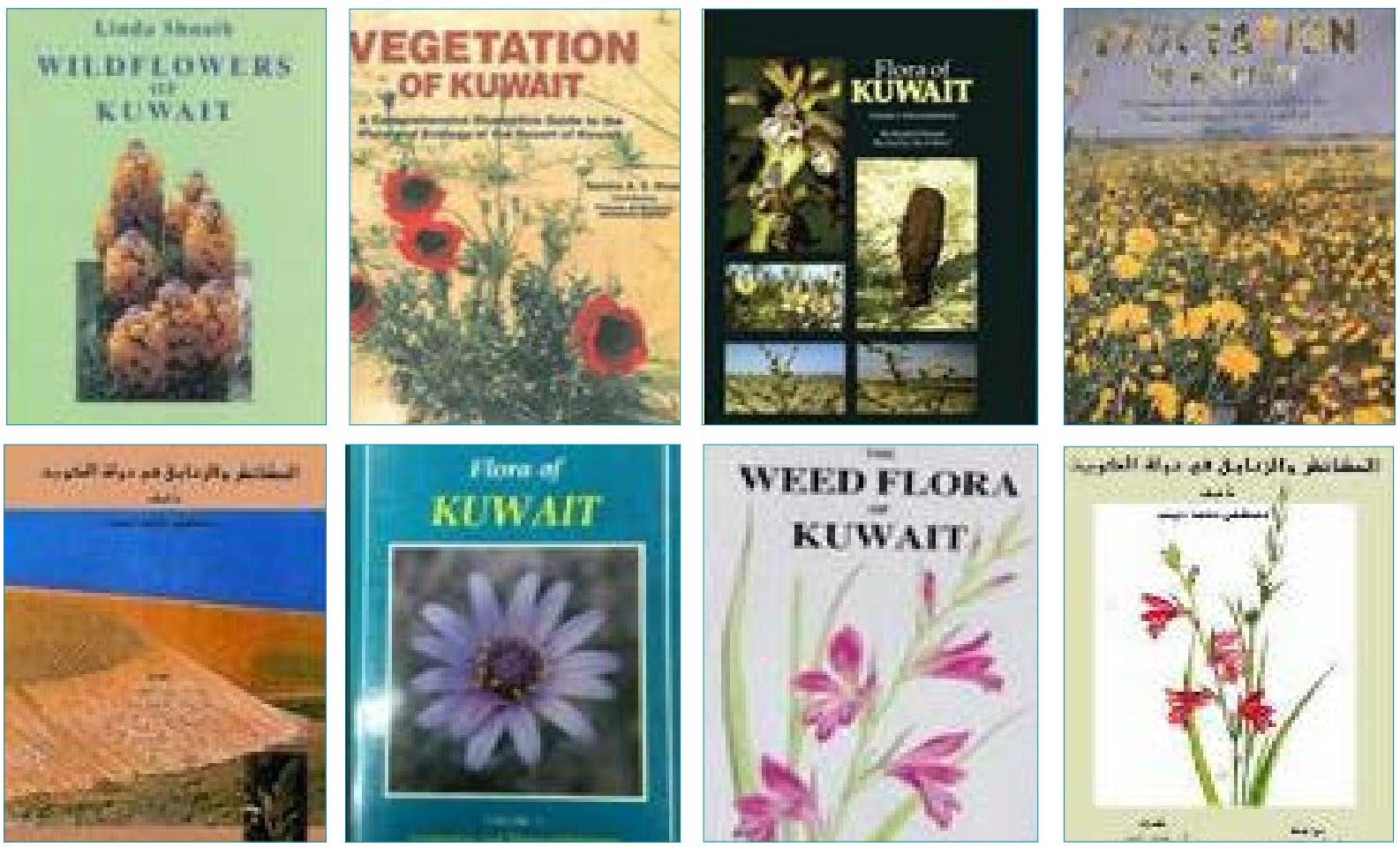

Figure 46: Books on the flora of Kuwait. 
flora of Kuwait include (Brutt \& Lewis, 1949, 1952 \& 1954; Dickson, 1955; Halwagy \& Macksad, 1972; Daoud \& Al-Rawi, 1985; Boulos \& Al-Hasan, 1986; Al-Rawi, 1987; Boulos, 1987; Boulos \& Armer, 1988; Boulos \& Al-Yahya, 1991; Abdullah, 2017). Several books illustared the flora of Kuwait (Figure 46-47).

The flora of some Kuwaiti islands was also studied (Al-Abbadi, 2008; Al-Abbadi, \& El-Sheikh, 2017) and National parks (El-Sheikh \& El-Abbadi, 2004; Al-Shehabi \& Murphy, 2017). Other studies on the ecology of the vegetation in Kuwait were published (Brown \& Porembski, 1998; Brown \& Schoknecht, 2001; Brown, 2003a \& b; El-Sheikh et al., $2006 \& 2010)$. A series of outstanding contributions on the ecology and vegetation types were published by Halwagy \& Halwagy (1974a \& b), Halwagy et al. (1982), El-Shora \& Jasim (1996), Omar (1990) and Omar et al. (2000, 2001; 2005; 2008), management of range land Omar \& Zaman, 1995 \& 1998). Traditional use of plants in Kuwait was studied by Middleditch \& Amer (2009).

Acacia pachyceras O. Schwartz. is the only native tree species of the Kuwaiti desert ecosystem, with only one surviving specimen remaining in Kuwait. It is famously termed "the Lonely Tree" and is located at the Sabah Al-Ahmad Natural Reserve. Taxonomic identification of the lonely tree was controvercial. Dickson (1955), Boulos \& Al-Dosari, (1994), Boulos (1995), Chaudhary, (1999) and Dannin (2000) identified that as $A$. pachyceras while Shuhaib claimed it to be $A$. gerrardii. A recent breakthrough research finding
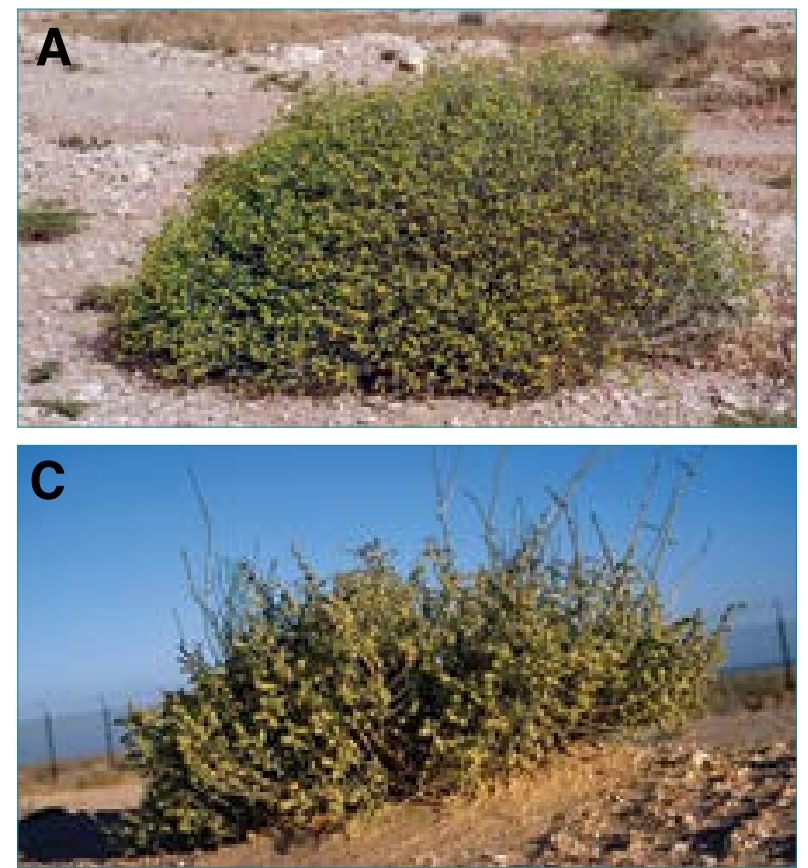

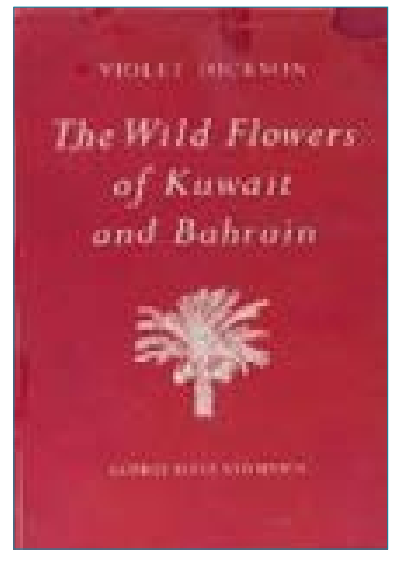

Figure 47: Cover of the historical book of the wild flowers of Kuwait and Bahrain by Violet Dickson (1955)

has confirmed that lonely tree species as Vachellia pachyceras (=A. pachyceras) using multilocus plastid gene sequence (Suleiman et al. (2017). Exceptional research contributions to understand and create a basic database on native plant seed storage, mass propagation, salinity tolerance, symbiotic relationships, microbial diversity in soil, revegetation measures for increasing the biodiversity were published by Zaman et al. (1997, 2006a, 2006b, 2009a, 2009b, 2009c Al-Houty, (1993), Suleiman et al. (2008, 2009a, 2009 b, 2010, 2011a, 2011b, 2011c, 2011d, 2017, 2018, 2019a, 2019b), Taha et al. (2016), Bhatt et al. (2018), Laila et al. (2017), Quoreshi et al. (2019),

Limonium failachicum was described from Failaka Islandw and is considered as the only endemic species to Kuwait (Erben \& Mucina, 2006).
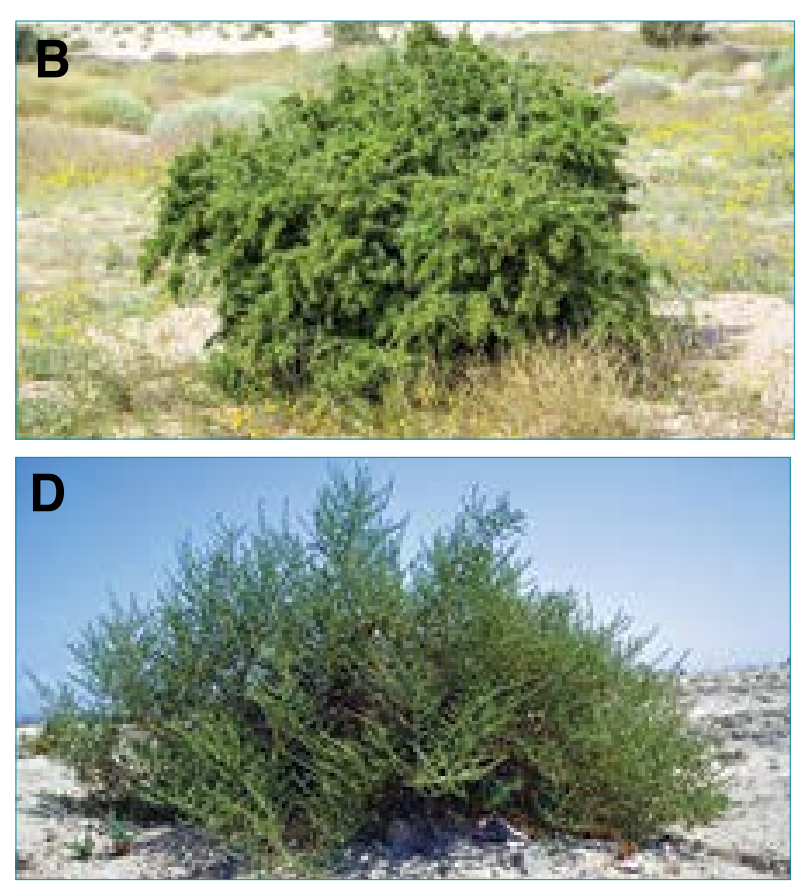

Figure 48: Bushes of Kuwait. A. Rhanterium epapposum. B. Lycium shawii. C. Haloxylon salicornicum. D. Salsola imbricata (All photos from Abdul Rahman Al-Sirhan). 

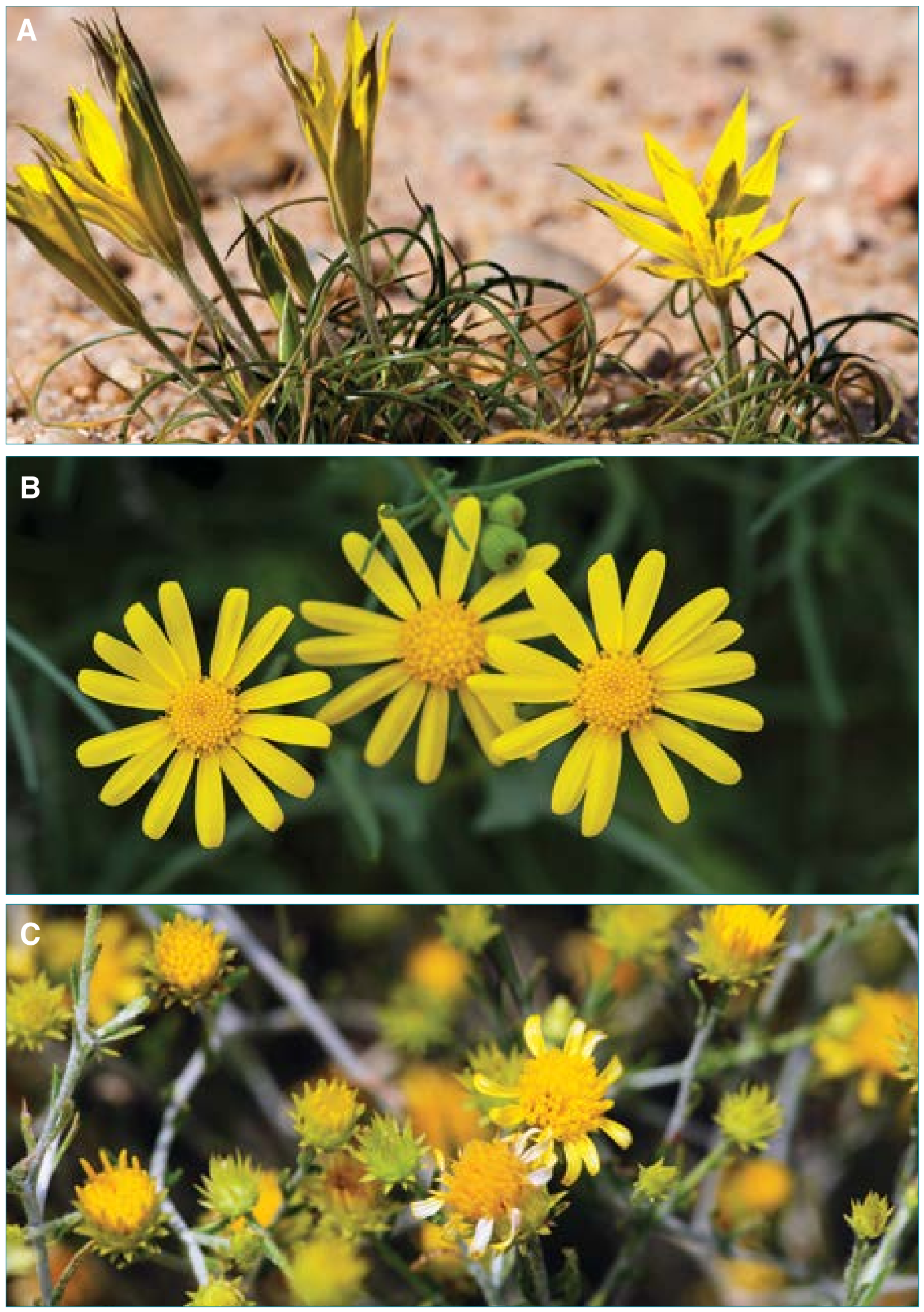

Figure 49: Some flowering plants from Kuwait. A. Gagea reticulata. B. Senecio glaucus. C. Rhanterium epapposum. (All photos from M. Al-Dosari). 

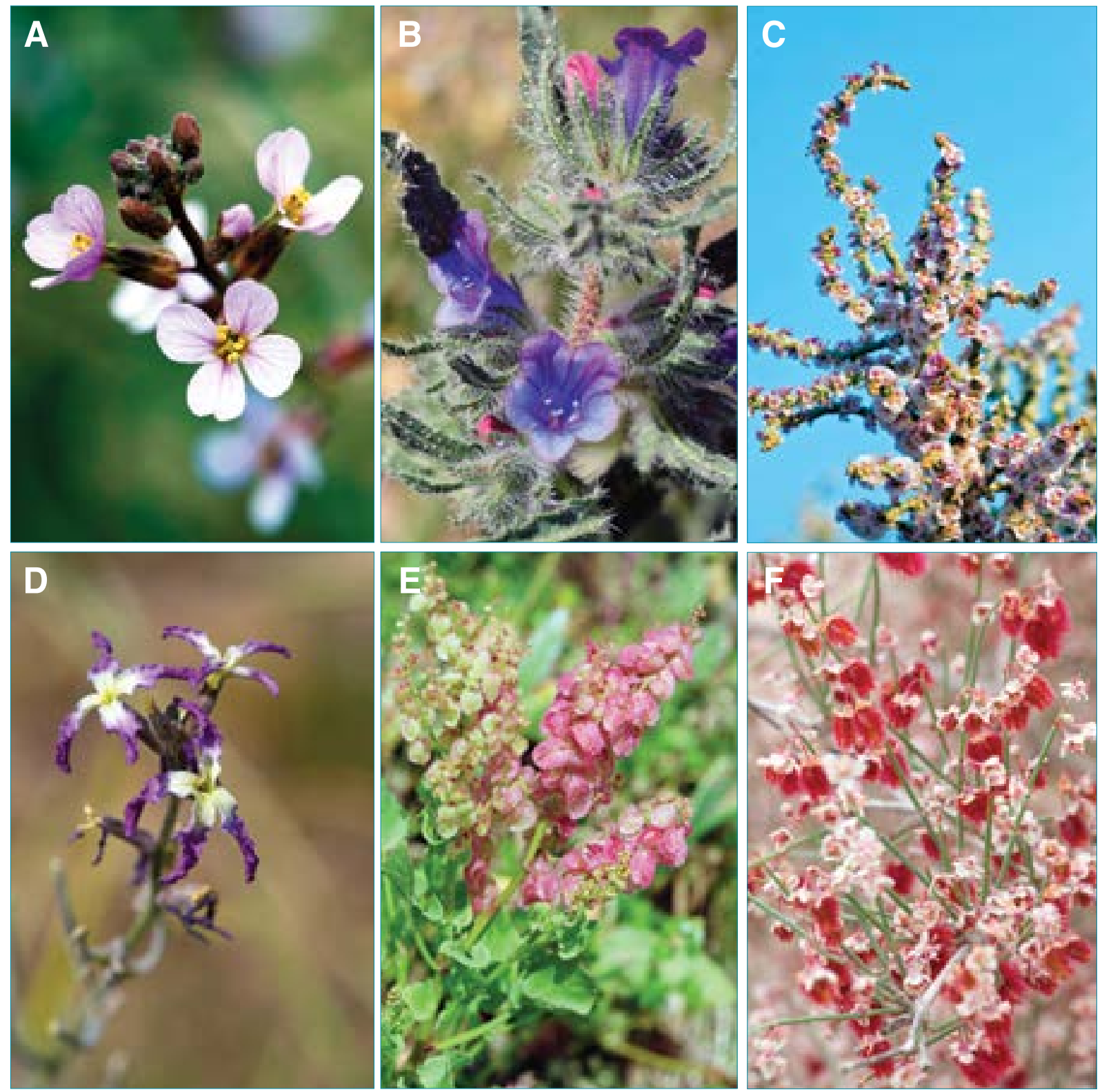

Figure 50: Some flowering plants from Kuwait. A. Cakile arabica. B. Echium rauwolfii. C. Haloxylon salicornicum. D. Mathiola longipetala. E. Rumex vesicarius. F. Calligonum comosum. (All photos from M. Al-Dosari).

\subsection{Gymnospermae and Pteridophyta}

One species of gymnosperms; Ephedra foliata Boiss (Ephedraceae), and one species of Pteridophyta, Ophioglossum aitchisonii d'Almeida, have been listed in the flora of Kuwait (Boulos \& Al-Dosari, 1994). 


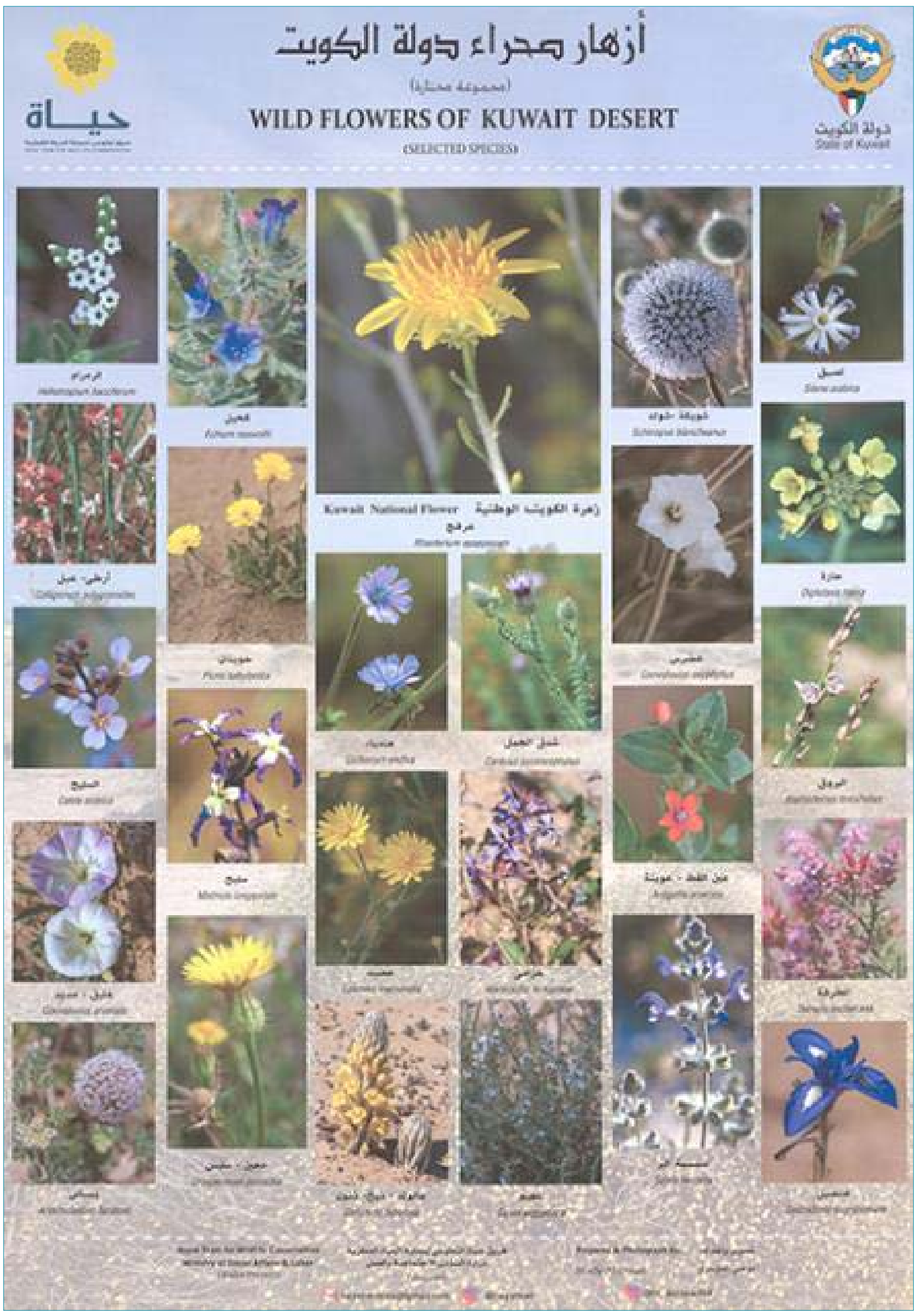

Figure 51: A poster showing some flowering plants from Kuwait. 


\section{References}

Abbadi, G.A. and El-Sheikhb, M. A. (2002). 'Vegetation analysis of Failaka Island (Kuwait)'. Journal of Arid Environments 50:153-165. doi.org/10.1006/jare.2001.0855

Abdullah, M. (2017). 'Conserving the biodiversity of Kuwait through DNA barcoding the flora'. Ph.D. thesis. University of Edinburgh.

Al-Abbadi, G.A. and El-Sheikh, M.A.E. (2017). 'Vegetation ecology and diversity of six Kuwait Islands: factors influence on species composition and richness'. Rendiconti Lince 28:117-131. doi. org/10.1007/s12210-016-0580-0

Al-Abbadi, G.A. (2008). 'On the flora of Kuwait Islands'. Kuwait Journal of Science \& Engineering 35:5170.

Al-Houty, W., Abdal, M. and Zaman, S. (1993). 'Preliminary assessment of the Gulf war on Kuwaiti desert ecosystem'. J. Environ. Sci. Health 28: 1705-1726. doi.org/10.1080/10934529309375972

Al-Mulla, L., Suleiman, M.K., Bhat, N.R., Jacob, S., Islam, M.A. and Thomas, R.R. (2017). 'Propagation studies on selected keystone plant species for use in restoration projects in Kuwait'. International Journal of agricultural Science 2: 27-31.

Al-Rawi, A. (1987). Flora of Kuwait 2, p 230. Kuwait University, Oxford.

Al-Shehabi, Y.and Murphy, K. (2017). 'Flora richness as an indicator of desert habitat quality in Kuwait'. Journal of Threatened Taxa 9: 9777-9785. doi.org/10.11609/jott.3364.9.2.9777-9785

Bhatt, A., Bhat, N.R., Suleiman, M.K. and Santo, A. (2018). 'Effects of storage, mucilage presence, photoperiod, thermoperiod and salinity on germination of Farsetia aegyptia Turra (Brassicaceae) seeds: implications for restoration and seed banks in Arabian Desert'. Plant Biosystems 153: 280-287. doi.org/10.1080/11263504.2018.1473524

Boulos, L. (1987). 'A contribution to the flora of Kuwait'. Candollea 42:263-275.

Boulos, L. (1988). The Weed Flora of Kuwait, pp 175. Kuwait: Kuwait University.

Boulos, L. and Armer, V. (1988). 'A contribution to the Flora of Kuwait 2'. Candollea 43:285-292.

Boulos, L. and Al-Hasan, R. (1986). 'Ten species new to the flora of Kuwait and Bahrain'.Arab Gulf Journal of Scientific Research 4:437-447.

Boulos, L. and Al-Yahya, Y. (1991). ' A contribution to the Flora of Kuwait 3'. Candollea, 46:75-80.

Boulos. L. and Al-Dosari, M. (1994). 'Checklist of the flora of Kuwait'. Journal of the University of Kuwait (Science) 21:203-218.

Brown, G. and Porembski, S. (1998). 'Flora and vegetational aspects of miniature dunes in a sanddepleted Haloxylonsalicornicum community in the Kuwait desert'. Flora 193:133-140.

Brown, G. and Schoknecht, N. (2001). 'Off-road vehicles and vegetation patterning in a degraded desert ecosystem in Kuwait'. Journal of Arid Environments 9:413-427. doi.org/10.1006/jare.2000.0772

Brown, G. (2003a). 'Factors maintaining plant diversity in degraded areas of northern Kuwait'. Journal of Arid Environment 54:183-194. doi.org/10.1006/jare.2001.0880

Brown, G. (2003b). 'Species richness, diversity and biomass production of desert annuals in an ungrazed Rhanteriumepapposum community over three growth seasons in Kuwait'. Plant Ecology 165: 53-68. doi.org/10.1023/A:1021425308451

Brutt, B. L. and Lewis, P. (1949). 'On the Flora of Kuwait I'. Kew Bulletin 4: 273-308.

Brutt, B. L. and Lewis, P. (1952). 'On the Flora of Kuwait II'. Kew Bulletin 7: 333-352.

Brutt, B. L. and Lewis, P. (1954). 'On the Flora of Kuwait IIl'. Kew Bulletin 9: 377-410.

Chaudhary, S. A.(1999). Flora of the Kingdom of Saudi Arabia. Ministry of Agri. And Water, Riyadh.

Danin. A. (2006). 'Flora of Israel online'. The Hebrew University of Jerusalem, Jerusalem, Israel. Published at http://flora.huji.ac.il/browse.asp. Accessed on October 30, 2013.

Daoud, H.S. and Al-Rawi, A. (1985). Flora of Kuwait 1, p 224. Kuwait University KPI, London.

Dickson, V. (1955). The wild flowers of Kuwait and Bahrain, p 144. Alien and Unwin Ltd., London.

El-Sheikh, M.A., El-Ghareeb, R.M. and Testi, A. (2006). 'Diversity of plant communities in coastal salt marshes habitat in Kuwait'. Rendiconti Lincei 17:311-331. doi.org/10.1007/BF02904769

El-Sheikh, M.A. and El-Abbadi, G.A. (2004). 'Biodiversity of plant communities in the Jal Az-Zor National Park, Kuwait'. Kuwait Journal of Science \& Engineering 31:77-105.

El-Sheikh, M.A., Abbadi, G.A. and Bianco, P. (2010). 'Vegetation ecology of phytogenic hillocks (nabkhas) in coastal habitats of Jal Az-Zor National Park, Kuwait'. Flora 205:832-840. doi. org/10.1016/j.flora.2010.01.002

El-Shora, H. and Jasim, R. (1996). Ecological Science and Desert Plants. Science Department, Faculty of Fundamental Education, Kuwait, 320pp. 2000 
Erben, M. and Mucina, L. (2006). 'Limonium failachicum (Plumbaginaceae) - new and so far the only endemic plant from Kuwait'. Folia Geobotanica 41: 229-235. doi.org/10.1007/BF02806481

Halwagy, R. and Macksad, A. (1972). 'A contribution towards a Flora of the State of Kuwait and the Neutral Zone'. Botanical Journal of the Linnean Society 65: 61-79. doi.org/10.1111/j.1095-8339.1972. tb00924.x

Halwagy, R., Moustafa, A.F. and Kamel, S.M. (1982). 'On the ecology of the desert vegetation in Kuwait'. Journal of Arid Environments 5:95-107. doi.org/10.1016/S0140-1963(18)31543-X

Halwagy. R. and Halwagy M. (1974a). 'Ecological studies on the desert of Kuwait l'. The physical environment. Journal of the University of Kuwait (Science) 1:75-86.

Halwagy. R. and Halwagy M. (1974b). 'Ecological studies on the desert of Kuwait Il'. The vegetation. Journal of the University of Kuwait (Science) 1:87-95.

Halwagy. R. and Halwagy M. (1974c). 'Ecological studies on the desert of Kuwai t II'. The vegetation. Journal of the University of Kuwait (Science) 1:87-95.

Suleiman, M.K., Bhat, N.R., Abdal, M. S., Zaman, S., Thomas, R.R. and Jacob, S. (2008).

Germination studies in Nitraria retusa (Forssk.) Asch'. Middle-East Journal of Scientific Research 3: 211-213.

Suleiman, M.K., Bhat, N.R. Abdal, M.S. Zaman, S., Jacob, S. and Thomas, R.R. (2009a). 'Germination studies in Rhanterium epapposum Oliv'. World Applied Sciences Journal 7: 468-471.

Suleiman, M.K., Zaman, S., Al-Dossery, S., Thomas, R.R.and Jacob, S. (2009b). 'Germination studies in Horwoodia dicksoniae Turril'. International Journal of Environmental Studies 66: 209 - 213. doi.org/10.1080/00207230902859978

Suleiman, M. K., Bhat, N. R., Abdal, M. S., Zaman, S., Jacob, S. and Thomas, R.R. (2010). 'Propagation Studies in Farsetia aegyptia Turra'. International Journal of Biodiversity and Conservation 2: 30-32.

Suleiman, M.K., Bhat, N.R., Jacob, S. and Thomas, R.R. (2011a). 'Effect of growth regulators on rooting of hardwood cuttings of Lycium shawii, Nitraria retusa and Farsetia aegyptia. Journal of Agricultural Science and Technology B1: 414-419.

Suleiman,M.K., Bhat, N.R., Jacob, S.and Thomas, R.R. (2011b). 'Germination studies in Lycium shawii Roem. and Schult'. World Journal of Agricultural Sciences 7:26-28.

Suleiman,M.K., Bhat, N.R.,Jacob, S., Thomas, R.R. and D'Cruz,G. (2011c). 'Performance of Selected Native Plants under Deficit Irrigation'. World Journal of Agricultural Sciences 7:19-25.

Suleiman, M. K., Bhat, N. R.,Jacob,S. and Thomas,R.R. (2011d). 'Germination studies in Ochradenus baccatus, Delite., Peganum harmala L. and Gynandriris sisyrinchium Parl'. Research Journal of Seed Science 4: 58-63. doi.org/10.3923/rjss.2011.58.63

Suleiman, M. K., Quoreshi, A. M.,Bhat,N. R. and Manuvel, A. J. (2018). 'Species identification of Vachellia pachyceras from Kuwait and its relatives Vachellia gerrardii and Vachellia tortilis, based on multilocus plastid gene sequences'. Edinburg Journal of Botany, 75: 73-90. doi. org/10.1017/S0960428617000385

Suleiman, M. K., Dixon, K., Merritt, D., Commander, L., Nevill, P., Bhat, N., Jacob, S.and Thomas, R. (2018). 'Seed Germinability and Longevity Influences Regeneration of Acacia gerrardii'. Plant Ecology 219: 591-609. doi.org/10.1007/s11258-018-0820-8

Suleiman, M. K., Dixon, K., Merritt, D., Commander, L., Nevill, P., Quoreshi, A., Bhat, N., Manuvel, A.and Sivadasan, M. (2019a). 'Assessment of the diversity of general fungal and arbuscular mycorrhizal fungi community composition associated with Acacia gerrardii and its rhizosphere soil from Kuwait desert'. Frontiers in Microbiology 10:63.

Suleiman, M. K., Dixon, K., Merritt, D., Commander,L.,Nevill, P.,Quoreshi, A., Bhat, N., Manuvel, A. and Sivadasan, M. (2019b). 'Evaluating the diversity of bacterial community composition associated with Acacia gerrardii and its Rhizosphere Soil'. Canadian Journal of Microbiology 65: 235-251. doi.org/10.1139/cjm-2018-0421

Mathew, K. T., Malallah, G. and Al-Dosari, M. (2012). 'Eleven new weeds in Kuwait'. Kuwait Journal of Science and Engineering 39:169-192.

Middleditch, B.S. and Amer, A.M. (1991). 'Kuwaiti plants, distribution, traditional medicine, phytochemistry, pharmacology and economic value'. In: Studies in Plant Science, 2. Elsevier.

Omar, S.A. and Bhat, N.R. (2008). 'Alteration of the Rhanterium epapposum plant community in Kuwait and restoration measures'. International Journal of Environmental Studies 65: 139-155. doi. org/10.1080/00207230701823332 
Omar, S.A. and Zaman, S. (1995). 'Post-War rangeland status of Kuwait'. In: West N.E. (ed.). Rangelands in a Sustainable Biosphere. pp. 414-415. Proceedings of the Fifth International Rangeland Congress. pp 651.

Omar, S.A. and Zaman, S. (1998). 'Kuwait rangelands status, development and research priorities'. In: Omar, S.A., Misak, R., Al-Ajmi, D. and Al-Awadhi, N. (eds). Sustainable Development in Arid Zones. Vol. 2: Management and Improvement of Desert Resources. pp. 403-421. Netherlands: Balkema. pp 737.

Omar, S.A. (1990). 'Dynamics of range plants following 10 years of protection in arid rangelands of Kuwait'. Journal of Arid Environments 21: 99-111. doi.org/10.1016/S0140-1963(18)30732-8

Omar, S.A., Al-Mutawa, Y. and Zaman, S. (2000). Vegetation of Kuwait: A Comprehensive Illustrative Guide to the Flora and Ecology of the Desert of Kuwait. 1st Edition. KISR, Kuwait, pp 159.

Omar, S.A., Al-Mutawa, Y. and Zaman, S. (2005). Vegetation of Kuwait: A Comprehensive Illustrative Guide to the Flora and Ecology of the Desert of Kuwait. 2nd Edition. KISR, Kuwait, pp 163.

Omar, S.A., Misak, R., King, P., Shahid, S., Abo-Rizq, H., Grealish, G. and Roy, W. (2001). 'Mapping the vegetation of Kuwait through reconnaissance soil survey'. Journal of Arid Environments 48: 341-355. doi.org/10.1006/jare.2000.0740

Omar, S.A.S., Al-Mutawa, Y. and Zaman,S. (2007). 'Vegetation of Kuwait, Kuwait: Kuwait', pp.47-89. Institute for Scientific Research.

Quoreshi, A.M., Suleiman, M.K., Kumar, V., Manuvel, A.J., Sivadasan, M.T., Islam, M.A. and Khasa, D.P.(2019). 'Untangling the bacterial community composition and structure in selected Kuwait desert soils'. Applied Soil Ecology 138: 1-9. doi.org/10.1016/j.apsoil.2019.02.006

Taha, K., Bhat, R. N., Suleiman, M. K. and Collett, B. (2016). Ecological preserves and restoration: Kuwaitis efforts in restoration of degraded ecosystems and creating public awareness. SER News, 30, Issue 3.

Zaman, S. (1997). 'Effects of rainfall and grazing on vegetation yield and cover of two arid rangelands in Kuwait'. Environmental Conservation 24:344-350.

Zaman S., Padmesh, S., Bhat, N.R. and Tawfiq, H. (2006a). 'Germination Studies in Selected Native Desert Plants of Kuwait'. European Journal of Scientific Research 3:339-345.

Zaman, S., Padmesh, S., Bhat, N.R. and Tawfiq, H. (2006b). 'Germination of Some Kuwait's Native Plants Under Saline Conditions'. American Eurasian Journal of Agriculture and Environmental Science 2:146-148.

Zaman, S., M., Padmesh, S., Bhat, N. and Tawfiq, H. (2009a). 'Germination characteristicsand storage behavior of Tamarix Aucheriana (Dence.) Seeds'. European Journal of Scientific Research 26: 533- 539 .

Zaman, S., Padmesh,S. and Tawfiq, H. (2009b). 'Effect of pre-germination treatments on seed germination of Helianthemum lippii (L.) Dum. Cours'. Desert Plants 25:18-23.

Zaman, S. and Padmesh, S. (2009c). 'Leaf anatomical adaptation of selected Kuwait's native desert plants'. European Journal of Scientific Research 37: 261-268. 


\subsection{Vegetation of Kuwait}

The native vegetation of Kuwait is of high values as it represents semi-arid and arid vegetation of the region and contains highly adaptable genes to the harsh environment, extreme drought, poor soil and organic matter and tolerates high salinity (Zaman et al., 2009). The vegetation types of Kuwait are mainly defined by geomorphological changes, soil types and climatic conditions. Four main vegetation types are recognised in Kuwait according to Halwagy \& Halwagy (1974):

- Sand dunes vegetation: comprises a series of low coastal dunes which extends along the southern to northern coastal strips. The soil is composed of loose coarse sand. It is usually dominated by Zygophyllum qatarense and/or Seidlitzia rosmarinus, with occasional by Atriplex leucoclada and Nitraria retusa. Common associates are Lycium shawii and Pennisetum divisum.

- Salt marshes 'sabkha' and saline vegetation: The marshes are influenced by tidal action and the shallow saline water table. Soil ranges from loamy sand to sandy clay. This vegetation type dominates in areas of Kuwait bay coasts and Khor Al-Sabiyah. It is also found in Bubiyan and Warba Islands. Chenopodiaceae dominates the vegetation with Halocnemum strobilaceum common near the shore and Nitraria retusa and Zygophyllum qatarensefurther inland.

- Desert plains vegetation: this type dominates most of the desert land area (west of the coastal region) and is represented by a number of communities:

a. Cyperus steppe: dominated by Cyperusconglomeratus and common to the south and south-west of Kuwait City. Commonly associated with
Panicum turgidum. The soil is of deep, moderately loose, coarse sand.

b. Rhanterium steppe: dominated by Rhanterium epapposum and found in the central and north-east of Kuwait. Common associates are Convolvulus oxyphyllus, Moltkiopsis ciliata and Stipagrostis plumosa. Found on shallow to moderately deep soils with a calcareous hardpan.

c. Haloxylon steppe: dominated by Haloxylon salicornicum found mainly in northern areas of Kuwait. Found on shallow soils with a hardpan.

The desert plateau vegetation: Found mainly in the extreme west of Kuwait; dominated by Haloxylon salicornicum with Citrullus colocynthis also occuring frequently. Annual plants densely cover areas where perennial plants are absent. These include Arnebia spp. Helianthemum spp. Astragalus spp. and Schismus barbatus. Zilla spinosa dominates Wadi AlBatin area. Found on thin soils consisting of generally of few inches of coarse or soft loamy sand, often mixed with pebbles and gravel, over a hardpan.

\subsection{Distribution of the vegetation}

Abdullah (2017) gave a comprehensive review on the distribution of vegetation in Kuwait. The following is a summary based on Abdullah, (2017). The first attempt to define the vegetation cover of Kuwait goes back to the med fifties; where in her book "Wild Flowers of Kuwait and Bahrain", Dickson (1955) included a map showing four plant communities;
Rhanteriumepapposum, Haloxylonsalicornicum, Panicumturgidumand Cyperusconglomeratus. Later, Kernick (1963) modified the later map by adding a fifth vegetation type, Zygophyllum qatarenses. Kernick (1966) modified the map, and included Anabasis vegetation community within the Haloxyloncommunity to the west of Kuwait. 
Halwagy (1973) studied the ecology of the desert vegetation of Kuwait, with emphasis on salt marshes vegetation. Halwagy \& Halwagy (1974a) identified the physical environment along with the geology of the State of Kuwait. In general, the country is a flat to moderately rolling desert with very limited elevations, wadis, with some low sand dunes and salt marshes. They also included some details on the soil types and the climate of Kuwait.

Halwagy \& Halwagy (1974b) recognizedthe five different plant communities, Their proposed map showedthat the Haloxylonplant community was the most widely distributed across Kuwait, followed by the Rhanterium community, while the Panicumplantcommunitydecreasedand the Zygophyllumcommunity decreased around coastal areas (Figure 52).

Omar et al. (2001) employed modern Geographical Information system (GIS), basedon soil types and vegetation data. This comprehensive study covered all Kuwait (Figure 53). The final map showed eight different vegetation types: Centropodietum, Cyperetum, Halophyletum, Haloxyletum, Panicetum, Rhanterietum, Stipagrostietum, and Zygophylletum (Omar et al., 2007).

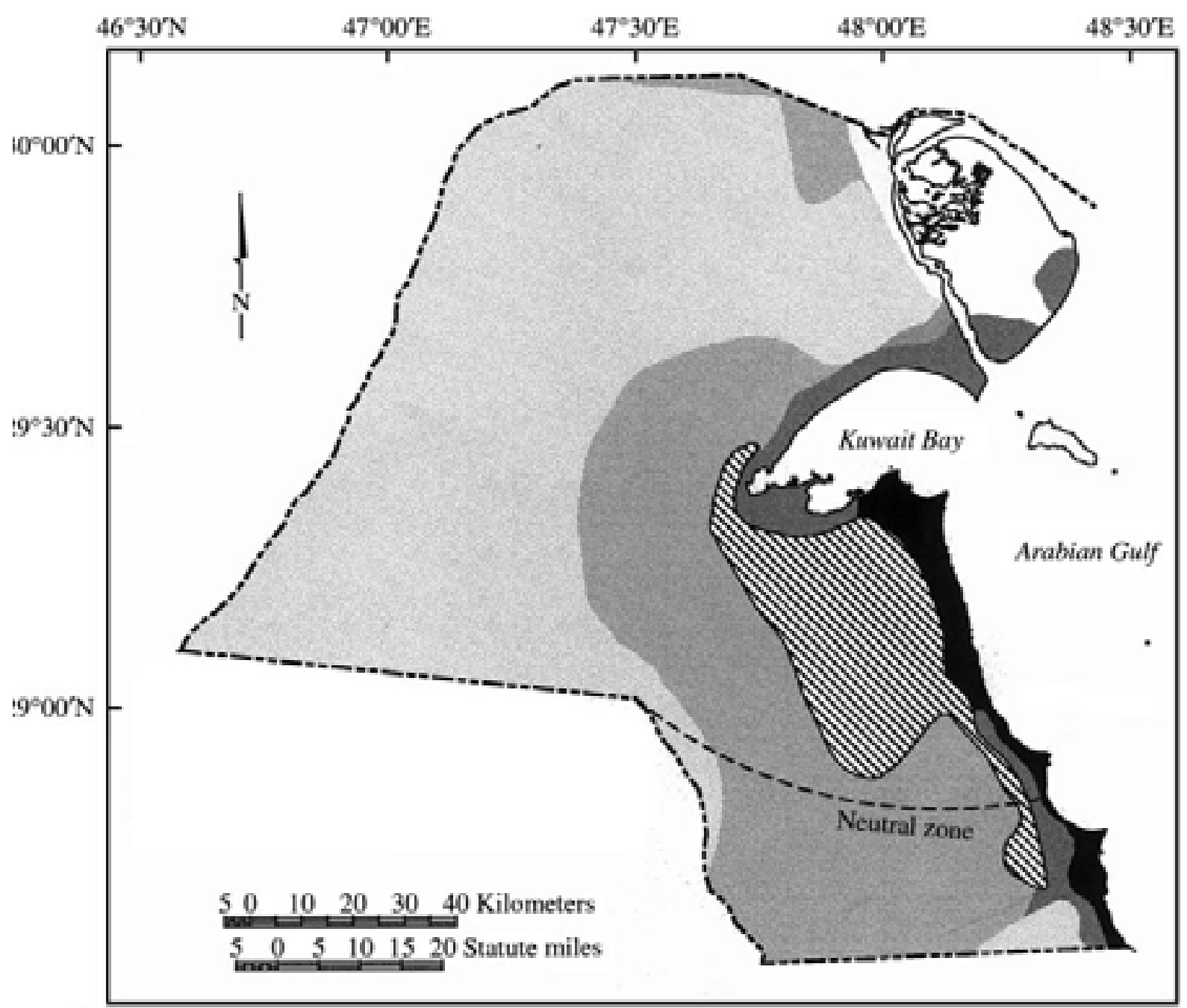

Figure 52: Vegetation map of Kuwait showing five plant communities (Source: Halwagy \& Halwagy, 1974). 


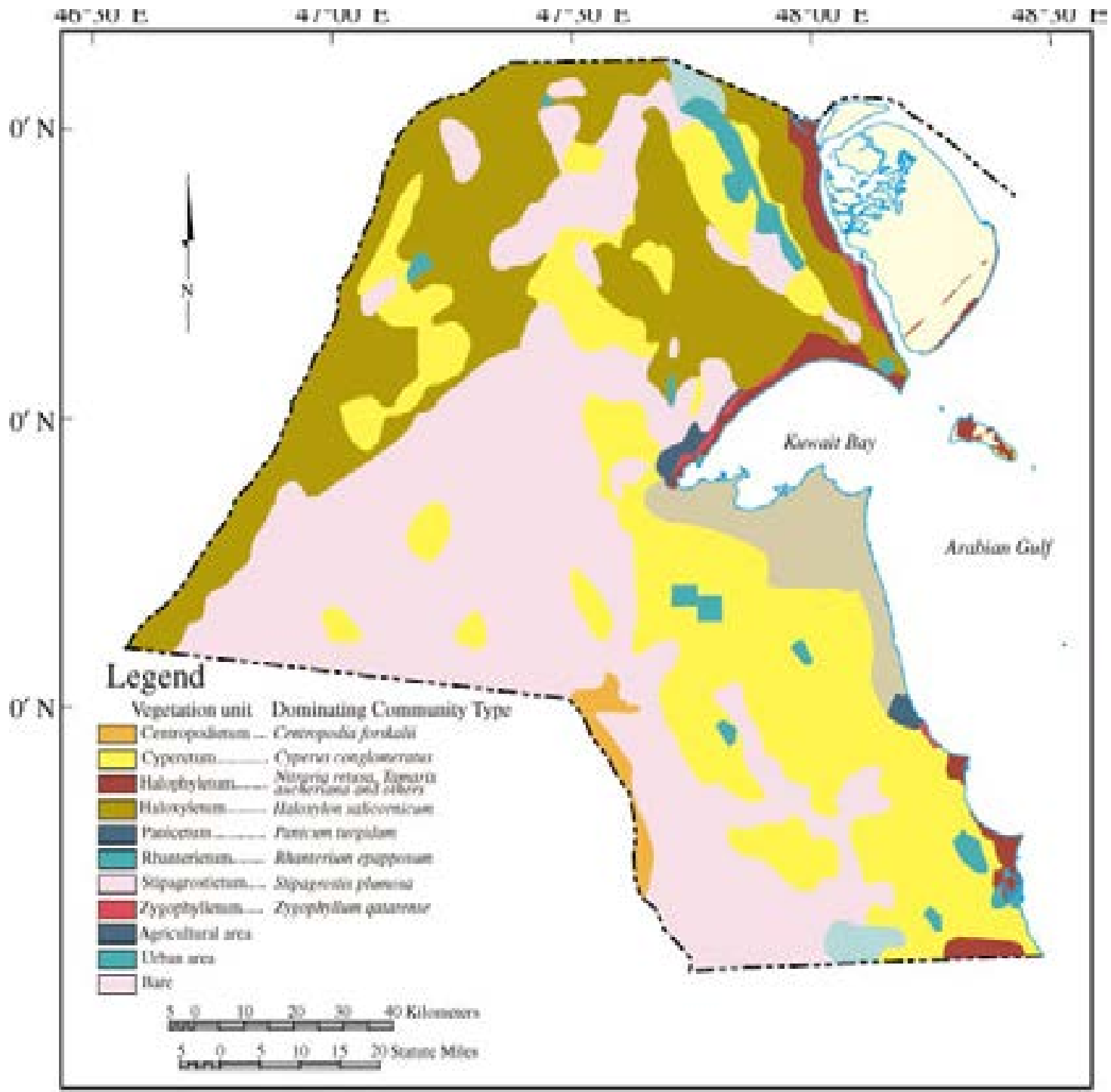

Figure 53: Current vegetation map of Kuwait (Source: Omar et al., 2001).

\subsection{Changes to plant communities}

Over a period of 25 years (1974-2001), Omar et al. (2001) compared vegetation communities of Kuwait based on Halwagy and Halwagy (1974b) and recent studies showed significant changes to the vegetation cover. It was concluded that some plant communities decreased while others had increased. Perennial shrubs accounted for about $27 \%$ of the studied area while perennial grass and sedge represented $67.9 \%$ (Omar et al., 2001). The main causes of land degradation in northern Kuwait were addressed by Brown (2003). He showed that Rhanteriumepapposum community in northern Kuwait was replaced by Haloxylonsalicornicum, due to over grazing of livestock on the edible and preferred Rhanterium.

Al-Awadhi et al. (2001) gave a comprehensive account on land degradation in Kuwait, thus affecting the vegetation cover. These changes were attributedto environmental factors; including 
climate change and human activities(e.g. overgrazing, uprooting of shrubs, soil compaction, military activities, and soil oil pollution).

Uddin etal. (2010) addressed the micro-climatic variations as a result of land-cover changes. They stated that the environmental catastrophes that emerged during the Gulf war (e.g. oil lakes and spills over land) left permanent damages. Additionally, Kuwait exhibited large scale of urban expansion. All these accounted for changes in the vegetation cover country wide.

Abdullah (2017) stated that the current status of vegetation communitiesin Kuwait underwent intensive land deterioration and reduction of plant communities such asRhanterium spp. and Haloxylon spp., while on the other hand, grasses and sedges communitiesincreased (e.g. Stipagrostis spp. and Cyperus spp.).

\section{References}

Abdullah, M. (2017). 'Conserving the biodiversity of Kuwait through DNA barcoding the flora'. Ph.D. thesis. University of Edinburgh.

Al-Shehabi, Y.and Murphy, K. (2017). 'Flora richness as an indicator of desert habitat quality in Kuwait'. Journal of Threatened Taxa 9: 9777-9785. doi.org/10.11609/jott.3364.9.2.9777-9785

Al-Awadhi, J., Omar, S.A.S. and Misak, R. (2005). 'Land degradation indicators in Kuwait'. Land Degradation \& Development 16:163-176. doi.org/10.1002/ldr.666

Brown, G. (2003). 'Factors maintaining plant diversity in degraded areas of northern Kuwait'. Journal of Arid Environment 54:183-194. doi.org/10.1006/jare.2001.0880

Dickson, V. (1955). The wild flowers of Kuwait and Bahrain, pp 144. Alien and Unwin Ltd., London.

Halwagy, M. (1973). 'Ecological studies of the desert vegetationof Kuwait with especialreferenceto the salt marshes'. M.Sc. Dissertation. University of Kuwait.

Halwagy. R. and Halwagy, M. (1974a). 'Ecological studies on the desert of Kuwait I. The physical environment'. Journal of the University of Kuwait (Science) 1:75-86.

Halwagy. R. and Halwagy, M. (1974b). 'Ecological studies on the desert of Kuwait II. The vegetation'. Journal of the University of Kuwait (Science) 1:87-95.

Halwagy, R. (1986). 'On the ecology and vegetation of Kuwait'. In: Kiirschner, H. (ed.): Contributions to the vegetation of Southwest Asia. pp. 81-109. L.R. Verlag, Wiesbaden.

Kernick, M. D. (1963). Natural vegetation and animal production in Kuwait. Third meeting of the FAO working party on the development of the grazing and fodder resources of the Near East. Damascus, Syria. Mimeo.

Kernick M.D. (1966). 'Plant resources, range ecology and fodder plant introduction'. Report to the Government of Kuwait. FAO, TA 181. Memo. pp. 14.

Omar, S.A.S., Al-Mutawa, Y. and Zaman, S. (2007). 'Vegetation of Kuwait', Kuwait: Kuwait, pp 47-89. Institute for Scientific Research.

Omar, S.A., Misak, R., King, P., Shahid, S., Abo-Rizq, H., Grealish, G. and Roy, W. (2001). 'Mapping the vegetation of Kuwait through reconnaissance soil survey'. Journal of Arid Environments 48: 341-355. doi.org/10.1006/jare.2000.0740

Uddin, S., Al Ghadban, A.N., Al Dousari, A., Al Murad, M. and Al Shamroukh, D. (2010). 'A remote sensing classification for land-cover changes and micro-climate in Kuwait'. Int. J. Sus. Dev. Plann. 5: 367-377. doi.org/10.2495/SDP-V5-N4-367-377 

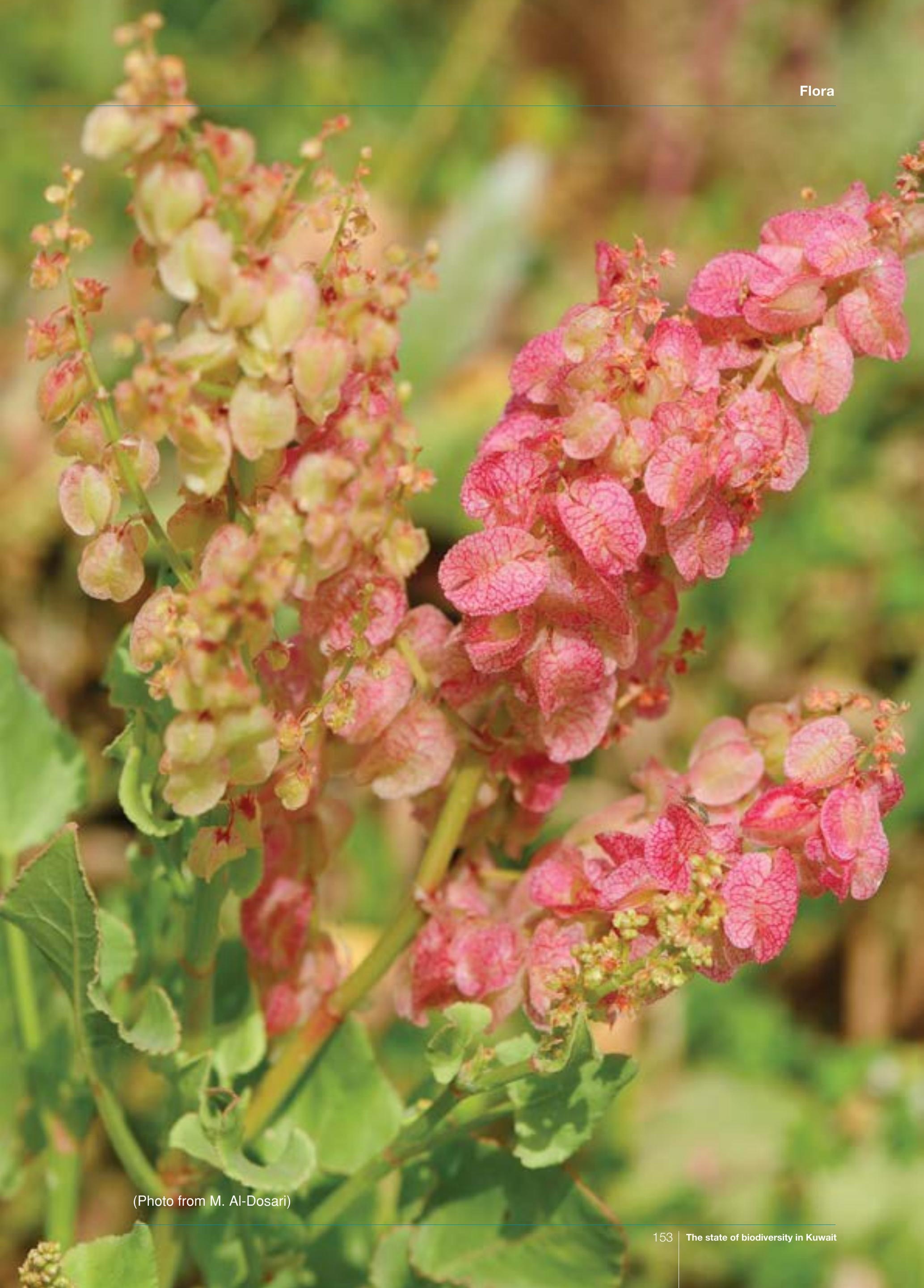


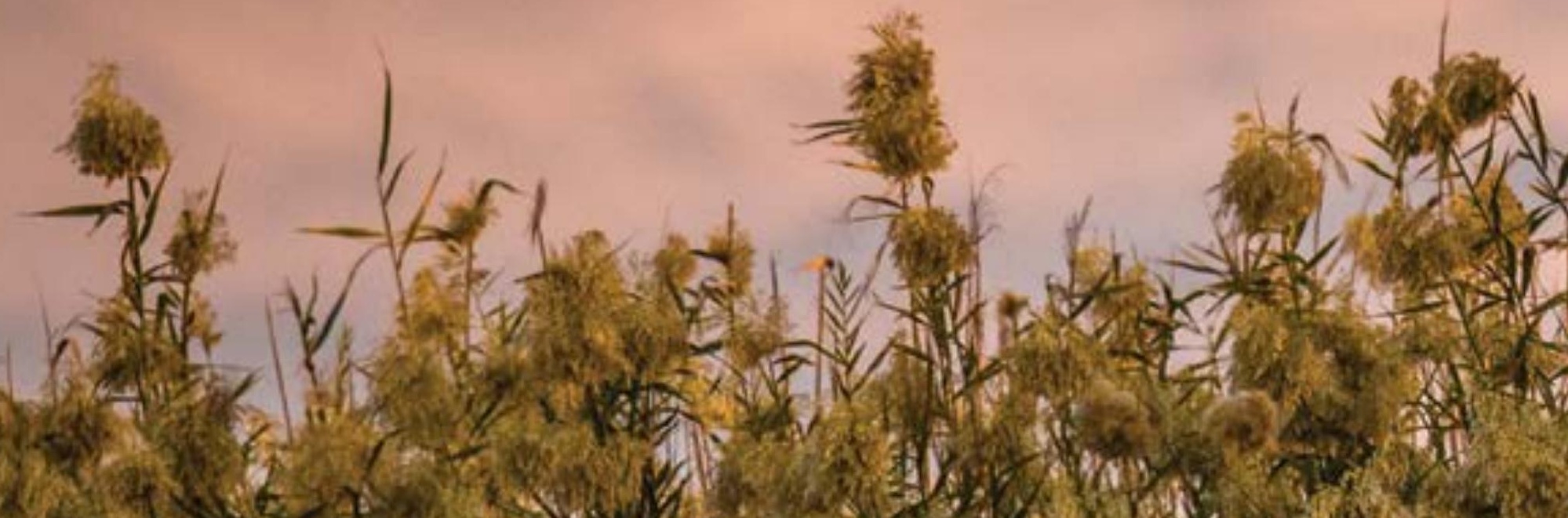

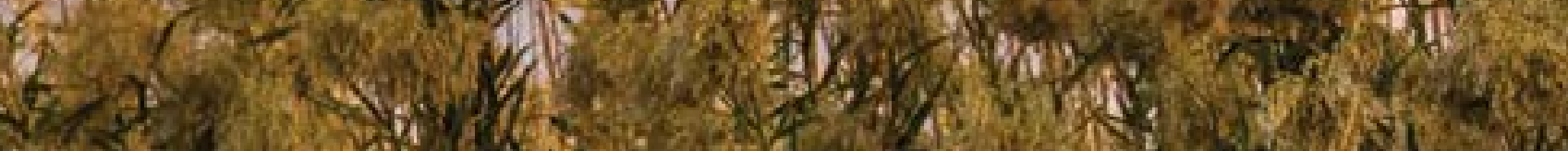

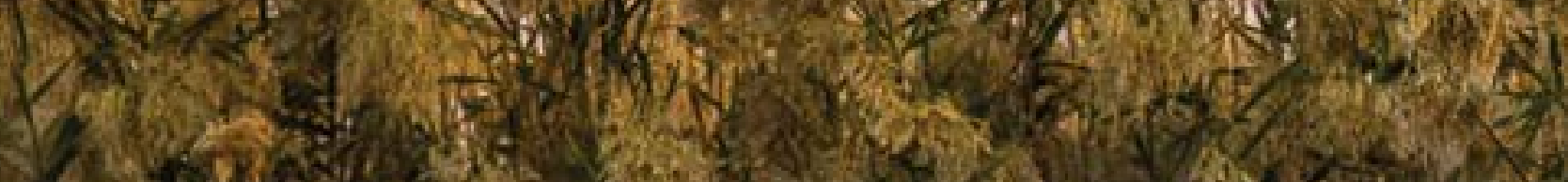

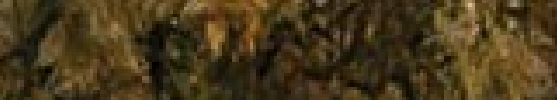

(9) (1) 10

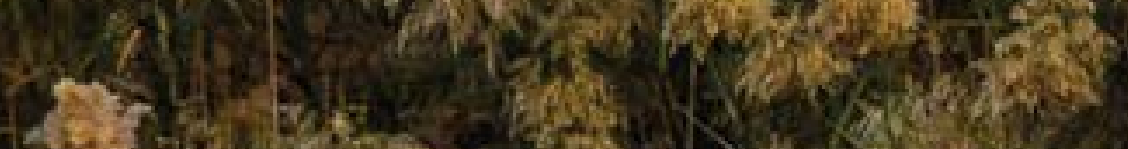
1. $15 \mathrm{x}$.

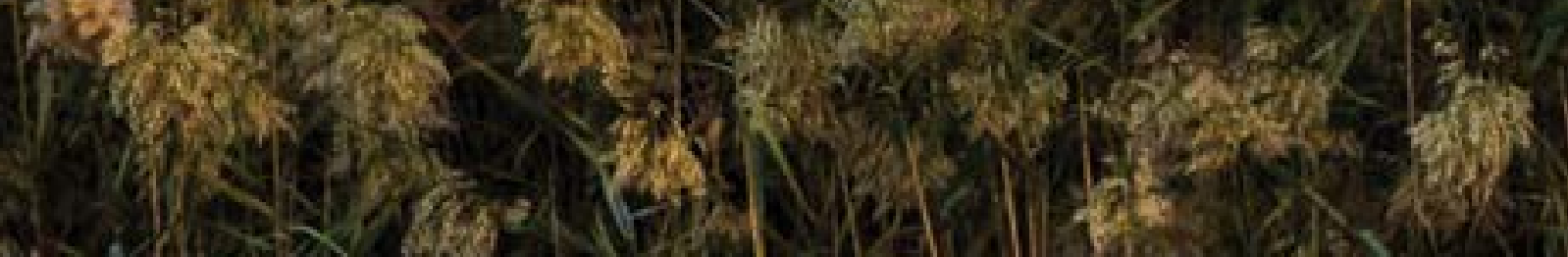

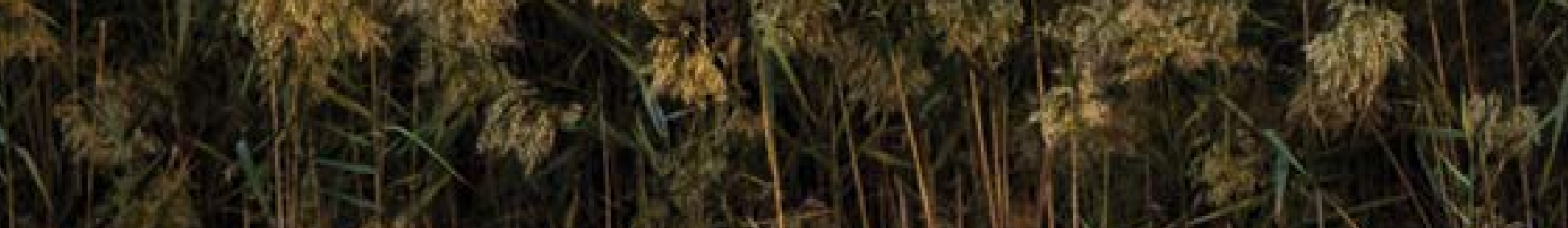

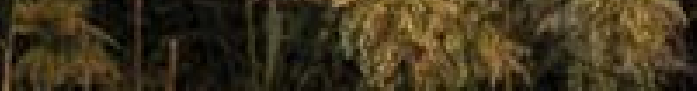
1.

and

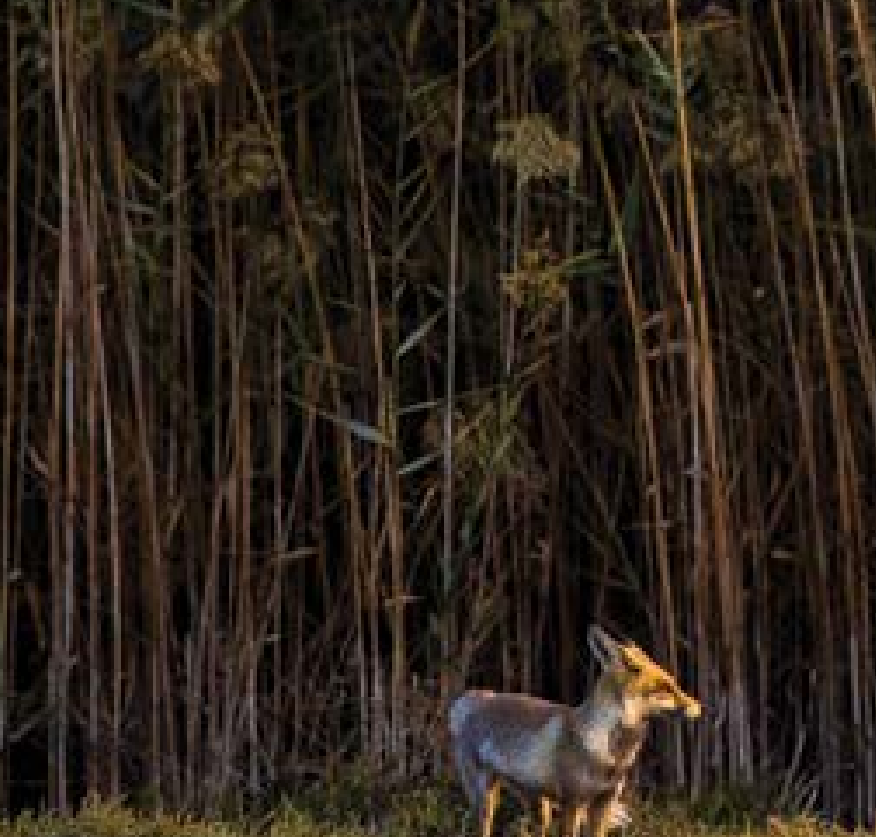
(a)

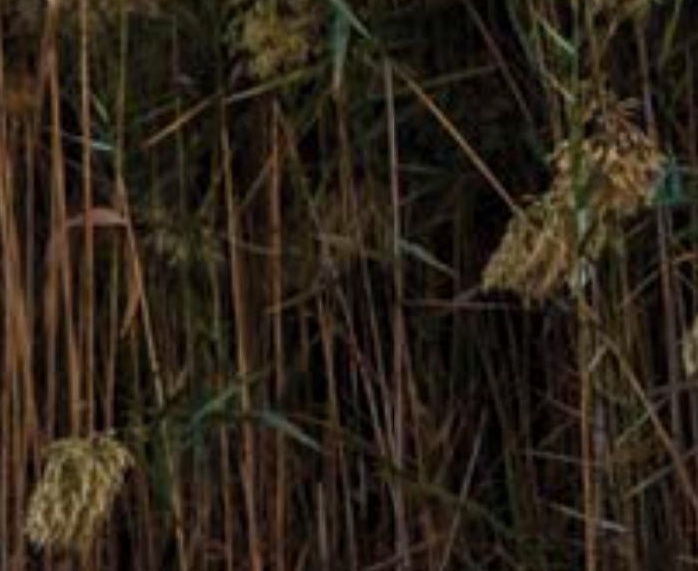
Wrf
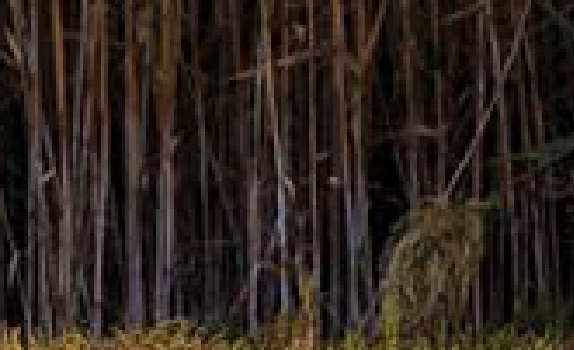
A. 


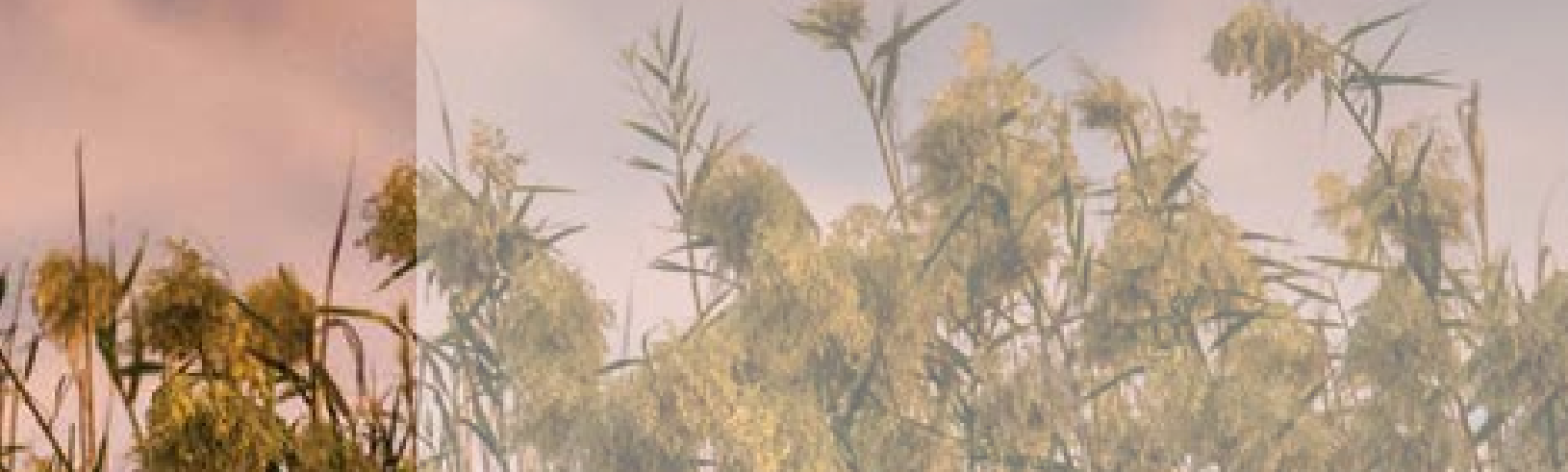

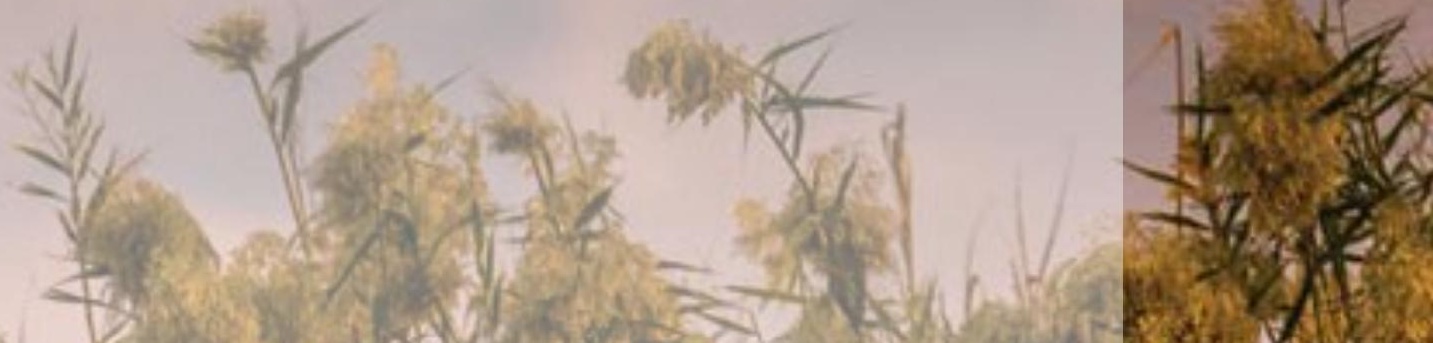
8) ${ }^{2}$ thy atser. (3) A M I t

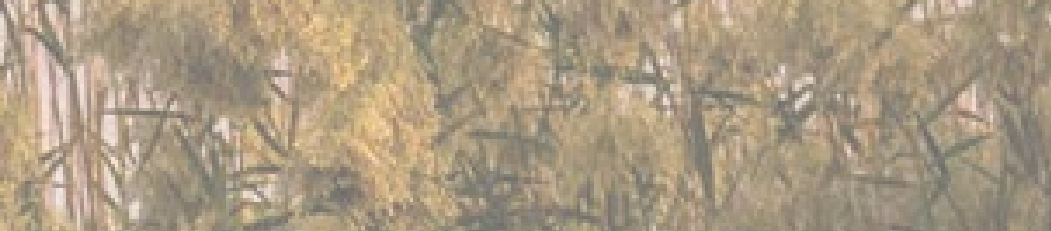

\section{Recommendations}

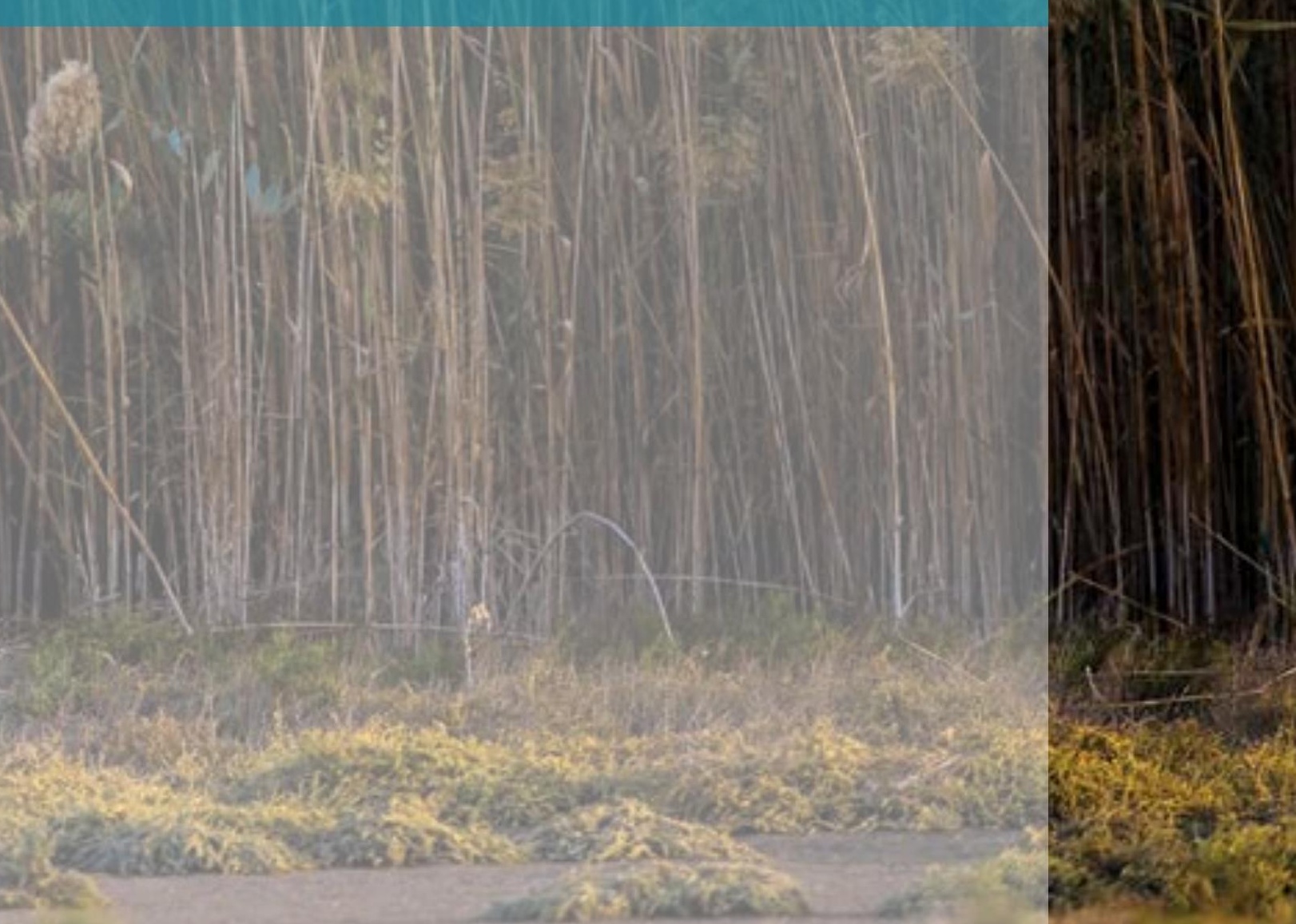




\section{Recommendations}

Gaps that should be addressed:

1. Scorpions

1. Spiders

2. Land and freshwater snails

3. Sponges

4. Invasive species

5. Status of mammals: marine and terrestrial (Population size, distribution and trends; life history and ecology; actions. Research and monitoring to support a conservation strategy)

6. Further studies on reptiles in eastern and southern Kuwait

7. Update in entomological research specially arthropods that can transmit diseases

8. Update the molluscan fauna of Kuwait.

9. Need for herpetology book for Kuwait.

10. Identification of threats for both terrestrial and marine fauna and flora

11. Gaps in knowledge of IUCN Red List species. The focus is on native, wild, threatened species, as defined in the IUCN Red List.

12. Kuronuma \& Abe $(1972,1986)$ books should be updated considering additional records for the fishes of Kuwait.

13. There is a growing need for large-scale research to guide management of reefs and their stressors, as these operate at much larger scales than the national borders within which most research currently occurs

14. Several monitoring and research needs are required to support conservation of sea turtles, including:

- Population size, distribution and trends.

- Life history and ecology.
- Threats and actions.

- Harvest and trade trends and management.

- Inventory and monitoring of populations.

- Monitoring of pelagic and near-shore fisheries operations.

15. Capacity building and training of EPA biologist in highly reputed centers and museums.

16. Application of modern methodologies in biodiversity studies (bat detectors, camera trapping, molecular systematics etc.)

17. There is a near total lack of research on the direct and indirect benefits of biodiversity, including studies on ecosystem services and valuing ecosystems.

18. Efforts should be made to conduct a new vegetation survey covering all parts of Kuwait and the changes in the last 15 years should be evaluated. These measures should be repeated every 15 years using modern techniques to have an updated data base.

19. Assess the positive impacts of recent revegetation and conservation measures on the plant biodiversity and revise the revegetation and conservation policies accordingly.

20. Digital documents of the database should be made available to all reseachers.

21. A robust system of documenting Kuwait's biodiversity was not found, nor an inclusive means for teams of experts to undertake assessments of the country's species and ecosystems and develop integrated strategies and action plans to address species and ecosystems.

22. The immediate need to establish a natural history museum to document fauna, flora and geology of Kuwait. 
23. Intergrated and coordinated approach of all the government organization is necessary to conserve biodiversity.

24. It is recommended that additional efforts are needed for research and documentation of seed ecology, biology of the unexplored native species and to opt for intensive revegetation programs to increase the biodiversity and create a database for the future generations.

25. Measures should be taken increase the availability of seed materials for revegetation programs for improving the biodiversity. Availability of native seeds from local or from neighbouring countries is a constraint to the revegetation programs.

26. Seed banks should be one of the national sources for seeds for revegetation programmes. Seeds should not be stored till they lose their viability as it prevents the natural or assisted upsurge in plant biodiversity.

27. Conservation and revegetation should be considered as national priority as it is the national identity and unique in its own way.

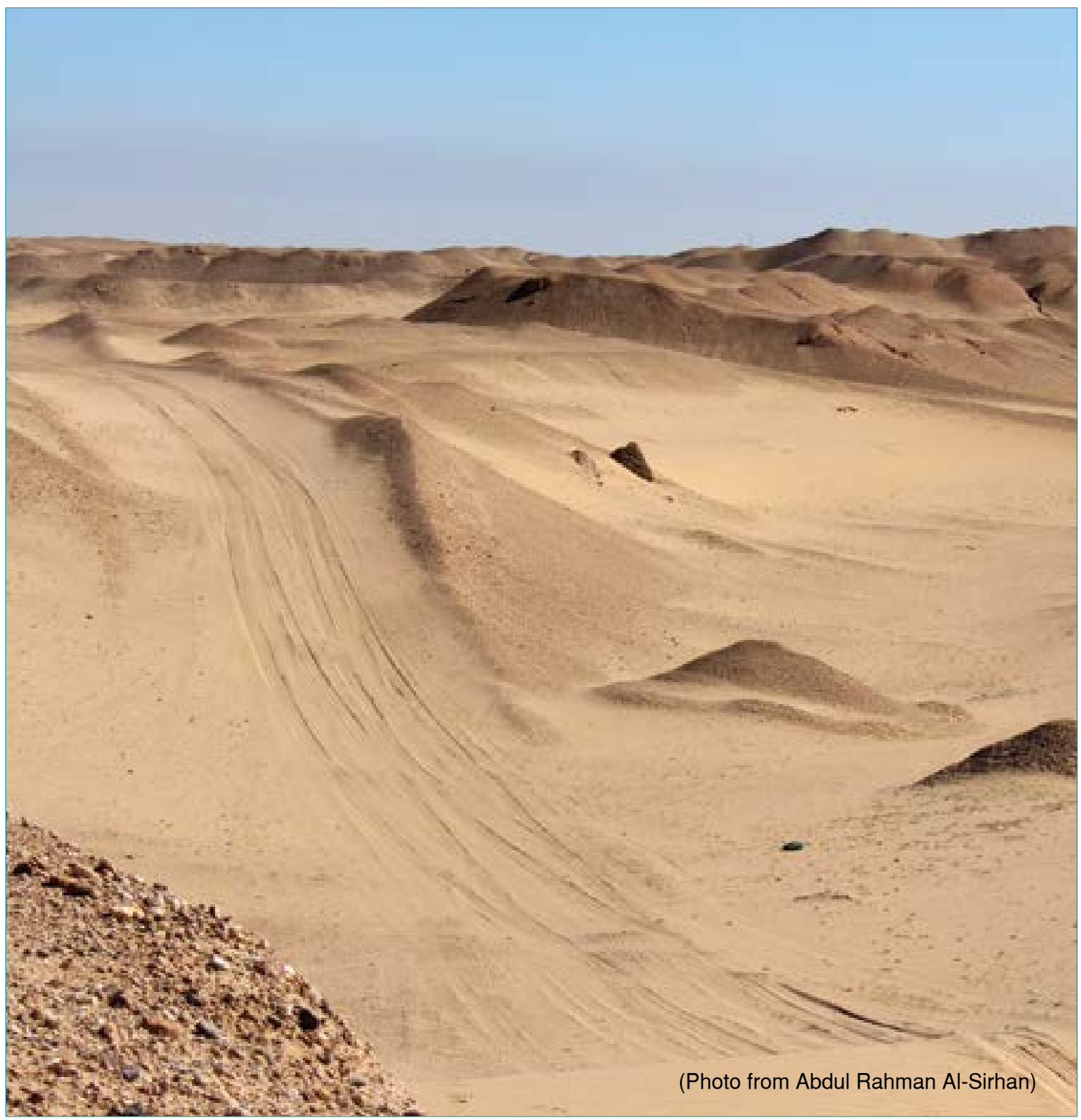




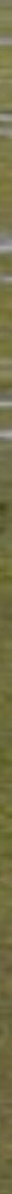

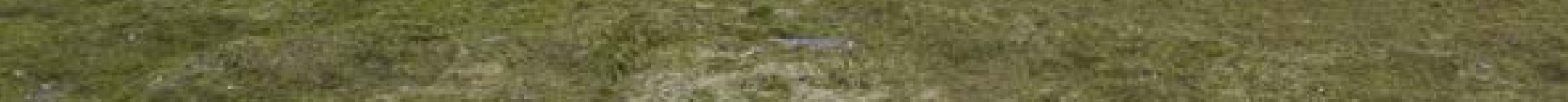

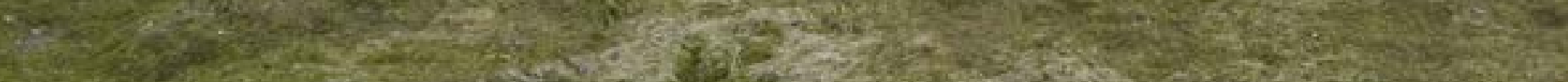

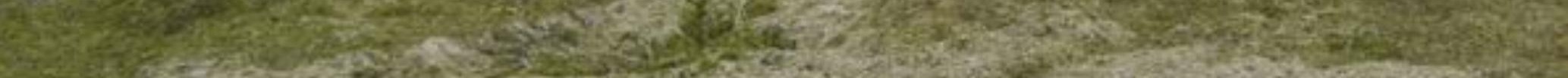

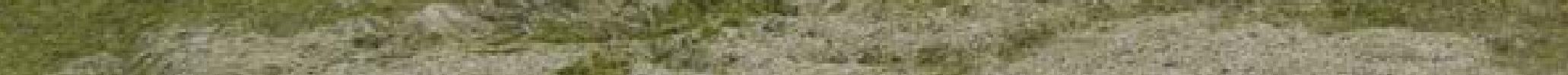
35 (Photo from Yousif Bouhadi) (Photo from Yousit Bounadi) (Photo from Yousif Bouhadi)

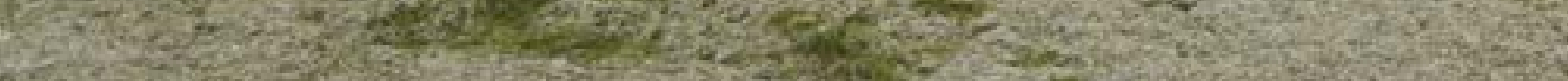
QSE 


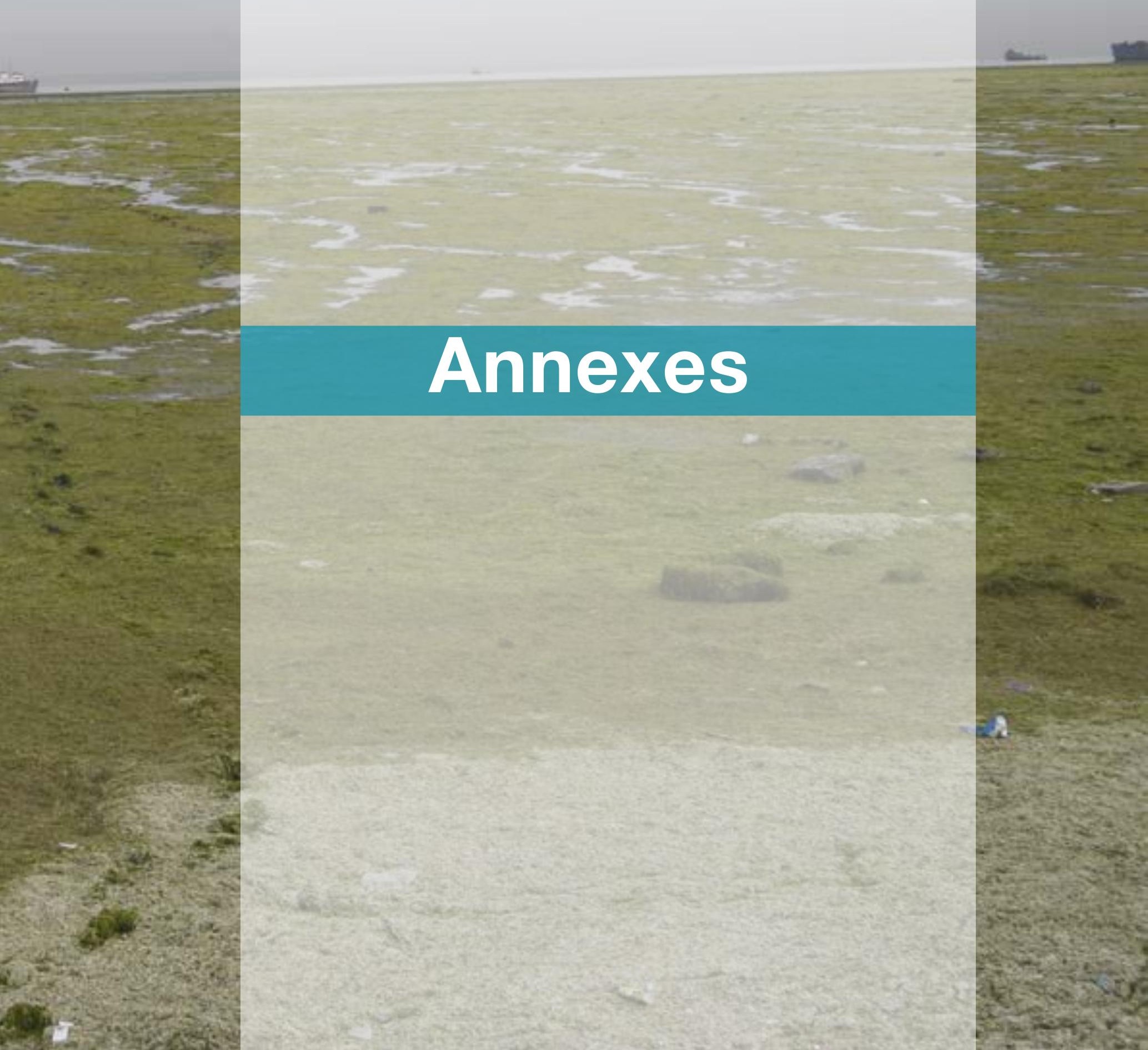




\section{Annex 1}

Birds of Kuwait (Source: Birdlife International \& http://www.kuwaitbirds.org/birds).

Birds of Kuwait (source: \& http://www.kuwaitbirds.org/birds) for the species recorded, whereas for scientific and English names are after (BirdLife nomenclature: del Hoyo \& Collar, 2014; 2016).

\begin{tabular}{|c|c|c|}
\hline Common name & Scientific name & Arabic name \\
\hline \multicolumn{3}{|l|}{ Phasianidae } \\
\hline Common Quail & Coturnix coturnix & 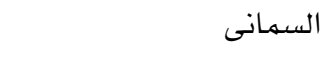 \\
\hline \multicolumn{3}{|l|}{ Anatidae } \\
\hline Eastern Greylag Goose & Anser anser rubrirostris & الإوز الرمادي الشرقي \\
\hline Greater White-fronted Goose & Anser albifrons & ال الإوز الأغر الكبير \\
\hline Mute Swan & Cygnus olor & التم الأخرس \\
\hline Common Shelduck & Tadorna tadorna & 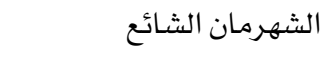 \\
\hline Ruddy Shelduck & Tadorna ferruginea & الشهرمان الأحمر \\
\hline Gadwall & Mareca strepera & البط السماري \\
\hline Eurasian Wigeon & Mareca penelope & البط الصواي \\
\hline Mallard & Anas platyrhynchos & 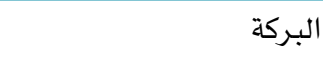 \\
\hline Northern Shoveler & Spatula clypeata & أبومجرف \\
\hline Northern Pintail & Anas acuta & البلبول الشائع \\
\hline Garganey & Spatula querquedula & الحذف الصيفي \\
\hline Common Teal & Anas crecca & الحذف الشتوي \\
\hline Marbled Duck & Marmaronetta angustirostris & الحذف الرخامي \\
\hline Common Pochard & Aythya ferina & البط كستائي الرأس \\
\hline Red-crested Pochard & Netta rufina & البط أحمر العرف \\
\hline Ferruginous Duck & Aythya nyroca & البط الكستتائي \\
\hline Tufted Duck & Aythya fuligula & الحذف المقنزع \\
\hline Long-tailed Duck & Clangula hyemalis & 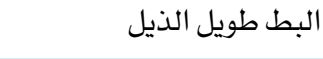 \\
\hline Red-breasted Merganser & Mergus serrator & البلقشة حمراء الصدر \\
\hline \multicolumn{3}{|l|}{ Procellariidae } \\
\hline Sooty Shearwater & Puffinus griseus & جلم الماء الفاحم \\
\hline Arabian or Persian Shearwater & Puffinus persicus & جلم الماء الفارسي \\
\hline \multicolumn{3}{|l|}{ Podicipedidae } \\
\hline Little Grebe & Tachybaptus ruficollis & الغطاس الصغير \\
\hline
\end{tabular}




\begin{tabular}{|c|c|c|}
\hline Common name & Scientific name & Arabic name \\
\hline Red-necked Grebe & Podiceps grisegena & الغطاس أحمر الرقبة \\
\hline Great Crested Grebe & Podiceps cristatus & الغطاس المتوج الكبير \\
\hline Horned Grebe & Podiceps auratus & الغطاس المعرف \\
\hline Black-necked Grebe & Podiceps nigricollis & الغطاس أسود الرقبة \\
\hline \multicolumn{3}{|l|}{ Phoenicopteridae } \\
\hline Greater Flamingo & Phoenicopterus roseus & النحام الكبير \\
\hline Lesser Flamingo & Phoeniconaias minor & النحام الصغير \\
\hline \multicolumn{3}{|l|}{ Phaethontidae } \\
\hline Red-billed Tropicbird & Phaethon aethereus & رئيس البحر \\
\hline \multicolumn{3}{|l|}{ Ciconiidae } \\
\hline Black Stork & Ciconia nigra & 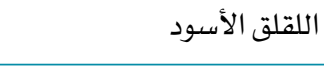 \\
\hline Western White Stork & Ciconia ciconia & اللقلق الأبيض الغربي \\
\hline \multicolumn{3}{|l|}{ Threskiornithidae } \\
\hline African Sacred Ibis & Threskiornis aethiopicus & الأنوق المقدس \\
\hline Glossy lbis & Plegadis falcinellus & الأنوق اللامع \\
\hline Eurasian Spoonbill & Platalea leucorodia & أبو ملعقة - أب \\
\hline \multicolumn{3}{|l|}{ Ardeidae } \\
\hline Eurasian Bittern & Botaurus stellaris & الواق الكبير \\
\hline Common Little Bittern & Ixobrychus minutus & الواق الصغير \\
\hline Black-crowned Night Heron & Nycticorax nycticorax & الواق الأخضر الصغير \\
\hline Green-backed Heron & Butorides striata & البلشون أخضر الظهر \\
\hline Squacco Heron & Ardeola ralloides & البلشون الذهبي \\
\hline Indian Pond Heron & Ardeola grayii & البلشون الذهبي الهندي \\
\hline Western Cattle Egret & Bubulcus ibis & أبو قردان الفربي \\
\hline Grey Heron & Ardea cinerea & البلشون الرمادي \\
\hline Purple Heron & Ardea purpurea & البلشون الأرجواني \\
\hline (Great) white Egret & Ardea alba & البلشون الأبيض الغربي \\
\hline Little Egret & Egretta garzetta & الغرنوق الأبيض الصغير \\
\hline Western Reef Egret & Egretta gularis schistacea & الغرنوق الأسود الهندي \\
\hline \multicolumn{3}{|l|}{ Fregatidae } \\
\hline Lesser Frigatebird & Fregata ariel & الفرقاط الصغير \\
\hline \multicolumn{3}{|l|}{ Pelecanidae } \\
\hline Great White Pelican & Pelecanus onocrotalus & البجعة البيضاء الكبيرة \\
\hline
\end{tabular}




\begin{tabular}{|c|c|c|}
\hline Common name & Scientific name & Arabic name \\
\hline Dalmatian Pelican & Pelecanus crispus & البجعة الكدراء \\
\hline \multicolumn{3}{|l|}{ Phalacrocoracidae } \\
\hline Pygmy Cormorant & Microcarbo pygmeus & 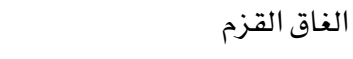 \\
\hline Great Cormorant & Phalacrocorax carbo & الغاق الكبير \\
\hline Socotra Cormorant & Phalacrocorax nigrogularis & 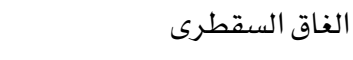 \\
\hline \multicolumn{3}{|l|}{ Anhingidae } \\
\hline African Darter & Anhinga rufa & الزقة - الزة \\
\hline \multicolumn{3}{|l|}{ Pandionidae } \\
\hline Osprey & Pandion haliaetus haliaetus & العقاب النساري \\
\hline \multicolumn{3}{|l|}{ Accipitridae } \\
\hline European Honey Buzzard & Pernis apivorus & عقاب العسل الحوامة \\
\hline Oriental Honey Buzzard & Pernis ptilorhynchus & عقاب العسل المقنزعة \\
\hline Black-winged Kite & Elanus caeruleus & 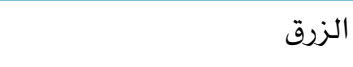 \\
\hline Black Kite & Milvus migrans & الحدأة الشائعة \\
\hline White-tailed Sea Eagle & Haliaeetus albicilla & العقاب بيضاء الذيل \\
\hline Egyptian Vulture & Neophron percnopterus & الرخمة المصرية \\
\hline Griffon Vulture & Gyps fulvus & النسر الأسمر (نسر جريفون) \\
\hline Cinereous Vulture & Aegypius monachus & النسر الأسود \\
\hline Lappet-faced Vulture & Torgos tracheliotos & 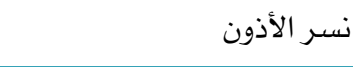 \\
\hline Short-toed Snake-Eagle & Circaetus gallicus & عقاب الحيات \\
\hline Western Marsh Harrier & Circus aeruginosus & مرزة البطائح الغربية \\
\hline Hen Harrier & Circus cyaneus & مرزة الدجاج \\
\hline Pallid Harrier & Circus macrourus & المرزة الباهتة \\
\hline Montagu's Harrier & Circus pygargus & أبو شودة \\
\hline Shikra & Accipiter badius & البيدق \\
\hline Levant Sparrowhawk & Accipiter brevipes & الباشق الشرقي \\
\hline Eurasian Sparrowhawk & Accipiter nisus & الباشق \\
\hline Northern Goshawk & Accipiter gentilis & البازي \\
\hline Eurasian Buzzard & Buteo buteo vulpinus & باز السهول \\
\hline Long-legged Buzzard & Buteo rufinus & السقاوة (الباز طويل الساق) \\
\hline Lesser Spotted Eagle & Aquila pomarina & العقاب المنقط الصغير \\
\hline Greater Spotted Eagle & Aquila clanga & العقاب المنقط الكبير \\
\hline Steppe Eagle & Aquila nipalensis & عقاب البادية \\
\hline
\end{tabular}




\begin{tabular}{|c|c|c|}
\hline Common name & Scientific name & Arabic name \\
\hline Eastern Imperial Eagle & Aquila heliaca & ملك العقبان الشرقي \\
\hline Golden Eagle & Aquila chrysaetos & العقاب الذهبية \\
\hline Bonelli's Eagle & Aquila fasciatus & عقاب بونلي \\
\hline Booted Eagle & Aquila pennata & السبر \\
\hline \multicolumn{3}{|l|}{ Falconidea } \\
\hline Lesser Kestrel & Falco naumanni & العويسق \\
\hline Common Kestrel & Falco tinnunculus & العوسق \\
\hline Red-footed Falcon & Falco vespertinus & البزيق الشائع \\
\hline Amur Falcon & Falco amurensis & البزيق الشرقي \\
\hline Sooty Falcon & Falco concolor & الصقر الأسخم \\
\hline Merlin & Falco columbarius & 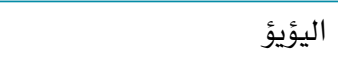 \\
\hline Eurasian Hobby & Falco subbuteo & صقر الكوبج \\
\hline Lanner Falcon & Falco biarmicus & صقروكري \\
\hline Saker Falcon & Falco cherrug & الصقر الحر \\
\hline Peregrine Falcon & Falco peregrinus peregtinus & شاهين بحري \\
\hline \multicolumn{3}{|l|}{ Otididae } \\
\hline Asian Bustard & Chlamydotis macqueenii & الحبارى الشرقية \\
\hline \multicolumn{3}{|l|}{ Rallidae } \\
\hline Western Water Rail & Rallus aquaticus & 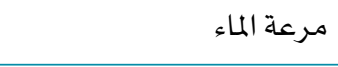 \\
\hline Corncrake & Crex crex & 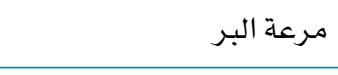 \\
\hline Little Crake & Porzana parva & مرعة رمادية البطن \\
\hline Baillon's Crake & Porzana pusilla & المرعة الصغيرة \\
\hline Spotted Crake & Porzana porzana & المرعة الرقطاء \\
\hline Purple Swamphen & Porphyrio porphyrio & دجاجة السلطان \\
\hline Common Moorhen & Gallinula chloropus & دجاجة الماء \\
\hline Eurasian Coot & Fulica atra & 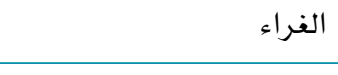 \\
\hline \multicolumn{3}{|l|}{ Gruidae } \\
\hline Demoiselle Crane & Anthropoides virgo & الرهو \\
\hline Common Crane & Grus grus & 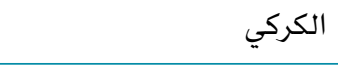 \\
\hline \multicolumn{3}{|l|}{ Burhinidae } \\
\hline Eurasian Thick-knee & Burhinus oedicnemus & 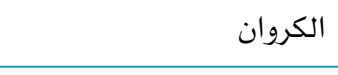 \\
\hline \multicolumn{3}{|l|}{ Haematopodidae } \\
\hline Eurasian Oystercatcher & Haematopus ostralegus & آكل المحار \\
\hline
\end{tabular}




\begin{tabular}{|c|c|c|}
\hline Common name & Scientific name & Arabic name \\
\hline \multicolumn{3}{|l|}{ Dromadidae } \\
\hline Crab-plover & Dromas ardeola & الحنكور زقزاق السرطان \\
\hline \multicolumn{3}{|l|}{ Recurvirostridae } \\
\hline Black-winged Stilt & Himantopus himantopus & الكرسوع \\
\hline Pied Avocet & Recurvirostra avosetta & 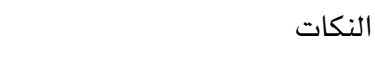 \\
\hline \multicolumn{3}{|l|}{ Charadriidae } \\
\hline Northern Lapwing & Vanellus vanellus & الزقزاق الشـامي \\
\hline Spur-winged Lapwing & Vanellus spinosus & الزقزاق ذو الجناح الناتئ \\
\hline Red-wattled Lapwing & Vanellus indicus & الزقزاق الهندي \\
\hline Sociable Lapwing & Vanellus gregarius & الزقزاق الأنيس \\
\hline White-tailed Lapwing & Vanellus leucurus & الزقزاق أبيض الذيل \\
\hline Eurasian Golden Plover & Pluvialis apricaria & الز الزقزاق الأوربي \\
\hline Pacific Golden Plover & Pluvialis fulva & الزقزاق الباسيفيكي \\
\hline Grey Plover & Pluvialis squatarola & الزقزاق الرمادي \\
\hline Common Ringed Plover & Charadrius hiaticula & الزقزاق المطوق الشائع \\
\hline Little Ringed Plover & Charadrius dubius & الزقزاق المطوق الصغير \\
\hline Kentish Plover & Charadrius alexandrinus & الزقزاق الاسكندراني \\
\hline Lesser Sand Plover & Charadrius atrifrons & زقزاق الرمل الصغير \\
\hline Greater Sand Plover & Charadrius leschenaultii & زقزاق الرمل الكبير \\
\hline Caspian Plover & Charadrius asiaticus & الزقزاق القزويني \\
\hline Eurasian Dotterel & Charadrius morinellus & الزقزاق الأغبر \\
\hline \multicolumn{3}{|l|}{ Scolopacidae } \\
\hline Eurasian Woodcock & Scolopax rusticola & 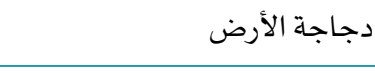 \\
\hline Jack Snipe & Lymnocryptes minimus & الشنقب الصغير \\
\hline Great Snipe & Gallinago media & الشنقب الكبير \\
\hline Common Snipe & Gallinago gallinago & الشنقب الشائع \\
\hline Black-tailed Godwit & Limosa limosa & بقويقة سلطانية \\
\hline Bar-tailed Godwit & Limosa lapponica & بقويقة مخططة الذيل \\
\hline Little Curlew & Numenius minutus & كروان الماء الصغير \\
\hline Whimbrel & Numenius phaeopus & كروان الغيط \\
\hline Eurasian Curlew & Numenius arquata & كروان الماء الكبير \\
\hline Spotted Redshank & Tringa erythropus & الطيطوى حمراء الساق الرقطاء \\
\hline Common Redshank & Tringa totanus & الطيطوى حمراء الساق الشائعة \\
\hline
\end{tabular}




\begin{tabular}{|c|c|c|}
\hline Common name & Scientific name & Arabic name \\
\hline Marsh Sandpiper & Tringa stagnatilis & طيطوى البطاح \\
\hline Common Greenshank & Tringa nebularia & الطيطوى خضراء السـاق \\
\hline Green Sandpiper & Tringa ochropus & النسناسة \\
\hline Wood Sandpiper & Tringa glareola & طيطوى الغيط \\
\hline Terek Sandpiper & Xenus cinereus & طيطوى الرمل \\
\hline Common Sandpiper & Actitis hypoleucos & الطيطوى الشائعة \\
\hline Ruddy Turnstone & Arenaria interpres & ق ق قنبرة الماء \\
\hline Great Knot & Calidris tenuirostris & الطيطوى الكبيرة \\
\hline Red Knot & Calidris canutus & الطيطوى الشمالية \\
\hline Sanderling & Calidris alba & المدروان \\
\hline Little Stint & Calidris minuta & الطيطوى الصغيرة الشائعة \\
\hline Temminck's Stint & Calidris temminckii & الطيطوى الصغيرة الرمادية \\
\hline Pectoral Sandpiper & Clalidris melanotos & الطيطوى داكنة الصدر \\
\hline Curlew Sandpiper & Calidris ferruginea & كروان الماء الأحمر \\
\hline Dunlin & Calidris alpina & الطيطوى الداكنة \\
\hline Broad-billed Sandpiper & Limicola falcinellus & الطيطوى عريضة المنقار \\
\hline Ruff & Philomachus pugnax & النفاش المثاكس \\
\hline Red-necked Phalarope & Phalaropus lobatus & الطيطوى حمراء الرقبة \\
\hline Red Phalarope & Phalaropus fulicarius & الطيطوى الرمادية (ويعرف أيضاً \\
\hline \multicolumn{3}{|l|}{ Glareolidae } \\
\hline Cream-coloured Courser & Cursorius cursor & 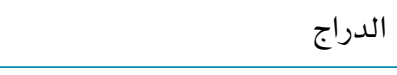 \\
\hline Collared Pratincole & Glareola pratincola & أبو اليسر الشائع \\
\hline Oriental Pratincole & Glareola maldivarum & أبو اليسر الشرقي \\
\hline Black-winged Pratincole & Glareola nordmanni & أبو اليسر أسود الجناح \\
\hline \multicolumn{3}{|l|}{ Laridae } \\
\hline Black-legged Kittiwake & Rissa tridactyla & النورس أسود الرجلين \\
\hline Little Gull & Hydrocoloeus minutus & النورس الصغير \\
\hline Slender-billed Gull & Larus genei & النورس دقيق المنقار \\
\hline Black-headed Gull & Larus ridibundus & النورس أسود الرأس \\
\hline Mediterranean Gull & Larus melanocephalus & نورس البحر الأبيض المتوسط \\
\hline Franklin's Gull & Larus pipixcan & نورس فرانكلين \\
\hline Pallas's Gull & Larus ichthyaetus & نورس السمك \\
\hline Mew Gull & Larus canus & النورس الشائع \\
\hline
\end{tabular}




\begin{tabular}{|c|c|c|}
\hline Common name & Scientific name & Arabic name \\
\hline Caspian Gull & Larus cachinnans & 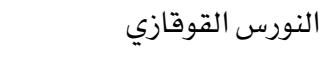 \\
\hline Armenian Gull & Larus armenicus & النورس الأرميني \\
\hline Lesser Black-headed Gull & Larus fuscus & النورس أسود الرأس \\
\hline Common Gull-billed Tern & Gelochelidon nilotica & الخرشنة نورسية المنقار \\
\hline Caspian Tern & Hydroprogne caspia & الخرشنة القزوينية \\
\hline Swift Tern & Thalasseus bergii & الخرشنة المتوجة الكبيرة \\
\hline Lesser Crested Tern & Thalasseus bengalensis & الخرشنة المتوجة الصغيرة \\
\hline Sandwich Tern & Thalasseus sandvicensis & خرشنة الساندويش \\
\hline Little Tern & Sternula albifrons & الخرشنة الصغيرة \\
\hline Bridled Tern & Onychoprion anaethetus & الخرشنة الملجمة \\
\hline Common Tern & Sterna hirundo & الخرشنة الشائعة \\
\hline White-cheeked Tern & Sterna repressa & الخرشنة بيضاء الخد \\
\hline Arctic Tern & Sterna paradisaea & الخرشنة القطبية \\
\hline Whiskered Tern & Chlidonias hybrida & الخرشنة المشوربة \\
\hline White-winged Tern & Chlidonias leucopterus & الخرشنة بيضاء الجناح \\
\hline Black Tern & Chlidonias niger & الخرشنة السوداء \\
\hline \multicolumn{3}{|l|}{ Stercorariidae } \\
\hline Pomarine Jaeger & Stercorarius pomarinus & الكركر الشمالي \\
\hline Arctic Jaeger & Stercorarius parasiticus & الكركر القطبي \\
\hline Long-tailed Jaeger & Stercorarius longicaudus & الكركر طويل الذيل \\
\hline \multicolumn{3}{|l|}{ Pteroclidae } \\
\hline Pin-tailed Sandgrouse & Pterocles alchata & الغطاطة \\
\hline Chestnut-bellied Sandgrouse & Pterocles exustus & 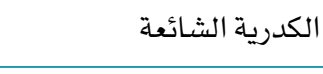 \\
\hline Spotted Sandgrouse & Pterocles senegallus & الكدرية غبراء الجناح \\
\hline Black-bellied Sandgrouse & Pterocles orientalis & الكدرية بيضاء الجناح \\
\hline \multicolumn{3}{|l|}{ Columbidae } \\
\hline European Turtle Dove & Streptopelia turtur & القمري \\
\hline Oriental Turtle Dove & Streptopelia orientalis meena & 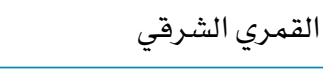 \\
\hline Stock Dove & Columba oenas & حمام أخضر الرقبة \\
\hline Common Wood Pigeon & Columba palumbus & 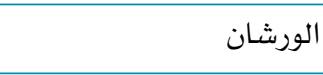 \\
\hline Rock Pigeon & Columba livia (forma domestica) & 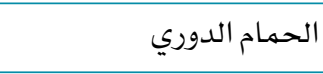 \\
\hline African Collared Dove & Streptopelia risoria & الفاختة الأفريقية \\
\hline Eurasian Collared Dove & Streptopelia decaocto & الفاختة الشائعة \\
\hline
\end{tabular}




\begin{tabular}{|c|c|c|}
\hline Common name & Scientific name & Arabic name \\
\hline Laughing Dove & Spilopelia senegalensis & الدبسي \\
\hline Namaqua Dove & Oena capensis & الحهحم \\
\hline \multicolumn{3}{|l|}{ Cuculidae } \\
\hline Western (Asian) Koel & Eudynamys scolopaceus & الكول الآسيوي \\
\hline Common Cuckoo & Cuculus canorus & الوقواق الشـائع \\
\hline Great Spotted Cuckoo & Clamator glandarius & الوقواق المنقط الكبير \\
\hline \multicolumn{3}{|l|}{ Psittaculidae } \\
\hline Rose-ringed Parakeet & Psittacula krameria & البراكيت الأخضر \\
\hline \multicolumn{3}{|l|}{ Tytonidae } \\
\hline Western Barn Owl & Tyto alba & 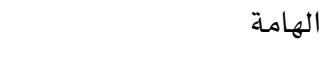 \\
\hline \multicolumn{3}{|l|}{ Strigidae } \\
\hline Pallid Scops Owl & Otus brucei & الثبج الباهت \\
\hline Eurasian Scops Owl & Otus scops & الثبج الأوربي \\
\hline Pharaoh Eagle Owl & Bubo ascalaphus & 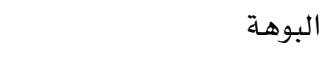 \\
\hline Lilith Owlet & Athene noctua lilith & البومة الصغيرة \\
\hline Northern Long-eared Owl & Asio otus & البومة طويلة الأذنين \\
\hline Short-eared Owl & Asio flammeus & البومة قصيرة الأذنين \\
\hline \multicolumn{3}{|l|}{ Caprimulgidae } \\
\hline Eurasian Nightjar & Caprimulgus europaeus & السبد الأوربي \\
\hline Egyptian Nightjar & Caprimulgus aegyptius & السبد المصري \\
\hline \multicolumn{3}{|l|}{ Apodidae } \\
\hline Alpine Swift & Tachymarptis melba & سمامة الألب \\
\hline Common Swift & Apus apus & السمامة الثائعة \\
\hline Little Swift & Apus affinis & السمامة الصغيرة \\
\hline Pallid Swift & Apus pallidus & السمامة الباهتة \\
\hline \multicolumn{3}{|l|}{ Coraciidae } \\
\hline Indian Roller & Coracias benghalensis & الشقراق الهندي \\
\hline European Roller & Coracias garrulus & الشقراق الأوربي \\
\hline \multicolumn{3}{|l|}{ Alcedinidae } \\
\hline White-breasted Kingfisher & Halcyon smyrnensis & القرلي أبيض الصدر \\
\hline Common Kingfisher & Alcedo atthis & القرلي الشـائع \\
\hline Pied Kingfisher & Ceryle rudis & خاطف ظله \\
\hline \multicolumn{3}{|l|}{ Upupidae } \\
\hline Common Hoopoe & Upupa epops & 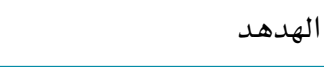 \\
\hline
\end{tabular}




\begin{tabular}{|c|c|c|}
\hline Common name & Scientific name & Arabic name \\
\hline \multicolumn{3}{|l|}{ Meropidae } \\
\hline Blue-cheeked Bee-eater & Merops persicus & القارية زرقاء الخدين \\
\hline European Bee-eater & Merops apiaster & آكل النحل أو الوروار \\
\hline \multicolumn{3}{|l|}{ Picidae } \\
\hline Eurasian Wryneck & Jynx torquilla & 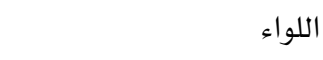 \\
\hline \multicolumn{3}{|l|}{ Laniidae } \\
\hline Red-backed Shrike & Lanius collurio & الصرد احمر الظهر \\
\hline Isabellone Shrike & Lanius isabellinus & الصرد أحمر الذيل \\
\hline Red-tailed Shrike & Lanius phoenicuroides & صرد تركستان الأكحل \\
\hline Long-tailed Shrike & Lanius schach & الصرد طويل الذيل \\
\hline Lesser Grey Shrike & Lanius minor & الصرد الرمادي الصغير \\
\hline Great Grey Shrike & Lanius excubitor & صرد الوادي الجنوبي \\
\hline Woodchat Shrike & Lanius senator & الدغناش الشامي \\
\hline Masked Shrike & Lanius nubicus & الدغناش القطبي \\
\hline \multicolumn{3}{|l|}{ Oriolidae } \\
\hline Eurasian Golden Oriole & Oriolus oriolus & الصفاري \\
\hline \multicolumn{3}{|l|}{ Dicruridae } \\
\hline Ashy Drongo & Dicrurus leucophaeus & الدرونجو الرمادي \\
\hline \multicolumn{3}{|l|}{ Corvidae } \\
\hline House Crow & Corvus splendens & الغراب الدوري \\
\hline Mesopotamian Crow & Corvus (cornix) capellanus & غراب البين العراقي \\
\hline Rook & Corvus frugilegus & الغداف \\
\hline Brown-necked Raven & Corvus ruficollis & الغراب بني الرقبة \\
\hline \multicolumn{3}{|l|}{ Hypocoliidae } \\
\hline Hypocolius & Hypocolius ampelinus & الجاثم المبرقع \\
\hline \multicolumn{3}{|l|}{ Paridae } \\
\hline Sombre Tit & Poecile lugubris & القرقف الحزين \\
\hline Great Tit & Parus major & القرقف الكبير \\
\hline Eurasian Penduline Tit & Remiz pendulinus & القرقف المقنع \\
\hline \multicolumn{3}{|l|}{ Alaudidae } \\
\hline Greater Hoopoe-Lark & Alaemon alaudipes & المكاء \\
\hline Thick-billed Lark & Rhamphocoris clotbey & القبرة عريضة المنقار \\
\hline Calandra Lark & Melanocorypha calandra & القبرة سوداء الصدر \\
\hline
\end{tabular}




\begin{tabular}{|c|c|c|}
\hline Common name & Scientific name & Arabic name \\
\hline Bimaculated Lark & Melanocorypha bimaculata & القبرة قصيرة الذيل \\
\hline Desert Lark & Ammomanes deserti & القبرة الصحراوية \\
\hline Bar-tailed Lark & Ammomanes cinctura & الحمرة سوداء الذيل \\
\hline Greater Short-toed Lark & Calandrella brachydactyla & القبرة قصيرة الإصبع الكبيرة \\
\hline Lesser Short-toed Lark & Calandrella rufescens & القبرة قصيرة الإصبع الصغيرة \\
\hline Arabian Lark & Eremalauda eremodites & الحمرة عريضة المنقار \\
\hline Crested Lark & Galerida cristata & القبرة الثائعة \\
\hline Black-crowned Sparrow-Lark & Eremopterix nigriceps & القبرة سوداء التاج \\
\hline Oriental Skylark & Alauda gulgula & قبرة الحقول الصغيرة \\
\hline Eurasian Skylark & Alauda arvensis & قبرة الحقول الشائعة \\
\hline Wood Lark & Lullula arborea & قبرة الغابات \\
\hline Temminck's Lark & Eremophila bilopha & الحمرة المقرنة الشرقية \\
\hline \multicolumn{3}{|l|}{ Pycnonotidae } \\
\hline White-eared Bulbul & Pycnonotus leucogenys leucotis & البلبل أبيض الخدين \\
\hline Red-vented Bulbul & Pycnonotus cafer & البلبل أحمر العجز \\
\hline \multicolumn{3}{|l|}{ Hirundinidae } \\
\hline Collared Sand Martin & Riparia riparia & خطاف الرمال \\
\hline Barn Swallow & Hirundo rustica & الخطاف الشائع \\
\hline Eurasian Crag Martin & Ptyonoprogne rupestris & خطاف الجبال \\
\hline Pale Rock Martin & Ptyonoprogne obsoleta & خطاف الصخور \\
\hline Northern House Martin & Delichon urbicum & خطاف المدن الشـائع \\
\hline Red-rumped Swallow & Cecropis daurica & الخطاف أحمر العجز \\
\hline \multicolumn{3}{|l|}{ Scotocercidae } \\
\hline Cetti's Warbler & Cettia cetti & الدخلة رمادية الأذن \\
\hline \multicolumn{3}{|l|}{ Phylloscopidae } \\
\hline Willow Warbler & Phylloscopus trochilus & دخلة الصفصاف \\
\hline Common Chiffchaff & Phylloscopus collybita & الدخلة الشائعة \\
\hline Mountain Chiffchaff & Phylloscopus sindianus & دخلة الجبال \\
\hline Wood Warbler & Phylloscopus sibilatrix & دخلة الغابات \\
\hline Eastern Bonelli's Warbler & Phylloscopus orientalis & دخلة بونلي الشرقية \\
\hline Hume's Leaf Warbler & Phylloscopus humei & دخلة أوراق هيوم \\
\hline Yellow-browed Warbler & Phylloscopus inornatus & الدخلة صفراء الحاجب \\
\hline Dusky Warbler & Phylloscopus fuscatus & 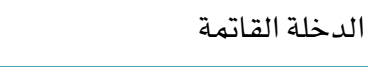 \\
\hline
\end{tabular}




\begin{tabular}{|c|c|c|}
\hline Common name & Scientific name & Arabic name \\
\hline Green Warbler & Phylloscopus nitidus & الدخلة الخضرا \\
\hline \multicolumn{3}{|l|}{ Acrocephalidae } \\
\hline Basra Reed Warbler & Acrocephalus griseldis & دخلة القصب البصرية \\
\hline Great Reed Warbler & Acrocephalus arundinaceus & دخلة القصب الكبيرة \\
\hline Clamorous Reed Warbler & Acrocephalus stentoreus & دخلة القصب الهندية \\
\hline Moustached Warbler & Acrocephalus melanopogon & الدخلة المشوربة \\
\hline Sedge Warbler & Acrocephalus schoenobaenus & دخلة البردي \\
\hline Common Reed Warbler & Acrocephalus scirpaceus & دخلة القصب الأوربية \\
\hline Marsh Warbler & Acrocephalus palustris & دخلة البطاح \\
\hline Paddyfield Warbler & Acrocephalus agricola & 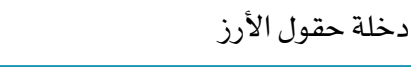 \\
\hline Blyth's Reed Warbler & Acrocephalus dumetorum & دخلة الشجر \\
\hline Booted Warbler & Iduna caligata & 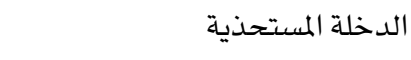 \\
\hline Sykes's Warbler & Iduna rama & 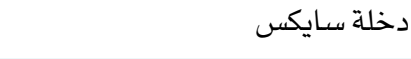 \\
\hline Olivaceous Warbler & Iduna pallida & دخلة الزيتون الشرقية \\
\hline Olive-tree Warbler & Hippolais olivetorum & دخلة شجر الزيتون \\
\hline Upcher's Warbler & Hippolais languida & دخلة الوديان \\
\hline Icterine Warbler & Hippolais icterina & الدخلة الصفراء \\
\hline \multicolumn{3}{|l|}{ Locustellidae } \\
\hline Common Grasshopper Warbler & Locustella naevia & دخلة الجنادب \\
\hline Savi's Warbler & Locustella luscinioides & دخلة الأنهار بيضاء الحنجرة \\
\hline River Warbler & Locustella fluviatilis & دخلة الأنهار \\
\hline \multicolumn{3}{|l|}{ Cisticolidae } \\
\hline Zitting Cisticola & Cisticola juncidis & الدخلة مروحية الذيل \\
\hline Graceful Prinia & Prinia gracilis & 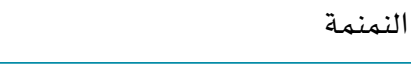 \\
\hline \multicolumn{3}{|l|}{ Leiothrichidae } \\
\hline Common Babbler & Argya caudata & الثرثار الأفغاني \\
\hline \multicolumn{3}{|l|}{ Sylviidae } \\
\hline Eurasian Blackcap & Sylvia atricapilla & أبوقلنسوة \\
\hline Garden Warbler & Sylvia borin & دخلة الحدائق \\
\hline Barred Warbler & Sylvia nisoria & الدخلة الموشاة \\
\hline Lesser Whitethroat & Sylvia curruca & الدخلة بيضاء الحنجرة الصغيرة \\
\hline Desert Whitethroat & Sylvia minula & الدخلة بيضاء الحنجرة الصحراوية \\
\hline Lesser Whitethroat & Sylvia althaea & دخلة هيوم بيضاء الحنجرة \\
\hline
\end{tabular}




\begin{tabular}{|c|c|c|}
\hline Common name & Scientific name & Arabic name \\
\hline Eastern Orphean Warbler & Sylvia crassirostris & 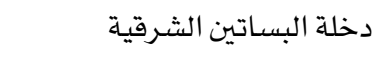 \\
\hline Asian Desert Warbler & Sylvia nana & دخلة الصحراء الآسيوية \\
\hline Common Whitethroat & Sylvia communis & الدخلة بيضاء الحنجرة الشائعة \\
\hline Ménétriés's Warbler & Sylvia mystacea & 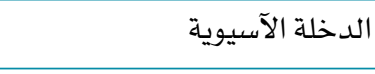 \\
\hline \multicolumn{3}{|l|}{ Regulidae } \\
\hline Goldcrest & Regulus regulus (Linnaeus, 1758) & 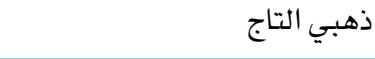 \\
\hline \multicolumn{3}{|l|}{ Troglodytidae } \\
\hline N Wren & Troglodytes troglodytes & العندليب قصير الذيل \\
\hline \multicolumn{3}{|l|}{ Sturnidae } \\
\hline Bank Myna & Acridotheres ginginianus & مينا الأنهار \\
\hline Common Myna & Acridotheres tristis & 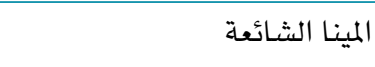 \\
\hline Rosy Starling & Pastor roseus & 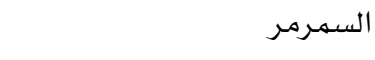 \\
\hline Common Starling & Sturnus vulgaris & الز الزرزور الشائع \\
\hline \multicolumn{3}{|l|}{ Turdidae } \\
\hline Eurasian Blackbird & Turdus merula & الشحرور الشائع الشع \\
\hline Black-throated Thrush & Turdus atrogularis & السهنة سوداء الحنجرة \\
\hline Dusky Thrush & Turdus eunomus & السمنة القاتمة \\
\hline Ring Ouzel & Turdus torquatus & الشحرور أبيض الحنجرة \\
\hline Redwing & Turdus iliacus & السمنة حمراء الجناح \\
\hline Fieldfare & Turdus pilaris & سمنة الحقول \\
\hline Song Thrush & Turdus philomelos & 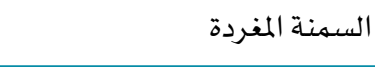 \\
\hline Mistle Thrush & Turdus viscivorus & السهنة الرقشاء \\
\hline \multicolumn{3}{|l|}{ Muscicapidae } \\
\hline European Robin & Erithacus rubecula & 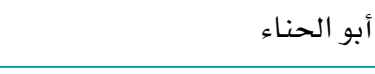 \\
\hline Bluethroat & Luscinia svecica & أزرق الحلق ذو البقعة الحمراء \\
\hline Thrush Nightingale & Luscinia luscinia & 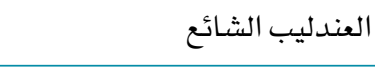 \\
\hline Common Nightingale & Luscinia megarhynchos & الهزار الشائع \\
\hline White-throated Robin & Irania gutturalis & أبو صبرة \\
\hline Rufous-tailed Scrub Robin & Cercotrichas galactotes & 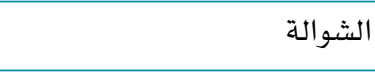 \\
\hline Black Scrub Robin & Cercotrichas podobe & 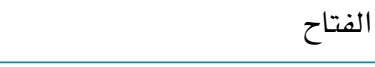 \\
\hline Eversmann's Redstart & Phoenicurus erythronotus & الحميراء بيضاء الكتف \\
\hline Eastern Black Redstart & Phoenicurus ochruros phoenicuroides & الحميراء الدبساء الشرقية \\
\hline Common Redstart & Phoenicurus phoenicurus & 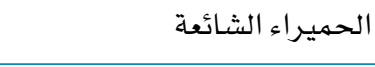 \\
\hline
\end{tabular}




\begin{tabular}{|c|c|c|}
\hline Common name & Scientific name & Arabic name \\
\hline Whinchat & Saxicola rubetra & البرقش الأحمر \\
\hline European Stonechat & Saxicola rubicola & البرقش الأوربي \\
\hline Byzantine Stonechat & Saxicola maurus variegatus & البرقش البيزنطي \\
\hline Pied Stonechat & Saxicola caprata & البرقش الأبقع \\
\hline Caspian Stonechat & Saxicola maurus hemprichii & البرقش القزويني \\
\hline Isabelline Wheatear & Oenanthe isabellina & الأبلق الرملي \\
\hline Northern Wheatear & Oenanthe oenanthe & 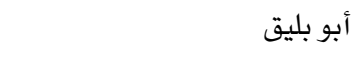 \\
\hline Kurdistan Wheatear & Oenanthe xanthoprymna & فقاقة كردستان \\
\hline Red-tailed Wheatear & Oenanthe chrysopygia & الفقاقة حمراء الذيل \\
\hline Pied Wheatear & Oenanthe pleschanka & الفقاقة البقعاء \\
\hline Eastern Black-eared Wheatear & Oenanthe hispanica melanoleuca & الفقاقة سوداء الأذن الشرقية \\
\hline Desert Wheatear & Oenanthe deserti & فقاقة البادية \\
\hline White-crowned Wheatear & Oenanthe leucopyga & الفقاقة السوداء بيضاء التاج \\
\hline Eastern Mourning Wheatear & Oenanthe lugens & الفقاقة الحزينة الشرقية \\
\hline Finsch's Wheatear & Oenanthe finschii & الفقاقة العربية \\
\hline Hume's Wheatear & Oenanthe albonigra & الفقاقة السوداء بيضاء البطن \\
\hline Hooded Wheatear & Oenanthe monacha & الفقاقة المقلنسة \\
\hline Rufous-tailed Rock Thrush & Monticola saxatilis & سمنة الصخور \\
\hline Blue Rock Thrush & Monticola solitarius & السمنة الزرقاء \\
\hline Spotted Flycatcher & Muscicapa striata & خاطف الذباب المرقط \\
\hline Collared Flycatcher & Ficedula albicollis & خاطف الذباب المطوق \\
\hline Semi-collared Flycatcher & Ficedula semitorquata & خاطف الذباب شبه المطوق \\
\hline Red-breasted Flycatcher & Ficedula parva & خاطف الذباب أحمر الصدر \\
\hline Taiga Flycatcher & Ficedula albicilla & خاطف الذباب التايجي \\
\hline \multicolumn{3}{|l|}{ Nectariniidae } \\
\hline Purple Sunbird & Cinnyris asiaticus & التمير الأرجواني \\
\hline \multicolumn{3}{|l|}{ Passeridae } \\
\hline House Sparrow & Passer domesticus & العصفور الدوري \\
\hline Spanish Sparrow & Passer hispaniolensis & العصفور الأندلسي \\
\hline Arabian Golden Sparrow & Passer euchlorus & العصفور العربي الذهبي \\
\hline Dead Sea Sparrow & Passer moabiticus & عصفور البحر الميت \\
\hline Pale Rockfinch & Carpospiza brachydactyla & عصفور الصخور الباهت \\
\hline Yellow-throated Sparrow & Gymnoris xanthocollis & العصفور أصفر الحنجرة \\
\hline
\end{tabular}




\begin{tabular}{|c|c|c|}
\hline Common name & Scientific name & Arabic name \\
\hline \multicolumn{3}{|l|}{ Estrildidae } \\
\hline Indian Silverbill & Lonchura malabarica & فضي المنقار الهندي \\
\hline \multicolumn{3}{|l|}{ Prunellidae } \\
\hline Radde's Accentor & Prunella ocularis & عصفور الشوك أبيض الصدر \\
\hline Dunnock & Prunella modularis & عصفور الشوك الشائع \\
\hline Black-throated Accentor & Prunella atrogularis & عصفور الشوك أسود الحنجرة \\
\hline \multicolumn{3}{|l|}{ Motacillidae } \\
\hline Forest Wagtail & Dendronanthus indicus & أصقع المروج \\
\hline Blue-headed Wagtail & Motacilla flava flava & راعية الخيل زرقاء الرأس \\
\hline White-headed Wagtail & Motacilla flava leucocephala & راعية الخيل بيضاء الرأس \\
\hline Sykes's Wagtail & Motacilla flava beema & راعية خيل سايكس \\
\hline Eastern Black-headed Wagtail & Motacilla flava 'melanogrisea' & راعية الخيل سوداء الرأس الشرقية \\
\hline Black-headed Wagtail & Motacilla flava feldegg & راعية الخيل سوداء الرأس \\
\hline Grey-headed Wagtail & Motacilla flava thunbergi & راعية الخيل رمادية الرأس \\
\hline Yellow-headed Wagtail & Motacilla flava lutea & راعية الخيل صفراء الرأس \\
\hline Citrine Wagtail & Motacilla citreola & الصقعاء \\
\hline Grey Wagtail & Motacilla cinerea & راعية الخيل الرمادية \\
\hline White Wagtail & Motacilla alba & 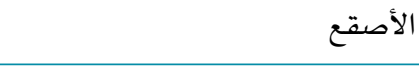 \\
\hline Masked Wagtail & Motacilla alba personata & الأصقع المقنع \\
\hline Richard's Pipit & Anthus novaeseelandiae richardi & الجشنة الكبيرة \\
\hline Tawny Pipit & Anthus campestris & 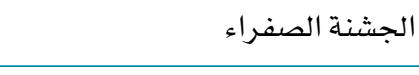 \\
\hline Meadow Pipit & Anthus pratensis & جشنة المروج \\
\hline Tree Pipit & Anthus trivialis & جشنة الشجر \\
\hline Olive-backed Pipit & Anthus hodgsoni & الجشنة زيتونية الظهر \\
\hline Red-throated Pipit & Anthus cervinus & الجشنة حمراء الصدر \\
\hline Buff-bellied Pipit & Anthus rubescens japonicus & الجشنة كدراء الصدر \\
\hline Water Pipit & Anthus spinoletta & جشنة الماء \\
\hline \multicolumn{3}{|l|}{ Fringillidae } \\
\hline Common Chaffinch & Fringilla coelebs & 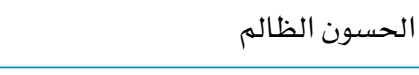 \\
\hline Brambling & Fringilla montifringilla & الشرشور \\
\hline European Greenfinch & Carduelis chloris & الحسون الاخضر الأوربي \\
\hline Eurasian Siskin & Carduelis spinus & 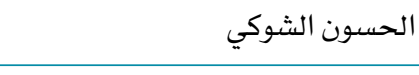 \\
\hline European Goldfinch & Carduelis carduelis & الحسون الذهبي \\
\hline
\end{tabular}




\begin{tabular}{|c|c|c|}
\hline Common name & Scientific name & Arabic name \\
\hline Eastern Goldfinch & Carduelis carduelis caniceps & الحسون الذهبي الشرقي \\
\hline Common Linnet & Carduelis cannabina & التفاحي \\
\hline Trumpeter Finch & Bucanetes githagineus & النغر الشائع \\
\hline Mongolian Finch & Bucanetes mongolicus & النغر المنغولي \\
\hline Desert Finch & Rhodospiza obsoleta & النغر الصحراوي \\
\hline \multicolumn{3}{|l|}{ Emberizidae } \\
\hline Common Rosefinch & Carpodacus erythrinus & الحسون الوردي \\
\hline Corn Bunting & Emberiza calandra & درسة الذرة \\
\hline Yellowhammer & Emberiza citrinella & الدرسة الصفراء \\
\hline Rock Bunting & Emberiza cia & درسة الصخور \\
\hline Grey-necked Bunting & Emberiza buchanani & بلبل الشعير رمادي الرقبة \\
\hline Eastern Cinereous Bunting & Emberiza cineracea semenowi & بلبل الشعير السوري الشرقي \\
\hline Ortolan Bunting & Emberiza hortulana & بلبل الشعير الشائع \\
\hline Striolated Bunting & Emberiza striolata & درسة مخططة الرأس \\
\hline Little Bunting & Emberiza pusilla & الدرسة الصغيرة \\
\hline Rustic Bunting & Emberiza rustica & درسة الخمائل \\
\hline Black-headed Bunting & Emberiza melanocephala & الدرسة سوداء الرأس \\
\hline Red-headed Bunting & Emberiza bruniceps & الدرسة حمراء الرأس \\
\hline Common Reed Bunting & Emberiza schoeniclus & درسة القصب \\
\hline
\end{tabular}

del Hoyo, J. \& Collar, N.J. 2014: 'HBW and BirdLife International Illustrated Checklist of the World'. Volume 1. Non-Passerines. Lynx Edicions, Barcelona.

del Hoyo, J. \& Collar, N.J. 2016: 'HBW and BirdLife International Illustrated Checklist of the World'. Volume 2. Passerines. Lynx Edicions, Barcelona. 


\section{Annex 2}

\section{List of fishes recorded from Kuwait (Based on Bishop, 2003).}

\begin{tabular}{|c|c|c|c|}
\hline Order & Family & Species & Common name \\
\hline \multirow[t]{5}{*}{ Orectolobiformes } & Hemiscylliidae & Chiloscyllium arabicum Gubanov, 19801 & Arabian Carpetshark \\
\hline & & Chiloscyllium griseum Müller \& Henle, 1838 & Grey Bambooshark \\
\hline & Ginglymostomatidae & Nebrius ferrugineus (Lesson, 1830) & Tawny Nurse Shark \\
\hline & Rhincodontidae & Rhincodon typus (Smith, 1828) & Whale Shark \\
\hline & Stegostomatidae & Stegostoma fasciatum (Hermann, 1783) & Zebra Shark \\
\hline \multirow[t]{16}{*}{ Carcharhiniformes } & Triakidae & Mustelus mosis Hemprich \& Ehrenberg, 1899 & Arabian Smoothhound \\
\hline & Hemigaleidae & Chaenogaleus macrostoma (Bleeker, 1852) & Hooktooth Shark \\
\hline & & Paragaleus randalli Compagno, Krupp \& Carpenter, 1966 & Slender Weasel Shark \\
\hline & Carcharhinidae & Carcharhinus albimarginatus (Rüppell, 1837) & Silvertip Shark \\
\hline & & Carcharhinus brevipinna (Müller \& Henle, 1839) & Spinner Shark \\
\hline & & Carcharhinus dussumieri (Valenciennes, 1839) & Whitecheek Shark \\
\hline & & Carcharhinus leucas (Valenciennes, 1839) & Bull Shark \\
\hline & & Carcharhinus limbatus (Valenciennes, 1839) & Blacktip Shark \\
\hline & & Carcharhinus melanopterus (Quoy \& Gaimard, 18247) & Blacktip Reef Shark \\
\hline & & Carcharhinus plumbeus (Nardo, 1827) & Sandbar Shark \\
\hline & & Carcharhinus sorrah (Valenciennes, 1839) & Spot-tail Shark \\
\hline & & Galeocerdo cuveri (Peron \& LeSueur, 1822) & Tiger Shark \\
\hline & & Rhizoprionodon acutus (Rüppell , 1837) & Milk Shark \\
\hline & & Rhizoprionodon oligolinx Springer, 1964 & Grey Sharpnose Shark \\
\hline & & Scoliodon laticaudus Müller \& Henle, 1838 & Spadenose Shark \\
\hline & Sphyrnidae & Sphyrna mokarran (Rüppell, 1837) & Great Hammerhead \\
\hline Lamniformes & Odontaspididae & Carcharias taurus (Rafinesque, 1810) & Sand Tiger Shark \\
\hline Pristiformes & Pristidae & Pristis zijsron Bleeker, 1851 & Green Sawfish \\
\hline \multirow[t]{2}{*}{ Torpediniformes } & Torpedinidae & Torpedo panthera Olfers, 1831 & Panther Electric Ray \\
\hline & & Torpedo sinuspersici Olfers, 1831 & Marbled Electric Ray \\
\hline \multirow[t]{2}{*}{ Rajiformes } & Rhinobatidae & Rhina ancylostoma Bloch \& Schneider, 1801 & Bowmouth Guitarfish \\
\hline & & Rhinobatos granulatus Cuvier, 1829 & Sharpnose Guitarfish \\
\hline
\end{tabular}




\begin{tabular}{|c|c|c|c|}
\hline \multirow[t]{2}{*}{ Order } & Family & Species & Common name \\
\hline & & Rhynchobatus djiddensis (Forsskål, 1775) & Giant Guitarfish \\
\hline & Dasyatidae & Himantura bleekeri (Blyth, 1800) & Bleeker's Whipray \\
\hline & & Himantura imbricata (Bloch \& Schneider, 1801) & Scaly Whipray \\
\hline & & Himantura uarnak ( Forsskål, 1775) & Reticulated Whipray \\
\hline & & Himantura sp. & Whipray \\
\hline & & Pastinachus sephen (Forsskål, 1775) & Cowtail Stingray \\
\hline & & Taeniura meyeni Müller \& Henle, 1841 & Blotched Fantail Ray \\
\hline & & Gymnuridae Gymnura poecilura (Shaw, 1804) & Longtail Butterfly Ray \\
\hline & Myliobatidae & Aetobatus narinari (Euphrasen, 1790) & Spotted Eagle Ray \\
\hline & & Aetomylaeus nichofii (Bloch \& Schneider, 1801) & Banded Eagle Ray \\
\hline & & Aetomylaeus sp. & Eagle Ray \\
\hline & & Rhinoptera javanica Müller \& Henle, 1841 & Javanese Cownose Ray \\
\hline \multirow[t]{4}{*}{ Anguilliformes } & Muraenidae & Echidna nebulosa (Ahl, 1789) & Starry Moray \\
\hline & & Gymnomuraena zebra (Shaw, 1797) & Zebra Moray \\
\hline & & Gymnothorax undulatus (Lacepe'de, 1803) & Undulated Moray \\
\hline & Muraenesocidae & Muraenesox cinereus (Forsskål, 1775) & Daggertooth Pike Conger \\
\hline \multirow[t]{17}{*}{ Clupeiformes } & Clupeidae & Anodontostoma chacunda (Hamilton-Buchanan, 1822) & Chacunda Gizzard Shad \\
\hline & & Dussumieria acuta Valenciennes, 1847 & Rainbow Sardine \\
\hline & & Herklotsichthys quadrimaculatus (Rüppell, 1837) & Bluestripe Herring \\
\hline & & Hilsa kelee (Cuvier, 1829) & Kelee Shad \\
\hline & & Nematalosa nasus (Bloch, 1795) & Bloch's Gizzard Shad \\
\hline & & Sardinella albella (Valenciennes, 1847) & White Sardinella \\
\hline & & Sardinella gibbosa (Bleeker, 1849) & Goldstripe Sardinella \\
\hline & & Sardinella longiceps Valenciennes, 1847 & Indian Oil Sardinella \\
\hline & & Sardinella melanura (Cuvier, 1829) & Blacktip Sardinella \\
\hline & & Sardinella sindensis (Day, 1878) & Sind Sardinella \\
\hline & & Tenualosa ilisha (Hamilton-Buchanan, 1822) & Hilsha Shad \\
\hline & Pristigasteridae & Ilisha compressa Randall, 1994 & Compressed llisha \\
\hline & & Ilisha melastoma Bloch \& Schneider, 1801 & Indian Ilisha \\
\hline & Engraulidae & Encrasicholina devisi Whitley, 1940 & Devis' Anchovy \\
\hline & & Encrasicholina punctifer Fowler, 1938 & Bucaneer Anchovy \\
\hline & & Stolephorus indicus (van Hasselt, 1823) & Indian Anchovy \\
\hline & & Thryssa hamiltonii (Gray, 1853) & Hamilton's Thryssa \\
\hline
\end{tabular}




\begin{tabular}{|c|c|c|c|}
\hline Order & Family & Species & Common name \\
\hline & & Thryssa vitrirostris (Gilchrist \& Thompson, 1908) & Orangemouth Anchovy \\
\hline & & Thryssa whiteheadi Wongratana, 1983 & Whitehead's Thryssa \\
\hline \multirow[t]{2}{*}{ Clupeiformes } & Chirocentridae & Chirocentrus dorab (Forsskål, 1775) & Dorab Wolf-Herring \\
\hline & & Chirocentrus nudus Swainson, 1839 & Whitefin Wolf-Herring \\
\hline Gonorhynchiformes & Chanidae & Chanos chanos (Forsskål, 1775) & Milkfish \\
\hline \multirow[t]{5}{*}{ Siluriformes } & Ariidae & Arius bilineatus (Valenciennes, 1840) & Roundsnout Sea Catfish \\
\hline & & Arius dussumieri Valenciennes, 1840 & Blacktip Sea Catfish \\
\hline & & Arius tenuispinis Day, 1877 & Thinspine Sea Catfish \\
\hline & & Arius thalassinus (Rüppell , 1837) & Giant Sea Catfish \\
\hline & Plotosidae & Plotosus lineatus (Thunberg, 1787) & Striped Eel Catfish \\
\hline \multirow[t]{3}{*}{ Aulopiformes } & Synodontidae & Saurida undosquamis (Richardson, 1848) & Brushtooth Lizardfish \\
\hline & & Synodus variegatus (Lacepe`de, 1803) & Variegated Lizardfish \\
\hline & & Trachinocephalus myops (Forster, 1801) & Bluntnose Lizardfish \\
\hline Batrachoidiformes & Batrachoididae & Austrobatrachus dussumieri (Valenciennes, 1837) & Flat Toadfish \\
\hline Lophiiformes & Antennariidae & Antennarius nummifer (Cuvier, 1817) & Spotfin Frogfish \\
\hline \multirow[t]{2}{*}{ Atheriniformes } & Atherinidae & Atherinomorus lacunosus (Forster, 1801) & Hardyhead Silverside \\
\hline & & Hypoatherina temminckii (Bleeker, 1853) & Samoan Silverside \\
\hline \multirow[t]{9}{*}{ Beloniformes } & Belonidae & Ablennes hians (Valenciennes, 1846) & Flat Needlefish \\
\hline & & Platybelone argalus platura (Rüppell, 1837) & Keeltail Needlefish \\
\hline & & Strongylura leiura (Bleeker, 1850) & Banded Needlefish \\
\hline & & Strongylura strongylura (van Hasselt, 1823) & Spottail Needlefish \\
\hline & & Tylesurus crocodilus crocodilus (Péron \& Lesueur, 1821) & Hound Needlefish \\
\hline & & Exocoetidae Cypselurus oligolepis (Bleeker, 1866) & Largescale Flyingfish \\
\hline & & Parexocoetus mento (Valenciennes, 1846) & African Sailfin Flyingfish \\
\hline & Hemiramphidae & Hyporhamphus sindensis (Regan, 1905) & Sind Halfbeak \\
\hline & & Hemiramphus marginatus (Forsskål, 1775) & Yellowlip Halfbeak \\
\hline Cyprinodontiformes & Cyprinodontidae & Aphanius dispar (Rüppell, 1828) & Arabian Pupfish \\
\hline \multirow[t]{3}{*}{ Syngnathiformes } & Syngnathidae & Hippocampus kuda Bleeker, 1852 & Spotted Seahorse \\
\hline & & Doryrhamphus excisus excisus Kaup, 1856 & Bluestripe Pipefish \\
\hline & Fistulariidae & Fistularia petimba La CepeHde, 1803 & Red Cornetfish \\
\hline Syngnathiformes & Centriscidae & Centriscus scutatus Linnaeus, 1758 & Grooved Shrimpfish \\
\hline \multirow[t]{2}{*}{ Scorpaeniformes } & Scorpaenidae & Apistus carinatus (Bloch \& Schneider, 1801) & Ocellated Waspfish \\
\hline & & Choridactylus multibarbus Richardson, 1848 & Orangebanded Stingfish \\
\hline
\end{tabular}




\begin{tabular}{|c|c|c|c|}
\hline Order & Family & Species & Common name \\
\hline & & Minous monodactylus (Bloch \& Schneider, 1801) & Grey Stingfish \\
\hline & & Pseudosynanceia melanostigma Day, 18751 & Blackfin Stonefish \\
\hline & & Pterois miles (Bennett, 1828) & Military Turkeyfish \\
\hline & & Pterois russellii Bennett, 1831 & Plaintail Turkeyfish \\
\hline & & Scorpaenopsis barbatus (Rüppell, 1838) & Bearded Scorpionfish \\
\hline \multirow[t]{25}{*}{ Perciformes } & Platycephalidae & Platycephalus indicus (Linnaeus, 1758) & Bartail Flathead \\
\hline & & Rogadius tuberculatus (Cuvier, 1829) & Tuberculated Flathead \\
\hline & & Thysanophrys celebicus (Bleeker, 1854) & Sulawesi Flathead \\
\hline & Serranidae & Cephalopholis hemistiktos (Rüppell, 1830) & Yellowfin Hind \\
\hline & & Epinephelus areolatus (Forsskål, 1775) & Areolate Grouper \\
\hline & & Epinephelus caeruleopunctatus (Bloch, 1790) & Whitespotted Grouper \\
\hline & & Epinephelus coioides (Hamilton, 1822) & Orangespotted Grouper \\
\hline & & Epinephelus latifasciatus (Temminck \& Schlegel, 1842) & Striped Grouper \\
\hline & & Epinephelus multinotatus (Peters, 1876) & Whiteblotched Grouper \\
\hline & & Epinephelus polylepis Randall \& Heemstra, 1991 & Smallscale Grouper \\
\hline & Pseudochromidae & Pseudochromis aldabraensis (Bauchot-Boutin, 1958) & Orange Dottyback \\
\hline & & Pseudochromis persicus Murry, 1887 & Persian Dottyback \\
\hline & Priacanthidae & Priacanthus tayenus Richardson, 1846 & Purple Spotted Bigeye \\
\hline & Teraponidae & Pelates quadrilineatus (Bloch, 1790) & Fourlined Terapon \\
\hline & & Terapon jarbua (Forsskål, 1775) & Jarbua Terapon \\
\hline & & Terapon puta (Cuvier \& Valenciennes, 1829) & Smallscaled Terapon \\
\hline & & Terapon theraps (Cuvier \& Valenciennes, 1829) & Largescaled Terapon \\
\hline & Apogonidae & Apogon coccineus Rüppell, 1838 & Ruby Cardinalfish \\
\hline & & Apogon cyanosoma Bleeker, 1853 & Yellowstriped Cardinalfish \\
\hline & & Apogon fasciatus (Shaw, 1790) & Twostripe Cardinalfish \\
\hline & & Apogon taeniatus Cuvier, 1828 & Striped Cardinalfish \\
\hline & & Cheilodipterus persicus Gon 1993 & Persian Cardinalfish \\
\hline & Sillaginidae & Sillago sihama (Forsskål, 1775) & Silver Sillago \\
\hline & Lactariidae & Lactarius lactarius (Bloch \& Schneider, 1801) & False Trevally \\
\hline & Rachycentridae & Rachycentron canadum (Linnaeus, 1766) & Cobia \\
\hline \multirow[t]{3}{*}{ Perciformes } & Echeneidae & Echeneis naucrates Linnaeus, 1758 & Live Sharksucker \\
\hline & Carangidae & Alectis indicus ( Rüppell, 1830) & Indian Threadfish \\
\hline & & Alepes Kleinii (Bloch, 1793) & Sharpbelly Scad \\
\hline
\end{tabular}




\begin{tabular}{|c|c|c|c|}
\hline Order & Family & Species & Common name \\
\hline & & Alepes djedaba (Forsskål, 1775) & Shrimp Scad \\
\hline & & Alepes melanoptera Swainson, 1839 & Blackfin Scad \\
\hline & & Alepes vari (Cuvier, 1833) & Herring Scad \\
\hline & & Atropus atropos (Bloch \& Schneider, 1801) & Cleftbelly Trevally \\
\hline & & Atule mate (Cuvier, 1833) & Yellowtail Scad \\
\hline & & Carangoides bajad (Forsskål, 1775) & Orangespotted Trevally \\
\hline & & Carangoides caeruleopinnatus (Rüppell, 1830) & Coastal Trevally \\
\hline & & Carangoides chrysophrys (Cuvier, 1833) & Longnose Trevally \\
\hline & & Carangoides ferdau (Forsskål, 1775) & Blue Trevally \\
\hline & & Carangoides fulvoguttatus (Forsskål, 1775) & Yellowspotted Trevally \\
\hline & & Carangoides gymnostethus (Cuvier, 1833) & Bludger \\
\hline & & Carangoides malabaricus (Bloch \& Schneider, 1801) & Malabar Trevally \\
\hline & & Carangoides praeustus (Bennett, 1830) & Brownback Trevally \\
\hline & & Caranx sexfasciatus Quoy \& Gaimard, 1825 & Bigeye Trevally \\
\hline & & Decapterus russelli ( Rüppell, 1830) & Indian Scad \\
\hline & & Gnathanodon speciosus (Forsskål, 1775) & Golden Trevally \\
\hline & & Megalaspis cordyla (Linnaeus, 1758) & Torpedo Scad \\
\hline & & Naucrates ductor (Linnaeus, 1758) & Pilotfish \\
\hline & & Parastromateus niger (Bloch, 1795) & Black Pomfret \\
\hline & & Scomberoides commersonnianus Lacepe`de, 1801 & Talang Queenfish \\
\hline & & Scomberoides lysan (Forsskål, 1775) & Doublespotted Queenfish \\
\hline & & Scomberoides tol (Cuvier, 1832) & Needlescaled Queenfish \\
\hline & & Selar crumenophthalmus (Bloch, 1793) & Bigeye Scad \\
\hline & & Selaroides leptolepis (Cuvier, 1833) & Yellowstripe Scad \\
\hline & & Seriola dumerili (Risso, 1810) & Greater Amberjack \\
\hline & & Seriolina nigrofasciata (Rüppell, 1829) & Blackbanded Trevally \\
\hline & & Trachinotus blochii (Lacepe'de, 1801) & Snubnose Pompano \\
\hline & & Trachurus indicus Nekrasov, 1966 & Arabian Scad \\
\hline & Carangidae & Ulua mentalis (Cuvier, 1833) & Longrakered Trevally \\
\hline & & Uraspis helvola (Foster, 1801) & Whitetongue Jack \\
\hline & Coryphaenidae & Coryphaena hippurus Linnaeus, 1758 & Common Dolphinfish \\
\hline & Menidae & Mene maculata (Bloch \& Schneider, 1801) & Moonfish \\
\hline & Leiognathidae & Leiognathus bindus (Valenciennes, 1835) & Orangefin Ponyfish \\
\hline
\end{tabular}




\begin{tabular}{|c|c|c|c|}
\hline Order & Family & Species & Common name \\
\hline & & Leiognathus decorus De Vis, 1884 & Decorated Ponyfish \\
\hline & & Leiognathus equulus (Forsskasl, 1775) & Common Ponyfish \\
\hline & & Leiognathus oblongus (Valenciennes, 1835) & Oblong Ponyfish \\
\hline & & Secutor insidiator (Bloch, 1787) & Pugnose Ponyfish \\
\hline & Lutjanidae & Lutjanus argentimaculatus (Forsskål, 1775) & Mangrove Red Snapper \\
\hline & & Lutjanus ehrenbergi (Peters, 1869) & Ehrenberg's Snapper \\
\hline & & Lutjanus fulviflamma (Forsskål, 1775) & Blackspot Snapper \\
\hline & & Lutjanus johnii (Bloch, 1792) & John's Snapper \\
\hline & & Lutjanus lutjanus Bloch, 1790 & Bigeye Snapper \\
\hline & & Lutjanus malabaricus Bloch \& Schneider, 1801 & Malabar Blood Snapper \\
\hline & & Lutjanus quinquelineatus Bloch, 1790 & Fivelined Snapper \\
\hline & & Lutjanus russelli (Bleeker, 1849) & Russell's Snapper \\
\hline & & Pinjalo pinjalo (Bleeker, 1850) & Pinjalo \\
\hline & Caesionidae & Caesio lunaris Cuvier, 1830 & Lunar Fusilier \\
\hline & & Caesio varilineata Carpenter, 1987 & Variablelined Fusilier \\
\hline & Lobotidae & Lobotes surinamensis (Bloch, 1790) & Tripletail \\
\hline & Gerreidae & Gerres acinaces Bleeker, 1854 & Longtail Silver-biddy \\
\hline & & Gerres filamentosus Cuvier, 1829 & Whipfin Silver-biddy \\
\hline & & Gerres oyena (Forsskål, 1775) & Common Silver-biddy \\
\hline & Haemulidae & Diagramma pictum (Thunberg, 1792) & Painted Sweetlips \\
\hline & & Plectorhinchus gaterinus (Forsskål, 1775) & Blackspotted Rubberlip \\
\hline & & Plectorhinchus pictus (Tortonese, 1935) & Trout Sweetlips \\
\hline & & Plectorhinchus sordidus (Klunzinger, 1870) & Sordid Sweetlip \\
\hline & & Pomadasys kaakan (Cuvier, 1830) & Javelin Grunter \\
\hline & & Pomadasys maculatum (Bloch, 1797) & Saddle Grunt \\
\hline & & Pomadasys stridens (Forsskål, 1775) & Striped Piggy \\
\hline & & Pomadasys taeniatus McKay \& Randall, 1995 & Bronzestriped Grunter \\
\hline & Sparidae & Acanthopagrus berda (Forsskål, 1775) & Picnic Seabream \\
\hline & & Acanthopagrus bifasciatus (Forsskål, 1775) & Twobar Seabream \\
\hline & & Acanthopagrus latus (Houttuyn, 1782) & Yellowfin Seabream \\
\hline & & Argyrops spinifer (Forsskål, 1775) & King Soldier Bream \\
\hline & & Cheimerius nufar (Valenciennes, 1830) & Santer Seabream \\
\hline & & Crenidens crenidens (Forsskål, 1775) & Karanteen Seabream \\
\hline
\end{tabular}




\begin{tabular}{|c|c|c|c|}
\hline Order & Family & Species & Common name \\
\hline & & Diplodus sargus kotschyi (Steindachner, 1876) & Onespot Seabream \\
\hline & & Rhabdosargus haffara (Forsskål, 1775) & Haffara Seabream \\
\hline & & Rhabdosargus sarba (Forsskål, 1775) & Goldlined Seabream \\
\hline & & Sparidentex hasta (Valenciennes, 1830) & Sobaity Seabream \\
\hline & Lethrinidae & Lethrinus borbonicus Valenciennes, 1830 & Snubnose Emperor \\
\hline & & Lethrinus lentjan (Lacepe`de, 1802) & Pinkear Emperor \\
\hline & & Lethrinus microdon Valenciennes, 1830 & Smalltooth Emperor \\
\hline & & Lethrinus nebulosus (Forsskål, 1775) & Spangled Emperor \\
\hline & Nemipteridae & Nemipterus bipunctatus (Valenciennes, 1830) & Delagoa Threadfin Bream \\
\hline & & Nemipterus japonicus (Bloch, 1791) & Japanese Threadfin \\
\hline & & Nemipterus peronii (Valenciennes, 1830) & Notched Threadfin \\
\hline & & Scolopsis bimaculatus Rüppell, 1828 & Thumbprint Monocle \\
\hline & & Scolopsis ghanam (Forsskål, 1775) & Arabian Monocle Bream \\
\hline & & Scolopsis taeniatus (Cuvier, 1830) & Blackstreaked Monocle Bream \\
\hline & & Scolopsis vosmeri (Bloch, 1792) & Whitecheek Monocle Bream \\
\hline & Polynemidae & Eleutheronema tetradactylum (Shaw, 1804) & Fourfinger Threadfin \\
\hline & & Polydactylus sextarius (Bloch \& Schneider, 1801) & Blackspot Threadfin \\
\hline & Sciaenidae & Johnius belangerii (Cuvier, 1830) & Belanger's Croaker \\
\hline & & Johnius sina (Cuvier, 1830) & Sin Croaker \\
\hline & & Otolithes ruber (Bloch \& Schneider, 1801) & Tigertooth Croaker \\
\hline & & Pennahia anea (Bloch, 1773) & Bigeye Croaker \\
\hline & & Protonibea diacantha (Lacepe`de, 1802) & Spotted Croaker \\
\hline & Mullidae & Mulloidichthys flavolineatus (Lacepe`de, 1802) & Yellowstripe Goatfish \\
\hline & & Parupeneus heptacanthus (Lacepe`de, 1801) & Cinnabar Goatfish \\
\hline & & Parupeneus margaritatus Randall \& Guézé , 1984 & Pearly Goatfish \\
\hline & & Upeneus doriae (Günther, 1869) & Gilded Goatfish \\
\hline & & Upeneus tragula (Richardson, 1845) & Freckled Goatfish \\
\hline & & Upeneus vittatus (Forsskål, 1775) & Striped Goatfish \\
\hline & Drepanidae & Drepane punctata (Linnaeus, 1758) & Spotted Sicklefish \\
\hline & Chaetodontidae & Chaetodon melapterus Guichenot, 1862 & Arabian Butterflyfish \\
\hline & & Chaetodon nigropunctatus Sauvage, 1880 & Dark Butterflyfish \\
\hline & & Heniochus acuminatus (Linnaeus, 1758) & Longfin Bannerfish \\
\hline & Pomacanthidae & Pomacanthus maculosus (Forsskål, 1775) & Yellowbar Angelfish \\
\hline
\end{tabular}




\begin{tabular}{|c|c|c|c|}
\hline Order & Family & Species & Common name \\
\hline & Pomacentridae & Abudefduf vaigiensis (Quoy \& Gaimard, 1825) & Indo-Pacific Sargeant \\
\hline & & Chromis flavaxilla Randall, 1994 & Arabian Chromis \\
\hline & & Chromis xanthopterygia Randall \& McCarthy, 1988 & Yellowfin Chromis \\
\hline & & Dascyllus trimaculatus (Rüppell, 1829) & Threespot Dascyllus \\
\hline & & Neopomacentrus sindensis (Day, 1873) & Arabian Demoiselle \\
\hline & & Pomacentrus aquilus Allen \& Randall, 1980 & Dark Damselfish \\
\hline & & Pomacentrus leptus Allen \& Randall, 1980 & Slender Damselfish \\
\hline & & Pomacentrus trichourus Playfair \& Günther, 1867 & Paletail Damselfish \\
\hline & Labridae & Halichoeres leptotaenia Randall \& Earle, 1994 & Thinstriped Wrasse \\
\hline & & Halichoeres marginatus (Rüppell, 1835) & Dusky Wrasse \\
\hline & & Halichoeres stigmaticus Randall \& Smith, 1982 & U-Spot Wrasse \\
\hline & & Labroides dimidiatus (Valenciennes, 1839) & Black-and-Blue Cleaner Wrasse \\
\hline & & Leptojulis cyanopleura (Bleeker, 1853) & Shoulderspot Wrasse \\
\hline & & Paracheilinus mccoskeri Randall \& Harmelin-Vivien, 1977 & McCosker's Wrasse \\
\hline & & Stethojulis interrupta (Bleeker, 1851) & Cutribbon Wrasse \\
\hline & & Suezichthys gracilis (Steindachner \& Döderlein, 1887) & Slender Wrasse \\
\hline & & Thalassoma lunare (Linnaeus, 1758) & Moon Wrasse \\
\hline & & Xyrichtys bimaculatus Rüppell, 1829 & Twospot Razorfish \\
\hline & Scaridae & Chlorurus sordidus (Forsskål, 1775) & Daisy Parrotfish \\
\hline & & Scarus ghobban (Forsskål, 1775) & Bluebarred Parrotfish \\
\hline & & Scarus persicus Randall \& Bruce, 1983 & Gulf Parrotfish \\
\hline & Mugilidae & Liza abu (Heckel, 1846) & Abu Mullet \\
\hline & & Liza klunzingeri (Day, 1888) & Klunzinger's Mullet \\
\hline & & Liza subviridis (Valenciennes, 1836) & Greenback Mullet \\
\hline & & Liza vaigiensis (Quay \& Gaimard, 1825) & Squaretail Mullet \\
\hline & & Mugil cephalus Linnaeus, 1758 & Flathead Mullet \\
\hline & & Valamugil seheli (Forsskål, 1775) & Bluespot Mullet \\
\hline & Opistognathidae & Opistognathus nigromarginatus ( Rüppell, 1830) & Bridled Jawfish \\
\hline & Cepolidae & Acanthochephala abreviata (Valenciennes, 1834) & Yellowspotted Bandfish \\
\hline & Pinguipedidae & Parapercis nebulosa Quay \& Gaimard 1825 & Barfaced Sandsmelt \\
\hline & & Parapercis robinsoni Fowler, 1932 & Smallscale Sandperch \\
\hline & Tripterygiidae & Enneapterygius ventermaculus Holleman, 1982 & Blotched Triplefin \\
\hline & Blenniidae & Antennablennius adenensis Fraser-Brunner, 1951 & Aden Blenny \\
\hline
\end{tabular}




\begin{tabular}{|c|c|c|c|}
\hline Order & Family & Species & Common name \\
\hline & & Antennablennius variopunctatus (Jatzow \& Lenz, 1898) & Orangedotted Blenny \\
\hline & & Escenius pulcher (Murry, 1887) & Gulf Blenny \\
\hline & & Mimoblennius cirrosus Smith-Vaniz \& Springer, 1971 & Fringed Blenny \\
\hline & & Omobranchus fasciolatus (Valenciennes, 1836) & Barred Arab Blenny \\
\hline & & Omobranchus punctatus (Valenciennes, 1836) & Muzzled Blenny \\
\hline & & Parablennius opercularis (Murray, 1887) & Cheekspot Blenny \\
\hline & & Petroscirtes ancylodon (Rüppell, 1838) & Arabian Fangblenny \\
\hline & Callionymidae & Callionymus filamentosus Valenciennes, 1837 & Filamentous Dragonet \\
\hline & & Acentrogobius cyanomos (Bleeker, 1849) & goby (no common name) \\
\hline & Gobiidae & Acentrogobius dayi Koumans, 1944 & Day's Goby \\
\hline & & Amblyeleotris diagonalis Polunin \& Lubbock, 1979 & Slantbar Shrimpgoby \\
\hline & & Amblyeleotris downingi Randall, 1994 & Downing's Shrimpgoby \\
\hline & & Amblyeleotris periophthalma (Bleeker, 1853) & Blotchy Shrimpgoby \\
\hline & & Amblygobius albimaculatus (Rüppell, 1830) & Tailspot Goby \\
\hline & & Amblygobius nocturnus (Herre, 1945) & Orangestriped Goby \\
\hline & & Apocryptodon madurensis (Bleeker, 1849) & Minature Mudskipper \\
\hline & & Asterropteryx semipunctatus (Rüppell, 1830) & Halfspotted Goby \\
\hline & & Bathygobius fuscus (Rüppell, 1830) & Dusky Frillgoby \\
\hline & & Boleophthalmus dussumieri Valenciennes, 1837 & Dussumier's Mudskipper \\
\hline & & Coryogalops monospilus Randall, 1994 & Onespot Goby \\
\hline & & Cryptocentrus filifer (Valenciennes, 1837) & Gafftopsail Shrimpgoby \\
\hline & & Cryptocentrus lutheri (Klausewitz, 1960) & Luther's Prawngoby \\
\hline & & Eviota pardalota Lachner \& Karnella, 1978 & Leopard Dwarfgoby \\
\hline & & Eviota sebreei Jordan \& Seale, 1906 & Redstripe Dwarfgoby \\
\hline & & Gnatholepis anjerensis (Bleeker, 1850) & Anjer Goby \\
\hline & & Gobiodon reticulatus Playfair \& Günther, 1867 & Reticulated Coral Goby \\
\hline & & Istigobius decoratus (Herre, 1927) & Decorated Goby \\
\hline & & Istigobius ornatus (Rüppell, 1830) & Ornate Goby \\
\hline & & Parachaeturichthys polynema (Bleeker, 1853) & Taileyed Goby \\
\hline & & Periophthalmus waltoni Koumans, 1941 & Walton's Mudskipper \\
\hline & & Scartelaos tenuis (Day, 1876) & Indian Ocean Slender Mudskipper \\
\hline & & Trimma winterbottomi Randall \& Downing, 1994 & Winterbottom's Goby \\
\hline & & Valenciennea persica Hoese \& Larson, 1994 & Gulf Goby \\
\hline
\end{tabular}




\begin{tabular}{|c|c|c|c|}
\hline \multirow[t]{2}{*}{ Order } & Family & Species & Common name \\
\hline & & Valenciennea sexguttata (Valenciennes, 1837) & Sixspot Goby \\
\hline & Microdesmidae & Ptereleotris arabica Randall \& Hoese, 1985 & Arabian Dartfish \\
\hline & Ephippidae & Ephippus orbis (Bloch, 1787) & Spadefish \\
\hline & & Platax teira (Forsskål, 1775) & Teira \\
\hline & Scatophagidae & Scatophagus argus (Bloch, 1788) & Spotted Scat \\
\hline & Acanthuridae & Acanthurus sohal (Forsskål, 1775) & Sohal \\
\hline & & Zebrasoma xanthurum (Blyth, 1852) & Yellowtail Surgeonfish \\
\hline & Siganidae & Siganus canaliculatus (Park, 1797) & White-spotted Spinefoot \\
\hline & & Siganus javus (Linnaeus, 1766) & Streaked Spinefoot \\
\hline & Sphyraenidae & Sphyraena barracuda (Walbaum, 1792) & Great Barracuda \\
\hline & & Sphyraena flavicauda Rüppell, 1838 & Yellowtail Barracuda \\
\hline & & Sphyraena fosteri Cuvier, 1829 & Bigeye Barracuda \\
\hline & & Sphyraena jello Cuvier, 1829 & Pickhandle Barracuda \\
\hline & & Sphyraena obtusata Cuvier, 1829 & Obtuse Barracuda \\
\hline & & Sphyraena putnamiae Jordan \& Seale, 1905 & Sawtooth Barracuda \\
\hline & & Sphyraena qenie Klunzinger, 1870 & Blacktail Barracuda \\
\hline & Trichiuridae & Eupleurogrammus glossodon (Bleeker, 1860) & Longtooth Hairtail \\
\hline & & Eupleurogrammus muticus (Gray, 1831) & Smallhead Hairtail \\
\hline & & Trichiurus lepturus Linnaeus, 1758 & Largehead Hairtail \\
\hline & Scombridae & Euthynnus affinis (Cantor, 1849) & Kawakawa \\
\hline & & Rastrelliger kanagurta (Cuvier, 1817) & Indian Mackerel \\
\hline & & Scomberomorus commerson (Lacepe'de, 1801) & Narrowbarred Spanish Mackerel \\
\hline & & Scomberomorus guttatus (Bloch \& Schneider, 1801) & Indo-Pacific King Mackerel \\
\hline & & Thunnus albacares (Bonnaterre, 1788) & Yellowfin Tuna \\
\hline & Stromateidae & Pampus argenteus (Euphrasen, 1788) & Silver Pomfret \\
\hline Pleuronectiformes & Psettodidae & Psettodes erumei (Bloch \& Schneider, 1801) & Indian Spiny Turbot \\
\hline & Bothidae & Bothus pantherinus (Rüppell, 1828) & Leopard Flounder \\
\hline & Paralichthyidae & Pseudorhombus arsius (Hamilton, 1822) & Largetooth Flounder \\
\hline & & Pseudorhombus elevatus Ogilby, 1912 & Deep Flounder \\
\hline & & Pseudorhombus javanicus (Bleeker, 1853) & Javan Flounder \\
\hline & & Pseudorhombus malayanus Bleeker, 1866 & Malayan Flounder \\
\hline & Cynoglossidae & Cynoglossus arel (Bloch \& Schneider, 1801) & Largescale Tonguesole \\
\hline & & Cynoglossus carpentieri Alcock, 1889 & Hooked Tonguesole \\
\hline
\end{tabular}




\begin{tabular}{|c|c|c|c|}
\hline Order & Family & Species & Common name \\
\hline & & Pararplagusia bilineata (Bloch, 1787) & Doublelined Tonguesole \\
\hline & Soleidae & Euryglossa orientalis (Bloch \& Schneider, 1801) & Oriental Sole \\
\hline & & Pardachirus marmoratus (Lacepe`de, 1802) & Finless Sole \\
\hline & & Solea elongata Day, 1877 & Elongate Sole \\
\hline & & Synaptura commersoniana (Lacepe`de, 1802) & Commonson's Sole \\
\hline & & Zebrias synapturoides (Jenkins, 1910) & Indian Zebra Sole \\
\hline \multirow[t]{15}{*}{ Tetraodontiformes } & Triacanthidae & Pseudotriacanthus strigilifer (Cantor, 1849) & Longspine Tripodfish \\
\hline & & Triacanthus biaculeatus (Bloch, 1786) & Shortnose Tripodfish \\
\hline & Balistidae & Abalistes stellatus (La CepeHde, 1798) & Starry Triggerfish \\
\hline & & Rhinecanthus assasi (Forsskål, 1775) & Picasso Triggerfish \\
\hline & & Sufflamen chrysopterus (Bloch \& Schneider, 1801) & Flagtail Triggerfish \\
\hline & Monacanthidae & Aluterus monoceros (Linnaeus, 1758) & Unicorn Leathersacket \\
\hline & & Stephanolepis diaspros Fraser-Brunner, 1940 & Reticulated Leathersacket \\
\hline & & Ostracion cubicus Linnaeus, 1758 & Yellow Trunkfish \\
\hline & Ostraciidae & Ostracion cyanurus Rüppell, 1828 & Bluetail Trunkfish \\
\hline & Tetraodontidae & Arothron stellatus (Bloch \& Schneider, 1801) & Stellate Puffer \\
\hline & & Chelonodon patoca (Hamilton, 1822) & Milkspotted Puffer \\
\hline & & Lagocephalus lunaris (Bloch \& Schneider, 1801) & Lunartail Puffer \\
\hline & & Lagocephalus sceleratus (Gmelin, 1788) & Elongate Puffer \\
\hline & Molidae & Mola mola (Linnaeus, 1841) & Ocean Sunfish \\
\hline & & Ranzania laevis (Pennant, 1776) & Slender Sunfish \\
\hline
\end{tabular}




\section{Annex 3}

\section{Coleopterans reported from Kuwait.}

\begin{tabular}{|c|c|}
\hline Family & Species \\
\hline \multirow[t]{2}{*}{ Anobiidae } & Lasioderma serricorne (Fabricius, 1792) \\
\hline & Stegobium paniceum (Linnaeus, 1758) \\
\hline \multirow[t]{2}{*}{ Anthicidae } & Anthicus formicarius (Goeze, 1777) \\
\hline & Stricticomus goebeli (Laferte, 1848) cited as Anthicus goebeli by Al-Houty (2011) \\
\hline \multirow[t]{4}{*}{ Bruchidae } & Bruchus lentis Forlich, 1799 \\
\hline & Callosobruchus maculatus (Fabricius, 1775) \\
\hline & Callosobruchus phaseoli (Gyllenhal, 1833) \\
\hline & Caryedon serratus (Olivier, 1790) \\
\hline \multirow[t]{2}{*}{ Buprestidae } & Steraspis speciosa Klug, 1829 \\
\hline & Julodis distincta Gory, 1840 \\
\hline \multirow[t]{17}{*}{ Carabidae } & $\begin{array}{l}\text { Acinopus megacephalus (P. Rossi, 1794) cited as Actinopus megacephalus } \\
\text { by Al-Houty (2011) }\end{array}$ \\
\hline & Anchomenus dorsalis (Pontoppidan, 1763) \\
\hline & Amara glenni (Baliani, 1934) \\
\hline & Amara rufescens (Dejean, 1829) \\
\hline & Anthia duodecimguttata Bonelli, 1813 \\
\hline & Bembidion saxatile Gyllenhal 1827 \\
\hline & Calosoma (Caminara) imbricatum deserticola Semenov, 1897 \\
\hline & Calosoma olivieri Dejean, 1831 \\
\hline & Chlaenius koenigi Semjonoff, 1888 \\
\hline & Cymbionotum semelederi (Chaudoir, 1861) \\
\hline & Cymindis andreae Menetries, 1831 \\
\hline & Cymindis suturalis Dejean 1825 \\
\hline & Daptus acutus Reitter, 1893 \\
\hline & Daptus vittatus Fischer, 1824 \\
\hline & Diodercarus arrowi Lutshnik, 1931 \\
\hline & Dyschirius beludscha Tschitscherine, 1904 \\
\hline & Egaploa crenulata (Dejean, 1829) \\
\hline
\end{tabular}




\begin{tabular}{|c|c|}
\hline \multirow[t]{9}{*}{ Family } & Species \\
\hline & Graphipterus minutus Dejean, 1822 \\
\hline & Heteracantha depressa Brulle, 1834 \\
\hline & Hypaetha singularis (Chaudoir, 1876) \\
\hline & Megacephala euphratica Dejean, 1822 \\
\hline & Metabletus fuscomaculatus (Motschulsky, 1844) \\
\hline & Poecilus (Ancholeus) wollastoni (Wollaston, 1854) \\
\hline & Pogonus gilvipes Dejean, 1828 \\
\hline & Sphodrus leucophthalmus (Linnaeus, 1758) \\
\hline Chrysomalidae & Colaphellus apicalis Ménétriés, 1849 \\
\hline \multirow[t]{5}{*}{ Cicindelidae } & Calomera alboguttata (Klug 1832) \\
\hline & Calomera aulica (Dejean 1831) \\
\hline & Cephalota zarudniana (Tschitscherine, 1903) \\
\hline & Cicindela littoralis Fabricius, 1787 \\
\hline & Myriochile melancholica Fabricius 1798 \\
\hline Cleridae & Necrobia rufipes (Degeer 1775) \\
\hline \multirow[t]{3}{*}{ Coccinellidae } & Coccinella undecimpunctata Reiche 1977 \\
\hline & Coccinella septemdentatus Linnaeus, 1758 \\
\hline & Henosepilachna elaterii orientalis Zimmermann, 1934 \\
\hline Cryptophagidae & Cryptophagus cellaris Scopoli 1763 \\
\hline Cucujidae & Oryzaephilus surinamensis (Linnaeus 1758) \\
\hline \multirow[t]{9}{*}{ Curculionidae } & Ammocleonus aschabadensis (Faust, 1884) \\
\hline & Ammocleonus hieroglyphicus (Olivier, 1807) \\
\hline & Hypera brunnipennis (Boheman, 1834) \\
\hline & Hypera isabellina (Boheman, 1834) \\
\hline & Hypolixus nubilosus (Boheman 1835) \\
\hline & Myllocerus arabicus Boheman, 1843. \\
\hline & Rhynchophorus ferrugineus (Olivier, 1790) \\
\hline & Sitophilus oryzae (Linnaeus 1763) \\
\hline & Sitophilus granarius (Linnaeus 1758) \\
\hline \multirow[t]{3}{*}{ Cybocephalidae } & Cybocephalus mesopotamicus Endrody-Younga 1968 \\
\hline & Cybocephalus rufifrons Reitter 1874 \\
\hline & Trachelus tabidus (Fabricius, 1775) \\
\hline Dytiscidae & Agabus conspersus (Marsham, 1802) \\
\hline
\end{tabular}




\begin{tabular}{|c|c|}
\hline \multirow[t]{2}{*}{ Family } & Species \\
\hline & Agabus solieri Aubé, 1837 \\
\hline & Coelambus inscriptus Sharp 1880 \\
\hline & Colymbetes piceus Klug, 1834 \\
\hline & Cybister lateralimarginalis (De Geer, 1774 \\
\hline & Cybister tripunctatus Castelnau 1835 \\
\hline & Eretes sticticus (Linnaeus, 1767) \\
\hline & Hydroglyphus signatellus (Klug 1834) \\
\hline & Hydrovatus sp. \\
\hline & Herophydrus musicus (Klug, 1834) \\
\hline & Hygrotus confluens (Fabricius, 1787) \\
\hline & Hygrotus enneagrammus (Ahrens, 1833) \\
\hline & Hygrotus inscriptus (Sharp, 1882) \\
\hline & Hygrotus lernaeus (Schaum, 1857) \\
\hline & Hydroporus inscitus Sharp, 1882 \\
\hline & Hydroporus planus (Fabricius, 1782) \\
\hline & Hyphoporus solieri (Aubé, 1838) \\
\hline & Laccophilus poecilus Klug, 1834 \\
\hline & Lancetes lanceolatus (Clark, 1863) \\
\hline & Nebrioporus lanceolatus (Walker, 1871) \\
\hline & Rhantus suturalis (Macleay, 1825) \\
\hline Dermestidae & Anthrenus coloratus Reitter 1881 \\
\hline & Anthrenus flavipes Le conte, 1854 \\
\hline & Attagenusfaeiatus (Thunberg, 1795) \\
\hline & Attagenus lobatus Rosenhauer, 1856 \\
\hline & Dermestes frisehii Kugelann, 1792 \\
\hline & Dermestes vulpinus Fabricius, 1781 \\
\hline & Phradonoma nobile (Reitter, 1881) \\
\hline E1ateridae & Aeoloides griseseens Germar 1927 \\
\hline & Lanelater notodonta (Latreille, 1827) \\
\hline & Trogoderma granarium Everts, 1898 \\
\hline Gyrinidae & Dineutes grandis Klug, 1834 \\
\hline & Gyrinus distinctus Aube, 1836 \\
\hline Histeridae & Carcinops -14striata (Stephens, 1835) \\
\hline
\end{tabular}




\begin{tabular}{|c|c|}
\hline \multirow[t]{8}{*}{ Family } & Species \\
\hline & Geomysaprinus goffi Ross, 1940 \\
\hline & Saprinus ehaleites (Illiger, 1807) \\
\hline & Saprinus ornatus Erichson, 1834 \\
\hline & Saprinus uvarovi Muller, 1954 \\
\hline & Saprinus (Saprinus) moyses Marseul \\
\hline & Pholioxenus mesopotamicus Olexa, \\
\hline & Paravolvulus syphax (Reitter, 1904) \\
\hline Helophoridae & Helophorus angustatus Motschulsky, 1890 \\
\hline \multirow[t]{3}{*}{ Hydraenidae } & Ochthebius notabilis Rosenhauer, 1856 \\
\hline & Ochthebius punctatus Stephens, 1829 \\
\hline & Ochthebius zugmayeri Kniz, 1909 \\
\hline \multirow[t]{16}{*}{ Hydrophilidae } & Berosus asiaticus Kuwert, 1888 \\
\hline & Berosus bispina Reiche \& Saulcy, 1856 \\
\hline & Berosus insolitus d'Orchymont, 1937 \\
\hline & Berosus spinosus Steven 1808 \\
\hline & Enochrus bicolor Fabricius 1792 \\
\hline & Enochrus ater (Kuwert, 1888) \\
\hline & Enochrus segmentinotatus (Kuwert, 1888) \\
\hline & Enochrus sinuatus d'Orchymont, 1937 \\
\hline & Enochrus ( Lumetus) politus (Küster, 1849) \\
\hline & Enochrus (Methydrus) sp.: \\
\hline & Hydrochara flavipes (Steven, 1808) \\
\hline & Hydroporus angustatus Sturm, 1835 \\
\hline & Hydrophilus aculeatus Solier 1834 \\
\hline & Paracymus relaxus Rey, 1884 \\
\hline & Paracymus aeneus (Germar, 1824) \\
\hline & Sternolophus solieri (Castelnau, 1840) \\
\hline \multirow[t]{6}{*}{ Meloidae } & Coryna dentieulata Marse 1871 \\
\hline & Croseheriehia litigiosa (Chevrolat 1838) \\
\hline & Croseheriehia nigriplantis (Klug 1845) \\
\hline & Croseheriehia sanguinolenta (Olivier 1811) \\
\hline & Croseheriehia tigrinipennis (Latreille 1823) \\
\hline & Cylindrothorax angustieollis Kaszab 1955 \\
\hline
\end{tabular}




\begin{tabular}{|c|c|}
\hline \multirow[t]{15}{*}{ Family } & Species \\
\hline & Cylindrothorax buettikeri Kaszab 1983 \\
\hline & Cylindrothorax palastinus (Kirsch 1870) \\
\hline & Decapotoma argentifera Kaszab 1969 \\
\hline & Diaphoroeera hempriehi Kaszab 1983 \\
\hline & Diaphoroeera johnsoni Kaszab 1983 \\
\hline & Lyttolydulus thiebaulti Kaszab 1983 \\
\hline & Lyttonyx bieolor (Walker 1871) \\
\hline & Meloe omanicus Kaszab 1983 \\
\hline & Mylabris brunnipes K1ug 1845 \\
\hline & Mylabris calida (Pallas 1782) \\
\hline & Mylabris elegans Olivier 1811 \\
\hline & My1abris semifasciata Pic 1895 \\
\hline & Mylabris talhouki Kaszab 1983 \\
\hline & Mylabris vigintipunctata ? \\
\hline Myceptophagidae & Typhaea stereorea (Linnaeus 1758) \\
\hline \multirow[t]{4}{*}{ Nitidulidae } & Carpophilus freemani Dobson 1956 \\
\hline & Carpophilus hemipterus (Linnaeus 1758) \\
\hline & Nitidula ciliata Erichson 1843 \\
\hline & Urophorus humeralis (Fabricius 1798) \\
\hline \multirow[t]{14}{*}{ Scarabaeidae } & Aphodius arabicus Harold 1875 \\
\hline & Aphodius assectators Balthasar 1961 \\
\hline & Aphodius klugi Schm. 1910 \\
\hline & Aphodius lividus (Olivier 1789) \\
\hline & Aphodius luciolus Klug 1845 \\
\hline & Aphodius pruinosus Reitter 1892 \\
\hline & Aphodius wollastoni Harold 1862 \\
\hline & Eremazus unistriatus Mulsant 1851 \\
\hline & Hybosorus illigeri Reiche 1853 \\
\hline & Gymnopleurus mopsus Pallas, 1781 \\
\hline & Onthophagus tripolitanus Heyden, 1890 \\
\hline & Oryctes agamemnon (Burmeister, 1847) \\
\hline & Pentodon kuwaitensis Endrödi \& Houty 1985 \\
\hline & Pentodon algerium Herbst \\
\hline
\end{tabular}




\begin{tabular}{|c|c|}
\hline \multirow[t]{13}{*}{ Family } & Species \\
\hline & Rhyssemus granosus Klug \& Erichson 1842 \\
\hline & Podalgus cuniculus Burmeister, 1847 \\
\hline & Phyllognathus excavates (Forster, 1771) \\
\hline & Polyphylla fullo (Linnaeus, 1758) \\
\hline & Mnematium silenus (Gray 1832) \\
\hline & Mnematium rotundipenne (Holdhaus, 1919) \\
\hline & Scarabaeus acuticollis Motschulsky, 1849 \\
\hline & Scarabaeus cristatus Fabricius 1775 \\
\hline & Scarabaeus irakensis Stolfa 1938 \\
\hline & Scarabaeus bannuensis Janssens, 1940 \\
\hline & Scarabaeus sacer Motschulsky 1849 \\
\hline & Tropinota squalida (Scopoli, 1783) \\
\hline Silvanidae & Oryzaephilus surinamensis (Linnaeus, 1758) \\
\hline Spercheidae & Spercheus belli babylonicus (Hebauer, 1990) \\
\hline \multirow[t]{6}{*}{ Staphylinidae } & Bledius capra Fauvel, 1875 \\
\hline & Gabronthus maritimus Motschulsky, 1858 \\
\hline & Paederus fuscipes Curtis 1826 \\
\hline & Philonthus quinquilarius (Gyllenhal 1810) \\
\hline & Philonthus irakoiraniens? \\
\hline & Scopaeus infirmus Erichson, 1840 \\
\hline \multirow[t]{13}{*}{ Tenebrionidae } & Adesmia aenescens Kuhnelt 1951 \\
\hline & Adesmia cancellata (Klug 1830) \\
\hline & Adesmia carinata Solier 1835 \\
\hline & Adesmia cothurnata Schatzmayer \& Koch 1934. \\
\hline & Adesmia lacunosa (Klug 1830) \\
\hline & Adesmia stockleini Koch 1940 \\
\hline & Akis elevata Solier 1836 \\
\hline & Alphitobius diaperinus (Panzer 1797) \\
\hline & Ammogiton buettikeri Kaszab 1979 \\
\hline & Anemia asperula Reitter 1884 \\
\hline & Anemia bidentula Fairmaire 1892 \\
\hline & Anemia brevicollis Wollaston 1864 \\
\hline & Anemia chobauti Reitter 1898 \\
\hline
\end{tabular}




\begin{tabular}{|c|c|}
\hline Family & Species \\
\hline & Anemia cornuta Pic 1898 \\
\hline & Apentanodes arabicus (Kirchsberg 1877) \\
\hline & Apentanodes buettikeri Kaszab 1979 \\
\hline & Apentanodes globosus (Reiche \& Saulcy 1857) \\
\hline & Belopus csikii Reitter 1920 \\
\hline & Blaps batesi Allard 1880 \\
\hline & Blaps kollari Seidlitz 1896 \\
\hline & Blaps mortisaga (Linnaeus 1758) \\
\hline & Blaps polychresta Forskol 1775 \\
\hline & Blaps taeniolata Ménétriése, 1832 \\
\hline & Blaps wiedemanni Solier 1848 \\
\hline & Clitobius oblongiusculus (Fairmaire 1875) \\
\hline & Crypticus maculosus Fairmaire 1870 \\
\hline & Cyphostethe ferruginea (Marseul 1867) \\
\hline & Erodius octocostatus Peyerimhoff 1907 \\
\hline & Erodius rubalkhalianus Kaszab 1981 \\
\hline & Erodius sauditus Kaszab 1981 \\
\hline & Erodius servillei Solier 1834 \\
\hline & Gedeon hierichonticus Reiche \& Saulcy 1857 \\
\hline & Gonocephalum besnardi Kaszab 1982 \\
\hline & Gonocephalum prolixum (Erichson 1843) \\
\hline & Gonocephalum setulosum (Faldermann 1837) \\
\hline & Gonocephalum simplex (Fabricius 1801) \\
\hline & Lobodera oblongopunctata Reitter 1904 \\
\hline & Mesostena arabica (Gestro 1881) \\
\hline & Mesostena puncticollis Solier 1835 \\
\hline & Mesostena rathjensi (Gebien 1938) \\
\hline & Micipsa arabica Kaszab 1981 \\
\hline & Microtelus careniceps Kaszab 1982 \\
\hline & Opatroides punctulatus Brulle 1832 \\
\hline & Oxycara buettikeri Kaszab 1979 \\
\hline & Oxycara ardoini (Kaszab 1979) \\
\hline & Paraplatyope arabica (Blair 1931) \\
\hline
\end{tabular}




\begin{tabular}{|c|c|}
\hline Family & Species \\
\hline & Pimelia ardiani Reitter 1915 \\
\hline & Pimelia arabica Klug 1830 \\
\hline & Pimelia longula Kwieton, 1981 \\
\hline & Pimelia schusteri Reitter 1915 \\
\hline & Pimelia zhenzhurist Bogatshev 1953 \\
\hline & Prionotheca coronata ovalis Ancey 1881 \\
\hline & Scaurus punticollis Solier 1836 \\
\hline & Scleron sulcatum Baudi 1876 \\
\hline & Sepidium mesopotamicum Reitter, 1914 \\
\hline & Storthocnemis saudita Koch 1965 \\
\hline & Tentyrina palmeri (Crotch 1872) \\
\hline & Tentyrina deserta Kaszab, 1981 \\
\hline & Thriptera crinita (Klug 1830) \\
\hline & Trachyderma hespida (Forskoll775) \\
\hline & Trachyderma philistina Reiche \& Saulcy 1857 \\
\hline & Trachyderma parvicollis Baudi, 1875 \\
\hline & Tribolium castaneum (Herbst 1797) \\
\hline & Tribolium confusum Jacquelin 1868 \\
\hline & Tribolium destructor Uyttenboogart 1933 \\
\hline & Trichosphaena arabica Kaszab 1961 \\
\hline & Vieta tuberculata Solier 1843 \\
\hline & Zophosis complanata Solier 1834 \\
\hline & Zophosis punctata medicoris Deyrolle 1867 \\
\hline
\end{tabular}




\section{Annex 4}

Species of suborder Heteroptera reported from Kuwait.

\begin{tabular}{|c|c|c|}
\hline Family & Common name & Species \\
\hline Aleyrodoidea & Whiteflies & Bemisia tabaci (Gennadius, 1889) \\
\hline \multirow[t]{2}{*}{ Alydidae } & broad-headed bugs & Alydus calcaratus Linnaeus 1758 \\
\hline & & Hypselopus gigas Burmeister, 1835 \\
\hline \multirow[t]{3}{*}{ Anthocoridae } & Minute pirate bugs & Xylocoris confusus Carayon 1972 \\
\hline & & Xylocoris etawahii Ghauri 1985 \\
\hline & & Xylocoris wasmiai Ghauri 1985 \\
\hline \multirow[t]{2}{*}{ Belostomatidae } & Giant water bugs & Lethocerus fakir (=Lethocerus cordofanus (Mayr, 1852) \\
\hline & & Lethocerus patruelis (Stål, 1854) \\
\hline Cimicidae & Bed bugs & Cimex lectularius Linnaeus 1758 \\
\hline \multirow[t]{4}{*}{ Coreidae } & & Arenocoris intermedius (Jakovlev, 1883) \\
\hline & & Anasa tristis (De Geer, 1773) \\
\hline & & Centrocoris volxemi (Puton, 1878) \\
\hline & & Coriomeris pallidus Reuter, 1900 \\
\hline \multirow[t]{2}{*}{ Corixidae } & Water boatman & Sigara lateralis (Leach, 1817) \\
\hline & & Heliocorisa vermiculata (Puton, 1874) \\
\hline Cydnidae & Burrower bugs & Macroscytus brunneus (Fabricius, 1803) \\
\hline \multirow[t]{11}{*}{ Lygaeidae } & Milkweed bugs & Camptocoris longicornis (Puton, 1874) \\
\hline & & Camptocera glaberrima (Walker, 1872) \\
\hline & & Cymophyes essabchana Seidenstucker, 1953 \\
\hline & & Dieuches armipes (Fabricius 1794) \\
\hline & & Emblethis gracilicornis Puton 1883 \\
\hline & & Engistus exsanguis (Stål, 1872) \\
\hline & & Geocoris acuticeps Signoret 1881 \\
\hline & & Geocoris nigriceps (=Geocoris chloroticus Puton, 1888) \\
\hline & & Geocoris phaeopterus (=Geocoris megacephalus (Rossi, 1790)) \\
\hline & & Ischnodemus caspius (Jakovlev, 1871) \\
\hline & & $\begin{array}{l}\text { Lachnesthus singalensis (=Lanchnophorus singalensis } \\
\text { (Dohrn, 1860) }\end{array}$ \\
\hline
\end{tabular}




\begin{tabular}{|c|c|c|}
\hline Family & Common name & Species \\
\hline & & Lethaeus fulvovarius Puton 1884 \\
\hline & & Nysius sp. \\
\hline & & Nysius cymoides (Spinola, 1837) \\
\hline & & Nysius senecionis (Schilling, 1829) \\
\hline & & Macropternella inermis (Fieber, 1852) \\
\hline & & Remaudiereana annulipes (Baerensprung, 1859) \\
\hline & & Spilostethus pandurus (Scopoli 1763) \\
\hline & & Spilostethus longulus (Dallas \& W.S., 1852) \\
\hline \multirow[t]{2}{*}{ Nabidae } & Damsel bugs & Nobis capsiformis (Germar 1837) \\
\hline & & Nabis viridulus Spinola, 1837 \\
\hline Nebidae & Water scorpions & Ranatra parvipes (Signoret, 1861) \\
\hline \multirow[t]{2}{*}{ Notonectida } & Backswimmers & Anisops sardeus Herrich-Schaeffer, 1849 \\
\hline & & $\begin{array}{l}\text { Notonecta marmorea Fabricius, } 1803 \\
\text { spelled as "marmorata" by Al-Houty (2011) }\end{array}$ \\
\hline \multirow[t]{8}{*}{ Miridae } & Capsid bugs & $\begin{array}{l}\text { Auchenocrepis alboscutellata Puton, } 1874 \\
\text { spelled as "Auchenocepis" by Al-Houty (2011). }\end{array}$ \\
\hline & & Campylomma unicolor Poppius, 1914. \\
\hline & & Eurystylus bellevoyei (Reuter, 1879) \\
\hline & & Reuterista desertorum (Reuter, 1900) \\
\hline & & Reuterista demeter (Linnavuori, 1974) \\
\hline & & Trigonotylus pallidicornis Reuter, 1899 \\
\hline & & Tuponia concinna (Reuter, 1875) \\
\hline & & Tuponia ninlil Linnavuori, 1984 \\
\hline Oxycarenidae & & Leptodemus minutus (Jakovlev, 1876) \\
\hline \multirow[t]{9}{*}{ Pentatomidae } & Stink bugs & Acrosternum breviceps (Jakovlev 1890.) \\
\hline & & Acrosternum millierei (Mulsant \& Rey, 1866) \\
\hline & & Carpocoris purpureipennis DeGeer 1773 \\
\hline & & Chroantha ornatula (Herrich-Schaffer 1842) \\
\hline & & Eurydema ornata (Linnaeus 1758) \\
\hline & & Eysarcoris incospicuus (Herrich-Schaffer 1844) \\
\hline & & Mecidea pallidissma Jensen-Haarup 1922 \\
\hline & & Nezara viridula (Linnaeus 1758) \\
\hline & & Tarisa subspinosa (Germar, 1839) \\
\hline
\end{tabular}




\begin{tabular}{|c|c|c|}
\hline Family & Common name & Species \\
\hline & & Ventocoris martini (Horvath 1880) \\
\hline \multirow[t]{3}{*}{ Pyrrhocoridae } & Red bugs & Pyrrhocoris apterus (Linnaeus 1758) \\
\hline & & Scantius aegyptius (Linnaeus, 1758) \\
\hline & & Scantius forsteri (Fabricius 1781) \\
\hline \multirow[t]{10}{*}{ Reduviidae } & & Coranus aegyptius (Fabricius, 1775) \\
\hline & & Coranus arenaceus Walker, 1870 \\
\hline & & Oncocephalus asiranus Miller, 1954 \\
\hline & & Lestomerus bicolor Villiers, 1948 \\
\hline & & Ectomocoris chiragra (Fabricius, 1803) \\
\hline & & Ectomocoris ululans (Rossi, 1790) \\
\hline & & Oncocephalus asiranus Miller, 1954 \\
\hline & & Reduvius annulipes (Reuter, 1881) \\
\hline & & Reduvius pallipes Klug, 1830 \\
\hline & & Vachiria natolica Stål, 1859 \\
\hline \multirow[t]{2}{*}{ Rhopalidae } & Scentless plant bugs & Leptoceraea femoralis (Horváth, 1897) \\
\hline & & Liorhyssus hyalinus (Fabricius 1794) \\
\hline \multirow[t]{2}{*}{ Stenocephalidae } & & Dicranocephalus insularis (Dallas, 1852) \\
\hline & & Dicranocephalus marginatus (Ferrari, 1874) \\
\hline Saldidae & & Saldula palustris (Douglas, 1874) \\
\hline \multirow[t]{2}{*}{ Tingidae } & & Galeatus scrophicus Saunders 1876 \\
\hline & & Monosteira alticarinata Ghauri 1965 \\
\hline Tropiduchidae & Tropiduchid planthoppers & Ommatissus binotatus Fieber, 1875 \\
\hline
\end{tabular}




\section{Annex 5}

\section{Hymenoptera reported from Kuwait.}

\begin{tabular}{|c|c|c|}
\hline Family & Common name & Species \\
\hline \multirow[t]{2}{*}{ Andrenidae } & Mining bees & Andrena savignyi Spinola 1838 \\
\hline & & Panurgus dentatus Friese, 1901 \\
\hline \multirow[t]{10}{*}{ Anthophoridae } & Digger bees & Amegilla byssina (Illeger 1806) \\
\hline & & Anthophora angolensis (Dalla Torre 1896) \\
\hline & & Anthophora spinolana Priesner 1957 \\
\hline & & Anthophora atriceps Pérez, 1879 \\
\hline & & Anthophora extricata Priesner, 1957 \\
\hline & & Eucera genovefae Vachal, 1907 \\
\hline & & Heliophila fayomensis (Priesner 1957) \\
\hline & & Icteranthidium ferrugineum (Fabricius, 1787) \\
\hline & & Synhalonia pulmila (Klug 1845) \\
\hline & & Xylocopa aestuans (Linnaeus 1758) \\
\hline Apidae & Honeybees & Apis mellifera (Linnaeus 1758) \\
\hline \multirow[t]{3}{*}{ Braconidae } & Braconid wasps & Disophrys caesa (Klug, 1835) \\
\hline & & Microbracon brevicornis (Wesmael) \\
\hline & & Aphidius picipes (Nees 1811) \\
\hline \multirow[t]{3}{*}{ Chrysididae } & Cuckoo wasps & Stilbum cyanurum (Forster 1771) \\
\hline & & Stilbum pici Buysson 1891 \\
\hline & & Stilbum splendidum (Fabricius, 1775) \\
\hline \multirow[t]{3}{*}{ Halictidae } & Sweat bees & Halictus variipes Morowitz 1876 \\
\hline & & Nomioides variegata (Olivier 1789) \\
\hline & & Pseudapsis nilotica (Smith 1875) \\
\hline \multirow[t]{2}{*}{ Eumenidae } & Mason wasps & Delta campaniforme (Saussure 1852) \\
\hline & & Delta dimidatipenne (Saussure 1852 \\
\hline \multirow[t]{2}{*}{ Evaniidae } & Hatchet wasps & Evania appendigaster Linnaeus 1758 \\
\hline & & Pimpla raborator?? \\
\hline \multirow[t]{2}{*}{ Formicidae } & Ants & Camponotus aegyptiacus Emery, 1915 \\
\hline & & Camponotus fellah_Dalla Torre, 1893 \\
\hline
\end{tabular}




\begin{tabular}{|c|c|c|}
\hline \multirow[t]{34}{*}{ Family } & Common name & Species \\
\hline & & Cataglyphis niger (Andre 1882) \\
\hline & & Camponotus xerxes Forel 1904 \\
\hline & & Camponotus sericeus (Fabricius, 1798) \\
\hline & & Camponotus thoracicus (Fabricius, 1804) \\
\hline & & Cardiocondyla shuckardi Forel, 1891 \\
\hline & & Cataglyphis diehli (Forel, 1902) \\
\hline & & Cataglyphis holgerseni n. sp. \\
\hline & & Cataglyphis lividus (Andre, 1881) \\
\hline & & Cataglyphis niger (Andre, 1881) \\
\hline & & Crematogaster antaris Forel, 1894 \\
\hline & & Lepisiota karawajewi (Agosti \& Collingwood, 1987) \\
\hline & & Messor aralocaspius (Ruzsky, 1902) \\
\hline & & Messor arenarius (Fabricius, 1787) \\
\hline & & Messor buettikeri Collingwood, 1985 \\
\hline & & Messor ebeninus Santschi, 1927 \\
\hline & & Messor medioruber Santschi, 1910 \\
\hline & & Messor meridionalis (Andre, 1883) \\
\hline & & Messor minor (André, 1883) \\
\hline & & Messor picturatus Santschi, 1927 \\
\hline & & Messor striaticeps (Andre, 1883) \\
\hline & & Monomorium abeillei Andre, 1881 \\
\hline & & Monomorium areniphilum Santschi, 1911 \\
\hline & & Monomorium buettikeri \\
\hline & & Monomorium buxtoni Crawley, 1920 \\
\hline & & Monomorium destructor (Jerdon, 1851) \\
\hline & & Monomorium hemame Collingwood \& Agosti, 1996 \\
\hline & & Monomorium venustum (Smith, 1858) \\
\hline & & Monomorium nitidiventre Emery, 1893 \\
\hline & & Monomorium salomonis (Linnaeus, 1758) \\
\hline & & Monomorium gracillimum (Smith 1861) \\
\hline & & Monomorium subdenticorne \\
\hline & & Monomorium pharaonsis (Linnaeus 1758) \\
\hline & & Monomorium subcomae Lush, 2008 \\
\hline
\end{tabular}




\begin{tabular}{|c|c|c|}
\hline \multirow[t]{8}{*}{ Family } & Common name & Species \\
\hline & & Pheidole teneriffana Forel, 1893 \\
\hline & & Pheidole megacephala (Fabricius, 1793) \\
\hline & & Tetramorium biskrense Forel, 1904 \\
\hline & & Tetramorium juba Collingwood, 1985 \\
\hline & & Tetramorium sericeiventre Emery, 1877 \\
\hline & & Tapinoma melanocephalum (Fabricius, 1793) \\
\hline & & Tapinoma simrothi Krausse, 1911 \\
\hline \multirow[t]{3}{*}{ Ichneumonidae } & Ichneumon wasps & Pimpla instigator Fabricius 1793 \\
\hline & & Simophion calvus Victorov, 1961 \\
\hline & & Tersilochus conotracheli (Riley, 1871) \\
\hline Mutillidae & Velvet ant & Tricholabiodes semistra \\
\hline \multirow[t]{2}{*}{ Pompilidae } & Spider wasps & Batazonellus lacerticida (Pallas 1771) \\
\hline & & Stolidia noscibilis (Kohl, 1906) \\
\hline Pteromalidae & & Pachyneuron aeneum Masi, 1929 \\
\hline \multirow[t]{4}{*}{ Scoliidae } & Flower wasps & Megascolia flavifrons (Fabricius 1775) \\
\hline & & Scolia flavifrons Fabricius, 1775 \\
\hline & & Scolia erythrocephala Fabricius, 1798 \\
\hline & & Campsomeriella thoracica (Fabricius, 1787) \\
\hline \multirow[t]{15}{*}{ Sphecidae } & Sphecid wasps & Ammophila rubripes Spinola 1838 \\
\hline & & Astata boops Schrank 1781 \\
\hline & & Bembix dahlbomi Handlirsch 1893 \\
\hline & & Bembix pallescens Priesner 1958 \\
\hline & & Cerceris pulchella Klug 1845 \\
\hline & & Cerceris straminea Dufour, 1854 \\
\hline & & Chlorion regale Smith 1873 \\
\hline & & Dienoplug formosus Jurine 1807 \\
\hline & & Diodontus friesci Kohl 1901 \\
\hline & & Diodontus minutus (Fabricius 1795) \\
\hline & & Diodontus oraniensis (Lepeletier, 1845) \\
\hline & & Dryudella bifasciata (Schulthess 1926) \\
\hline & & Dryudella tricolor (Vander Linden 1829) \\
\hline & & Gastrosericus waltlii Spinola 1838 \\
\hline & & Laphragogus pictus Kohl 1889 \\
\hline
\end{tabular}




\begin{tabular}{|c|c|c|}
\hline Family & Common name & Species \\
\hline & & Larra analis Fabricius 1804 \\
\hline & & Liris agilis (Smith 1856) \\
\hline & & Miscophus pardoi Andrede 1945 \\
\hline & & Oxybelus collaris Kohl 1884 \\
\hline & & Oxybelus curviscutis Arnold 1917 \\
\hline & & Oxybelus lamellatus Olivier 1811 \\
\hline & & Palarus laetus Klug 1845 \\
\hline & & Palarus saundersi Morice 1897 \\
\hline & & Parapiagetia mongolica Morawitz 1889 \\
\hline & & Parapsammophila turanica Morawitz 1890 \\
\hline & & Philanthus genalis Kohl 1891 \\
\hline & & Philanthus triangulum Fabricius 1775 \\
\hline & & Philanthus variegatus Spinola 1838 \\
\hline & & Podalonia ebenina (Spinola 1838) \\
\hline & & Podalonia minax (Kohl 190I) \\
\hline & & Padalonia tydei (Le Guillou 1841) \\
\hline & & Prionyx crudelis (Smith 1856) \\
\hline & & Prionyx niveatus (Dufour 1863) \\
\hline & & Prionyx macula (Fabricius, 1804) \\
\hline & & Sphex argentatus Fabricius 1785 \\
\hline & & Stizus marnonis Handlirsch 1829 \\
\hline & & Stizus savignyi Spinola 1838 \\
\hline & & Tachysphex grandissimus Gussakovskij 1933 \\
\hline & & Tachysphex nitidus Spinola 1805 \\
\hline Tiphiidae & Tiphiid wasps & Iswara chobauti (Andre 1898) \\
\hline \multirow[t]{3}{*}{ Vespidae } & Hornets & Pterocheilus fousti (Morawitz 1873) \\
\hline & & Vespa orientalis Linnaeus 1771 \\
\hline & & Polistes wattii Cameron, 1900 \\
\hline
\end{tabular}




\section{Annex 6}

Polychaeta species reported from Kuwait (After Al Kandari et al., 2018).

\begin{tabular}{|c|c|}
\hline Family & Species \\
\hline \multirow[t]{28}{*}{ Ampharetidae } & Isoldaalbula (Mohammad,1971) \\
\hline & Melinna cf. palmata (Grube, 1870) \\
\hline & Linopherushirsuta (Wesenberg-Lund, 1949) \\
\hline & Capitella cf. capitata (Fabricius, 1780) \\
\hline & Dasybranchuscaducus (Grube, 1846) \\
\hline & Heteromastussimilis (Southern, 1921) \\
\hline & Notomastus cf. latericeus (Sars, 1851) \\
\hline & Rashgua rubrocincta (Wesenberg-Lund, 1949) \\
\hline & Scyphoproctus aciculatus Mohammad, 1980 \\
\hline & Spiochaetopterus sp. \\
\hline & Bhawania goodei (Webster, 1884) \\
\hline & Chrysopetalum debile (Grube, 1855) \\
\hline & Aphelochaeta filiformis (Keferstein, 1862) \\
\hline & Caulleriella typhlops (Willey, 1905) \\
\hline & Cirratulus sp. \\
\hline & Cirriformia sp. \\
\hline & Dodecaceria sp. \\
\hline & Monticellina sp. \\
\hline & Tharyx sp \\
\hline & Cossura sp. \\
\hline & Schistomeringo sincerta (Schmarda, 1861) \\
\hline & Eunice sp. \\
\hline & Lysidice collaris (Grube, 1870) \\
\hline & Lysidice unicornis (Grube, 1840) \\
\hline & Marphysas anguinea (Montagu, 1813) \\
\hline & Marphysa sp. \\
\hline & Paucibranchia gemmata (Mohammad, 1973) \\
\hline & Palola siciliensis (Grube, 1840) \\
\hline
\end{tabular}




\begin{tabular}{|c|c|}
\hline Family & Species \\
\hline & Euphrosine foliosa Audouin \& H Milne (Edwards, 1833) \\
\hline & Fabricidae g. sp. \\
\hline & Glycera tridactyla (Schmarda, 1861) \\
\hline & Glycera sp \\
\hline & Glycinde bonhourei Gravier, 1904 \\
\hline & Goniada sp. \\
\hline & Goniadidae g. sp. \\
\hline & Hesione ceylonica Grube, 1874 \\
\hline & Leocrates claparedii (Costa, 1868) \\
\hline & Oxydromus angustifrons (Grube, 1878) \\
\hline & Podarkeopsis sp. New genus \\
\hline & Augeneria sp. New genus \\
\hline & Lumbrineriopsis paradoxa (Saint-Joseph, 1888) \\
\hline & Lumbrineris sp. \\
\hline & Kuwaita magna Mohammad, 1973 \\
\hline & Ninoe pulchra Wesenberg-Lund, 1949 \\
\hline & Scoletoma impatiens (Claparède, 1868) \\
\hline & Magelona cf. falcifera Mortimer and Mackie, 2003 \\
\hline & Magelona pulchella Mohammad, 1970 \\
\hline & Magelona obockensis Gravier, 1905 \\
\hline & Euclymene cf. lombricoides (Quatrefages, 1866) \\
\hline & Euclymene cf. oerstedii (Claparède, 1863) \\
\hline & Leiochone annulata (Mohammad, 1980) \\
\hline & Petaloproctus terricolus Quatrefages, 1866 \\
\hline & Aglaophamus sp. \\
\hline & Nephtystulearensis Fauvel, 1919 \\
\hline & Ceratonereismirabilis Kinberg, 1865 \\
\hline & Gymnonereis sp. New genus \\
\hline & Leonnates decipiens Fauvel, 1929 \\
\hline & Leonnates indicus Kinberg, 1865 \\
\hline & Ceratonereis (Composetia) sp. \\
\hline & Namalycastis abiuma (Grube, 1872) \\
\hline & Neanthes deplanata (Mohammad, 1971) \\
\hline
\end{tabular}




\begin{tabular}{|c|c|}
\hline Family & Species \\
\hline & Neanthes unifasciata (Willey, 1905) \\
\hline & Neanthes trifasciata (Ehlers, 1901) \\
\hline & Nereis coutieri Gravier, 1899 \\
\hline & Nereis (Nereis) neogracilis Mohammad, 1970 \\
\hline & Nereis persica Fauvel, 1911 \\
\hline & Perinereis arabica Mohammad, 1971 \\
\hline & Perinereis cultrifera (Grube, 1840) \\
\hline & Perinereis nigropunctata (Horst, 1889) \\
\hline & Perinereis nuntia (Lamarck, 1818) \\
\hline & Perinereis vancaurica (Ehlers, 1868) \\
\hline & Perinereis sp. \\
\hline & Platynereis sp. \\
\hline & Pseudonereis sp. \\
\hline & Pseudonereis anomala Gravier, 1899 \\
\hline & Simplisetia erythraeensis (Fauvel, 1918) \\
\hline & Tylonereis bogoyawlenskyi Fauvel, 1911 \\
\hline & Nerilla sp. \\
\hline & Arabella iricolor (Montagu, 1804) \\
\hline & Drilonereis sp. \\
\hline & Oenone fulgida (Savigny in Lamarck, 1818) \\
\hline & Diopatra neapolitana Delle Chiaje, 1841 \\
\hline & Onuphis sp. \\
\hline & Armandia sp. \\
\hline & Polyophtalmus pictus (Dujardin, 1839) \\
\hline & Leodamas chevalieri (Fauvel, 1902) \\
\hline & Naineris laevigata (Grube, 1855) \\
\hline & Phylo kuwaitica Mohammad, 1970 \\
\hline & Phylo kubbarensis Mohammad, 1980 \\
\hline & Scoloplos sp. \\
\hline & Owenia persica Dutrieux \& Gil, 2006 \\
\hline & Pholoe sp. \\
\hline & Aricidea sp \\
\hline & Paradoneis sp \\
\hline
\end{tabular}




\begin{tabular}{|c|c|}
\hline Family & Species \\
\hline & Pholoe sp. \\
\hline & Eulalia sp. \\
\hline & Nereiphylla castanea (Marenzeller, 1879) \\
\hline & Phyllodoce sp. \\
\hline & Sigambra sp. \\
\hline & Synelmis albini (Langerhans, 1881) \\
\hline & Pisione $s p$ \\
\hline & Poecilochaetus aff. serpens Allen, 1904 \\
\hline & Polygordius sp \\
\hline & Harmothoe dictyophora (Grube, 1878) \\
\hline & Harmothoe hirsuta Johnson, 1897 \\
\hline & Lepidonotus carinulatus (Grube, 1870) \\
\hline & Lepidonotus tenuisetosus (Gravier, 1902) \\
\hline & Malmgreniella murrayensis Pettibone, 1993. \\
\hline & Parahalosydna sp. \\
\hline & Parahalosydnopsis tubicola (Day, 1973) \\
\hline & Paralepidonotus ampulliferus (Grube, 1879) \\
\hline & Protodrilus sp \\
\hline & Sabellaria alcocki Gravier, 1906 \\
\hline & Amphiglena mediterranea (Leydig, 1851) \\
\hline & Branchiomma cingulatum (Grube, 1870) \\
\hline & Branchiomma sp. \\
\hline & Dialychone collaris (Langerhans, 1881) \\
\hline & Laonome sp. \\
\hline & Notaulax phaeotaenia (Schmarda, 1861) \\
\hline & Pseudopotamilla sp. \\
\hline & Saccocirrus sp. \\
\hline & Asclerocheilus sp. \\
\hline & Oligobregma sp. \\
\hline & Hydroides bulbosa ten Hove, 1990 \\
\hline & Hydroides elegans (Haswell, 1883) \\
\hline & Hydroides heterocera (Grube, 1868) \\
\hline & Hydroides homoceros Pixell, 1913 \\
\hline
\end{tabular}




\begin{tabular}{|c|c|}
\hline Family & Species \\
\hline & Hydroides cf. operculata (Treadwell, 1929) \\
\hline & Hydroides sp.n. \\
\hline & Protula palliata (Willey, 1905) \\
\hline & Serpula cf. concharum Langerhans, 1880 \\
\hline & Spirobranchus cf. kraussii (Baird, 1865) \\
\hline & Spirobranchus cf. tetraceros (Schmarda, 1861) \\
\hline & Vermiliopsis glandigera Gravier, 1906 \\
\hline & Sphaerodoridae g. sp. \\
\hline & Euthalenes sadigitata (Mclntosh, 1885) \\
\hline & Sthenelais boa (Johnston, 1833) \\
\hline & Aonides cf. oxycephala (Sars, 1862) \\
\hline & Dipolydora cf. capensis (Day, 1955). \\
\hline & Dipolydora cf. normalis (Day, 1957). \\
\hline & Dipolydora sp. C \\
\hline & Malacoceros indicus (Fauvel, 1928) \\
\hline & Microspio sp.. \\
\hline & Paraprionospio sp. A. \\
\hline & Paraprionospio cf. cordifolia Yokoyama, 2007. \\
\hline & Polydora aff. hoplura Claparède, 1868 \\
\hline & Polydora sp. A \\
\hline & Polydora cf. narica Light, 1969. \\
\hline & Polydora cf. haswelli Blake and Kudenov, 1978 \\
\hline & Polydora sp. C \\
\hline & Polydoraspondylana Mohammad, 1973 \\
\hline & Polydora vulgaris Mohammad, 1972 \\
\hline & Prionospio cf. krusadensis Fauvel, 1929. \\
\hline & Prionospio rotalis Mohammad, 1970 \\
\hline & Prionospio sp. 01 \\
\hline & Prionospio sp. 02 \\
\hline & Prionospio sp. 03 \\
\hline & Prionospio sp. 04 \\
\hline & Prionospio sp. 05 \\
\hline & Prionospio sp. 06 \\
\hline
\end{tabular}




\begin{tabular}{|c|c|}
\hline Family & Species \\
\hline & Pseudopolydora cf. corniculata Radashevsky \& Hsieh, 2000. \\
\hline & Pseudopolydora sp. A \\
\hline & Pseudopolydora sp. B \\
\hline & Pseudopolydora sp. C \\
\hline & Rhynchospio sp. \\
\hline & Scolelepis sp. A \\
\hline & Scolelepis sp. B \\
\hline & Scolelepis sp. C \\
\hline & Scolelepis sp. D \\
\hline & Spio sp. \\
\hline & Spionidae g. sp. \\
\hline & Sternaspis thorsoni Sendall \& Salazar-Vallejo, 2013 \\
\hline & Syllidae g. sp. \\
\hline & Loimia cf. medusa (Savigny, 1822) \\
\hline & Mesopothelepusmacrothoracicus (Mohammad, 1980) \\
\hline & Neoleprea clavata Mohammad, 1973 \\
\hline & Nicoleagra cilibranchis (Grube, 1878) \\
\hline & Polycirrus coccineus (Grube, 1870 ) \\
\hline & Pseudostreblosoma longum(Mohammad, 1973) \\
\hline & Streblosoma sp. \\
\hline & Terebella sp. \\
\hline & Thelepus japonicus Marenzeller, 1884 \\
\hline & Terebellides persiae Parapar, Moreira, Gil \& Martin, 2016 \\
\hline
\end{tabular}




\section{Annex 7}

Marine gastropods reported from Kuwait.

\begin{tabular}{|c|c|}
\hline Family & Species \\
\hline Bursidae & Bufonaria echinata (Link, 1807) \\
\hline Buccinidae & Cantharus wagneri (Anton, 1838) \\
\hline \multirow[t]{3}{*}{ Calyptraeidae } & Calyptraea pellucida (Reeve, 1859) \\
\hline & Calyptraea sp. \\
\hline & Ergaea walshi (Reeve, 1859) \\
\hline Caecidae & Caecum sp. \\
\hline \multirow[t]{2}{*}{ Cassidae } & Casmaria ponderosa (Link, 1807) \\
\hline & Semicassis bisulcata (Schubert \& J. A. Wagner, 1829) \\
\hline Conidae & Conus sp. \\
\hline \multirow[t]{6}{*}{ Cypraeidae } & Luria pulchra (Gray, 1824) \\
\hline & Mauritia grayana Schilder, 1930 \\
\hline & Naria lamarckii (J.E. Gray, 1825) \\
\hline & Naria turdus (Lamarck, 1810) \\
\hline & Palmadusta lentiginosa (J.E. Gray, 1825) \\
\hline & Purpuradusta gracilis (Gaskoin, 1849) \\
\hline \multirow[t]{5}{*}{ Cystiscidae } & Gibberula mazagonica (Melvill, 1892) \\
\hline & Gibberula sueziensis (Issel, 1869) \\
\hline & Granulina oodes (Melvill, 1898) \\
\hline & Cypraea turdus (Lamarck, 1810) \\
\hline & Granulina isseli (G. Nevill \& H. Nevill, 1875) \\
\hline \multirow[t]{3}{*}{ Drilliidae } & Drillia booleyi Melvill \& Sykes, 1897 \\
\hline & Splendrillia lucida (G. Nevill \& H. Nevill, 1875) \\
\hline & Splendrillia sp. \\
\hline Epitoniidae & Epitonium sp. \\
\hline \multirow[t]{3}{*}{ Eulimidae } & Hypermastus epiphanes (Melvill, 1897) \\
\hline & Melanella cumingi (A. Adams, 1854) \\
\hline & Melanella sp. \\
\hline Iravadiidae & Pseudonoba alphesiboei (Melvill, 1912) \\
\hline
\end{tabular}




\begin{tabular}{|c|c|}
\hline Family & Species \\
\hline & Pseudonoba columen (Melvill, 1904) \\
\hline Littorinidae & Echinolittorina arabica (El Assal, 1990) \\
\hline \multirow[t]{10}{*}{ Mangeliidae } & Agathotoma sp. 1\# \\
\hline & Citharomangelia elevata (E. A. Smith, 1884) \\
\hline & Citharomangelia townsendi (G. B. Sowerby III, 1895) \\
\hline & Eucithara edithae (Melvill \& Standen, 1901) \\
\hline & Eucithara striatella (E. A. Smith, 1884) \\
\hline & Gingicithara lyrica (Reeve, 1846) \\
\hline & Mangelia albolabiata (E. A. Smith, 1884) \\
\hline & Mangelia recta Smith, E.A., 1888 \\
\hline & Mangilia posidonia Melvill, 1904 \\
\hline & Pseudorhaphitoma phaea (Melvill \& Standen, 1901) \\
\hline \multirow[t]{16}{*}{ Muricidae } & Hexaplex kuesterianus (Tapparone-Caniferi, 1875) \\
\hline & Hexaplex rileyi (D’Attilio \& Myers, 1984) \\
\hline & Homalocantha anatomica (Perry, 1811) \\
\hline & Ergalatax contracta (Reeve, 1846) \\
\hline & Ergalatax junionae (Houart, 2008) \\
\hline & Murichorda fiscellum (Gmelin, 1791) \\
\hline & Murex carbonnieris (Jousseaume, 1881) \\
\hline & Murex scolopax Dillwyn, L.W., 1817 \\
\hline & Rapana rapiformis (Born, 1778) \\
\hline & Rapana venosa (Valenciennes, 1846) \\
\hline & Semiricinula konkanensis (Melvill, 1893) \\
\hline & Semiricinula tissoti (Petit de la Saussaye, 1852) \\
\hline & Tylothais savignyi (Deshayes, 1844) \\
\hline & Indothais lacera (Born, 1778) \\
\hline & Indothais scalaris (Schub. \& Wagr, 1829) \\
\hline & Semiricinula tissoti (Petit de la Saussaye, 1852) \\
\hline \multirow[t]{5}{*}{ Naticidae } & Glossaulax didyma (Röding, 1798) \\
\hline & Cellana rota Gmelin, 1791 \\
\hline & Eunaticina papilla (Gmelin, 1791) \\
\hline & Polinices mammilla (Linnaeus, 1758) \\
\hline & Polinices peselephanti (Link, 1807) \\
\hline
\end{tabular}




\begin{tabular}{|c|c|}
\hline \multirow[t]{2}{*}{ Family } & Species \\
\hline & Natica cincta Récluz, 1850 \\
\hline & Natica buriasiensis Récluz, 1844 \\
\hline & Neverita didyma (Röding, 1798) \\
\hline & Sigatica pomatiella (Melvill, 1893) \\
\hline & Sinum planulatum (Récluz, 1843) \\
\hline & Tanea lineata (Röding, 1798) \\
\hline \multirow[t]{6}{*}{ Ancillariidae } & Ancilla castanea (Sowerby I, 1830) \\
\hline & Ancilla farsiana (Kilburn, 1981) \\
\hline & Ancilla ovalis (G. B. Sowerby II, 1859) \\
\hline & Crenavolva traillii (A. Adams, 1855) \\
\hline & Diminovula concinna (G. B. Sowerby II in A. Adams \& Reeve, 1848) \\
\hline & Fusinus arabicus (Melvill, 1898) \\
\hline Ranellidae & Cymatium sp. \\
\hline \multirow[t]{2}{*}{ Anabathridae } & Amphithalamus alphesboei Melvill, 1912 \\
\hline & Amphithalamus microthyra von Martens, 1880 \\
\hline Omalogyridae & Omalogyra atomus (Philippi, 1850) \\
\hline \multirow[t]{10}{*}{ Rissoidae } & Hyala vitrea (Montagu, 1803) \\
\hline & Iraqirissoa xanthias (Watson, 1886)? \\
\hline & Phosinella clathrata (A. Adams, 1853) \\
\hline & Pseudonoba aristaei (Melvill, 1912) \\
\hline & Pyramidelloides mirandus (A. Adams, 1861) \\
\hline & Rissoina sp. \\
\hline & Rissoina distans (Anton, 1838) \\
\hline & Stenothyra iraqensis Dance \& Eames, 1966 \\
\hline & Stosicia annulata (Dunker, 1859) \\
\hline & Voorwindia tiberiana (Issel, 1869) \\
\hline Rissoinidae & Phosinella seguenziana (Issel, 1869) \\
\hline \multirow[t]{4}{*}{ Strombidae } & Canarium fusiforme (G. B. Sowerby II, 1842) \\
\hline & Conomurex persicus (Swainson, 1821) \\
\hline & Tibia insulaechorab Röding, 1798 \\
\hline & Terebellum terebellum (Linnaeus, 1758) \\
\hline Tonnidae & Tonnidae gen. sp. \\
\hline Terebridae & Terebra sp. \\
\hline
\end{tabular}




\begin{tabular}{|c|c|}
\hline Family & Species \\
\hline \multirow[t]{4}{*}{ Vanikoridae } & Vanikoro cancellata (Lamarck, 1822) \\
\hline & Vanikoro expansa (G.B. I Sowerby, 1842) \\
\hline & Vanikoro quoyiana A. Adams, 1854 \\
\hline & Vanikoro sp. \\
\hline Vermetidae & Serpulorbis variabilis Hadfield \& Kay, 1972 \\
\hline Xenophoridae & Xenophora corrugata (Reeve, 1842) \\
\hline Borsoniidae & Tomopleura nivea (Philippi, 1851) \\
\hline \multirow[t]{2}{*}{ Cancellariidae } & Merica melanostoma (G. B. Sowerby II, 1849) \\
\hline & Scalptia scalariformis (Lamarck, 1822) \\
\hline \multirow[t]{7}{*}{ Cerithiidae } & Bittium sp. \\
\hline & Cerithidium cerithinum (Philippi, 1849) \\
\hline & Cerithium caeruleum Sowerby, 1855 \\
\hline & Cerithium scabridum Philippi, 1848 \\
\hline & Clypeomorus bifasciata (G. B. Sowerby II, 1855) \\
\hline & Colina pinguis A. Adams, 1855 \\
\hline & Rhinoclavis kochi (Philippi, 1848) \\
\hline \multirow[t]{3}{*}{ Columbellidae } & Mitrella blanda (Sowerby, 1844) \\
\hline & Zafra selasphora (Melvill and Standen, 1901) \\
\hline & Zafra atrata (Gould, 1860) \\
\hline \multirow[t]{3}{*}{ Cerithiopsidae } & Horologica semipicta (Gould, 1861) \\
\hline & Seila sp. \\
\hline & Seila hinduorum (Melvill, 1898) \\
\hline \multirow[t]{4}{*}{ Clathurellidae } & Clathurella horneana (E. A. Smith, 1884) \\
\hline & Lienardia mighelsi Iredale \& Tomlin, 1917 \\
\hline & Nannodiella acricula (Hedley, 1922) \\
\hline & Paraclathurella koweitensis (J.C. Melvill, 1904) \\
\hline \multirow[t]{4}{*}{ Costellariidae } & Orphanopusia osiridis (Issel, 1869) \\
\hline & Vexillum malcolmense (Melvill \& Standen, 1901) \\
\hline & Costellaria sp. \\
\hline & Vexillum (Costellaria) diaconalis (Melvill \& Standen, 1903) \\
\hline \multirow[t]{3}{*}{ Dialidae } & Alaba virgata (Philippi, 1849). \\
\hline & Diala semistriata (Philippi, 1849) \\
\hline & Diala sulcifera (A. Adams, 1862) \\
\hline
\end{tabular}




\begin{tabular}{|c|c|}
\hline Family & Species \\
\hline \multirow[t]{6}{*}{ Epitoniidae } & Epitonium robillardi (Sowerby III, 1894) \\
\hline & Epitonium aculeatum (G. B. Sowerby, 1844) \\
\hline & Epitonium alatum (G. B. Sowerby II, 1844) \\
\hline & Epitonium deificum (Melvill \& Standen, 1903) \\
\hline & Epitonium simplex (Sowerby III, 1894) \\
\hline & Epitonium replicatum (G. B. Sowerby II, 1844) \\
\hline Eulimidae & Eulima gentilomiana Issel, 1869 \\
\hline Ficidae & Ficus subintermedia (d'Orbigny, 1852) \\
\hline Fasciolariidae & Fusinus townsendi (Melvill, 1899) \\
\hline Horaiclavidae & Epideira multiseriata (E. A. Smith, 1877) \\
\hline \multirow[t]{2}{*}{ Littorinidae } & Echinolittorina millegrana (Philippi, 1848) \\
\hline & Peasiella isseli (Issel, 1869) \\
\hline \multirow[t]{4}{*}{ Mitridae } & Cancilla circula (Kiener, 1838) ? \\
\hline & Neocancilla clathrus (Gmelin, 1791) \\
\hline & Quasimitra bovei (Kiener, 1838) \\
\hline & Scabricola desetangsii (Kiener, 1838) \\
\hline \multirow[t]{11}{*}{ Nassariidae } & Bullia tranquebarica (Röding, 1798) \\
\hline & Nassarius albescens (Dunker, 1846) \\
\hline & Nassarius arcularia (Linnaeus, 1758) \\
\hline & Nassarius concinnus (Powys, 1835) \\
\hline & Nassarius emilyae Moolenbeek and Dekker, 1994 \\
\hline & Nassarius frederici (Melvill and Standen, 1901) \\
\hline & Nassarius glans (Linnaeus, 1758) \\
\hline & Nassarius marmoreus (A. Adams, 1852) \\
\hline & Nassarius mammilliferus (Melvill, 1897) \\
\hline & Nassarius persicus (Martens, 1874) \\
\hline & Nassarius sp. \\
\hline \multirow[t]{2}{*}{ Planaxidae } & Macromphalus thelacme (Melvill, 1904) \\
\hline & Planaxis sulcatus (Born, 1778) \\
\hline \multirow[t]{2}{*}{ Potamididae } & Pirenella cingulata (Gmelin, 1791) \\
\hline & Pirenella conicus (de Blainville, 1829) \\
\hline Pseudomelatomidae & Epidirona multiseriata (EA Smith, 1877) \\
\hline
\end{tabular}




\begin{tabular}{|c|c|}
\hline Family & Species \\
\hline & Inquisitor griffithi \\
\hline & Inquisitor sp.1 \\
\hline \multirow[t]{6}{*}{ Raphitomidae } & Kermia foraminata (Reeve, 1845) \\
\hline & Pseudodaphnella daedala (Reeve, 1846) \\
\hline & Pseudodaphnella lemniscata (G. Nevill \& H Nevill, 1869) \\
\hline & Pseudodaphnella martensi (G. Nevill \& H. Nevill, 1875) \\
\hline & Pseudodaphnella sp. 2-1 \\
\hline & Veprecula sykesii (Melvill \& Standen, 1903) \\
\hline \multirow[t]{4}{*}{ Scaliolidae } & Finella pupoides A. Adams, 1860 \\
\hline & Finella purpureoapicata Preston, 1905 \\
\hline & Finella scabra A. Adams, 1860 \\
\hline & Scaliola arenosa A. Adams, 1862 \\
\hline \multirow[t]{2}{*}{ Terebridae } & Strioterebrum lividum (Reeve, 1860) \\
\hline & Terebra cingulifera Lamarck, 1822 \\
\hline \multirow[t]{11}{*}{ Triphoridae } & Coriophora granosa (Pease, 1871) \\
\hline & Latitriphora maxillaris (Hinds, 1843) \\
\hline & Monophorus perversus (Linnaeus, 1758) \\
\hline & Triphora acicula Issel, 1869 \\
\hline & Triphora acuta (Kiener, 1841) \\
\hline & Triphora capensis Bartsch, 1915 \\
\hline & Triphora distincta Deshayes, 1863 \\
\hline & Triphora incolumis Melvill, 1918 \\
\hline & Triphora tristoma (Blainville, 1824) \\
\hline & Viriola cingulata (A. Adams, 1854) \\
\hline & Viriola corrugata (Hinds, 1843) \\
\hline \multirow[t]{3}{*}{ Turritellidae } & Turritella fultoni Melvill, 1897 \\
\hline & Turritella aurocincta Martens, 1882 \\
\hline & Turritella torulosa Kiener, 1843 \\
\hline \multirow[t]{2}{*}{ Vermetidae } & Thylacodes arenarius (Linnaeus, 1758) \\
\hline & Vermetus sp. \\
\hline \multirow[t]{2}{*}{ Bullidae } & Bulla ampulla Linnaeus, 1758 \\
\hline & Bulla arabica (Malaquias \& Reid, 2008) \\
\hline Cylichnidae & Cylichna collyra Melvill, 1906 \\
\hline
\end{tabular}




\begin{tabular}{|c|c|}
\hline \multirow[t]{2}{*}{ Family } & Species \\
\hline & Cylichna cylindracea Pennant, 1777 \\
\hline & Cylichna sp. \\
\hline \multirow[t]{5}{*}{ Haminoeidae } & Atys pellyi (Smith, 1872) \\
\hline & Atys sp. \\
\hline & Aliculastrum cylindricum (Helbling, 1779) \\
\hline & Haminoea vitrea (A. Adams in Sowerby, 1850) \\
\hline & Haminoea sp.2-1 \\
\hline \multirow[t]{3}{*}{ Scaphandridae } & Tornatina inconspicua H. Adams, 1872 \\
\hline & Tornatina persiana Smith, 1872 \\
\hline & Tornatina sp. \\
\hline \multirow[t]{2}{*}{ Neritidae } & Nerita albicilla Linnaeus, 1758 \\
\hline & Smaragdia souverbiana (Montrouzier in Souverbie \& Montrouzier, 1863) \\
\hline \multirow[t]{4}{*}{ Ellobiidae } & Allochroa bronnii (Philippi, 1846) \\
\hline & Allochroa layardi (H. \& A. Adams, 1855) \\
\hline & Ellobium sp. \\
\hline & Laemodonta monilifera (H. \& A. Adams, 1854) \\
\hline \multirow[t]{7}{*}{ Fissurellidae } & Diodora funiculata (Reeve, 1850) \\
\hline & Diodora rueppellii (G.B. Sowerby I, 1835) \\
\hline & Diodora bombyana (Swerby, 1862) \\
\hline & Diodora imbricate (Swerby, 1862) \\
\hline & Emarginula dilecta A. Adams, 1852 \\
\hline & Emarginella incisura (A. Adams, 1852) \\
\hline & Macroschisma elegans \\
\hline \multirow[t]{5}{*}{ Chromodorididae } & Goniobranchus annulatus (Eliot, 1904) \\
\hline & Chromodoris obsoleta Rüppell \& Leuckart, 1828 \\
\hline & Glossodoris cf. pallida (Rüppell \& Leuckart, 1831) \\
\hline & Hypselodoris dollfusi (Pruvot-Fol, 1933) \\
\hline & Hypselodoris maculosa (Pease, 1871) \\
\hline Discodorididae & Discodoris sp. \\
\hline \multirow[t]{4}{*}{ Dendrodorididae } & Dendrodoris maculosa \\
\hline & Dendrodoris cf. nigra (Stimpson, 1855) \\
\hline & Doriopsilla cf. miniata (Alder \& Hancock, 1864) \\
\hline & Dendrodoris fumata (Rüppell \& Leuckart, 1831) \\
\hline
\end{tabular}




\begin{tabular}{|c|c|}
\hline Family & Species \\
\hline & Dendrodoris dollfusi \\
\hline Dorididae & Sebadoris fragilis (Alder \& Hancock, 1864) \\
\hline Dotidae & Doto kya Marcus, 1961 \\
\hline Eubranchidae & Leostyletus misakiensis (Baba, 1960) \\
\hline \multirow[t]{2}{*}{ Flabellinidae } & Flabellina amabilis Hirano and Kuzirian, 1991 \\
\hline & Flabellina bicolor (Kelaart, 1858) \\
\hline Phyllidiidae & Phyllidia (Fryeria) rüeppelii Bergh, 1869 \\
\hline Polyceridae & Plocamopherus ocellatus Rüppell \& Leuckart, 1831 \\
\hline Tergipedidae & Cuthona albocrusta (MacFarland, 1966) \\
\hline Samlidae & Samla bicolor (Kelaart, 1858) \\
\hline \multirow[t]{6}{*}{ Siphonariidae } & Siphonaria asghar (Biggs, 1958) \\
\hline & Siphonaria belcheri Hanley, 1858 \\
\hline & Siphonaria carbo Hanley, 1858 \\
\hline & Siphonaria crenata (Blainville, 1827 \\
\hline & Siphonaria laciniosa (Linnaeus, 1758) \\
\hline & Siphonaria savignui Krauss, 1848 \\
\hline \multirow[t]{2}{*}{ Onchidiidae } & Peronia peronii (Cuvier, 1804) \\
\hline & Peronia verruculata (Cuvier, 1830) \\
\hline \multirow[t]{2}{*}{ Phasianellidae } & Tricolia fordiana (Pilsbry, 1888) \\
\hline & Phasianella solida (Born, 1778) \\
\hline \multirow[t]{13}{*}{ Trochidae } & Clanculus pharaonius (Linnaeus, 1758) \\
\hline & Clanculus tonnerrei (G. Nevill \& H. Nevill, 1874) \\
\hline & Conotalopia musiva (Gould, 1861) \\
\hline & Ethalia carneolata Melvill, 1897 \\
\hline & Ethminolia degregorii (Caramagna, 1888) \\
\hline & Euchelus asper (Gmelin, 1791) \\
\hline & Gibbula declivis (Forskål, 1775) \\
\hline & Monilea chiliarches Melvill, 1910 \\
\hline & Monilea solanderi (Philippi, 1851) \\
\hline & Monodonta nebulosi (Forsskål in Niebuhr, 1775) \\
\hline & Monodonta vermiculata (P. Fischer, 1874) \\
\hline & Pagodatrochus variabilis (H. Adams, 1873) \\
\hline & Perrinia stellata (A. Adams, 1864) \\
\hline
\end{tabular}




\begin{tabular}{|c|c|}
\hline \multirow[t]{12}{*}{ Family } & Species \\
\hline & Priotrochus obscurus (W. Wood, 1828) \\
\hline & Pseudominolia biangulosa (A. Adams, 1854) \\
\hline & Pseudominolia gradata (G. B. Sowerby III, 1895) \\
\hline & Stomatella auricula Lamarck, 1816 \\
\hline & Stomatella duplicata (G. B. Sowerby I, 1823) \\
\hline & Stomatella planulata (Lamarck, 1816) \\
\hline & Stomatia phymotis Helbling, 1779 \\
\hline & Trochus erithreus Brocchi, 1823 \\
\hline & Trochus fultoni Melvill, 1898 \\
\hline & Trochus scabrosus Philippi, 1850 \\
\hline & Umbonium vestiarum Linnaeus, 1758 \\
\hline \multirow[t]{3}{*}{ Turbinidae } & Lunella coronata (Gmelin, 1791) \\
\hline & Leptothyra filifer (Deshayes, 1863) \\
\hline & Turbo radiatus Gmelin, 1791 \\
\hline \multirow[t]{3}{*}{ Acteonidae } & Acteon sp. \\
\hline & Pupa affinis (A.Adams, 1855) \\
\hline & Acteon pulchrior Melvill, 1904 \\
\hline Amaltheidae & Amalthea tricostata (Gmelin, 1791) \\
\hline \multirow[t]{2}{*}{ Amathinidae } & Amathina tricarinata (Linnaeus, 1767) \\
\hline & Leucotina gratiosa Melvill, 1898 \\
\hline \multirow[t]{2}{*}{ Anatomidae } & Anatoma munieri (P. Fischer, 1862) \\
\hline & Scissurella peilei \\
\hline Aplysiidae & Aplysia cornigera G. B. Sowerby I, 1869 \\
\hline \multirow[t]{3}{*}{ Architectonicidae } & Architectonica sp. \\
\hline & Heliacus sp. \\
\hline & Pseudomalaxis zanclaeus (Philippi, 1844) \\
\hline \multirow[t]{2}{*}{ Chilodontaidae } & Vaceuchelus foveolatus (A. Adams, 1853) \\
\hline & Granata sulcifera (Lamarck, 1822) \\
\hline Limapontiidae & Placida daguilarensis Jensen, 1990 \\
\hline \multirow[t]{4}{*}{ Liotiidae } & Circulus novemcarinatus (Melvill, 1906) \\
\hline & Cyclostrema ocrinium Melvill \& Standen, 1901 \\
\hline & Cyclostrema quadricarinatum Melvill \& Standen, 1901 \\
\hline & Cyclostrema solariellum Melvill, 1893 \\
\hline
\end{tabular}




\begin{tabular}{|c|c|}
\hline Family & Species \\
\hline \multirow[t]{3}{*}{ Phenacolepadidae } & Phenacolepas arabica Thiele, 1909 \\
\hline & Phenacolepas evansi Biggs, 1973 \\
\hline & Phenacolepas omanensis Biggs, 1973 \\
\hline \multirow[t]{23}{*}{ Pyramidellidae } & Chrysallida edgari (Melvill, 1899) \\
\hline & Chrysallida sp. 5-1 \\
\hline & Egilina callista (Melvill, 1893) \\
\hline & Kleinella amaena A. Adams, 1853 \\
\hline & Miralda sp. 1 \\
\hline & Odostomia eutropia Melvill, 1899 \\
\hline & Odostomia major (Melvill \& Standen, 1901) \\
\hline & Odostomia sp. 1 \\
\hline & Orinella sp. 1 \\
\hline & Oscilla faceta Melvill, 1904 \\
\hline & Oscilla sp. 1 \\
\hline & Pyramidella mitralis A. Adams, 1855 \\
\hline & Pyramidella sp. \\
\hline & Rissosyrnola aclis (A. Adams, 1853) \\
\hline & Syrnola aclys (A. Adams, 1854) \\
\hline & Syrnola brunnea (A. Adams, 1854) \\
\hline & Syrnola mekranica Melvill \& Standen, 1901 \\
\hline & Syrnola sp. 1 \\
\hline & Turbonilla colpodes Melvill, 1910 \\
\hline & Turbonilla icela Melvill, 1910 \\
\hline & Turbonilla sp. 2-1 \\
\hline & Turbonilla linjaica (Melvill \& Standen, 1901) \\
\hline & Pyramidellidae gen. sp. \\
\hline \multirow[t]{4}{*}{ Terebridae } & Duplicaria duplicata (Linnaeus, 1758) \\
\hline & Duplicaria spectabilis (Hinds, 1844) \\
\hline & Euterebra fuscobasis (EA Smith, 1877) \\
\hline & Granuliterebra tricincta (EA Smith, 1877) \\
\hline Rissoellidae & Rissoella sp. 1 \\
\hline \multirow[t]{2}{*}{ Omalogyridae } & Omalogyra japonica (Habe, 1972) \\
\hline & Omalogyra sp. 1 \\
\hline
\end{tabular}




\begin{tabular}{|l|l|}
\hline \multicolumn{1}{|c|}{ Family } & \multicolumn{1}{c|}{ Species } \\
\hline Ringiculidae & Ringicula propinquans Hinds, 1844 \\
\hline & Ringicula cf. minuta (H. Adams, 1872) \\
\hline Retusidae & Retusa sp. \\
\hline & Retusa tarutana Smythe, 1979 \\
\hline & Retusa truncatula (Bruguière, 1792) \\
\hline Tornatinidae & Tornatinidae incertae sedis inconspicua (H. Adams, 1872) \\
\hline & Acteocina involuta (G. Nevill \& H. Nevill, 1871) \\
\hline & Tornatina persiana Smith, 1872 \\
\hline Cylichnidae & Cylichna pellyi \\
\hline & Cylichna sp. 1 \\
\hline
\end{tabular}




\section{Annex 8}

Bivalevs reported from Kuwait.

\begin{tabular}{|c|c|c|}
\hline Order & Family & Species \\
\hline \multirow[t]{2}{*}{ Adapedonta } & Solenidae & Solen dactylus Cosel, 1989 \\
\hline & Hiatellidae & Hiatella flaccida (Gould, 1861) \\
\hline \multirow[t]{26}{*}{ Arcida } & Arcidae & Acar abdita Oliver and Chesney, 1994 \\
\hline & & Acar plicata (Dillwyn, 1817) \\
\hline & & Anadara antiquata (Linnaeus, 1758) \\
\hline & & Anadara ehrenbergi (Dunker, 1868) \\
\hline & & Anadara secticostata (Reeve, 1844) \\
\hline & & Anadara uropigimelana (Bory de Saint-Vincent, 1827) \\
\hline & & Anadara sp. \\
\hline & & Arca sp. \\
\hline & & Barbatia trapezina (Lamarck, 1819) \\
\hline & & Barbatia amygdalumtostum (Röding, 1798) \\
\hline & & Barbatia candida (Helbling, 1779)= helblingii \\
\hline & & Barbatia foliata (Forsskål in Niebuhr, 1775) \\
\hline & & Barbatia fusca (Bruguiere, 1789) \\
\hline & & Barbatia lacerata (Bruguière, 1789) \\
\hline & & Barbatia setigera (Reeve, 1844) \\
\hline & & Barbatia trapezina (Lamarck, 1819) \\
\hline & & Barbatia sp. \\
\hline & & Mosambicarca erythraeonensis (Jonas in Philippi, 1851) \\
\hline & & Trisidos tortuosa (Linnaeus, 1758) \\
\hline & Cucullaeidae & Cucullaea petita Iredale, 1939 \\
\hline & Glycymerididae & Glycymeris livida (Reeve, 1843) \\
\hline & & Glycymeris pectunculus (Linnaeus, 1758) \\
\hline & & Glycymeris striatularis (Lamarck, 1819) \\
\hline & & Tucetona audouini Matsakuma, 1984 \\
\hline & & Tucetona guesi (Jousseaume, 1895) \\
\hline & Noetiidae & Congetia chesneyi (Oliv. \& Ches., 1994) \\
\hline
\end{tabular}




\begin{tabular}{|c|c|c|}
\hline Order & Family & Species \\
\hline & & Didimacar tenebrica (Reeve, 1844) \\
\hline & & Sheldonella lateralis (L.A. Reeve, 1844) = cafria \\
\hline \multirow[t]{5}{*}{ Carditida } & Carditidae & Beguina gubernaculum (Reeve, 1843) \\
\hline & & Carditella sp. \\
\hline & & Cardites sp. \\
\hline & & Cardites bicolor (Lamarck, 1819) \\
\hline & & Cardita ffinchi (Melvill, 1898) \\
\hline Carditida & Condylocardiidae & Carditopsis majeeda (Biggs, 1973) \\
\hline Cardiida & Solecurtidae & Solecurtus subcandidus (Sturany, 1899) \\
\hline Euheterodonta & Periplomatidae & Periploma indicum Melvill, 1898 \\
\hline \multirow[t]{17}{*}{ Galeommatida } & Galeommatidae & Amphilepida spp. \\
\hline & & Amphilepida elongata (Sowerby, 1897) \\
\hline & & Amphilepida faba (Deshayes, 1856) \\
\hline & & Galeommatidae sp. A \\
\hline & & Lepirodes ambiguus (Deshayes, 1856) \\
\hline & & Marikellia pustula (Deshayes, 1863) \\
\hline & & Scintillula cf. variabilis (Sturany, 1899) \\
\hline & & Scintilla sp. \\
\hline & & Scintilla rosea Deshayes, 1856 \\
\hline & & Scintilla layardi \\
\hline & Cardiidae & Fragum sueziense (Issel, 1869) \\
\hline & & Fulvia fragilis (Forsskål, 1775) \\
\hline & & Trachycardium assimile (Reeve, 1845) \\
\hline & & Vasticardium lacunosum (Reeve, 1845) \\
\hline & & Vasticardium rubicundum (Reeve, 1845) \\
\hline & & Vasticardium flavum (Linnaeus, 1758) \\
\hline & & Cardiidae gen. sp. \\
\hline \multirow[t]{4}{*}{ Gastrochaenida } & Gastrochaenidae & Cucurbitula cymbium (Spengler, 1783) \\
\hline & & Dufoichaena dentifera (Dufo, 1840) \\
\hline & & Gastrochaena cuneiformis (Spengler, 1783) \\
\hline & & Gastrochaena sp. \\
\hline \multirow[t]{2}{*}{ Limida } & Limidae & Limatula leptocarya (Melvill, 1898 \\
\hline & & Limaria fragilis (Gmelin, 1791) \\
\hline
\end{tabular}




\begin{tabular}{|c|c|c|}
\hline Order & Family & Species \\
\hline \multirow[t]{11}{*}{ Lucinida } & Lucinidae & Anodontia edentula (Linnaeus, 1758) \\
\hline & & Bellucina seminula \\
\hline & & Cardiolucina semperiana (Issel, 1869) \\
\hline & & Chavania erythraea (Issel, 1869) \\
\hline & & Ctena divergens (Philippi, 1850) \\
\hline & & Divalucina cumingi (A. Adams \& Angas, 1864) \\
\hline & & Euanodontia cf. ovum juv. (Reeve, 1850) \\
\hline & & Pillucina angela (Melvill, 1899) \\
\hline & & Rugalucina vietnamica (Zorina, 1978) \\
\hline & & Scabrilucina victorialis (Melvill, 1899) \\
\hline & Ungulinidae & Transkeia raveyensis (Sturany, 1899) \\
\hline \multirow[t]{22}{*}{ Mytiloida } & Mytilidae & Arcuatula japonica (Dunker, 1857) \\
\hline & & Brachidontes pharaonis (Fischer, 1870) \\
\hline & & Brachidontes variabilis (Krauss, 1848) \\
\hline & & Brachidontes sp. \\
\hline & & Botula cinnamomea (Gmelin, 1791) \\
\hline & & Gregariella coralliophaga (Gmelin, 1791) \\
\hline & & Gregariella ehrenbergi (Issel, 1869) \\
\hline & & Gregariella petagnae (Scacchi, 1832) \\
\hline & & Lithophaga robusta (Jousseaume MS in Lamy, 1919) \\
\hline & & Lithophaga teres (Philippi, 1846) \\
\hline & & Leiosolenus nasutus (Philippi, 1846) \\
\hline & & Leiosolenus peruvianus (d'Orbigny, 1846) \\
\hline & & Leiosolenus tripartitus (Jousseaume, 1894) \\
\hline & & Leiosolenus sp. \\
\hline & & Lithodomus sp. \\
\hline & & Modiolus auriculatus (Krauss, 1848) \\
\hline & & Musculista senhousia (Benson, 1842) \\
\hline & & Musculus coenobitus (Vaillant, 1865) \\
\hline & & Musculus cf. costulatus (Risso, 1826) \\
\hline & & Musculus viridulus (H. Adams, 1871) \\
\hline & & Rhomboidella vaillanti (Issel, 1869) \\
\hline & & Septifer bilocularis Linnaeus, 1758) \\
\hline
\end{tabular}




\begin{tabular}{|c|c|c|}
\hline Order & Family & Species \\
\hline Myida & Pholadidae & Aspidopholas tubigera (Valenciennes, 1846) \\
\hline \multirow[t]{5}{*}{ Nuculida } & Yoldiidae & Scissileda tropica (Melvill, 1897) \\
\hline & Nuculanidae & Ennucula layardii (A. Adams, 1856) \\
\hline & & Nucula inconspicua H. Adams, 1871 \\
\hline & & Nucula sp. \\
\hline & & Saccella brookei (Hanley, 1860) \\
\hline \multirow[t]{22}{*}{ Ostreida } & Ostreidae & Alectryonella plicatula (Gmelin, 1791) \\
\hline & & Alectryonella cf. crenulifera (Sowerby, 1871) \\
\hline & & cf. Booneostrea subucula (Lamy, 1925) \\
\hline & & cf. Nanostrea deformis (Lamarck, 1819) \\
\hline & & Lopha cristagalli (Linnaeus, 1758) \\
\hline & & Crassostrea sp. \\
\hline & & Ostrea sp. \\
\hline & & Minnivola pyxidata (Born, 1778) \\
\hline & & Saccostrea cucullata (Born, 1778) \\
\hline & Gryphaeidae & Hyotissa hyotis (Linnaeus, 1758) \\
\hline & Malleidae & Malleus anatinus (Gmelin, 1791) \\
\hline & & Malleus regula (Forsskål in Niebuhr, 1775) \\
\hline & & Malleus sp. \\
\hline & Pinnidae & Pinna bicolor Gmelin, 1791 \\
\hline & & Pinna muricata Linnaeus, 1758 \\
\hline & Isognomonidae & Isognomon legumen (Gmelin, 1791) \\
\hline & & Isognomon nucleus (Lamarck, 1819) \\
\hline & Pteriidae & Pinctada margarinifera (Linnaeus, 1758) \\
\hline & & Parviperna dentifera \\
\hline & & Pinctada radiata (Leach, 1814) \\
\hline & & Pteria hirundo (Linnaeus, 1758) \\
\hline & & Pteria tortirostris (Dunker, 1849) \\
\hline \multirow[t]{5}{*}{ Pectinida } & Pectinidae & Azumapecten ruschenbergerii (Tryon, 1869) \\
\hline & & Chlamys livida (Lamarck, 1819) \\
\hline & & Mimachlamys crassicostata (Sowerby II, 1842) \\
\hline & & Mimachlamys sanguinea (Linnaeus, 1758) \\
\hline & Plicatulidae & Plicatula complanata (Deshayes in Maillard, 1863) \\
\hline
\end{tabular}




\begin{tabular}{|c|c|c|}
\hline \multirow[t]{9}{*}{ Order } & Family & Species \\
\hline & Placunidae & Placuna placenta (Linnaeus, 1758) \\
\hline & Spondylidae & Plicatula plicata (Linnaeus, 1767) \\
\hline & & Spondylus gaederopus Linnaeus, 1758 \\
\hline & & Spondylus nicobaricus Schreibers, 1793 \\
\hline & & Spondylus marisrubri Röding, 1798 \\
\hline & & Spondylus spinosus Schreibers, 1793 \\
\hline & & Spondylus variegatus Schreibers, 1793 \\
\hline & Yoldiidae & Scissileda nicobarica (Bruguière, 1789) \\
\hline \multirow[t]{25}{*}{ Venerida } & Veneridae & Callista florida (Lamarck, 1818) \\
\hline & & Callista umbonella (Lamarck, 1818) \\
\hline & & Circe scripta (Linnaeus, 1758) \\
\hline & & Circenita callipyga (Born, 1778) \\
\hline & & Clementia papyracea (Gray, 1825) \\
\hline & & Dosinia alta (Dunker, 1849) \\
\hline & & Dosinia erythraea Römer, 1860 \\
\hline & & Dosinia contracta (Philippi, 1844) \\
\hline & & Dosinia sp. \\
\hline & & Dosinella caelata (Reeve, 1850) \\
\hline & & Gafrarium pectinatum (Linnaeus, 1758) \\
\hline & & Gouldiopa consternans (Oliver \& Zuschin, 2001) \\
\hline & & Irus macrophylla (Deshayes, 1853) \\
\hline & & Lioconcha ornata (Dillwyn, 1817) \\
\hline & & Marcia cordata (Forsskål in Niebuhr, 1775) \\
\hline & & Marcia opima (Gmelin, 1791) \\
\hline & & Marcia recens (Holten, 1802) \\
\hline & & Paphia sp. \\
\hline & & Paratapes textilis (Gmelin, 1791) \\
\hline & & Paratapes undulatus (Born, 1778) \\
\hline & & Placamen lamellatum (Röding, 1798) \\
\hline & & Pelecyora ceylonica (Dunker, 1865) \\
\hline & & Petricola fabagella (Lamarck, 1818) \\
\hline & & Placamen lamellata (Röding, 1798) \\
\hline & & Protapes cor (Lamarck, 1818) \\
\hline
\end{tabular}




\begin{tabular}{|c|c|c|}
\hline \multirow[t]{34}{*}{ Order } & Family & Species \\
\hline & & Protapes rhamphodes (Oliver \& Glover, 1996) \\
\hline & & Tapes deshayesi (Sowerby, 1852) \\
\hline & & Tapes sulcarius (Lamarck, 1818) \\
\hline & & Timoclea arakana (Nevill \& Nevill, 1971) \\
\hline & & Venerupis rugosa (Sowerby, 1854) \\
\hline & Chamidae & Chama brassica Reeve, 1847 \\
\hline & & Chama pacifica Broderip, 1835 \\
\hline & & Chama sp. \\
\hline & & Circe intermedia Reeve, 1863 \\
\hline & Ungulinidae & Diplodonta (Felaniella) crebristriata (Sowerby, 1905) \\
\hline & & Diplodonta (Transkeia) globosa (Forsskål in Niebuhr, 1775) \\
\hline & & Diplodonta (Transkeia) moolenbeeki (Aartsen \& Goud, 2006) \\
\hline & & Diplodonta genethlia Melvill,1898 \\
\hline & & Diplodonta holosphaera (Melvill,1899) \\
\hline & & Diplodonta sp. \\
\hline & & Diplodonta subrotunda (Issel,1869) \\
\hline & Corbulidae & Corbula sulculosa H. Adams, 1870 \\
\hline & & Corbula taitensis Lamarck, 1818 \\
\hline & & Corbula cf. subquadrata (Melv. \& Standen, 1907) \\
\hline & Lasaeidae & Curvimysella sp. \\
\hline & & Kellia leucedra (Melvill \& Standen, 1907) \\
\hline & & Mysella sp. 1 \\
\hline & & Mysella sp. 2 \\
\hline & & Mysella sp. 3 \\
\hline & Donacidae & Donax sp. \\
\hline & & Donax cf. erythraeensis (Bertin, 1881) \\
\hline & Psammobiidae & Asaphis violascens (Forsskål, 1775) \\
\hline & & Gari maculosa (Lamarck, 1818) \\
\hline & & Gari cf. insignis (Deshayes, 1855) \\
\hline & & Hiatula ruppelliana (Reeve, 1857) \\
\hline & & Hiatula rosea (Gmelin, 1791) \\
\hline & Lucinidae & Loripes sp. \\
\hline & Mactridae & Mactra lilacea Lamarck, 1818 \\
\hline
\end{tabular}




\begin{tabular}{|c|c|c|}
\hline Order & Family & Species \\
\hline & & Mactrinula sp. \\
\hline & & Mactrotoma depressa (Spengler, 1793) \\
\hline & Mesodesmatidae & Atactodea subobtusa (Jousseame,1895) \\
\hline & Semelidae & Cumingia mutica (G. B. Sowerby I, 1833) \\
\hline & & Ervilia purpurea (Smith, 1906) \\
\hline & & Ervilia scaliola (Issel,1869) \\
\hline & & Ervilia sp. \\
\hline & & Semelangulus rosamunda (Melv. \& St., 1907) \\
\hline & & Semele cordiformis (Holten, 1802) \\
\hline & & Syndesmya sp. \\
\hline & & Theora cadabra (Eames and Wilkins, 1957) \\
\hline & Tellinidae & Confusella muscatensis (Oliver \& Chesney, 1997) \\
\hline & & Hanleyanus immaculatus (Philippi, 1849) \\
\hline & & Iridona methoria (Melvill,1897) \\
\hline & & Jactellina clathrata (Deshayes, 1835) \\
\hline & & Jitlada arsinoensis (Issel, 1969) \\
\hline & & Macomopsis dubia (Deshayes., 1835) \\
\hline & & Nitidotellina unifasciata (Sowerby, 1867) \\
\hline & & Pseudotellidora pellyana (A. Adams, 1873) \\
\hline & & Tellinimactra edentula (Spengler, 1798) \\
\hline & & Tellina arsinoensis Issel, 1869 \\
\hline & & Tellina donacina (Linnaeus, 1758) \\
\hline & & Tellina methoria Melvill, 1897 \\
\hline & & Tellina (Pinguitellina) pinguis (Hanley, 1844) \\
\hline & & Tellina valtonis Hanley, 1844 \\
\hline & & Tellina vernalis Hanley, 1844 \\
\hline & & Tellina sp. \\
\hline & & Soletellina rosea (Gmelin, 1791) \\
\hline & & Loxoglypta rhomboides (Quoy and Gaimard, 1835) \\
\hline & Trapezidae & Neotrapezium sublaevigatum (Lamarck, 1819) \\
\hline \multirow{2}{*}{$\begin{array}{l}\text { Superorder } \\
\text { Anomalodesmata }\end{array}$} & Thraciidae & Thracia cf. adenensis (Melvill, 1898) \\
\hline & Laternulidae & Laternula erythraea (Morris \& (Morris, 1993) \\
\hline
\end{tabular}




\section{Annex 9}

Dinoflagellates reported from Kuwait.

\begin{tabular}{|c|c|c|c|}
\hline Class & Order & Family & Species \\
\hline \multirow[t]{8}{*}{ Dinophyceae } & Prorocentrales & Prorocentraceae & Prorocentrum sp.1 \\
\hline & & & Prorocentrum balticum (Lohmann) Loeblich III 1970 \\
\hline & & & Prorocentrum compressum (Baily) Abé ex Dodge 1975 \\
\hline & & & Prorocentrum gracile Schütt 1895 \\
\hline & & & Prorocentrum lima (Ehrenberg) stein 1878 \\
\hline & & & Prorocentrum micans Ehrenberg 1833 \\
\hline & & & Prorocentrum rhathymum Loeblich III, Sherley and Schmidt 1979 \\
\hline & & & Prorocentrum triestinum Schiller 1918 \\
\hline \multirow[t]{20}{*}{ Desmophyceae } & Dinophysiales & Dinophysiaceae & Dinophysis acuta Ehrenberg 1841 \\
\hline & & & Dinophysis caudata Saville-Kent 1881 \\
\hline & & & Dinophysis miles Cleve \\
\hline & & & Dinophysis mitra (Schutt) Abé 1967 \\
\hline & & & Dinophysis norvegica Claparède and Lachmann 1859 \\
\hline & & & Dinophysis rotundata Claparède and Lachmann 1859 \\
\hline & & & Histioneis costata Kofoid and Michener 1911 \\
\hline & & & Ornithocercus magnificus Stein 1883 \\
\hline & & & Pseudophalacroma nasutum Kofoid and Skogberg 1928 \\
\hline & Gymnodinialis & Gymnodiniaceae & Amphidinium sp. 1 \\
\hline & & & Cochlodinium sp. 1 \\
\hline & & & Akashiwo sanguinea (Hirasaka) G. Hansen et Moestrup 2000 \\
\hline & & & Gymnodinium spp. cf. aff. gracilentum \\
\hline & & & Gyrodinium sp. 1 \\
\hline & & & Katodinium glaucum (Lebour) Loeblich III 1965 \\
\hline & & & Torodinium robustum Kofoid and Swezy 1921 \\
\hline & & Kareniaceae & Karenia selliformis Haywood, Steidinger and Mackenzie 2004 \\
\hline & & & Karenia cf. brevis (Davis) G. Hansen and Moestrup 2000 \\
\hline & & Polykrikaceae & Polykrikos schwartzii Bütschli 1873 \\
\hline & Noctilucales & Noctilucaceae & Noctiluca scintillans (Macartney 1836) Kofoid and Swezy 1921 \\
\hline
\end{tabular}




\begin{tabular}{|c|c|c|c|}
\hline Class & Order & Family & Species \\
\hline & & & Pronoctiluca pelagica Fabre-Domergue 1889 \\
\hline & Gonyaulacales & Ceratiaceae & Ceratium breve (Ostenfeld and Schmidt) Schröder 1906 \\
\hline & & & Ceratium furca (Ehrenberg 1836) Claparéde and Lachmann 1859 \\
\hline & & & Ceratium fusus (Ehrenberg 1834) Dujardin 1841 \\
\hline & & & Ceratium lineatum (Ehrenberg) Cleve 1899 \\
\hline & & & Ceratium massiliense (Gourret) Jörgensen 1911 \\
\hline & & & Ceratium trichoceros (Ehrenberg) Kofoid 1908 \\
\hline & & & Ceratium tripos (O. F. Müller 1781) Nitzsch 1817 \\
\hline & & & Ceratium sp. 1 \\
\hline & & Cladopyxidaceae & Cladopyxis hemibrachiata Balech 1964 \\
\hline & & Goniodomataceae & Alexandrium insuetum Balech 1985 \\
\hline & & & Alexandrium leei Balech 1985 \\
\hline & & & Alexandrium minutun Halim 1960 \\
\hline & & & Alexandrium tamarense (Lebour) Balech 1985 \\
\hline & & & Alexandrium sp. 1 \\
\hline & & & Goniodoma polyedricum (Pouchet) Jörgensen 1899 \\
\hline & & & Pyrodinium bahamense var. compressum (Böhm) Steidenger, Tester, \& Taylor 1980 \\
\hline & & Gonyaulacaceae & Gonyaulax polygramma Stein 1883 \\
\hline & & & Gonyaulax sp.1 \\
\hline & & & Lingulodinium polyedrum (Stein) Dodge 1989 \\
\hline & & & Protoceratium reticulatum (Claparéde \& Lachmann) Bütschli 1885 \\
\hline & & & Protoceratium sp. 1 \\
\hline & & Oxytoxaceae & Corythodinium tesselatum (Stein) Loeblich Jr. \& Loeblich III 1966 \\
\hline & & & Oxytoxum gracile Schiller 1937 \\
\hline & & & Oxytoxum sceptrum (Stein) Schröder 1906 \\
\hline & & & Oxytoxum sp. 1 \\
\hline & & Pyrocystaceae & Pyrocystis obtusa Pavillard 1931 \\
\hline & & & Pyrocystis fusiformis Wyville-Thomson in Murray 1885 \\
\hline & & Pyrophacaceae & Pyrophacus horologicum Stein 1883 \\
\hline & & & Pyrophacus steinii (Schiller) Wall \& Date 1971 \\
\hline & & Calciodinellaceae & Scrippsiella trochoidea (Stein) Loeblich III 1976 \\
\hline & Peridiniales & Kolkwitziellaceae & Diplopsalis lenticula Bergh 1881 \\
\hline & & & Diplopsalopsis Meunier 1910 \\
\hline
\end{tabular}




\begin{tabular}{|c|c|c|c|}
\hline Class & Order & Family & Species \\
\hline & & & Diplopsalopsis orbicularis (Paulsen) Meunier 1910 \\
\hline & & & Diplopelta parva (Abé) Matsuoka 1988 \\
\hline & & & Oblea rotunda (Lebour) Sournia 1973 \\
\hline & & & Preperidinium meunieri (Pavillard) Elbrächter 1993 \\
\hline & & Peridiniaceae & Heterocapsa sp.1 \\
\hline & & Protoperidiniaceae & Protoperidinium biconicum (Dangeard) Balech \\
\hline & & & Protoperidinium bipes (Paulsen 1904) Balech 1974 \\
\hline & & & Protoperidinium cerasus (Paulsen 1904) Balech 1974 \\
\hline & & & Protoperidinium claudicans (Paulsen) Balech 1974 \\
\hline & & & Protoperidinium conicum (Gran) Balech 1974 \\
\hline & & & Protoperidinium crassipes (Kofoid) Balech 1974 \\
\hline & & & Protoperidinium curtipes (Jörgensen) Balech 1974 \\
\hline & & & Protoperidinium depressum (Bailey 1855) Balech \\
\hline & & & Protoperidinium divergens (Ehrenberg) Balech 1974 \\
\hline & & & Protoperidinium elegans (Cleve) Balech 1974 \\
\hline & & & Protoperidinium grande Kofoid 1907 \\
\hline & & & Protoperidinium leonis (Pavillard) Balech 1974 \\
\hline & & & Protoperidinium marie-lebourae (Paulsen) Balech 1974 \\
\hline & & & Protoperidinium minutum (Kofoid) Leoblich III 1970 \\
\hline & & & Protoperidinium murrayi Kofoid 1907 \\
\hline & & & Protoperidinium ovatum Pouchet 1833 \\
\hline & & & Protoperidinium pellucidum (Bergh) Balech 1974 \\
\hline & & & Protoperidinium pentagonum Gran 1902 \\
\hline & & & Protoperidinium punctulatum (Paulsen 1907) Balech \\
\hline & & & Protoperidinium spiniferum (Schiller) Balech 1974 \\
\hline & & & Protoperidinium steinii (Jorgensen) Balech 1974 \\
\hline & & & Protoperidinium subinerme (Paulsen) Leoblich III 1970 \\
\hline & & & Protoperidinium thorianum (Paulsen) Balech 1974 \\
\hline & & & Protoperidinium ventricum (Abé) Balech 1974 \\
\hline & & & Protoperidinium sp. 1 \\
\hline & & & Blepharocysta splendormaris Ehrenberg 1859 \\
\hline & & Podolampaceae & Podolampas palmipes Stein 1883 \\
\hline & & & Podolampas bipes Stein 1883 \\
\hline
\end{tabular}




\section{Annex 10}

\section{Diatoms reported from Kuwait.}

\begin{tabular}{|c|c|c|c|}
\hline Class & Order & Family & Species \\
\hline \multirow[t]{28}{*}{ Coscinodiscophyceae } & Rhizosoleniales & Probosciaceae & Proboscia alata (Brightwell) Sundström \\
\hline & & & Proboscia indica (Péragallo) Hernández-Becerril \\
\hline & & Rhizosoleniaceae & Dactyliosolen phuketensis (Sundström) Hasle \\
\hline & & & Guinardia delicatula (Cleve) Hasle \\
\hline & & & Guinardia flaccida (Castracane) Péragallo \\
\hline & & & Neocalyptrella robusta (Norman ex Ralfs) Hernández-Becerril et Meave \\
\hline & & & Pseudosolenia calcar-avis (Schultze) Sundström \\
\hline & & & Rhizosolenia bergonii Péragallo \\
\hline & & & Rhizosolenia (Pseudosolenia?) cochlea Brun \\
\hline & & & Rhizosolenia hyalina Ostenfeld \\
\hline & & & Rhizosolenia imbricata Brightwel \\
\hline & & & Rhizosolenia setigera Brightwell \\
\hline & Triceratiales & Triceratiaceae & Triceratium dubium Brightwell \\
\hline & & & Triceratium robertsianum Greville \\
\hline & Stephanopyxales & Stephanopyxidaceae & Stephanopyxis palmeriana (Greville) Grunow \\
\hline & Corethrales & Corethraceae & Corethron histrix Hensen \\
\hline & Asterolamprales & Asterolampraceae & Asteromphalus cleveanus Grunow \\
\hline & & & Asteromphalus flabellatus (Brébisson) Greville \\
\hline & & & Asteromphalus heptactis (Brébisson) Ralfs \\
\hline & & & Asteromphalus sarcophagus Wallich \\
\hline & Coscinodiscales & Aulacodiscaceae & Schuettia annulata var. minor (Grunow) De Toni \\
\hline & & Coscinodiscaceae & Coscinodiscus asteromphalus Ehrenberg \\
\hline & & & Coscinodiscus granii Gough \\
\hline & & & Coscinodiscus janischii Schmidt var. arafurensis Grunow \\
\hline & & & Coscinodiscus marginatus Ehrenberg \\
\hline & & & Coscinodiscus nobilis Grunow \\
\hline & & & Coscinodiscus oculus-iridis Ehrenberg \\
\hline & & & Coscinodiscus perforatus Ehrenberg \\
\hline
\end{tabular}




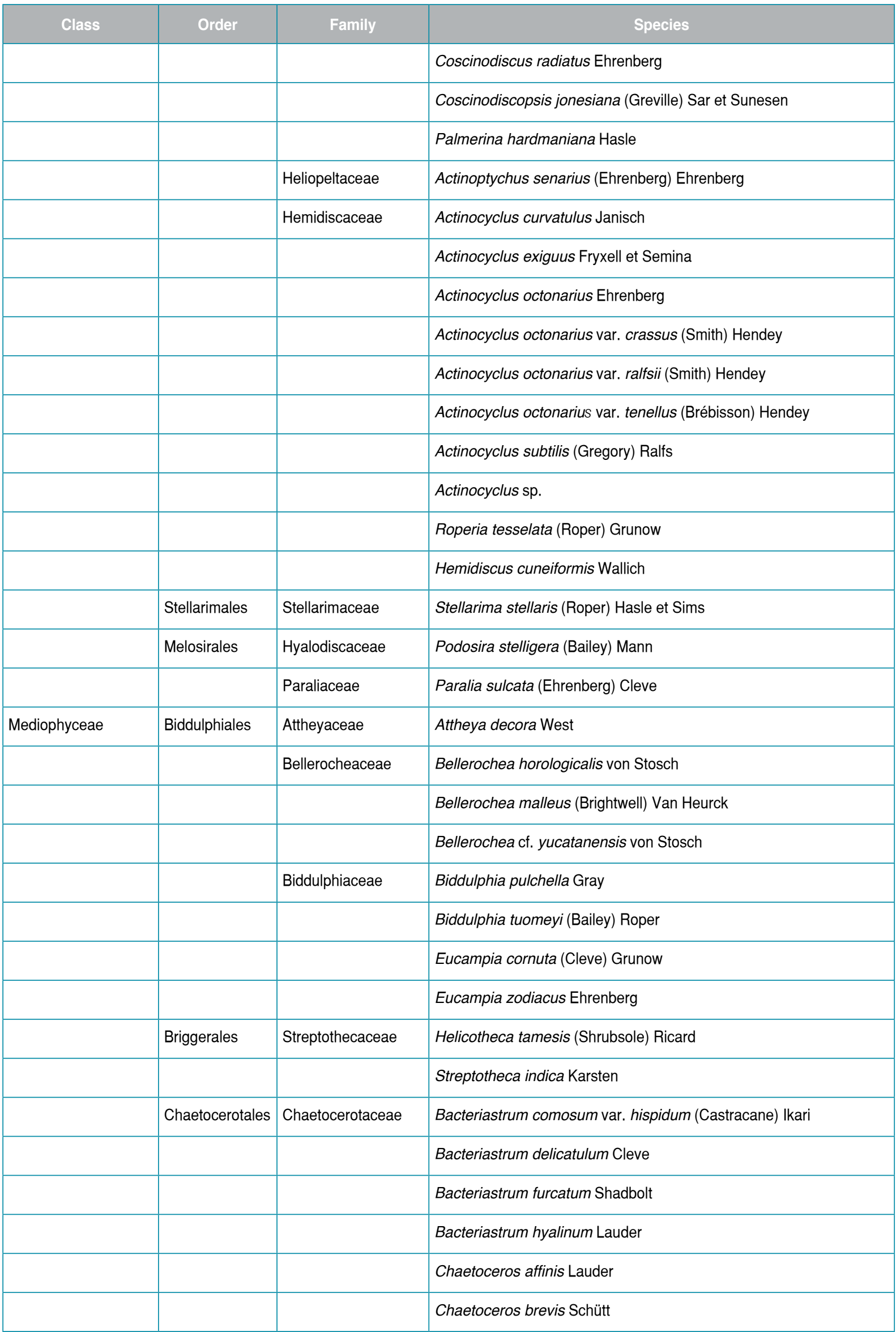




\begin{tabular}{|c|c|c|c|}
\hline Class & Order & Family & Species \\
\hline & & & Chaetoceros coarctatus Lauder \\
\hline & & & Chaetoceros compressus Lauder \\
\hline & & & Chaetoceros costatus Pavillard \\
\hline & & & Chaetoceros curvisetus Cleve \\
\hline & & & Chaetoceros danicus Cleve \\
\hline & & & Chaetoceros decipiens Cleve \\
\hline & & & Chaetoceros denticulatus Lauder \\
\hline & & & Chaetoceros diadema (Ehrenberg) Gran \\
\hline & & & Chaetoceros didymus Ehrenberg \\
\hline & & & Chaetoceros distans Cleve \\
\hline & & & Chaetoceros diversus Cleve \\
\hline & & & Chaetoceros laciniosus Schütt \\
\hline & & & Chaetoceros lauderi Ralfs \\
\hline & & & Chaetoceros lorenzianus Grunow \\
\hline & & & Chaetoceros paradoxus Cleve \\
\hline & & & Chaetoceros peruvianus Brightwell \\
\hline & & & Chaetoceros peruvianus Brightwell f. gracilis (Schröder) Hustedt \\
\hline & & & Chaetoceros protuberans Lauder \\
\hline & & & Chaetoceros pseudobrevis Pavillard \\
\hline & & & Chaetoceros pseudocurvisetus Mangin \\
\hline & & & Chaetoceros seiracanthus Gran \\
\hline & & & Chaetoceros socialis Lauder \\
\hline & & & Chaetoceros subtilis var. abnormis Prosckina-Lavrenko \\
\hline & & & Chaetoceros tenuissimus Meunier \\
\hline & & & Chaetoceros teres Gran \\
\hline & & & Chaetoceros tortissimus Gran \\
\hline & & & Chaetoceros vanheurckii Gran \\
\hline & & Leptocylindraceae & Leptocylindrus danicus Cleve \\
\hline & & & Leptocylindrus mediterraneus (Péragallo) Hasle \\
\hline & & & Leptocylindrus minimus Gran \\
\hline & Hemiaulales & Hemiaulaceae & Cerataulina bicornis (Ehrenberg) Hasle \\
\hline & & & Cerataulina dentata Hasle \\
\hline & & & Cerataulina pelagica (Cleve) Hendey \\
\hline
\end{tabular}




\begin{tabular}{|c|c|c|c|}
\hline Class & Order & Family & Species \\
\hline & & & Climacodium frauenfeldianum Grunow \\
\hline & & & Hemiaulus hauckii Grunow \\
\hline & & & Hemiaulus membranaceus Cleve \\
\hline & & & Hemiaulus sinensis (chinensis) Greville \\
\hline & Cymatosirales & Cymatosiraceae & Cymatosira lorenziana Grunow \\
\hline & Eupodiscales & Eupodiscaceae & Odontella aurita (Lyngbye) Agardh \\
\hline & & & Odontella weissflogii (Grunow) Grunow \\
\hline & & & Trieres mobiliensis (Bailey) Ashworth et Theriot \\
\hline & & & Trieres sinensis (chinensis) (Greville) Ashworth et Theriot \\
\hline & Lithodesmiales & Lithodesmiaceae & Ditylim brightwellii (West) Grunow ex Van Heurck \\
\hline & & & Ditylim sol (Grunow ex Van Heurck) de Toni \\
\hline & Stephanodiscales & Stephanodiscaceae & Cyclotella atomus Husted \\
\hline & & & Cyclotella choctawhatcheeana Prasad \\
\hline & & & $\begin{array}{l}\text { Cyclotella litoralis/cubiculata complex: Cyclotella cubiculata Sar, } \\
\text { Sunesen et Lavigne }\end{array}$ \\
\hline & & & Cyclotella stylorum Brightwell \\
\hline & Thalassiosirales & Lauderiaceae & Lauderia annulata Cleve \\
\hline & & Skeletonemataceae & Skeletonema grevillei Sarno et Zingone \\
\hline & & Thalassiosiraceae & Cymatotheca minima Voigt \\
\hline & & & Detonula pumila (Castracane) Gran \\
\hline & & & Planktoniella sol (Wallich) Schütt \\
\hline & & & Porosira pentaportula Syvertsen et Lange \\
\hline & & & $\begin{array}{l}\text { Shionodiscus oestrupii var. venrickiae (Fryxell et Hasle) Alverson, } \\
\text { Kang et Theriot }\end{array}$ \\
\hline & & & Thalassiosira andamanica Gedde \\
\hline & & & Thalassiosira cathariensis García \\
\hline & & & Thalassiosira cf. concava Semina \\
\hline & & & Thalassiosira concaviuscula Makarova \\
\hline & & & Thalassiosira decipiens (Grunow) Jørgensen \\
\hline & & & Thalassiosira delicatula Ostenfeld \\
\hline & & & Thalassiosira diporocyclus Hasle \\
\hline & & & Thalassiosira eccentrica (Ehrenberg) Cleve \\
\hline & & & Thalassiosira exigua Fryxell et Hasle \\
\hline & & & Thalassiosira hendeyi Hasle et Fryxell \\
\hline
\end{tabular}




\begin{tabular}{|c|c|c|c|}
\hline \multirow[t]{2}{*}{ Class } & Order & Family & Species \\
\hline & & & Thalassiosira lineata Jousé \\
\hline & & & Thalassiosira Iundiana Fryxell \\
\hline & & & Thalassiosira mala Takano \\
\hline & & & Thalassiosira minima Gaarder \\
\hline & & & Thalassiosira minuscula Krasske \\
\hline & & & Thalassiosira nanolineata (Mann) Fryxell et Hasle \\
\hline & & & Thalassiosira simonsenii Hasle et Fryxell \\
\hline & & & Thalassiosira sinica Li et Guo \\
\hline & & & Thalassiosira teleata Takano \\
\hline & & & Thalassiosira tenera Proschkina-Lavrenko \\
\hline & & & Tryblioptychus cocconeiformis (Grunow) Hendey \\
\hline Bacillariophyceae & Rhaphoneidales & Rhaphoneidaceae & $\begin{array}{l}\text { Asterionellopsis glacialis (Castracane) Round ex Round, Crawford } \\
\text { et Mann }\end{array}$ \\
\hline & & & Delphineis surirella (Ehrenberg) Andrews \\
\hline & & & Diplomenora cocconeiformis (Schmidt) Blazé \\
\hline & & & Perissonoë cruciata (Janisch et Rabenhorst) Andrews et Stoelzel \\
\hline & Licmophorales & Licmophoraceae & Licmophora abbreviata Agardh \\
\hline & Rhabdonematales & Grammatophoraceae & Grammatophora oceanica Ehrenberg \\
\hline & Thalassionematales & Thalassionemataceae & Thalassionema frauenfeldii (Grunow) Tempère et Péragallo \\
\hline & & & Thalassionema nitzschioides (Grunow) Mereschkowsky \\
\hline & & & Thalassionema pseudonitzschioides (Schuette et Schrader) Hasle \\
\hline & Cocconeidales & Cocconeidaceae & Anorthoneis excentrica (Donkin) Grunow \\
\hline & & & Cocconeis coronatoides Riaux-Gobin et Romero \\
\hline & & & Cocconeis neothumensis var. marina De Stefano, Marino et Mazella \\
\hline & & & Cocconeis placentula var. euglypta (Ehrenberg) Grunow \\
\hline & & & Cocconeis scutellum Ehrenberg sensu lato \\
\hline & Lyrellales & Lyrellaceae & Lyrella abrupta (Gregory) Mann \\
\hline & & & Lyrella lyroides (Hendey) Mann \\
\hline & & & Petroneis granulata (Bailey) Mann \\
\hline & & & Petroneis marina (Ralfs) Mann \\
\hline & Mastogloiales & Mastogloiaceae & Mastogloia rostrata (Wallich) Hustedt \\
\hline & Naviculales & Diploneidaceae & Diploneis weissflogii (Schmidt) Cleve \\
\hline & & Naviculaceae & Caloneis elongata (Grunow) Boyer \\
\hline & & & Gyrosigma balticum (Ehrenberg) Rabenhorst \\
\hline
\end{tabular}




\begin{tabular}{|c|c|c|c|}
\hline Class & Order & Family & Species \\
\hline & & & Gyrosigma tenuissimum (Smith) Griffith et Henfrey \\
\hline & & & Haslea gigantea (Hustedt) Simonsen \\
\hline & & & Haslea howeana (Hagelstein) Giffen \\
\hline & & & Haslea cf. meteorou Hinz et Sterrenburg \\
\hline & & & Haslea wawrikae (Hustedt) Simonsen emend. Sterrenburg et Hinz \\
\hline & & & Mastoneis biformis (Grunow) Cleve \\
\hline & & & Navicula directa (Smith) Ralfs \\
\hline & & & Navicula palpebralis Brébisson ex Smith \\
\hline & & & Seminavis robusta Danielidis et Mann \\
\hline & & & Trachyneis antillarum (Cleve et Grunow) Cleve \\
\hline & & & Trachyneis aspera (Ehrenberg) Cleve \\
\hline & & & Trachyneis debyi (Leudiger-Fortmorel) Cleve \\
\hline & & Plagiotropidaceae & Ephemera planamembranacea (Hendey) Paddock \\
\hline & & & Plagiolemma confusa (Hendey) Paddock \\
\hline & & & Meuniera membranacea (Cleve) Silva \\
\hline & & & Plagiotropis lepidoptera (Gregory) Kuntze \\
\hline & & & Plagiotropis tayrecta Paddock \\
\hline & & Pleurosigmataceae & Pleurosigma decorum Smith \\
\hline & & & Pleurosigma diversestriatum Meister \\
\hline & & & Pleurosigma elongatum Smith \\
\hline & & & Pleurosigma falx Mann \\
\hline & & & Pleurosigma formosum Smith \\
\hline & & & Pleurosigma inflatum Shadbolt \\
\hline & & & Pleurosigma inscriptura Harper \\
\hline & & & Pleurosigma intermedium Smith \\
\hline & & & Pleurosigma javanicum Grunow \\
\hline & & & Pleurosigma speciosum var. javanicum Péragallo \\
\hline & & & Pleurosigma strigosum Smith \\
\hline & & & Toxonidea insignis Donkin \\
\hline & & Amphipleuraceae & Amphiprora angustata Hendey \\
\hline & & & Amphiprora gigantea var. sulcata (O'Meara) Cleve \\
\hline & & Berkeleyaceae & Climaconeis Iorenzii Grunow \\
\hline & & & Climaconeis undulata (Meister) Lobban, Ashworth et Theriot \\
\hline
\end{tabular}




\begin{tabular}{|c|c|c|c|}
\hline Class & Order & Family & Species \\
\hline & & & Climaconeis sp. \\
\hline & Bacillariales & Bacillariaceae & Bacillaria paxillifera (Müller) Marsson \\
\hline & & & Cylindrotheca closterium (Ehrenberg) Reimann et Lewin \\
\hline & & & Cymatonitzschia marina (Lewis) Simonsen \\
\hline & & & Giffenia cocconeiformis (Grunow) Round et Basson \\
\hline & & & Gomphotheca sinensis (Skvortzov) Hendey et Sims \\
\hline & & & Nitzschia amabilis Suzuki \\
\hline & & & Nitzschia bicapitata Cleve \\
\hline & & & Nitzschia braarudii Hasle \\
\hline & & & Nitzschia dissipata (Kützing) Rabenhorst \\
\hline & & & Nitzschia distans Gregory \\
\hline & & & Nitzschia distans var. tumescens Grunow \\
\hline & & & Nitzschia fluminensis Grunow \\
\hline & & & Nitzschia hybrida Grunow \\
\hline & & & Nitzschia lanceolata Smith \\
\hline & & & Nitzschia longissima (Brébisson) Ralfs \\
\hline & & & Nitzschia lorenziana Grunow \\
\hline & & & Nitzschia pellucida Grunow \\
\hline & & & Nitzschia reversa Smith \\
\hline & & & Nitzschia sigma (Kützing) Smith \\
\hline & & & Nitzschia sigmaformis Hustedt \\
\hline & & & Nitzschia spathulata Brébisson \\
\hline & & & Nitzschia ventricosa Kitton \\
\hline & & & Nitzschia sp. 1 \\
\hline & & & Nitzschia sp. 2 \\
\hline & & & Psammodictyon panduriforme (Gregory) Mann \\
\hline & & & Psammodictyon roridum (Giffen) Mann \\
\hline & & & Tryblionella coarctata (Grunow) Mann \\
\hline & & & Tryblionella compressa (Bailey) Poulin \\
\hline & & & Pseudo-nitzschia americana (Hasle) Fryxell \\
\hline & & & Pseudo-nitzschia cf. calliantha Lundholm, Moestrup et Hasle \\
\hline & & & Pseudo-nitzschia pungens (Grunow ex Cleve) Hasle \\
\hline & & & Pseudo-nitzschia sp. 1 \\
\hline
\end{tabular}




\begin{tabular}{|c|c|c|c|}
\hline Class & Order & Family & Species \\
\hline & & & Pseudo-nitzschia sp. 2 \\
\hline & Surirellales & Entomoneidaceae & Entomoneis alata (Ehrenberg) Ehrenberg \\
\hline & & & Entomoneis paludosa (Smith) Reimer \\
\hline & & & Entomoneis punctulata (Grunow) Osada et Kobayasi \\
\hline & & Surirellaceae & Campylodiscus cf. fastuosus Ehrenberg \\
\hline & & & Campylodiscus iyengarii Subrahmanyan \\
\hline & & & Campylodiscus sp. \\
\hline & & & Coronia daemeliana (Grunow) Ruck et Guiry \\
\hline & & & Petrodictyon gemma (Ehrenberg) Mann \\
\hline & & & Surirella comis Schmidt \\
\hline & & & Surirella fastuosa (Ehrenberg) Kützing \\
\hline & Mastogloiales & Mastogloiaceae & Tetramphora decussata (Grunow) Stepanek et Kociolek \\
\hline & & & Tetramphora lineolata (Ehrenberg) Mereschkowsky \\
\hline & & & Tetramphora lineolatoides Spepanek et Kociolek \\
\hline & & & Tetramphora ostrearia (Brébisson) Mereschkowsky \\
\hline & Thalassiophysales & Catenulaceae & Amphora hyalina Kützing \\
\hline & & & Amphora laevis Gregory \\
\hline & & Thalassiophysaceae & Thalassiophysa hyalina (Greville) Paddock et Sims \\
\hline
\end{tabular}




\section{Annex 11}

Dicotyledoneae recorded from Kuwait.

\begin{tabular}{|c|c|}
\hline Family & Species \\
\hline Acanthaceae & Avicennia marina (Forssk.) Vierh. \\
\hline \multirow[t]{3}{*}{ Aizoaceae } & Aizoon canariense $\mathrm{L}$. \\
\hline & Aizoanthemum hispanicum (L.) \\
\hline & Mesembryanthemum nodiflorum $\mathrm{L}$. \\
\hline \multirow[t]{24}{*}{ Amaranthaceae } & Aerva javanica (Burm. f.) \\
\hline & Agathophora alopecuroides (Delile) Fenzl. ex Bunge \\
\hline & Amaranthus graecizans $\mathrm{L}$. \\
\hline & Amaranthus hybridus L. \\
\hline & Amaranthus lividus $\mathrm{L}$. \\
\hline & Anabasis lachnantha Aellen \& Rech. \\
\hline & Anabasis setifera Moq. \\
\hline & Atriplex dimorphostegia Kar. \& Kir. \\
\hline & Atriplex leucoclada Boiss \\
\hline & Bassia eriophora (Schrad.) Asch. \\
\hline & Bassia muricata (L.) Asch \\
\hline & Bassia scoparia (L.) \\
\hline & Beta vulgaris $\mathrm{L}$. \\
\hline & Bienertia sinuspersici Akhani \\
\hline & Caroxylon cyclophyllum (Baker) Akhani \& Roalson \\
\hline & Caroxylon imbricatum (Forssk,) Akhani \& Roalson \\
\hline & Chenopodiastrum murale (L.) S.Fuentes, Uotila \& Borsch \\
\hline & Chenopodium album L. \\
\hline & Chenopodium ficifolium Sm., F \\
\hline & Chenopodium glaucum $\mathrm{L}$. \\
\hline & Chenopodium opulifolium Schrad. \\
\hline & Cornulaca aucheri Moq \\
\hline & Cornulaca monacantha Delile \\
\hline & Halocnemum strobilaceum (Pall.) M. Bieb. \\
\hline
\end{tabular}




\begin{tabular}{|c|c|}
\hline \multirow[t]{8}{*}{ Family } & Species \\
\hline & Halothamnus iraqensis Botsch. \\
\hline & Hammada salicornica (Moq.) Iljin \\
\hline & Salicornia europaea L. \\
\hline & Seidlitzia rosmarinus Bunge ex Boiss. \\
\hline & Suaeda aegyptiaca (Hasselq.) Zohary \\
\hline & Suaeda vermiculata Forssk. ex J.F. Gmel \\
\hline & Traganum nudatum Delile \\
\hline \multirow[t]{6}{*}{ Apiaceae } & Ammi majus $\mathrm{L}$. \\
\hline & Anisosciadium isosciadium Bornm. \\
\hline & Anisosciadium lanatum Boiss. \\
\hline & Bupleurum semicompositum L. \\
\hline & Ducrosia anethifolia (DC.) Boiss. \\
\hline & Pituranthos triradiatus (Hochst. ex Boiss.) Asch. \& Schweinf \\
\hline Apocynaceae & Calotropis procera (Aiton) W.T. Aiton \\
\hline \multirow[t]{19}{*}{ Asteraceae } & Aaronsohnia factorovskyi Warb. \& Eig \\
\hline & Artemisia inculta Delile \\
\hline & Acantholepis orientalis Less \\
\hline & Achillea fragrantissima (Forssk.) \\
\hline & Anthemis melampodina Delile \\
\hline & Anthemis pseudocotula Boiss. \\
\hline & Anvillea garcini (Burm.f.) \\
\hline & Aster squamatus (Spreng.) \\
\hline & Atractylis carduus (Forssk.) C. Chr \\
\hline & Calendula arvensis (Vaill.) L. \\
\hline & Calendula tripterocarpa Rupr \\
\hline & Carduus pycnocephalus L. \\
\hline & Carthamus oxyacantha M.Bieb. \\
\hline & Centaurea bruguierana (DC) \\
\hline & Centaurea mesopotamica Bornm. \\
\hline & Cichorium endivia $\mathrm{L}$. \\
\hline & Erigeron bonariensis (L.) \\
\hline & Echinops polyceras Boiss \\
\hline & Filago pyramidata L. \\
\hline
\end{tabular}




\begin{tabular}{|c|c|}
\hline \multirow[t]{2}{*}{ Family } & Species \\
\hline & Flaveria trinervia (Sprengel) C. Mohr \\
\hline & Gnaphalium uligoinosum L. \\
\hline & Gymnarrhena micrantha Desf \\
\hline & Ifloga spicata (Forssk.) Sch. Bip. \\
\hline & Koelpinia linearis Pall. \\
\hline & Lactuca serriola L. \\
\hline & Launaea angustifolia (Desf.) \\
\hline & Launaea capitata (Spreng.) Dandy \\
\hline & Launaea nudicaulis (L.) Hook.f. \\
\hline & Leontodon laciniatus (Bertol.) Widder \\
\hline & Matricaria aurea (Loefl.) Sch. Bip. \\
\hline & Picris babylonica Hand.-Mazz \\
\hline & Pulicaria undulata (L.) C.A. Mey. \\
\hline & Pallenis hierochuntica (Michon) Greuter \\
\hline & Reichardia tingitana (L.) Roth \\
\hline & Rhanterium epapposum Oliv. \\
\hline & Scorzonera papposa DC. \\
\hline & Scorzonera tortuosissima Boiss., FI. Orient. $775: 3$. \\
\hline & Senecio glaucus L. \\
\hline & Senecio vulgaris $\mathrm{L}$. \\
\hline & Sonchus oleraceus L. \\
\hline & Sonchus tenerrimus $\mathrm{L}$. \\
\hline & Urospermum picroides (L.) F.W. Schmidt \\
\hline & Xanthium strumarium L. \\
\hline Boraginaceae & Anchusa hispida Forssk. \\
\hline & Arnebia decumbens (Vent.) Coss. \& Kralik \\
\hline & Arnebia linearifolia A. DC. in DC. Prodr. $1846.10: 95$ \\
\hline & Arnebia tinctoria Forssk \\
\hline & Echium rauwolfii Delile \\
\hline & Heliotropium bacciferum Forssk. \\
\hline & Heliotropium kotschyi Gürke \\
\hline & Heliotropium lasiocarpum Fisch. \& C.A. Mey \\
\hline & Lappula spinocarpos (Forssk.) Asch. ex Kuntze \\
\hline
\end{tabular}




\begin{tabular}{|c|c|}
\hline \multirow[t]{3}{*}{ Family } & Species \\
\hline & Moltkiopsis ciliata (Forssk.) I.M. Johnst. \\
\hline & Ogastemma pusillum (Coss. \& Durand ex Bonnet \& Baratte) Brummitt \\
\hline \multirow[t]{31}{*}{ Brassicaceae } & Alyssum homolocarpum (Fisch \&Mey.) \\
\hline & Alyssum linifolium Steph. ex Willd., \\
\hline & Anastatica hierochuntica L. \\
\hline & Brassica juncea L. \\
\hline & Brassica tournefortii Gouan \\
\hline & Cakile arabica Velen \\
\hline & Carrichtera annua (L.) DC \\
\hline & Cardaria draba (L.) Desv. \\
\hline & Capsella bursa-pastoris (L.) \\
\hline & Coronopus didymus (L.) J. E. Smith \\
\hline & Descurainia sophia L. \\
\hline & Diplotaxis acris (Forssk.) Boiss. \\
\hline & Diplotaxis harra (Forssk.) Boiss \\
\hline & Eruca vesicaria (L.) Cav. \\
\hline & Farsetia aegyptia Turra \\
\hline & Farsetia burtonae Oliv. \\
\hline & Horwoodia dicksoniae Turrill \\
\hline & Lepidium aucheri Boiss. \\
\hline & Leptaleum filifolium (Willd.) DC \\
\hline & Lepidium sativum L. \\
\hline & Malcolmia africana (L.) \\
\hline & Malcolmia grandiflora (Bunge) Kuntze, 1887 \\
\hline & Malcolmia pygmaea (DC.) \\
\hline & Matthiola longipetala (Vent.) DC. \\
\hline & Notoceras bicorne (Aiton) \\
\hline & Savignya parviflora (Delile) Webb \\
\hline & Schimpera arabica Hochst. \& Steud. ex Steud. \\
\hline & Sinapis arvensis $\mathrm{L}$. \\
\hline & Sisymbrium erysimoides Desf. \\
\hline & Sisymbrium irio L. \\
\hline & Sisymbrium orientale L. \\
\hline
\end{tabular}




\begin{tabular}{|c|c|}
\hline \multirow[t]{3}{*}{ Family } & Species \\
\hline & Sisymbrium septulatum DC. \\
\hline & Zilla spinosa (L.) Prantl \\
\hline \multirow[t]{5}{*}{ Caprifoliaceae } & Valerianella dufresnia Bge. ex Boiss. \\
\hline & Seetzenia lanata (Willd.) Bullock \\
\hline & Tribulus macropterus Boiss., Diagn. PI. Or. Ser. 1:61 .1 \\
\hline & Tribulus terrestris $\mathrm{L}$. \\
\hline & Zygophyllum qatarense Hadidi. \\
\hline \multirow[t]{20}{*}{ Caryophyllaceae } & Gypsophila capillaris (Forssk.) \\
\hline & Herniaria hemistemon J. Gay \\
\hline & Herniaria hirsuta L. \\
\hline & Leoflingia hispanica L. \\
\hline & Paronychia arabica (L.) DC \\
\hline & Polycarpaea repens (Forssk.) Asch. \& Schweinf \\
\hline & Polycarpaea robbairea (Kuntze) Greuter \& Burdet \\
\hline & Polycarpon tetraphyllum (L.) \\
\hline & Pteranthus dichotomus Forssk \\
\hline & Sclerocephalus arabicus Boiss \\
\hline & Silene arabica Boiss \\
\hline & Silene conoidea L. \\
\hline & Silene arenosa C. Koch \\
\hline & Silene villosa Forssk \\
\hline & Spergula fallax (Lowe) E.H.L. Krause \\
\hline & Spergularia diandra (Guss.) Boiss \\
\hline & Spergularia marina (L.) Griseb \\
\hline & Stellaria media (L.) Vill \\
\hline & Telephium sphaerospermum Boiss \\
\hline & Vaccaria hispanica (Mill.) Rauschert \\
\hline \multirow[t]{4}{*}{ Cistaceae } & Helianthemum kahiricum Delile \\
\hline & Helianthemum ledifolium (L.) \\
\hline & Helianthemum lippii (L.) Dum.-Cours \\
\hline & Helianthemum salicifolium (L.) \\
\hline \multirow[t]{2}{*}{ Convolvulaceae } & Convolvulus arvensis $\mathrm{L}$. \\
\hline & Convolvulus cephalopodus Boiss. \\
\hline
\end{tabular}




\begin{tabular}{|c|c|}
\hline \multirow[t]{5}{*}{ Family } & Species \\
\hline & Convolvulus oxyphyllus Boiss. \\
\hline & Convolvulus pilosellifolius Desr \\
\hline & Cressa cretica L. \\
\hline & Cuscuta planiflora Ten \\
\hline Crassulaceae & Crassula alata (Viv.) A. Berger \\
\hline Cucurbitaceae & Citrullus colocynthis (L.) Schrad. \\
\hline Cynomoriaceae & Cynomorium coccineum $\mathrm{L}$. \\
\hline \multirow[t]{3}{*}{ Caprifoliaceae } & Lomelosia olivieri (Coulter) Greuter \& Burdet \\
\hline & Lomelosia palaestina (L.) Rafin \\
\hline & Valerianella dufresnia Bunge ex. Boiss \\
\hline \multirow[t]{11}{*}{ Euphorbiaceae } & Chrozophora obliqua (Vahl) Adr. Juss. ex Spreng., \\
\hline & Chrozophora tinctoria (L.) Raf \\
\hline & Euphorbia densa Schrenk \\
\hline & Euphorbia granulata Forssk., FI. \\
\hline & Euphorbia grossheimii (Prokh.) \\
\hline & Euphorbia isthmia Täckh. \\
\hline & Euphorbia helioscopia L. \\
\hline & Euphorbia hirta L. \\
\hline & Euphorbia indica Lam., Encycl. Meth. Bot. 423 :2 \\
\hline & Euphorbia peplus Radium \\
\hline & Euphorbia serpens Kunth \\
\hline \multirow[t]{12}{*}{ Fabaceae } & Alhagi graecorum Boiss. \\
\hline & Astragalus annularis Forssk \\
\hline & Astragalus bombycinus Boiss. \\
\hline & Astragalus corrugatus Bertol. \\
\hline & Astragalus hauarensis Boiss. \\
\hline & Astragalus schimperi Boiss \\
\hline & Astragalus sieberi DC. \\
\hline & Astragalus spinosus Muschl. \\
\hline & Astragalus tribuloides Delile \\
\hline & Coronilla scorpioides (L.) W.D.J. Koch \\
\hline & Hippocrepis areolata Desv. \\
\hline & Hippocrepis unisiliquosa $\mathrm{L}$. \\
\hline
\end{tabular}




\begin{tabular}{|c|c|}
\hline Family & Species \\
\hline & Lathyrus aphaca L. \\
\hline & Lotus halophilus Boiss. \& Spruner \\
\hline & Medicago laciniata (L.) Mill. \\
\hline & Medicago polymorpha L. \\
\hline & Medicago rotata Boiss. \\
\hline & Melilotus indicus (L.) All. \\
\hline & Melilotus alba Medik. \\
\hline & Onobrychis ptolemaica DC. \\
\hline & Ononis reclinata $\mathrm{L}$. \\
\hline & Ononis serrata Forssk. \\
\hline & Prosopis farcta (Banks \& Sol.) \\
\hline & Scorpiurus muricatus L. \\
\hline & Trifolium lappaceum L. \\
\hline & Trifolium resupinatum $\mathrm{L}$. \\
\hline & Trigonella anguina Delile \\
\hline & Trigonella hamosa L. \\
\hline & Trigonella stellata Forssk. \\
\hline & Vachellia pachyceras O. Schwartz \\
\hline Frankeniaceae & Frankenia pulverulenta L. \\
\hline \multirow[t]{5}{*}{ Geraniaceae } & Erodium ciconium (L.) L'Hér. \\
\hline & Erodium cicutarium (L.) L’Hér. \\
\hline & Erodium glaucophyllum (L.) L'Hér. \\
\hline & Erodium laciniatum (Cav.) Willd \\
\hline & Monsonia nivea (Decne.) Webb \\
\hline \multirow[t]{6}{*}{ Lamiaceae } & Lallemantia royleana Benth. in Wall. \\
\hline & Salvia aegyptiaca L. \\
\hline & Salvia lanigera Poir. \\
\hline & Salvia spinosa L. \\
\hline & Teucrium oliverianum Ging. ex Benth. \\
\hline & Teucrium polium $\mathrm{L}$. \\
\hline \multirow[t]{3}{*}{ Malvaceae } & Althaea ludwigii L. \\
\hline & Hibiscus trionum L. \\
\hline & Malva nicaeensis All. \\
\hline
\end{tabular}




\begin{tabular}{|c|c|}
\hline Family & Species \\
\hline & Malva parviflora L. \\
\hline Neuradaceae & Neurada procumbens $\mathrm{L}$. \\
\hline \multirow[t]{5}{*}{ Orobanchaceae } & Cistanche tubulosa (Schrenk) Wight \\
\hline & Orobanche aegyptiaca Pers. \\
\hline & Orobanche cernua Loefl. \\
\hline & Orobanche minor Sm. \\
\hline & Orobanche ramosa $\mathrm{L}$. \\
\hline Oxalidaceae & Oxalis corniculata L. \\
\hline \multirow[t]{6}{*}{ Papaveraceae } & Fumaria parviflora Lam. \\
\hline & Hypecoum pendulum L. \\
\hline & Hypecoum littorale Wulfen in Jacq., \\
\hline & Glaucium corniculatum (L.) Rudolph. \\
\hline & Papaver rhoeas L. \\
\hline & Roemeria hybrida (L.) DC. \\
\hline Phyllanthaceae & Andrachne telephioides $\mathrm{L}$. \\
\hline \multirow[t]{9}{*}{ Plantaginaceae } & Linaria albifrons Spreng. \\
\hline & Linaria simplex (Willd.) DC. \\
\hline & Plantago amplexicaulis Cav \\
\hline & Plantago boissieri Hausskn. \& Bornm \\
\hline & Plantago ciliata Desf. \\
\hline & Plantago coronopus L. \\
\hline & Plantago notata Lag. \\
\hline & Plantago ovata Forssk \\
\hline & Plantago psammophila Agnew \& Chal.-Kabi \\
\hline \multirow[t]{3}{*}{ Plumbaginaceae } & Limonium carnosum Kuntze \\
\hline & Limonium lobatum (L.f.) Kuntze \\
\hline & Psylliostachys spicata (Willd.) Nevski \\
\hline \multirow[t]{5}{*}{ Polygalaceae } & Calligonum polygonoides L. \\
\hline & Emex spinose (L.) \\
\hline & Polygonum patulum M. Bieb. \\
\hline & Rumex pictus Forssk. \\
\hline & Rumex vesicarius $L$. \\
\hline Portulacaceae & Portulaca oleracea L. \\
\hline
\end{tabular}




\begin{tabular}{|c|c|}
\hline Family & Species \\
\hline Primulaceae & Anagallis arvensis $\mathrm{L}$. \\
\hline Ranunculaceae & Adonis dentata Delile. \\
\hline \multirow[t]{6}{*}{ Resedaceae } & Caylusea hexagyna (Forssk.) M.L.Green \\
\hline & Ochradenus baccatus Delile \\
\hline & Oligomeris linifolia (Vahl) J.F. Macbr \\
\hline & Reseda arabica Boiss. \\
\hline & Reseda decursiva Forssk. \\
\hline & Reseda muricata C. Presl. \\
\hline \multirow[t]{2}{*}{ Rubiaceae } & Crucianella membranacea Boiss. \\
\hline & Galium tricornutum Dandy \\
\hline Rutaceae & Haplophyllum tuberculatum (Forssk.) Juss. \\
\hline Scrophulariaceae & Scrophularia deserti Del. \\
\hline \multirow[t]{7}{*}{ Solanaceae } & Datura innoxia Mill. \\
\hline & Hyoscyamus muticus $\mathrm{L}$. \\
\hline & Hyoscyamus pusillus L. \\
\hline & Lycium shawii Roem. \& Schult. \\
\hline & Physalis angulata $\mathrm{L}$. \\
\hline & Solanum nigrum L. \\
\hline & Withania somnifera (L.) \\
\hline Tamaricaceae & Tamarix aucheriana (Decne.) Baum \\
\hline \multirow[t]{2}{*}{ Thymelaeaceae } & Thymelaea mesopotamica (C. Jeffrey) B. Peterson \\
\hline & Nitraria retusa (Forssk.) Asch. \\
\hline Nitrariaceae & Peganum harmala L. \\
\hline Nyctaginaceae & Boerhavia diffusa $\mathrm{L}$. \\
\hline Urticaceae & Urtica urens L. \\
\hline \multirow[t]{2}{*}{ Verbenaceae } & Phyla nodiflora (L.) Greene \\
\hline & Verbena tenuisecta L. \\
\hline \multirow[t]{3}{*}{ Zygophyllaceae } & Fagonia bruguieri DC. \\
\hline & Fagonia glutinosa Delile \\
\hline & Fagonia indica Burm. f \\
\hline
\end{tabular}




\section{Annex 12}

Monocotyledoneae recorded from Kuwait.

\begin{tabular}{|c|c|}
\hline Family & Species \\
\hline \multirow[t]{2}{*}{ Asparagaceae } & Bellevalia saviczii Woronow \\
\hline & Dipcadi erythraeum Webb \& Berthel \\
\hline \multirow[t]{2}{*}{ Asphodelaceae } & Asphodelus tenuifolius Cav. \\
\hline & Asphodelus viscidus \\
\hline Cymodoceaceae & Halodule uninervis (Forssk.) Asch. \\
\hline \multirow[t]{2}{*}{ Cyperaceae } & Cyperus conglomeratus Rottb., PI. Rar. Descr. 16. \\
\hline & Cyperus rotundus $\mathrm{L}$. \\
\hline Hydrocharitaceae & Halophila ovalis (R. Br.) Hook. $f$ \\
\hline \multirow[t]{2}{*}{ Iridaceae } & Gladiolus italicus Mill. \\
\hline & Moraea sisyrinchium (L.) \\
\hline Ixioliriaceae & Ixiolirion tataricum (Pall.) Herb. \\
\hline Juncaceae & Juncus rigidus Desf. \\
\hline \multirow[t]{4}{*}{ Amaryllidaceae } & Allium longisepalum \\
\hline & Allium sindjarense Boiss. \& Hausskn. ex Regel \\
\hline & Allium sphaerocephalum L. \\
\hline & Gagea reticulata (Pall.) Schult. \& Schult.f. \\
\hline \multirow[t]{12}{*}{ Poaceae } & Aegilops bicornis (Forssk.) Jaub. \& Spach \\
\hline & Aegilops kotschyi Boiss. \\
\hline & Aegilops triuncialis $\mathrm{L}$. \\
\hline & Aeluropus lagopoides (L.) Trin. ex Thwaites \\
\hline & Aeluropus littoralis (Gouan) Parl., FI. Ital. 461 :1. \\
\hline & Ammochloa palaestina Boiss. \\
\hline & Avena barbata Pott ex Link. \\
\hline & Avena fatua $\mathrm{L}$. \\
\hline & Avena sativa. $\mathrm{L}$. \\
\hline & Avena sterilis $\mathrm{L}$. \\
\hline & Brachypodium distachyum (L.) P. Beauv. \\
\hline & Bromus catharticus Vahl. \\
\hline
\end{tabular}




\begin{tabular}{|c|c|}
\hline Family & Species \\
\hline & Bromus danthoniae Trin. \\
\hline & Bromus madritensis $\mathrm{L}$. \\
\hline & Bromus sericeus Drobov \\
\hline & Bromus tectorum $\mathrm{L}$. \\
\hline & Cenchrus ciliaris $\mathrm{L}$ \\
\hline & Cenchrus setigerus Vahl \\
\hline & Centropodia forsskalii (Vahl) Cope \\
\hline & Cutandia dichotoma (Forssk.) \\
\hline & Cutandia memphitica (Spreng.) Benth. \\
\hline & Cymbopogon commutatus (Steud.) Stapf \\
\hline & Cynodon dactylon (L.) Pers. \\
\hline & Dactyloctenium aegyptium (L.) Willd. \\
\hline & Dactyloctenium aristatum Link, Hort. Berol. 59 :1. \\
\hline & Dichanthium annulatum (Forssk.) Stapf \\
\hline & Dichanthium foveolatum (Delile) Roberty \\
\hline & Digitaria ciliaris (Retz.) Koeler \\
\hline & Digitaria sanguinalis (L.) Scop. \\
\hline & Dinebra retroflexa (Vahl) Panzer \\
\hline & Echinochloa colona (L.) Link \\
\hline & Eleusine indica (L.) \\
\hline & Eragrostis barrelieri Daveau \\
\hline & Eragrostis minor Host, Gram. Austr. 4:15. \\
\hline & Eremopoa persica (Trin.) Rozhev. \\
\hline & Eremopyrum bonaepartis (Spreng.) Nevski \\
\hline & Eremopyrum distans (C. Koch) Nevski \\
\hline & Hordeum marinum Huds. \\
\hline & Hordeum murinum L. \\
\hline & Imperata cylindrica (L.) Raeusch. \\
\hline & Lasiurus scindicus Henrard \\
\hline & Leptochloa fusca (L.) Kunth \\
\hline & Lolium rigidum Gaudin \\
\hline & Lolium multiflorum Lam. \\
\hline & Lolium temulentum $\mathrm{L}$. \\
\hline
\end{tabular}




\begin{tabular}{|c|c|}
\hline Family & Species \\
\hline & Melinis repens (Willd.) Zizka \\
\hline & Panicum antidotale Retz. \\
\hline & Panicum turgidum Forssk. \\
\hline & Parapholis incurva (L.) C.E. Hubb. \\
\hline & Pennisetum divisum (J.F. Gmel.) Henrard \\
\hline & Phalaris minor Retz. \\
\hline & Phalaris paradoxa $\mathrm{L}$. \\
\hline & Phragmites australis (Cav.) Trin. ex Steud. \\
\hline & Poa annua L. \\
\hline & Poa sinaica Steud., Syn. PI. Glum. 1:256. \\
\hline & Poa infirma Kunth. \\
\hline & Polypogon monspeliensis. (L.) Desf. \\
\hline & Rostraria cristata (L.) Tzvelev. \\
\hline & Rostraria pumila (Desf.) Tzvelev \\
\hline & Schismus arabicus Nees \\
\hline & Schismus barbatus (L.) Thell. \\
\hline & Setaria verticillata (L.) P. Beauv \\
\hline & Setaria viridis (L.) P. Beauv \\
\hline & Sorghum halepense (L.) Pers. \\
\hline & Sporobolus arabicus Boiss., Diagn. ser. $1.47: 13,1$ \\
\hline & Stipa capensis Thunb. \\
\hline & Stipagrostis ciliata (Desf.) De Winter \\
\hline & Stipagrostis drarii (Täckh.) De Winter. \\
\hline & Stipagrostis obtusa (Delile) Nees \\
\hline & Stipagrostis plumosa (L.) Munro ex T. Anderson \\
\hline & Trisetaria linearis Forssk. \\
\hline Typhaceae & Typha domingensis (Pers.) Poir. ex Steud. \\
\hline
\end{tabular}





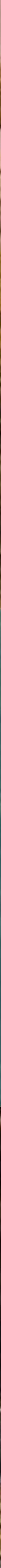

